Andrews University

Digital Commons @ Andrews University

1992

\title{
Historical/Analytical Study Of The Contributions Of Alma E. McKibbin To The Seventh-Day Adventist Church School System
}

Marie Louise Myers

Andrews University, myersm@andrews.edu

Follow this and additional works at: https://digitalcommons.andrews.edu/dissertations

Part of the Curriculum and Instruction Commons, and the History Commons

\section{Recommended Citation}

Myers, Marie Louise, "Historical/Analytical Study Of The Contributions Of Alma E. McKibbin To The Seventh-Day Adventist Church School System" (1992). Dissertations. 593.

https://digitalcommons.andrews.edu/dissertations/593

https://dx.doi.org/10.32597/dissertations/593

This Dissertation is brought to you for free and open access by the Graduate Research at Digital Commons @ Andrews University. It has been accepted for inclusion in Dissertations by an authorized administrator of Digital Commons@ Andrews University. For more information, please contact repository@andrews.edu. 


\section{INFORMATION TO USERS}

This manuscript has been reproduced from the microfilm master. UMI films the text directly from the original or copy submitted. Thus, some thesis and dissertation copies are in typewriter face, while others may be from any type of computer printer.

The quality of this reproduction is dependent upon the quality of the copy submitted. Broken or indistinct print, colored or poor quality illustrations and photographs, print bleedthrough, substandard margins, and improper alignment can adversely affect reproduction.

In the unlikely event that the author did not send UMI a complete manuscript and there are missing pages, these will be noted. Also, if unauthorized copyright material had to be removed, a note will indicate the deletion.

Oversize materials (e.g., maps, drawings, charts) are reproduced by sectioning the original, beginning at the upper left-hand corner and continuing from left to right in equal sections with small overlaps. Each original is also photographed in one exposure and is included in reduced form at the back of the book.

Photographs included in the original manuscript have been reproduced xerographically in this copy. Higher quality 6" $\times 9$ " black and white photographic prints are available for any photographs or illustrations appearing in this copy for an additional charge. Contact LiMI directly to order.

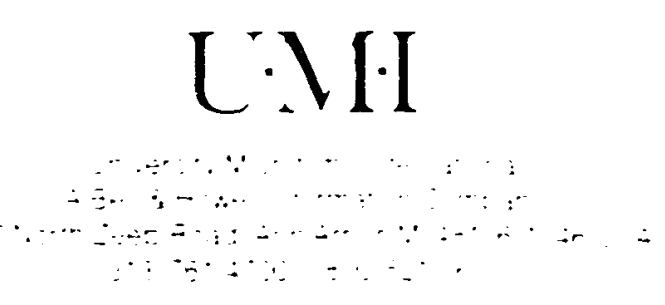


Historical/analytical study of the contributions of Alma E.

McKibbin to the Seventh-day Adventist church school system

Myers, Marie Louise, Ph.D.

Andrews University, 1992

Copyright $\mathrm{C} 1992$ by Myers, Marie Louise. All rights reserved.

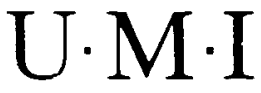

i(x) N. Zeert, Ru.

Ann Artor. MI $4811 \%$ 


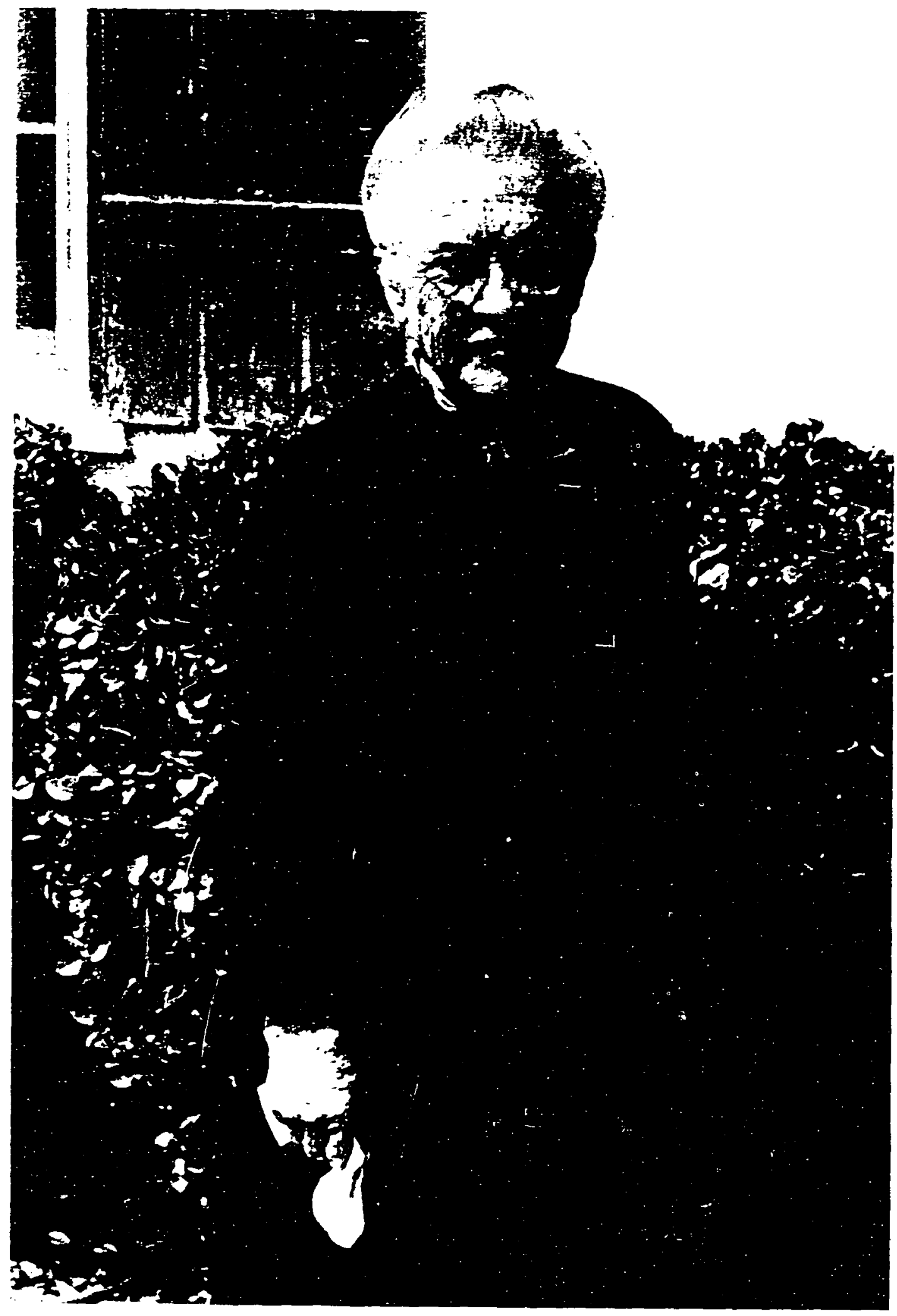




\title{
Andrews University
}

School of Education

\section{HISTORICAL/ANALYTICAL STUDY OF THE CONTRIBUTIONS OF ALMA E. MCKIBBIN \\ TO THE SEVENTH-DAY ADVENTIST CHURCH SCHOOL SYSTEM}

\author{
A Dissertation \\ Presented in Partial Fulfillment \\ of the Requirements tor the Degree \\ Doctor of Philosophy
}

by

Marie Louise Myers

June 1992 
- Copyright by Marie Louise Myers 1992

All Rights Reserved 


\title{
HISTORICAL/ANALYTICAL STUDY OF THE CONTRIBUTIONS OF ALMA E. MICKIBBIN \\ TO THE SEVENTH-DAY ADVENTIST CHURCH SCHOOL SYSTEM
}

\author{
A dissertation \\ presented in partial fulfilliment \\ of the requirements for the degree \\ Doctor of Philosophy
}

by

Marie Louise Myers

APPROVAL BY THE COMMITTEE:

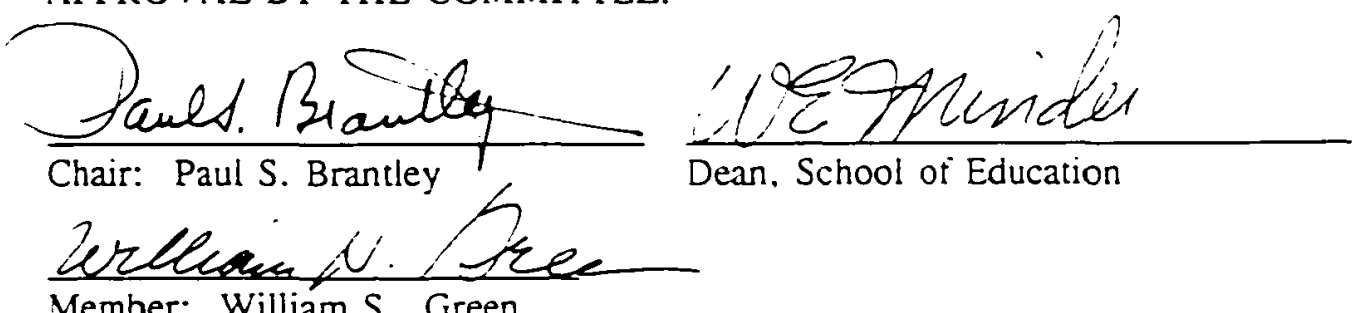

Member: William S. Green

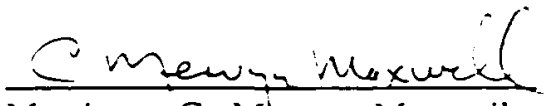

Member: C. Mervyn Maxwell

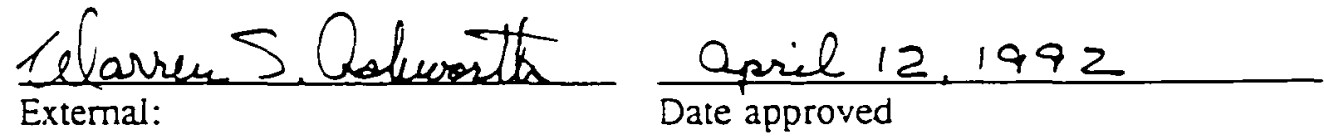




\section{ABSTRACT}

\section{HISTORICAL/ANALYTICAL STUDY OF THE CONTRIBUTIONS OF ALMA E. MCKIBBIN \\ TO THE SEVENTH-DAY ADVENTIST CHURCH SCHOOL SYSTEM}

by

Marie Louise Myers

Chair: Paul S. Brantley 


\title{
ABSTRACT OF GRADUATE STUDENT RESEARCH
}

Dissertation

\author{
Andrews University \\ School of Education
}

Title: $\quad$ HISTORICAL ANALYTICAL STUDY OF THE CONTRIBUTIONS OF ALMA E. MCKIBBIN TO THE SEVENTH-DAY ADVENTIST CHURCH SCHOOL SYSTEM

Name of researcher: Marie Louise Myers

Name of degree of faculty chair: Paul S. Brantley, Ph.D.

Date completed: December 1991

"If we don't understand our roots, we lose sight of our mission" (G. Ralph Thomoson). Alma E. McKibbin, the first Seventh-day Adventist church school teacher in Califomia, is little known among Seventh-day Adventists outside that state, where she began teaching in 1896. She developed a Bible curriculum that was used for over half a century in the Seventh-day Adventist church school educational system--a private, religious, parochial organization of over four thousand schools all around the world.

The purpose of this study is to document the contributions she made to that system, with a special emphasis given to the analysis and description of her classroom teaching methodology and of the content of her Bible textbooks. which 
were written for grades four through nine. A secondary purpose is to examine the integration of her values and philosophy with the content and methods she used in her textbooks and instruction.

This study is presented within a chronological, biographical framework, and includes a brief, contextual background of the educational milieu of the small, rural, multigrade classrooms of the late 1890 s, into which the seed of the church school fell. Although the major focus of the study is on elementary education in the state of Califomia, where most of Alma McKibbin's writing and teaching took place, information on her secondary, college, and Sabbath school teaching is also included.

Major sources included historical documents from archival and personal collections of materials, oral histories, books, and Seventh-day Adventist periodicals, and from over one hundred interviews by the author. Sources for contextual background included the qualitative studies of Barbara Finkelstein (Governing the Young) and Larry Cuban (How Teachers Taught). In the conclusion, an initial list of implications reflects several of the church school dilemmas and critical challenges of religious education and teacher training pertinent to the 1990 s. 
Dedicated to

church school teachers

and teacher educators

everywhere 


\section{OF ALMA E. MICKIBBIN ON HER 93rd BIRTHDAY}

She stands not high from ground to sky, Her strength at times is weak;

She makes no claim to title or fame, For honor she does not seek.

Through her years of more than ten and four score, Grave trials she's met, and more;

For lack of wealth, sorrow and poor health, Have all knocked at her door.

But her wealth doth mount in things that count, Her aim: to be God's child; Her measure of worth, above things of earth:

That her name in the Book of Life be tiled.

Her joy is to share her experience of God's care, And help win the soul of another;

Still teaching, reading, praying, and leading, Twice blessed--herself and others.

Her spirit is not dim, while she's waiting for Him, Though evil must bring its storms; She lives by faith and dwells beneath The Everlasting Arms. 
TABLE OF CONTENTS

FRONTISPIECE $\ldots \ldots \ldots \ldots \ldots \ldots \ldots \ldots \ldots \ldots \ldots \ldots \ldots$

POEM .................... vi

LIST OF ILLUSTRATIONS $\ldots \ldots \ldots \ldots \ldots \ldots \ldots \ldots \ldots$ xii

LIST OF TABLES $\ldots \ldots \ldots \ldots \ldots \ldots \ldots \ldots \ldots \ldots \ldots \ldots$

PREFACE $\ldots \ldots \ldots \ldots \ldots \ldots \ldots \ldots \ldots \ldots \ldots \ldots \ldots \ldots$

Chapter

1. PREPARATION YEARS: $1871-1889 \ldots \ldots \ldots \ldots \ldots 1$

Alma McKibbin's Family Ancestry $\ldots \ldots \ldots \ldots \ldots$

Early California Years . . . . . . . . . . . . . . . 8

The Move Back East ................ 11

The Move to Colorado ................. 13

Contextual Sketch of Saguache . . . . . . . . . . . 15

The Baker Family Income ... . . . . . . . . . . 20

Education in Rural Colorado .............. 24

Religion in Alma's Life . . . . . . . . . . . . $\quad 32$

Summary and Observations .............. 39

2. COLLEGE AND MARRIAGE YEARS: $1889-1896 \ldots \ldots \ldots+4$

Califomia Normal School Education 1889-1892 ...... 41

General Course Work ............... 45

Professional Course Work ............ 49

Healdsburg College $1889-1992 \ldots \ldots \ldots \ldots \ldots$

Alma's Arrival at Healdsburg ............ 55

Description of the College . . . . . . . . . 57

Teacher Training at Healdsburg 1889-1892 ........ 62

General Course Work .......................... 65

Professional Course Work ... . . . . . . . . 69

Practice Teaching in the Sabbath School .......... 70

Ellen G. White ........................ 74

Alma's Frivate Life at Healdsburg College . . . . . . . 76

vii 
Summary and Observations $\ldots \ldots \ldots \ldots . \ldots . \ldots . \ldots$

3. EARLY TEACHING YEARS: $1896-1911 \ldots \ldots . \ldots . \ldots 8$

Prevailing Teaching Practices in U.S. Rural

Elementary Schools in the $1890 \mathrm{~s} \ldots \ldots \ldots . \ldots . . . . .88$

Teaching Practices in California ............ 91

Educational Philosophy of the Seventh-day Adventist

Church ..................... 95

The Church School Movement . . . . . . . . . . . 97

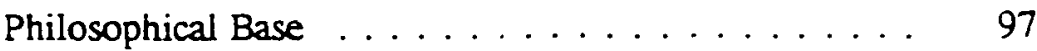

Church Milieu . . . . . . . . . . . . . . 100

Difficulties in Beginning Church Schnols ....... 102

Denominational Certification $\ldots \ldots \ldots \ldots$

Church Periodicals That Stimulated

Church Schools ................... 108

Experimentation with a Home School,

Winter, $1897 \ldots \ldots \ldots \ldots \ldots 113$

Centralia. . . . . . . . . . . . . . . . . . 124

Alma's Teaching Methods and Practices ....... 136

Alma Is Tested . . . . . . . . . . . . . . 140

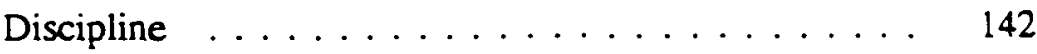

She Finishes the Year ............... 148

First Seventh-day Adventist Church School

Teacher Education in Califomia . . . . . . . . . . 154

Teacher Training at Summer Schcols . . . . . . . 156

Responsibilities at Healdsburg ............ 164

Healdsburg Preparatory School . . . . . . . . . . . . 167

Curriculum and Methods ............... 169

Discipline . . . . . . . . . . . . . . . 177

Church Work .................... 182

Alma's Friendship with Mrs. Ellen G. White . . . . . . 184

Lonnie . . . . . . . . . . . . . . . . . 188

Summary and Observations: Integration of

Alma McKibbin's Faith and Methodology ........ 193

\section{FIRST BIBLE TEXTBOOKS}

FOR SEVENTH-DAY ADVENTIST CHURCH SCHOOLS:

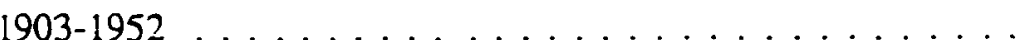

Protestant Religious Education

at the Turn of the Century . . . . . . . . . . . . . . 197

Sources Alma McKibbin Used

When Constructing Bible Lessons . . . . . . . . . . . 202

Analysis of Bible Lessons and Revisions . . . . . . . . . . 210

viii 
Original Editions $\ldots \ldots \ldots \ldots \ldots \ldots \ldots \ldots \ldots \ldots$

1903 Printing . . . . . . . . . . . . . 210

1904 and 1905 Printings,

Healdsburg College Press $\ldots \ldots \ldots \ldots \ldots .220$

1905 Printing, Pacific Press . . . . . . . . . . 220

1918 Old Testament History for Ninth Grade . . . . . 223

Church School Manuals . . . . . . . . . . . . . . 225

1906 Church School Manual . . . . . . . . . . . . 225

1914 Bible Lesson Manual . . . . . . . . . . . . . 229

1918 Church School Manual . . . . . . . . . . . . . 232

Revisions and Translations . . . . . . . . . . . 233

1909 Lily of the Valley Books, One, Two, and Three . 233

1912 Lily of the Valley Book Four . . . . . . . . 239

1909 Bible Lessons Book One (Not Revised) . . . . 242

1921 Life of Jesus, Grade Six . . . . . . . . . . . 243

1926 Last of Old Testamens Times, Fifth Grade . . . 244

1926 Gospel to All the World, Seventh Grade . . . . . 247

1927 Revised Old Testament History . . . . . . . . . 249

1940 Gospel to All the World, Seventh Grade . . . . . 251

Spanish Translations . . . . . . . . . . . . 252

Comparing Alma McKibbin's Texts with Those

That Followed . . . . . . . . . . . . . . . . 253

Third and Fourth-grade Texts . . . . . . . . . 254

Fifth and Sixth-grade Texts . . . . . . . . . . 255

Seventh and Eighth-grade Texts . . . . . . . . . 258

Ninth-grade Manual of Old Testament History . . . . 261

Use and Opinion of Alma McKibbin's Bible Texts . . . . 263

Alma McKibbin's Opinion . . . . . . . . . . . . 268

Summary and Observations . . . . . . . . . . . . . . . 269

Integration of Alma McKibbin's Faith and Methodology . . 269

Controversies over Alma McKibbin's Bible Books . . . . . 273

5. LATER TEACHING YEARS: $1911-1927 \ldots \ldots \ldots \ldots \ldots$

Bible Teacher, Pacific Union College 1911-1928 _ . . . . 278

Classes Alma McKibbin Taught . . . . . . . . . . . 284

Faculty Duties . . . . . . . . . . . . . . . . . . . . 285

Ellen G. White . . . . . . . . . . . . . . . . . 293

Alma McKibbin's Teaching Methods and Philosophy

at Pacific Union College . . . . . . . . . . . . . . 294

Her Relationship with Students . . . . . . . . . . 301

P.U.C. Students' Opinions of Mrs. McKibbin and

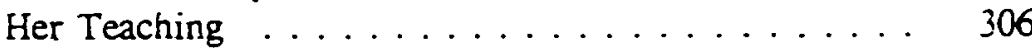

The Effect of the Influenza Epidemic of $1918 \ldots \ldots \ldots 312$

The Move to Mountain View . . . . . . . . . . . 313 
Mountain View Academy $\ldots \ldots \ldots \ldots \ldots \ldots \ldots$

Her Teaching Miethods and Philosophy . . . . . . 317

Her Relationship with Students at Mountain View Academy 325

Mountain View Academy Students' Opinions of Mrs.

McKibbin and Her Teaching . . . . . . . . . 330

Other Activities . . . . . . . . . . . . . . . 332

Summary and Observations . . . . . . . . . . . 333

Integration of Her Faith with Her Methodology . . . . 333

6. RETIREMENT YEARS: $1927-1974 \ldots \ldots \ldots \ldots \ldots \ldots$

Sabbath School Teacher . . . . . . . . . . . . . . . 342

General Lesson Study . . . . . . . . . . . . . . . . . 342

Spirit of Prophecy ............... 343

Prophecy, a Guiding Light . . . . . . . . . . 349

The Seven Deacons . . . . . . . . . . . . . . 353

Teacher of Teachers . . . . . . . . . . . . 356

Teacher and Tutor . . . . . . . . . . . . . . . . . . 359

Author of Books and Articles . . . . . . . . . . . . 373

Public Speaker . . . . . . . . . . . . . . . . . . . . . 375

Counselor and Mentor . . . . . . . . . . . . . 381

Student Contacts . . . . . . . . . . . . . . . 386

Awards and Recognition . . . . . . . . . . . . . . . 388

The End. . . . . . . . . . . . . . . . . . . . . . . . 389

Summary of Interviewees' Comments about Alma McKibbin . . 394

Summary and Observations . . . . . . . . . . . . . . . . 399

Methodology ................... 400

Integration of Faith and Practice . . . . . . . . . . 401

7. CONCLUSIONS ..................... $\$ 04$

Summary of Alma McKibbin's Contributions . . . . . . . 405

The Bible Curriculum . . . . . . . . . . . . . . . . . . 407

Summary . . . . . . . . . . . . . . . 407

Implications . . . . . . . . . . . . . . 410

Her Teaching Methods . . . . . . . . . . . . 417

Summary . . . . . . . . . . . . . . . . 417

implications . . . . . . . . . . . . . . 419

Integration of Faith, Leaming, and Practice . . . . . . . $\$ 22$

Recommendations .................. 425

For Researchers . . . . . . . . . . . . . 425

For Practitioners . . . . . . . . . . . . . 428

APPENDIX

A. Samples of McKibbin Bible Books . . . . . . . . . . . . . . 439 
B. He Leadeth Me, by Alma E. McKibbin . . . . . . . . . . . . 492

GLOSSARY ......................... 551

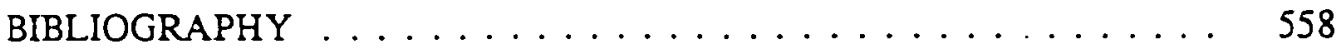

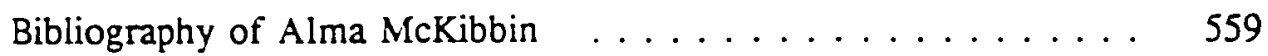

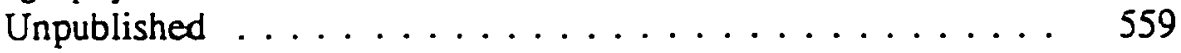

Letters and Autographs ................... 559

Manuscripis ...................... 561

Interviews and Tape Recordings .......... 563

Published ............................. 564

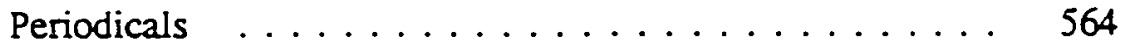

Books and Pamphlets ................ 569

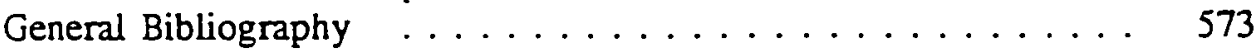

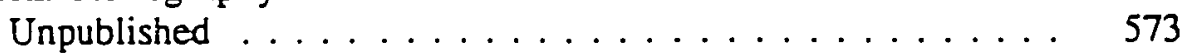

U.S. Census and County Records ................ 573

Minutes of Meetings . . . . . . . . . . . . . . 573

Letters . . . . . . . . . . . . . . . . . . . 574

Manuscripts and Maps . . . . . . . . . . . . . 578

Theses and Dissertations ............... 581

Interviews and Tape Recordings . . . . . . . . . . 582

Published . . . . . . . . . . . . . . . . . . 589

Catalogues and Bulletins .............. 589

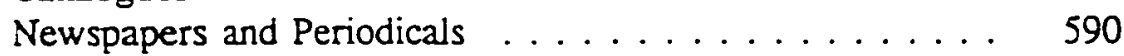

Books and Pamphlets ................ 596

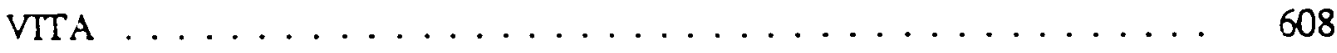




\section{LIST OF ILLUSTRATIONS}

Figure 1. Frontispiece $\ldots \ldots \ldots \ldots \ldots \ldots \ldots \ldots \ldots \ldots \ldots$

Figure 2. County Map of Iowa, 1870 s $\ldots \ldots \ldots \ldots \ldots \ldots .4$

Figure 3a. The Baker Home, Saguache, Colorado, c. 1880 . . . . 17

Figure 3b. Sangre de Cristos Mountain Range and San Luis Valley as Seen from Alma's Home ... 17

Figure 4a. The Baker Home, Formerly the Pumphrey Ranch $\ldots \ldots \quad 23$

Figure 4b. The Baptist Church Alma Attended in Saguache, c. $1883 \ldots \ldots \ldots \ldots \ldots \ldots \ldots \ldots$

Figure 5a. San Pasqual Valley $\ldots \ldots \ldots \ldots \ldots \ldots \ldots \ldots$

Figure $5 \mathrm{~b}$. The Henry Johnson Home, San Pasqual, California $\ldots . .115$

Figure 6a. Edwin and Lorin McKibbin's Graves, San Pasqual . . . 119

Figure 6b. First Church School in San Pasqual, 1898, Opened after Alma McKibbin Left the San Pasqual Valley ...... 119

Figure 7. Map of Orange County, c. $1891 \ldots \ldots \ldots \ldots \ldots$

Figure 8a. Alma McKibbin, $1898 \ldots \ldots \ldots \ldots \ldots \ldots \ldots$

Figure 8b. Alma McKibbin in the 1924-25 Mountain View Academy Annual . . . . . . . . 128

Figure 9. A Shoestring Book and the Book of Remembrance . . . . 153

Figure 10. E. G. White Home in Healdsburg, which Alma Rented, c. 1902 . . . . . . . . 186

Figure 11. Faculty, Pacific Union College, $1911-12 \ldots \ldots \ldots .280$ 
Figure 12. Dedication, Mountain View Academy Annual, 1924-25 . . 304

Figure 13. Alma McKibbin, c. $1960 \ldots \ldots . \ldots \ldots$

Figure 14a. Alma McKibbin's Home, 525 Palo Alto Avenue,

Mountain Viaw, California ............ 341

Figure 14b. Mountain View SDA Church on Springer Road,

Where Alma Attended ............. 341

Figure 15. Alma McKibbin's 100th Birthday Surrey Kide . . . . . . . 391

Figure 16. An Example of How to Teach a Story according to the

Developmental Model of Bible Teaching ....... +35 


\section{LIST OF TABLES}

Table 1. Course of Instruction, California Normal School,

San Jose, $1889-1890 \ldots \ldots \ldots \ldots \ldots$

Table 2. Course of Study, California State Normal School,

Los Angeles, $1892-1893 \ldots \ldots \ldots \ldots \ldots$. . . . . . $\$ 7$

Table 3. Course of Instruction for the Normal Course

at Healdsburg College $\ldots \ldots \ldots \ldots \ldots . \ldots \ldots$

Table 4. Alma McKibbin's Textbooks and Revisions . . . . . . . . 212

Table 5. Alma McKibbin's Textbooks at a Glance . . . . . . . . . . 214

Table 6. Comparison of Readability Levels of Alma McKibbin's

Books with Those That Replaced Them ......... 255

Table 7. Alma McKibbin's Classes at Pacific Union College,

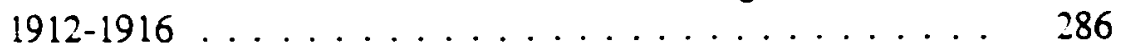

Table 8. Alma McKibbin's Classes at Pacific Union College,

$1916-1919 \ldots \ldots \ldots \ldots \ldots \ldots \ldots . \ldots \ldots$ 


\section{PREFACE}

In the 1990s, there are few Seventh-day Adventists, especially outside the state of California, who know that the first Bible textbooks used in Seventhday Adventist church schools were written by Alma McKibbin. Few know that until the 1970s, many academy students used Bible books that still reflected her influence. As the Seventh-day Adventist educational system grew rapidly from eighteen church schools in 1895 to 535 in 1908, Mrs. McKibbin's Bible textbooks played a significant part in providing uniformity for the newly formed elementary school system, not only in California, but throughout North America.

In addition to writing Bible books, Mrs. McKibbin achieved two other "firsts" in Seventh-day Adventist education: she taught the first churchconnected school and the first teacher education program for Seventh-day Adventist church school teachers in Califormia.

She helped establish the Califomia Seventh-day Adventist church school system when church members were reluctant to initiate what was considered an unnecessary expense. She was largely successful in helping to obtain both participation and support for the church school system from a constituency that was "bumed out" from the huge indebtedness of Healdsburg College and other institutions begun not many years before. 
Alma McKibbin began studying good teaching methodology as an eight-year-old student and continued studying and teaching it well into her nineties. The integration of her philosophy with her teaching was apparently well accepted in her context and continues to provide a model for educators today.

Teacher, tutor, author, leader, administrator, counselor, pubiic speaker, and friend are some of the roles Alma McKibbin filled in her lifetime. She personally taught over 1300 students, many of whom later functioned in various capacities in denominational work all over the world. It is impossible to know how many others she encouraged to serve God through her textbooks and extra-classroom ministry.

\section{Purpese of the Study}

The major purpose of this study is to examine and docurnent as many as possible of the extensive contributions Alma McKibbin made to the Seventhday Adventist church school system, with a special emphasis given to the analysis and description of her teaching and textbooks. A secondary purpose is to examine the integration of her beliefs with the content of her textbooks and classroom teaching methodology. Another goal is to enhance acquaintance with Alma McKibbin herself as a person.

\section{Need for the Study}

The problems Alma McKibbin faced were essentially not unlike those that educators deal with in today's schools. Seventh-day Adventist educators in 
the field of curriculum and instruction and other interested readers may be able to draw implications from her experiences and successes that will be of help in solving today's church school dilemmas.

Published and unpublished arcounts about Alma McKibbin occur mainly in general Adventist histories, none of which attempt to make an exhaustive study of her contributions. Most quote her as a historian, for she knew much about early Adventist history. She wrote a short autobiography at age ninety but devotes only twenty-three pages to her teaching and textbook writing, with few details, dates, or locations, and little documentation. The book written by her brother, Alonzo L. Baker, consists largely of sections from her autobiography with an update of more recent stories about her life; however, it is not documented. It appears that there is very little published material available about Alma McKibbin.

\section{Scope and Delimitations of the Study}

The main thrust of this study focuses on Alma McKibbin's impact on the Seventh-day Adventist church school system in California from its beginnings in 1897, although much evidence is included that establishes the widespread use of her books throughout North America and other countries. This investigation focuses mainly on AIma's contribution to elementary schooling in California, her elementary textbooks, and her main subject, Bible.

This study is not intended to provide a detailed biography of Alma McKibbin, except where biographical data is important to a greater

$$
\text { xvii }
$$


understanding of the historical context and of her personality, character and beliefs. The development of the educational milieu which directly affected the Seventh-day Adventist church school movement is not comprehensive, for it has been treated adequately in other research studies.

\section{Previous Studies}

\section{Published Accounts}

Alma McKibbin's name is not mentioned in the following Seventh-day Adventist general church histories: Arthur Whitefield Spalding's Origin and History of Seventh-day Adventists, J. N. Loughborough's The Great Second Advent Movement, W. A. Spicer's Pioneer Days, Matilda Erickson Andross's Story of the Advent Message. Gary Land's Adventism in America, C. Mervyn Maxwell's Tell it to the World, and M. Ellsworth Olsen's Origin and Progress of Seventh-day Adventists. George R. Knight, in Earty Adventist Educarors, apologized for not including Alma McKibbin. John Beach overlooked her name in Notable Women of Spirit, and Maurice Hodgen did not mention her in School Bells and Gospel Trumpers.

Edward Miles Cadwallader, in "A History of Seventh-day Adventist Education," quoted approximately three pages of Alma McKibbin's description of her early teaching days, including some of the hardships other early Seventhday Adventist teachers experienced. Harold O. McCumber, in Pioneering the Message in the Golden West, quoted Alma's description of an 1872 California camp meeting in which her parents witnessed a sacrificial offering for the

xviii 
founding of the Pacific Press. Walter Utt cited Alma's account of the early days of Pacific Union College in his history of that institution.

At age ninety Mrs. McKibbin wrote a ninety-six-page autobiography, Step by Step, which appeared first as a series for the Review and Herald. This book narrated several of her life experiences. Although a rich source for her philosophy, it provides a scant twenty-three pages about her early experiences in church school teaching and textbook writing, lacking much important documented information, names and dates.

\section{Unpublished Accounts}

One would expect to find Alma's name mentioned in unpublished dissertations and theses about Seventh-day Adventist educational history. But Vilbur A. Burton (1987) does not include her work in his dissertation, "A History of the Mission of Seventh-day Adventist Education 1844-1900." nor does Mary Kelly Little in "Development of the Elementary Schools of SDA's in the U. S." However, George S. Ashlock does mention her as a teacher in Centralia and Healdsburg in "The Establishment of White SDA Elementary Schools in the U. S." She is also listed as a teacher of Bible History on a photocopy of a 1916-1917 college catalogue included in Marion Cady's "Seventh-day Adventist Denominational Schools on the Pacific Coast," and as a textbook author on a page in Walton Brown's Chronology of SDA Education. John C. Haussler's four pages cite in general terms the impact she made on the church school system in California. Eighteen pages in "The History of SDA Education in Califomia," a

$$
\text { xix }
$$


dissertation by George F. Jackson, contain the most informative account of her contributions to California Seventh-day Adventist educational work. An unpublished thesis by Lars C. Christensen, 1938, "A Short History of the Beginnings and Development of the Seventh-day Adventist Work in California," includes nineteen pages of material from interviews with Alma McKibbin in a chapter entitled, "The Beginnings of Church School Work in California." This material elaborates some of her published early experiences as a church school teacher and writer of textbooks.

\section{Major Sources}

The primary sources for this study, which include manuscripts, oral histories, taped speeches, catalogues from Healdisburg College and Pacific Union College, dissertations and theses, correspondence, and Seventh-day Adventist Bible textbooks and periodicals (Review and Herald, Signs of the Times, Youth's Instructor, Our Little Friend, Joumal of True Education, Sabbarh School Worker, and Pacific Union Recorder) were obtained mainly from the Adventist Heritage Centers and Ellen G. White Research Centers at Andrews University, Berrien Springs, Michigan; Loma Linda University, Loma Linda, California; La Sierra College, Riverside, Califomia; and Pacific Union College, Angwin. California, and General Conference of Seventh-day Adventists, Silver Spring, Maryland.

Other information. including normal school catalogues of the 1890s, California educational history, and political codes, was researched in archives at 
the University oi Califomia at Berkeley; San Jose State University, San Jose, California; Orange County Archives, Santa Ana, California; and California State Library, Sacramento.

Historical societies which provided documents, including census records, local history, International Sunday School lessons, and marriage certificates, were the Colorado State Historical Society, Denver; Escondido Historicai Society, Escondido, Califomia; American Baptist Historical Society, Valley Forge, Pennsylvania; and Iowa Genealogical Society, Des Moines. The offices of statistics and records in the states of California and Iowa provided death certificates.

Interviews were conducted with over one hundred individuals who were acquainted with Alma McKibbin. Several taped interviews, housed in the Adventist Heritage Centers listed above, also provided primary source material for Alma's church school history. Many individuals, in response to several advertisements for information in contemporary Seventh-day Adventist periodicals, wrote, telephoned, or sent information, including pictures, letters, books, taped recordings, articles in periodicals, and manuscripts for this study.

\section{Type of Study}

This is a historical documentary study designed to deal systematically with the examination of primary and secondary sources. 


\section{Design of the Study}

A chronological approach has been followed in presenting the basic biographical information about Alma McKibbin, listing her contributions in context, with an emphasis on the examination and description of her teaching and textbook writing. The fourth chapter, an analysis of the McKibbin Bible texts, digresses from the chronology, for her books spanned a period of almost fifty years. The summaries at the end of each chapter trace the integration of her philosophy with the content of her books and with her classroom teaching methodology. To aid the reader's understanding, a glossary of terms is included at the end of the dissertation, which includes religious and educational terminology that may not be familiar to the reader.

Chapter 1 outlines Alma's family background. Her college years and brief marriage to Edwin McKibbin comprise Chapter 2; chapter 3 describes her early church school teaching in San Pasqual, Centralia, and Healdsburg. After the analysis of her Bible books in Chapter 4, her later teaching years in the preparatory department at Pacific Union College and at Mountain View Academy foilow in Chapter 5. Chapter 6 outlines the final years of teaching, lecturing, writing, and counseling, succeeded by the conclusions in Chapter 7 .

\section{Acknowledgments}

Although the names of the many donors and interviewees who have kindly lent and have given freely of their personal collected materials and oral recollections for this dissertation are not listed here, many of these kind

\section{xxii}


individuals can be found in the bibliography. Without the aid of this group of people, this dissertation could not have been written. Several, whom I had not met before my data-gathering trip to Califomia, extended invitations to stay in their homes while I gathered research in their vicinities: Reg and Edith Meikle, Edward and Bessie Martella, and Cathryn Rogers. Space will not permit the enumeration of many other kindnesses.

Appreciation is also expressed to the workers in the James White Library, who endeavored to retrieve books and documents from not only their own collections, but from libraries all over the United States. Many unsolicited courtesies from the workers helped to ease the workload of gathering materials.

Drs. Paul Brantley, Bill Green, and Mervyn Maxwell offered useful suggestions and criticism from perspectives that have been passed on to the reader in this study. It was Dr. Maxwell's idea to research the life of Alma McKibbin. Bonnie Proctor, the dissertation secretary, and Joyce Campbell and Hilary Daly, who typed the hard copy, spent many hours preparing the manuscript for final printing.

My family provided financial support and added my share of responsibilities to their own to enable the completion of the manuscript.

Most importantly, I am grateful to God, who preserved my health, energized my mind, provided the help of dedicated friends, and granted the opportunity to learn lessons from the life of a great teacher.

xxiii 


\section{CHAPTER !}

\section{PREPARATION YEARS}

$1871-1889$

For lack of wealth, sorrow and poor health. Have all knocked at her door.

\section{tIma .IcKibbin's Familv Ancestry}

Headlines in the New York Times on 26 November 1871. Alma Baker's birthday, announced Apache and Comanche Indian raids in Arizona and Texas. ${ }^{1}$ in Colorado, where Alma would spend her girlhood, the federal peace treaty with the Ute Indians would not be signed for another two years. Stories of Indian attacks did not stop migrating settlers, left in poverty by the Civil War. from moving west with their tamilies. Gold and silver mines were proliferating in Colorado, the Black Hills. and sections of California. Among those lured west by gold was Alma's father. Alonzo Baker.

Alonzo Lafayette Baker led an adventurous lifestyle that included sampmates such as Wild Bill Hickock and Calamity Jane. A Civil War veteran

Vew York Times. 26 Tovember $137 !$. :. 
for the Union. Baker had been born on the Illinois irontier in 1846.' Having only a few months of schooling in his life, he became a self-educated man:-

By contrast, his tather, Nathan IV. Baker, a tarmer who raised stock all of his working years, was a graduate of Ohio State University. His mother, Permelia Wilson Baker, a native of Kentucky, was a "proud, sensitive southern woman" ${ }^{3}$ who reared twelve children and, apparently, bequeathed them her nervous temperament. Alonzo, in this respect. was evidently the child most like her. Alma said, "His nerves were so sensitive he would wake if a cat walked across the tloor." ${ }^{\text {These }}$ "Baker nerves" appeared later in his children. Alma, the oldest, born in Webster County, lowa, later wrote, " . . but for the grace of God I would be moody. irritable and often bitter . . but I must be alone to regain my nerve tone and keep sweet." ${ }^{5}$. Nell, second born, also in Iowa, was "mean." Anne, born in the San Luis Valley of Colorado. and who. according to Alma was the brightest, most charming member of her tamily, developed

\footnotetext{
-Alonzo Laiayette Baker." in Progressive Hen of Western Coloracto (Chicago: A. W. Bowen and Company, 1905), 457 .

Ibid.: Alma McKibbin, interview by James Nix and James Barnard. 2 August 1967. ranscript, Loma Lirda Oral History Collection. Adventust Heritage Center. Loma Linda University, Loma Linda, Calif., 24.

'Alma McKibbin. Mountann View. Calit., o Bertha Parmenter. Mourian View, Calif., :1 August 1958, in the hand of Bertha Parmenter, Deer Park. Calit.

‘bid.

'Ibid.

'Interviewees $\$ 50,51$, and 54 , who wish to remain anonymous, tnterviews by author. 24 February 1991.
} 
Figure 2. County Map of Iowa. 1870s. Courtesy, Iowa Geneological Society. 


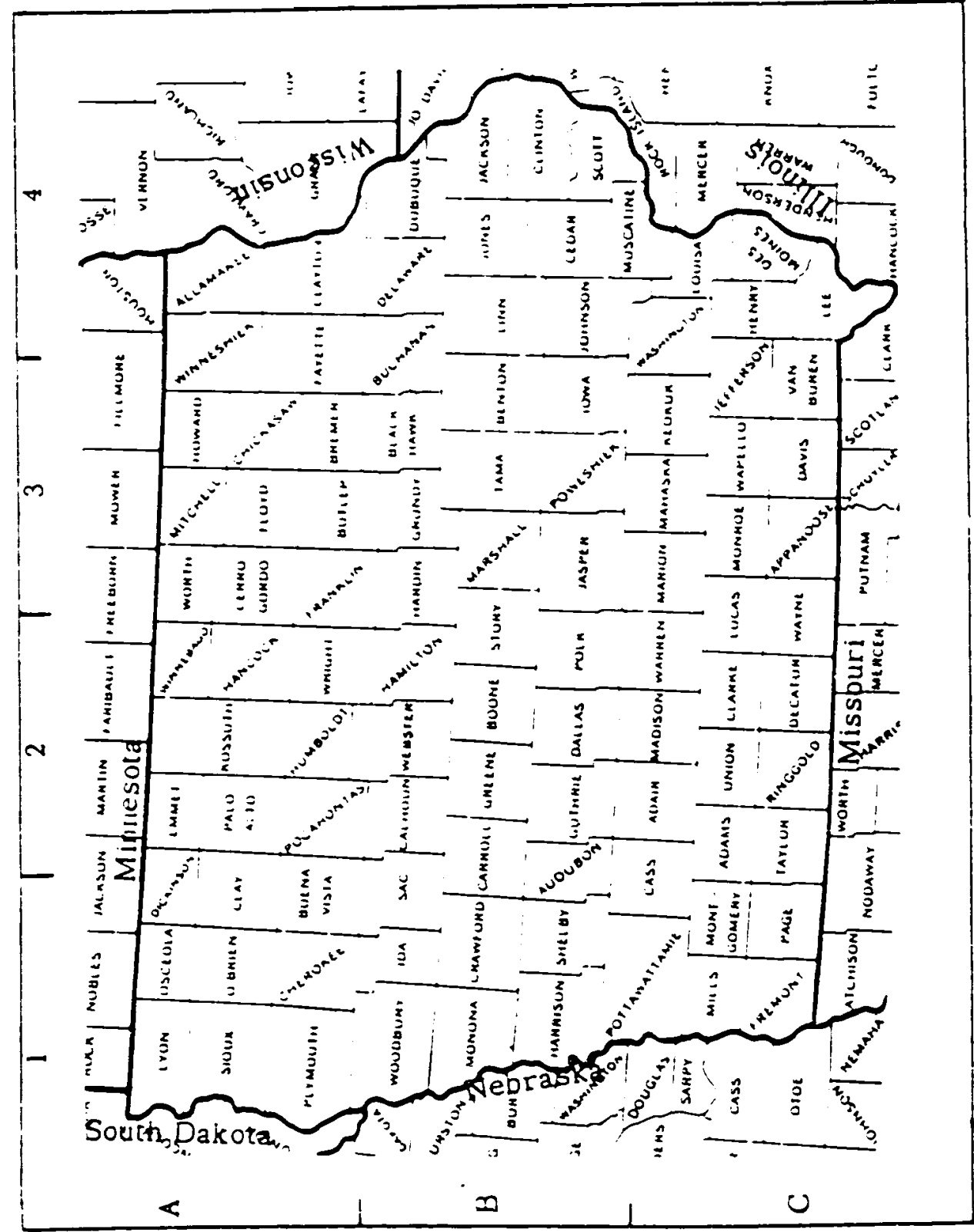


temper outbursts and bouts of depression after her husband's death.' This family defect would become a cross to Alma for many years. She does not mention whether it affected Alonzo Lafayette Baker, Jr. (hereafter referred to as "Lonnie"), bom twenty-two years after his oldest sister.

Lonnie, reared at his father's home only the first seven years of his life, inherited his father's wanderlust. His daughter one day would say of him, "If Alonzo Baker was in California, he wanted to be in Colorado; if he was in Colorado, he wanted to be in California." 2 This family characteristic would affect Alma's life in many different ways; in fact, it became the vehicle by which she was introduced to the Seventh-day Adventist Church.

On 25 November 1870, Alonzo Baker, Sr., and Stella Tucker walked into the Webster. Iowa, County Courthouse to apply for a marriage license. ${ }^{3}$ They werc married on December $15,1870 .^{4}$

Stella, who had turned eighteen the previous month, was one of thirteen children belonging to John P. Tucker and Marcia Phelps Tucker. Marcia, bom in Ohio in $1813,^{\circ}$ became a widow when her three children were

\footnotetext{
McKibbin to Parmentier.

:Janet Taylor, interview by author, 24 February 1991, Chowchilla, Calif.

'Webster County (lowa| Genealogical Society, Application ior Marriage License, 25 November 1870 , Fort Dodge, lowa.

'Webster County Marriages, Fort Dodge, Iowa, a. d.

'George W. Rine, 'Stella Antoinette Baker," obituary, Review and Heraid 88, no. 19 (11 May [911): 23 .

'Aima McKibbin. "Marcta Phelps Tucker." obituary, Review and Herald 82, ao. 46 (16 November 1905): 23 .
} 
small, and then married John Tucker, who had six of his own children.

Together they had four more, making thirteen. Stella was born of this later union, in Ohio.' John Tucker moved his family from Ashtabula, Ohio, to Webster County, Iowa, in $1855^{2}$

Marcia lived the hard life of an early pioneer woman on the frontiers of Ohio, Missouri, Iowa, and Colorado. She spun wool, wove cloth, and made candles for her large family. ${ }^{3}$ Perhaps it was the stories told to her by her father, a soldier in the Revolutionary War, or a perhaps natural love of history that drove her to walk seven miles to borrow Hume's History of England. She remembered its historical accounts and later repeated them to little Alma. ${ }^{4}$

One story Grandmother Tucker told featured her father, who owned a farm near Lake Erie during the War of 1812. Alma later related this story as she remembered it:

He often crossed the lake to sell his produce in Canada--It was Sept. 11 . 1813, the day after Perry's Victory in which Captain Perry had fought a naval battle with the British and had been victorious, that Grandfather Phelps started across the lake with a barge load of peaches. He was haled [sic] by a lookout from Perry's flag ship and was asked what he was transporting. "Peaches" was the reply.

"Will you sell your peaches to an American?" Would he? No, but he would gladly give them to an American who needed them.

\footnotetext{
McKibbin, interview, 20.

:lowa Genealogical Sociery Surname Index (Des Moines, lowa: Iowa Genealogical Society, a. d.).

'McKibbin. "Marcia Phelps Tucker.' 23.

'Alma McKibbin, Srep by Step (Mountain View, Calif.: Pacific Press Publishing Assoctation. (964). 4 .
} 
"I need them," said Perry, for it was he himself. "I need them for my sick and wounded."

So the peaches were brought on board, loaded on the deck from which sailors had just scrubbed the blood and grime, and carried down to the poor suffering soldiers below deck.'

Perhaps it was this grandfather's tather who was kidnapped by sailors

in England when he was a boy. They sold him in the New World to a tarmer.

When he gained his freedom at age 21 , he tried his hand at becoming a whaler

before he finally settled down to tarming in Otio.:

Grandfather Tucker, too, could tell stories of the early days of this

country. As a boy he lived in a cottage near Clark (Platt Rogers) Spencer, the inventor of the Spencerian system of penmanship. Spencer lived in a cottage by the banks of a river that flows from Niagara Falls. Alma later recorded the experiences her Grandfather had with the inventor:

Now Clark [Platt Rogers] Spencer could go to school all the time because his parents had a considerable amount of money. But little John Tucker was an orphan. His father and mother were dead. And a little lady that he always called Aunt Betty, had given him a home. But because he was an orphan boy, and had no money, he had to work. And while Clark Spencer was in school leaming to read and to write. little John Tucker was out in the fields working. But when work hours and school hours were over. these two little boys went down to the banks of this river. And Clark Spencer had a stick that he had whittled to a nice point. And [he] made another one for John. And he said. 'Now John. I'm going to make letters here in the sand.' He just loved to experiment, you know. And he made all those wondertul flourishes that you know are characteristic of the Spencerian system. Well that's where he practiced them. In that white sand. On the river bank.

\footnotetext{
Alma MeKibbin. Mountan View, Calif., oo Sister Mohr. Buffalo, V. Y.. 15 June 1953. in the hand of Bertha Parmentier. Deer Park. Calit.

"Mary Anne Evans. "She Knew Him. jut He Didn'? Know lt until i2 Years Later." Sunnvale Daily Standard. 31 july 1961. 9. Alma referred to ham as "great-great-grandfather."
} 
And he taught my grandpa to write Spencerian. And Grandfather [thought he] was the tirst pupil that ever wrote Spencerian, and he was taught by the author of Spencerian system.

Grandfather told Alma other stories, such as the tollowing, which she later recorded:

In 1824 he stood on the dock when General Latayette made his famous retum trip to America. When the General landed from the boat that brought him to Buffalo, all the townspeople were there to greet him. To one side stood a group of young journeyman carpenters, my grandfather one of them. The General made a speech to the people, and at one point he turned to these young men and said. "Young men, may you be as true to your country as your fathers were."

Alma later wrote regarding the influence these anecdotes had on her life, "My family was very patriotic and all these stories made a little patriot of me. I often told these stories at school and made little speeches for "my country.'"s This historical heritage would also serve her well in her later years of teaching.

\section{Early California Years}

Following their marriage, the Bakers did not remain long on their lowa farm, irue to Alonzo's unstable tendencies. He moved his tamily in the spring

Ama McKibbin. interview by James Nix and James Barnard, 30 September 1967. transenpt, Loma Linda Oral History Collection. Adventust Hentage Center. Loma Linda University. Loma Linda, Calif.. it.

McKibbin to Mohr.

Thid. 
of 1872 to Sonoma County, Califomia, near relatives-the Gorleys, Marcia's daughter by Grandfather Phelps, and Stella's half-sister. ${ }^{1}$

Alma states that the Bakers stayed "several years" in California.

Alonzo found ranch work, and apparently the family was pleased with the mild winters and the kindness of their relatives. Alma was only six months old when they arrived. She mentions that she attended the Yountville camp meeting, October 2-11, 1874, which was about two and a half years after they arrived in Califomia.:

In 1874 the Seventh-day Adventist Church, which was organized in Michigan in 1863, was just beginning in Califormia. In 1868, J. N. Loughborough and D. T. Bordeau, two eager young evangelists from the East, had arrived by boat in San Francisco. They held tent meetings all over Sonoma

\footnotetext{
'In her nirst of three versions of the California move. Alma states that when she was "not a year old" she came to stay with relatives who had adopted a new religion. She further states that these relatives were "between Petaluma and Healdsburg," which is where Fruitvale is located, the town the Gorleys lived in. The second account states she visited relatives in Califoraia when about "six months old." A third version mentions her visiting relatives, the Gorleys, who had adopted a new religion, Seventh-day Adventism, when she was a year and a balf old. It is likely these were the same relatives as in the other two acccunts. Ama's account also differs from Lonnie's (see note below) when she states that her parents were there only for a visit, but that California weather and welcoming relatives won out over lowa winters, and so they stayed "several years." This account sorresponds with the two different visits to the relatives in question. The first visit. when she was under a year, may have been when they arrived: the second, when she was older. was likely when the Bakers attended tent meetings near the Gorley's home. It is probabie, too, that Lonnie learned his version from his sister. who was dearer the source by twenty-two years. It would be more feasible for him, rather than for Alma, to get the account incorrect. It is possible, of course, that all three decounts are correct. See Alma E. McKibbin, "Alma McKibbin Remembers Elder J. N. Loughborough." Pacific Union Recorder.4 March 1968. 2; idem, interview. 2 August 1967. 20: idem. Siep by Step. 3.

:-Baker." 458, in Progressive .1/en. 5-6: McKibbin. Step by Step; idem. interview, 2 August 1967. 20-21: idem. "Alma McKibbin Remembers," 2: idem. "As I Remember," Signs of the Times 71, no. 22 (1944): 6: Harold Oliver McCumber. "Beginnings of the Seventh-day Adventist Church in Califorma* (Ph.D. diss.. University of California, 1934), 121.
} 
County, having been invited to initiate their efforts in Petaluma. When they came to Fruitvaie, a family by the name of Gorley accepted their message a few months before the Bakers' arrival.'

Elder J. N. Loughborough returned to Fruitvale during the Bakers' stay and again held meetings, personally inviting the Bakers to attend. ${ }^{2}$ Stella, who had fainted from an all-too-vivid hell-fire sermon when she was fifteen and had not been to church for years, balked at going to Elder Loughborough's meetings. Leaming of Stella's fears, Elder Loughborough immediately proved to her from the Bible that there was no hellfire in the sense she understood it, and so, much relieved, she and her husband attended the entire series of meetings. They took little Alma, who appeared very interested in Elder Loughborough's gestures and movements, imitating his voice and putting her hands up like he did. ${ }^{3}$

Some time after the meetings, the Bakers were invited to attend a camp meeting at Yountville, now well-known, at which the small constituency of the Califomia Conference was asked to contribute funds to start a Seventh-day Adventist publishing work in Califomia. Marcia, Stella and Alonzo took Alma, who was Grandmother's special charge. Alma remembered this meeting:

Because of my thin skin--you see the evidence of it--she made a little bonnet for me and she held an umbrella over me all the way there. And yet, when

\footnotetext{
McKibbin, Interview, 2 August 1967, 20.

"Tbid.: :dem. "Alma McKibbin Remembers." 2.

McKibbin, interview, 2 August 1967, 21.
} 
I arrived there my cheeks were bumed. And she went some distance away to a tarmer. got some cream and put it all over my tace. and she made a little mask for me, because she wanted to go to the meetings. Took a piece of muslin and cut eye holes in it . . and she'd sit way back in the back of the tent, while Father and Mother sat up in iront. And it was at that meeting that they gave their $\$ 1+.000$ to establish a printing establishment on this coast. Well, I was there ... when one of them laid down a little piece of yellow metal . . [Grandma] whispered in my ear, It was gold.'

Alma later wrote regarding this important occasion:

My parents had but recently come from the Middle West, where money of any kind was scarce. especially gold coin. When the people were asked to contribute to this contemplated enterprise. my tather, looking about over the assembled congregation, said to himselt: These people will not give enough to buy the ink for the tirst edition.

But the hands that went into the pockets of blue jeans or the folds of print dresses brought out not silver, but gold--gold coins and, more amazing still, unminted gold in bars and wedges. Soon thousands of dollars lay heaped upon the rostrum--the gifts of a humble people moved by a great faith.'

\section{The Move Back East}

Before any of the Bakers were able to reach a decision to become baptized members of the new church. they were suddenly called back to lowa by the illness of Grandfather Tucker.' Stella settled in Webster County again with Alma, but apparently Alonzo stayed in Iowa only long enough to get his tamily settled. He had read about gold being discovered in the Black Hills and was anxious for an adventure. The tinancial Panic of 1873 may have affected the Bakers, or it may have been hunger or tamily bills that explain why he "caught

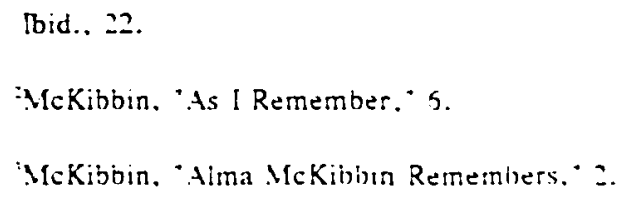


the infection of the Black Hills gold fever." 1 He had to cover much of the distance to the Dakotas on foot, suggesting the family means were meager. He withstood "threatening savages, wild beasts," ${ }^{2}$ freezing temperatures and storms, but found no gold iduring his twelve months' stay. Turning toward Iowa almost penniless, it was his misfortune to embark on a river boat that "burned to the water's edge and sank in the night at Hot Springs, on the Missouri. ${ }^{3}$ He stayed long enough to help the women and children escape the flaming vessel, finally managing to retum home to Webster County in the fall of $1877 .^{\mathrm{s}}$

The reunions when Alonzo returned home were not always happy. Alma writes of much contention in the home over religion. Apparently the social pressure of worshipping on a different day proved 100 great for Alonzo. for he soon retumed to his former skepticism.

Stella would steal the hours when he was away to teach little Alma the stories of the Bible. When Alma gave public talks in later years, she spoke of these impressionable times as her "happiest memor[ies]":6

My mother was one of the simplest, most unassuming persons. But I don't think I've forgotten a word she ever taught me. And she was so timid. But when we were alone $(.$. my tather didn't want her to teach

\footnotetext{
"Baker," in Progressive ifen, 458.

:Tbid.

'ibid.

Tayior, interview.

"-Baker." 458.

'McKibbin, Step by Step. 5.
} 
me), she'd take out her Bible and I'd sit right close to her and lean on her knee ... while she read the Bible to me. . . .

We always had our three publications: the Review, the Yourh's Instructor, and the Good Health. And you could get all three for two dollars and a half a year. If it' $d$ been more than that I' $m$ afraid we couldn't've had it, because we were very poor. But we always had it.'

Alonzo, too, had an influence on Alma during these early years in Iowa. From her earliest days, Alma remembers his calling her "the teacher," 2 telling her that's what she was to be someday, and that she must go to school.

\section{The Move to Colorado}

By the following August, the Bakers were on the move again. When they reached Alamosa, Colorado, they stopped briefly. From Alamosa to Saguache there were no main rail routes or toll roads; only a long valley that could be crossed by wagon. ${ }^{3}$ If the family traveled from Iowa by covered wagon, the trip must have taken about three months. A bank panic reached Alamosa in September of 1878 , forcing a delay in further tracking for the railroad from Alamosa north to Denver. ${ }^{4}$ A brand new town in the San Luis

\footnotetext{
McKibbin, interview, 2 August 1967, 24.

:Ama McKibbin, Mountain View, Calif., to Ethel Young, Washington, D.C., 6 February 1966, in the hand of Ethel Young, Russell, Penn.

'Saguache. Colo., Map, Orange County Archives, Santa Ana, Calif., 1879.

'Virginia McConnell Simmons. The San Luis Valley: Land of the Six-Amed Cross (Boulder. Colo.: Pruett Publishing Company, 1979), 88.
} 
Valley, Alamosa appeared almost overnight on July 10,1878 , when the Denver and Rio Grande Railroad reached the Rio Grande River.'

It is likely that gold played a part in the Bakers' move west. Lonnie later wrote that Alonzo read in a San Francisco newspaper about gold being discovered in some of the boom towns just west of the San Luis Valley in Colorado.' Gold and silver discovered in Stunner, a town about eighty miles west of Alamosa, had stimulated prospecting all over the San Luis Valley in the 1870s. Even more significant were the new silver mines in Leadville, 150 miles north of Saguache, drawing thousands of people to Colorado in the late 1870 s. Other discoveries much closer, such as in Bonanza and Kerber, followed in 1880-81 and several years thereafter. As new mines were discovered, population increased and businesses were stimulated; people left when mine activity ceased. The San Luis Valley was affected by these ups and downs. ${ }^{3}$

Whatever their reason for leaving Alamosa, the Bakers pushed on by wagon over a windy pass to Saguache, ${ }^{\star}$ a supply town for the mines in the area.

\footnotetext{
'John Lawrence, Fronner Eyewriness: Diary of John Lawrence. 1867-1908, ed. Bernice Martin. Saguache County Museum (Monte Vista, Colo.: San Luis Valley Historian. (1987)), 103.

:Baker, 6.

'Simmons, 108.

"Baker" in Progressive Men, +58.
} 


\section{Contexulual Sketch of Saguache}

Although most of Colorado was sold by Napoleon to the United States as part of the Louisiana Purchase in 1803, a section of the San Luis Valley was granted by the Mexican government. The settlers. of Spanish blood, mestizos and Indians, brought their language. names. customs and architecture to the area. Due to the valley's isolation, these settlers retained their own language and culture well into the twentieth century. When the Bakers arrived, the valley resembled rural northem New Mexico. Alonzo remarked, regarding the houses with the igloo-shaped horniros (ovens) in the back yards, that the ratio of Mexicans to white families was eight hundred to one. A passing Mexican shepherd once granted Alma's request to care for a small lamb that had fallen, which died before the next morning. Herds of cattle and sheep by day and camptires that gleamed at night were common sights sine could view trom her window:

Saguache, a small town that started in $: 87+$ at the northern end of the San Luis Valley, is called the valley's "northern gateway." The San Luis Valley is one hundred miles long and sixiy-iive miles wide. bordered by the San Juans to the west and the Sangre de Cristos to the east. Several peaks in the Sangre de Cristo range reach 14.000 feet, and these "fourteeners" create a view Alma McKibbin would miss when she left the vailey. Twenty miles north is Poncho

Taylor, interview.

-McKibbin. Step by Step. :. 
Figure 3a. The Baker Home. Saguache, Colorado. ¿. 1880.

Figure 3b. Sangre de Cristos Mountain Range and San Luis Valley as Seen from Alma McKibbin's Home. 

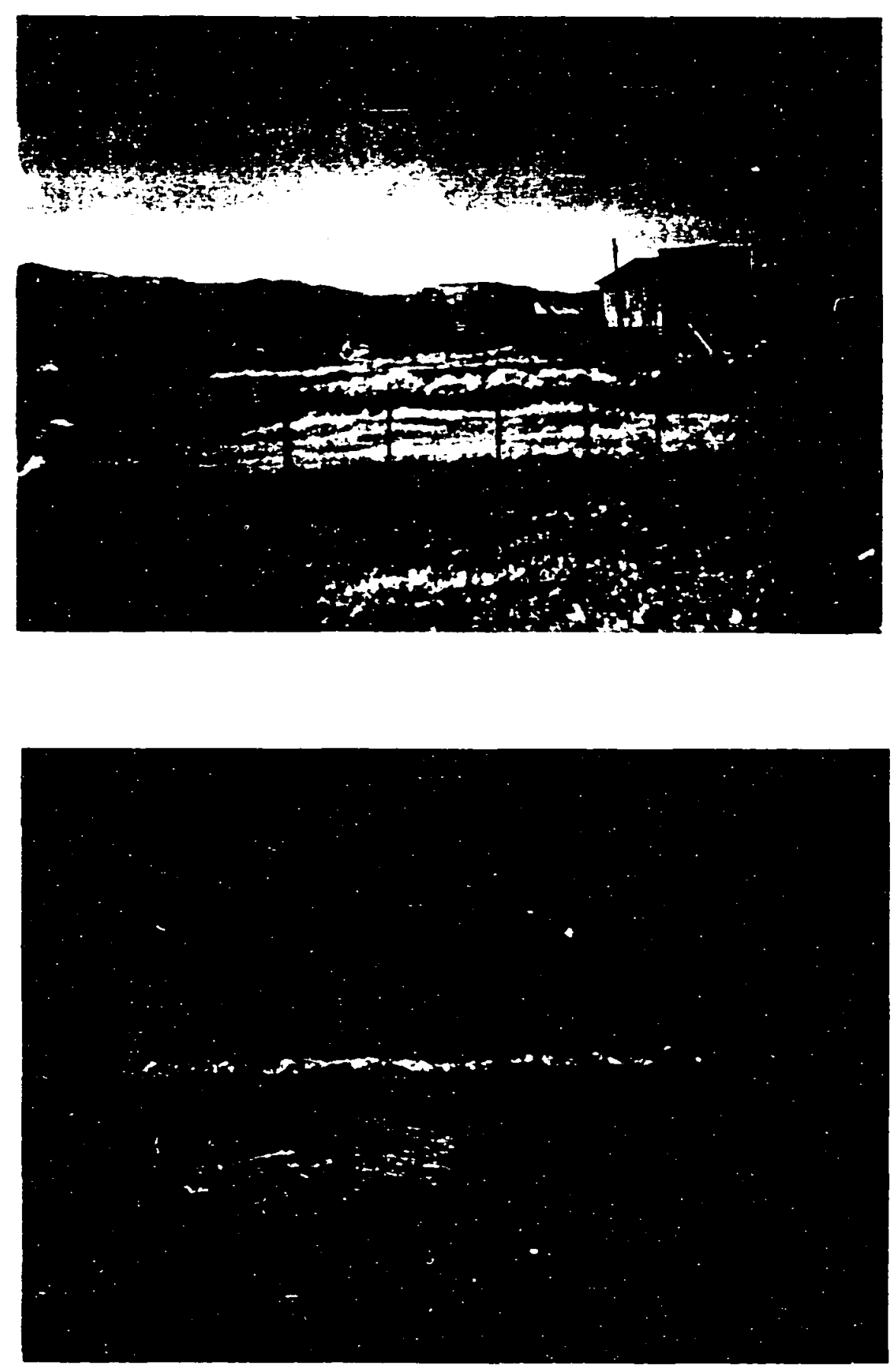
Pass, the basin area for the Rio Grande River. On the north side of the pass is the basin for the Arkansas River. To the south, the valley has no natural border. Temperatures in the region have been known to fall as low as forty degrees below zero. ${ }^{1}$ Considerable snowfall in winter accumulates in the valley, and summer temperatures are warm. ${ }^{2}$ The largest inland dunes in the United States are in the San Luis Valley, causing dust storms to build in the basin and hurl themselves against the Sangre de Cristos. In her later years, Alma told stories of wearing a scarf around her face on the way to school, to protect herself not from the weather but from the dust storms that cast rocks and sand in her face. ${ }^{3}$ It is likely the Bakers crossed these dunes on their way through the valley from Alamosa to Sagauche. an isolated trek punctuated by few homes.

By 1873 the Utes had surrendered most of their lands in the valley, ${ }^{4}$ but there were skirmishes long after Alma left for college.s The mother of Sarah Fullerton, Alma's best young Adventist friend in Saguache and seven years younger, used to hide her children in the grain bins, for Indians were thought to be child-stealers. ${ }^{5}$

\footnotetext{
Margaret Finnerty, interview by author. 9 February 1991. Saguache, Colo.

:Paul M. O'Rourke. Fronner in Transition: A History of Soushwestern Colorado. Culsural Resource Series. ao. 10 (Denver: Bureau of Land Managemeat. 1980), 6.

'Taylor, interview.

'O'Rourke, i.

'George H. Ham. M.D., interview by author. 28 February 1991, Angwin. Calif., notes in author's private collection. Berrien Springs, Mich.

'Ibid.: Lawrence, 54.
} 
Once when Chief Ouray was gone, his young bucks got restless and wanted to start a war. Chipita, the Chiet"s squaw. moved into the home of Feleciana Trujilio Fullerton and James Fullerton. Sarah's parents, where the squaw hung out a rug for a sign of protection irom Indian raids. When the Indians saw the blanket, they knew Chipita was there and left Sarah's family unharmed.

A tragedy occurred one night when Chipita's brother came to his home drunk. He threw his baby girl into the tire. Relatives who rescued the girl took her to the Fullerton home, where she was cared for and raised until she died of tuberculosis at nineteen or twenty years of age:

Railroads reached the San Juans in the 1880s, stimulating the development of supply towns such as Saguache. Cattle, staple crops, and specialized food such as sugar beets, potatoes, and fruits (apples, pears, etc.) were raised in the region during the three-month growing season: The town was known for its tine white llour. more pleasing to Americans than the coarsely ground Mexican tlour then available. ${ }^{3}$

At the time Alonzo Baker chose to settle in the valley there was much mining excitement in the San Juans. When mining activity slowed in one area. prospectors found new locations, extending lode prospecting to the entire San

Ham. interview.

:O'Rourke. it.

'Simmons, :-: 
Juan region. ${ }^{1}$ Miners often lived in tents, owning few earhly goods. Some who were fortunate enough to own homes could not afford to keep them when prices soared and mines ceased activity. Many burned their homes to avoid having to pay back taxes. ${ }^{2}$

Saloons, dances, wives smashing liquor bottles in bars that sold their husbands too much (only to have their husbands' accounts charged with the smashing bill), and mail and stage holdups were all part of the Saguache lifestyle when the Bakers moved there. Alma related, "It was a supply town for cattlemen, ranchers, and miners. The chief amusements were dancing and card playing. ${ }^{3}$

\section{The Baker Family Income}

Gold fever may parially explain why Alonzo didn't seem to hold a steady job during his Colorado years. He managed the Pumphrey ranch until 1880, when he discovered and claimed a portion of the Klondike claims as a prospector. He sold his claims in 1899 to an investment company in Cripple Creek. ${ }^{4}$ The census of 1880 lists him as a "farm laborer. ${ }^{n 5}$ and that of 1885 .

Lawrence. 65.

:Finnerty, interview.

'Alma E. McKibbin "The Light from Heaven." Signs of the Times 74. ao. II (22 August 1950): 7

"'Baker" in Progressive Men. 458.

'U.S. Bureau of the Census, 1880 Census, in Special Collections, Colorado Historical Society, Denver, Colo.. text-micronilm. 
as a tarmer. ${ }^{1}$ Alma wrote in her autobiography that he dealt in real estate and sold a large ranch, the proceeds from which financed most of her college education. A staunch Republican, he was active in county affairs. He also served as deputy sheriff in the county for eleven years, apparently known for inis efficiency, courage, and resourcefulness. ${ }^{2}$

Alma found it difficult to win her father's favor. She commented sadly that "only twice in my life did he ever express approval of anything I ever did. and I tried so hard to please. ${ }^{3}$ Partly as a result she was a rather timid chiid and apparently as an adult did not often feel adequate to the tasks she had to perform.

Nonetheless, there were things about her father that Alma admired.

She later wrote:

Father had his . . . Frank Leslie's magazine, and the papers, and tnere was always conversation in our home. Father would come in from his work in town, bring the paper and sit down and read it and comment upon it and I listened to every word. My father never forgot anything. He was absolutely periect on names and dates and events.

\footnotetext{
'United States Bureau of the Census, Firss Census of the State of Colorado: Population of Saguache Counn, Central Microtilm Unit. USA 123:11/67 (250) (Denver. Colo.: Division of State Archives and Public Records, 1885).

"Baker" in Progressive Men, 458.

'McKibbin to Parmentier.

'McKibbin, interview, 2 August 1967, 24.
} 
Figure 4a. The Baker Home, Formerly the Pumphrey Ranch.

Figure 4b. The Baptist Church Aima Attended in Saguache, c. 1883. 

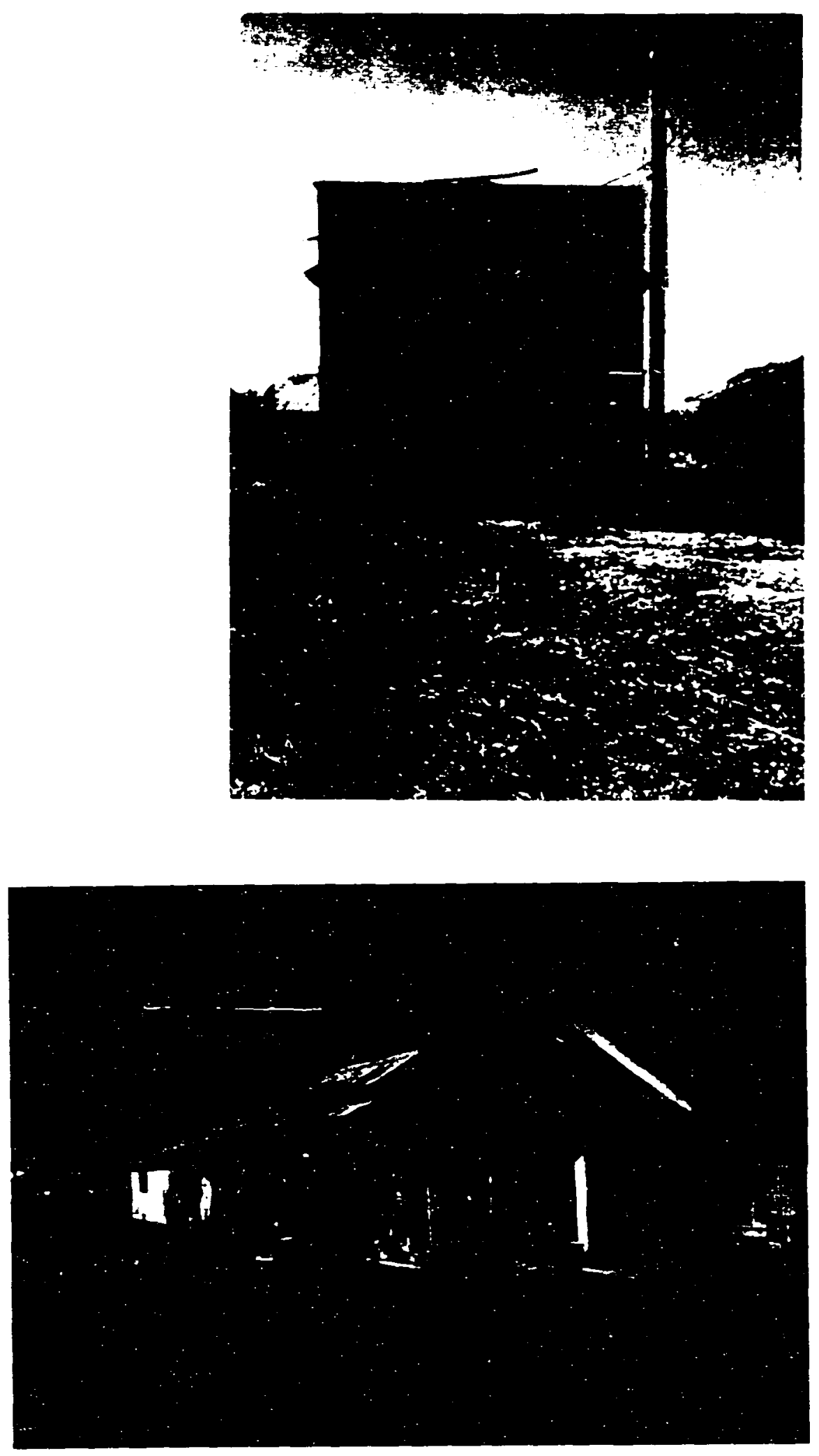


\section{Education in Rural Colorado}

In January 1877. iwo years beiore Alma started school, the Colorado Teachers' Association voted to decrease the required 120 school days per year to sixty. The group did not succeed. Colorado law provided for a uniform system of free public schooling throughout the state for residents between the ages of six and twenty-one years.

Children in small villages and on tarms attended schools in one-room schoolhouses that were built on ranches. Schools in town, if not built separately, might consist of a room in a business building. John Lawrence, one of the early settlers of Saguache, built the first schoolhouse there in 1872, a building which today houses the county museum. Before the structure was ready for school, Lawrence helped move benches over to "Santannas [sic] house as we have got his house for the winters [sic] school.": Many rural schools were built crudely and were dangerously cold in winter or unbearably hot in summer. ${ }^{3}$

A group of neighbors would hire a teacher. who usually had little more than an eighth-grade education. Quality of instruction was upgraded by attendance at teachers' institutes. If teachers could pass a qualifying

\footnotetext{
Proceedings of the Second Annual Sesston of the Colorato Teachers' tssocianon as Boslder. January 3 and 4 . 1877 (Denver: Tribune Stean Printung House. 1877 , 6. 13.

:Lawrence. 102.

'R. Freeman Butts and Lawrence A. Ciemin. A Histon: of Educanon in tmencan Culture (New York: Henry Holt and Company. :953). :-75.
} 
examination, they received a cerificate that authorized them to teach at the grade level specified. ${ }^{1}$

Alma attended a large, ungraded country school during the 1878-79 school year. Like most classrooms of the earlier part of the century, backless benches were used for seats, and Alma used a slate for writing and ciphering. By 1850 many rural classrooms had replaced benches around the central teacher's desk with desks in rows.?

It was not uncommon in rural schools of the 1870 s to have a variety of ages in one room, îrom age four or five up into the teens. By 1860 schools in urban areas, however, were divided into classes and grades in many parts of the Union. ${ }^{3}$ By contrast, Alma's school, though large and crowded, was ungraded. After the manner in which some classes were divided then, children were classified according to their ability to reproduce the contents of the textbook. The number of classes may nave been determined by the textbook series. The six McGuffey readers often generated six classes. The four books in Ray's arithmetic series generated four classes. Alma wrote of her own class standing in an ungraded classroom of the 1870s:

In ungraded schools of those days a pupil was rated according to the Reader he was studying. I could read them all; so arithmetic must be my

Simmons, $143+4$.

Barbara Finkelstein, Governing the Young (New York: Falmer Press, 1989), 21.

'Butts and Cremin. 274-75.

'Finkelstein, 43 . 
standard. . . I I was permitted to study geography, which was considered a higher subject.'

Instruction for Alma likely tollowed the practice of teachers who "placed the burden oi leaming almost entirely on the students, confining their own role to that of intellectual overseer."' Apparently teachers did not often use explanation, elaboration, or discussion as they guided their students. For example, the relationship between letters and sounds was typically not taught until after the $A B C s$ were mastered. ${ }^{3}$ In addition. Alma mentioned that she had a hard time in school "because many teachers in large ungraded schools had no time for beginners."

Typically, in the 1870 's. spelling was taught betore reading. In Webster's popular American Spelling Book, spe!ling lessons preceded the first reading lesson by one hundred pages. However, this practice waned in the latter half of the nineteenth century in many rural schools.' Mr. Goif, Alma's teacher, compelled her to learn spelling by printing words she could not read on her slate all day long. When he asked her to spell them. she could not. It

\footnotetext{
McKibbin. Step by Step. 16.

Finkelstein. 4 .

Ibid.. $+7+3$.

MeKibbin to Young.

Finkelstein. 46. 52.
} 
comes as no surprise that Alma lailed most of her first year of schooling. Mr.

Goff pronounced her the slowest child he had ever known.

Teachers' goals seemed to be for their students to acquire data from textbooks, with meaning and application subordinate to memorization.'

Leaming was considered to have occurred when students could imitate the skills or repeat the content of the text. The catechetical exercise, a common method of testing knowledge, epitomized these goals. The students were required to repeat both questions and answers. as illustrated in the following example:

Q. How is the Art of Writing acquired?

A. By learning to draw and combine six principal strokes.

Q. Is it needful to know what these strokes are?

A. Yes; for unless we get a perfect idea of each separately we can never write handsomely. ${ }^{3}$

Alma modified the $\mathrm{Q} / \mathrm{A}$ method when writing Bible Lessons for children. Instead of supplying the answer tor the children to memorize, Alma included with each question a Bible reterence. which the student could look up to ind the answer.

Discipline often involved stern methods, such as the use of the dunce cap that Alma was destined to wear during her iirst year. Such methods were in keeping with the prevalent belief that children were sintul beings. ${ }^{+}$Rewards for

\footnotetext{
McKibbin. Step by Srep. 12-i3.

:Butts and Ciemin. $2: 4$.

'Finkelstein, $\$ 4-45$.

'Ibid.
} 
carefully-learned lessons consisted of a smile or a blow with a stick, depending on the effectiveness of the recitation.

In the latter half of the nineteenth century, many females, thought to be more cost-effective and better nururers of school-age children than males, replaced male teachers,' although this was not the case for Alma's tirst teacher.

All Alma's school experiences were not negative. After missing several months of school from pneumonia and symptoms of brain tever that first year, she returned to school in the spring of 1879 . with only a tew weeks of classes remaining before vacation. Trembling, fearful at having to retum to the awful Mr. Goff. Alma was pleasantly surprised to learn that Mr. Gotf had been replaced by a new teacher. Miss Gould. Alma was immediately impressed with Miss Gould's motherly kindness. By school's end. Alma had read her primer through, blossoming under Miss Gould's nurturing personality. She later described her subsequent determination to become a teacher like Miss Gould.

Miss Gould praised everything I tried to do. She was sure no one ever learned so quickly as I did. Ify parents were pleased, and that filled my cup of joy. Vow I was willing to be a teacher. I would be a teacher like Miss Gould, only I called her .Miss Gold. She was gold--pure gold."

McKibbin. Siep by Step, 13: Butts and Cremin. 274-75.

:Finkelstein, 18.19.

'Tbid.

McKibbin. Siep by Siep. 5 (ilalics supplied). 
With her attitude about schooling and teaching more positive, Alma

"taught" her younger sisters. She later reminisced:

I used to put their little chairs side by side as in school and try to teach them even before I could read [by myself]. I would take a book or paper and pretend to read to them. They would listen to me for a few minutes then run off to play, while I continued to read to the empty chairs or ask them questions and pretend they answered.

I had to teach somehow! . . . . but when I did finally have a kind understanding teacher I learned rapidly. Reading is my most delightful pastime [sic]; next best is to tell what I have learned. ${ }^{1}$

Alma later wrote that during this period of her life she enjoyed school life, begrudged vacations, and "would have been glad to be in school all the time. ${ }^{2}$

When she was twelve, Alma moved into town to live with her grandparents in order to attend school. Apparently her parents still lived in the country, although they moved to town that same year. One wonders whether Alma's move to her grandparents' home in town may have been to preserve her irail health from the dust storms and cruel weather she encountered on her way to the country school. Her twelfth birthday was November 26, 1884 . Her plain. country dress and braided hair were noticeable in the town school. Desperate to alleviate peer taunts, Alma used some freckle-removing lotion. ${ }^{3}$

McKibbin to Young.

:McKibbin, Lighs from Heaven. 7.

McKibbin. Step by Step, 19-25 (italics supplied). 
Years later. Alma elaborated on this crucial time, which apparently aifected her

health and sapped her morale::

When I was a child, my schooimates otten greeted me with the crushing morning salute:

"Here comes Fatty, Fatty!

Turkey egg, turkey egg!

Gobble, gobble, gobble!"

This was their way of reminding me that I was fat and freckled. As if I did not know! I was not a robust child and was bashful and sensitive. The constant reminders that I was an ugly duckling atfected my health and destroyed my morale.

My grandmother, who had an understanding heart. divined my trouble: but she did not embarrass me by talking about it. Instead. she gave me a story to read. It was the !ife history of a Frenchwoman supposed to have been the ugliest woman in the world. So ugly was she that she wore a veil over her face always that she might not horrify people by the sight of her deformed features. She was of noble birth. but she never attempted to mingle in the society to which her station entitled her. Instead she devoted her life and fortunes to the help of the poor. the aiflicted. the ignorant-those as uniortunate as herself. She was greatly beloved, and when she died, more sincere mourners followed her bier to the grave than ever formed the funeral cortege of any other person. however great, in all France.

This story changed my whole outlook on life. Its impressions live with me stiil. I was about twelve years old. From that time on l ceased to worry about my appearance. Fuce and form could not be changed. but my heart and mind could. I grew less timid, and when I had courage to talk to Grandmother about it. she very wisely said. "It is not your tace, my dear, that will make you usetul and beloved. but the strength of your mind and the kindness of your heart."

The above excerpt is taken from a three-part sertes on teaching people to understand children. Many times Alma repeated that "children have troubles

\footnotetext{
McKibbin, interview. 2 August 1967 .

"MfcKibbial. Teach Me to Lnderstand--Part 3." Rewew and Herald 120 (27 May 1943): $14-15$.
} 
just as deep and heartbreaking to them as ours are to us. ${ }^{n 1}$ Her painful experiences in her early years of schooling gave her understanding and sympathy for others with like problems. This theme of understanding others often appeared in her articles for church papers.

About the spring of 1887 , Alma had another experience that would affect her career and later contributions. For a class assignment, she researched the history of Saguache, working early and late gathering oral history. She presented her written material for a Friday afternoon recitation period for the public. The editor of the town newspaper, who was present, published her composition. Alma remarked that upon reading it in the paper, her father gave her "the first unqualified praise I had ever received from him. "2 Her mother commented, Someday perhaps you will write for our [denominational] papers!'"3 Alma did write many articles for church papers, beginning as early as 1900 , about three years after her mother's prediction.

In high school Alma began to understand math. Although she had had trouble with fractions and percentages during her elementary schooling, a high-

Tbid., 15; Maryan Stirling of San Jacinto, Calif., telephone interview by author, Berrien Springs, Mich., 3 January 1990.

:McKibbin. Step by Step. 29.

'Tbid.

"McKibbin, 'What May Reasonably be Expected of Officers and Teachers-Par 1." Sabbuth School Worker 16. no. 9 (September 1900): 131-32: idem. "What May Reasonably be Expected of Officers and Teachers-Part 2." Sabbath School Worker 16. no. 10 (October 1900): 14748. 
school math teacher unlocked the mysteries. and her grades improved. She later wrote regarding this time:

We had a teacher who seemed to understand the principles of pedagogy better than most. and under his direction everyone did better work. Unknown to him or to anyone, I look nores on his methods, for was I not going to be a teacher?'

Alma's high-school years were spent at the local Saguache High

School." She graduated as valedictorian and gave the valedictory, "Never Too Old to Leam." Later she still recalled the tinal lines:

Though the hairs of our heads become as white as the snow on the peaks that surround our mountain home. we shall never be too old to learn new things nor to share them with orhers."

\section{Religion in Alma's Life}

In 1876 the Baptists built a church in Saguache. ${ }^{5}$ As soon as Aima and her family moved into town. she. her mother. and possibly her sisters attended this church and studied the Sunday school materials regularly. The nearest Seventh-day Adventist church was in Denver. so Siella telt it was wise to attend the Baptist church, apparently the only church in Saguache at the time. It was staffed by the American Baptist Publication Society. which continued to help

\footnotetext{
MoKihbin. Srep by Sien. 29 (malies sunplied).

'Lawrence, i54. The Saguache High School tima attended burned down in 1906.

MeKiobin, Step by Step. 36.

thid.

Matude Locketr. "Early Days or Saguacne." :951 TMs [photocopyl, p. 4. Colorado Historical Soctely, Denver.
} 
support missionary pastors there until about 1900. when the local congregation became self-sutficient. The church in Saguache, the mission headquarters for the entire area. enjoyed the advantage of having a missionary pastor from Boston.

Pastor M. A. Clarke and his wife were retined. cultured people who used a multitude of materials irom the East. ${ }^{\prime}$ Alma recalled an incident that described the importance of her Bible training during the early 1880s:

Every Sabbath [Saturday] morning we sat down together and studied our Sunday school lesson. Hother drilled me on memory verses so that I never failed when called on to recite them. and I was the only child in my class who could draw a map or Palestine and locate the places mentioned in the lesson. Mother was most thorough.

But one Sabbath morning mother was ill, too ill even to talk to me. I read the Youth's Instructor and some things in the Review and Herald, but I neglected the Sunday school lesson. Somehow it did not seem to occur to me that I could study it by myself.

The next morning mother was better, but still not able to be out of bed. As I was dressing for Sunday school she said to me. "Did you study your lesson yesterday?"

"No. I didn't, mother. I was kind of waiting for you, I guess, though I knew you were too sick even to talk."

"I am very sorry," she said. And when mother was "very sorry" I knew she was, for my mother was a most sincere person. She never said anything she did not mean.

After a long silence she repeated. "I am very sorry," and then she added. "My dear girl. I know it is not really your lault that you did not study your lesson, but atter this if I am too sick to study with you, I want you to study the lesson by yourself. It is really wrong, I believe. to go to Sunday school knowing nothing about the lesson. I should be ashamed to be there myself with no lesson prepared. To neglect the Bible is dishonor to God. and to go to Sunday School with no lesson is disrespect to your teacher."

There was another long silence, and then I spoke. "Do you think. mother. I had better stay at home and study my lesson and not go to Sunday school today?"

\footnotetext{
McKibbin. Step by Step, 23: Betty J. Layton. Liorary/Arthives Assistant, American Baptust Histoncal Society, American Baptust Archives Center, Valley Furge. Penn., :o author. 30 November 1990.
} 
"I will let you decide, my dear, but I really think it would be a good thing to do."

And so that bright Sunday moming while the bells were ringing and other children were trooping away to Sunday School, one little girl sat down by her mother's bed and studied the miracle of the feeding of the five thousand, and with it learned another lesson, indelibly impressed. From that day to this I have never gone to Sunday school or Sabbath school with an unprepared lesson.'

Alma benefitted from this experience the rest of her life. In subsequent years she required her students to be able to draw a map of Palestine free hand and to locate imporant places on it without the aid of an atlas. She was haunted by the memory of how she had to miss Sunday school because of her own negligence.2 She was well prepared--as always--when in her nineties, as a minuteman, she took over for a sick teacher in the Mountain View church. ${ }^{3}$

The influence of the Baptist church apparently did not extend into Alma's social life. Until she was sixteen years of age, she knew no Adventists but her mother and grandmother.' Besidesfeeling physically unattractive, she suffered exclusion from her peers because of her "queer" religion. She recalled in later years:

\footnotetext{
Alma E. McKibbin. "What We Miss When We Are Not Members of the Sabbath School-Part 2.' Sabbath School Worker 50, no. 6 (June 1934): 166 (italics supplied).

:Alma McKibbin. "What We Miss When We Are Not Members of the Sabbath SchoolPart 1." Sabbath School Worker 50, no. 5 (May 1934): 134-135.

'C. Mervyn Maxweli of Bernen Springs, Mich., telephone interview by author, 13 November 1989. Berrien Springs, Mich.: Dierdre Maxwell of Angwin, Calif., telephone interview by author. 4 March i991. Anguin. Calif.

'Alma E. McKibbin, "My Memories of Sister White," lecture at prayer meeting, Mouncain View Church. Mountain View. Calif., 15 February 1956, transcript of tape recording, Document File 967. Ellen G. White Research Center, Andrews University, Berrien Springs, Mich.
} 
I read a great deal, because I enjoyed reading, and also because I was lonely. I had no intimate triends. Ny schoolmates thought I was queer. They did not exactly avoid me. but no one sought my company. So I buried myself in books.

Alma telt ambivalent. She could not decide whether to follow the singular lifestyle of a Seventh-day Adventist. which could result in continued isolation from friends, or to compromise her beliefs in order to gain peer acceptance. She later recorded her teelings about this struggle:

There came a time... when books could no longer satisty. I wanted company--the society of others of my age. I was lifteen when the isolation could no longer be borne. I must have iriends. even if it meant to lower my standards, to give up the principles my mother had taught me. So I began to dress, to speak, and to behave like my schoolmates. I found that I could tell a tunny, silly story and set a whole roomrul laughing.

The young people began to notice me. They said I was fun. But there was still a hindrance to my full acceptance. I did not dance. I knew it would break my mother's heart. For months I considered the matter. I was terribly tempted, and I grew restless and irritable from my indecision.'

Alma learned that she could have friends if she would give up her ideals and her plans to someday be one of "Mother's people." ${ }^{3}$ One day in desperation she prayed. "Dear Lord. I can't hold out any longer by myself. Please send an Adventist to our town to help me. and lorgive me all my foolishness."

\author{
Mckiboin. Liph jrom Heaven. -. \\ :lbid. \\ MeKibbin. Siep by Siep. $: 2$. \\ 'bid.
}


Two weeks later Elders Charles P. Haskell and B. F. Stureman arrived to hold a Seventh-day Adventist evangelistic tent crusade in Saguache. Their meetings proved to be a turning point in her life. which she later described in an article:

The conviction came to me that what they taught was truth, and it was beautiful. The plan of salvation opened to my mind. I wanted to accept, but the evil one said. "You have gone too far: you cannot be forgiven, your sins are too great." Despair seized me. I sutfered agonies of remorse and regret, for I thought I was lost. I told no one. but kept on attending the meetings. I could not stay away.

At length on a Sabbath day the minister preached on the treasure hid in the field. I felt I would give all for that treasure if only I could be freed from my sins. I felt unworthy to sit with Christians, and I went away and knelt in the corner of the room and wept with a broken heart. I pleaded, "Oh, take my sins away."

Then a wondrous thing occurred. A glorious light shone upon me, and a voice that I felt was the voice of Jesus said. "I torgive you." Immediately the sense of sin left me. I was iree from condemnation, and a marvelous joy which I cannot describe filled my whole being. I arose and exclaimed. "I am torgiven. IIy sins are all taken away." Jesus saved me" ... I had been converted.

On our way home we passed the dance hall. and I wondered why I had ever wanted to go there. The spell of the world was broken.'

Aima telt she was accepted as God's inild. and her gratitude changed

her perspective. Her service for Him from now on would be a joy. In later years, many of Alma's artucles reflected the privilege, not duty, of doing whatever God asks. In 1910 she wrote an article entitled "Amusements," ${ }^{2}$ in which she applied some of the principles she had adopted at her conversion:

I was born with a love tor work: I have cultivated a love for play. Man was commanded to work: . . no less does his being demand that he

\footnotetext{
McKïbin. Light from Heaven,.

Alckibbin, Amusements, Pactic Cinon Recorder 9. no. f2 (19 May 1910): 6-8.
} 
sometimes play. . . His play should be as excellent in quality as his work. but never so great in quantity. . . .

Who would believe me if I should say that more effort, a larger experience, and greater wisdom are necessary to play properly, beneficially, than to work successfully! Yet this is what observation and experience teach me. ...

But to whom would [one] apply for instruction in the principles that should guide him in the selection of those forms of recreation that would build up his body, rest the mind, and refresh the soul,--in a word re-creare him ... ? There are a few such teachers, but they are not popular, for the world in general feels no need of direction in its play.

Desire is the only guide for the vast majority. Their rule, if they have any, seems to be this: When you work, do what is necessary and best . . . but when you play, do as you please ... . You may come from your play exhausted in body and delirious in mind, but that is of little consequence if you had a "good time."

She offered the following as one solution among many, for how to engage in appropriate play:

If we got the "fun" out of our wood chopping, our dish washing, that there is in these homely occupations; if we met one another about our daily duties with a glad and happy spirit, and tumed even embarrassing accidents into diverting incidents, we should have a grand good time all the while, a high class entertainment every hour of the day.

Alma, her mother, and her grandmother were the only ones baptized at the close of the tent meetings. ${ }^{3}$ Her best friend Sara Fullerton, along with Sara's two sisters, attended the meetings, but were nor captized. Later they became converted and kept the Sabbath the rest of their lives. ${ }^{4}$

'boid., 7.

:Tbid., 3.

'George H. Ham, M.D., Angwin. Calif., to Walter E. Macpherson, M.D., Glendale, Cal., 26 February 1990.

'See George H. Ham. M.D., Angwin. Calif., to author, 6 December 1990. Sara (Fullerton) Ham in due course named her baby girl "Alma." In 1916 Sara wrote to Alma at Pacific Union College, asking her to look after her son George, who was to enroll at the college that fall. 
A small nucleus of believers tormed as a result of the meetings, and Elder and Mrs. E. H. Gates visited them during Alma's senior year in high school. After organizing a Sabbath school at the close of the meetings, Elder and Mrs. Gates initiated Alma as superintendent and teacher of the children. The group met in the Baker sitting room. Mrs. Gates spent much time instructing Alma in her duties and helping her prepare lesson aids, and Alma took her new role seriously. The experience she gained in this Sabbath school was her first opportunity to practice real teaching, further influencing her career choice. She later wrote:

I think of my tirst Sabbath school class. It was in the primary division that I leamed to teach. Yes, this nicest of arts, this most wondertul profession, I learned in the Sabbath school! Suppose the Sabbath school had been subtracted from my life in my youth. Probably I should never have been a teacher, never pursued the vocation which was the joy of my life for many years...

When Alma was a senior, both mother and daughter caretully laid plans for the following school year. Stella wished for her daughter to go to Healdsburg College in California, a Seventh-day Adventist boarding school not many miles irom her mother's Seventh-day Adventist relatives. Stella sent for a Healdsburg College catalog, but Alonzo pressured Alma to begin teaching at once in Colorado. Alma received permission to ake the teacher's examination. although she was under age. Mother and daughter continued to lay plans. however. When Alonzo, in the real estate business at the :ime, sold a large McKibbin. "What We Miss--Part 1." :35. 
ranch and made a good commission, one of the ministers persuaded him to use the proceeds to rinance Alma through college. He agreed and accompanied her on her journey there, staying with her until she was registered and settled in the dormitory.

\section{Summary and Observations}

The "Preparation Years," as this chapter is entitled, could perhaps be dubbed the "Impression Years." The comerstone of Alma's value system laid in these early years later bore fruit in her teaching methodology and textbook writing. The recurring theme of the integration of faith and practice in the life of a Christian educator will be seen in succeeding chapters.

Alma's experience in the Baptist Sunday school and her teaching the primary grades in the little Sabbath school of believers in her home affected her methods of teaching later. such as her habit of requiring students to make maps.: Her early study habits, such as spending days gathering research for her composition on Saguache history, later stood her in good stead as she struggled to put together a Bible curriculum for the fledgling Seventh-day Adventist church school system.

Early school incidents likely affected her future teaching, writing, and values. Her familiarity with ungraded textbooks in a large, ungraded classroom may partially explain why her first Bible texts were ungraded. The method.

:McKibbin. Siep by Srep, 36.

:McKibbin, interview, 2 August 1967, 31. 
albeit modified, of using questions in her Bible lessons tollowed by Bible texts the children could look up to find answers, probably originated from the catechetical Q/A method used in most of the textbooks of her grade school days, and from Bible Readings for the Home Circle, a book of Bible readings likely found in Stella's library as well as in Alma's own.

Her experiences with poor classroom discipline in grade school, during some of the must impressionable years of her life moved Alma to strive for effective classroom management in later years.

Her early habits of thoroughness and hard work to get to the bottom of a subject, such as when she researched Saguache's history. would later be manifest in her Bible textbooks and teaching.

The pneumonia, brain tever, and other health problems, apparently precipitated by traumatic school tailures and a poor self image during Alma's early years. may well have contributed to the trailty and illness that plagued her the rest of her life.

In summary, the preparation years may partally provide a background of Alma's personal characteristics, experiences, cultural exposures, and choices on which to base the study of her tuture philosophy, teaching, and textbook writing. 


\section{CHAPTER 2 \\ COLLEGE AND MARRIAGE YEARS}

$1889-1896$

But her wealth doth mount in things that count, Her aim: to be God's child.

\section{Califomia Normal School}

Education 1889-1892

California's teacher training program was much like that in other states in the nation in the 1890s. Massachusetts, where probably the highest standards in the nation were maintained, required applicants to have completed high school or the equivalent. In California, even a grammar school diploma could be waived by examination. Perhaps because of the difference in admission requirements, Massachusetts offered only a two-year program until 1900. whereas Califomia offered a ihree-year degree for elementary teachers, and a four-year degree for high school teachers.

Many normal schools in the rest of the nation accepted entering students with two years of high school and offered programs of from one to three years in duration. In general. most teacher-training programs consisted of 
four years beyond elementary school. Many teachers stayed for a much shorter duration, such as for a few weeks at a teachers' institute.

Normal-school training was basically a high school education, a fact which made it difficult for pedagogy to be accepted into higher education. ${ }^{1}$ Normal schools did not begin offering B.A. degrees until 1905, when the Michigan State Normal College, Ypsilanti, granted the first such degree.

There were two public state normal schools in operation in California in 1889. The earliest one, the California State Normal School, San Jose, was founded in 1862 as one of the earliest state normal schools in the United States. It was begun in San Francisco and moved to San Jose in 1871. A branch in Chico was established in 1889 , and another branch became a separate institution, Califomia State Normal School, Los Angeles, in 1887. The latter school eventually became a part of the University of California. ${ }^{3}$

The primary mission of these normal schools was to provide teachers for the state's public school system. An entering student had to sign a document that she promised to teach in the public schools of California or in her state of

:Butts and Cremin, $449-50$.

-By 1890 there were ninety-two normal schools in the nation, indicative of increasing demand for better teachers. See Stuart G. Noble, A History of American Education (New York: Holt. Rinebart and Winston. 1954), 311.

'San Jose State University, Historical Sketch of the State Normal School at San Jose. California (Sacramento: State Office, J. D. Young. Supt. State Priating, 1889), 7, 9. 90; Verna A. Stadtman. The University of California. 1868-1968 (New York: McGraw-Hill Book Company, 1970), 219: Dennis L. Bitterlich, Assistant Archivist, University of California Library, Los Angeles, to author. 13 December 1990. 
residence when she was tinished with her training. ${ }^{2}$ Post-graduate diplomas were revoked if graduates broke the following obligation, which they had to sign on their diplomas:

I agree to report to the principal of the school from which I graduated at least twice per year for three years after graduation and once per year thereafter as long as I teach in the profession. When I leave the profession I report this to him, as well as the cause. Failure to do so will constitute revocation of my diploma. ${ }^{2}$

The school year at San Jose consisted of two terms, from the beginning of September to the end of January, and from beginning of February to the end of June. ${ }^{3}$ Students attended 120 lectures on me:iods, grading, discipline, and philosophy of education. They were also required to practice in the training department until critic teachers were convinced of their teaching ability, normally one class per day for three quarters of the senior year. The first ten weeks were spent in observation; the last five months in practice teaching.

The training department or school in which the student did her practice teaching was an imporant part of the students' program. The training school in

\footnotetext{
'San Jose State University, Casalogue and Circular of the California Stase Normal School, San Jose, for the School Year Ending June 27, 1890 (Sacramento: State Office. J. D. Young. Supt. State Printing, 1890), 26: Idem, Catalogue and Circular of the California State Vormal School Year Ending June 27, 1889 (Sacramento: State Office, J. D. Young, Supt. State Printing, 1889), 64; University of Califoraia, Los Angeles, Series $\$ 252$, California State Normal School. Los Angeles, Minutes of Meetings of Faculty and Administrative Committees 1883-1918. 34: idem, Los Angeles. California State Normal School Caralogue and Circular (Sacramento: State Printing. 1892), 22.

:San Jose State University, Caralogue. 1890. 27.

Ibid.. 1889, 16.

‘San Jose State University, Historical Sketch. 84, 86.
} 
San Jose consisted of nine grades on campus. The normal school in Los Angeles used four grades of the Los Angeles public schools for its student training.

These training schools offered practice opportunities for students to teach while under the supervision of a critic teacher, who lectured students on educational theory in addition to giving individual criticism and suggestions to each student. Students recorded their class observations, personal reactions, and criticisms of other student teachers were written out during the ten weeks of observation. ${ }^{1}$

Entrance requirements were the attainment of sixteen years of age, good health, moral character, and a California County Grammar School Diploma. Applicants from out of state could present their high school diploma or primary grade teaching certificate, and those not holding a diploma could meet entrance requirements by examination. In 1890 , eighty-one out of 283 applicants failed to reach the required standard score on the entrance exam. The normal school at Los Angeles updated its standards of admission in 1892 . turning away more than 50 percent of those applying for admission by examination.:

Although tuition was free, students had to pay for their board and room, finding places in the surrounding community. Boarding houses enforced

Tbid.: University of Califomia, Caralogue. 20.

University of Califiornia. Casalogue, 25. 59: idem. Minutes of Faculty Meeting, 18: Idem. Los Angeles. Series $\# 1$. Califorma State Normal School, Los Angeles, Minutes of the Board of Trustees. 35. Those who could not meet entrance requirements could, nonetheless. practice their protessions if they passed their local county exam. 
strict rules with evening study hours; boarders were required to present semimonthly reports of conduct, signed by boarding matrons.

The dress code was enforced as a training for future professional dress. The faculty discouraged "all extravagance, such as expensive dress, and costly presents, especially at graduation exercises. ${ }^{\text {I }}$

Physical exercise, calisthenics and manual training in subjects such as clay modeling, wood-working, industrial drawing, and sewing were part of the curriculum. Although school requirements encouraged physical fitness, students were discouraged from working while attending school. The faculty felt that labor along practical lines would do ari injustice to both school work and the students' health.'

The courses of instruction at the two California normal school systems are listed in tables 1 and 2 .

\section{General Course Work ${ }^{3}$}

General course work in the language arts--namely, reading, composition, rhetoric, grammar and literature--involved traditional drill and repetition, with much attention to detail and accuracy. In addition, a student's

68.

University of Califomia, Caralogue, 24; San Jose State University, Caralogue, 1890.

'San Jose State University, Casalogue, 1892, 13; idem. Historical Skerch. 85; idem. Catalogue. 1890, 27. 54-55; University of California, Catalogue. 15.

The course details that follow are from San Jose State University, Cafalogue, 1890. $31-51$. 
Table 1.--Course of Instruction, California Normal School, San Jose,

$1889-1890^{1}$

\section{Junior Year}

Professional: Educational psychology, teacher conduct, methods in numbers and geography.

Language: Grammar, word analysis, spelling, compostion, literature.

Mathematics:

Science:

Misc.:

Arithmetic, bookkeeping, methods in numbers and penmanship.

Misc.:

Botany, zoology, physiology, methods in botany and zoology.

Exercises:

Drawing, reading, geography, methods in drawing.

Music. spelling, penmanship, hyggene lectures, general news, Delsarte exercises.:

\section{Middle Year}

Professional:

Language:

Pedagogy, training school observation.

Mathematics:

Reading, thetoric, methods in reading and language.

Science:

Misc.:

Exercises:

Geometry, algebra, methods in geometry and algebra.

Human physiology, physics. methods in human physiclogy and physics.

Drawing, history, Constitution. methods in history.

Music, manual training. gereral news.

\section{Senior Year}

Professional: Pedagogy, observation in training school, teaching in training school, methods. school law. school government.

Language: Literature, grammar, methods in grammar.

Mathematics: Anthmetuc, geometry, methods in anthmetic and geometry.

Science: Chemustry, physics, physical geography, methods in chemustry and physics.

Misc.: $\quad$ Drawing, music. Delsarte. vocalization. physical exercise.

\section{Post Graduate Year}

Professional: Philosophy of education, higher methods.

Language: Latun.

Mathematics: Algebra, geometry, tngonometry.

Scieace: Geology, astronomy.

Misc.: General history, political economy, directed readings.

Exercises: Vocal music, methods in music.

San Jose State University. Camalogue. 1990. 29-30.

:Calisthenics. 
Table 2.--Course of Study, California State Normal School. Los Angeles, 1892-1893'

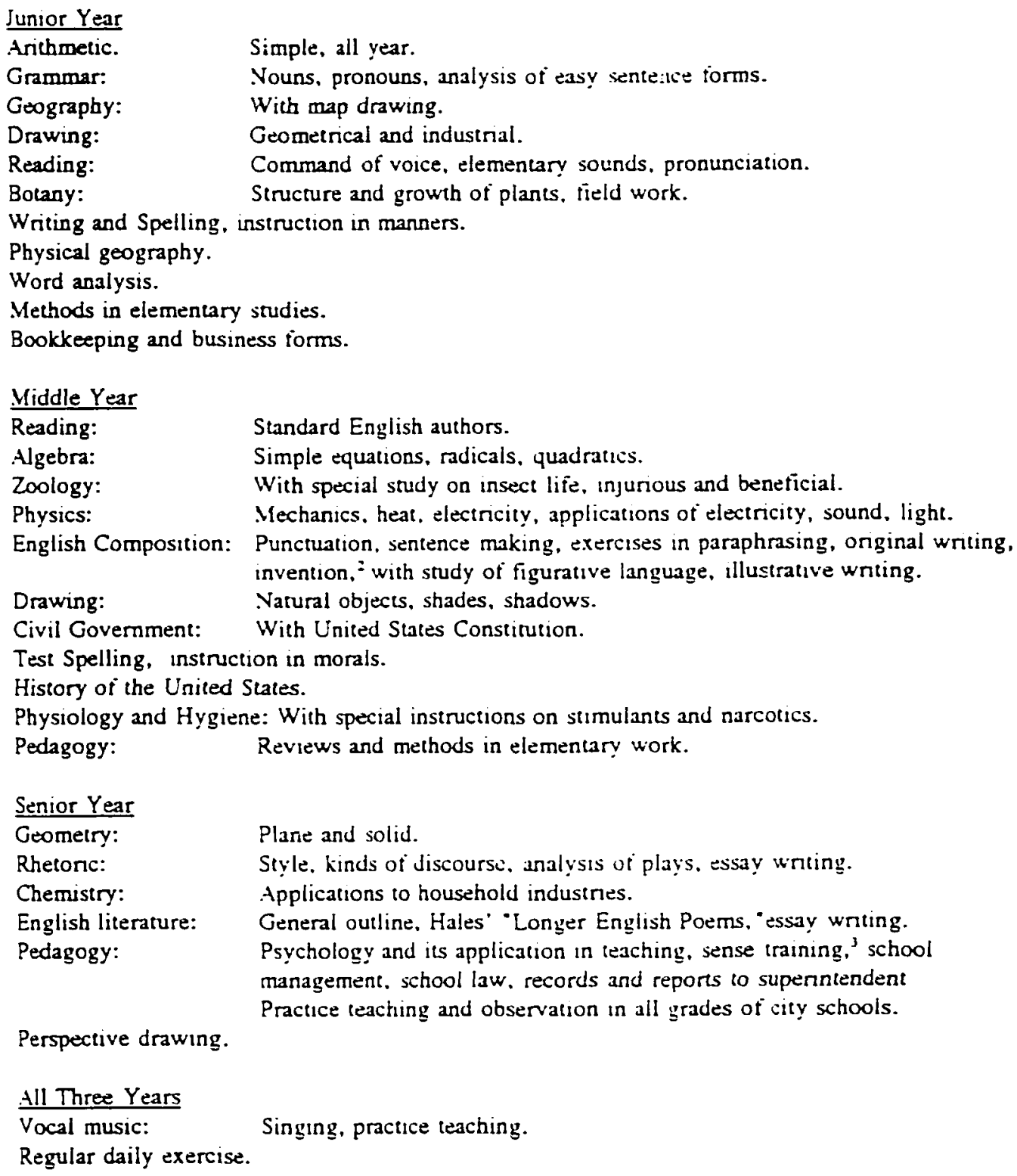

Middle Year

Reading:

Algebra:

Zoology:

Physics:

English Composition:

Drawing:

Test Spelling, instruction in morals.

History of the United States.

Physiology and Hygiene: With special instructions on stumulants and narcotics.

Pedagogy:

Reviews and methods in elementary work.

Senior Year

Geometry:

Rhetonc:

Chemistry:

English literature:

Pedagogy:

Perspective drawing.

til Three Years

Vocal music:

Regular daily exercise.

Standard English authors.

Simple equations, radicals, quadratıes.

With special study on insect life, injurious and beneficial.

Mechanics, heat, electncity, applications of electricity, sound, light.

Punctuation. sentence making, exercises in paraphrasing, onginal writing, invention," with study of figurative language, illustrative writing.

Natural objects, shades, shadows.

With United States Constitution. 
thinking was to be stimulated by the writing of many papers and the study of literature.

Science was taught with the elementary tacher in mind. Students observed nature specimens, including animais, plants and common soils. In chemistry they analyzed household substances and took field trips to the brickyard and pottery. Students constructed simple batteries, magnets, and a galvanometer and commutator for studying electricity. The teaching of physiology required the "ordinary Grammar School course in physiology" as a prerequisite. This prerequisite course taught hygienic and sanitary science, including school ventilation, drainage and sewerage, disinfection, food preparation and selection, physical training, hygienic dress, healthful habits of study, proper methods of breathing, and the physiological effects of alcohol. tobacco and narcotics.

In mathematics, students were taught the concepts of what they would teach in the elementary grades. Geometry consisted of measurement and the construction of triangles by the law of sines. For one term no textbook was used: the students were led by the question method to discover concepts regarding geometric figures, and then to demonstrate the theorems stated. Arithmetic included a basic review of what would be taught in the elementary school, with part of the course devoted to methods of teaching. In algebra, as in other subjects of the curriculum, the end was as follows:

San Jose State University, Caralogue, 1890, 35. 
The end in mind was not necessarily to cover advanced content, but to exchange . . . the more complicated examples and problems . . . for a larger number of simpler and more typical exercises, this work being considered much more valuable for the public schools, and, indeed, for any limited course in algebra."

History and geography, considered inseparable, were taught together.

It is interesting to note that when Alma developed Bible Lessons, she felt strongly about teaching Bible history with the aid of an atlas and maps. History at Califormia State Normal included both general and United States history.

Drawing class was correlated with the practical needs teachers would have in their other classes and in teaching elementary subjects. Drawing of the leaves of trees and of plants, of insects, geometrical forms, illustrations for visual aids in teaching, and mechanical drawing constituted the course work. Manual training consisted of clay modeling of previous drawings, and lessons in how to use the following tools: hammer, saw, chisel, bit and brace, drawknife, sandpaper, grindstone, and oilstone. Elementary principles of joinery included grooving, gluing, doweling, and the use of square and miter.

\section{Professional Course Work}

General methods of teaching, psychology, and methods in numbers were based on "training each mental faculty considered. school work being recognized as a means to this end." 2 Students studied "perception, attention,

:Tbid., 46.

Thid.. 40. 
memory, imagination, association, comparison, judgment, classification, generalization, inductive and deductive reasoning, and the syllogism."

This curricular idealism was offset by methods that were likely influenced by Pestalozzi, Froebel, and Herbart. Examples of these methods included observation of nature specimens, study of the local schoolroom and yard, and the use of sand maps. Geography students also used the globe as a leaming tool and made "rapid outline maps" of the lands they studied. Their textbook was Francis Parker's Merhods in Geography. According to Butts and Cremin, ${ }^{2}$ Parker took the best of Pestalozzi. Froebel, and Herbart in forming his educational views on the centrality of the child and the principles of correlation and concentration. He advocated functionalism as a criterion for school work and introduced arts and crafts, elementary science, and everyday problems in arithmetic. Language was to be taught as a tool for communication rather than as "lifeless material for study and analysis."

Pestalozzi, a "kindly old pedagogue. " influenced Seventh-day Adventist schools, for many of his ideas were in harmony with Seventh-day Adventist educational philosophy. Following is a very brief summary of his teachings:

Ibid. 'Syllogism' in be compared to today's course work in logic. More specifically, it is an argument with two premises and a concluston.

'Butts and Cremun. 383.

'Ibid.. 438 .

'Noble. 224. 
1. He brought the nurturing environment of the home into the school, leading eventually to the elimination of corporal punishment in the schools and to a more respectful attitude on the part of teachers toward their students;

2. He joined education with practical labor and duties, influencing curriculum to include vocational subjects, industrial arts, crafts, and home economics;

3. He revolutionized instruction by appealing to the senses via collected objects and specimens, thus adding to the elementary curriculum nature study, science, and methods such as the use of visual aids, and learning centers or laboratories. These methods stimulated higher levels of thinking than rote memorization and drill.

Alma McKibbin told a story that illustrates how she integrated Pestalozzian methods and principles with her evaluation of the imporance of the child. The incident, which took place in Orange County, California in 1898. involved a boy who scoured the nearby woods and fields for specimens for Alma's nature study class. Orange County had suffered a drought tor two years, and food was hard to come by. Alma's diet and likely that of most of her constituency that year consisted mainly of wainuts; they were cheap and plentiful in the area: the drought hadn't affected them, and no one could afford to eat much else.

It's really hard to teach nature study when there's no rain. He'd spend his Sundays trying to find some specimens for me. And one evening he was out so long, he was late to supper, and that was against the family rules. So his father brought him down to my boarding place and he said. "This 
boy was late to supper. Now my rule is a thrashing if they come late to a meal. But somehow, something kept me back tonight, so I brought him down, and I want you to punish him." The dear little fellow stood there, just trembling, and looking so [scared]. I said, "Do you know why Dare was late to supper?"

"No," he said, "I didn't ask for the reason. He's known the rule."

"I know the reason." And, I took little Dare's face in my hands and I said, "Dare, have you had supper yet? You run home now, and tell your mother that the teacher said that you were to have some supper, and then you go to bed. And everything will be all right in the moming." Off he went like that! And, I invited the tather into the house and gave him the thrashing! I took him in, and I said, "Do you know, I know why Dare was late. He was looking for specimens for the nature study class, to help me. I can't go out all over this country looking for plants. I'm not able to do it. And that's what he does. And it gets more difficult as the drought goes on, and that's what made him late. That little boy will never say a word for himself. And unless you encourage him, and have contidence in him, he's going to have a hard time in life. He's timid, and he'll be misunderstood." "Well," he said. "I won't punish Dare." He got up and went home."

Alma used many of the methods taught at the California normal schools. For geography, history and Bible. she had her children at Centralia construct sand maps. At Pacific Union College, where she taught many teachers and students, she was known as the "map lady." She also used the "rapid outline method," requiring her students to sketch quickly an outline of Palestine in her Bible classes.

Reading methods in the California State Normal School at San Jose included correct pronunciation, diacritical marking, reading naturally, proper breathing, voice training, comprehension, expression, vocal drill, and the ant of questioning. When Alma later wrote Bible Lessons. she inciuded vocabulary, 
pronunciation, diacritical marking, and questions with Bible texts containing the answers.

Because Alma's Bible books were largely composed of questions with Bible texts provided for the students to look up answers, it may be well to examine how the questioning method was used in her day. As mentioned in preceding paragraphs, Alma trained and taught in an era of many reforms in education. The reforms were not uniformly adopted or geographically distributed; therefore, one could find any kind or combination of traditional and contemporary methods being used in any given classroom of the later nineteenth century in this country.

One teacher, by using the catechetical method, might rigidly test how well students memorized material or rules. Other teachers might assign myriads of questions to look up at the end of the textbook chapters, and still cthers might use questions in class as a method of inquiry to stimulate student thinking. In the first two examples, the authority was either the teacher or the textbook: in the third, it lay within the student or whatever source he chose. Although Alma's textbooks used questions for students to look up, her questions were not meant to supplant teacher preparation or other complementary methods. ${ }^{2}$

Finkelstein. 44-45: Butts and Cremin, 435. 439 .

:See Church School Manual for Parents and Teachers. General Conference of Seventh-day Adventust Missionary Educational Convention. College View. Nebraska. June 29 to July 10. 1906 (Mountan View, Calif.: Pacific Press Publishing Association. 1906). 199-205. 
However, in looking up Biibie texts for answers, the student placed the Bible as the authority, rather than teacher or textbook.

Besides the use of questions, vocabulary, pronunciation, and diacritical marking, reading methods in the California State normal schools included proper breathing and voice culture. It may be that attention was given to proper breathing at the turn of the century because of the tight-fitting corsets worn by women, and possibly because of the prevalence of tuberculosis. Proper breathing was apparently important to Alma, not only because it was emphasized as a part of Adventist beliefs about healthful living, but because tuberculosis became a formidable enemy in her own life. Alma's interest may have been sparked by the messages she heard about proper breathing by Ellen $G$. White, spiritual guide and prophet of the Seventh-day Adventist Church. ${ }^{1}$

A story, told by a woman whom Alma coached for a speech at a young people's meeting, illustrates the methods of voice training and pronunciation common in the early 1900s. In 1907, when Vera Wheeler was about twelve years old, Alma had asked her to give a presentation at a convention for young people in a town near Healdsburg. When Vera hesitated, Mrs. McKibbin replied, "Don't fear, child; I'll help you." In the practice session, when Vera came to the line. "The orange blossoms are lovely this time of year," she remembered that her coach was extremely particular about inflection, intonation. and pronunciation. Teacher and student spent a great deal of time on the word,

Alma E. McKibbin. "Mrs. McKibbin and Sister White" (May 1962) TMs. 14-16. 
"Orange." It was to be pronounced, "Ah-runge," and Vera remembered much practice on that word. The talk went reasonably well, and Vera never forgot the experience or the thoroughness that went into the successful delivery of even a very simple speech. ${ }^{1}$

Healdsburg College 1889-1892

Healdsburg College, begun as a ten-grade academy with eighteen students in April, 1882, was the second Seventh-day Adventist institution of higher leaming, after Battle Creek College. Located sixty-five miles north of San Francisco, Healdsburg could be reached by train and also by ferry. People who sent advance notice were met by carriage at the train station in Healdsburg.

\section{Alma's Arrival at Healdsburg}

In the fall of 1889 , when Alma was seventeen, her father brought her to the Healdsburg College campus and stayed with her for two days, until she was established in the dormitory, promising he would pay her tuition for two years.:

At first she felt out of place:

I came from my Colorado home. . . I knew no one, but everyone was so very kind and considerate that I managed fairly well, though I was often embarrassed as I realized that my manners and speech were provincial. I

iVera Wheeler Johnson, interview by author, 2 March 1991. Angwin. Calif.

McKibbin, Step by Step, 36. 
tried to learn better forms as rapidly as possible, and was grateful that no one seemed to notice wherein I was different from native Califormians.'

Alma's provincial background betrayed her in other ways besides in

her speech:

When I came to California as a student I saw my first bathtub. I wouldn't have you think I had never had a bath, but you know we used the wash tub in those days for a bathtub. The preceptress, in the dormitory, took me to the bathroom and had to show me how to use it. Why I had never drawn water out of a tap in my life, I had never seen one! I drew water up out of the old well at home. It was such good water and I thought this was very convenient but it wasn't as good as the water at home.

I got so homesick I used to dream about it at night. ${ }^{2}$

Apparently her grades suffered as she adjusted to the different

school system, and she was tempted to leave.

I suffered secret tortures in class and elsewhere when my grades were not as good as they had been in former years, and I imagined that everybody knew it and was talking about it. I misinterpreted many things, as all sensitive persons do. I finally got into a discouraged, depressed state of mind--so discouraged that I even contemplated leaving the school and retuming to my home in Colorado. I was very homesick. The world was indeed dark. ${ }^{3}$

An understanding teacher, under God, saved me from leaving the school: and more than that. he saved my soul from shipwreck. In a philosophy class we were discussing sensitiveness, and the teacher said this: "Sensitiveness is an extreme form of selfishness .... The sensitive person often has ... a consuming desire to be well thought of, to have the approval of his fellow men."

And he added: "A sensitive person must cease to make himself the center of his life."

I went out of that classroom stunned. I, selfish! I had always abhorred selfishness, and prided myself--yes. I knew it now--prided myself on being unselfish. But "sensitiveness is an extreme form of selfishness" 1955), 7.

Alma McKibbin. "Sensitiveness," Journal of True Educarion 18, no. 1 (October

McKibbin. "Mrs. McKibbin and Sister White." 10.

McKibbin, "Senstiveness," 7. 
rang in my ears. As I thought it over, I knew that Professor Rine was right. I was always thinking of myself, worrying about what impression I was making, wondering what others thought of me, what I could do to win the approbation of others.

I resolved to overcome. It was a long, slow battle; and I did not even get a semblance of victory until I taught church school.'

Kindness shown to her during these times was long remembered.

Florence Butcher was the first young lady in Healdsburg College who spoke to me and made me welcome. I came from Colorado, a timid bashful girl, a stranger. She met me at the door of the chapel, took me to a seat and hoped I would be happy among them. ${ }^{2}$

\section{Description of the College}

Nestled in vineyard country, one of the landmarks of the college was nearby Mount Fitch. Not long after Alma arrived that she became acquainted with this familiar landmark:

I heard the students expressing themselves as very happy to be back where they could see dear old Mt. Fitch. I had come from Colorado high up amoung the Rocky Mountains. I looked up in the sky for Mount Fitch. One of the girls finally pointed out what to me was a hill, but soon that hill became Mount Fitch to me and as dear to me as to any other student. . . .

Yes, it was our playground. We thought we owned it, for our right to it was never disputed by any, but the birds, the chipmunks, and the squirrels. I wonder if those who now live on the Mount do not hear shouts and youthful laughter coming from the rocks and trees and the river below. Seems as if there must be echoes there. ${ }^{3}$

Tbid.

-Mrs. Butcher later became George W. Rine's wife. Mr. Rine and Alma Baker were the same age. See McKibbin. 'Courtesy, Talk given at Young People's Meeting, Mountain View SDA Church. Mountain View. Calif., c. 1945 AMs. p. 11. in the hand of Elna Quade. Yountville. Calif., 12: Alma E. McKibbin. Mountain View. Calif., to Fedalma Ragon. 13 October 1953. Adventist Heritage Center, Loma Linda University, Loma Linda. Calif.

'Alma E. McKibbin. 'Reminiscences." Talk at seventy-fifth anniversary of Pacific Union College. Angwin. Calif., 30 March 1957 TMs [photocopy], p. 1. Adventist Heritage Center. Pacific Union College. Angwin. Calif. 
The college was located two blocks from the business section of town on two different plots of two and nine acres each. The buildings consisted of the main college class building and the church on the two acres, and an orchard and eight buildings on the nine acres, including the student home, shop, laundry building, blacksmith shop, tank house, engine house, and bam. ${ }^{1}$

The library was comprised of 1000 volumes; the labs were "well supplied" with apparatus (with the exception of a telescope), and a room was provided with showcases to house specimens for the museum. ${ }^{2}$

The mission of the college was stated plainly in the school catalogue. As for scholarship and culture, it was assumed that graduates should compare tavorably with comparable schools.

In moral stamina--that which is of greatest worth--they ought to excel, for the development of character has been the chief aim of the school management from the beginning. We believe that true education consists in harmoniously developing all the powers of the student--mental, moral, and physical. ${ }^{3}$

Alma remembered that the college was established "to prepare workers for the cause of God. ${ }^{n 4}$

The Ninth Annual Casalogue of the Healdsburg College Consaining General Information Concerning Its Distinctive Features. Courses of Study. Rules and Regulasions. Studenis' Expenses. Esc., for the College Year Ending May 11, 1892 (Oakland, Calif.: Pacific Press Publishing Company, 1892), 22-23. Registrar's Files, Pacific Union College, Angwin. Calif.

Tbid.. 28-29.

Thid., 21.

'McKibbin, 'Reminiscences." 1. 
Apparently students were taught not to wait to be of service

until they finished school.

We were to begin at once to work for others. This did not apply to purely spiritual work alone.

Many times I have seen young men shoulder axes and go off into the lown or the country to cut up a cord of wood for a poor widow's stove, or take a hoe to help in a sick man's garden. No sick person whose needs were known ever lacked for such care as young people could give.

I recall that before I had been in the school two weeks I had $m y$ missionary assignment. This was to visit an old lady who lived alone and was nearly blind. Each Sunday afternoon I went to her home, put her house in order, wrote her letters, and read to her. I continued this for a year and a half until the poor blind eyes closed in their last long sleep. ${ }^{1}$

The above "missionary assignment" was a surprise to Alma as she heard her name read in a missionary volunteer meeting the second weekend she attended services. Alma considered the training for service the students received at Healdsburg to be one of the school's strongest assets. She recalled of her own graduating class, "We couldn't wait to get out and finish the Lord's work."

When Alma attended the college as a student in the fall of 1889 , William C. Grainger was president as well as professor of mental science and logic. Alma spoke in loving terms of this humble, fatherly man, who himself graduated from a normal college in the east. To save expenses, he was not oniy president and teacher, but also business manager, bookkeeper, and dean of the

'McKibbin, "Unchanging Values," Founders' Day Address (1946) TMs [photocopy], p. 3. Adventist Heritage Center. Pacific Union College, Angwin. Calif. (italics supplied).

McKibbin, "Vital Religion-A Retrospect" Christian Educarion 4, No. 4 (January 1913), 142-3: Donna Jacobs, interview by author, 26 February 1991. Angwin. Calif. 
college, as well as tirst elder of the church--and "father to everyone. ${ }^{n 1}$ A family atmosphere pervaded the school, much of it due to Professor Grainger.'

President Grainger bore much of the responsibility for the spiritual tone of the school. He read his Bible at moming and evening worship in the Student Home, with all present. Chapel services were also times of Bible reading and spiritual dedication. Students visited townspeople on Sunday afternoons, doing what they could for those who needed a helping hand or were interested in studying the Bible. ${ }^{3}$

Entrance requirements were a good moral character and a certificate from the student's last teacher. Entrance examinations classified students according to their grade levels and needs."

Tuition was held very low: twenty dollars per month, or one hundred eighty dollars for a nine-month year, which included board, tuition, room, lights, and washing.

The health of the students being a primary goal, they were required to have systematic exercise daily in calisthenic and gymnastic exercise, plus two hours a day in domestic or manual labor. Domestic labor consisted of cleaning

McKibbin, 'Founders' Day Address," 9 April 1954 TMs [photocopy], p. 3. Adventist Heritage Center, Pacific Union College, Angwin. Calif.

'Ibid.. I. 4: Alma E. McKibbin, interview by Walter C. Utt (1955), transcript, Adventist Heritage Center. Pacific Union College, Angwin. Calif.

'McKibbin. 'Founders' Day Address.' 3: idem. Step by Step, 37. 40.

‘Healdsburg College Caralogue, 25, 31. 
the Student Home, while manual labor for girls included printing, sewing, cooking, and general housekeeping. Students were served two meals a day, for the faculty felt two meals daily to be more healthful for study and mental improvement than three. There was an extra charge for those whose parents requested their son or daughter to have three meals.

Students were asked to observe plainness and modesty in dress, avoiding the "absurdities" of the "extreme and silly fashions of the day." They were also not to wear "useless omaments of any kind."

Alma lived in the Student Home, also referred to as North Hall, with men on the third floor, women on the second, and originally, the President himself and his family on the first. Later, the president moved into his own residence. The matrons and single faculty also lived in the Home. ${ }^{2}$ The rules governing conduct were strict. There was to be "no dating." Study hours were late afternoons, $4: 30$ to $6: 00$, and evenings $7: 00$ to $9: 00 .^{3}$ Permission was seldom given for students to go to town; students were at the college for serious work. ${ }^{+}$

Sbid.. 30.

Walter C. Utt, ed., Diogenes Lantern, 75th Anniversary ed. (Angwin, Calif.: Student Association, 1957), 45; Richard John Engel, "The History of Healdsburg College. M.A. thesis, Pacific Union College, 1957. 54: McKibbin. 'Reminiscences, 1; idem. 'Founders' Day Address," 4 .

'Pacific Union College. The Seventh Annual Casalogue of the Healdsburg College. Consaining General informasion Concerning its Distincrive Features. Courses of Srudy, Rules and Regulations. Students' Expenses, Etc., for the College Year ending Mov 29th, 1890. (Oakland. Calif.: Pacific Press Publishing Company, 1890), 24-26, 30: McKibbin. "Reminiscences. "3.

‘Engel, 55-56. 
Although rules were strict, they differed little from those in other California schools. Rules, schedules and dress standards in the Califomia Normal School and Healdsburg catalogues were similar. Alma lamented,

I despair of being able to make people of this generation understand or comprehend how different were the standards of morals and behaviour sixty and seventy years ago. The thinking of the people has entirely changed. I insist that this present world is not at all the world into which I was born and brought up.'

The curriculum of the college included four deparments: collegiate, biblical, normal and elementary. The collegiate department offered a four-year classical course (with two-year preparatory course) and a four-year scientific course. The biblical department included one course of four years; the elementary department four years; the normal, three.

\section{Teacher Training at Healdsburg 1889-1892}

Alma Baker attended Healdsburg College from 1889 io 1892 . The normal department began in 1888. Daily instruction was to be given in school management, methods of teaching, and other subjects. ${ }^{3}$ The course outline for the normal department is listed in table 3 on the next page.

McKibbin, "Founders' Day Address," 7.

:Healdsburg College Caralogue. 1890, 35.

${ }^{3} \mathrm{U}$ tt. 46. 
Table 3.--Course of Instruction for the Normal Course at Healdsburg College ${ }^{1}$

First Year

Mathematics:

English Language:

Geography:

United States History:

Natural science:

Civil Govemment:

School Tactics:

Second Year

Mathematics:

English Language:

Varural Science:

General history:

Latin:

School Management:

Methods of teaching:

Third Year

Mathematics:

Natural Science:

Mental science:

Moral Science:

English literature:

American literature:

Latin:

Theory and practuce of teaching: Fall term.

Philosophy of education: Spring term.

First Year

Mathematics:

Latin:

English Language:

Bible:

Second Year

Mathematics:

Latin:

English language:

Natural science:

School Management:

1990-1891 Cillalogue

Spring term.

\section{9-1890 Curalogue}

Arithmetic, fall and spnng terms.

Grammar, fall and spring terms.

Fall and spring ierms.

Fall and spring terms.

Physiology, fall and spring terms.

Fall term.

Spring term.

Algebra, fall and spring terms.

Composition, tall term; rhetoric, spnng term.

Varural philosophy, tall and spning terms.

Fa!! and spring terms.

First lessons. tall and spring terms.

Fall term.

Spring term.

Elements of geometry, fail term: elements of trigonometry, spring term.

Chemistry, iall term: botany, spning term.

Fall term.

Spring term.

Fall term.

Spring term.

Prose composttion. Caesar. Cicero: tall and spnng terms.

Algebra tinished, fall term: book keeping, second term.

First lessons, fall and spning terms.

Rhetonc. fall and spring terms.

Old Testament history, fall term: Vew Testament History, spnng term.

Geometry, plane: tail term only.

Caesar and grammar, tall term: Cicero and grammar, spring term.

English literature. iall and spring terms.

Physics, fall and spring terms.

Healdsburg College Catalogue. 1890. 44-45: Pacintic Lnion College. The Eighth Annual Casalogue of the Healdsburg College. Containing General Informarion Concerning its Distinctive Features, Courses of Srudy. Rules and Reguilations. Students' Erpenses. Etc. for the College Year Ending .Mory 27, 1891 (Oakland. Calif.: Pacific Press Publishing Company, 1891), 38-39: Healdsburz College Cataloque. 1992. $43-44$. 


\section{Table 3. Cunsinued}

Third Year

Mathematics:

Trigonometry, plane: fall term.

Natural science: Chemstry, fall term: botany, spnng term.

Mental science: Fail term.

Moral Science: Spnng term.

Modern History: French, fall term; English, spnng term.

Theory and practice of teaching: Fall term.

Philosophy of education: Spring term.

All Year

Two theses will be required per year.

Reading, spelling, penmanship, drawing and vocal music taught to proticiency

First Year

Mathematics:

Rhetoric:

History:

Elocution:

School Management:

Second Year

English Literature:

Logic:

Bible:

Science:

Latin:

Political Economy:

\section{1-1892 Cutralogue}

Plane Geometry, first and second terms; ingonometry. third term.

All three terms.

All three terms.

First and second terms.

Third term.

First and second terms.

Third term.

All year.

Physics and Chemustiy all year.

First term: second term optional.

Third term.

\section{Third Year}

Mental Science: First and second terms.

Moral Science: Third term.

History: All year.

Science: Zoology, first term: botany, third term.

Theory and practice of teaching: Second term.

Bible

All year.

thll Year, all courses of study

Drawing.

Vocal music: $\quad$ Thirty muntes dally elass drill for those who do not understand the principles of music.

Three theses per year for all except full time Elementary students. 


\section{General Course Work}

Although three subjects constituted a tull load for normal students in 1891-92, students were expected to carry four. In the 1890s students came and left at will, and some teacher recruits took classes only part time. ${ }^{\prime}$ In comparing textbooks between the state normal schools and Healdsburg, it appears that the Healdsburg faculty adopted the textbooks recommended by the state for all subjects except zoology, history and logic. The state textbooks in these areas may not have conformed to Adventist philosophy. Professor Goodloe H. Bell's Grammar was used Alma's first year, but thereatter discontinued.' In comparing the catalogues of the Califomia normal schools with that of the Healdsburg College the curriculums are tound to be similar. Both systems offered training to all normal students throughout their program in music, penmanship, spelling and drawing. Both offered essentially the same courses, but comparing their content is impossible. since the Healdsburg catalogues did not describe course content. In most cases, both schools used the same textbooks.

The differences between courses were more apparent in areas in which the philosophy of the teachers of state and Seventh-day Adventist schools differed. The purposes for offering manual training differed in the systems;

Healdsburg College Caralogue. 1890, 29. 31: Healdsburg College Caralogue. 1892. 30. 35: Utt. 50-5i.

:San Jose State University, Catalogue. 1390. 52: University of Californa. Catalogue. 1893, 27: Healdsburg College Caralogue. 1390. 44-45: Healdsburg College Caralogue. 1891. 3839: Healdsburg College Caralopue. 1392. +3-4t. 
curriculum planners at the state school apparently felt that if students did manual labor, the added work would connict with their study program by physically overtaxing students, and thus disabling them for serious study. The Healdsburg staff believed the opposite to be true. Theretore, manual training in the state school consisted chiefly of doing crafis, such as those mentioned previously. Manual training at Healdsburg, while it did not exclude crafts, emphasized manual labor, for the students's health and experience, and to reduce expenses.

Other differences in course work included Bible courses and practice teaching in the Sabbath school at Healdsburg, as well as a greater emphasis on character development at the Seventh-day Adventist school.

Although Healdsburg College offered only minimum course work. students were taught to be thorough in whatever they did. This principle of thoroughness applied not only to schoolwork but also to all other aspects of student life. Students took pride in keeping their Home and the grounds well groomed and beautiful. "The motto of 'Old Healdsburg' was: 'Vot How Much but How Well. ${ }^{\prime-1}$

Alma attributed the excellence of the school not to the curriculum or to the physical plant, but to the teachers.

As I stated before it was a simple school. Its curriculum was not broad. The education given was not broad but it was deep: it was thorough in what it did do. The school excelled only because of its teachers: it had great teachers.:

\footnotetext{
McKibbin. "Founders" Day Address," 5 (italics supplied).

-McKibbin. "Unchanging Values." 3
} 
Three protessors stand out in Alma's speeches, letters and aricles:

George W. Rine, teacher of English: Elder R[oderick] S[terling] Owen, Bible

instructor, and Protessor Grainger, her critic teacher. When delivering a

Founders' Day address at Pacific Union College. Healdsburg's successor

institution, Alma commented on Professor Grainger's influence at Healdsburg:

We were taught to respond cheeriully and promptly when given any duty and never to refuse. We might feel very incompetent to till a position in the Sabbath school or to take part in the Literary and Debating Society, but we did not refuse, and did our best, all our friends encouraging us.

This is a gocd habit to have, this habit of response to a call to duty. It is one that is hard to break when once it is acquired. It follows one even to old age. I am quite sure that this is why I could not refuse to speak to you today.'

English was a tavorite subject. which Alma would teach in later years

for both college and preparatory students. Alma eulogized Professor Rine, her

English teacher at Healdsburg:

Many years ago it was my privilege to teach under the direction of a leader who exemplied [sic] these principles so well that to my mind he has always been "The pertect gentleman."

He at all times showed the deepest respect for his pupils and fellow teachers that I ever saw manifested. This was evident in everything he said or did. He listened with attention to the requests of pupils and gave thoughtful consideration to the suggestions of his teachers.

I stood by his desk one day as he received an assignment of themes. I noted how carefully he held each paper. It seemed to increase in value by his very touch. I can see him yet as he placed them edge to edge so carefully and commented.

"This is John's theme. I shall be so interested to read what he has written on the subject."

"Ah. here is Mary's paper. It will be a treat. She is always original."

And so on as a miser would count his gold.

Ibid. 
And tho [sic] in the end some of these would be returned "bleeding at every vein" because of many corrections, yet the writers were made to feel that their efforts were appreciated, and they would do better next time.

He said hard things in the kindest way.

Professor Rine wrote a textbook. The Essentials of English, and at least one self-proclaimed "mediocre" student asserted that in Rine's class even "the dullest student could learn English."2

Elder R. S. Owen also took a personal interest in his students. ${ }^{3}$ It

appears that he influenced Alma's teaching of the Bible:

I could not explain how Elder Roderick Owen made the Bible to glow with heavenly light, and its truths so plain and precious that we forgot all else in our desire to acquire these treasures for ourselves. Hours spent in its study seemed but minutes, and all too short for our purposes. I have tried for years to teach the Bible as he taught it, but I sadly acknowledge that I follow afar off."

Bible was an important subject to Alma. In college she apparently studied Bible doctrines. the life of Christ, and the epistles of Paul. ${ }^{5}$ Although

McKibbin. "Courtesy," 11.

:Herber H. Dexter, T.Ms [photocopy), Adventist Heritage Center. Pacific Union College, Angwin, Calif.

'Ibid.

"McKibbin, 'Remuniscences." ב.

'Apparently no Bible was offered in the nomal cumculum when Alma Baker amved on campus at Healdsburg. However. during her second year Old and New Testament were added for first-year normal students. By her third year the requirement for second-year students had been changed to Bible Doctrnes (all year subject), while requirng third-year students to take Acts of the Apostles and Epistles of Paul. It might be reasonable to assume that she took the latter subjects her last two years of college. except that she specifically mentions having taken Bible doctrines (one year), the life of Christ (one half year), and the epistles of Paul (one halfvear). She also states that she did not study the Old Testament, whici she claims was not offered 1889-1892. The sense in which it was "not offered" could be understood to mean that Old Testameat was normally offered to the elementary students: college students were not required to iake it. The subject. Bible Doctnnes, however, was required for both elementary and for those 
she evidently did not feel deticient in Bible while in college, in later years she would admit her lack, and the lack of other teachers, from not having taken Old Testament history while there. According to Alma, she was later called by President Irwin to supply this lack by teaching Old Testament history at Pacific Union College.

\title{
Professional Course Work
}

Alma apparently studied professional subjects very similar to those included in the curriculum of the California normal schools. Catalogues of the California state schools and Healdsburg, and various pedagogy books from 1890s

\begin{abstract}
in the college who had not taken it in the elementary course. Acts and Epistles were for the academic course only, and offered in the normal course for the first time during Alma's third year. That same year, Old and New Testameat were deleted from the requirements for normal students. Whether they were both offered in the normal course is debatable. Since so many progrars changes in the normal course occurred during her three years at Healdsburg, she may have been free to "pick and choose" one of the Bible classes. One more possible explanation for the discrepancy berween the catalogue and Alma's account may be that the actual content of Old Testament history was not fully representative of what was later considered to be typical of an Old Testament survey course. Until 1903, when Mrs. Ellen White loaned Alma her manuscript for Prophets and Kings for ber church school textbook on the latter balf of the Old Testament. Alma could not find sources on that topic from Seventh-day Adventist authors. It is possible that Mrs. McKibbin may bave remembered incorrectly the classes ste took at Healdsburg. The latter explanation is unlikely in view of (1) Alma's having mentioned the lack of Old Testament background at Healdsburg on more than one occasion; (2) her high regard for accuracy, which caused her to recheck facts before repeating them for public consumption; (3) the relative Importance that her Bible background was to ber life goals and career; (4) her seemingly excellent memory and the testimony of scores of people that ber mind was "sharp" until she went into the nursing home: and finally, (5) the relative burden she csrried for years regarding the lack of training in Old Testament History for church school teackers at Healdsburg. See Healdsburg College Caralogue, 1891. 37-38: Healdsburg College Catalogue, 1892, 40: Alma E. McKibbin. Mountain View, Calif.. to Ethel Young, Washington. D. C.. 27 January 1964: idem. interview, 2 August 1967, 1-3: McKibbin, "Mrs. McKibbin and Sister White" [photocopy], p. 24, talk given at Mountain View Seventh-day Adventist Church, Mountain View, Calif., in the hand of Paul Ricchiuti, Nampa, Idaho: idem, A Story of the Origin of Bible Lessons for the Church Schoois." Journal of True Educasion 27, по. 3 (January-February 1965): 19.
\end{abstract}

McKibbin to Young, 27 January 1964. 
reveal that the normal curriculum consisted of classroom management, theory and methods of teaching, philosophy of education, observation and student teaching.

Most of the pedagogy books Alma used at Healdsburg were influenced by Pestalozzian methods, as described above in the section under California normal school training.

No training school is mentioned in the Healdsburg catalogues from 1889 to 1892 , but Alma wrote in later years that there was always an elementary school connected with Healdsburg College, and that Mrs. Grainger taught the elementary grades. She adds that it was not a church school in the accepted sense; that is, it was not established or directed by the local church but by the college, and generally followed the public school course of study and used public school textbooks. Mrs. Grainger, however, taught the Sabbath school lesson and had the children commit Bible passages to memory.' It is possible that Alma did some of her practice teaching in this school; however, if she did, she is silent about having done so. She did write, however, about the Sabbath school playing an important role in her practice teaching.

\section{Practice Teaching in the Sabbath School}

Apparently the needs of the church were so great, and perhaps, too, the training was deemed so important. that students were officially or unofficially

Alma E. McKibbin. Educational History [1957],' AMs [photocopy], p. 2. Adventist Heritage Center, La Sierra College, Riverside. Calif. 
employed in varying capacities in the church as part of their education. Thus, students were "workers" before they left school, carrying a sense of responsibility for the church's needs into their succeeding lives.

Besides being trained for service in various lines of work in a church with burgeoning growth needs, students caught the mind-set of service from their teachers, who worked in the various departments of the church. Professors Rine and Owen conducted tent meetings during the summers, during which ministerial students would work with their teachers. ${ }^{1}$ W. C. Grainger was first elder at the Healdsburg Church, and Elder Owen held a position as Conference Sabbath School Superintendent, along with their school responsibilities.

Alma was groomed for service in the Sabbath school in later years by the training she received at the Healdsburg Sabbath school. Evidently that Sabbath school was a pervading influence on campus:

From the first day of school to the last President Grainger impressed upon every one the importance of the Sabbath School, the one school in which every member of the church engages in regular, systematic Bible study. Most of the students were definitely preparing for the ministry or other Bible teaching. He called the Sabbarh School the practice school of the Normal Department. "Here," he said, "you will learn how to teach the Bible to all ages. Begin with the children and advance division by division until you can teach adults."

One was not long a student before he was asked to take a position in the Sabbath school. It was an unwritten rule that no one was to refuse any task assigned him, and also that help would be provided according to our need.

President Grainger was the critic teacher. Those soft black eyes saw everything, but they were kind, because his heart was kind. He was a most understanding observer of a beginner's efforts. Each student teacher or

Dexter, 1 . 
leader knew that he would be near sometime during the session and that in the following week he could go to him for his criticisms and suggestions, all so kindly given. The student went away feeling that President Grainger was more anxious that he succeed than he was himself. But that can be said of all good teachers.'

Calling herself "an inexperienced girl," Alma writes of the President giving "a whole hour ... teaching an inexperienced girl how to develop a

Sabbath School lesson so that she could teach it successiully." ${ }^{2}$

The Sabbath school was evidently adapted to the needs of preservice teachers:

Here the work of each member, especially student members, was carefully planned. Systematic instruction was given in all departments of Sabbath-school work, with special attention to the art of teaching. The principles underlying this art were as carefully taught as in our present normal-training departments, and as carefully supervised. Each reviewer expected the superintendent to visit his department during the sessions of the teachers' meeting, and also during the regular Sabbath-school session. We student-teachers should have telt that something was surely wrong if Protessor [Grainger] had not visited us tor a tew minutes each Sabbath to note our work as instructors. This caretul, painstaking supervision has had its results. The students of those days who now bear responsibilities in the cause of God are ever and always intelligent and devoted workers in the Sabbath-school. ${ }^{3}$

During her senior year A!ma was leader of the Primary Department in the Healdsburg Sabbath school. The Sabbath school was controlled by the Califomia Conference of Seventh-day Adventists, and college personnel were participants, office holders, and members. That same year, 1891-92, Alma

\footnotetext{
MfcKibbin. "Founders Day Address." $4-5$ (italics supplied).

ibid.

Mckibbin. "Vital Religıon." 142.
} 
prepared to be a "general Sabbath School worker." likely in the adult division.

Another experience that contributed to Alma's practice teaching, as well as increased her empathy for others, occurred as a result of misfortune. At the close of her second year, her father wrote that he would not be able to pay her tuition for the next year. Alma wrote back, asking whether she might not stay one more year and finish the normal course. His reply indicater that he felt she had had enough education and should come home and teach in a public school. ${ }^{2}$

Her closest friend and roommate, Clara Couey, had an idea. Alma related what happened:

What was I to do? I told my troubles to Clara. She then revealed to me that she had told Elder Owen she wanted to take some Bible classes the next year, but could not do so and carry full work as secretary.

Now she suggested that I do half her work and she would divide her salary, and sn it was arranged. ${ }^{3}$

The arrangement provided much experience for Alma in a new vocation in the Conference Sabbath School Department.

But oh! the good times we had together in our room. We each devoted four hours to the secretarial work. There were quite a number of isolated members who studied alone on the Sabbath. Some were women with children whose husbands were not Sabbath keepers. These mothers tried to conduct a little Sabbath School in their own homes. This was the Home Department.

"McKibbin. "My Beloved Friend, Clara Couey Burg," [n. d.] TMs [photocopy], p. 3. paper wntien in remembrance of Clara Couey Burg, in the hand of Verda Burg Becraft. Shingletown. Calif.

:Tbid., 40: idem, "My Beloved Friend." 1.

McKibbin. 'M!y Beloved Friend, 2. 
Clara appointed me to have charge of this deparment. I wrote a personal letter to each one each quarter full oi suggestions.

\section{Ellen $G$. White}

Perhaps no other influence was greater on Alma during her life time than her acquaintance with Mrs. Ellen G. White, prophet and guide of the Seventh-day Adventist Church. During the years in Saguache Alma had read the writings of this spiritual leader in church publications and had also leamed about Mrs. White from her mother.

When Alma arrived at Healdsburg she discovered she was the only student at the college who had never seen Mrs. White. She described her anticipation: "Ellen G. White was my spiritual heroine, and I could hardly wait to see her." 2 Mrs. White was out of town, and it was a long time before Alma saw her. Curiosity led to walks past her home $e^{j}$ and excuses to deliver messages, but tinally, the first opportunity for Alma to hear Mrs. White speak came on September 21, 1889 at the Healúsburg Church.

Ibid.

McKibbin. "Sister White Was My Friend." Part 1, The Youth's lisstructor 112 (2 June 1964): 3 .

'Mrs. White's home in Healdsburg was the same one she rented to Alma in later vears.

"McKibbin. "Sister White Was .Ify Friend." Part 1. j; Ellen G. White. MS 21. 1889. Ellen G. White Research Center. Andrews University, Bernen Spnngs, Mich.: "Ellen G. White. Her Friends and Fellow-Workers: Mrs. Alma McKibben " [sic] (1970) TMs [photocopy], 19691970 Spiritual Emphasts Week Matenals. Document File 967. Ellen G. White Research Center. Andrews Universtty, Bemen Spnngs, Mich. 
The influence of the sermon Alma heard that September Sabbath morning was so profound that Alma could still quote its contents into her nineties. Perhaps what impressed her most was Mrs. White's concern for the understanding and nurturing of the young people of the church. Although Alma studied pedagogy at Healdsburg, she claimed that "the most precious lesson and the best pedagogy that I ever learned I learned from her. ${ }^{n 1}$

I learned then this, first of all: she [Mrs. White] said, "You must study to understand your children. The children are very important. That little fellow that is so restless is a very important person. . . Watch what he does when he is alone: study the expression of his face. Don't forget to look in his eyes."

You know I have looked into the eyes of 1300 students in my lifetime, no two of them alike, but the lesson she taught me that has been of the very greatest advantage to me as a teacher-it is the eye. It is the eye that tells the story. . . . She said, "Parents and teachers, don't ever be discouraged. . . . It may seem today that they are not heeding, that they don't understand, that they are not listening, but they are. ${ }^{2}$

Alma listened to Mrs. White's sermons for about twenty-tive years, often hearing the theme of the importance of understanding and educating children, and she recalled much of the content of those sermons for future audiences. She was impressed that Mrs. White preached for parents and teachers to love, understand, and educate children.

Alma's first impression of Mrs. White as a person was developed during these college years. The simple fumishings of the church leader's home.

McKibbin. "Mrs. McKibbin and Sister White." 13.

Thid. (italics supplied). 
ner frugality and kind demeanor, and the hardships she endured were memories

Alma passed on to later generations who revered but never saw the prophet.

\section{Alma's Private Life at \\ Healdsburg College}

In spite of her shyness, Alma made many lasting friendships. She

chose Clara Couey to be her closest friend.

I was immediately drawn to her. She was a very quiet girl, but so perfect in her life as a Christian that I felt her intluence for good at once. We became tast friends. This was the school year 1890-1891.'

Alma related an experience during her senior year that illustrates what kind of friend Clara was.

Our preceptress did not understand girls at all. She had worked in an insane asylum. She knew how to put a poor afflicted woman in a strait jacket, but she did not know how to manage girls.

One evening all the girls poured into our room very disturbed. They declared the preceptress was arbitrary, unjust and really they could not stand it any longer.

I was shocked beyond words. Such a thing as rebellion against a teacher or helper had never been known before. Somehow I knew it was ail wrong but what to say or do I did not know.

And then in this crisis, dear, quiet Clara stood up in that room and began to talk. How I wish I had her words. They were so wise, so true... . The room became very quiet. . .

And then she said. "Let us pray about it" . . . We were all weeping. When we rose irom our knees, not another word was said. We kissed one another goodnight and the girls went away and not another word was said about our preceptress.

Silently I prayed and thanked God for dear Clara who had saved the girls from making a great mistake. O how I loved and admired her:"

McKibbin, "My Beloved Friend." 1.

-Tbid.. 4 . 
Their friendship continued until Clara passed away, but Alma looked forward to its continuation in the New Earth. ${ }^{1}$

Another friendship of Alma's while she was in college was with Edwin McKibbin.' Edwin called on her regularly, although there is some question as to how, with such strict regulations for separation of the sexes. ${ }^{3}$ Whether he had more privileges as a faculty member is doubtful. He asked for her hand in marriage, but she felt an obligation to her father, who had asked her to help her sisters after she finished college. Alma asked Edwin to wait, and he agreed.

During the summers most students worked to defray college expenses, many by selling books for the church. Although it is uncertain what Alma did during the summer of 1890 , she does mention attending the Bible Training School in Oakland during the summer of 1891 under the direction of Georgia Burrus. President Grainger thought the experience would provide background and training for her secretarial work in the Conference Sabbath school with Clara Couey the following year. At Oakland she learned many principles of soul winning. Besides being a student at Oakland, she was asked to substitute for an

itbid., 4.

'He came to Healdsburg for the 1885-86 school year at approximately twenty years of age. Athough he was not listed in the 1886-87 Healdsburg College Caralogue, his name appears again during the years 1888 through 1891 as a student. After graduating in 1891 from the Normal Department he was listed as assistant professor in mathematics, history, and English language in the 1892 and 1893 Healdsburg catalogues, as well as in the California Conference Year Book for 1893-94. It is likely that Alma studied history under him her senior year. See Healdsburg College Catalogues, 1886-1893; Yearbook of the California Conference of Seventhday Advensisss (Oakland. Calif.: Pacific Press Publishing Association. 1894), 63.

55.

'Edith Meikle, interview by author, 19-22 February 1991, Los Gatos. Calif.: Engel, 
instructor with ill health. A reader was assigned as her assistant. Alma writes that she had a part in helping this assistant to become a Sabbath keeper.'

However, that same summer, when the training school term was over, Alma canvassed for book and magazine subscriptions for six weeks in Berkeley. The weather became so hot that some elderly people died of the heat. Alma herself succumbed to the extreme temperatures, suffering a partial sunstroke. The incident was a foreboding of evil to come."

A persistent pain in her spine after the heat stroke shadowed Alma's senior year, steadily growing worse, until on January 14 an explosion in chemistry lab precipitated convulsions. She was diagnosed as having spinal meningitis and given up to die before morning. That night as Alma's body lay writhing, guarded by loving attendants, the faculty and students prayed for her. Sensing imminent death, her mind was tortured by the thought of urgent duties left undone, perhaps magnified by her suffering, and, according to her own words, by the evil one. As she cried out in her distress for forgiveness, she saw an angel wrap her in a beautiful white robe, which she understood to be the robe of Christ's righteousness. Peace and rest followed: the pain eased, and she lived. $^{3}$

McKibbin. Step by Step, 40.

Tbid., 41: idem. 'My Beloved Friend, 3.

'McKibbin. Step by Step. 45-46; Althea G. Taylor. Maitland, N.S.W., Australia, to author. 22 February 1991. 
Characteristically, when her tather was informed of her illness, he wrote to the college president: "I took a perfectly well girl to you. If she is sick it is because of the way you Adventists live. So take care of her. ${ }^{.1}$

Alma never again entered a classroom as a student. Professor Grainger kept her in his living room in his own home for several months, but she felt she was imposing on him. When the doctor held out no hope of recovery, she asked to be taken to the county poorhouse. This delicate matter was resolved by a gallant gesture trom Edwin McKibbin, who offered to marry Alma to keep her from the poorhouse. To the doctor who held out no hope, he stated, "Well, you told me I didn't do such a bad job with my mother when she was ill." Edwin and Alma would be married the day after graduation, and he would nurse her to health. Alma felt that such a one-sided contract would be selfish: she would not have accepted, were it not for the gentle persuasion of her friend, Clara Couey:

Missing graduation exercises. one of the high points of the year. depressed Alma. As she thought of her own disappointment at not graduating, she realized how much she would also disappoint her tather and mother. These thoughts weakened her faith, and she felt a sudden urge to scream. She had spent long nights waiting for daylight. and these too. had taken their toll on her mental health. Because of the doctor's remarks. she knew her future held only

McKibbin. Step by Step. $45-46$.

ifbid.. 47-48: Merkle, interview. 
death. In looking forward to the New Earth she remembered that there would be no night in heaven, and made plans tor the song, "No Night There," to be sung at her funeral.' She felt God encouraged her in this trying time:

Then the words of Job seemed spoken to me out of the darkness. "What? shall we receive good at the hand of God, and shall we not receive evil?" Poor Job! He lost everything. Even his wife and his friends added to his grief. Yet he held fast his faith in God.

All at once I felt ashamed that I had doubted the goodness of God. I prayed that $\mathrm{He}$ would give me a spirit of cheerful submission to His will. I began to plan to be a cheerful, happy invalid, and resolved that Edwin should remember only my smiles, not my tears.

Then a wondrous thing occurred. The room so dark was filled with a beautiful pearly light, and I heard music so soft and beautiful that it socthed my soul. It was as the sound of a harp played by angel hands.

When Mrs. Grainger came home she ... said my face was still alight, and a peace that she could feel filled the room.:

Twice during her illness she nad sensed the presence of an angel. The first time she was not able to be rational. and it appeared that the angel was sent in mercy to her pain-racked body. The second time she was depressed and tempted to lose faith in God for not being able to graduate, but then chose to entertain more hopeful thoughts that were not in harmony with her feelings. As at her conversion when she asked God to forgive her. she resisted Satan's attempts to discourage her. To Alma, it seemed that God rewarded her willingness to resist depression by sending a special light and peace.

A pleasant surprise at the wedding was President Grainger's presentation of her diploma just betore the ceremony. The board saw fit to grant

Ruth Bowen, interview by author. 6 March 1991. Los Gatos. Calif. (This story was told by Mrs. McKibbin at worship in the giris' dormutory, Lodi Academy, Lodi, Calif.. ¿. i924).

McKibbin. Srep by Srep, 49. 
it on the basis of her extracurricular activities. especially her Sabbath school work for the Conference." After the simple wedding, Alma was moved to Edwin's quarters in his sister's home two blocks away.

Tragedy afflicted the newlyweds. Only months after the wedding, while Alma was still bedridden. Edwin was diagnosed as having advanced tuberculosis. Hearing the sad news, a triend, who had spent the previous night praying for the newlyweds, invited Alma, though still bedridden, to a nearby prayer meeting that evening. At the close of the meeting, this same friend invited others to join with her in a special season of prayer for her. After prayer, she took Alma by the hand and said, "Sister McKibbin, in the name of Jesus of Nazareth, rise up and walk." Alma was apparently healed.'

The young couple had many happy times together. Edwin worked in evangelistic tent meetings with other ministerial students in Benicia, Califormia, one summer. where the workers lived in tents. During the meetings, the students' wives helped, and iriendships resuited. One of the student workers' wives was expecting a baby, which was bom at night in her tent. As soon as Alma heard the news, she went to the tent. where the baby was in bed with its mother. Alma called, pulled back the tent tlap and asked if she might see the

Ibid.. 52: Meikle, intervew.

-Alckibbin. Step by Siep. 54. 
baby. The mother drew back the little blanket and said, "With your permission, I'd like to name her 'Alma.'"'

"We were poor all week long, but the richest on Sabbath," Edwin used to say. ' Alma never ceased to marvel at his ability to shed his cares and burdens on the Sabbath day and be truly free irom them. ${ }^{3}$

As Edwin's health worsened and medical bills mounted, Alma hitched her horse to a wagon and headed for town to trade or sell her own butter and eggs. Often she was separated from her husband. either by being forced to take jobs in the city, where she had to board. or by his absence while at the sanitarium. He would at various times get better, raising their hopes. Henry Johnson, with whom the McKibbins stayed in the San Pasqual Valley off and on during 1893-1896. wrote news of Edwin in the 1893 Escondido Times:

"Professor McKibbin started yesterday morning for his home in the northern part of the state, considerably improved in health." Just how long he taught is

\section{Calif.}

Meikle, interview; Eleanor Baker, interview by author. 24 February 1991. Modesto.

Meikle. interview.

'Bob Jacobs, interview by author. Z6 February 1991, Angwin, Calif.

Meikle. interview.

'Escondido Times. 26 January 1993. Ruth Collings, intervew by author. 15 March 1991. Ms. Collings explained that Henry Johnson was corresponding reporter for the local news from San Pascual Valley. 
uncerain, but during the 1892-93 school year, Alma taught his classes at Heaidsburg when he was ill.'

In 1893 baby Lorin was born to the young couple. A sickly boy from birth, he brought his parents muted joy. Shortly after Lorin's birth, Edwin was relieved of his duties as teacher at Healdsburg, for the faculty felt that a tubercular teacher might endanger the health of the students. Another tragedy then added to the parents' grief when Lorin died of his father's malady at only eleven months. This loss stayed with Alma the rest of her life, perhaps affecting her deep love for children more than any other experience.

By the grave of my only child I promised the Lord that henceforth all the children of my people should be my children. For them I would spend and be spent as if they were my very own--the children of my schools were mine, not for a day, nor a year, but so long as life shall last. ${ }^{2}$

Only the peace of knowing Lorin was released from suffering and that she would see him again in heaven allowed Alma to accept his death in $1894 .^{3}$

Death followed for Edwin on November 4, 1896. Sensing its imminence, he had built his own pine coffin, which was carried by wagon to the small cemetery on an Indian knoll in the San Pasqual Valley. Alma and the

General Conference of Seventh-day Adventists. "Sustentation Fund Application for Alma E. McKibbin. 22 September 1930 D; McKibbin. Step by Step, 55.

"Alma E. McKibbin. "The Joy and Reward of the Christian Teacher," address given at Teachers' Instimte. San Jose. Calif., I December 1942, TMs p. 2, in the hand of Else Nelson. Grand Terrace. Calif.

McKibbin. 'Sister White Was My Friend. Part 1.' 4: Baker. 37. 
driver comprised most of the moumers, and it was she who preached his iuneral sermon.

The Johnsons, friends in San Pasqual, kindly invited Alma to live with them after Edwin's death. While living there, she experienced much grief and sickness. In January 1897 with a weak body and a sore heart, she went to Saguache to visit her mother.

Weary and lonely I was trying to reach a street car line in the suburbs of the city [San Diego] on my way to the station. I struggled along in the gathering twilight with a heavy suit case. I was still a third of a block from the car line when my strength gave out and I was obliged to stop and sit down on my satchel with no power to go on though I saw my car approaching. There seemed nothing to do but to let it pass and wait for the next in the hope that I should recover my strength in the mean time.

What was my astonishment to see the car stop and the conductor get down and come toward me. With a smile he said, "Did you wish to take this car?"

"Yes, I did, but I gave out before I reached the street comer and was obliged to sit down to rest."

"Let me help you. You might miss your train if you wait for another. and you would be very cold I fear."

So saying he took my arm and helped me along till we reached the street car, when as my knees buckled under me, he iiterally lifted me on to the steps and to a seat inside. When we reached the station, he beckoned a red cap and asked him to see that I got sately aboard my train.'

Under these conditions, with Alma depressed in body and spirit, God would call her to the church school work.

Bessie Martella, Hantord. Calif., to author. It January 1991.

:McKibbin. Courtesy, 5-7. 


\section{Summary and Observations}

This chapter continues the antecedents that would bear init in Alma's teaching and writing years.

The educational milieu of Alma's day prepared the soil into which the seed of the church school fell. The pedagogical methods of her times-geography correlated with history, map study, the object method, the art of questioning, and thoroughness in drill and research--she would employ as she developed her own teaching style, methods, and content for the pioneer church school work in Califormia. These pedagogical methods, supported by the biblically-based philosophy she learned at Healdsburg and from Mrs. Ellen G. White, were the underpinnings of Alma's own philosophy and practice.

Alma esteemed her education at Healdsburg as the highest she could have received in the land. On the other hand, it must be acknowledged that her college years were not adequate preparation tor the church school work she was called to do. The college was still in the process of integrating its philosophical base with its curriculum in 1889-92. The normal curriculum. only a year old in 1889. was not in great measure different trom that of the state school. Church schools per se were not in existence. Thus, not surprisingly, nine years later, when Alma wrote to her professors at Healdsburg for help during her induction year of church school teaching, she received none: in tact, she was isolated from any support. Her greatest need would be to integrate biblical principles into a 
curriculum for children. What was lett undone at Healdsburg she later had to compensate, not just for herself, but for others in like circumstances.

Alma's years as a college student and young married woman were lined with tragedy mixed with hope. In eight years, she experienced marriage, motherhood. death of her husband and child. a life-threatening illness, an apparently supernatural healing, conierence staif work in the Sabbath school, a college education, and elementary teacher certification. In 1896 a widow at 24 years old, having graduated from Healdsburg College three and one-half years earlier. Alma embarked on a career. She had already begun working in the Sabbath school, which would become a lifelong service.

In retrospect, it seems that the years away at college and her brief marriage weaned her from her childhood family; Alma never went back home to live. though later her tamily came to live with her. She changed from the bashful, timid seventeen-year-old who came from a barren town in the Rockies. Her father's disapproval did not stop Alma from pursuing her life goals. She rose above his criticism. and. by her actions, challenged his desires for her to leave the service of the church. She left behind the provincialism and backward ways of an isolated western town and the contentions of a somewhat dysfunctional family, leaming new ways and better methods to live. She chose new values, friends, and lifestyle. Saguache was no longer "home:" her loyalties were transterred to a new "Wother in Israel" and to a heavenly Father. "Mother's people" were now her people. 
Though this chapter leaves her in mourning as she returned to

Saguache, the next chapter begins in San Pasqual in the home of the Johnsons.

There she would begin her first atiempts at integrating her Pestalozzian training and value system into a church school curriculum. 


\title{
CHAPTER 3
}

\section{EARLY TEACHING YEARS}

\author{
$1896-1911$
}

Her measure of worth, above things of earth:

That her name in the Book of Life be filed.

\section{Prevailing Teaching Practices in U.S. Rural \\ Elementary Schools in the 1890s'}

In 1890 , over 77 percent of the children in the United States attended rural schools. "Rural" meant districts serving towns under four thousand people. Not all country schools were graded; the length of a rural school year was often short of nine months, and teachers in rural areas often had little formal training beyond grammar or nigh school. Other characteristics of rural schools included: (1) 65 percent of elementary teachers were femaie, (2) desks bolted to the floor laced the teacher in rows, (3) prescribed courses of study set boundaries for what was taught, and (4) report cards and homework were part of standard class tare. Rural schools expended less than half the amount per pupil spent by their 
urban counterparts: they were usually housed in older tacilities and supplied with insufficient books, supplies, and equipment.

By 1890, many of the secliar educational retorms popularized after the Civil War were being used inappropriately. Many teachers reduced the object lesson to a list of steps. They also tended to order their students, lockstep fashion, through the Herbartian tive steps of learning. In general, although many practical subjects replaced old ones, and some of the old subjects were altered. students still recited their lessons much as they had in the past.

The elementary teaching protession in the 1890s was not well respected. Teachers' jobs were often dependent on the good will of their trustees, who annually decided whether they would be re-hired. Classrooms were overcrowded. Teachers with little training had to teach up to ten subjects and a variety of skills daily. For these reasons, textbooks were "the teacher's primary tool and the student's main source of knowledge."

Students of the 1890 s typically spent their day being taught as a group, listening to teacher. reciting, and working on textbook assignments. Pupils were not allowed out of their seats excep! with permission, or while doing laboratory work during science class.

The dominant educational theorists of the 1890 s advocated that children learn best throligh repetition and memorization. Scientitic "knowledge" about bureaucratic eificiency, organizational unitormity and standardization, reinforced Cuban. 24 . 
these theories. However, the heavy use of repetition and memorization was somewhat offset by a "common-sense. atheoretical, practical"' instruction in rural one-room schools, which lacked materials but enjoyed a sense of group or tamily cohesiveness. An "intuitively tlexible" teacher permitted the students to get up and move around. Such a teacher aiso gave more individual attention and discussed subjects within the context of the students' own community.

About the tum of the century, prominent educational thought leaders such as John Dewey, Edward Sheldon, and Francis Parker attempted to increase the relevance of education to the needs of children. Child-centered classroom practices appeared in the literature of the 1890s. and some teachers began experimenting with Parker's and other thought leaders' ideas on their own. One such idea was called "correlation." the integration of classes in order to help children see the connections between science. art. geography, and other subjects. Integrated, thematic instruction. rather than the teaching of separate subjects allowed basic skills to be taught within a meaningtul context of content areas. A host of practical subjects subsequently appeared in the curriculum. including cooking, sewing, pottery-making, gardening and weaving, along with expression through art, music and drama.

In place of uniform recitation, students could be tound working together on activities tha! uyere guided, rather than directed. by teachers. Older Ibid., 31 . :ibid. 
students were granted more decision-making freedom and were allowed to teach others. Student work was displayed at bi-monthly festivals in some schools.

Although many of the above innovations did not aifect many public schools before the 1920s, a number of changes that were in harmony with Seventh-day Adventist educational philosophy were being implemented by some church school teachers as early as the late 1890s:

\section{Teaching Practices in Califomia}

California elementary schools were required to teach reading, writing, orthography, arithmetic. geography. grammar, history of the United States. elements of physiology and hygiene (with instruction on the eifects of alcohol and narcotics), vocal music, elementary bookkeeping, industrial drawing, civil government, and instruction in manners and morals.:

Students were to be expelled from school for willful disobedience or defiance, and suspended for protanity, vulgarity. or vandalism.;

The state required teachers to tile their certinicates with their local superintendents and to notify their superintendents of the opening and closing days of their schools. It also required teachers to adhere to a state-authorized course of study, use the authorized textbooks, be responsible for students'

Jessie O. Barber Osbome. 'Teacher Educauon in the Early Days.' Journal of True Education 15, no. 5 (June 1953): 11-13.

James H. Deenng. The Political Cuide of the State uf California ISan Francisco: Bancroft-Whitney Co.. 1397), sections 1665. 1663.

Ibid., section 1684. 
conduct on the way to and from school and on the playground before and after school, suspend any pupil for good cause, keep a school register of grades and recitations, and make annual reports and any other reports required by the superintendent.

Alma likely received her state teaching certificate from her local (Orange) county board of education, which had power to grant a cerificate to holders of "California Normal School diplomas." Whether Healdsburg College or other private normal schools were included in this designation is not specified in the Political Code. If they were not, she was presumably required to take an examination. $^{3}$

Three county certificates were listed as being issued to teachers in 1889: primary school, grammar school, and high school. After holding one of these county certificates and teaching for ten years, a teacher could be granted a

'lbid., section 1696.

Nathan Newmark. The Political Code of the Siase of California as Enacted in 1872. und Amended in 1889 (San Francisco: Bancroti-Whitney Co.. 1889), section 1775.

'Healdsburg may have been included in the following category: " . . any other unstitution in the United States which the State Board of Education of this State shall have recommended as being of the same rank as the State University of California, when the Diploma of Graduation from said institution shall be accompanied by a recommendation from the faculty thereof, showing that the holder of the diploma has bad academic and professional training equivalent to that required by the State University. See Orange County Board of Education. Manual of the Public Schools of Orange Couny, Calif., Consaining the Course of Study, Suggestions to Teachers, List of Library Books, and Miscellaneous Marters, 1900 County Courthouse Time Capsule Contents 1887-:900, Orange County Archives (Santa Ana, Calif.: Evenung Blade Office, 1895), 52 . In those days, teachers were certified by the county in which they taught. It is likely that Alma applied for her first teaching certificate in Orange County, in which Centralia, her first church school, was located. 
life diploma.' Her Healdsburg training apparently qualified Alma for both elementary and secondary certification, since we find her teaching subjects in grades one through rine in Centralia in 1898.

Alma read the Orange County Manual of Public Schools. ${ }^{2}$ It contained a copy of the certification laws for teachers, teachers' duties, and general suggestions for teachers. The manual offered not just a list of subjects but also included the scope and sequence for each subject. Though Alma could not use the textbooks listed in the back of the manual, she was still able to follow the guidelines for what each pupil needed to learn in each subject. An example follows, from the mathematics section:

First Year

A knowledge of numbers from 1 to 10 developed by the use of objects.

Counting to 50 .

Counting by twos, threes, fours, and fives to 30 .

One-half, one-third, one-fourth, one-fifth of numbers not greater than 10 , the answers to be whole numbers.

The dollar, half dollar. quarter dollar, and ten cent piece.

Second Year

Combination of numbers according to Grube Methods. ${ }^{3}$ results not to exceed 35 .

Irwin Taylor, Public School Law of the Unised States, as Administered by the Courts (Topeka, Kans.: George W. Crane and Company, 1892), 336; Lars C. Christensen. "A Short History of the Beginnings and Development of the Seventh-day Adventist Work in Califomia (B.A. thesis. Pacific Union College. 1938), 87. Mr. Christensen hired two secretaries to accompany him to take down shorthand notes of Mrs. McKibbin's interview with him on 21 March 1938.

:Orange County Board of Education.

'Intended for children from ages four to six, a method used in Germany in which teachers taught all possible combinations and comparisons of numbers from one to ten: 1 . e., for the number three, the combinations are $1-1+1=3 ; 2-1=3 ; 1-2=3: 3-1=2: 3$. $2=1: 3 \times 1=3 ; 1 \times 3=3 ; 3 / 1=3$. 
Primary Number Lessons, to page 55.

Text-book to be used as a reader by the pupil.

Write and read numbers to 1000 .

Wuch practice in adding.

Multiplication and division tables as tar as 6 times 10 .

Review denominate numbers and add the ounce and pound.

Teach yard, foot, and inch. Practical work in measurements.

Fractions 1.2, 1.3, 1.4. 3.4, with equivalent fractions to 12ths.

Practical oral problems involving United States money, tables, and iractions.

The Orange Counry .Manual of Public Schools suggestions for teachers

emphasized the subject of mythology.

The basis ior ethical training in elementary education is to be found primarily in a graduated course in classical literature, beginning with fairy tales, myths, legends, and folklore .. The importance of this work cannot be overestimated.'

No other remarks on how to teach were included in this manual.

When Alma taught church school in Centralia, board members admonished her not to use books that had myths or tairy tales in them. Thus, when she nirst stared teaching she faced a serious challenge in the lack of appropriate textbooks.

Orange County Board of Education. 12.

ibid.. $+1+2$.

McKibbin. Step by Step, 0 . 


\section{Educational Philosophy of the Seventh-day Adventist Church'}

Seventh-day Adventist philosophy encompasses an education that is broader than what transpires at school; it encompasses all of life's experiences, and its purpose is to fit one for service to God on this earth and in heaven. Although man possesses power and desire for goodness, which are implanted by God, there is an antagonistic bent to evil in man's nature, which, unaided, he cannot resist. Therefore, education must train and develop not just the mental, but the physical, social, and spiritual powers that man possesses, and do so harmoniously.

In the second half of the nineteenth century, it appeared to Seventh-day Adventists that no existing educational theory, practice, or school system adequately embraced so broad a definition or so high a goal. Seventh-day Adventists believed that God intended for them to start afresh on an entirely different plan than any in existence.

Applying the principles enunciated above for all the youth of the church cost strenuous, continual effort. The church could not expect to have workers preparing to serve God in this life and in the next life by training them

Summarized from Allan G. Lindsay, The Influence of Ellen White upon the Development of the Seventh-day Adventist School System in Australia, 1891-1900" (M.A. thesis. University of Newcastle. N.S.W.. Australia, 1978), 19-26; also. see Wilbur Arthur Burton. "A History of the Mission of Seventh-day Adventist Education 1844-1900* (Ph.D. diss.. Kansas State University, 1987), 367-85; also an entıre book about Seventh-day Adventist educational philosophy by Edward Miles Cadwallader. Principles of Education in the Writings of Ellen G. White" (portion of doctoral diss., University of Nebraska. n. d.). For a concise, brief. but official statement of Seveath-day Adventist educational philosophy, see General Conference of Seventh-day Adventists. North American Division Office of Education. Educarion Code, K-12. sections 1010-1030 (Washington. D.C.: Review and Herald Publishing Association, June, 1978). 
merely to mimic their teachers. In order to etfectively carry responsibility for God's work, students had to be taught to think independently, to operate from reason and principle. and to govern themselves.

To develop harmoniously the students' mental, physical, and spiritual powers, the Seventh-day Adventist educational system devised the following: providing work-study programs, locating schools in rural areas, adding Bible and Christian service to the curriculum, and including tarms and industries with schools. Active labor and exercise in iresh air enabled students to concentrate better and to leam more in a given time than they could by study alone, and also helped them prepare for life's practical duties.

Much of the popular curriculum of the day, with its classical languages. philosophy. myths, fairy tales and other fiction that was not true-tolife. was not considered by Adventists to be appropriate to an educational goal of service to God. In place of these studies were to be substituted practical. vocational courses and authentic experiences that equipped learners with iundamental skills and knowledge.

Since emphasis was on service for God. the curriculum was to be based first on the Bible and secondarily on the book of nature, two sources of His revealed will according to the Seventh-day Adventist understanding of the Bible and the writings of Adventist leader Ellen $G$. White. 


\section{The Church School Movement}

\section{Philosophical Base}

How could the Bible be made the foundation for leaming in the 1890 s?

Mrs. McKibbin later wrote:

No other principle revealed to us occasioned so much perplexity and discussion as did this one. The Bible was to be the "groundwork and subject matter of education." What did these expressions mean, and how were they to be carried out? ${ }^{2}$

The problem that Mrs. McKibbin verbalized, of not knowing how to systematize an education based on the Bible, caused Adventists to delay their efforts to form a separate educational system for their children.

As early as 1872 , Ellen G. White had enjoined parents to give their children a Bible-based education and thus preserve them from the alleged evils and false teachings of the public school system. However, in view of the difficulties and expense of implementing such an education, church members were slow to accept the idea and claimed that the public schools were doing an adequate job after all. With few exceptions, no Adventist elementary school was begun in the 1870 s or even the 1880 s.

For a more complete discussion of the Church School Movement in America, see Warren Sidney Ashworth. 'Edward Alexander Sutherland and Seventh-day Adventist Educational Reform: The Denominational Years, 1890-1904" (Ph. D. diss.. Andrews University, 1986), 141-16: Arthur Whitefield Spalding, Origin and History of Seventh-day Adventists, vol. 2 (Washington, D.C.: Review and Herald Publishing Association, 1962), 353-71; Lindsay, 11429.

:Alma E. McKibioin. "The Way the Lord Has Led Us," November 1943 TMsS [photocopy], p. 2, address given at Teachers' Institute, La Sierra College, La Sierra, Calif., in the hand of Ethel Young. Russell. Penn. 
However, Adventists did develop institutions of higher leaming: Battle Creek College in 1874 and Healdsburg College and South Lancaster Academy in 1882, with several more colleges in the 1890 s. When these institutions tailed to implement the educational retorms necessary to tully achieve the goal, Mrs. White stared a school in Australia as a beneficial pattern of what kind of education God had in mind for His Church.

From Australia, during the period 1891-1900. Mrs. White wrote to church leaders in America, sharing with them the educational progress and pattem in Australia. The content of these messages, or "testimonies" as they were called, were published in various church publications. many in the Review.'

Many of these testimonies were aimed at institutions of higher education. However, in the last halt of the 1890s. Mrs. White sent specific applications and guidance tor the establishment of elementary schools. Alma McKibbin summarized these principles in her own words:

1. All of our children must be gathered out of the public school.

2. We must establish a school in each church even though there were only six children.

3. The character of the work done in our church schools should be of the very highest order.

4. The work should not be patterned after the schools of the world.

5. A child should be trained and guided and taught by his parents till he is eight or ten years ot age. . .

Short for Adient Revew and Sabbath Herald, a weekly publication of ancles and ttems of interest to church members. Lindsay, 127: George R. Knight. Early Aciventist Education in Australia: A Report of Recent Research." The Journai of Adventist Education th. no. + (April-May 1982): 11 . 
6. The physical and spiritual powers of the child [are] to be developed, as well as the mental.

7. "God's word must be made the groundwork and subject matter of education. . . . This book is the foundation of all true knowledge."

Counsels to Parents. Teachers and Students, pp. 15, 16.

8. "The book of nature is a great lesson book which ... with the Scriptures we are to teach to others. All need this teaching." Christ's Object Lessons, p. 24.

9. Schools should be in the country.

10. Useful manual labor must be taught, especially domestic science [sic] and agriculture.

11. "Teach fundamentals. . . . The common branches should be fully and prayerfully taught."

12. ["]No books containing a perversion of truth should be in the hands of children and youth." (myths, fairy tales, fiction).

13. The choice of a teacher of the children requires great care; they should be like Jesus. Counsels to Parents, Teachers and Students. pp. 150, 151.'

Mrs. McKibbin also understood from Ellen White's instruction to church members that young children, ages five to eight, were to be left free to run and play as lambs; teachers were to supplement the role of parents. guiding the children as though they were their very own. A godly character was the goal, the Bible was the foundation, and the schoolroom, the setting. Classrooms were to be light, well ventilated, and clean."

One of the letters from Ellen White in Australia, published in the 1890s, stated. "Wherever there are a few Sabbath keepers, the parents should unite in providing a place for a day school where their children and youth can be

:McKibbin. 'Educational History, 2-3.

Ibid. 
instructed. "I Alma McKibbin recorded her reaction and those of other church members:

Now that came somewnat like a bombshell. I can remember . . . whenever the Review came, we tore off the wrapper hastily, to see what Sister White said this week about this matter. Every church was discussing it. "Why," one would say to another, "Sister White has sent a testimony, and she says that we should have schools for all of our children from the first grade onward." And the next question would be, "How in the world are we to do it? ${ }^{n 2}$

\section{Church Milieu}

There were many obstacles in the way of implementing a new educational system for Seventh-day Adventist children. Some members felt that other pressing needs, such as medical and educational institutions already in existence, should take priority. Some responded to Mrs. White's counsels by supplementing their children's public school education with summer church schools. ${ }^{3}$ Californians, in particular, were hard pressed to pay the bills of the heavily indebted Healdsburg College and San Femando Academy. Churches were continually being urged to meet the seemingly insatiable needs of these institutions.

Ellen G. White, "Church Schools," in Testimonies to the Church, vol. 6 (Mountain View. Calif.: Pacific Press Publishing Assoctation, 1900), 199 (italics supplied). This article was originally published in the late 1890s.

:Alma E. McKibbin. "Church School Beginnings in California," talk given in 1957 TMs [photocopy], pp. 5-6, transcnpt in Adventist Heritage Center. Loma Linda University, Loma Linda, Calif.

'Stephen N. Haskell, Review and Herald 62 (14 April 1885): 12. 
Some church members argued that the public schools struggled for years to establish their school system; how could a small, insigniricant organization of poor people support an entire educational system? Others warned that if church members used their resources for church schools, the newly-established international mission outreach would have to be severely curtailed, preventing the growth of the global enterprises and institutions of the church.

A dearth of trained teachers was seen as a formidable obstacle. The calling for a teacher to accomplish a work of such high and noble ideals was no light matter. Certainly no public school could train a suitable teacher. "Who was 'sufficient for these things?'"!

Financial obstacles seemed particularly formidable because the nation was in the midst of a depression, precipitated by the Panic of 1893. Over six hundred banks closed. leaving depositors to shoulder their losses. Sharp cutbacks resulted in high unemployment and widespread misery. Paralyzed businessmen and impoverished tarmers joined other disillusioned citizens on a pilgrimage to Washington to demand resolution of the problems that caused their empty pockets.: To add to these woes, southern California expenenced a drought for two years.;

McKibbin, "Educational History.'4.

:Rober H. Wiebe. The Search for Order 197,-1920 ( Vew York: Hill and Wang. 1967), 22. 91 .

McKibbin. 'Educational History. 5. 
Even leading church educators feared to meet the demands of the new

principles of education:

Some accepted them and wanted to act upon them at once, but others hesitated and said they were impracticable, and could not possibly succeed. They were so different from the accepted systems of education and called for such radical changes in methods that conservative minds were unable to conceive how they could be carried out. They said, "We do not know how." "

To many, it seemed a hopeless matter, and some felt that church schools were unnecessary anyway. State schools were good schools. They had educated the fathers and mothers. Why were they not good enough for their children?

All these and many more objections were made in every church, and were no small part of the difficulties that had to be overcome. ${ }^{2}$

\section{Difficulties in Beginning Church Schools}

The first difficulty confronting churches willing to implement an educational program for their children was to find a teacher. Church leaders first attempted to recruit individuals whose training specialized in education.

The recruiters found that not one could be persuaded to undertake this new kind of school:

Each said, "I am interested. The plan is beautiful, but I would not know how to carry it out. I never taught the Bible in school, and how would I make it the "groundwork and subject matter of education?" "I know something of nature study, but not the kind that is called for in Christian schoois."

The search went on. All the "likely" people were searched out and invited to undertake the task, but all the "likely" people refused also. So sacred seemed the work that no one volunteered. No one dared to take up a work so high, so important. so holy. That is the way it seemed to all.

McKibbin. "The Way the Lord Has Led Us." 5-6.

:McKibbin. Educational History," 4. 
When the church was unable to persuade anyone to undertake the work, He who had said that schools must be established, called some very "unlikely" people to be teachers.'

Since so few trained teachers started teaching church schools, and since those who did start teaching them had so little training, E. A. Sutherland regretted in 1899 that some teachers were sent out who knew "little or nothing of the principles of Christian education. ${ }^{2}$

Many of these teachers worked in isolation, without support from knowledgeable professionals. Supervisory help for church school teachers was unavailable until 1900, when Professor E. S. Ballenger became the California Conference's first Educational Superintendent. Even a church school manual did not appear until $1901 .^{3}$

As anticipated, support of teachers was indeed a problem. Church members could not always come up with the teacher's monthly stipend, or paid it a few weeks late. Church periodicals after the turn of the century were full of appeals to church members to systematize a stable fund for paying teachers. ${ }^{+}$

McKibbin. "The Way the Lord Has Led Us." 7.

:Ashworth, 146.

'John C. Haussler. The History of the Seventh-day Adventist Church in Califomia (Ph. D. diss., University of Southern Califomı. 1945), 187-88.

'E. A. Sutherland. 'Support of Church Schools.' Training-School Advocase 1, ao. I (January 1899): 90: I. C. Colcord. "Report of the Church School Deparment." Pacific Union Recorder 9. no. 30 (24 February 1910): 13. 
There were no textbooks to tacilitate the use of the Bible as a Foundation for all subjects. Educational leaders urged teachers to prepare textbooks "free from the errors common to those used in the secular schools." I Evolution, myths, and fairy tales were considered by many Adventists to be examples of common errors.

The doctrine of evolution was beginning to appear in public school textbooks. In one Geography the tirst ten pages were lessons on evolution, and the Readers were iull of myths and fairy tales. All this made it necessary to write our own textbooks, a very difficult task.'

New Seventh-day Adventist educational periodicals helped fill the void by publishing many suggestions ior teachers. However, these publications did not solve ali the problems. such as the lack of textbook uniformity.

The teachers at the various leveis carried out their personal ideas of how schools should be managed and mostly were doing quite well, but it was no small task to tind books for the various subjects that were acceptable. Some made over the public school books, others mimeographed their own outlines. It is needless to say that the ideas of the various teachers were not alike.

One more problem that quickly presented itselt to church members was where to put a school. Those that had Sabbath school rooms naturally thought of these rooms as a place tor the school. 1903): 20.

M. Bessie DeGraw. 'Educational Institute." Review and Herald 80, no. 30 (28 July

:Alma E. MeKibbin, Retorms and Retormers, n. A. A.MsS. in the hand of Ethel Young, Russell, Penn. togwin. Calif.

G. E. Johnson. n. J. AMsS. Adventist Heritage Center. Pactic Linion College. 
The objections to this use of rooms in a church were loud and long, and not without good reason. However, the first church schools were held in Sabbath school rooms if they had them.

The churches that had only a one room church building, the auditorium, were in a dilemma. Some, if the school was small, held it in a private home, and a few built an addition to the church.'

While local churches were grappling with these problems, some church leaders, in spite of continued difficulties, put their shoulders to the task. These leaders included E. A. Sutherland, Percy T. Magan, Bessie DeGraw, and Frederick Griggs in the Midwest, and Marion E. Cady and E. S. Ballenger in California. Some of them joined Mrs. White in writing articles on educational reform in church periodicals. the most helptul to Alma being those by Professor Cady (president of Union and then Healdsburg College).' But in spite of his hard work in trying to establish the reiorms, he suffered much opposition. Alma wrote:

I am very sorry to record that not all heeded his teaching--and some even opposed and contormed to public school customs and principles. Several times Prot. Cady visited Elmshaven and conferred with Sister White. She encouraged him and on one occasion said to him. "Brother Cady. I undersiand your problems. I know. because God has shown me. but be of good courage: before the end our people will return to the true principles of Christian Educarion. ";

Alma ielt that one of the greatest problems church schools taced was the prevalent resistance to depart from or to modify the course of study or practices of the public school.

\footnotetext{
McKibbin. Educational History. 5.

:Cady was president ot Healdsbury and Linton Colleges.

McKibbin, 'Retorms and Retormers" litalics supplied).
} 
The greatest hindrance to any reform is the difficulty of the human mind to be different from the majorin. The image of the public school was ever before the mind. How difficult to conceive of anything different from our old school books, or a school with different standards of thought and decorum.'

In spite of all the discouragements, church schools mushroomed in a "whirlwind of expansion." from six in 1890 to $\geq 20$ in 1900.

How could a movement begun with such resistance and fraught with so many shortages and deficiencies have expanded so rapidly? Burton has suggested that a vital ingredient of the movement was a spirit of sacrifice. ${ }^{3}$ Alma felt it was a grass roots movement in response to the articles by Mrs. Ellen White.

The duty to establish church schools affected our lay members very seriously. But no group of educators or Conierence officials made any effort to establish church schools on the Pacific Coast. The first schools were established by local churches. each acting independently of every other, and with no help or advice from any source except what the members read in the Review.

The time had come tor this work to begin. and begin it must. even if it must be by iaithful people whose zeal was much greater than their knowledge of how to establish and conduct uny school. much less one that was to be like that of the schools of the prophets.

Alma believed it was mothers who took the initiative:

It usually began with some humble mother burdened over her children who timidly sounded out another mother on the subject. and she another.

Ibid. (italics supplied).

Ashworth. 142

Surton. 324.

"AcKibbin. Educational Histor:" 3 (italics supplied). 
Then tathers became interested and the matter grew until finally it became the serious purpose of a local church. at least of a part of the church. ${ }^{1}$

Some parents sent requests to Battle Creek College tor students to teach their children. Within a lew years, notices appeared in local church papers urging church representatives to attend Teachers' Institutes in order to meet a prospective teacher who would start a school for their church.' Maude Wolcott (later Spalding) was one teacher who responded to a request tor a teacher. She described her teelings as tollows:

We students in Battle Creek College had been alerted . . . to the prospect of being called into service on the lower levels of church education. . . The continual calls trom the pen or inspiration [Mrs. White] fired the souls of that class of 97 and gave us a real vision of the needs of the hour. We carried the spirit with us into all our classes.... We studied as for our very lives, that we might be used of God to meet the needs of the hour. ${ }^{3}$

Some Battle Creek students answered calls for church school teachers in Michigan; others traveled as tar as California. The search for teachers was acute, and Alma ielt it was a miracle of God that so many teaching positions were filled.

When the churches iailed to get teachers, the Lord who had said schools should be established. alled persons who had never taught nor even thought of teaching. Persons were pressed into the work by the compulsion of the Spirit.

\footnotetext{
Mckibbin. The Way the Lord Has Led L's." 6.

:Ashworth. 143: E. S. Ballenger. "Church-Schools." Pacific Cnion Recorder I (1 August 1901): 10.

"Maude Wolcott Spalding. "Volunters of 97." The fournal of True Education 15. no. 5 (June 1953). 3.
} 
I wish to make this subject of the selection of teachers very clear, for to me it seems one of the most unmistakable evidences that this matter of church schools was of God. Patrons and teachers were alike wholly unprepared in any way for this work. The mistakes of the School Boards of some of the first schools would make one smile, if this were not so serious a subject. Yet, in spite of the unbelief of some, and the ignorance of all concerned, and the poverty of most of our people, schools were opened, struggled for life, and finally survived. It is one of the many miracles of the Lord's work in Califomia.'

\section{Denominational Certification}

When the church school movement started, there were no requirements for certification in the denomination. In 1904, the California Conference Educational Committee voted to prepare a certification examination for teachers of grades one through ten. They would issue levels of teaching certificates on the basis of scores attained on the examination. By the end of the 1904 eightweek summer session, these examinations and certificates were already being issued. $^{2}$

\section{Church Periodicals That Stimulated Church Schools}

Alma McKibbin increased her understanding of the principles of educational reform by reading in church periodicals. The publications that were

McKibbin. 'Educational History," 6.

Faussler, 193; 'Pacific Union Educational Council," Pacific Union Recorder 3, no. 30 (28 July 1904): 7; J. S. Osborne. 'Report of the Church-school Work in the Califomia Conference for the Years 1902-1904. "Pacific Union Recorder 4, no. 3 (18 August 1904): 6: Mary Kelly Little. 'Development of the Elementary Schools of Seventh-day Adventists in the United States," (M.A. thesis. University of Washington. 1932), 41: M. Bessie DeGraw, "An Educational Conference." Review and Heraid 80, no. 21 (26 May 1903): 16. 
available to her in the early 1890s were the Youth's Instructor and the Review and Herald.

Beginning in 1897. the tirst Seventh-day Adventist educational joumal authorized by the General Conierence. Christian Educator, was published in Battle Creek, Michigan. Frank Howe, editor, included an article by Ellen G. White in the tirst issue. as he would in many succeeding issues. In that first article Mrs. White contrasted secular education with Christian education. Secular education, she wrote, imbued students with "selfish ambition" and crowded their minds with unnecessary knowledge that excluded God, thereby estranging them from Him and strengthening their pride. The goal of Christian education is to honor God and serve Him. As God's word is studied, a vital connection with Him is maintained that brings out noble character traits.

Mrs. White explained the high, sacred character of the work of the Christian teacher. and she enjoined teachers to unite with the Holy Spirit in becoming active powers tor good. She cautioned them to watch carefully for the empowering Holy Spirit:

The Holy Spirit has often come to our schools, and has not been recognized, but has been treated as a stranger. perhaps even as an intruder. Every teacher should know and welcome this heavenly guest. If the teachers will open their own hearts to receive the Spirit. they will be prepared to cooperate with it in working for their students: and when it is given free course, it will effect wondertul transtormations.

Ellen G. White. 'Teachers and Teaching." Christian Educaror 1. no. I (July 1897), 2. This article had previousiy appeared in Specal Tesmmontes on Education (Battle Creek. Mich.: Review and Herald Publishing Assoctation. 1997). Ellen G. White Research Center. Andrews Universily. Bernen Springs. Mich. 
Her conclusion elevated the goal for Christian teachers: "The great aim of the teacher should be the perfection of Christian character, in himself and in his students."

The editor of Christian Educator sprinkled Mrs. White's statements about church schools throughout his joumal. The quotations embodied the heart of the philosophy outlined in the paragraphs above.

Early issues of Christian Edlucator contained articles from W. W. Prescott, Mrs. S. M. I. Henry, George Irwin. J. H. Kellogg, E. J. Waggoner. Frederick Griggs, E. A. Sutherland, and M. E. Cady. Some other articles were reprinted from secular educational joumals or from educational leaders of other religious institutions. By 1898 the Christian Educator boasted eleven departments, offering items of general interest to teachers and students, including classroom aids, experiments for home or school, thought-provoking questions for students: articles on true. normal, and industrial education: nature lessons, and lessons on physiology and hygiene.

A sample listing of titles from 1897 to 1899 tollows:

True Education.

The Need of Church Schools.

The Distinctive Field of the Church School.

School Surroundings.

Text-books vs. Nature.

God and Nature.

Science and the Bible.

The Function of the Church School.

Church-School Work.

!bid. 
Suggested School Reforms.

The Bible as a Text-book.

Alma mentioned articles by M. E. Cady as being especially helpful to her. It appears that one of Cady's articles above all others may have affected her textbook writing, and may have been in part the basis on which she organized the Scripture lessons for her first home school:

In the simplest manner possible bring the child's mind back to "the beginning" of things.... If the child can read, have him tum to the Scriptures and read it for himself. He should be taught to answer in the language of the Scripture as far as possible, so that in after years he may be able to give a reason for what he has been taught. ${ }^{1}$

Alma organized her home school Bible curriculum in the way Cady suggested:

I began where the Bible begins, "in the beginning," and based my lessons on the first chapter of Genesis. I believe the Lord heiped me in a most wonderful way. ${ }^{2}$

Later she wrote in the introduction to Bible Lessons, Book 1, "The questions may be answered in the exact words of Scripture. ${ }^{3}$ These lessons began with Adam in the Garden of Eden.

Another excerpt from these first issues of the Christian Educator, likely written by the editor, Frank Howe, may also have seminally influenced Alma's thinking:

Marion Emest Cady, "Nature Study at Home." Christian Educaror 1, nos. 3 and 4 (September and October 1897): 58 (italics supplied).

McKibbin, interview, 30 September 1967, 2.

Alma E. McKibbin. Bible Lessons for the Church School [Book Onel (Healdsburg, Calif.: Healdsburg College Press, 1903), 3. 
We heard somebody recently say that all a parent has to do in order to educate his growing child at home is to answer its questions-and the remark is true. Let the "question" stand for every need of the child, consciously or unconsciously expressed, and the "answer" must include the whole course of its life education. Curiosity is the child's birthright. He lives and grows by the divine right of interrogation. Happy the parent who has the patience and the wisdom, the benign, prophetic eye, to see the child's highest need and direct his questioning soul ever up to Him who said, "Ask, and ye shall receive." "Suffer the little children to come unto me, and forbid them not."

Don't shut the child away from God's answer.'

While still living in Healdsburg, Alma wrote an article on her feelings

about children's questions:

In no other way does [a child] so fully reveal himself as in his questions. It is almost the only verbal expression he ever gives of his own individuality.

By his questions we learn the subject of his thought, what interests him and what perplexes him. By these he makes known to us how much he comprehends and how little.

A man took a band of little children for a short walk. When he started, they were all strangers to him; when he retumed, he was well acquainted with each little one in his company. Did each tell the man his history, formally express his emotions, or his likes and dislikes?--Nothing of the kind; they merely asked questions. . . .

Simple questions that we hear every day; not anything in them, you say. Be not so fast. This man thought there was much in them, for he was a wise man; and by those simple questions . . . he read the minds of all those little boys and girls, and being patient as he was wise, he answered every question. The children therefore went home wiser than when they started, and with love and respect in their hearts for the big man who answered little children's questions; for the patient answering of children's queries does beget love and respect. And is not this a great reward for so small a deed? ${ }^{2}$

\footnotetext{
[Howe, Frank W.], Christian Educator 1, no. 1 (July 1897): 17.

'Alma E. McKibbin. 'Answering Children's Questions." Christian Education 2, no. 3 (January-February 1911): $43-44$.
} 


\section{Experimentation with a Home School, Winter, $1897^{1}$}

In January, 1897. after Edwin's death the previous November. Alma went to visit her old home in Saguache. Her visit may have been cut short by her father, who had forbidden her to return home because of her faith. ${ }^{2}$ Apparently she did not stay long, for she retumed that winter to her friends, the Johnsons, in San Pasqual. They were friends who had kindly invited Alma to live with them after Edwin's death and lived in the beautiful, secluded and somewhat isolated San Pasqual Valley in southem California, a few miles east of Escondido. There she experimented with a home school in the Johnsons' living room for eight months in 1897.

There were other Seventh-day Adventists in the San Pasqual Valley in 1897. The second white family to settle there, in 1875, was that of John Bacon Judson, a Seventh-day Adventist. The Johnsons settled in the valley a little later in 1875, and subsequently, some of their family members married into the

\footnotetext{
Alma McKibbin accepted the verdict of many Californians that this was the first Adventist church school in California. This little school in the sitting room of the home of the Johnsons was in early 1897 and so far as I can learn was the first attempt anyone in California made to teach children as the Spirit of Prophecy has said that we should. . . There were no Union Conference weekly papers to keep us informed of what our churches or workers were doing. And so. the little home school in San Pasqual was never remembered until later times. . . . For some years I said nothing, but others did some research work on the subject and reported that that little school of three beginners was the first church school in the state." See Alma E. McKibbin. Mountain View, Calif., to Ethel Young, Washington, D. C.. 18 March 1966, in the hand of Ethel Young, Russell. Penn. The Sevienth-day Advensist Encyclopedia also sites this school in San Pasqual as the first in California, and qualifies that statement under "San Pasqual Academy" as "the oldest continuously operated church school in Califormia." See Seventh-day Advensist Encyclopedia. 1975 ed., s. v. "McKibbin. Alma E. Baker" and "San Pasqual Academy." See note under the subheading, Centralia, p. 124.

'McKibbin, "Church School Begunnings in California," 15.
} 
Figure 5a. San Pasqual Valley.

Figure 5b. The Henry Johnson Home. San Pasqual. California. Photograph by Ruth Collings. 


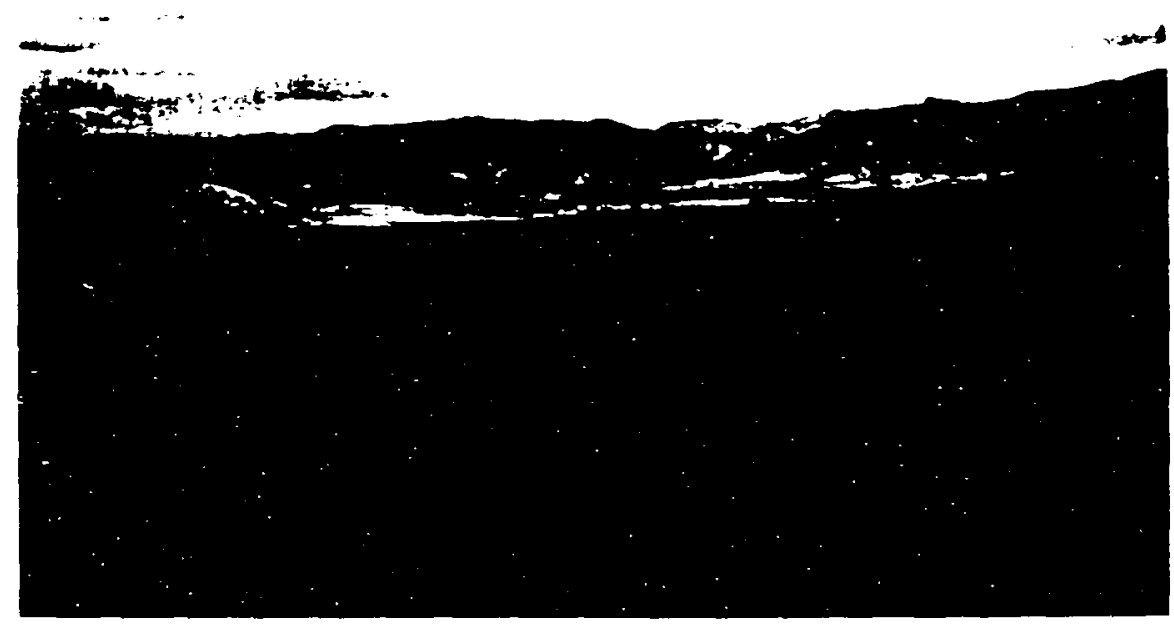

$\because$

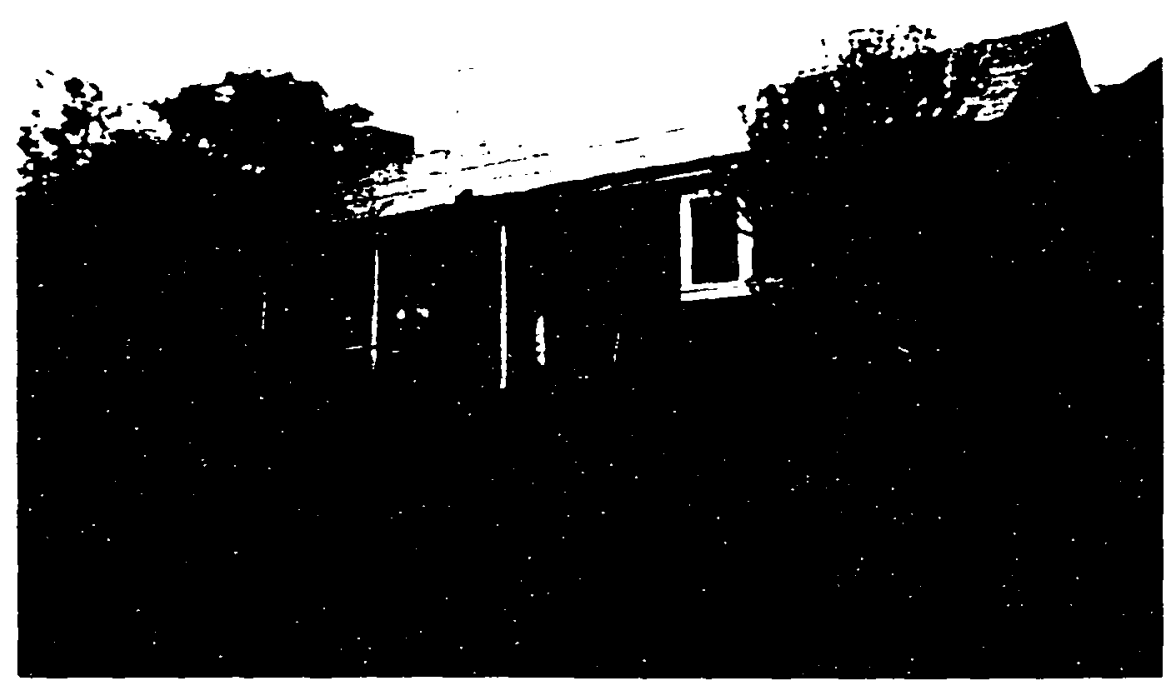


Judson family. Alma lived with Florence Judson Johnson, the granddaughter of John B. Judson, and Florence's husband Henry.

Florence had been a public school teacher before her marriage and now had six children. The oldest was at Healdsburg College, three were in public school, and two were still at home. The twins. Jesse and Roy, age six. were wholesome country children who had their own gardens and could compute the tithe from the produce they sold. Florence and Henry had been following the instruction of Ellen G. White, whom they believed to be God's prophet. which advised parents not to send their chiidren to school at the age of six.:

As we talked over the principles that Sister White enunciated, we were consulting as to how to carry them out, especially the principle that said the Bible should be made the ground work and subject matter of all education.

And we talked and talked about it. Finally she said. "Well, why not take the three ${ }^{3}$ children and try to carry out these principles. I'm willing that you should experiment with my children." So, they gave me the parlor for a school room. ${ }^{+}$

Under these circumstances and in these simple surroundings, the grand experiment began.

Brother Johnson made some little tables that the children could use for desks. and they had small chairs. and he got a blackboard for me. I tell

Mary Keiser. The Spirit of San Pasqual (privately printed. 1986), 10-11; Julit Judson. telephone interview by Ruth Collings. Escondido Historical Soctety Research Volunteer, February 1991. Escondido. Calif.: Julit Judson, interitew by author. 15 March 199!, San Pasqual Valley, Calif.

: HeKibbin. interview, 30 September 1967. 2.

'Ibid. A seven-year old girl cousin who had not yet attended school joined the little home school in the living room of the Johnson home.

'Tbid. (italics supplied). 
you, I believe in blackboards. I made lessons, and put them on the blackboard, taught those children to print, and print words.

I had to learn. Oh, I'd taken the normal courses . . . [and learned] to put ... . [pedagogical principles] . . . into practice, but in eight months those children were reading their lesson from Our Little Friend. One evening we were all surprised; I was as much surprised as anyone. Little Jesse said, when her father took the Bible to conduct evening worship, "Daddy, I could read twelve verses from the Bible if you'd like to have me."

"Well," he said, "Jesse, read me twelve verses."

"Well," she said. "they begin just the same as the tirst chapter of Genesis that we've been studying." She looked through the Bible and found "In the beginning was the word." And I'd noticed she'd come several times to me with new words. And she read the first twelve verses of John: "In the beginning was the Word, and the Word was with God, and the Word was God." And she read it with emphasis, and I sat there just as much astonished as her parents were to hear that girl read that. And she read it as if she understood it.

The church members became excited about the children's progress and began laying plans for a church school. They decided to ask Alma to teach all of the children in the church and to integrate biblically-based principles of educational reform into all the grades.

Alma did not welcome their hopes.

She was not well. She had fallen down the stairs and broken her left ankle. and during her recovery. while in a depleted state of health from the stress of her husband's death, had lost most of her hair. What little remained had to be cut for a scalp treatment, and it would not grow long again, apparently because of her low vitality. In those days it was a disgrace for a woman to wear

Ibid., $2-3$ (italics supplied). 
Figure 6a. Edwin and Lorin McKibbin's Graves, San Pasqual. Photograph by Lennart Ahlkvist.

Figure 6b. First Church School in San Pasqual, 1898, Opened after Alma McKibbin Lett the San Pasqual Valley. Photograph by Lennart Ahlkvist. 

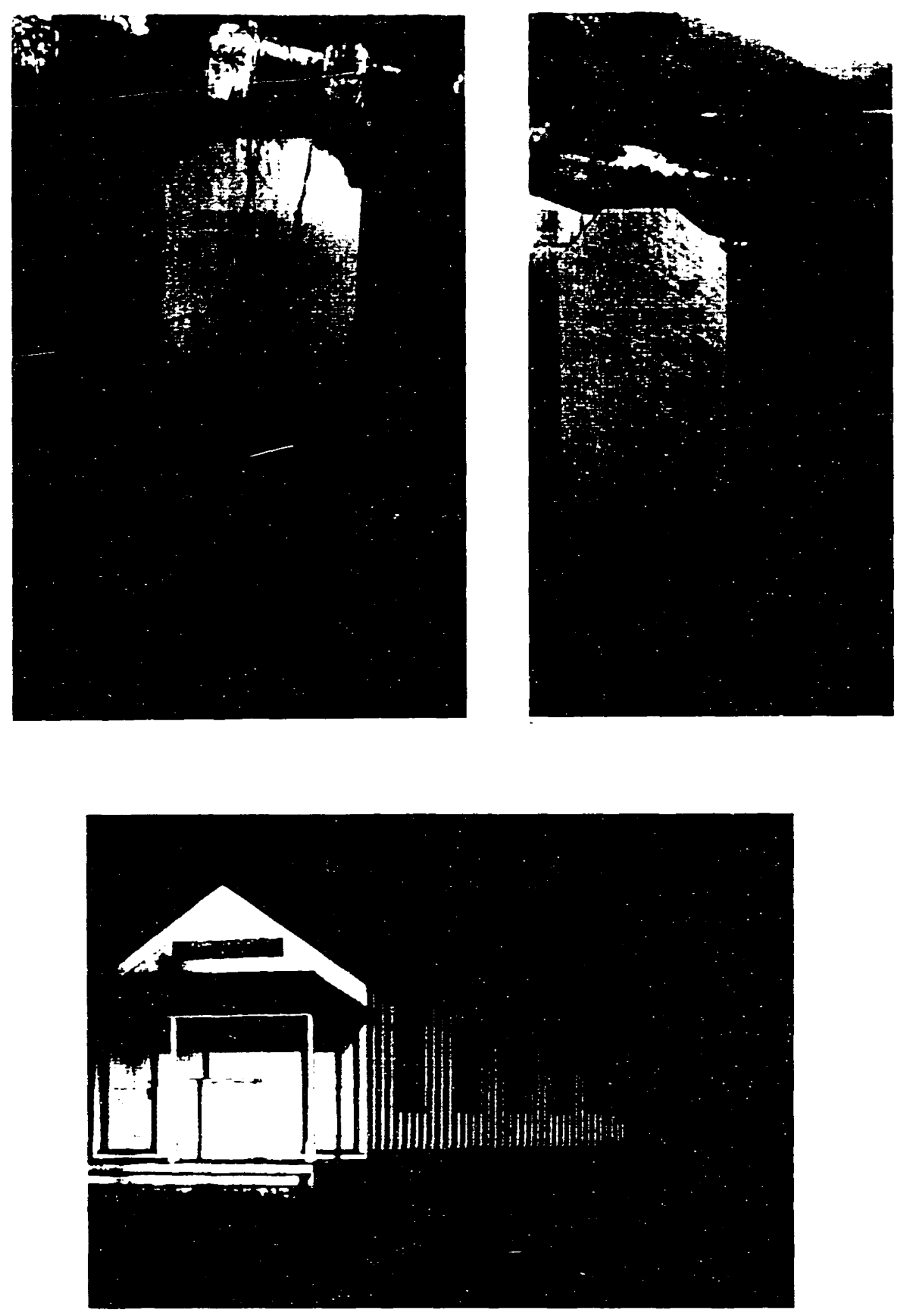
her hair shor, and, under the circumstances, Alma longed for rest, low stress, and a low protile."

She looked at the sixteen- and seventeen-year-old children at church, taller than she was, knowing she was not a good disciplinarian.2 How she longed to teach just the young children. She had already begun planning what she would teach in the second grade, and she wanted to develop a church school curriculum gradually, one grade at a time.

From remarks dropped now and then I felt they were going to ask me to teach. How I longed to do it! I thought of it by day and dreamed of it by night. But I knew I could not do it. I had no strength, no nerve, no brain left. It was impossible. Who was I to aspire to so great a task? Why, these principles were new, and nobody could give me a bit of help. I read everything that was written, but there was nothing specific. There were principles, but how to carry them our ' $^{\text {t }}$

I could not bear to refuse people who had been so kind to me, so, like Jonah, I just got up and left, left the only home I had in this world and went to Los Angeles to a family, not Christians, for whom I had worked some years before, and endeavored to keep house for them. The work was too hard for me, and I was still troubled with dreams of a grear work the Lord wanted done and no one to do it. I told Him over and over again. "You know, Lord, I want to teach, but I cannot. I am sick and tired, and I cannot remember, and I cannot study, and I do not know how a church school should be taught, and there is nobody to teach me. ${ }^{\text {s }}$

These were dark times for Alma. She siept little, for she felt she was running from the work God wanted her to do.

Ibid.. 17. 45: idem. "The Way the Lord Has Led Us," 8.

-McKibbin, Step by Siep, 67.

"McKibbin. "The Way the Lord Has Led Us." 3.

‘McKibbin, interview, 30 Septemier 1967. 4 (italics supplied).

"McKibbin. "The Way the Lord Has Led Us," I (italics supplied). 
I wasn't happy. Night or day, something was saying to me, "You should be teaching. You should be teaching a church school." I couldn't get away from it.'

In later years she looked back remorsetully on the time when she left

San Pasqual and considered it one of the saddest errors she ever made.

It was a great mistake for me to make, for I knew everybody in that church, and they were my friends. When you make a mistake you are orten given something more difficult to do.'

Why, it was much more difficult to go among strangers there, and young people that I'd never seen betore. I knew everyone of these at San Pasqual. Oh, it was a foolish thing for me to do and I paid for it. I tell you. ${ }^{3}$

Alma "ran away" to Los Angeles. She did take another teaching

position about a year after moving to Los Angeles. While she was struggling over whether to heed her calling to teach, the Centralia Church in Santa Ana, Orange County, California (located where Disneyland is now), was scouting for a teacher. The members had had a sad experience the previous year. Instead of integrating the Bible with the whole curriculum, their tirst church school teacher had merely taught the children a Bible reading atter school. She had also had serious discipline problems, and had quit with no notice after only five months to marry one of her students. But the Centralia Church refused to be discouraged

Mckibbin, intervew. 30 September 1967. 4.

:lbid.

McKibbin. Interview. 30 September 1967. 11. 
and determined to find a teacher who would not get married during the school term.

When Elder George Snyder, an old schoolmate of Alma's from Healdsburg days, saw her in church in Los Angeles early in September, 1898, he took immediate action. He asked the pastor to slip Alma a note asking her to remain after services. When Alma managed to slip away before the closing hymn two weeks in a row, the pastor sent an usher to follow her to the home where she was housekeeping.

The following Sunday evening, the pastor and Elder Snyder comered Alma in the kitchen as she was preparing dinner for the family, and asked her to teach in Centralia. To her objections, they answered, "The Lord will help you. This is the Lord's work. He has ordained that now we should begin church schools. And He will help you." 2 Rejecting their request, she excused herself to serve dinner to the family. The ministers refused to accept her unwillingness and said they would be back the next moming for her reply.

That night she did her best to go to sleep, to no avail.

I have spent the last year thinking of nothing else; I will not waste another night thinking about it. But I did not sleep the night through--not a wink. You know someone had written a long time before the world war a book entitled. The Fifteen Decisive Battles of the World: well, there has been one more. It seemed that night as if the room was so dark and so stuffy. It stifled me. Then I said to the Lord, "You know I cannot go. You know how I feel"--and I was tou proud to fail. It is remarkable how

Ibid.. 9: idem. 'Educational History." 9: Christensen. 87.

:McKibbin, interview, 30 September 1967, 6. 
much pride has to do with the decisions in this world. I am too proud to go and start a school and fail. I could not do that.

Then I said, "You know I would do it if I could." Then the darkness would deepen, and it seemed I would suffocate and desperation would come over me. It seemed as if the Lord would leave me and I could not bear that. There I was, all alone in the world. I had no relatives out here. I had lost everything. I had no home, only God.

At that thought I had begun to think over and over how I had been thinking for a year. How I would teach a church school if I had to do such a thing. Then the room would become lighter, and I would be confronted with the difficulties that would rise up. So it was, back and forth all night, and finally toward dawn I told the Lord I would go. That I would go and fail. That was all the taith I had when I started out.

I had to make up my mind that God had called me; He cailed me in my weakness, and in our weaknesses there are many victories to gain.'

The following morning she gave the two men her decision that she would "go and try and tail." 2

While on the train from Los Angeles to Buena Park, she hoped the train would be wrecked so she would not have to go through with her decision. In imagination, she climbed the thirteen steps to the death chamber in San Quentin. She brooded over Centralia's past church-school fiasco and about the tailures of two other schools in Fresno and Oakland, where aquaintances of hers had terminated their efforts in discouragement. She felt they were much stronger and better prepared than she was. The more she thought about Centralia, the more convinced she became that her approaching task was insurmountable. "I went," she recalled later. "only because God called me to do it. I dared not refuse." She chose to subdue her turbulent teelings when she

Christensen, 38. 39.

:tbid. 
remembered that when God has a work to do on this earh, it is the devil who tries all the harder to keep his servants from its accomplishment. ${ }^{1}$

\section{Centralia $^{2}$}

Until the 1898-99 school year, apparently all prior attempts to establish a church school in Califomia had been aborted, due to at least one of the following factors: 1) the school was not well organized or supported, 2) the teacher did not stay to complete the terms of the teaching contract, 3) the school closed after one year, 4) the school had not incorporated sufficient educational reforms to be labeled a church school, or 5) in some other way the church school did not accomplish its objectives or leave a record of success. Attempts in Los Angeles, Garden Grove, Fresno, Oakland, and Centralia were unsuccessful for any or all of the above reasons. Most church schools before 1898 ran their curriculums much like the public schools. The school board might call in the pastor to teach a Bible class, or teachers might outline the Sabbath school lesson, but no church school boards specifically hired a teacher

Ibid., 89-90.

-The Seventh-day Adventist Encyclopedia lists the Oakland school, opened in 1889, as "believed to be" the first church school in Califomia. See Seventh-doy Adventist Encyclopedia. 1975 ed.. s. v. "Califomia Cunference." As noted under the previous heading. Experimentation with a Home School, the Seventh-day Adventist Encyclopedia also credits San Pasqual with that distinction. However, others, including Alma McKibbin herself, cite Centralia as "The church which has the distinction of being the first to build such a schoolroom" [meaning that the room was added on to the church|. See McKibbin, "Educational History," 5: idem, interview, 30 September 1967, 34 . 
Figure 7. Map of Orange County, c. 1891. Courtesy of Orange County Historical Association. 


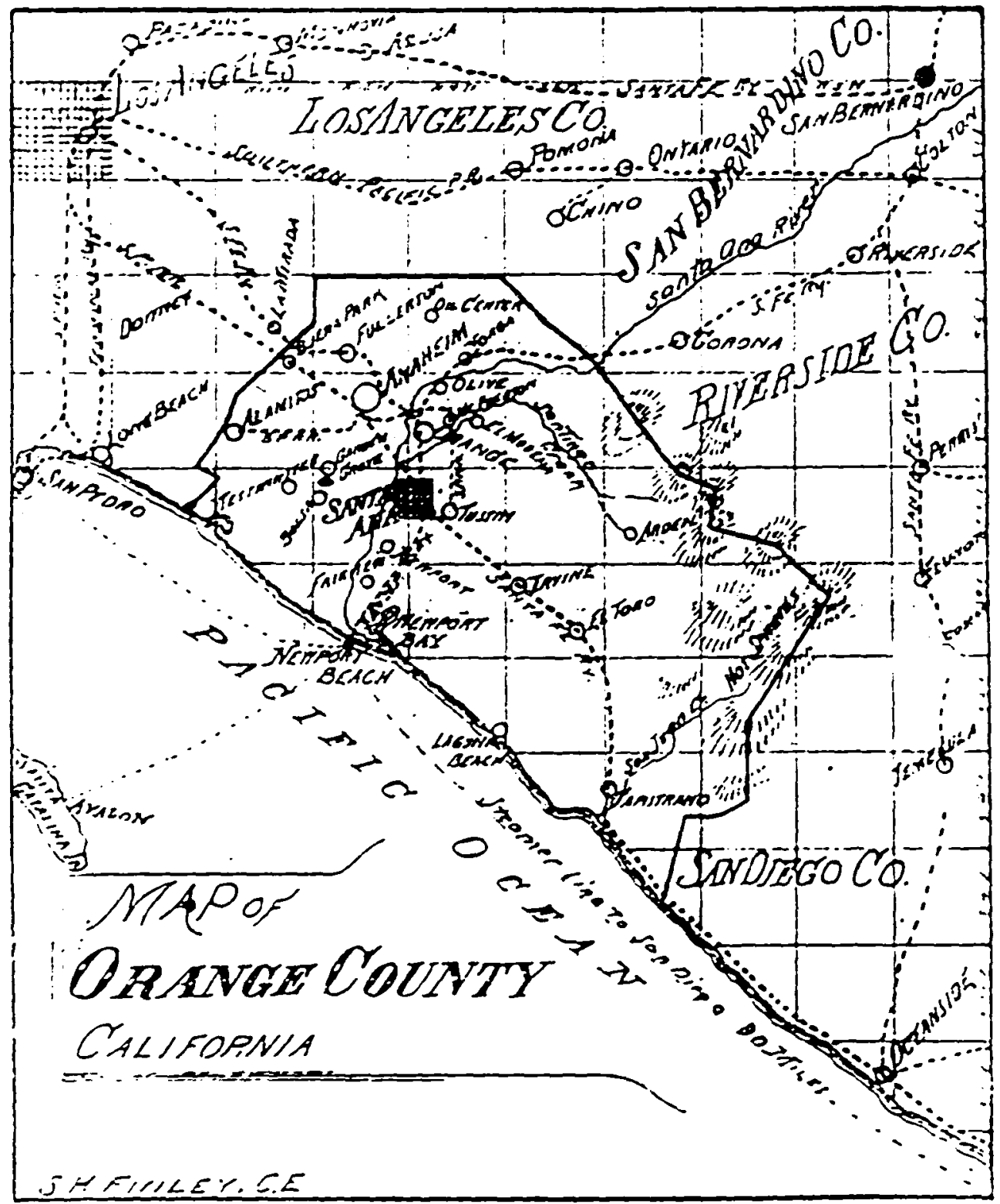

Reproduced with permission of the copyright owner. Further reproduction prohibited without permission. 
Figure 3a. Alma McKibbin, 1898. Courtesy of Bessie Bobst Martella.

Figure 8b. Alma McKibbin in the 1924-25 Mountain View Academy Annual. Courtesy of Bessie Bobst Martella. 

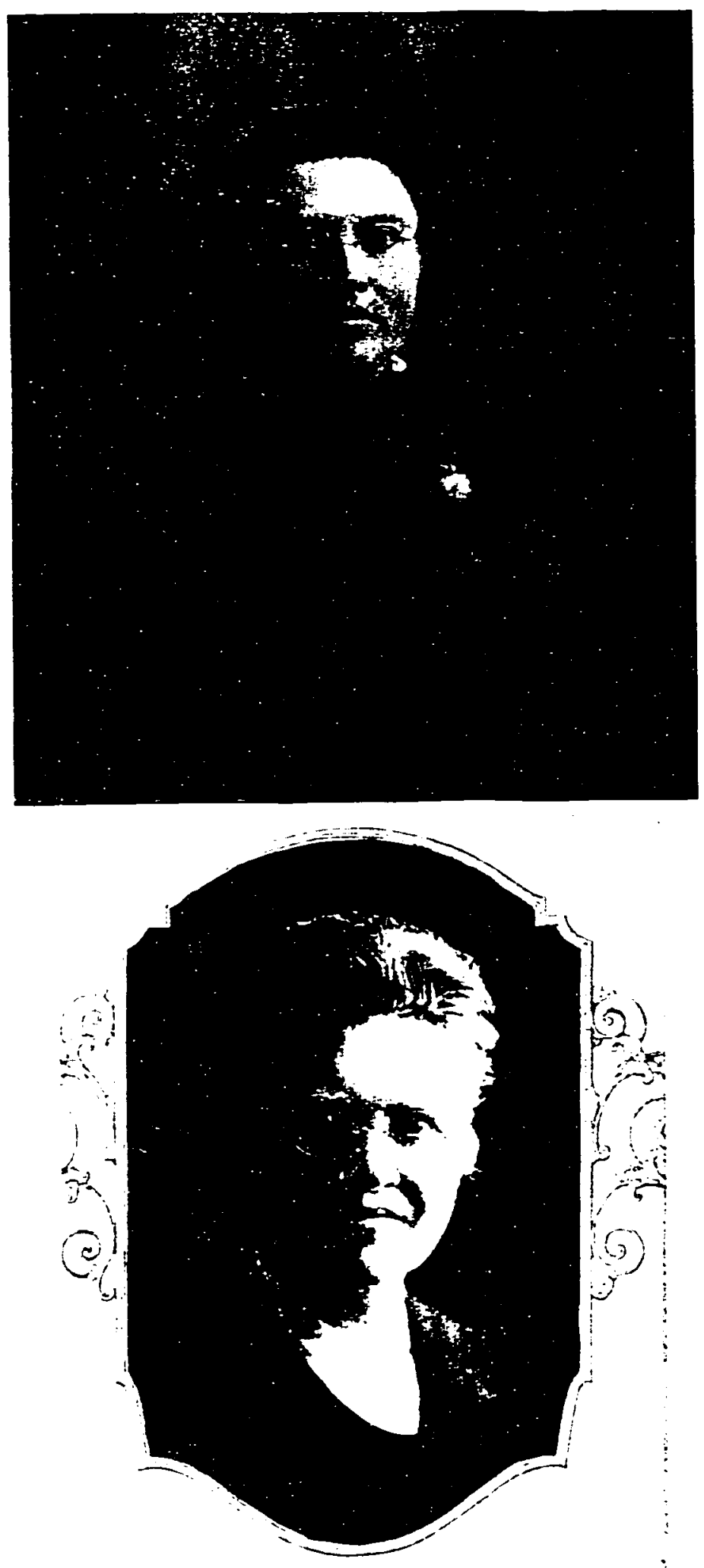
to teach their children a course of study that integrated all of the educational reforms. ${ }^{1}$ It will be seen that Centralia was different.

Located in the smallest county of southern California, Orange County, Centralians had suffered a drought since 1895 , when the nation was in a depression. With no feed for the livestock, by 1898 the remaining horses were being sold at the soap factory for $\$ 1.50$ a head. The sale of walnuts and cow pumpkins kept some people solvent; other workers traveled long distances to find work. ${ }^{2}$

Not only were the church members poor, but theirs was not a model church. It was riddled with problems. One of two brothers was saved from disgracing the church when an elder rushed to keep him from telling the police to arrest his sister-in-law because she talked too much. This elder was the same man whom Alma later prevented from giving his son a thrashing for being late collecting specimens in the drought. This elder demanded an explanation for Alma's short hair. Alma later reflected, "I don't know of any people who were less qualified to start a school than they were. ${ }^{3}$

"But somehow," she remembered, "they took to heart the Testimonies that came. ${ }^{n t}$

'Christensen, 85-86; McKibbin, •Educational History, $6-9$.

'Christensen, 87: McKibbin. interview, 30 September 1967. 24.

McKibbin. interview, 30 September 1967, 45.

'Ibid. Alma referred to a collection of letters Mrs. White wrote to various church members, using light given her by God to intervene or intercede in their lives. 
When Mrs. McKibbin arrived one week after her pivotal decision to teach at Centralia. she was given definite directions:

1. She was to teach everything required in the course of study for the public schools,

2. Although the children had missed several months of schooling the previous year, they were not to be put back in their grades,

3. She was to teach everything suggested in the Spirit of Prophecy, but. because of the drought, she was not required to teach gardening,

4. She was not to use any public school books, with the exception of the arithmetics, or any other books that contained evolution. myths, fairy tales or fiction. ${ }^{2}$

5. Although she was to teach all nine grades, she was not to double up any of the grades in teaching. ${ }^{3}$

The Board admonished her, "Above all things do not get behind the public schools in any subject. If you do, the children will begin to complain and want to go back to public school. ${ }^{n t}$ Not only would she have to teach the four solid subjects in the public school (reading-language arts, math, science,

Another name for the church's prophet and guide. Mrs. Ellen G. White.

-McKibbin, "Educational History," 9-10; idem, Mountain View, Calif., to Alta Ellegard (Robinson), Oakland, Calif., 17 April 1928.

${ }^{3}$ McKibbin, 'Expenences." n. d. AMs [photocopy], p. 4. Adventist Heritage Center. La Sierra College, Riverside. Calif.

Ibid. 
geography-history), but she would have to add Bible and nature study to every

grade, making six subjects per grade.

And then they expected me to do and produce just the same results that a public school teacher would who had only one grade with four subjects. Well, the dear people, you know, they were just like me--they didn't know any better.'

She was never able to resolve the problem of making a church school curriculum consist of a public school course of study plus the books of Bible and nature.

Again and again it nas been said that work in our church schools is harder than in the public schools. Quite true. Committees on Courses of study have wrestled long and eamestly with this problem with no satisfactory results. They have endeavored to make $4+2=4$. It cannot be done. "Figures will not lie."

Later we dropped nature study. How sad. Still we could not make 4 $+1=4$. Now what is to be done? Shall we eliminate the Bible to make our figures come right? ${ }^{2}$

I want to tell you a secret now: our eyes are still too much on the public schools. The testimonies that God sent, the light which He gave, was for something different trom the public school. ${ }^{3}$

Mrs. McKibbin arrived in Centralia on a Sunday. School was to begin the next day, October 3, 1898. She had sent for the Manual of the Public Schools of Orange Counr, California, but it did not arrive until the day school started. She was careful to conceal it from her Seventh-day Adventist landlady, fearful of the attitude of the church members toward the public schools.

Notwithstanding their affinity for adhering to the public school curriculum. they

\footnotetext{
'McKibbin. 'Church School Beginnings in Calitomia.' 18.

:McKibbin. 'Educational History,' 11.

'McKibbin. 'Church School Beginnings in Califomia." 13.
} 
did not want her to use a public school textbook because of what Mrs. White had written about infidel authors. They felt that any books written by people who were not Seventh-day Adventists were not safe to use in the school.'

Before coming to Centralia, Mrs. McKibbin had followed many leads to secure help as to how to teach a church school. She had written to the president at Healdsburg College, Roderick S. Owen, who had also been her former Bible teacher, for advice.

He had replied, "I believe in church schools because God has said we should have them. but I cannot help you because I have never taught one and I know no one who knows anything about how they should be conducted." 2

Professor Owen then reminded her that the church school work was new, and that attempts in the East and in other parts of California had failed. In closing, he added. "Since God has called you. He will help you. He is the Great Teacher. ${ }^{3}$

Alma had written to Battle Creek College, but the protessors there apparently had no materials for her. either. ${ }^{+}$

McKibbin. Step by Step, 70: Christensen. 92. There is a discrepancy between Alma's 1962 autobiographical account of finding the Orange County manual in the attic, and the account told by Lars Christensen, 1938. in which Mrs. MeKibbin says she sent for the manual and concealed it from the land lady. It would seem that the earlier of the two accounts would be more accurace.

:McKibbin. Interview, 30 September 1967,9-10.

'Ibid.

"Mckibbin. "Church School Beginnings in Califorma." 16. 
The night of her arrival, the little girl of the house had given her a workbook, hoping her new teacher would use a new method of handwriting called "Vertical.". By moming Alma had mastered Vertical.'

The next morning on the way to school, dried comstalks and withered trees seemed to reflect her spirit:

I wonder if you can see me the tirst morning I went to school. Three times I went back to my room to pray before I got courage to go on to the school house. It was a mile away, a long walk for my lame foot. ${ }^{2}$ It still was weak and bandaged, and I had to walk . . . through plowed ground to get there. I had a crutch and a cane. But I put them out of sight; I went early. $^{3}$ I carried my Bible, a notebook and pencil. my sole equipment.

She recorded a description of the schoolroom at Centralia. Jim Bobst had built the school as an added room on the back of the church. The people had done the best they could with what they had, but it was far from ideal. "The walls were unplastered . . . and the cracks between the boards were wide enough so that the children had been able to watch the courtship of their predecessor through them." 5 She described the school room as follows:

In the room there were ten double seats, cast-offs from some public school. There were 35 pupils to sit in these seats. As this was a physical impossibility, we hunted boxes. chairs, and benches which trequently lost their equilibrium and tumbled over. My "desk" was a three-legged table. A fourth leg was provided in the form of a packing box which I arranged so as to form a "swivel" chair. For a blackboard we had one twelve-inch

\footnotetext{
McKibbin. interview. 30 September 1967.13-16. Vertical is a way to teach cursive wnting by transferring manuscript letters into cursive, keeping the letters upright and adding connecing strokes.

-McKibbin. "The Way the Lord Has Led Cs," 9.

Mckibbin, interview, 30 September 1967, 17-18.

"McKibbin. "The Way the Lord Has Led Lis," g.

'Christensen. 90.
} 
board painted with ordinary black paint. There was a stove which smoked when the wind blew and that was the only time we needed a tire. It was so dark in the room when dust was in the air that I sometimes opened the door, but the wind then blew on my back and I took cold which resulted in a permanent neuralgia. trom which I have suifered ever since.'

When the Santa Ana winds blew with their characteristic force, sand inevitably crept in between the cracks.

The church members at Centralia had sacrificed to build their school. On Sabbath. Alma wondered why the hands of the congregation were black. Her boarding lady replied, "Oh. they have been picking walnuts; the only thing they can get to do here this time of year."

Alma's living conditions were poor, also. Her room had no stove. meaning that she would have to write lessons at night while suffering from cold. The lady who boarded her tried to discourage her. for it was the lady's secret wish for the school to discontinue. She had been disillusioned by the school's previous sad experience; but when the church members met her objection of having no funds by asking her to board the teacher. she had been left without excuse. She advised Mrs. McKibbin not to unpack all her things, telling her. "You won't last two weeks. Nobody can control these Centralia boys." ${ }^{3}$ Then,

McKibbin to Ellegard.

:ibid.

MoKibbin. interview. 30 September 1967, 12-13; Chnstensen, 93. 
every morning, she greeted Mrs. McKibbin with. "Well, are you really going to try it another day ${ }^{n 1}$

In addition to the land lady's remarks, church members in general had no respect for a teacher who "lived around, ${ }^{2}$ and consequently, they also treated her unkindly. The following example illustrates their lack of understanding when she had to delay teaching physiology for two months while waiting for textbooks that had been advertised before they were printed.

The first elder, characteristically, became very much agitated over the fact that physiology was not being taught in the school. He did not ask the reason, but at a meeting of the church at which I was not present expressed his conviction that the school was sadly failing, for physiology is a fundamental subject. Thus encouraged, other members found other defects, especially in discipline. All of this with all my pupils present.

I tell this incident not to disparage those dear people, nor to excite sympathy for myself, but to illustrate the attitude of mind of our people toward their teachers in those early times. They really expected their teachers to be miracle workers, to produce a perfect something out of almost nothing, and, above all things, to change their children overnight into obedient, respectful, model boys and girls. In many cases they had almost lost control of their older children, and their zeal in promoting a school was their hope that a teacher, a Christian teacher, would do for their children what they had not been able to do. ${ }^{3}$

For a long time. Alma begged God to let her out of these troublesome circumstances. 4

McKibbin. Step by Step, 71.

McKibbin, "Educational History," 12. In those days, school teachers often boarded at the nomes of their constituents.

${ }^{3}$ Ibid.

"McKibbin. "Church School Beginnings in Califormia," 19. 


\section{Alma's Teaching Methods and Practices}

In spite of her hardships. Alma set to work with a will. The iirst day she passed out cards and asked the children to write on them pertinent demographic data. Though she had no eighth graders, she had thirty-five children in grades one through nine, with one of them older than she.' Wisely she asked the upper grade students to come in the morning and the younger ones to come at noon. When the younger children arrived, the older ones would study their lessons.: She made out a grade plan for a church school and included Bible, using what materials she had--which were whatever nature provided. With no equipment, no library, no maps, and no help, she realized more urgently her dependence on God.

For geography class the children didn't mind digging out oceans, rivers, lakes, and bays for reliet maps outdoors on the ground. They built mountains out of dirt and sand and used blue Christmas wrap for water, since water was scarce. At tirst Aima attempted to teach geography trom the Bible. Later she was able to secure a geography text trom Battle Creek, written by Eliza Morton.: The board had wanted her to base United States history entirely on the Bible. but she felt she could not do this and teach eight grades.

\footnotetext{
McKibbin to Ellegard. Mckibbin. Inteniew. 30 September 1967. 19. The latter account states thirty-six children.

:rbid.

'Chnstensen. 93: McKibbin. Step by Step. 71.
} 
For nature study, Dare, the church elder's son, collected specimens from the nearby marshes, tields and woods. Although Aima had no nature outlines to follow at tirst, she finally secured some from Protessor Cady at Healdsburg. She still had to write lessons and gather materials and provide visual aids.

For science, Alma sent for Dr. J. H. Kellogg's physiology textbooks as soon as she saw them advertised in Good Health. but they did not arrive until two months after school had started. In addition to physiology, the board wanted her to teach health reform, but they dropped this request when Alma talked to the children about their eating at every recess. The parents now told her "not to interfere with the children's lunches."

Although she was permitted to use the public school arithmetic texts, later in the year one of the church members heard of an arithmetic manual that was based on the Bible, written by someone in Michigan. The informant pressured Alma to use this manual and discard the public school arithmetic texts.

I examined the manual and found that ... the problems were not graded, and there was no sequence of presentation, but I knew by this time not to say very much about any such matters. I realized that everyone interested in church schools was doing his very best to carry out the principles outlined in the Spirit of Prophecy. Necessarily iirst efforts must be crude and incomplete. So I welcomed the manual, and was careful to give one or more problems from it each day, but we still used the arithmetics.'

Christensen. 94.

:AlcKibbin. "Educatonal History" 11. 
Alma studied right along with the children in the arithmetic text. She amazed them when her answers agreed with those in the text. After the children told their parents. "The teacher in the public school said that answer was wrong, and Mrs. McKibbin said it was right," little did they know that she worked out every problem in her cold attic room at night.

For writing, she taught the vertical method.' The first day of school she wrote a message on the blackboard in this latest method. delighting and impressing the children. Since the blackboard was not large enough to put lessons on, she dictated the lessons to the children, using the dictation for their writing lesson.

She used Protessor Bell's Grammars, revised by Sarah Hall. There were three of them for different levels. ${ }^{+}$

For reading, Alma first examined the public school texts. She found that "most of the readers used in that county seemed especially iull of Greek mythology." 50 avoid those, she asked her children to read from Our Little

McKibbin, interview, 30 September 1967. 21-22.

Ibid.. 16.

'Christensen, 94.

Thid.

"McKibbin. "The Way the Lord Has Led Lis." 10. 
Friend, the Bible, Christ Our Saviour, and Bible Child Life.' The older children used Patriarchs and Prophets and The Desire of Ages. ${ }^{2}$

She taught woodworking as well. Each one of her children made a small footstool, at least one of which is still in existence. ${ }^{3}$

For Bible, the school board had wamed her,

"Now, we understand that in a church school you teach the Bible, but you don't spend all the time teaching the Bible, and nothing else. Now we like our older students to be taught the book of Daniel, and the younger ones the stories of the Bible. That's what we like to have taught. The teacher we had before taught one Bible lesson on the second coming of Christ, and that's all she taught. And the children can't even find the places in the Bible." say it."

"Well," I thought, "Why don't you parents teach them?" But I didn't

In spite of being wamed not to double up on grades. Alma split Bible into two classes; grades one through four started with the story of Creation, and grades five through nine, the prophecies of Daniel. To teach Bible, she faced a real difficulty: not only were there no public school texts to be used for reference, but no church school texts either. She had to write two lessons every night for Bible, and outline a nature lesson. ${ }^{5}$

Tbid., idem, Srep by Siep, 71.

:Christensen. 92.

James Nix. Director of the Adventist Heritage Center, Loma Linda University, interview by author, 12 March 1991, Loma Linda, Calif.

McKibbin, interview, 30 September 1967, 16-17.

'ibid.: McKibbin. "Bible Lessons for the Church Schools," 18. 
The first day, the children brought the books they had used in the public schools. Requesting them to leave these books for her to look over and to bring their Little Friends and other church papers, she dismissed the children early, for she had lessons to prepare.'

Besides I had to study each lesson in every subject before I taught it, because I had forgotten the things I once knew so well. I began to get my education the second time. It was hard and laborious. I taught from eight in the moming until six at night, and then sat up at night to get my own lessons."

\section{Alma Is Tested}

A few weeks after school began, some friends in Los Angeles invited her to visit them. They were interested in how her teaching was progressing. During her visit in Los Angeles, she was invited to the home of another friend for dinner. At this home she saw a doctor friend, who had come all the way from Oakland to Los Angeles to try to persuade her to give up teaching church school.

I [had] laught two months. I was in the very hardest of the battle. When he came and said, "See here, you're sick." I was. I wasn't telling anybody, though. . . .

"Now you just give it up, and you come up to Oakland with me." He had a sanitarium. "I'll take care of you. You'll get well. And then I'll get you a position where there'll be a salary. And you'll have something adequate to eat. Now," he said, "the public schools were good enough for you and me. It [sicl did us no harm."

That was the wisdom of this world. I said, "No, my friend, God called me here and here I'll stay until He tells me I'm excused."

He says. "It'll cost you your life."

Christensen, 92.

-McKibbin. "The Way the Lord Has Led Us." 10-11. 
[With tears in her voice, ${ }^{\prime}$ she] said, "Maybe so. He called me here, and here I'm going to stay." 2

When she returned to Centralia that evening, tired and discouraged, but determined to continue, dissatisfied board members confronted her with their grievances. Why wasn't she teaching physiology and agriculture? When she explained the books were delayed, they asked why she could not write her own physiology text until the new books arrived. Mrs. McKibbin long remembered that it took all her courage to explain that she could not do more than the three lessons she was already writing nightly. She later commented on the difficulties at Centralia:

I lived on prayer; I did not have much else to eat as my board was light and not always that which I could eat, so I lived on prayer. I think the early teachers did the same thing. Sometimes it would seem as if the devil would just come and choke me around the neck, and the room would get so dark. I would have seasons of despair and discouragement until it seemed as if it would kill me. I was not a person of very great faith, but the efforts of the early work developed it. ${ }^{3}$

Not long after this experience a former schoolmate of Alma's who was now the principal of the public school in Anaheim invited her to spend a Sunday afternoon with him and his wife. He offered her a position in the public school, predicting that she would fail at teaching church school. He pressured her, scorning her salary, and bringing every objection that he could to persuade her

\footnotetext{
'Alma E. McKibbin, -Development of the Seventh-day Adventist Church School System." 1956, tape recording, in the hand of Robert and Donna Jacobs. Angwin. Calif.

- McKibbin, 'Church School Beginnings in California," 9 (italics supplied); Christensen, 95.

'Christensen. 96.
} 
to join his staif, but she held her ground. "She was determined to teach her school." !

\section{Discipline}

Of all the trials she had to bear that year, none burdened her so much as applying discipline.

My mother [used to say], "You can never teach unless you leam to manage children--when you are left alone with your sisters you do not control them. You let them do much as they please. You cannot even discipline the cat. You spoil all the cats on the place."

I have no natural gift for understanding and controlling others, and I had some mistaken notions about this matter of control. I had seen so much harshness and severity in homes, so much heartache and sorrow, that I had decided that since I was teaching a Christian school I would persuade my pupils to do right--I wouid rule by love.

I thought I would make their work so interesting and love them so much that my pupils would just naturally behave, but alas! They did not behave, and my first school almost ran away with me.

Problems with discipline were compounded in Alma's thinking, not only by her background and experience, but also by her ideas of what discipline in a Christian school should be like. Her struggle over discipline seemed to be a turning point in her career. Her future success as a teacher and the continuance of God's blessings on her etforts depended on the outcome of this struggle:

When church schools were started there was much talk of how different they should be from state schools. even in discipline. A Christian

\footnotetext{
Ibid.

'McKibbin. "The Joy and Reward of the Chnstian Teacher." 2.

"McKibbin. The Way the Lord Has Led Ls." 11.

"Mickibbin. The Joy and Reward of the Christian Teacher." 2.
} 
school should be ruled by love, not by torce, it was said, and I was fully convinced of :his and endeavored to control the pupils by love, but alas! I soon discovered there was something wrong either with the principle or maybe my way of applying it.

I knew I loved those boys and girls . . . I lived to do them good, but they did not understand somehow, and every day they grew more disorderly until finally one Friday when I closed school I knew that by another Friday if things went as they had been going that they would probably tell me they did not need me any longer, that they could run the school themselves. Yes, I had failed--failed in discipline, and if a teacher tails in discipline, he fails in everything.

This is what I had to think about all that long, sad Sabbath. Every time the train whistled. I begged the Lord to let me go--go away and never come back, and the long, dark, sleepless night brought no relief. When the light of Sunday came, with it came an inner light which was not welcome. It was like a voice which said. "You can control these boys and girls if you will change ycur methods. You must always rule in love but rule you must somehow if you would do your duty by the boys and girls and be blameless at last. They will be ruined if they do not learn to obey and to be orderly and you will be responsible for their souls in the day of judgment."

Oh, what a struggle went on in my soul that day. I never had even tried to control anything or anybody in all my life. It was contrary to my nature. . . My first great task was with myself--to get the will to compel obedience into my own soul. . . There was an almost irresistible desire to give up. . . . It was too hard. this having to make other people's children mind. They wouldn't understand. Why, they might even dislike me. perhaps hate me. This tortured my soul, but always the voice called me back and said. "This is your duty because it is My will." At length, exhausted in body and mind. I gave up and said. "I will do it at whatever cost."

She walked the mile to school that morning determined to conquer her fear of disciplining the children. She trankly contessed to the pupils her mistake in discipline methods, informing them that she was changing her methods to do what God wanted her to do. She also reminded them that they represented the first church school in California, and that they were setting an example. She 
asked them if she acted like a real church school teacher, and her students pointed out her weaknesses in discipline. They helped her write rules for the teacher on the blackboard, as well as rules for themselves. All went well, for a time, and "it was heavenly. ${ }^{\text {I }}$ However, Coy Fewel soon brought things back to earth. Alma recalled:

What do you think he did? He tumed right around in his seat, and put his feet up on the desk behind him in the face of the girl that was there--his big brogans, and then used his feet as a prop for his geography.

I walked back and said, "What does this mean, Coy?"

"Oh, I'm so tired of being good. If you had begun right in the first place the first day I might have got used to it. But I have got so used to the other way I can't be good any longer. I'm tired." He'd been good all the forenoon. Half-a-day. And he was tired.

"Well," I said, "Coy. Are you rested now so you can take your feet down? Do you refuse to take them down?" I stood there a moment. "Well," I said. "Coy, I'd hoped that you and I could work together for eight months. But since you refuse to conform, there's only one thing that I can do. I must ask you to take your books, and go home until you're ready to conform. When you're ready to conform you may return."

Why, he was down, and quicker than "Scat" he had gathered those books up, and started to the door. . . . He never came back. ${ }^{2}$

While this episode had a sobering effect on the other children, Mrs.

McKibbin suffered immeasurably, finally getting so ill that she had to leave school. ${ }^{3}$ She blamed herself for Coy's leaving and grieved over this episode for years. In ensuing years, she would ask friends from Centralia about Coy. Finally, one woman remembered to convey a message he had sent to Mrs.

'Tbid., idem, interview, 30 September 1967, 26-28.

:McKibbin, interview, 30 September 1967, 28-29.

Ibid., 30-31: idem to Ellegard. 
McKibbin. In the message, he explained that the reason he left school that day was that he really didn't want to go to school anymore. His tather had accepted his decision and put him to work at home as an apprentice in carpentry. Coy conveyed his repentant feelings to her:

I've lived long enough to know that I made an awful mistake that day. I'm the elder of the church here, and I'm trying to set a good example, and I'm glad to know that my children love to go to school. But that's because of their good mother. But you tell Mrs. McKibbin that I made an awful mistake when I went. and refused to come back. I know that it broke her heart.'

She had a helper with discipline problems in Centralia, although this helper could not solve them all. Warren Daugherty, whom church members wrongly accused of courting Alma, was twenty-seven. a year older than Alma. He wanted to be a nurse but needed ninth and tenth grade to qualify for the nurse's course. She did her best for him. One day during lunch hour, while she was eating outside with the children. two cousins began fighting. These were the boys of the two brothers mentioned earlier who didn't get along, and this was not their first tight.

The blood just tlew all over those . . blackboards. . . . Warren saw it through the window. So he went right in and he did what he could but they were so angry that he tinally came out, and told me .... Oh. it was a sad thing.'

She sent them both home and requested that the board deal with them.

The board apparently loathed getting into the tamily feud and did nothing.

McKibbin, intervew. 30 September 1967. 30.

ibid.. $4+45$. 
Finally, the parents of the non-aggressor came to her and stated that they felt their boy should be permitted to return. Upon checking with the board, Alma found they felt the same way as the boy's parents but had been unwilling to tell her. She therefore allowed this student to return. The second boy approached her at her boarding house a tew days later. wondering why he couldn't retum. Admitting he was the aggressor, he offered to take the whipping if the board would give it to him. The board again did nothing. With only two weeks of school left betore he would be taken out for spring planting, he returned to Mrs. McKibbin, telling her that he felt it was her duty to give the whipping. He then made an appointment for his punishment.

On this day she asked one of the older boys of the school to go to some of the trees nearby and get her some switches. Shortly after all the children had gone home. the young man to be punished, dressed in his very best clothes. driving his poor bony horse. hitched to a nice clean buggy with a nice ribbon on the whip stock, drove onto the school grounds, tied his horse to the hitching post and sauntered up to the building. When he came into the schoolroom he saw the switches lying on the table; looking nirst at the teacher and then at them. he seemed to hesitate as to whether he would come in. Finally he did, and atier taking a chair and talking with her for a while. Mrs. McKibbin took the switches and whipped him.

She says she does not think she hit hard enough to hurt a flea, but his eyes were filled with tears and so were hers. Later she found out that he went home and told his mother that he felt so sorry for Mrs. McKibbin that afternoon that if it had not been for the "pesky neighbors" who might gossip, he would have asked her to have gone out for a buggy ride after the punishment.

Years later at a camp meeting, one day, he came to her tent and introduced his wife and two little children, and said he brought them for their "grandmother's" blessing, and that he wanted his wife to see the only woman that had ever whipped him. 
After this ordeal there was no more discipline trouble in the school for the rest of the year.'

She felt that the Lord had helped her to be tirm: "At last I won out."

Warren Daugherty, Alma's student and helper, did later take the nurse's course; he was accepted into the course on the basis of his one year with Alma. He spent years in Mexico as a missionary nurse "and tinally died, like Livingstone, by the bedside of a poor, sick Mexican." ${ }^{3}$

As the years passed. Alma sought out news of Dare, her specimen collector, too. When she heard that his wife had put him in prison on trumpedup charges of incest, she wrote to the warden in Dare's defense.

The regard she carried for her students, as a parent for a child, cost her her healtin. The stress of discipiine and the constant cold temperatures at school and at home led in time to double pneumonia. A "Santa Ana" blew so much dust through the cracks in the walls that her students couldn't wipe off their school books last enough to keep reading them. In a hoarse voice, she dismissed the children for Christmas vacation a week early. While she was packing, two board members came to her room.

They looked around and said. "Where's your stove? Where's your heat?"

I said. "I haven't any."

Christensen, 97-99.

:Ackibbin to Ellegard.

Mckibbin. intervew. 30 September 1967. 33.

Ibid.. 48 . 
"Have you lived here all this time without any heat in your room?"

I said. "I have no heat here and I have none at the school. . . You remember I sent you a card, a note saying that I couldn't use the stove because it smoked so badly?"

"Oh, I believe you did do that. But we forgot. We've had so many problems ourselves." "I

She went back to San Pasqual, where Mrs. Johnson administered hot fomentations to her lungs for six weeks. Mrs. Johnson also wrote a letter to the school board, educating them about the conditions under which their teacher had labored. Alma saw her sickness as a way out of teaching and did not plan to go back to Centralia. But soon letters of apology came, pleading tor her to retum, and asking what could be done to induce her. She answered, listing the conditions under which she would comply with their request, assuming those poor people would not carry out her stipulations. But they did.

Doing all the work themselves, they plastered the schooiroom, made real blackboards on three walls. moved a window. and installed a stove that worked and seats enough for all the pupils. In two weeks they iniormed her that all was done that she had asked. and that in addition they had secured her a place to board next door to the school.

\section{She Finisines the Year}

Shortly after this experience, the school board ran out of money. They had strained their budget to the limit with all of the improvements and now could not meet their salary obligations. She had signed a contract for eight months.

Ibid.. 23. 
and when she walked into that "funeral"' board meeting she witnessed long faces, crying and weeping. They told her they could not bear to lose their teacher after only five months.

By this time, Alma had gotten her "second wind:" 2

I became fully convinced that the devil was trying to drive me away, and I finally ceased to pray that the Lord would let me go. I only said, "Lord, You keep me here for these eight months. . . . You uphold me for eight months, because I promised. ${ }^{3}$

She asked them if they could pay the five dollars for her board in lieu of the promised fifteen dollars a month. One of the women church members helped meet this obligation by selling a precious family heirloom she had brought over from England. She managed to survive by eating a diet consisting largely of walnuts, eating so many that it took years for her stomach to heal. By August those board members had managed to supply the forty-five dollar balance, and Mrs. MrKibbin said she never lost a cent teaching church school. She later wrote,

In spite of poor health and many other difficulties, the fact that I fulfilled my contract to teach eight months proves to me that when God asks us [to]

'Tbid.

-McKibbin, "Church Schooi Beginnings in California," 19.

'Ibid., 19-20.

"McKibbin. 'A Story of the Origin of Bible Lessons for the Church Schools." 18: McKibbin, interview, 30 September 1967, 22-25; Emily Hixson. interview by author. 12 March 1991. Loma Linda. Calif.; Christensen. 100-101: McKibbin to Ellegard. 
do something for Him, He gives the strength and power to accomplish even a seeminglly] impossible task.'

John Haussler, who wrote a dissertation on the history of the Seventhday Adventist church in California, concluded from his interviews with Mrs. McKibbin that her success at Centralia carried a lot of weight in changing church members' attitudes toward church schools. ${ }^{2}$ In fact, her achievement directly influenced the building of the church school in San Pasqual in February of 1899. William Potts, who had gone to Centralia for the wainut harvest, learned of the "successful work of the Centralia Church in establishing a school. ${ }^{\text {3 }}$ When his colleagues in San Pasqual did not all agree that San Pasqual needed a school to be built, he forced the issue by putting his farm up for sale so that he could move his family of six children to Centralia. The brethren conceded and built a school. ${ }^{+}$

It was at Centralia that Alma McKibbin was given her famous "Book of Remembrance." On her birthday the children wrote on the cover of this scrapbook,

'McKibbin. 'Experiences." 6.

THaussler. 184.

3"Then and Now-A History of San Pasqual Academy and Its Valley," AMs. pp. 2-3. San Pasqual Adventist Academy, Escondido. Calif.

"Ibid.: Elizabeth Judson Roberis, "A Historical Gathering," 14 May 1950, AMs, p. 2. San Pascual Adventist Academy, Escondido, Calif. 
"A Birthday present to our Teacher, Mrs. Alma McKibbin, by the seventh grade pupils at Centralia, California. November 26, 1898. A book of remembrance." 1

In it were inscribed all the names of her students, with her picture and a picture of the Board of Education. She would continue to inscribe in this book the names of the thirteen hundred pupils she had in her lifetime, with little anecdotes about each one. It became very meaningful to her students to be included there:

Back sometime before 1962, I read a serial by Mrs. Alma MfKibbin in the [Review and Herald], to my husband. When she mentioned her "Book of Remembrance," Eddie said. "My name is there." Without telling him. I wrote to her about him. In a beautiful reply, Mrs. McKibbin told of turning to a certain page in her memory book. and there was "little Eddie's name." Listening to the letter, he wept."

Throughout her entire year of service to the Centralia Church, noone came from the Conference to encourage or counsel her. Churches didn't even have enough pastors in those days, and there were no educational supervisors or superintendents.

Every church said. "You must stand on your own two teet." The ministers must go out to teach the truth to the people. They can't hover over the churches. Not a minister came near there. It was "Sink or swim; Survive or perish. ..." The church schools began with nothing. We hadn't a textbook. . . If God was not in [this movement], do you think with such a beginning as that it ever could have succeeded?

There wasn't a Bible lesson tor a church school anywhere. I had to write them and teach them the next day. There wasn't a nature study lesson. I wrote them at night. There was one little boy in school [who would] go out to the marshes and hunt up all kinds of specimens for me. He'd come in with his pockets iull of them. A crab in one and a little garter snake in another and a beetle in his hand, perhaps. Specimens for

:McKibbin, interview. 30 September 1967. 20.

:E. Frances (Reed) Vielhauer, Lebanon. Oregon. to author. 31 December 1990. 
Figure 9. A Shoestring Book and the Book of Remembrance. Courtesy of Pacific Press Publishing Association. 


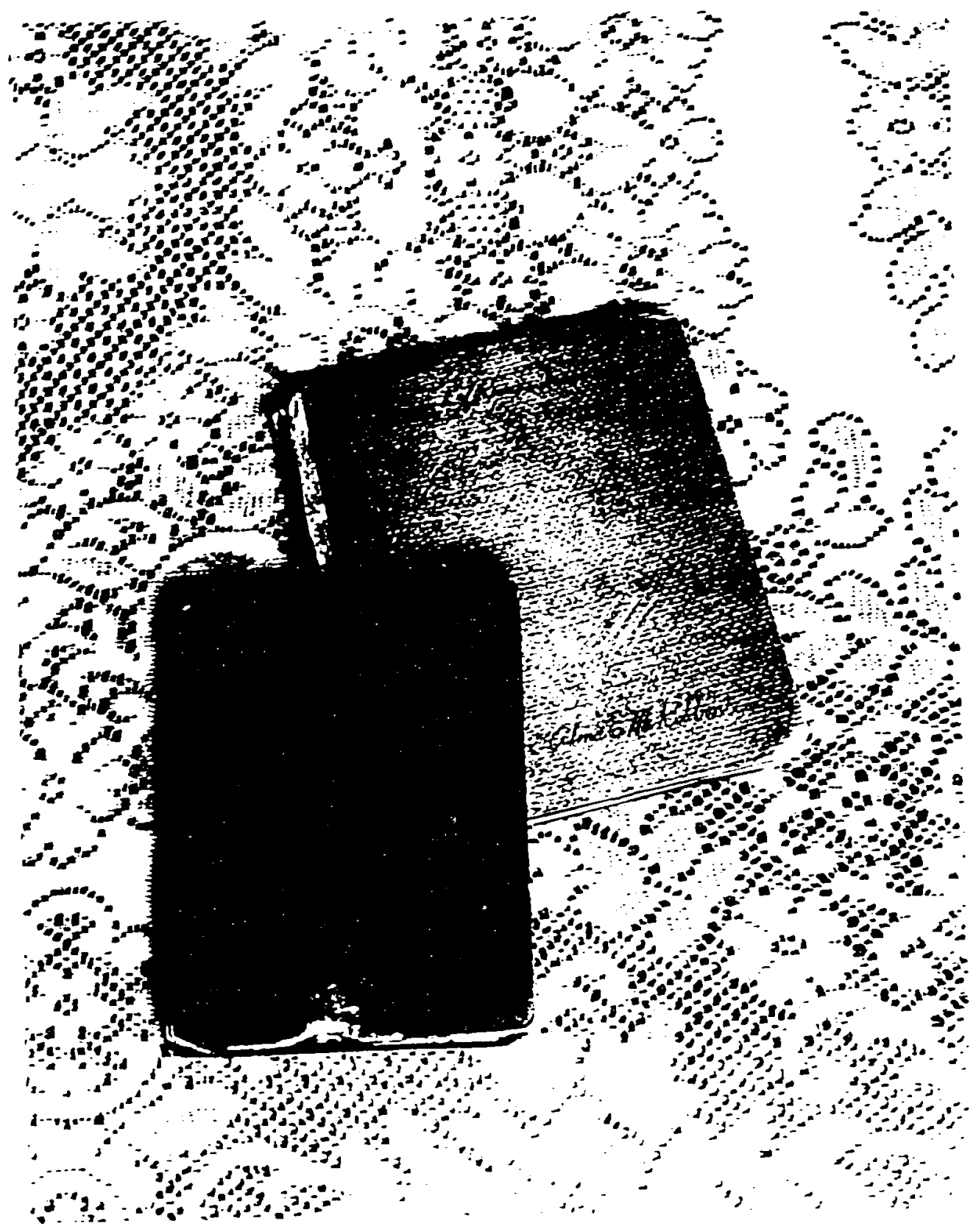


me. Why, that's the way we did it then. And God, somehow, somehow out of all of our ignorance, developed a church school system.'

\section{First Seventh-day Adventist Church School} Teacher Education in California

The California Conference president sent Alma a telegram, requesting her to come to the Stockton camp meeting to receive some important information. He also sent her a train ticket. She closed school a few days early, on May 5, 1899, so that she could arrive in time. She learned that she was to work with the primary division at camp meeting. She was also offered a position to teach the four lower grades at the church school in Healdsburg. Another teacher would teach the upper grades. But on the basis of the experience at Centralia, she had resolved never to teach again until someone showed her how:

M. E. Cady, president-elect at Healdsburg, persuaded her to accept the teaching position by assuring her that the very problems that were bothering her would be solved following camp meeting at a new teacher's institute offered at Healdsburg College. He told her he was actually at camp meeting for the purpose of recruiting teachers for that summer school. His plans were to train in one summer enough teachers to staff several new church schools beginning in the

Mfckibbin. "Church Sihool Beginnıngs in Califorma." 23-24 (italics supplied).

:AfcKibbin. "Bible Lessons for the Church Schools," 18. 
state that fall. He had advertised in the Review that "in one summer Healdsburg College would fit a mature person to teach in either public or church school."

Rejoicing at the prospect of being instructed how to run a church school, Alma accepted the position at Healdsburg. Imagine her dismay when she learned the night before the institute was to begin, that since she was the only one who had had any experience teaching in a church school, she would be the instructor for the summer school. She would teach all the church school subjects except arithmetic, and all methods except principles of education. Eleven new recruits from camp meeting would be her students.

She vigorously protested, but Professor Cady insisted, pointing out that these recruits had never taught at all, and she had had a whole year of experience. Besides, he needed to return to Union College to pack up for Healdsburg, and Professor E. S. Ballenger would be present at the summer school as principal to help shoulder the burden." Alma revealed her feelings:

I am not a stranger to disappointment, but none was greater than this. I had a bad night, a very bad night. I leamed a hard lesson. I learned not to expect human help, not to lean on others. ${ }^{3}$

\footnotetext{
Christensen. 101.

'Ibid., 101-102; McKibbin, 'Bible Lessons for the Church Schools,' 18-19: idem to Ellegard.

'McKibbin, "Bible Lessons for the Church Schools," 19.
} 
Teacher Training at Summer Schools

At night Alma had to manutacture methods "out of nothing, "' for

"eleven persons that had been impelled by the Spirit of God as I had been. who trembled just as I did." ?

Each day ... she went to her classes as if she knew all they needed to know and encouraged the raw recruits as they poured over their problems together, but she felt a greater need of instruction for herself than those who had not taught were able to feel toward their own needs. ${ }^{3}$

I can see those eleven teachers. . . sitting there before me with their mouths open. They look in every word I said. And I'd go home and I'd say, "Lord, You'll have to tell me what to teach them tomorrow; You know I don't know. "

Before Alma taught them how to use a sand map, this group had never before seen one. They experimented also with salt and flour maps in Alma's room, and made a tairly representative map of South America. "In a few days there were South America maps all over the place."

She strongly believed in teaching the fundamentals, and drilled those who needed basic skills.

Some of them had forgotten their multiplication table. We drilled on the multiplication table. And as for fraction and percentage, just had to drill. drill, drill, by the hour.

'McKibbin. 'Church School Beginnungs in Califorma," 22.

تtbid.

'Christensen, 102.

"McKibbin. "Church Sthool Begunnungs in Califomia." I2 (italics supplied).

'Ibid.

'Mckibbin, interview, 30 September 1967, 36. 
For thireen weeks during June, July and August, 1899, teachers and students studied all of Christian Education. Alma stayed up many nights "preparing outlines and seeking to make the Bible the groundwork of every subject. ${ }^{n 1}$ She also wanted to make the difficult portions of each subject clear to her students. Together they outined a year of Bible lessons, beginning in Genesis, and consisting only of the name of the lesson topics and questions with Scripture references. Although Alma had taught the upper grade students the prophecies of Daniel the preceding school year, she did not follow that precedent. Some teachers felt that beginning with the book of Daniel in the upper grades was too difficult, and that the Bible stories should be outlined first. Alma agreed, feeling that the Bible should be taught chronologically. She recommended that each teacher write her own lessons from the outlines Alma provided, and the recruits consented. Each teacher was given a hectograph copy.:

Many times Professor Ballenger joined her and the eleven in prayer. "And God blessed our efforts. Many times as we thirteen prayed together, the Spirit of God came down to encourage and enlighten. ${ }^{3}$

Ibid.

:McKibbin. 'Educational History," 15-16; idem. 'Bible Lessons for the Church Schools." 19; idem, interview, 30 September 1967. 36. A hecrograph is a device for making coples of a writing, etc., from a prepared gelatin surface to which the original writing has been transferred.

'McKibbin. 'Educational History," 14. 
Although Professor Ballenger had no authority to credential these recruits, he examined them at the end of the summer and gave each "a sort of recommendation. ${ }^{n 1}$ By fall, ten new church schools had opened in California and had hired ten of those eleven teachers. ${ }^{2}$ There is no record as to what happened to the eleventh teacher.

Summer schools became regular events, and teacher preparation became one of the most emphasized activities hosted by Heaidsburg College. ${ }^{3}$ Apparently in the early 1900s, Healdsburg College was the center of activity for Califomia church and conference work, especially in the northern part of the state.

Many of Alma's original eleven teachers retumed to the 1900 summer school in San Jose for additional training. These 1899 students had written to her regarding teaching Bible, saying, "I cannot write lessons," or, "I have no time," or, "I do not feel competent." Since no Bible textbooks were available, teachers laboriously copied lessons Alma had written in old, battered notebooks when she taught church school. Alma's thoughts regarding the plight of these teachers reflect a value that would affect future textbook writing:

'Tbid.. 16.

'Christensen, 102-103.

'Engel, 101.

"McKibbin, "Educational History," 17; Gsorge Fred Jackson. "The History of Seventh-day Adventist Education in Califomia" (Ed.D. diss., University of Califomia, 1959), 179. 
I was very disappointed, for I was coming firmly to believe that Christian Education in a sense, more than any other system of education, demands originality and independence of thought. What a blessing it would have been if each teacher had become the author of the lessons she used, and if not a writer of Bible lessons, at least a master of the subject. ${ }^{1}$

At this 1900 summer school, which followed the San Jose camp meeting, Alma worked on a committee that revised the course of study for church schools. The result was a small booklet. Course of Study for Church Schools, which was well received in the rield.'

The institute held in the summer of 1901 added a new teacher to its staff, Jessie O. Barber Osborne. She and Alma became lifelong friends. ${ }^{3}$

The Pacific Union Recorder announced in its very tirst issue (1 August 1901) that the teachers' institute would begin August 26,1901, and would run for three weeks, to September 13. In a subsequent issue. Mrs. Alma E. McKibbin was listed as lecturing at the institute on "The Relation of Patrons to Our Church-Schools, and Vice Versa." ${ }^{\text {" }}$.Mrs. Ellen G. White was a Sunday aftemoon speaker at this institute, and at many other institutes. as well.

\footnotetext{
McKibbin. 'Educational History.' 16.

irbid.

'See p. 167.

"Church-Schools: Notice to Churches in Hualdsburs College District." Pacific Union Recorder 1, no. 1 (1 August 1901): 10: 'Program of Teachers' Instutute at Healdsburg. Califomia, Aug. 26 to Sept. 13." Pacific Chion Recorder 1. no. 3 (15 August 1901): 11.
} 
The next summer institute began July 2, 1902. Alma's name is not listed in the Pacific Union Recorder as an instructor, likely due to her breakdown in health.' She was also engaged in textbook writing.

Haussler states that Alma was on the committee to improve the "old course of study" in 1903 in order to facilitate a uniform course of study for the church schools of the conference. The first complete school manual for Pacific Union elementary teachers was published in 1903, and revised and republished for the denomination as a whole in $1905 .^{2}$

Alma's first edition of Bible Lessons for the Church School came off the press in 1903. This edition, consisting of two books, was apparently ready in time for Teachers' Institute August 3, and was recommended as "just what the teachers needed," being the "outgrowth of actual experience by one of our most successful and talented church school teaciers. ${ }^{3}$ Alma evidently had to be persuaded to publish the textbooks.

At length Professor Cady insisted that I have my lessons printed. He thought it necessary to have uniform lessons for all, for some teachers taught no Bible at all except in morning exercises, because they had no prepared lessons, and he feared that soon they would make no attempt at all. If the Bible was not taught, then all our effort to establish church schools was in vain.

"Notice," Pacific Union Recorder 1, no. 23 (19 June 1902): 16; McKibbin. interview, 2 August 1967, 16; Alma E. McKibbin, 'A Teacher's Satisfactions, "Youth's Instructor 92, no. 21 (23 May 1944): 5: idem. "The Joy and Reward of the Christian Teacher," 4.

:Haussler, 186.

'California Conference of Seventh-day Adventists (Oakland, Calif.), Minutes, 1 June 1904. 127-8. 
Thus presented, I could not refuse to do what I could to supply lessons for our schools. And so, once more I must do what I did not know how to do-write books and publish them. Even after all these years I still cannot understand why teachers do not prefer to prepare their own Bible lessons, or teach directly from the Bible. Our teachers have always leaned too heavily upon their leaders, but I remember that is what I wanted to do and would have done if there had been anyone to lean upon.'

In the summer of 1904 Alvin S. Kellogg, President of the CaliforniaNevada Conference, called together the first meeting to systematize the schoolbooks for church schools in the denomination. The meeting was held at St. Helena, with professors Cady, Howell, Sharp and Sarah Peck in charge. ${ }^{2}$ The group chose the three areas in which textbooks were most urgently needed: Bible, nature, and reading. Alma was to write Bible for grades four through eight; Professor Cady and Katherine B. Hale were to work on nature study, and Sarah Peck, on readers. ${ }^{3}$

That same summer Mrs. Alma E. McKibbin was listed on the editorial staff of a new monthly publication that was to provide suitable reading material for church school students.

According to Christensen, the editorial committee met again at Sara Peck's home, right after Teacher's Institute in St. Helena, California, in the summer of 1906. Alma's assignment was to cover Bible for all grades.

\footnotetext{
'McKibbin, "Educational History,' 17.

:Aivin S. Kellogg, Nice. Calif., to Alma E. McKibbin, Mountain View, Calif., 26 March 1946. Apparently M. E. Cady felt that he was the one who called this meeting. See Haussler. 190. Adventist Heritage Center, Pacific Union College, Angwin. Calif.

${ }^{3}$ Haussler, 190-91.

'Tbid., 190: "Pacific Union Educational Council." 6.
} 
Katherine Hale, readers for grades one and two, and Miss Peck, readers for grades three and four, with grades five and six added when another committee member could not do his work. Professor Cady agreed to write the readers for grades seven and eight. ${ }^{1}$

By the summer of 1908, Alma's name was at the head of the list of instructors for the teacher's institute. Bible for grades four, five and six was listed first among the subjects offered. Besides teaching Bible methods, her responsibilities at the 1908 institute also included presenting a paper on "Literature for Children." 2

Alma continued to labor in summer schools for the Pacific Union Conference for many years. ${ }^{3}$ She taught methods in the common branches and in Bible. Alma required her teachers to purchase Rand McNally maps for Bible lands. In later years, when the Pacific Press began to publish her materials, she drew maps and had them printed in packets for teachers at twenty-five cents each. These packets were published for years "until a new set of teachers came that didn't use maps. "4

'Christensen, 105.

:"Teachers' Institute. Pacific Union Recorder 7, no. 40 (7 May 1908): 2.

${ }^{3}$ On July 27, 1909. Delpha Miller sent Alma a postcard in care of the Western Oregon Teachers' Institute in Gaston. Oregon. Delpha encouraged Alma to stay with her before traveling to the next institute that same summer. See Delpha S. Miller. College Place, Washington, to Alma E. McKibbin. Gaston, Oregon, 27 July 1909. in the hand of Paul Ricchiuti, Nampa, Idaho.

'McKibbin. interview. 2 August 1967, 29-30. 
Alma believed geography was indispensable for teaching Bible history. She used a map to illustrate Israel during the days of David and Solomon, which was the only time the small country ever possessed all the land that it was promised. By the use of maps Alma demonstrated how borders changed when the kingdom was divided. Knowledge of these boundaries was necessary to understand what lands were lost when the ten tribes were carried away. Alma strongly valued maps as visual aids that confirmed textual material in students' minds:

Before I made that [map] I never could make it very, very plain that Israel was carried away; the ten tribes, and that as a people, they never came back. I never could get it into every head. But, when we had copied that [the map] down, it was clear.'

The 1910 California-Nevada Teachers' Institute arranged for Alma to give daily presentations. In nature class she emphasized God's creation of the world and Satan's attempts to usurp world ownership by inscribing his own markings in nature. Alma advised students to look beneath Satan's marks and see God's name in creation. On another occasion, an animated discussion followed her talk. "The Influence of the Teacher." In still another presentation she stressed reading as a means of imparting truth. Her tinal speech at the institute accented four points to be considered in church school work: subject matter, modes of expression, composition and character sketching.:

ibid.. 29.

'Lida Ackley. 'Secretary's Day-by-Day Report of the Califomsa-Nevada Teachers' Institute." Pacific Union Recorder 10. no. 9 (29 September 1910): +. S. N. Haskell. 'Teachers' Instrute." Pacific Union Recorder 10. no. 9 (29 September 1910): 7. 
Throughout the next decade, many teachers attended summer institutes in which Alma was the Bible methods instructor. One teacher expressed her reaction:

I had the privilege of a lifetime. Alma McKibbin, the author of our first elementary Bible books, was the Bible teacher. We spent the class time repeating Bible texts. Each day we would start with the first text and go through ihe list.'

Summer schools were not the only time Mrs. McKibbin helped to train teachers. In 1899, church school teachers in the training school, where student teachers did their practice teaching, worked closely with these preservice teachers.

\section{Responsibilities at Healdsburg}

From 1899 to 1903. Alma worked in the "revived education deparment" of the Healdsburg Preparatory School under the Cady administration of Healdsburg Coilege.: She was principal of the school from 1899 to 1902 and taught the intermediate grades.

Alma herself taught church school until 1902, when her doctor required her to limit her activities, in consequence of her impaired health and the

'Enid Sparks in Miriam Wood. "Good Old Adventist Golden Rule Days," 1990 TMs, adventist Heritage files, La Sierra College, Riverside, Calif., 16.

35.

:Seventh-day Adventist Encyclopedia, 1975 ed., s. v. "Pacific Union College"; Utt.

'McKibin, Educational History, 17: General Conference of Seventh-day Adventists (Washington. D. C.), Bulletin 3. no. 8 (Fourth Quarter 1900): 216; idem. (Washingion. D. C.), Bulletin 4. no. 3 (Third Quarter 1901): 535: Pacific Union College, Healdsburg College 19011902 Eighreenth Annual Calendar [Healdsburg. Calif.: Healdsburg College Press, 1901], 4. 
strain of church school teaching. After the 1901-02 school year, her teaching was limited to academy classes.'

During the 1902-03 school year, Alma was secretary of the Correspondence (home study) Department at Healdsburg College; in 1903-04, she was assistant in English in the preparatory school. During 1904-05 she was assistant in the intermediate department, ${ }^{2}$ with Jessie O. Barber as principal; in 1905-06 she was listed under the "Intermediate Department." The faculty of the training school were not listed in the 1906-07 calendar; in 1907-08 Alma was a teacher of methods in Bible and English at Healdsburg. ${ }^{3}$

In a faculty meeting during the fall of 1906 , it was announced that Alma and one other Bible teacher would not be rehired because of the lack of finances and because other jobs could be found for them. At this news, Jessie Barber Osborne offered up her salary, stating she would live on her husband's income in order that the two college teachers could stay. Her offer was accepted, but the terms were apparently not met both ways; besides losing her salary and continuing to carry her own responsibilities, Mrs. Osbome was also

\footnotetext{
'Alma E. McKibbin. 'A Teacher's Satisfactions,' 5; idem, interview, 2 August 1967. 16: idem. The Joy and Reward of the Christian Teacher. 4.

:After 1903, "intermediate grades" meant grades eight and nine.

'Pacific Union College, Healdsburg College 1902-1903 Nineteenth Annual Calendar (Healdsburg, Calif.: Healdsburg College Press, 1902), 2; Pacific Union College. The Alethian, Souvenir of Healdsburg College, 1903-1904 (Healdsburg, Calif.: Heaidsburg College Press), 3: Pacific Union College. Thenry-first Annual Calendar of Healdisburg College, 1904-1905. (Healdsburg, Calif.: Heaidsburg College Press. [1904]), 2: Idem. Healdsburg College Twentysecond Annual Calendar 1905-1906 (Healdsburg. Calif.: Healusbur College Press, [1905]), 2; Idem. Healdsburg College Annual Calendar 1907-1908 (Healdsburg. Calif.: Healdsburg College Press. 1906), 3.
} 
asked to teach two of Alma McKibbin's classes.' Mrs. McKibbin went to teach at the Western Normal Institute.

In June, 1908. Healdsburg Coilege was closed." College indebtedness and insufficiency of land for incorporating agriculture into the curriculum contributed to the reasons for closing the school. Alma added that some teachers and administrators had departed irom the school's original foundational principles. $^{3}$

On September 24. 1908. Alma began as an instructor at the newlyopened Western Normal Institute, a conference school in Lodi that enrolled students who had been attending Healdsburg. Although Pacific Union College, Healdsburg's successor, opened in Angwin in 1909, the Western Normal Institute continued until the spring of 1910. at which time its name was changed to Lodi Normal Academy. The Recorder announced, regarding Westem Normal's opening year in 1908: "Mrs. McKibben [sic], one of our best Bible teachers, will assist in the Biblical Deparment." ${ }^{4}$ However. just betore school opened in the fall of 1909, another article, while listing Alma's name as an

Walter C. Uit, A History of Pactic L'mion College Angwin. Calif: Alumni Association, 1968), 39.

:H. W. Cottrell. "The Pactic Linion College.' Pacific Union Recorder 8, no. 12 (22 October 1908), 1.

Mckibbin. interview. 1955.

"Seventh-day Adventist Encyclopedit, 1975 ed.. s. : "Lodi Academy": E. D. Sharpe. -A Statement of the Organization and Present Standing of the Western Normal Institute, and Recommendations Conceming its Future. Pacific Cinion Recorder 9. no. 29 (17 February 1910): 5-6: idem. Announcement of the Pacitic Lnion Normal Insthtute. Pacific Union Recorder 7, no. ? (12 September 1907): 2 . 
instructor, announced that the "instructors for Bible and vocal music will be announced later. ${ }^{11}$

Alma's friendship with Jessie Barber Osborne may have been significant. Their kinship was demonstrated by Jessie's 1906 selfless offer. The women were the same age, were married, had had one child, each had lost her husband after three or four shor years and had remained widows. Both Jessie's and Alma's husbands were buried in the little cemetery on the Indian chief's knoll at Healdsburg. Jessie and Alma may have become acquainted in San Pasqual, or when Jessie co-instructed at the 1901 Teachers' Institute at Healdsburg. The two women had much in common proiessionally also, and had shared their ideas and opinions about their work and philosophy.'

\section{Healdsburg Preparatory School}

In later years, Alma wrote and spoke extensively about her church school teaching at Healdsburg. It was during those three years. from 1899 to 1902. that she retined her methods and published her first Bible lessons. Her experiences at Healdsburg Church School (also called Healdsburg Preparatory School in 1899) are included in the following paragraphs.

\footnotetext{
E. D. Sharpe, 'Fall Announcement of the Western Normal Institute, Lodi. Calif.." Pacific Union Recorder 8. no. 5 (3 September 1908): 3.

:Barbara Osbome Westphal. Calistoga, Calif., to author, 3 December 1990.
} 
Two weeks after school began in 1899. Protessor Cady escorted Alma into the upper grade room instead of the lower. where she had been teaching for two weeks.

The teacher who was supposed to teach the intermediate grades was called to Australia two weeks after Alma began teaching the primary grades. The day the other instructor left, Professor Cady informed Alma that she would now be the teacher of the upper grades, and a new teacher would be hired for grades one to four.' With no prior notice or preparation, she was to begin teaching grades four through eight. Her wits were instantly tested.

Professor Cady had barely finished introducing her, when a seventhgrader challenged Alma's ability to handle him and his class members, asking whether she would explain some Bible statements the children couldn't understand. The boy's mother was a Seventh-day Adventist, but his father, was a lawyer and a skeptic. The boy wondered how the resurrection was possible if the body :ums to dust at death or is destroyed in some tragedy.

Praying for help. Alma focused on the backgrounds of her students, whom she had heard were interested in physiology. Looking at lamiliar faces that she remembered teaching in Sabbath school her senior year at Healdsburg, she remarked.

"How strange that I should recognize [John and Nellie], since there is not a particle of matter in their bodies or in mine that was there when we knew one another seven years ago. Identity does not depend upon matter

McKibbin. Step by Step. -9 . 
but upon personality, and character. The only thing we can take to heaven is character. We shall have new bodies. I am glad that I shall have a new incorruptible, immortal body that will never know sickness, pain, or death. "i

In later years, sensing the imporance of defending God's name to the students, she encouraged others to "learn to justify the ways of God to men." Alma grieved when a young Sabbath school teacher raised doubt in the minds of his students about God's wisdom:

His first question was this: "Was God justified in destroying the earth by a flood?" He meant changing the earth. It was not destroyed. And he did not answer his own question, nor did anyone else. But there is an answer. ${ }^{3}$

Her answer was described in a letter to a future Bible teacher, with the hope that the lessons Alma had to learn under times of stress could be of help to others. ${ }^{*}$

\section{Curriculum and Methods}

Under the Cady administration, it is possible that Alma was free to pursue some of her ideals in church school teaching. But because the school was

"McKibbin, Step by Step, 79. The "identity" question was agitated within the Seventh-day Adveatist church in the 1850 s through 1870 s. Dr. J. H. Kellogg wrote a book that settled the question for most church members. See Harmomy of Science and the Bible on the Varure of the Soul and the Doctrine of the Resurrection (Battle Creek. Mich.: Steam Press of the Seventh-day Adventist Publishing Association, 1879). Adventist Heritage Center, Andrews University, Berrien Springs, Mich. See also Ellen G. White. The Desire of Ages (Oakland. Calif.: Pacific Press Publishing Association, 1898), 605.

1967.

-McKibbin. Mountain View. Calif., to James Nix. Bakersfield, Calif., if August

'Tbid.

‘tbid. 
held in the Healdsburg Church Sabbath school rooms. there was no appropriate place outdoors for a school garden, one of the tools she wished to integrate with the practical teaching of God and His works. She compromised with a window garden in the schoolroom, which encouraged many of her students to start experimenting with their own gardens at home.

Alma taught practical subjects and duties. She found that both boys and girls wanted to learn sewing and quilting,' and she gave her students specific instructions for cleaning the schoolroom: they were to "begin at the ceiling and clean downward."2

Just as Alma used maps in trying to teach the division of the twelve tribes of Israel, she also used visual aids to teach lessons that would develop character. It may have been at Healdsburg that she first taught the meaning of Matthew 23:25, 26. Jesus' description of the hypocrisy of the scribes and pharisees. She took her breakfast dishes to class, making sure she had a plate with lots of runny egg that would stick when left to dry. In class, she set up dishwashing and proceeded to teach the lesson as she washed her breakfast dishes in front of the children. Careful to wash only the bottoms of the dishes, she asked the students to dry. They were repulsed and embarrassed in their attempts to dry such dirty dishes and did not know how to respond. Tongue-incheek. Alma remonstrated with her students, stating that those dishes were clean:

McKibbin. Step by Step, 79-80.

:McKibbin. 'A Teacher's Salustacuons." 12. 
she had washed them nerself, and why were they not drying them? Much discussion followed on the meaning and application of the word, "hypocrisy." The children never forgot the lesson:

Alma believed strongly in good reading matter for children. She felt that if adults needed to be careful about what they read, surely her children who were not able to judge what reading material is appropriate, had a right to be required to read only truth. Her heart was stirred by the thought that "a people, a whole people, have decided that truth--pure, unadulterated--shall be the food of every mind, that never at any time or place shall the false, the unreal, the impossible as expressed in the tiction of fable. myth, fairy-tale, novel, tradition, or superstition, be represented as necessary either to the mental activities or to the spiritual life."2

Alma realized that accomplishing so sweeping a reform as supplying only good literature required a decision of faith. and that one of the consequences of such a choice was that:

we tum our backs upon the literary productions of some of the greatest minds the world has ever known: we deny ourselves some examples of literary style that are considered indispensable to our education and culture. But "what is the chatf to the wheat" though presented in a jeweled casket?

Althea Schneider, interview by author. 11 March. 1991. Pacific Press Publishing Association. Nampa. Idaho. July 1908): 2

-Alma E. McKibbin. 'Literature for Children. Pacticic L'nion Recorder 7. no. 51 (23

ibid. 
She then demonstrated how the Bible might be used as one of the reading textbooks for children. In so doing, she orten upheld Daniel Webster as an example:

Teamsters who watered their oxen in the big trough before the Webster home often said one to another, "Let us go in and hear little Dan read a psalm." The little boy always cheerfully complied with their request. The furtive tears stealing down the cheeks of his auditors as they leaned upon their whipstocks to listen. showed that it was not curiosity alone that brought them there nor kept them there long after their teams were ready to continue their plodding way down the country road .... .

Little Dan understood what he read. Is it not possible that we and our children may understand the Bible and leam to read it so well that men shall pause to listen?'

Alma felt strongly about teaching the children to read the Bible aloud.

The Bible, she thought, was never as beautiful as when read aloud.

Children should be encouraged to read aloud whenever and wherever they have a suitable opportunity. Our forefathers read to their children, and their children to them. They talked with their children of the things they had read. But this good old custom has well-nigh passed away.'

Alma believed that other literature, besides the Bible. should be appealing and comprehensible to children. She emphasized that children like stories about life, not death: they like action, which is restful; not inaction, which is often wearisome to them. To a child. wrote Alma, beauty is right and ugliness is wrong. She itemized a list of categories from which teachers could choose appropriate reading material for their children: books of travel, biography, history, and science. However. to enable parents and teachers to

Ibid.. 3.

:rbid. 
choose appropriate $n$ rratives, Alma generated what she believed were necessary guidelines.

The following principles represent Alma's values for choosing good literature for children:

1. Choose that which is worthy of repeated rereading, so that when the child discusses the selection with his or her elders, they may reinforce and have the child reread the worthwhile material. Alma felt strongly that children should not skim through reading material as adults sometimes have to do. "What he reads should become a part or him, gorie over again and again until . . . its truth is tixed upon his soul."

2. Choose that which will add not only knowledge but character. Alma felt that a list of books of this caliber should be provided for parents and teachers.

She highly recommended the church's reading material, especially the Youth's Instructor. Alma believed the Instructor to be an excellent source of information on almost every subject taught in elementary schools.

She formulated a rationale ${ }^{2}$ ior teaching Old Testament before other biblical topics. She outlined her purposes for doing so in an article explaining how to teach children to study the Bible. First, the teacher must be prepared by believing that God will bless his or her efforts, which must be systematic.

Ibid.

The paragraphs explanne Alma's ratıonale are taken from Alma E. McKibbin. -Bible Study for the Children." Christian Elucarion 1. no. 5 (May-June 1910): 30-32. 
Teachers cannot afford to teach the Bible in a haphazard tashion and expect the minds of their students to become strong.

History should be studied before doctrine, so that when students do study the doctrines, history can provide appropriate background information. How can a child study about heaven. Alma wondered, except he be acquainted with the story of its loss, and the promise of its restoration, as presented in Adam's and Abraham's life histories?

Bible history explains world history. If Bible history is leamed first. from the beginning, students can appreciate the world's history in its relationship to God's plans.

Old Testament history explains many books in the New. Alma believed that concepts like salvation and faith snould not be taught to children as abstract principles but as concrete tacts illustrated by real people. Obedience, patience. and submission should be learned "walking by the side of Moses all throughout his childhood, youth, manhood and age." ${ }^{\prime}$ By so doing the child would learn much about the law of cause and effect, and the law of choice and consequences.

Climbing with Moses to the top of Pisgah the student "hears him plead to be allowed to tread the coveted promised land, and listens, to the firm, "Thou shalt not go over thither:" he witnesses the cheeriul submission, and in his mind and soul there is a . . realization . . . that though our Heavenly Father is a God of love, He is also a God of justice, and that no sin, however small we esteem it, will be passed by in the Judgment. ${ }^{2}$

Ibid.. 31.

-ibid. 
Alma remembered how her students at Healdsburg verbalized their growing knowledge about the people in the Bible. At first, the children were skeptical, full of questions and remarks. When they began to study the Bible, they found it difficult to speak and study in the language of Canaan.

They would say, "It happened one day that Moses saw a buming bush," and "Abraham took a joumey and found a new country, traveled around a good deal and never settled down." Now they say, "By taith Abraham went out, not knowing whither he went. By taith he sojoumed in the iand of promise, as in a strange country," and they understand what the words mean.

At the beginning of their study they never seemed to draw a conclusion or to make a practical application of the truths leamed: now the teacher is orten surprised by a question or remark at the beginning of a recitation which shows that they saw and made the application when they were studying the lesson.

When studying the death of Joshua and the subsequent apostasy of Israel, one little girl said, "I am so sorry Joshua died. If he had lived, he would have tried to keep Israel true to God. He was such a faithful man!" Several remarks were made by the class that revealed the fact that the children had been deeply impressed with the power of personal influence. The Spirit of God had been able to teach them this truth through the study of a life experience.'

Toward the end of the Healdsburg years. Alma observed an improvement in the minds and manners of her students. She witnessed in them a deeper reverence for things sacred, a kinder regard for one another, and a more respectiul attitude toward her. Students voluntary confessions of wrong doing were evidence that God's Spirit was working in their lives.'

She firmly believed that none of the abstract principles she taught, such as love and obedience. would be of value unless the children saw them

Ibid., 31-32 (ita!ics supplied).

:Ibid. 
demonstrated. Instead of lecturing the children on how to be sympathetic toward others, she enlisted their efforts in helping the poor. In class, she expressed sympathy for the deformed and mentally deficient in the community. When addressing the children's wrongdoing, she spoke kindly, showing them how grieved she was that they chose to do wrong. ${ }^{1}$

Alma believed that children in every schoolroom should be surrounded with a carefully nurtured spiritual atmosphere for the susceptible and impressionable child. This atmosphere could be created in part by prayers of parents and teachers, but also by the child's own prayers.

The child should not be taught to pray in meaningless singsong fashion, but with "real expression of gratitude and supplication. ${ }^{n 3}$ Each one should be taught why we should pray and how. She wrote, "When praying with them, let your prayer be a model for theirs. Let them know that you pray about everything, that you could not live without prayer."

Like most teachers, Alma enjoyed a responsive, spontaneous pupil who, challenged by the task. chose to use his mind to grasp the depth of a subject. Even more important, she desired her students to integrate right principles into their daily conduct.

\footnotetext{
'Alma E. McKibbin, The Spiritual Training of Our Children," Home and School 23, no. 6 (June 1931): 16 .

:ibid.

'Tbid.

'Tbid.
} 
Best of all I like the pupil who practices what he is taught, who lives what he learns, for some day I know he will be a pupil of the Great Teacher in the school above.

This is the kind of pupil I like. I will now tell you the kind of pupil I love. I love--them all.'

\section{Discipline}

Like other true reforms in education, discipline for a church school teacher was much broader than that for teachers in the public school. The goal of discipline was the achievement of character; it was a means to an end. Mrs. McKibbin wrote her views on discipline in 1906, shortly after her experiences with Healdsburg elementary school children:

Let all discipline be on the basis of doing the will of God, of pleasing Him. Teach them [the children] that we are always in the presence of God. "Thou God seest me." He sees and hears all we do or say, and knows our thoughts. He is looking down upon us not to find fault but to help and encourage. ${ }^{2}$

Apparently Alma had her share of discipline problems while at the Healdsburg Church School. Because her aim was to save every boy and girl, and her vow. made at her baby Lorin's graveside, was to love and care for all children as if they were her own, her burden for students was like that of a parent. She later wrote her views of the burden of the Christian teacher:

The love and care of parents follows the child all his life; so it is with the Christian teacher. When one has a child in his care, even for a short time, he leaves his impress upon him. Forever after that child reflects that influence, and influence is a shoreless sea. It never ends. Therefore, our

'Alma E. McKibbin. "The Kind of Pupil I Like," Sabbarh School Worker 20, no. 5 (May 1906): 67.

Tlbid. 
love and interest and prayers for these adopted children of ours must never end. ${ }^{\prime}$

These words of wisdom were written long after her discipline problems with church school children. Those problems did not end at Centralia, but followed her to the church school at Healdsburg.

Because of her love for the children at Healdsburg, Alma resolved to use firm discipline methods. This decision was tested the second week of school. She had assigned a poem in reading class, and later described what had happened:

A little boy in a back seat said. "I do not like poetry. I will not read poetry. It is sissy stutf." I tried to show him the use and beauty of poetry and hoped to have no further trouble with him. But the next day he refused to read. He had not studied, would not even open his book in class. I told him positively he must read the poem. . . .

If he should retuse, I did not know what to do, but had a real conviction that I must compel him to obey, even if he must be punished.

While I was wondering just what I should do for the boy or with him, he solved his own problem. Behind him was an open window. He rose from his seat, mounted his desk, and went out through that open window. I expected him to come back soon and then we would settle the matter.

He did return in about an hour on his horse, galloped past the window and with a cowboy yell vanished down the street. He never came back to school. He was never in school again anywhere. His parents left town a few days later. He refused to go to school so they retumed to their home in the hills and Duke became a cowboy. He had been in church school only two weeks and now he would never go again. I reproached myself bitterly for not knowing how to keep him.

From that day I prayed as never betore that God would help me to learn the secret of control over children, and how to hold them in our schools. I did not want to drive another boy out of school. But Duke was never out of my mind. ${ }^{2}$

Mckibbin. The Joy and Reward of the Christian Teacher, ?

ibid.. 3 . 
For ten years Alma prayed for Duke, and then her brother-in-law said he had worked that day with a man nar.ed Duke, who admitted he knew Mrs. McKibbin. Duke had regretted his decision to leave school and had asked how his former teacher was. Alma was gratetul for Duke's attitude toward her. Another five years passed when she learned that Duke and his wife had become baptized church members.

Was not that a great reward for two weeks' work--two weeks and a mistake? He remembered the Bible lessons he had learned in those two weeks and could repeat each one. He said. "We have worship in our home now." The great burden lifted.'

To Alma, prayer was a part of discipline. The following experience

with one of her students illustrates how she combined discipline and prayer.

Katie, a beautiful ten-year-old girl who had a talent for singing, was determined

not to believe in God and to hinder others' belief in Him:

She led me a terrible life for three years. Her intluence was detrimental in every way-- I went to the president of the school board with this word trom the Testimonies: "Among those who attend school there will be some who are in a sense Satan's agents. They have no respect for all the rules... and they demoralize all who associate with them. After the teachers have done all they can ... by personal etforts . . . and prayer ... and they refuse all the efforts made in their behalf and continue in their course ... it will be necessary to separate them from the school so others may not be contaminated by their evil intluence." 2

He looked straight into my eyes and said. "Do you mean to say that a ten-year-old girl has a greater influence in that school than you have?"

That was all he said. I went back to my work and this is what I said to the Lord: "Dear Lord. the power of that girl is greater than anything in me, but You are greater than the one who controls her. Give me power to help the

\footnotetext{
Ibid.

'Ellen G. White. Testimonies for the Cinurch. Vo. 29 (Battle Creek. Mich.: Seventhday Adventist Publishing Association. 1980). 422.
} 
other children. save them from her influence, and save her if it is possible." i

After a revival, which convicted many students, Katie did her best to undo the work of God's Spirit and persuaded some of those students to give up their efforts to be Christians. Alma's anguish while witnessing Katie's work of evil among her students culminated in torcing the worn-out teacher to quit teaching church school. Sometime near the end of the 1901-02 school year, Alma was taken from her schoolroom to a sanitarium, where she stated that she lay with a broken heart for many months. She brought her prayer list with her, which included Katie's and Duke's names.'

Katie's next teacher induced her to apologize to Alma, who described the encounter:

She said very stiffly, "I have come to apologize. Will you torgive me?"

I said, "I forgave you long ago. I believe in not letting the sun go down until all is torgiven."

"You do nor dislike me?"

"No, I love you. You are one of my children, and a mother never turns from her child. She would even follow a child to San Quentin to help him. So would I."

Katie rose to leave. At the door she turned and said, "You have a prayer list, don't you? If my name is on that list, will you please take it off?"

"Katie. if there is any other thing you would like me to do for you. I shall be glad to do it. But this one thing I cannot do."

\footnotetext{
McKibbin. "The Joy and Reward of a Chrisuan Teacher." 4 .

ibid.

'Ibrd.
} 
Katie married and made the young man's life as miserable as she had made Alma's. Her husband divorced her, her mother died, and Katie's heaith failed. For years, Alma continued to watch and pray. A friend wrote to Alma,

I went to visit Katie. She is very ill. She may not live. Her heart is broken. She said, "Will you please write to Mrs. McKibbin and tell her that at last I have been converted. I almost killed her years ago!"

"Yes, you shortened her life," said my triend.

Katie continued, "Ask her whether she believes God can ever forgive me."

Alma felt that when repentance is as sincere and deep as hers was,

God freely forgives. In 1940 Alma visited Katie's church, and later wrote of this visit:

I saw a crippled woman coming down the street, supported by a younger woman. The younger woman's hair was gray, her face wan, her beauty gone, but her tace was kind, sympathetic. It was Katie. She who once had seemed to live only to hurt others was now helping an old lady to come to church.

A woman sitting beside me said. "Katie has the kindest heart in this church." Who would want greater joy than mine! Who could ask for more? $?^{2}$

Alma's discipline methods reached the ears of Professor Ballenger.

who at that time was the tirst superintendent of education for the California

Conference of Seventh-day Adventists.

I heard that you have had some serious trouble in discipline, but that, after trying every other means, you resorted to the rod with good results. I heartily approve of your methods, and am holding you up as an example to other teachers who are iailing in discipline.

Ibid.. 5 .

:ibid.

McKibbin. 'Educational History.' 15 . 
When Alma finally had to quit teaching church school as a result of the stress of long hours, book writing, caring for invalids, and the burden she carried for the children's souls, she did not want to terminate:

My heart is in the church school--to that I was called. I like to lay foundations. Church school teaching is the most important work in our whole educational system. It carries the greatest opportunities next to parenthood.'

On her hospital bed she had some insights into what constitutes failure or success:

I thought when I began teaching that I should see favorable results at once, but the years went by, two, three, four, and in the discouragement of my soul I had to acknowledge to myself that my pupils seemed no better than when I began, and in some cases even worse.

My health, never too good, broke down completely, and I was taken away to a sanitarium, and there after months of illness, I began to see the matter more clearly. It seemed the Lord spoke to me and said, "You did this work for $\mathrm{Me}$, and did the best you knew how. I am responsible for the results. Do not say your work is either a failure or a success. You do not know." 2

\section{Church Work}

Alma worked for the Seventh-day Adventist Church as both a professional and as a layperson. After she moved to Healdsburg, she was part of a conference committee on Young People's and Children's Work. ${ }^{3}$

'McKibbin. "The Joy and Reward of a Christian Teacher." 4.

:Tbid., 1 (italics supplied).

${ }^{3}$ Year Book of the California Conference of Seventh-day Adventists, 19. 
Alma worked for the Califomia Conference from 1909 to 1911 , accepting a position as assistant to Elder Ben Beddoe in the Young People's Missionary Volunteer Committee for the Conference.' She was giving a talk to the young people at camp meeting, when Elder Beddoe slipped into the back seat to listen. An Eastemer who had just arrived in California, Beddoe felt he needed an assistant and soon after requested Alma McKibbin. The co-workers traveled from Oakland to Tahachapi, establishing Young Peoples' Societies. ${ }^{2}$

The Pacific Union Recorder carried information about the meetings Elder Beddoe and Alma McKibbin held in churches and schools in Mountain View, Chico, Lodi, Sebastopol, Fresno, and San Jose. Alma also conducted meetings by herself for young people at camp meetings. In one particular meeting at the Visalia camp meeting, she gave an afternoon study on the life of Moses. Following the meetings, the young people gave their testimonies for more than three hours. Prayers, testimonies, repentance, and confession, convinced those present that God's Spirit had blessed the meeting. ${ }^{3}$

When Healdsburg College closed, church attendance in Healdsburg dropped from over five hundred to sixty. Few leaders were left, so the congregation asked Mrs. McKibbin to lead Sabbath school and prayer meeting.

General Conference of Seventh-day Adventists, "Sustentation Fund Application."

McKibbin, interview, 2 August 1967, 13-14.

'Mr. and Mrs. W. G. Wilson, "Mountain View Church School, Pacific Union Recorder 10. no. 26 (26 January 1911): 6: Ben E. Beddoe. 'The Missionary Volunteer Department Report for 1910, Pacific Union Recorder 10. no. 32 (9 March 1911): 5. 
After a while. they asked her to conduct church services. The conference president visited her in person to authorize her as a "deaconess at large," to do all the work of a minister except to baptize, hold communion service, and perform marriage ceremonies. Alma McKibbin was granted conference missionary credentials and did the work of a church pastor, in addition to her other responsibilities. '

Pastoring was very stressful, and after solving some trying church difficulties, Alma lay in a sanitarium for seven months before taking up her duties at the newly relocated Pacific Union College.

\section{Alma's Friendship with Mrs, Ellen G. White}

About 1902 or 1903, Alma rented Mrs. White's home in Healdsburg, after Mrs. White retumed from Australia and took up residence at Elmshaven, near St. Helena. The rent at first was eight dollars a month, and Alma stayed there for about eight years. ${ }^{3}$ Mrs. White often visited this home in Healdsburg, and thus the two women became friends. Alma also was a frequent guest at Mrs. White's home at Elmshaven. Grace Jacques, a granddaughter of Mrs.

\footnotetext{
McKibbin, interview, 2 August 1967, 25-26: Claude Conard, California Conterence Missionary Credentials," Pacific Union Recorder 10, no. 31 (2 March 1911): 3.

McKibbin, interview. 2 August 1967, 27. This seven months is not to be confused with Mrs. McKibbin's seven-month stay at the St. Helena Sanitarium in 1902 after she dealt with Katie in the Healdsburg Church School. Mrs. McKibbin's bealth made her a frequent inpatient at the St. Helena Sanitarium; she once admitted she spent over two years of her life there.

'Tbid.: idem. 'My Memories of Sister White." 6: Sarah Elizabeth Peck. Sanitarium. Calif., to Alma E. McKibben [sic], Healdsburg, Calif., 19 March. I806 [sic]; W. C. White. Sanitarium. Calif., to Alma McKibbon [sic], Healdsburg. Calif., 17 December 1906;
} 
Figure 10. E. G. White Home in Healdsburg, which Alma Rented, c. 1902. Photograph by Lennart Ahlkvist. 


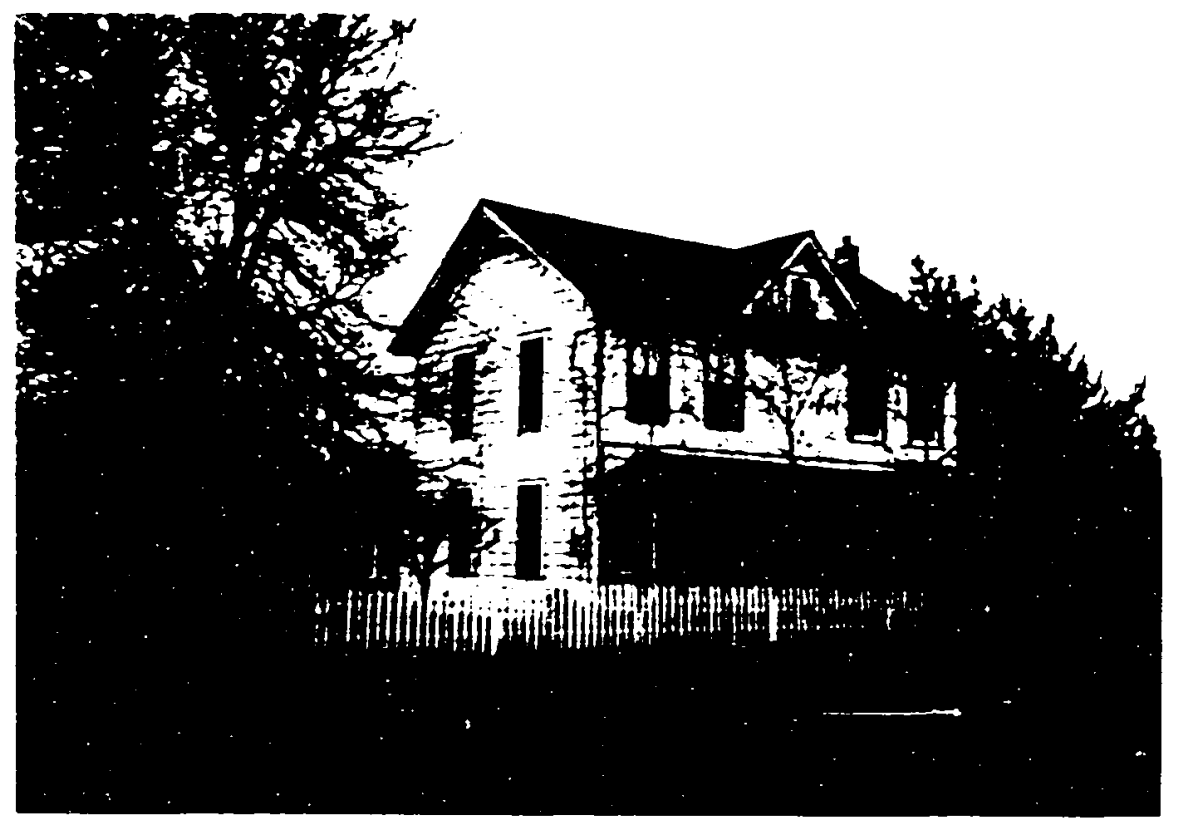


White, remembered years later that as a child she was struck by Alma's fondness for her grandmother.'

Many years later, Alma described her observations of Mrs. White to large audiences, recalling many details about the prophet: her light step, her love of flowers, her sadness at leaving old and tamiliar places, her delight at holding newly hatched chicks in her lap, and her practicality in putting on galoshes to see newbom calves. Alma could repeat many stories about Ellen White: of secretaries who had to be tired because they altered her writings, of her greens being smuggled into the college cafeteria by her nurse, of her compassion when her nurse spoiled a pantry full of canned peaches, and even a story of her reproving Alma for having let ligs go to waste on the ground. ${ }^{2}$

So there were the tigs all around and the secretary had seen it, and had told Sister White that I was wasting the iruit .. . "Well, I said, "that's true. Sister White, they were: they were even on my bed, and I'll tell you why. I had been very sick tor three days. You know, my mother and grandmother are in bed most of the time. and little brother was out working for others. I was not able to pick up the iruit."

"Oh," she said, "that makes it altogether different." And so it did!

So if anyone should ever say, "Did you ever know of anybody that was reproved by Sister White?" you can say, "Yes, Sister McKibbin was reproved by Sister White." 3

It was during her teaching years at Healdsburg that Alma McKibbin wrote and revised many oi her textbooks. Mrs. Ellen White was a great

McKibbin, "My Memones of Sister White." 6: Grace Jacques, interview by author. 25 February 1991. Yountville. Calif.

:McKibbin, My Memones of Sister White." $11-13$.

rbid.. !3-14. 
inspiration and help to her in this project. During one of Mrs. White's visits, she saw Alma's manuscripts on her desk.

"What are you writing?"

I said, "I'm trying to write some little lesson books for the children in the church school. You know we have Sabbath School lessons, but we have not lessons for the children in the church school.

"Oh," she said, "that's a very important work. And how are you getting along?"

"Well," I said, "I'm trying to write the history of the latter part of the Old Testament, and I'm having some difficulties, because this has never been taught in our schools. even in our colleges. I never had the opportunity of studying under anyone. and there are some things I don't understand very well."

This significant interchange resulted in the visit of one of Mrs. White's secretaries, Elder C. C. Crisler, who selected books on the latter part of the Old Testament for Alma from his personal library and from that of Mrs. White. Mrs. White's unpublished manuscript tor Prophets and Kings was on the top of the big box he carried in.:

\section{Lonnie}

Although most people are tamiliar with Alma McKibbin as a textbook author and Sabbath school teacher. not so many are acquainted with her as a surrogate mother. One of the mos! important events that occurred during her early teaching years was that she reared her six-year-old brother. A child of Stella Baker's later years, the boy was too much for her. for her health was failing. About 1900 or 1901 . Alma's tather brought Mother and Grandmother.

\footnotetext{
Mckibbin, interitew. 2 August 1967. 1.

:ibid.. 2 .
} 
now an invalid widow, tor her to take care of.' Alma telt that God had brought her a son to take Lorin's place. who would have been about Lonnie's age.'

Life with two invalids and a bright. energetic boy was not easy, Mrs. McKibbin had a hard time keeping him "on the reservation" ${ }^{3}$ at Healdsburg. Lonnie once invented a way for his friend. Lou Wallace, to wake him up to go fishing without awakening any of the other members of the household. Carefully tying a string around his toe, Lonnie hung it out the window the night before. and Lou pulled it the next morning."

Lonnie's and Alma's personalities were very different. She was a steady presence. stable, solt-spoken. and low key. He was a rapid-fire speaker, able to do many things at once. His drive was "two octaves above hers," although she had much endurance. He could taik on the telephone, write a book, and dictate a letter at the same time. During the years when the brother and sister lived at Pacific Union College, where it was the custom for faculty to name their homes. Alma chose "La Siesta." On the sign underneath those restful words, Lonnie inscribed, "Up-and-at-'em." Although their personalities were so

Eleanor Baker, intenilew.

:Fack Provonsha, telephone intervew with author, 26 March 1991.

'F. O. Rittenhouse, telephone interview by author. 27 February 1991. Angwin. Calif.: Delmer Kyle, ielephone sonversation with author, 15 November 1990.

"Luan Wallace Strachan, interview by author, + March 1991. Deer Park. Calif.: Meikle, interview.

'Provonsha, interview. 
different, both were very bright, articulate, and talented in writing and public speaking.

Alma used creative methods to teach Lonnie. When he was young, she took him to a saloon and perched him on the main counter, near the liquor bottles. Helping him to take in the scene, she adr snished him never to drink alcoholic beverages. He never forgot that awesori: ip, and later became an avid temperance crusader and prohibitionist.:

Alma did not always show Lonnie sympathy for life's setbacks.

Lonnie (Alonzo Baker, Jr.) wrote the following account:

Now when I was a youngster growing up in Healdsburg, I lived in the north end of the town. and it was mostly Catholic and Italian. The church school was 'way down here on Filth Street. . . The public school was right across the street. I had to walk up to Sister White's house, which was [in a neighborhood that was] mostly Italian and mostly Catholic. As soon as I'd get rid of these boys that I walked with. these Italian boys . . . would begin to yell at me.

"Bran-eater, Bran-eater, Bran-eater!"

And I went home and told my sister, "You know those ... Catholickers ..."

She said, "No. no, don't say hat; that isn't nice; don't call them Catholickers because they are Catholic."

I said. "You know what they ca!! me? A Bran-eater!"

She said. "You should be proud of it! If you eat plenty of bran. rough coarse things, you 11 live lots longer . . . etc." ${ }^{3}$

Ibid.

C. Mervyn Maxwell, ielephone conversation with author. 13 November 1989: Dierdre Maxwell. telephone conversation with author 27 . May 1991: Malcolm Maxwell, telephone conversation with author. 12 June 1991.

'Alonzo L. Baker. intervew by Kent Hansen. spnng 1976. Riverside Calif.. transenpt. tape 4. p. 28. in the hand of Kent Hansen. Corcoa. Calif. 
In spite of varied interests that pulled him many ways, Alma tried to

guide Lonnie's thinking without making his decisions for him. He described her influence in the following account:

I count as one of the turning-points in my life, the day that I came home with twenty-tive dollars that I eamed picking up prunes. You who have not lived nor visited in California, where prune picking is one of the main sources of revenue for the schoolboy during late vacation days, and who do not know what back-breaking toil it is to crawl around all day long over the clods gathering up the fruit that has fallen from the trees, will perhaps not appreciate what the twenty-tive dollars meant to me ... There were so many things I wanted,--a better bicycle, more baseball paraphemalia, et cetra.--[sic] that choice seemed impossible. So I asked my good sister what she would advise. Her answer was.

"Brother, if I were you, I should send for a set of John Lord's Beacon Lights of History. I saw in the Literary Digest only yesterday an advertisement of those volumes. You can get them for twenty-tive dollars, postpaid."

Now, history books were as far from the things I had wanted, as the nadir is from the zenith, and the suggestion fell upon seemingly fallow ground. My sister, seeing the disappointment registered on my face. immediately launched into an extended dissertation on the value of reading, the companionship of books, and the ephemeralness of baseball and bicycles. For the climax to her argument, she told me that Professor Rine, who at that time, as since, had captivated me with his abundant information and ceaseless /sic/ flow of language. was largely what he was. because of his continual reading of worth-while books and magazines. It seems that in some of my few confiding moments. I had told my sister that I wished some day to be just such a man as Professor Rine, and so, when she emphasized the point that the path to my ambitions was by way of the bookshelf, I capitulated.'

Alma leased her brother a shelt in her small home library, and he began reading the lives of Elijah. Paul, Mohammed. Luther. Peter the Great. 
and Bismarck. He tinished the titteen volumes within a year, and attributed his life-long love for good reading to that set of books.'

It may have been her experience with Lonnie that prompted Alma to write, "A healthy child is always active." She despaired of people who complained that their lively children made them nervous or who punished their bored children for mischief, when the root cause was that the child had nothing to do. She cautioned,

Give him something to do and help him to do it. Keep him occupied with something trom the time he can hold a sott woolly ball till he holds his college diploma:

In this same article. Alma also wrote that the child's self worth should be protected by administering correction and reproof in private. She believed in treating children with politeness and consideration. ${ }^{3}$

Alma apparently gave Lonnie a stability and love that provided him an opportunity to rise above the damaging hereditary and environmental influences of his first home. He became an editor, teacher. and public speaker. In later years, people said that Lonnie !oved his sister so much that when he talked about her his voice warmed, his eyes sottened, and a glow came over him. ${ }^{+} \mathrm{A}$

Ibid.

Alma E. McKibbin. Teach Me To Lndersiand. Part 3." Review and Herald 120 (27 May 1943): 14.

Ibid.. 15.

Nix, interiew. 
relative quoted him as saying, "Anybody who could rear me and keep me in line must have been something. ${ }^{n !}$

After the college closed and life at Healdsburg diminished in interest for a young teen, Alma sent Lonnie, who liked to rough it, up to Pacific Union College for its second year of operation, 1910-11.2

\section{Summary and Observations: Integration of Alma McKibbin's Faith and Methodology}

The earlier chapters covered the foundational years of Alma McKibbin's life; this chapter presented the first phase of her implementation of the principles of true education in church schools. In subsequent decades, she refined some of these principles in practice as she used her influence to maintain foundational educational standards.

Mrs. McKibbin felt that her first efforts to contribute to Christian education bore little fruit. She felt distressed about publishing Bible textbooks. If teachers used them, they might forego the necessary study and independent thought that produced excellent Bible students; if they did not, they might not teach Bible at all.

She sensed little satisfaction from becoming a more experienced disciplinarian, because the price she paid for a firm hand was, it seemed to her, the loss of some students' souls. The rewards for teaching were not necessarily

\footnotetext{
'Aline Tait and Betty Tait, interview by author, 5 March 1991, Napa, Calif.

McKibbin, interview. 2 August 1967, 25; idem, "Unchanging Values," 5: S. N. Haskell. "The New Califomia College." Review and Herald 86 (21 October 1909): 16.
} 
in this life. She labored for that which she could not see: the character and salvation of her students.

San Pasqual provided a non-threatening initial laboratory environment for her church school ideas. The church people knew her well and seemed to appreciate her efforts with the Johnson children. In this first home school for three students, Alma made her first attempt to integrate a church school curriculum with her philosophy. She did not use the public school primers but developed a method for beginning reading directly from the Bible and Our Little Friend. She taught the children a limited, sequenced vocabulary from Genesis. Within eight months, they were reading their lessons in the Little Friend themselves.

During her speaking engagements in later years, Alma alleged that on the following occasions she had seen either a supernatural light or an angel: at her conversion, (2) during convulsions from meningitis, while she was a student at Healdsburg College, (3) when she resolved to cheerfully accept death from meningitis, and 4) when she obeyed what she inferred was "God's call" for her to teach church school. ${ }^{1}$ All incidents apparently required Alma to depend on God in order to bridge the gap from despair to peace and subsequent rest or action. These supernatural manifestations may have contributed to the reverence and awe with which people regarded her in succeeding years.

'McKibbin. Light from Heaven, 7: idem. Step by Step, 33, 45, 49, 69: Christensen, A Short History," 89: Bowen, interview; Meikle, interview. 
It appears that God tested Alma's willingness to depend on and serve Him, "whatever the cost." throughout her tirst thinty-tive years. At age sixteen, when she persevered in going to the Saguache tent meetings even though she did not feel forgiven, she received peace: during her senior year in college, when she cried out for forgiveness during convulsions, she was symbolically comforted by an angel; after Alma decided to become a cheerful invalid for Edwin, she was healed; when she gave up her pride and became willing to fail at church school teaching, she succeeded; after disciplining the children the way she felt God wanted her to, a few of her students left school forever, never to retum, yet in time became exemplary Christians: when she longed to escape the trials at Centralia, she received better otfers to teach public school; when she decided to cast her lot with church schools, she got sick and could not carry on; when she couid no longer carry on. the church members, who had not appreciated her when she was well, rallied to her support. She later telt that these experiences strengthened her resolve to serve God. ultimately, as a church school teacher.

Alma felt inadequate as a church school teacher. It may be that if she had felt she had known how to leach a church school. she would have been chained to traditional, ineffective methods of education.

At Healdsburg Preparatory Schcol. Alma retined the church school curriculum. She taught practical subjects, such as sewing and gardening, and improvised gardens by using window boxes. 
By presenting the Bible lessons chronologically, she torged a foundational program for teaching Bible that had not been previously used in any Seventh-day Adventist school. She developed a rationale, which was followed for decades, for teaching the history of the Bible before other Bible subjects. Her textbooks were published in 1903 and were revised and used for almost fifty years in denominational church schools.

Her highest goal was for her students to integrate their actions with the Bible standards she strove to model and teach. She treated the children with respect, enlisted their cooperative effort in helping others, prayed with and for her students, and demonstrated an especially sympathetic attitude toward those with physical and mental handicaps.

She revised her conceptions of love and discipline, learning that making class work challenging or loving her students would not correct the defects in their characiers. She learned that love can be firm, and that even to use the rod't to spare a child from a lifetime of suffering could be a genuine expression of love.

Alma "stuck with" her studenis into their adulthood in an effort to establish them as mature and well-grounded Christians. They knew she prayed for them. Although she served the church in other capacities, her greatest contribution may have been to set the pattern for Seventh-day Adventist church school teachers for caring about students.

\footnotetext{
A term commonly used by Aima MleKihhin for last-resort. reasonable corporal punishment.
} 
CHAPTER 4

\section{FIRST BIBLE TEXTBOOKS FOR SEVENTH-DAY}

ADVENTIST CHURCH SCHOOLS: 1903-1952

Her joy is to share her experience of God's care. And help win the soul of another.

\section{Protestant Religious Education at the Tum of the Century}

By 1860 , Protestant education in general had merged with the public school system. Most American Protestants felt that the public schools, which basically promoted Protestant values, were taking care of the religious education of their children. The immigration to America of cultures embracing many varied religions had coerced the various Protestant bodies to pare down their religious teaching in public schools to include only what was general to all Protestant creeds. This toleration broke the monopoly of sectarianism in common schools but constrained American Catholics to form their own educational system. By 1900 most Protestant day schools had disappeared, while the Catholic school system was just beginning.'

'William Bean Kennedy, The Shaping of Protestans Educarion, Monographs in Christian Education, ed. C. Ellis Nelson. no. 4 (New York: Association Press, 1966), 27: Harry G. Good and James D. Teller. A History of American Education. 3d ed. (New York: 
In comparing Protestant religious education at the turn of the century with Seventh-day Adventist education, it is necessary to look at the public school texts, which were vehicles for dominant Protestant values, and to focus on the Sunday schools, which were the main means for Protestant sectarian or doctrinal teachings. Since Alma was exposed to the Methodist and Baptist teachings in her youth, this section focuses on public school texts and Sunday school lessons in those denominations.

Although nonsectarian Bible reading was encouraged in the public schools of the nineteenth and early twentieth centuries,' most moral instruction occurred in readers and spellers. Three fundamental themes in these texts emerged: (1) nature as an educational tool and teacher of moral values, (2) patriotism and the superiority of the United States as a nation ordained of God to promote democratic and biblicai principles, and (3) conservative social codes of diligence, temperance, honesty, and a compliant or cooperative spirit. Most educators felt that Sunday school alone was inadequate for children's religious teaching; therefore, schoolbooks of the period, especially readers, heavily emphasized religion and morality, but not doctrine." As mentioned previously,

Macmillan Company, 1973), 165; Thomas C. Hunt and Marilyn M. Maxson, eds., Religion and Morality in American Schooling (Washington, D. C.: University Press of America, 1981), 1216: Kennech Blaine Perry, 'Educational Trends in American Education from 1830-1870 Influencing the Formation of the Seventh-day Adventist Educational System" (M.A. thesis, Seventh-day Adventist Theological Seminary, 1952), 35.

'Hunt and Maxson, 15; Kennedy, 28-29.

'Timothy Walch, "Catholic School Books and American Values: The Nineteenth Century Experience," Religious Educarion 73, no. 5 (September-October 1978): 588-84: Kennedy, 29-30. 
no sectarian teaching was allowed in the public schools: creeds or beliefs fundamental to the various churches were to be taught to the children in Sunday school.

Before 1860 , the word, "Sunday school," meant a public common school that met daily for both secular and religious instruction. Sunday school men and clergymen were often leaders in the common school movement and were very active on the frontier. The Sunday school movement was a precursor and pioneer of the public school system. When public schools became a function of the local and state governments, the Sunday schools shifted to specialized sectarian, doctrinal teaching on Sundays.

After 1860, Sunday schools complemented the religious teaching of the public schools for Protestant children. The specialized role of the Sunday school being an adjunct to the public school training proved to be disadvantageous. First, the primary religious instruction of children was done daily in the public school, diminishing the sense of the importance of the Sunday school. Second, ascribing the role of teaching "religion" or indoctrination only to Sundays kept religion isolated from its application to daily life: conversely, in the public schools, religion was a part of daily life. Sunday schools came to be thought of as uninvolved with much of the mainstream of life:

Kennedy, 24-25.

ibid., 34-35. 
The public schools, burdened with the major part of the moral and religious training of Americans, tended to mix a "national morality and lowestcommon-denominator' theology." Looking to the public schools tor moral instruction diminished the role and importance of the churches and lowered the standards of moral education by watering them down to skirt the divisive traditions of the various sects."

With the primary assignment of responsibility given to the public schools, their work would have immense effect upon the understanding of religion gradually absorbed by Americans. . . Religion was tied to nationalism in a very subtle and close way, and the Bible became a patriotic as well as a religious symbol. The large majority of Christian people in America evidently were quite content to have it so. ${ }^{3}$

The Protestant Sunday schools did their best to give children of the land religious instruction. The aim of these schools was to lead children and youth to conversion and to help them acquire knowledge of the Scriptures, using a variety of methods.

By 1899, evangelical Sunday schools (Methodist, Baptist. Presbyterian) offered international, uniform lessons for both children and adults. ${ }^{5}$ Catechisms were no longer used in most denominational Sunday schools, with the exception

Tbid.

Trid., 36-37.

!bid., 38.

\Ibid.. 252.

'Robert W. Lynn and Elliott Wright. The Big Linte School: 200 Years of the Sunday School. 2d ed. (Birmingham. Ala.: Religicus Educat:on Press, 1980), 101. 108. 
of the Lutheran and Episcopal Churches: However, although the use of the catechism declined, the catechetical method did not." The uniform lesson helps were largely "expositional, didactic, and material-centered." ${ }^{3}$ The goal was to get the pupils acquainted with the biblical material, not necessarily to relate it tc their daily needs and problems. Gradually, however, as various denominational writers wrote helps, new methods emerged, containing explanations and illustrations that stimulated discussion. The aim changed from a heavy emphasis on memory work to the goal of obtaining deeper meaning of the Scriptural passages through explanation and discussion.

Examination of the International Sunday school lessons, which Alma McKibbin likely used in the Baptist Church in Saguache, reveals similarities between the layout of the lessons and that of her Bible books. Lessons began with a Scripture passage of approximately ten to tifteen verses, usually printed in entirety. All lessons included a "Golden Text" to memorize, notes on the meaning of biblical phraseology, and practical lessons that were terse, one-ortwo-sentence, numbered applications. A series of questions beginning with who, what, where, how. or why, followed the scriptural passage. "Readings" to be read during the week included Scripture passages or lessons helps from Bible dictionaries, histories. or commentaries.

Frank Glenn Lankard. A Hision: of the Americun Sundory School Curriculum (New York: Abingdon Press. 1927). 112-27.

Tbid., 104. 153.

'Ibid., 253. 
International Sunday school lessons included maps and listed many geographical, as well as historical, references. ${ }^{+}$Reviews consisted of several numbered questions on the lessons for the whole quarter.

Only brevity distinguished children's lessons from those written for adults. Usualiy on the same subject as the adult reading, lessons for young people offered short answers, catechetical-style, immediately following the questions on the Scripture passage.

Adults and young adults had to read the passage or the notes in order to find answers to their questions. Since sectarian beliefs were incorporated into the notes, one wonders whether Mrs. McKibbin's mother may have cautioned her to reiy more on the Bible than on the notes, thereby freeing her to think independently when studying the Bible.

\section{Sources Alma McKibbin Used When Constructing Bible Lessons}

Seventh-day Adventist books and materials that would have been available for Alma McKibbin to use included Professor Bell's small volumes of Bible lessons for youth, ${ }^{2}$ originally written for Seventh-day Adventist Sabbath

'American Baptist Publication Society, The Primary Quarterly, Intemational Series 2, no. I (January to March 1885): 6-30; idem. The Intermediare Quarterty, International Series 5. no. 2 (April to June 1884): 34-63; idem. The Advanced Quarterly, International Lessons 10, no. 4 (October 1888): 98-124; idem. The Senior Quarterly, International Series 1, no. 1 (January to March 1884): 1-11; idem. The Primary Quarterly. International Sunday School Lessons 12, no. 4 (October 1895): 9-20. The preceding are found in the archives of the American Baptist Historical Society, Valley Forge, Penn.

¿Goodloe Harper Bell, Bible Lessons for the Sabbath School, Number One. Progressive Series, No. I (Battle Creek. Mich.: Steam Press of the Seventh-day Adventist Publishing Association. c. 1877); idem. Progressive Bible Lessons for Children: To Be Used in 
schools but also used in Seventh-day Adventist intermediate, and, possibly, church schools, as late as the first decade of the 1900 s.' The 1872 volume for children gave Bell's philosophy as obliging the leamer to "go to the Bible for nearly every answer, and, in most cases, a concise and direct answer may be found in the exact words of some portion of the text. ${ }^{22}$ Bell's questions began with who, what, where, when, how, and why. A Bible text was not given for each question, but, rather, several questions followed each text. No memory verses were specified. Short reviews followed each three or four lessons, and a general review completed each section. Sections divided the Bible lessons into main events (such as Creation and the Flood, etc.) and characters, which followed a chronological sequence. The 1877 volumes, Bible Lessons for Little Ones and Progressive Bible Lessons for Youth, were similar, but Bible Lessons for Little Ones added a short paragraph of introduction to each lesson.

The adult Sabbath school lessons Alma McKibbin doubtless used in Seventh-day Adventist Sabbath schools were noticeably similar to the Bible books she later published. The type face and layout were similar to her 1905 edition of Bible Lessons, printed by the Pacific Press, which also printed the

Sabbarh Schools and Families (Battle Creek. Mich.: Steam Press of the Seventh-day Adventist Publishing Association. 1872); idem. Progressive Bible Lessons for Youth: To Be Used in Sabbarh Schools, Bible Classes, and Families (Battle Creek, Mich.: Steam Press of the Seventhday Adventist Publishing Association, 1877). All of the preceding are in the archives of the Adventist Heritage Center, Andrews University, Berrien Springs, Mich.

'Allan Gibson Lindsay, Goodloe Harper Bell: Pioneer Seventh-day Adventist Christian Educator" (Ed.D. diss., Andrews University, 1982), 147: McKibbin. "Educational History," 2.

:Bell. Progressive Bible Lessons for Children, 11. 
Sabbath school lessons. Memory work included a "Golden Text," references for memory work, and a memory passage. Questions and notes were similar in format to those in the Bible books. A Bible text followed each question.'

Another Adventist reference available to Alma McKibbin, probably in her own library as well as that of her mother's when she lived in Saguache, was Bible Readings for the Home Circle. ${ }^{2}$ This book was a series of Bible subjects presented by questions, each followed by a Scripture text answer, printed in full or in part, and by notes on the subject from nonbiblical sources. The questionand-answer method had been used in Bible study for centuries in catechisms, as previously noted. However, the question-and-answer method with a Bible text in answer to each question was initiated during the 1870 s, when several Adventists grouped together during a rainstorm on a Sabbath afternoon at a California camp meeting. They decided to study the Bible a new way: some would ask questions, but the answers could only be given from the Bible. This new method of Bible study became the precursor of Bible Readings for the Home Circle. which was widely read and used by Seventh-day Adventists.

Alma McKibbin attributed her "burden for writing lessons from the Old Testament" ${ }^{\prime 3}$ to a realization thai Seventh-day Adventist students and church

'Sabbash School Lessons for Senior Classes from the OLd Testament. Bible Students Library, no. 91 (Oakland, Calif.: Pacific Press Publishing Company, March 1892), Adventist Heritage Center. Andrews University, Berrien Springs, Mich.

:Bible Readings for the Home Circle: To Which Is Added the Game of Life, a Pictorial Allegory (Battle Creek. Mich.: Review and Herald Publishing Company, 1888).

${ }^{3}$ McKibbin, interview, 2 August 1967, 3. 
members did not have much background in Old Testament history. She states that she herself never had a lesson in the Old Testament at Healdsburg.'

About 1902, when Alma McKibbin began writing Bible lessons on the

Old Testament for publication, she used the book Patriarchs and Prophets by

Ellen White, a book Mrs. McKibbin said she prized.

It was the one I studied most earnestly when I began writing Bible Lessons.

As you turn the pages of Patriarchs and Prophers, you will find underscored passages. I leamed much from this book of detail and explanation of events.?

It is likely that Patriarchs and Prophets was Alma's aid in writing the first Bible lessons up in the cold attic room in Centralia in 1898.

I had a very great experience when I tried to write the little lessons for the church school many years ago. I was alone in my first church school with nobody with whom I could consult. As I began with the first verse of the Bible, oh, for a help. There was a help. I took a book, and as I studied and studied and studied. I read here a clear and plain explanation of the Word, and so, all through the long years that I taught the Word of God, I have had this wonderful help to help me understand it--the work of the Spirit of Prophecy.

Alma McKibbin used the apocrypha and Josephus' works to write the introductory chapters in Bible Lessons, Book 3, on the intertestamental period. Mrs. White's secretary, Clarence C. Crisler, brought over a large box of materials from his and Mrs. White's personal libraries. On the top of the box 1964.

:Tbid., idem. 'Bible Lessons for the Church School." 19; idern to Young, 27 January

:Alma E. McKibbin, Mountain View, Calif., to James R. Nix, Riverside, Calif., 26 September 1967.

"McKibbin. "Mrs. McKibbin and Sister White." 5. 
was the unpublished manuscrip $t^{l}$ for Prophets and Kings, and inside were many other books on Old Testament history. ${ }^{2}$

In all my struggles to provide Bible lessons, nothing ever encouraged me sc much as this loan of books and manuscript. For some time I literally lived with those books. It was these materials that fumished the basis of my introduction to my third book, The Life of Christ, for the sixth grade. ${ }^{3}$

She also used the box of materials when she wrote on the latter part of the Old Testament in Book Two.

I was writing lessons on the latter part of the Old Testament, which, if you have ever tried it, is the most difficult part to write upon, and I was greatly concerned about some question of chronology and other events in the restoration of the Jews when they came back from the Babylonian captivity ....

[Brother Crisler lent me] his books, books he had gotten in London. They were the old commencaries of the English Divines, who studied their Bibles most eamestly, and they were just what I needed."

Alma McKibbin placed confidence in the books by Mrs. White. She often used the writings of the Spirit of Prophecy to introduce a subject, and would tell her students how much these quotations had helped her to understand a text in the Bible that had been difficult. She collected these quotes and often shared them in classes and with friends.

'Prophets and Kings was published posthumously in 1917.

McKibbin, "Mrs. McKibbin and Sister White." 24: idem. "Bible Lessons for the Church Schools." 19.

'McKibbin, "Bible Lessons for the Church Schools," 19.

"McKibbin, "Mrs. McKibbin and Sister White, 24.

'McKibbin. interview, 2 August 1967. 8. 
In each of her books for the 1909 and 1912 editions, Mrs. McKibbin

listed the authorities she used in the lessons. Those she used for Books One and

Two are the same:

Analysis of Sacred Chronology, Sylvester Bliss

The Story of Daniel the Prophet, Stephen N. Haskell

The Empires of the Bible. Alonzo T. Jones

Daniel and the Revelation, Uriah Smith

Bible Dictionary, William R. Smith

Old Testament History, William R. Smith

The Desire of Ages, Ellen G. White

Education. Ellen G. White

The Great Controversy, Ellen G. White

Patriarchs and Prophets. Ellen G. White

Testimonies to the Church. Ellen G. White

Pulpit Commentary

For Book Three, ${ }^{2}$ she used:

Life of Christ. William Blakeslee

Life of Christ, John Cunningham Geikie

Four Centuries of Silence, Robert A. Redford

Bible Dictionary, William R. Smith

Vew Testament History, William R. Smith

Old Testament History. William R. Smith

Christ's Object Lessons, "Ellen G. White

The Desire of Ages, Ellen G. White

The Great Controversy, Ellen G. White

Thoughts from the Mount of Blessing. Ellen G. White

'Alma E. McKibbin. Bible Lessons in Old Testament History, Books One and Two. [new rev. ed.] (Mountain View, Calif.: Pacific Press Publishing Association. 1909), xvi. Ellen $G$. White Research Centers and Adventist Heritage Centers, Andrews University, Berrien Springs, Mich.; La Sierra College. Riverside, Calif.: Loma Lincia University, Loma Linda. Calif.; Pacific Union College, Angwin. Calif.: Pacific Press Publishing Association. Nampa. Idaho.

:Alma E. McKibbin. Bible Lessons. The Life of Jesus, Book Three. [new rev. ed.] (Mountain View, Calif:: Pacific Press Publishing Association, 1909), xvı. Adventist Hentage Centers. Andrews University. Berrien Sprnngs, Mich.: La Sierra College, Riverside. Calif.; Loma Linda University, Loma Linda. Calif.: Pacıric Union College, Angwin. Calif.: Pacific Press Publishing Association, Nampa, Idaho. 
Book Four' quoted the tollowing authorities:

Clarke's Commentary, Adam Clarke

The Temple, Alfred Edersheim

Life of Christ, John Cunningham Geikie

Ansiquities of the Jews, Josephus

Bible Dictionary, William R. Smith

Vew Testament History, William R. Smith

Daniel and the Revelation. Uriah Smith

Heralds of the Morning, Asa O. Tait

Acts of the Apostles, Ellen G. White

Christian Temperance, Ellen G. White

Christ's Object Lessons, Ellen G. White

The Desire of Ages, Ellen G. White

Early Writings, Ellen G. White

Education, Ellen G. White

The Great Controversy, Ellen G. White

Ministry of Healing, Ellen G. White

Mouni of Blessing, Ellen G. White

Patriarchs and Prophets, Ellen G. White

Skerches from the Life of Paul. Ellen G. White

Spirit of Prophecy, Ellen G. White

Steps to Christ, Ellen G. White

Testimonies to the Church. Ellen G. White

Questions and Answers, M. C. Wilcox

His Glorious Appearing, James White

Alma McKibbin's ninth-grade Old Testament history book (1918)

added the following sources:

The Cross and Its Shadow. Stephen N. Haskell

'Aima E. McKibbin, Bible Lessons. The Acts of the Apostles and The Plan of Salvation, Book Four (Mountain View. Calif.: Pacific Press Publishing Association. 1912), xvi. Ellen G. White Research Centers and Adventist Heritage Centers, Andrews University. Berrien Springs. Mich.: La Sierra College, Riverside. Calif.; Loma Linda University, Loma Linda. Calif.; Pacific Union College, Angwin. Calif.: Pacific Press Publishing Association. Nampa. Idaho.

:Alma E. McKibbin. A . Wanual of Lessons in Old Testament Hissory for Academic Grades (Mountain View. Calif.: Pacific Press Publisning Association. 1918), 12. Ellen G. White Research Centers and Adventist Heritage Centers, Andrews University. Berrien Springs, Mich.; La Sierra College. Riverside. Calif.: Loma Linda University, Loma Linda. Calif.: Pacific Union College, Angwin, Calif.: Pacıfic Press Publishing Association. Nampa. Idaho. 
A Bible Atlas, J. H. Hurlbutt History of Ancient Egypt, George Rawlinson Five Grear Monarchies, George Rawlinson The Monuments and the Old Testament, George McReady Price Beacon Lights of History, John Lord

Alma McKibbin also recommended in the introduction to Book Four that the teacher use J. S. Howson's The Life and Epistles of the Apostle Paul. She reminded the teachers that for "spiritual significance and principles of the book of Acts," the best source was Mrs. White's Acts of the Apostles. ${ }^{1}$ In the Church School Manual for 1906, she recommended Schaff's Bible Dictionary, Laberton's Historical Atlas, and J. H. Vincent's Pictorial Bible Geography for Little Students. ${ }^{2}$

In the 1916-17 Pacific Union Conference Church School Manual, ${ }^{3}$ the following sources were suggested for teachers using Alma McKibbin's books to purchase for use in teaching Bible: Cruden's Concordance, The Caprivity and Restorarion of Israel (same as Prophets and Kings), by Ellen G. White, and Stephen N. Haskell's Seer of Patmos.

In addition to all of the books listed above, there likely were other sources from Seventh-day Adventist philosophy and beliefs that may have

'McKibbin, Bible Lessons, Book Four, 1912, vii-viii.

'General Conference of Seventh-day Adventists. Church School Manual for Parenss and Teachers, 1906. 205.

'California and Northwestern California Conferences of Seventh-day Adventists, Pacific Union Conference Church Schools of Seventh-day Adventists. Announcement for 1916-17 (Oakland, Calif.: Pacific Press Publishing Association [1916]), Adventist Heritage Center, Pacific Union College, Angwin, Calif. 
influenced Alma McKibbin's own philosophy and textbook writing. A notable illustration is the 1891 Harbor Springs Convention, in which educators tried to decide whether or not each school subject was to have the Bible as its main textbook, or whether other textbooks should be discarded as inferior. Although neither of these ideas were carried, the centrality of the Bible in the curriculum that emerged from Harbor Springs likely influenced Alma McKibbin's views.

\section{Analysis of Bible Lessons and Revisions}

Original Editions

1903 Printing

The first printing of Alma McKibbin's Bible Lessons for the Church School was done in 1903 at the Healdsburg College Press, ${ }^{2}$ at her own expense. Only Books One and Three of this printing are available; nowever, a 1905 printing by the Pacific Press still bears the 1903 copyright, and its pagination fits the index in the 1903 Book One, making it possible for Book Two to be compared with Books One and Three of the 1903 run. The three little books that were published in $1903^{3}$ evidently had identical covers and title pages, but the indices and content were different. The index in Book One was for all three

\footnotetext{
'See "Table Number 4. Alma McKibbin's Books and Revisions" on p. 212.

-These books were listed as official textbooks for the Pacific Union for the 1904-05 school year. See "Course of Study for Church Schools," Pacific Union Recorder 4, no. 6 (8 September 1904): 5-6; "Courses of Study, Church Schools." Pacific Union Recorder 4. no. 9 (29 September 1904): 6 .

"These three books were called a "three-book series of Bible lessons" by Marion Ermest Cady. 'Educational and Young People's Work." Pacific Union Recorder 15, no. 18 (9 December 1915): 1 .
} 
books, the contents oi each book being listed separately under grade levels. Books Two and Three had no indices in them. The subtitles for the three books listed in the index in Book One are as follows: "Old Testament History (Designed for Grade IV.)": "Old Testament History (Designed for Grade V.)"; and "New Testament History. Life of Christ (Designed for Grade VI.)." In the introduction to Book One. Alma McKibbin called the books "series" of Bible lessons," to be used as guides to aid the pupils in their study of the Bible. She explained in the introduction that the best material for children to study was the history of the Bible and that the questions would focus the student's mind on the meaning of the biblical events studied. ${ }^{3}$

Mrs. McKibbin encouraged teachers not to restrict their questions to those in the lessons only but to add many more questions in the recitation period. She noted that the references and notes were specifically for the use of the teacher, but "may be read with protit by the pupil, or by the parents for the benerit of their children." ${ }^{\prime \prime}$ In view of the confusion in later years by other readers, teachers, administrators, and students over the difficulty of the reading level of these notes and reterences. Alma McKibbin did make clear in the 1903 introduction that the notes and references were for teachers. In later years, she

McKibbin. Bible Lessons. Book 1. 1903. 5-9.

Ibid., 3.

'tbid.

'Ibid.. 4 . 


\section{2}

Table 4.--Alma McKibbin's Textbooks and Revisions

\begin{tabular}{ccc}
$\begin{array}{c}\text { Copyright } \\
\text { Date }\end{array}$ & Reprinting & Rate \\
Date \\
\hline
\end{tabular}

1903 The following books were printed, signatures

Bonks Published by Healdshurg College Press only, because the supply could not keep up with the demand:

Bible Lessons, Book 1 , th grade. This book covered the Ist half of the O. T.

Bible Lessons, Book 2, 5th grade. This book covered the and half of the $O$. T.

Bible Lessons. Book 3. 6ih grade. This book covered the life of Christ.

1903 This reprinting was called the Shoestring edition, in which Alma punched holes in signatures, tying them berween pasteboard covers provided by the press.

Bible Lessons. Book l. th grade. Bible Lessons. Book 2, 5th grade. Bible Lessons, Book 3. 6th grade.

1903 The press provided bound covers for this edition.

Bible Lessons, Book 1 . th yrade.

Bible Lessons. Bcok 2 jth grade.

Bible Lessons. Book 3, 6ih grade.

\section{Bonks Princed hy Pacific Press Publishing Company}

1905 The press provided bound covers for these books, which in appearance are like those above.

Bible Lessons, Book 1 . th grade. This book covered the ist half of the $O$. T.

Bible Lessons, Book 2. 5th grade. This book covered the 2nd half of the O. T.

Bible Lessons, Book 3. 6th grade. This book covered the life of Christ.

Bible Lessons. Book 4. The Acts of the Apostles and Bible Doctrines. 7th and Sth grade. This book may or may not have been published at this time: it has not been found.

1909 These books are expanded and revised editions of the zarlier Bible Lessons. Books 1 . 2. and 3 listed above:

Bible Lessons in Old Testament History. Book 1. th grade. 1915 This book covered the 1 st half of the $O$. T.

Bible Lessons in Old Testumem History. Book 2. 5ih grade. 1915 This book covered the Ind half of the $O$. $T$. 
Table 4-Continued

Copyright

Reprinting

Revision

Date

Date

Date

Bible Lessons, Book 3. The Life of Jesus, 6th grade.

1915

1909

This book covered the Life of Christ.

1912 Bible Lessons. Book 4. The Acts of the Apostles and

The Plan of Salvation. 7th \& 8th grade.

This book covers two years of work:

grade 7 covers Acts and Paul's writings;

grade 8 covers Bible doctrines (the

plan of salvation).

1914 Bible Lesson Manual for Parents and Teachers.

This was wntten by request, explaining how to teach Bible.

1918 A Manual of Lessons in Old Testament History for Academic Grades, 9th grade.

Aime McKibbin wrote this for academy students.

1921 Bible Lessons. The Life of Jesus, 6th grade.

This book is a revision of the 1909 Book 3 .

1924 Bible Lessons, The Life of Jesus. Gth grade.

Although this book is not a revision of the 1921

edition, it bears a copyright date of 1924 .

Bible Lessons: Last of Old Testament Times. Sth grade. This book is a revision of the 1909 Book 2 .

1926 Bible Lessons: The Gospei to All the World. 7th grade. This book is a revision of the 1912 Book 4. Only the first part. "Part I: The Acts of the Apostles," is wntten by Alma McKibbin. The second parr. "The Plan of Salvation," was replaced in 1922 by Sarah Peck's God's Greas Plan. written for grade 8 .

1940 The Gospel to All the World, Bible Lessons

for the Seventh Grade. 7th grade

This book is a revision of the 1926 Gospel to all the World. Alma McKibbin wrote only the first part, "Part I: In the Days of the Apostles." 
Table 5.--Aima McKibbin's Textbooks at a Glance

\begin{tabular}{|c|c|c|c|}
\hline Date & $\begin{array}{l}\text { Bible Lessons, Bk 1: } \\
O . T \text {. History. } \\
\text { lst half-4th grade }\end{array}$ & $\begin{array}{l}\text { Bible Lessons, BK 2: } \\
\text { O. T. Hisiory, } \\
\text { 2d half-5th grade }\end{array}$ & $\begin{array}{l}\text { Bible Lessons, Bk } 3 \text { : } \\
\text { Life of Christ- } \\
\text { 6th grade }\end{array}$ \\
\hline Copyright Date & $\begin{array}{l}\text { 1903, Healdsburg } \\
\text { College Press } \\
1905 \text {. Pacific Press } \\
\text { Pub. Assa. } \\
1909\end{array}$ & $\begin{array}{l}\text { 1903, H/B Press } \\
1905, \text { PPPA } \\
1909 . \\
1926\end{array}$ & $\begin{array}{l}\text { 1903, H/B Press } \\
1905, \text { PPPA } \\
1909 . \\
1921 \\
1924\end{array}$ \\
\hline Reprint Date & 1915 & 1915 & 1915,1928 \\
\hline Date Out of Print & 1921 & 1952 & 1951 \\
\hline Replaced by: & $\begin{array}{l}\text { When the World was } \\
\text { Young (Grade 3); } \\
\text { From Egypt to } \\
\text { Canaan (Grade 4) }\end{array}$ & $\begin{array}{l}\text { Messengers of the } \\
\text { Promise (Grades } 5 \\
\text { and } 6 \text { ) }\end{array}$ & $\begin{array}{l}\text { Day by Day With } \\
\text { Jesus (Grades } 5 \text { and } \\
6 \text { ) }\end{array}$ \\
\hline
\end{tabular}

\begin{tabular}{|c|c|c|c|}
\hline Date & $\begin{array}{l}\text { Bible Lessons, BK 4: } \\
\text { Part I: Acas of the } \\
\text { Apostles/Part II: } \\
\text { Plan of Salvarion- } \\
\text { 7th grade } \\
\text { Later called Gospel } \\
\text { ro All the World }\end{array}$ & $\begin{array}{l}\text { A Manual of Lessons } \\
\text { in } O . T \text {. History- } \\
\text { gth grade }\end{array}$ & $\begin{array}{l}\text { Bible Lesson } \\
\text { Manual for Paren's } \\
\text { and Teachers }\end{array}$ \\
\hline Copyright Date & $\begin{array}{l}{[1905 ?]} \\
1912 \\
1926 \\
1940\end{array}$ & $\begin{array}{l}1918 \\
1927\end{array}$ & 1914 \\
\hline Reprint Date & 1915. 1946 & & \\
\hline Date Out of Print & 1952 & 1949 & [1951?] \\
\hline Replaced by: & $\begin{array}{l}\text { Witnesses for Jesus } \\
\text { (1952, Grades } 7 \& \\
\text { 8); God's Grear Plan } \\
\text { (1922, Grade 8) }\end{array}$ & $\begin{array}{l}\text { Life and Times of the } \\
\text { Old Testamens (Grade } \\
\text { 9) }\end{array}$ & $\begin{array}{l}\text { Teachers Guide } \\
\text { editions of the } \\
\text { textbooks }\end{array}$ \\
\hline
\end{tabular}


wrote that "it is a mistake to write books for both pupils and teachers."

Mrs. McKibbin considered Book Two, for grade nive, to be more difficult for children than Book One, mentioning that frequent review and drill would be necessary. In the preiace, she wrote that children would receive more benefit if they drew iheir own maps than if they only memorized the ones in the books. She suggested that children fill in the names on the maps as they leamed them. In Book Two. Mrs. McKibbin repeated that for the children to answer the questions in the exact wording of the Bible would be superior to using their own words. "No human paraphrase can ever equal in power and effectiveness the simple Word of God." ${ }^{2}$ She advocated that children write out the full wording of the text rather than merely cite the reierence, but noted that "this may be only an occasional exercise, or it may be pursued until the habit is firmly fixed. ${ }^{n}$

For teachers and students who complained about the requirement to commit a verse to memory each day. Alma McKibbin supported the practice by stating that the memory would be strengthened by irequent and systematic exercise. She also ielt that thorough drill could enable students to both pronounce and spell long, uniamiliar Bible names.

Her final comments in the preface to Book Two gave her underlying assumptions for all who teach Bible, whether or not they used her books:

McKibbin. 'Educational History.' is.

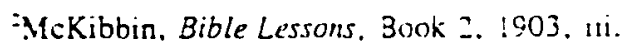

Ibid. 
All these suggestions, and many more, may be given and faithfully followed, and still the Word of God tind no place in the hearts of the children. These methods or any others of human devising are not the prime essentials. They are only supplements to the great and essential aid, the Holy Spirit. Without His power added to human effort, the best must fail; with it, the humble, consecrated teacher may expect at last to shine "as the stars forever and ever." because of having turned many to righteousness. May this be the reward of all who "feed the lambs" of the flock of God."

The introduction to Book Three, grade six, explained that emphasis was given to Old Testament prophecies that reached their fulfillment in the life of Christ, and that knowledge of the historical context of Jesus' day would aid the student to better understand His ministry. Alma McKibbin suggested that each child draw a map on which to write in the places Jesus visited, using a new map for each year of His three-year public ministry. Thus, in addition to being an aid to memory, the map would serve as a framework on which to review Christ's life. Mrs. McKibbin also recommended The Desire of Ages by Mrs. White to supplement the Bible lessons.

Alma McKibbin presented Bible history chronologically throughout the ihree books. In $10+$ lessons. Book One began with the story of Adam and ended with the death of Moses. Book Two began with Joshua, and, after 117 lessons, finished with the restoration of Jerusalem aiter the Babylonian captivity of the Jewish nation. The 106 lessons in Book Three covered the life experiences of Christ, beginning with the birth of John the Baptist and ending with the ascension.

Ibid., iv. 
Each lesson covered important events centering on a Bible character or kingdom. Under each lesson title was a Scripture reierence to study and a text to memorize, followed by approximately ten to twenty questions (see sample in Appendix). Most questions began with who, what, when, where, why, and how. The Bible lessons were correlated with reading and language arts. Difficult words selected from the reading were listed, with a footnote instructing the teacher to have the children spell. derine. and use the words in sentences, either orally or written. Mrs. McKibbin speciñed that the words were to "be defined according to their use in the text, and each sentence should express some truth learned in the lesson."1

At the end of each !esson, which comprised about one or two pages of text, were references and notes for the teacher. The endnote for lesson one reminded teachers:

These references are especially for the teacher's use. but a part or all may be assigned to the pupils at the teacher's discretion. The parents can very materially assist and encourage both teacher and pupils by reading these references to their children at home, particularly the readings in Patriarchs and Prophers.

The references consisted of correlated Bible passages or books by Ellen $G$. White which amplified the subject of the lesson." Notes appear to be points

McKibbin. Bible Lessons. Book 1. 1903, 10.

'Ibid.

'These books are from the 'Contlict of the Ages' sernes of five books by Mrs. Ellen G. White. Mrs. White's book about the tirst part of the Old Testament is Parriarchs and Prophets; on the latter part. Propiners and Kings: on the life of Chrnst. The Desire of Ages; on later New Testament times. Acts of the fpostles: and on the history of God's kingdom and people 
Alma McKibbin felt were important to teach but which were not explicitly stated in the lesson. In addition to the questions, she included charts. Book One included three charts:

1. The names and ages of the patriarchs beginning with Adam, showing how Adam could have spoken with nine generations. At a glance children could see when each patriarch was born. how long he lived, and with whom he was contemporary.

2. Noah's three sons and their descendants illustrated the peopling of the earth.

3. The Hebrew calendar enabled students to understand when the Hebrew religious festivals occurred.'

Long after their school days ended, many of Alma McKibin's students remembered a chart included in Book Two: the "Table of the Divided Monarchy." This table listed the years and length of the reigns of the kings of Israel and Judah, along with contemporary prophets and rulers of surrounding nations. ${ }^{2}$

Book Three, grade six. contained a chart of the chronology of the rulers of Rome, Judea, and Galiles trom Jesus birth to the destruction of the

throughout the ages to modern imes. The Great Cuntroversy.

McKibbin. Bible Lessons. Book 1. 1903, 16-17. 23, :2.

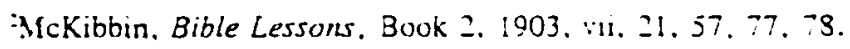


temple in A.D. 70, which enabled students to understand the relationships among the Herods, Pontius Pilate, and the Caesars.

Each book included a midterm and a final review of 77 to 199 questions. The review questions did not duplicate those in the lessons but were based on the material. Questions might be comprehensive, such as, "Give the life history of Miriam" and "Write ten lines on the character of Moses." 1 Since there were no lessons on Miriam's life or Moses' character, the pupils would have to analyze material they had leamed in several lessons, in class, or in the reference material. Other review questions asked for the citation for a Bible story, listing book and chapter(s) in the Bible. The last section of the review listed quotations of Bible characters. Students were to write who said each quotation, to whom, and under what circumstances.

Sarah Peck was on the committee with Alma McKibbin to revise church school textbooks. Wiss Peck wrote the following suggestions on the tly leaf of the 1903 edition of Bible Lessons, Book One:

Precede each set of questions with Bible text in good, clear type--same as used in reader for this year.

Precede Bible text with spelling words--pronounced.

Suggestions for written work--Write compositions from "pictures for stories" for year four:"

:McKibbin. Bible Lessons, Book 1. 1903. 112.

'Sarah Elizabeth Peck, handwritten notes on the Ily leat of Biole Lessons, Book I, 1903. Adventist Hentage Center. Andrews Lnversity. Berrien Sprngs, Mich. 
1904 and 1905 Printings, Healdsburg

College Press

Mrs. McKibbin regretted that the first editions were inadequate to meet the demand. At first, the Healdsburg Press, newly in operation in 1903 under Arthur Haines with meager, primitive equipment, ${ }^{1}$ could not keep up with the orders from teachers. Because of the urgency of teachers' requests, she sent the signatures to each teacher, one at a time, as they came unbound off the press.

In 1904, the Healdsburg College Press reprinted the 1903 edition with pasteboard covers. Mrs. McKibbin punched holes in the signatures and bound them together with shoestrings. In 1905, the College Press bound the 1903 edition "in proper style." 2

1905 Printing, Pacific Press

It was difficult to find a Seventh-day Adventist publishing house that would print any church school textbooks, even though they could print larger editions in a shorter period than the college presses and could have kept up with the demand.

We had three publishing houses at this time and all of them were "not interested" in the new project. They could not see the use of publishing our own books. One house offered to do so upon reconsideration if the money would be advanced before the work started, but as all work so far was gratis and as there was no fund for this purpose the outlook was not very bright. $^{3}$

McKibbin. "Bible Lessons for the Church Schools," 19.

:MeKibbin. "Educational History." 18, 19.

'Christensen. "A Short History." 103. 
With the help of Marion E. Cady, President of Healdsburg College, and M. H. Brown, Manager of the Pacific Press, the Press finally consented to print Alma McKibbin's books, as well as those of Katherine B. Hale, M. E. Cady, and Sarah Peck. Unwilling to take risks on books that were "still in the experimental stage" and not yet approved by the General Conference for use in Seventh-day Adventist church schools, the Press refused to print the texts on a royalty basis, stating that they would bill Mrs. McKibbin for payment as her books were printed. ${ }^{1}$

In 1905, having learned to print larger quantities, McKibbin ordered more books than ever, still at her own expense.

The Pacific Press burned on 21 July 1906, and Alma McKibbin's large order of printed books burned with it, leaving her with the bill for $\$ 219$. However, soon after the fire, a letter arrived from the General Conference stating that they had accepted and approved the manuscripts for Books One and Two for use in Seventh-day Adventist church schools, and that if she would send the manuscript for Book Three, they would accept it also. ${ }^{2}$ The Press soon followed with a letter that they would be ready to print books again, this time on a royalty basis. When the Press set up their type cases under awnings on the

'Ibid.: McKibbin, "Educational History,' 19.

"McKibbin, 'Educational History," 19; General Conference of Seventh-day Adventists. Church School Manual for Parents and Teachers. Missionary Educational Convention. 169-170: "Suggestive Outline for Courses of Study," The Educational Messenger 2, nos. 14 and 15 (15 July 1906): 4-5: "The Story of the Convention." Central Union Conference Bulletin 2. no. 3 (October, 1906): 31-33. 
lawn, they printed Alma McKibbin's books with a new type face, maps, and with diacritical markings on the unfamiliar words for biblical names and places (refer to table 1 of "Alma McKibbin's Books and Revisions," 1905 printing under "Pacific Press Publishing Association")."

Only Book Two of the 1905 edition, presumably printed after the fire, is available in any of the archives of the Adventist Heritage Centers. The publishing date is 1905 , possibly because that is when the books were originally printed by the Pacific Press before the fire. ${ }^{2}$

Two references mention Book Four, on the Acts of the Apostles and Bible Doctrines, which may have been printed at this time or may have been planned to be published, although no Book Four has been located in any archives or in anyone's private possession. ${ }^{3}$

'McKibbin, "Educational History, 19, 20; Christensen, 104-5.

:Alma E. McKibbin, Bible Lessons for the Church School, Number Two (Healdsburg, Calif.: Healdsburg College Press, 1903, repr., Mountain View, Calif.: Pacific Press Publishing Association. 1905), Adventist Heritage Centers, Andrews University, Berrien Springs, Mich.; Loma Linda University, Loma Linda, Calif., Pacific Union College, Angwin, Calif.

'Book Four was listed in the suggested outline for course of study in the 1906 educational convention at College View. Neb. It was called, 'Mrs. McKibbin's Bible Lessons. Number Four." The subject matter was listed as "Acts of the Apostles and Doctrinal Subjects." See "Suggestive Outline for Courses of Study," 5; "Story of the Convention," 33. The 1906 Church School Manual cites, "The field of Bible study is quite well covered. Mrs. McKibben's [sic] 'Bible Lessons' supply the need in grades four, five, six, and eight." See General Conference of Seventh-day Adventists. Church School Manual for Parents and Teachers. 1906. 169-170. In 1907, Bible Lessons. Book One, could be obtained for S.50, and Books Two and Three were noted as being out of print. Book Four was not mentioned. In 1908, Alma McKibbin's Books One and Two were listed for use in the fourth and fifth grades, but grades six through eight bad books other than Mrs. McKibbin's listed. See "Church Scbools. Attention," Pacific Union Recorder 6, no. 24 (10 January 1907): 8; •Recommendations Passed at the Pacific Union Conference Teachers' Institute, July 3, 1908." Pacific Union Recorder 7, no. 49 (9 July 1908): 2. 
1918 Old Testament History

for Ninth Grade

In 1918. Alma McKibbin published what she considered her "best

book," A Manual of Lessons in Old Testament History for Academic Grades."

She had been teaching Old Testament history for the ninth grade in the

preparatory department at Pacific Union College without a textbook since the

1911-12 school year. Students copied their lessons into permanent notebooks

from Alma McKibbin's outlines on the blackboard. She explained,

During the recitation period they added notes. When the year was ended, each had a textbook in Old Testament History. This suited me perfectly, but as other teachers wanted the lessons, they were published in $1918 .^{3}$

A prefatory note from the General Conference Department of

Education announced that the 1918 edition of Old Testament History for ninth grade would be published in temporary form for classroom testing before the tinal edition would be issued in permanent form. " However, Alma McKibbin did not revise this text until 1927.

In the introductory note to teachers, Alma McKibbin admitted that eye trouble had prevented her from collecting sufficient notes for the lessons, and

\footnotetext{
'Alma E. McKibbin. interview by unnamed person. 25 March 1959. Adventist Heritage Center. La Sierra College, Riverside, Calif.

:Alma E. McKibbin. A Manual of Lessons in Old Tesramens History for Academic Grades (Mountain View, Calif.: Pacific Press Publishing Association, 1918). This book was listed for use in church schools in the General Conference 1924 School Manual. 3.

${ }^{3}$ McKibbin. 'Educational History." 21.

"McKibbin, A Manual of Old Testament History, 1918, vii.
} 
she solicited more references from ieachers for future editions. She notified teachers that the illustrated maps in the book were available in looseleaf form for the students' notebooks and drill. She suggested using proper names for quizzing students by asking, "Who was taron? What was Abana?"1

The maps in the book were of one color and were only outlines without names. A "Diagram for Bible History," a time line in the 1914 manual, was included at the beginning of the Old Testament history book. Charts in the ninth-grade book were similar to those in the fourth- and fifth-grade texts, but students were to fill in some of the chronologies. The appendix included lists of words with diacritical markings for pronunciation exercise. Five review sections, similar in format to those for the elementary school, completed the book.

Lessons for ninth grade were longer than in the grade school books but were based on approximately three chapters of Bible reading, plus one chapter of reading in Patriarchs and Prophers or Prophers and Kings. The ninth-grade book covered in one year all of the material in the 1909 grade-school Books One and Two. Many subjects in the tifth-grade volume were deleted in Old Testament History, but those that were included in the ninth grade volume were studied in greater depth. In the elementary grades, for example, the tables listed Ibid. . vii. 
the judges for the children; in grade nine. students were to generate their own chronology, adding the length of the judges' terms.

The format of the ninth-grade lessons was simple: (1) a passage to study, (2) approximately fifteen to twenty questions on the passage, (3) other questions with accompanying texts, and $(\downarrow)$ occasionally a note or notes at the end of the lesson. Some of the questions were the same as in the fourth-and fifth-grade texts; however, there were added notes and references in the ninthgrade book, revealing different aspects that were not covered in the elementary text. For example, in tifth grade, students studied that King David took the throne; in ninth. students studied in two lessons David's reign at Hebron and at Jerusalem.

\section{Church School Manuals}

Alma McKibbin wrote suggestions for ieaching Bible Lessons in the church school manuals. and also wrote a manual of her own.

\section{Church School Manual}

The Church School Manual published in 1906 is the earliest General Conference manual for teachers, although two California conference manuals,

'Mckibbin. Bible Lessons in Old Tesrament Hisron: Book One. 1909. 17: idem. A Manual of Old Testament Histor: 1913. 112.

:McKibbin. A . Mamual of Old Tesfument Hisfur: 1913. 133. 134: Bible Lessons in Old Testament Histong. Book Two. 1909. is. 
which Alma McKibbin helped to prepare. Were published in 1900 and $1903 .^{\prime}$ In the 1906 manual, under the section on Bible course work, she recommended correlating language and geography with the Bible lessons. For language, she advised occasionally asking the students for written answers, stressing capitalization, punctuation, and grammar. When themes were assigned, outlines were required. Outlines were also to be used for review.'

Instruction in geography included how to use and construct a globe to illustrate the land masses arter the Flood. The one map essential to purchase for the schoolroom was a map of the worid. Mrs. McKibbin considered other maps more usetul if drawn by the children themselves. Directions were given for making hectograph copies of outline maps for pupils. To understand the peopling of the earth after the Flood, Alma McKibbin suggested that pupils color Map I in three different colors to differentiate the areas settled by Noah's three sons. In the next lesson, teachers were to instruct pupils to print on those colored areas the grandsons of Noah. By this point the students were to have mastered Genesis 10. Teachers were to supplement the map studies with "a simple explanation of the origin of the principal nations of the earth."

\footnotetext{
Cady. 'Educational and Younֻ Penple's Work.' 1: McKibbin. 'Educational History, 16: Haussler, 196.

General Conference of Seventh-day Adventists. Church School Manual for Parents and Teachers, 1906. 200. Since some of these sugyestions duplicate material in the footnotes to the teacher in Book One, some are corielated with the materal in Alma McKibbin's Bible books, and other comments stress use of maps that parallels Alma's own geography and Sunday school training, it is likely that Alma wrote the suggestions in the manual herself.
}

Ibid.. 202. 
Map II focused on Asia and the Middle East, tracing the joumeys of Abraham. "Every mountain, lake, river, sea, and country has some very important history connected with it." "which students were to leam thoroughly. Students were to recognize the relationship between Map II and the map of the world--that Map II was a section of the larger map, but drawn on a larger scale. Having already located Mount trarat and Babel on the map of the world, students were to place these on their smaller maps. Alma McKibbin hoped teachers would describe in words the valleys of the Tigris and Euphrates Rivers, as well as the people who lived there in Bible times. The students were to identify with these people and places, and travel "in company with Abraham. Doubtless they will feel with him the disappointment of tinding [Canaan] full of Canaanites." 2

The new Map III was of Canaan. Students were to see the relationship between Map II and Map III, the latter being an enlargement of a small portion of the former. Using Empires of the Bible ${ }^{3}$ as a reference, students were to nill in by memory the names of the heathen tribes or Canaan in Abraham's day.

Since God's people lived in Egypt over $\$ 00$ years. students were to learn some Egyptian geography and ancient history using Map IV. Alma

\footnotetext{
'Ibid.

Ibid.

'Alonzo Trevier Jones. The Emprres of the Bible (Battle Creek: Review and Herald Publishing Company, 1897).
} 
McKibbin cautioned teachers not to tear taking time for such exercises.

"Remember, this study helps to make the Bible a real book to the children."

Map III was to be reused when the children of Israel left Egypt to enter Canaan, but a new map. $V$. was to show the resettling of the country by the twelve tribes of Israel. Mrs. McKibbin felt that the fifth-year students, using Book Two, were capable of drawing their own maps. Although they could enlarge or reduce outline maps with the aid of squares, they were to be required to draw a free-hand map of Palestine. Such drawing was to be drilled until students could reproduce the map rapidly and accurately from memory. Teachers were to have a map of Palestine on the blackboard at all times but were not to print the names of places, requiring pupils to name these as they pointed them out.

For tifth grade. Alma McKibbin suggested to teachers that the children mimic the Israelites. who likely studied carefully the new land they recenty possessed. The pupils were to discover and reproduce on a relief map, either outside on the ground or in a sandbox. Palestine's topography, and to learn the climate and products of each section as well. Their source book being the Scriptures, they were to make lists of the animal, vegetable and mineral products of Palestine. Teachers could also require them to select texts describing seasons. forests, mountains, lakes and rivers.

Map VI illustrated the extension of Israel under David and Solomon. This map was also to be used for the division of Israel and Judah. After both 


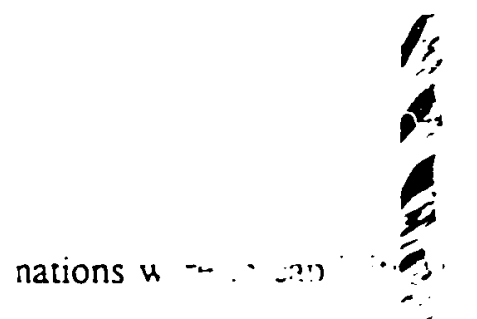

captors.

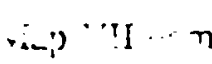

three prc ‥ If 'Ld

describe : ‘ ‘

governmi: ... ..... ז.

ministry $. r . \quad$ ce ne.

of His $\mathrm{m}$

heaven.

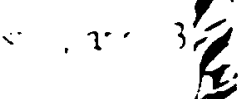

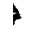

pupil in $\quad \therefore$ rip.....

the conte $11: 00-m$

areas.
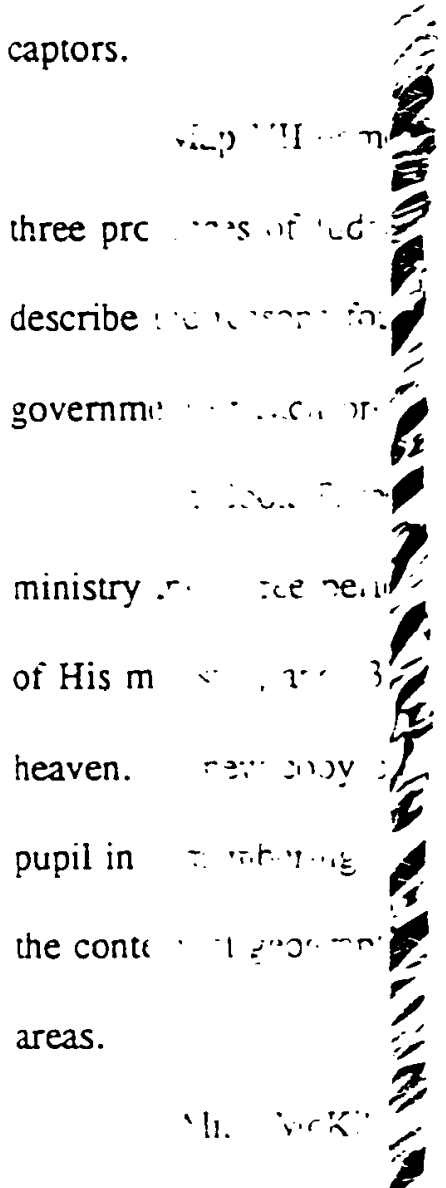

Manual: :

studying $\cdots, \ldots$...

1914 Bil . ener, 'at

$\because$.

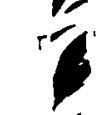

wrote a

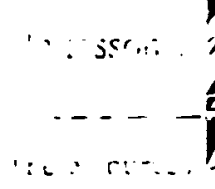

Bible Boo

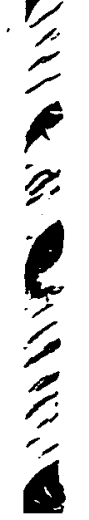

Reproduced with permission of the copyright owner. Further reproduction prohibited without permission. 
nations were in captivity, teachers were to use Map Ii to show the lands of the captors.

Map VII demonstrated Palestine during the life of Christ. Showing the three provinces of Judea, Samaria, and Galilee, teachers were to explain and describe the reasons for the divisions, the settlement of the people, and the government of each province.

In Bcok Three, grade six. 1905. Alma McKibbin divided Christ's ministry into three periods: (1) His birth to His baptism. (2) the first two years of His ministry, and (3) the last year of His ministry until His ascension to heaven. A new copy of Map VII was to be used for each period, to aid the pupil in remembering the events of Christ's life. Time was to be spent studying the contextual geography and history of Jesus' countryside and surrounding areas.

Alma McKibbin closed the helps for Bible in the Church School Manual by citing several sources ieachers could use for securing maps and studying geographical and historical background for the lessons taught.'

\section{Bible Lesson. Vhanial}

In 1914, in response to urgent requests from teachers, Mrs. McKibbin wrote a Bible lesson manual of methods to use for the Bible books. She

These sources are listed under the preceding section. Sources for .tlma McKibbin's Bible Books. 
commented, "I do not know whether it ever helped anyone or not." At the front of the book was a folded insert, almost two feet in length: a "Diagram of Bible History" time line, from 4004 B. C., creation, to A.D. 70.

The manual, eighty-eight pages long, had no index or table of contents but was divided into two major sections, (1) "Preparation for Bible Teaching," which included the teacher's devotional preparation, a rationale for teaching Bible history, an introduction to the format of each lesson, and a section on how to teach Bible geography; and (2) specific methods to follow for the Bible lessons.

In the first section, when discussing the teacher's own devotional preparation, Alma McKibbin revealed the secret to excellent Bible teaching:

The teacher who loves the Bible, who is absorbingly interested in teaching it, will never need to express his love and interest in words. Voice and eyes and face are giving a true index of the heart. Consciously or unconsciously every child knows just the degree of real interest his teacher has in the subject. ${ }^{2}$

Mrs. McKibbin explained how to teach children to study the lesson:

First, make it very clear that they are to study the Bible, not "Bible Lessons."

Take time for a week or more to assist the children in the preparation of the lesson. Time spent in this way is well spent, and means rapid

'McKibbin, 'Educational History,' 20.

:Alma E. McKibbin. Bible Lesson Manual for Parenss and Teachers (Mountain View, Calif.: Pacific Press Publishing Association. 1914), 8. Adventist Heritage Centers: Andrews University, Berrien Springs, Mich.: Loma Linda University, Loma Linda. Calif.; Pacific Union College. Angwin. Calif.; Pacific Press Publishing Association, Nampa, Idaho. 
progress later. Be sure that they understand perfectly how to proceed to study a lesson. Drill until they establish correct habits of study.'

She encouraged teachers to freely use illustrations and visual aids, and gave practical instructions on how to teach Bible geography. Teachers were to study Bible geography themselves until they had a mental image of Bible lands, particularly of Palestine. ${ }^{2}$

The method Alma McKibbin used to teach the fourth day of creation illustrates the correlation of science with Bible, the use of visual aids, class paricipation, and a variety of methods:

The relation of the sun, the moon, and the earth may be illustrated by three children. Choose the tallest boy in the class to represent the sun, a girl to represent the earth, and the smallest girl to represent the moon. Draw upon the ... ground the orbit of the earth. This represents the path of the earth in its yearly revolution around the sun.

Place the boy at one of the focuses of this orbit. Be scientifically accurate in your illustration. Instruct the girl to walk in this orbit. When she has gone around once, teach the year, then have her go around again. This time instruct her to whirl around and around to represent the rotation of the earth upon its axis. The class will then understand what causes the day and the night, and how many days make a year. ${ }^{3}$

Mrs. McKibbin explained that four principles ran like threads throughout Book One: (1) God's plan of government. (2) types and shadows, (3) the covenants, and (4) the justice and mercy of God in the destruction of the wicked. Teachers were to review and emphasize these principles whenever possible. Each lesson also had one or two principles that were to be emphasized. For

:Tbid., 17, 18.

:Tbid.. 20.

${ }^{3}$ bid. 
example, the first lesson, about the first day of creation, stressed (1) God's

purpose for creating the world and (2) the creative power of His Word.

\section{Church School Manual}

Alma McKibbin wrote the section on methods for Bible teaching in the 1918 teacher's manual for church schools.' In it she stressed the necessity for the teacher to be a suitable instrument to be used by God to convey His Word to the pupils. The teacher, she emphasized, must teach from experience, from having lived and incorporated the principles he or she would be teaching into his or her own spiritual life.

Motives must be pure and holy, or one cannot teach the Bible so that it will affect for good the heart of another. . . . The Spirit attends only the words from a heart that is honest in its purposes. Our words impress children only as our characters reflect our teachings. No subterfuge will pass muster. We must be what we teach.

Consciously or unconsciously every child knows just the degree of real interest his teacher has in the subject. ....'

One of the reasons why boys and girls find religious truth wearisome and distasteful is that it is stale. Stale food is never appetizing. Divine truth must come fresh and warm and living from the brain and heart of the teacher or it cannot take root in the heart of the learner.

Mrs. McKibbin felt that Bible teaching was worthy of a teacher's best preparation and best efforts, for the following reasons:

'General Conference of Seventh-day Adventists. Teacher's Handbook on the Elementary Curriculum (Mountain View, Calif.: Pacific Press Publishing Association, 1918). Because the handbook was not available, the material in following paragraphs is from a condensed version of the 1918 manual that was reprinted in Journal of True Educarion (see next footnote).

McKibbin. "How to Teach the Bible," Journal of True Education 27, so. 3 (JanuaryFebruary 1965): 6.8.

'Ibid., 26. 
Your presentation of a Bible lesson must be interesting. Is the Bible fascinating to you? Do you revel in it? It is sometimes puzzling to know why a teacher who presents geography or arithmetic in a bright, vivid manner should be so dull and dry and emotionless when teaching a Bible lesson. Jesus did not teach like the Pharisees, but some of us do.

You do not have the time? Is the price of preparation for teaching the Bible too high? Then consider seriously the results of careless or inadequate preparation. Note the reaction on the boys and girls. First will be lack of interest; then follow indifference to the truth taught, unwillingness to study the lessons, and still greater reluctance to recite what they do know-the impression growing stronger as the days go by that the Bible is a very dull book. Sooner or later there is positive dislike for religious teaching, the conscience growing dull and hard under the reiteration of divine truth unaccompanied by the tender impressions and impulses of the Holy Spirit.

\section{Revisions and Translations}

There seems to be no way to accurately discern which changes in the revisions of Alma McKibbin's books were made by the editors and which by herself, nor which changes she approved of regardless of who made them. Therefore, the following section merely reports the changes which were made in her books without indicating who made them.

1909 Lily of the Valley Books,

One, Two, and Three

Alma McKibbin's first revision of the 1903 Bible Lessons was published in $1909,{ }^{2}$ under the title "Lily of the Valley Books." The covers

Ibid.

These books were planned for and approved by the General Conference Educational Department. Se Pacific Press Publishing Association (Mountain View, Calif.), Minutes of the Board of Directors, 7 April 1909, 77; Frederick Griggs, "New Textbooks," Review and Heralt 86. no. 34 (26 August 1909): 10; General Conference of Seventh-day Adventists (Washington. D. C.), Department of Education Staff Minutes, 4 June 1909. 2-3. Microfiche. Adventist Heritage Center. Andrews University, Berrien Springs, Mich. Book One was ready first, and was used in one conference as a resource for the teacher to use with Professor Bell's Sabbath 
pictured three strands of lilies of the valley in white and green, on a brown cloth background. These books were much larger, both in size and length, than the original editions, appropriate to the much larger type employed and the inclusion of teachers' notes and additional references. Books One and Two, labeled simply, Bible Lessons in Old Testament History, Book One and Bible Lessons in Old Testament History, Book Two, had no other titles. Book Three was entitled, Bible Lessons, Book Three, The Life of Jesus.'

Perhaps experience in teaching both students and teacher-recruits led Alma McKibbin to remark in the pretace of Books One and Two: "The lesson in the teacher's soul, not the one in these books, is the impression that remains in the child's heart." 2 She also stated the teacher's purpose: To cause the

school lessons for the pupils. Se W. E. Straw, Manual of Proceedings of the Lake Union Conference Educasional Board (Berrien Springs, Mich.: Emmanuel Missionary College Press, 1909), 28. Book Two was to be ready by fall, 1909. See "New Textbooks," 18. Alma's first three books printed in 1909 were used in grades four. five, and six in the Lake Union Conference by 1913, and were advertised in Christian Education in 1912. See Lake Union Conference of Seventh-day Adventists, Manual of Proceedings of the Lake Union Conference Educarional Board (Berrien Springs, Mich.: Emmanuel Missionary College Press, 1913), 28; Christian Education 4, no. 1 (September-October 1912): 30. Book Two, at least, was reprinted in 1915, and all four books were listed in the General Conference Bulletin and school manual of 1915. and the North American Division Educational Council of 1918. See General Conference of Seventh-day Adventists (Washington. D. C.). Department of Education, Bulletin No. 13 (1915): 8, 10. 12, 13; idem. Bulletin No. 14 (1916): 3-5; idem. School Manual for Secretaries and Superintendents, Elementary, Intermediate, and Normal Teacters. School Patrons and Churcin Members, Local Church School Boards (Mountain View, Calif.: Pacific Press Publishing Association. 1918), Adventist Heritzge Center, Andrews University, Berrien Springs, Mich.. 7830. 88-89. 92: idem. Educational Recommendations, 1918-19, 4 September 1919. Microfiche. Adventist Heritage Center, Andrews University, Berrien Springs, Mich.; North American Division Conference of Seventh-day Adventists, Council Proceedings of the Joint Council of the Educational and Missionary Volunteer Departments (Washington. D. C.: Review and Herald Publishing Association, 1915), 116, 217, 219, 243-44.

:McKibbin, Bible Lessons, Books One. Two, and Three, 1909.

-McKibibin, Bible Lessons in Old Testament History, Book One, 1909, vii. 
students, "by means of these stories, io understand the principles of the law of God, which is the true end of all Bible study and teaching."

Two pages of suggestions for teachers followed the preface to Books One and Two. The tirst page was the same as the preface to the 1905 edition, with the addition of a reference to ihe revised and enlarged teachers' notes. Apparently Alma McKibbin had mixed feelings about writing notes:

This has been done with some reluctance. A wise use of notes is helpful, but it is very easy to abuse them. Do not depend on notes for the spiritual application of the lesson, nor even ior tacts.

Nothing is so beneticial as original, independent study of any subject. ${ }^{2}$

A poem that taught the books of the Bible was included in the 1909 edition, following the teachers' suggestions in each of Books One, Two, and Three.

There were a tew additions and changes to the Bible stories in Book One. Several lessons on Creation were added, preceding the story of Adam. Stories about Job were added to precede those on Jacob. A lour-page narrative about Egypt (no questions), giving some of the religious history and customs, the pyramids, sphinx. temples, and obelisks, introduced the section about Moses. Attention was drawn to the opportunity God gave the Egyptians to become His people, their subsequent rerusal. and restilting prophetic reference to them as a symbol of darkness and unbeliet.

Ibid.

ibid., ix. 
The lessons about Joshua, having earlier been included in Book Two, were transferred to Book One in 1909. Four pages of narrative on the geography and history of Palestine preceded the lessons about Joshua. Attention was drawn to the surrounding nations and to Israel's opportunity to witness to them about the true God. Descriptions followed of the Jordan River, Jordan Valley, Dead Sea, and nearby Mountains of Lebanon, explaining briefly their ties with Israelite history, or leaving those connections for following lessons. She ended with the universality of Israel's climate, animals, and vegetation:

Because [the animals and the vegetation of Palestine] are so varied, one who reads the Bible, no matter in what part of the world he may live, finds something mentioned with which he is tamiliar.

This is one of the things that makes the Bible a universal book--a book for all the people of all the world.'

Few changes were made in the lessons of all three 1909 books. In some cases, the name of the lesson was changed or shortened, such as from "Hagar in the Wilderness" to "Isaac and Ishmael." perhaps because the lesson contained more content about the latter individuals than the former. The questions, however, remained unchanged. In other cases, a jew vocabulary words were added. Diacritical markings were maintained throughout the three volumes. Colored maps and illustrations were added, and memory verses were printed in full, rather than the reterence only. as in the 1903 edition.

The greatest changes in the three volumes were the extensive notes that were added. largely quotations irom Ellen G. White's books. References 
specified whole chapters of Spirit of Prophecy books, rather than two or three pages.

In Book One, charts were labeled and elaborated to make their meaning more clear, and one chart was added that described the 150 days that Noah spent in the ark. A double-page colored map showed the earth divided among Noah's three sons, and two other maps were added to Book One: (1) "Aoraham's Country", and (2) "Division of the Land of Canaan Among the Twelve Tribes". Many names of cities and people from these maps were added to the vocabulary section of the lessons on those subjects, such as the lesson on the Cities of Refuge. A tew review questions were added to include questions on the new additional lessons.

The changes in Book Two were similar to those in Book One. Several lessons were added. inciuding "the Song of Deborah and Barak," "Ruth," "Jonah," "Destruction of Sennacherib's Army." "Daniel," also a three-page poem about Ezion-Geber, an explanatory section on the kings of Media-Persia, and the stories of Esther. As in Book One, the lessons were essentially the same and in the same order in both the 1903 and 1909 editions of Book Two. A few review questions and many illustrations were added, and the maps were printed in three colors. The Table of the Divided Monarchy. Israel and Judah, with their contemporary kings and prophets. was placed just betore the story of Esther in the 1909 edition. perhaps because the Persian kings were iisted there. Vocabulary words in Book Two were deleted. 
The preface to Book Three suggested using an outline of the three periods of Jesus' life, as mentioned previously, as a tramework for His joumeys through Palestine, and to aid the memory. Alma McKibbin mentioned the period between the Testaments as being important to study because of its effects on the Jewish people. Thus, the story of the four intertestamental centuries was added in Book Three, with genealogical outlines to tie together the two Testaments.

Alma McKibinin underlined the importance of teachers' following the suggestions for making outline maps for each period of Christ's life, stating that His life would have more meaning if the children could "trace His footsteps from place to place through the hills and valleys of Judea and Galilee."

In addition to these lessons, iwelve lessons on the Prophecies of the First Advent were added in the 1909 edition of Book Three. Two lessons were omitted: "Fishers of .Men" and "The Ten Lepers": ihree were added: "Jesus Is Rejected in Galilee," "Evil Plottings Against Jesus," and "The Rich Young Ruler." A three-color map of Palestine during the life of Christ and a chart of the 490 years allotted to the Jews were added in the 1909 edition. At the end of each period of Christ's life was a summary of the most important places $\mathrm{He}$ visited, with a brief history of the area. These summaries, Alma McKibbin advised in the pretace, were to be used as reterence material in connection with the lessons in which the places xere mentioned, as well as for review. A short McKibbin. Bible Lessons. Book Mirce. 1909. ix. 
section on map work was listed at the end of the summaries. Students were asked to draw an outline map of Palestine and to locate, as they studied the lessons, the places Jesus visited on this map.

Instead of one long tinal review of 200 questions, there were four reviews, one at the end of each period and one at the end of the intertestamental period. The final review was over the third period, rather than over the whole book as in the original edition.

1912 Lily of the Valley Book Four

After Alma McKibbin tinished her Bible books for grades four, tive, and six in 1909, the textbook committee of the General Conference requested her to write a seventh-grade textbook on the Acts of the Apostles.' Before it was finished, the committee requested her to write an eighth grade book on Bible doctrines. To conserve expense, both manuscripts were printed in the same volume, with one table of contents at the beginning. It was divided into Part I, Acts of the Apostles, and Part II. The Plan of Salvation. There is only one introduction for both sections, at the beginning of the volume. As in Alma

General Conterence. Minutes. $\&$ June 1909. At a special meeting of the board of directors. it was voted for Sarah Peck to unite with Alma .McKibbin to complete this volume. See Pacific Press. 7 April 19!2. 2. In the introduction to Book Four. Alma acknowledged the helpful suggestions and assistance of my friend Miss Sarah E. Peck." See McKibbin. Bible Lessons. Book Four, wii. Later, in the Pacific Linion Recorder, an announcement mentioned Ama McKibbin's name only (not that of Sarah Peck's) as has naving completed the manuscript. See Pacific Union Recorder 12 (12 Sepiember 1912): 3. It is possible that although Book Four was mentioned in the Church school manual of 1906. Mrs. Mckibbin may not have completed it. due to ill health or other reasons. She was asked to write Bible lessons for grades tour through elght in 1904, and for "all grades" in 1906. possibly implying that Book Four was not yet completed. See Kellogg to McKibbin: Haussler 190-91: Christensen. 105. 
McKibbin's other Bible books published in 1909, nowhere in Book Four, 1912 , is the grade level specified, nor is it specified that the book was to cover two grade levels, as Alma McKibbin elsewhere stated that it was.'

Book Four was approximately the same size and appearance, and used the same type face in the body of the book, as the other three volumes. Books One through Three, published in 1909, had a precedent of having been used for grades four through six in the 1903 and 1905 editions, but Book Four had no precedent; only the request of the General Conference for grade levels seven and eight. For these reasons, and perhaps others, teachers assumed Book Four was to be covered in one year, and many complained that the material thas excessive. ${ }^{2}$

Before Book Four was revised in 1926, there were two officiai references that requested that "'Mrs. McKibbin's Bible Book, No. 4' and 'Plan of Salvation' for Grades 7 and $8 \ldots$ be divided as outlined in each union conference. ${ }^{3}$ Bible for grade seven was listed under grade seven, and Bible for

'McKibbin. 'Educational History, 20.

Thid.; Book Four was advertised for seventh grade (not for eighth) in Christian Educarion 5. no. 10 (August 1914): 320. Max Hill's eighth grade Bible lextbook was advertised in "A Notice to Teachers," and in "Eighth-grade Bible Textbook." Pacific Union Recorder 15, no. 6 (16 September 1915): 6-7. Book Four was also listed for seventh grade only (not eighth) in the North American Division, Council Proceedings of the Joins Council, 244.

'General Conference of Seventh-day Adventists (Washington, D. C.), Proceedings of the Educational and Missionary Volunseer Deparments of the General Conference of Seventh-day Adventists in World Convention (Washington. D. C.: Review and Herald Publishing Association, 1923), 442: idem. School Manual for Secretaries and Superintendents, Elementary. Secondary, and Normal Teachers. Schuol Boards, Pasrons and Church Members (Mountain View, Calif.: Pacific Press Publishing Association. 1924), 83. Adventist Heritage Center, Andrews University, Berrien Springs, Mich. 
grade eight, "Plan of Salvation," under grade eight. ${ }^{1}$ Perhaps this was a temporary solution until the textbook for grade eight, God's Great Plan, 1922. by Sarah Peck, would be used or purchased by most of the church schools.

Book Four began with the ascension of Christ, where Book Three finished. Book Four, Part I, ended with the last letter of Paul from Rome to Timothy. All of Paul's writings were studied except Hebrews, but Alma McKibbin wamed that the lessons were far from comprehensive. She felt that the theme of Part I, that is, Paul's writings, was to fulfill the Gospel commission, "Go ye into all the world, and preach the gospel to every creature. ${ }^{n 2}$ She hoped that those who read the book would desire and receive God's Spirit, so that they, too, could "witness for God as did the apostles of old. ${ }^{n 3}$

Alma McKibbin's purpose in writing lessons on the epistles was not so much to focus on their themes as it was to enable students to understand Paul's overall purpose in writing the different letters. Tracing his journeys and following the historical links in Paul's life would aid the pupils in understanding this purpose. The lessons in Pari I were to inspire the sharing of the subject matter presented in Part II.

Part II, the Plan of Salvation, was presented chronologically as Alma

McKibbin. School Manual, 1924, 83.

McKibbin, Bible Lessons, Book Four, 1912, vii.

'Ibid. 
McKibbin understood the subjects as they appeared in the history of the great controversy between Christ and Satan. Teachers were to impress upon students that each lesson was a fulfillment in time of the great plan God devised to restore man to his lost estate. Beginning with lessons on the Bible and the persons of the Godhead, Mrs. McKibbin introduced God's law and how that law was broken by angels. Creation, the institution of the Sabbath, man's fall, and God's plan for his redemption and conversion were traced until the final events of earth's history culminated in man's living in the new earth.

At the request of many teachers, ${ }^{\prime}$ between 1909 and 1912 Mrs.

McKibbin included many notes and references to the Bible and to Ellen G.

White's books in all four Bible books.

1909 Bible Lessons Book One

(Not Revised)

In 1921 Mrs. McKibbin was asked to revise Book One. She explained later why she could not do this:

I was quite willing to do this until I learned that it was desired that I write the Bible lesson in story form in my own language. The reason given was that children do not comprehend Bible language. This I do not believe. I could not consent to paraphrase the Bible, so the contents of Book One was divided and two books were written by other persons. They are for the third and fourth grades. They are called When the World Was Young and The Story of the Exodus. Book One, of course, went out of print. ${ }^{2}$

McKibbia. "Educational History", 20-21.

Thid.; General Conference of Seventh-day Adventists Dept. of Education (Washington. D. C.), Staff Minutes, 12 July i921. Microfiche, Adventist Heritage Center. Andrews University, Berrien Springs, Mich. 
Eleven years earlier, in the 1909 edition of Book One, Alma McKibbin had expressed her expectation that the fourth-grade children who would be using Book One would be required to read the Bible:

Each question may be answered in the exact words of the Bible, and if so answered, will prove a blessing to the child who answers it. No human para-phrase [sic] can ever equal in power and effectiveness the simple word of God.'

It must be remembered that although it was likely the King James Version of the Bible Mrs. McKibbin was referring to children of the first half of the century were familiar with its phrases, hearing King James English regularly in church, family worship, and prayers.

1921 Life of Jesus. Grade Six

In 1921 Alma McKibbin revised Book Three on the life of Jesus. This book was to be used in the fifth and sixth grades during school years beginning with an even number, in those multigrade schools which alternated subjects biennially. The 1921 edition did not include the chapters on the intertestamental material. Mrs. McKibbin lamented,

Each of my books has been revised at least once since they were printed by the Pacific Press. The Acrs of the Apostles has been revised twice, each time losing something of value in my estimation. Book Three now called The Life of Jesus has had all introductory chapters removed.'

The 1921 edition of Book Three began with the first period of Christ's life, or chapter five of the former (1909) edition. "The Birth of John." Except

McKibbin. Bible Lessons, Book Two, 1909, viii.

-McKibbin. 'Educational History." 21. 
for the removal of the authorities quoted in the lessons, the rest of the book was identical to the earlier version.

The 1924 edition was also the same except for a shining star in place of the lilies of the valley and the removal of the four-color illustration of Jesus that appeared in the 1909 and 1921 editions. In the place of the colored portrait was the map of Palestine in one color, having been in three colors in the earlier editions. The only other change was the addition of a full-page black-and-white portrait of Jesus. A reprinted 1921 copyrighted edition with a printing date of 1928 sported a shining star on the cover and replicated the 1924 edition.

1926 Last of Old Testament Times, Fifth Grade

In 1926, Alma McKibbin revised Book Two for the fifth grade in 1926. ${ }^{1}$ Its name was changed to Bible Lessons For the Fifth Grade: Last of Old Testament Times; Stories from lsrael. Mrs. McKibbin noted: "This time I wrote it for children only, not for teachers. I deeply regretted that the notes were printed in small type. This should not be. ${ }^{n 2}$

Perhaps because of her experience with Book One, Alma McKibbin wrote in the introduction to Bible Lessons: Last of Old Testament Times:

General Conference of Seventh-day Adventists (Washington. D. C.). Department of Education. Staff Minutes, 15 November 1921. Microfiche. Adventist Heritage Center, Andrews University, Berrien Springs, Mich.: idem. Proceedings of the Educarional and Missionary Volunseer Departments, 421.

:McKibbin, "Educational History." 18. 
With proper guidance, even little children may understand the Bible. Teachers do not have time to give all the necessary direction to the child's efforts; hence these lessons.

The format was like that of the 1921 and 1924 editions of Bible

Lessons: The Life of Jesus, with headings and paragraph clusters of questions. Several changes in the introductory notes for the teacher inciuded changing memory work from a daily memory verse to two memory verses per week. New maps were added, in one color. with only the names of the places on them that the child needed to learn.

Alma McKibbin suggested that teachers use for visual aids objects such as torches, pitchers, trumpets, siings, idols, crowns, ancient lamps, rolls, a tleece of wool, a scourge, sandals, a bow, and arrows. She also advised that teachers prepare students carefully for writing or telling the Bible stories. She wrote, "Story-telling is a great art, and should be cultivated in childhood, and encouraged in all periods of life."' Several lessons provided only an outline of a story already studied, such as the story of Ruth, and required the children to write out the Bible story, using the outline provided.

Alma McKibbin noted the most important change in the revision:

The most important change made in this revision of Bible Lessons is the elimination of certain lessons which have seemed to be difficult and not

Alma E. McKibbin. Bible Lessons for the Fifth Grade: Last of Old Testament Times: Stories from Israel. 2d. ed., rev. I Mountain View. Calit.: Pacific Press Publishing Association, 1926), $\because$.

"Tbid.. $*$. 
as interesting as others. or which contain incidents or principles not readily comprehended by children.

The stories of several judges and kings of Judah and Israel were deleted from the revised edition. In their place. Alma McKibbin emphasized the work of the prophets in the history of Israel. "The stories of the work of Elijah and Elisha are in the foretront. while the wicked kings are only a dark background." 2

The poem to help in memorizing the books of the Old Testament and the list of authorities quoted for reterences were missing trom the 1926 edition. The chief expansion to the newer revision was the notes. Mrs. McKibbin cautioned.

A wise use of notes is helptul, but they can very easily be abused. The thoughts, principles. and lessons that come warm from the teachers' own study and experience are worth more than the second-hand wisdom of even a Solomon. ${ }^{3}$

She also lamented.

I also added a tew notes--never enough to satisty the teachers. . . . Professor Ballenger kept reporting: "Our teachers are very weak in Bible. You must give them more helps." Never a word about the children. Always it was. "The teachers need help." The help they needed was to be induced to study the Bible for themselves seriousiy, earnestly, thoroughly,-at least that portion which they were to teach.'

Ibid.

Ibid, , vil.

ibid.

"Mckibbin. 'Educatunal History." is. 
Alma McKibbin changed several questions in the lessons, possibly to make the wording clearer for children. Some of the vocabulary words were written twice; once with no diacritical markings, and once phonetically spelled with the markings. A portion of the quotations from Ellen White's books was deleted, possibly because those sections were about topics that were not feit to be easily understood by children. Perhaps these deletions were what Alma

McKibbin referred to when she wrote in 1957 ,

At the earnest request of the teachers I gave references to the Bible and the Spirit of Prophecy. In after years I was required to remove the words and references because they were "too hard" for the children. They were not intended for the children.'

Review lessons were not as comprehensive, were given more frequently, and covered less material. A short, fill-in-the-blanks review of an unnamed Bible story, a short series of questions, and a section labeled "Who Said It? Under What Circumstances?" completed the final review. ${ }^{2}$

1926 Gospel to All the World. Seventh Grade

In the same year, 1926, the Press published the revision of Book Four, Bible Lessons, Gospel to All the World, seventh grade. ${ }^{3}$ Part I, on the Acts of

Stbid.

McKibbin. Last of Old Testament Times, 1926. 213-20.

'Alma McKibbin was asked to revise Part I of Gospel to the World in 1921. See General Conference of Seventh-day Adventists (Washington. D. C.), Deparment of Education. Staff Minutes, 15 November 1921. Adventist Heritage Center, Andrews University, Berrien Springs, Mich. About this time Sarah Peck began publishing workbooks for each one of the Bible books in grades three through eight. Mrs. McKibbin and Sarah Peck were known to be friends. having worked on many educational committees together. The weight of evidence 
the Apostles, by Alma McKibbin was revised, and Part II, the section on Bible Doctrines, was eliminated. In the place of Part II was a 236-page narrative section by Gladys Robinson Stearns, entitled, "Since the Days of the Apostles," about early and medieval church history, the reformers, and Seventh-day Adventist worldwide institutional development. Alma McKibbin explained the reason for the changes:

The lessons on Bible doctrines in Book Four have been discarded as too difficult.

Indeed, all my books are considered too difficult. The Bible is a profound book. I did not write it. so I am not responsible if it requires deep and thorough study. One may always discard books about the Bible without great loss. But alas! How great will be our loss if we ever discard the Bible itself?'

The two sections of Book Four were to be taught during the seventhgrade year. The entire volume was entitled, Bible Lessons for the Seventh Grade: The Gospel to All the World. The eighth-grade volume, a topical study of Daniel, Revelation, and the great controversy and rebellion in heaven, had been written by Sarah Peck and published in 1922 .

In the revised 1926 edition of Gospel to All the World, Alma McKibbin advised teachers to teach students to consult a Bible dictionary for proper pronunciation of biblical names. She also counseled,

Link the past with the present. Many of the cities of Acts remain to this day, some with names unchanged . . . The daily news often has interesting items concerning the countries and cities of New Testament

suggests a cordial relationship between the two; however. some question exists whether at times there may have been some feelings of alienation on the part of Miss Peck.

:McKibbin, "Educational History," 21. 
history, and church papers report the progress of the gospel message in the places where Paul and others preached so long ago.'

The lessons on the letters to the Thessalonians, Corinthians, Galatians, Romans, Ephesians, Colossians, Philemon, Philippians, Timothy, and Titus were deleted; the list of authorities quoted was shortened, and several memory verses and the color illustration were removed. A four-color map in the 1912 edition was replaced by a black-and-white map for Paul's missionary joumeys. The remaining lessons were in the same order, with no other changes.

\section{Revised Old Testament History}

The ninth-grade text, A Manual of Old Testament History, was revised in 1927 with many more notes, and illustrations, and with maps with the names of places filled in.

The "Suggestions to Teachers" was seven pages long, including much material from the 1914 manual of Bible teaching. In this section, Alma McKibbin stressed the great principles running as threads throughout the Old Testament, which she felt should be emphasized by teachers at every available opportunity:

1. The presence and work of Christ in the Old Testament period

2. God's plan of government and its modifications

3. The meaning of sacrifices and offerings

4. God's purpose for Israel

5. Covenants and their meaning

'Alma E. McKibbin. Bible Lessons: The Gospel to All the World. Seventh Grade, rev. ed. (Mountain View, Calif.: Pacific Press Publishing Association, 1926), vi. Adventist Heritage Centers, Andrews University, Berrien Springs, Mich.: La Sierra College, Riverside. Calif.; Loma Linda University, Loma Linda. Calif.: Pacific Union College, Angwin. Calif. 
6. The justice and mercy of God in His judgments

7. Apostasy and its results

8. Prophets and their work.

Students were to become proficient in the use of such helps as a concordance and a Bible dictionary.

The format of the revised lessons was different from that of the original. Under headings and references, questions appeared in clusters, or paragraphs, instead of in long lists. The headings, in boldface, served as locators for subject areas. Additions included thought questions and extensive notes following each lesson, with more notes in an appendix. Reviews were more frequent.

Mrs. McKibbin wrote new lessons on the great controversy between Christ and Satan. Lucifer's rebellion and the fallen angels were part of these lessons. Other lessons were added in this edition, such as the geographical and historical sections on Egypt and Palestine, and the lesson on the Passover. Some lessons were omitted or combined with others: "The Schools of the Propinets," "David Numbers Israel," and "The Prophet Jeremiah."

Similarities between the 1918 and 1927 editions consisted of the folded time line insert, pronunciation guide to biblical names, and the absence of required memory verses.

She revised 1927 Old Testament History was used until 1949, when the General Conference textbook, Life and Times of the Old Testament, for ninth or tenth grade, replaced it. 
1940 Gospel to All the World.

Seventh Grade

The last revision of The Gospel to All the World was published in 1940. This seventh-grade book, most recently revised in 1926, was revised more times than any of Alma McKibbin's books. If the original printing was in 1903 or 1905 , this book, of which only Part I, "Acts of the Apostles, " was written by Alma McKibbin, was revised in 1909, 1926, and 1940. Part I of the 1940 edition, revised by Alma McKibbin, was named, "In the Days of the Apostles," and Par II, Gladys Stearns' section, was revised by Sarah Peck. The format of grouping questions under topical paragraph headings provided a topical outline for study. Memory verses were fewer in number, and a list of phonetic pronunciations of vocabulary words were listed at the back of Part I. References were primarily for the teacher, but notes were to be required reading for all students. A new set of maps was printed to accompany the new edition. Alma McKibbin mentioned in the notes to the teacher that a workbook (prepared by Sarah Peck) was available to accompany the text. A chronology of contemporary Roman emperors and Judean and Galilean rulers that was first introduced in Bible Lessons, Book Three, sixth grade, 1909, did not appear in the 1926 seventh-grade Gospel to All the World, but was included in the 1940 revision.

Additions to the 1940 edition included an extra map, geographical exercises to introduce the area in which Paul traveled, and two three-color maps, one double-paged. The two lessons on "The Council at Jerusalem" and "The 
Decision of the Council" were deleted, and in their place was substituted a short two-page narrative that explained how the Council at Jerusalem solved the problem of Jewish Christians wanting the Gentiles to keep the old ceremonial laws. A lesson was added that explained Paul's citizenship. The notes were expanded and simplified, and the readings in Bibie passages and books by the Spirit of Prophecy were reduced. Some questions were omitted; in others, the wording was changed or simplitied.

Other changes included summary lessons, which ilighlighted and numbered the events for each of Paul's missionary joumeys. The reviews were separated into two sections; the tirst included questions on the previous division of lessons, and the second section entitled, "Who Said It? To Whom?"1

\section{Spanish Translations}

The five Bible Lessons for grades four through seven and grade nine were translated into Spanish in Serie de Lecciones Biblicas (Bible Lessons Series). The archival collections at the Adventist Heritage Centers in Michigan

'Alma E. McKibbin. The Gospel to .All the World. Bible Lessons for the Seventh: Grade, rev, ed. (Mountain View, Calif: Pacific Press Publishing Association, 1940), 145. Adventist Heritage Centers. Andrews Lnuversty. Bemen Springs, Mich.: La Sierra College. Riverside. Calif.: Loma Linda Lnuversity, Loma Linda. Calif.: Pacific Union College, Angwin. Calif.: Teaching Matenals Center, James White Library. Andrews Universily, Bernen Springs, Mich.; Pacific Press Publishing Association, Nampa. Idaho. Part I. "In the Days of the Apostles," was written by Alma E. McKibbin. and Part II. "Since the Days of the Apostles," was written by Gladys Robinson Steams and revised by Sarah Elizabeth Peck. 
translation was 1955 for Book One. Lecciones Biblicas de Historia en el Antiguo

Testamento (Bible Lessons in Old Testament History). ${ }^{1}$

\section{Comparing Alma McKibbin's Texts with Those That Followed ${ }^{2}$}

Alma McKibbin's grade-school Bible texts, with the exception of Book One for grade four, which went out of print about 1921, were used in church schools until 1951, when a new Bible series replaced them. Until 1951. conferences used Alma McKibbin's Last of Old Testament Times and Life of Jesus for grades five and six in altemating years, allowing multigrade rooms to double up on grades." Alma McKibbin's The Gospel to All the World altemated years for grades seven and eight with Sarah Peck's God's Great Plan.

The names of the texts which replaced Alma McKibbin's for grade four in 1921 have already been mentioned; the work was split between two grades: When the World Was Young, 1921 (grade three), and From Egypt to Canaan, 1925 (grade four). The texts replacing Alma McKibbin's for grades five and six were those sponsored by the General Conference Department of

Four of the five volumes are located in the Adventist Heritage Center. Andrews University, Bernen Springs, Mich., and are listed in the bibliography.

:See Table 6 "Comparison of Readability Levels of Alma McKibbin's Book with Those that Replaced Them." on following page.

'Lake and Columbia Union Conferences. Deparments of Education. The Course of Study, as Adopted and Arranged for the Elementary and Intermediate Schools in the Litke and Columbia Union Conjerences of Seventh-day Adventists ([n. p. : Lake and Columbia Union Conference Departments of Education, 1944), 330. 
Education, Messengers of the Promise (1952) and Day by Day with Jesus (1951), and for grade seven. Witnesses for Jesus (1952). ${ }^{1}$

Third-and Fourh-grade Texts

The third- and fourth-grade texts that followed Alma McKibbin's fourth-grade Bible Lessons in Old Testament History, Book One, 1926, both featured narrative, short stories at what was assumed to be third-and fourthgrade reading levels, each followed by a series of about fifteen questions that began with who, what, where, when, how, and why. A memory verse and an activity for the children to do, often in their workbooks, with references for the teacher, completed the section at the end of the narrative. The authors paced stories at the rate of approximately one per week. The outline of Bible stories followed, in general, that of Alma McKibbin's previous volume. A Fry readability test has yielded a grade level of 5.0 for Alma McKibbin's Bible Lessons, Book One, 1909. which was replaced by the third grade When the World Was Young, which tested at the 6.5 grade level, and the fourth grade text, From Eygpt to Canaan, which yielded a grade of 6.2 . It must be remembered that tests of readability level were not used when these books were published.

General Conference of Seventh-day Adventists. Deparment of Education. The School Manual, Elementary and Intermediase (Washington, D. C.: General Conference of Seventh-day Adventists, Department of Education. 1950), 103-4. 
Table 6.--Comparison of Readability Levels of Alma McKibbin's Books with Those That Replaced Them ${ }^{1}$

\begin{tabular}{|c|c|c|c|}
\hline McKibbin Textbook & Readability Level & Replacement Text & Rerdability Level \\
\hline $\begin{array}{l}\text { Grade 4, BK I, O. T. } \\
\text { History (1909) }\end{array}$ & 5.0 & $\begin{array}{l}\text { Grade 3, When the } \\
\text { World Was Young, } \\
\text { 1921; } \\
\text { Grade 4. From Egypt } \\
\text { to Canaan. } 1925\end{array}$ & $\begin{array}{l}6.5 \\
6.4\end{array}$ \\
\hline $\begin{array}{l}\text { Grade } 5, B K 2,0 . T . \\
\text { History (1926 rev.) }\end{array}$ & 7.1 & $\begin{array}{l}\text { Grades } 5 \& 6, \\
\text { Messengers of the } \\
\text { Promise. } 1952\end{array}$ & 4.7 \\
\hline $\begin{array}{l}\text { Grade 6. Bk 3, Life } \\
\text { of Christ. 1921 }\end{array}$ & 4.8 & $\begin{array}{l}\text { Grades } 5 \text { \& 6. Day } \\
\text { by Day with Jesus. } \\
1951\end{array}$ & 4.6 \\
\hline $\begin{array}{l}\text { Grade } 7 . B k 4 \text {. Pt. I: } \\
\text { In the Days of the } \\
\text { Apostles, } 1940\end{array}$ & 7.1 & $\begin{array}{l}\text { Grades } 7 \text { \& } 8 \text {, } \\
\text { Witnesses for Jesus. } \\
1952\end{array}$ & 8.7 \\
\hline $\begin{array}{l}\text { Grade } 8, B k 4 . \text { Pt. 2: } \\
\text { Plan of Salvation. } \\
1912\end{array}$ & 8.0 & $\begin{array}{l}\text { Grade 8, God's Great } \\
\text { Pletn. 1922; } \\
\text { Grade 7, Fi. 2, Plan } \\
\text { of Salvasion, } 1926\end{array}$ & $\begin{array}{l}8.0 \\
9.3\end{array}$ \\
\hline $\begin{array}{l}\text { Grade } 9 . \text { A Manual } \\
\text { of Lessons in O.T. } \\
\text { Hisrory, } 1927\end{array}$ & 7.9 & $\begin{array}{l}\text { Grade 9, Life and } \\
\text { Times of the Old } \\
\text { Testamens, } 1949\end{array}$ & 8.7 \\
\hline
\end{tabular}

Fifth- and Sixth-grade Texts

The fifth- and sixth-grade replacements for Alma McKibbin's Last of

Old Testament Times, 1926, and The Life of Jesus, 1924, were Messengers of the

Promise, 1952, and Day by Day with Jesus, 1951. Both books were written by

:The author tested all of Alma McKibbin's books, using the Fry Readability Graph. See Edward Fry, Fry Readability Graph (New Jersey: Rutgers State University, 1977). The readability level would have scored significantly lower in all books if the references to Ellen White's writings were not included. These writings in general scored at the eighth- or ninthgrade levels and were usually included for the teacher. 
committee members hired by the General Conference of Seventh-day Adventists, which absorbed all royalties. The 1950 s Bible series was vastly different in form and substance from the McKibbin Bible books. The 1950s format consisted of two-to-tour-page narrative Bible stories written in fifth-grade level vocabulary, with no references in the text. The only similarity between the new texts and the McKibbin tifth-and sixth-grade texts was that the content of the stories came from the same time periods. All references, memory verses, vocabulary words, and enrichment activities were restricted to the teachers' guide, which was published as a separate volume.

Some of the authors and compilers of the fifth and six-grade texts have confirmed that they borrowed nothing from Alma McKibbin's books; they had not wished to. It was the committee's purpose to devise books for the fifth and sixth grade that could be read by children at their own level, which tested at 4.7 and 4.6, respectively, for .Hessengers of the Promise and Day by Day with Jesus. The books they replaced. Bible Lessons Book Two, for the iffth grade, and Bible Lessons Book Three, sixh grade, had shown levels of 7.1 and 4.8 . respectively.

The General Conierence reading committee hoped to break what they felt was the cycle of memorization of isolated facts into which Bible teaching in many church school classrooms had degenerated.' In the teacher's guide to

Interviewees $\$ 116$ and $\# 117$. who wish to remain anonymous. 
Messengers of the Promise, the compilers counseled against children's unguided reading of the Bible:

The acquisition of facts and texts alone will not save our children. Their emotions must be aroused and directed into behavior patterns by which they will voluntarily choose the right and shun the wrong.

The teacher should frequently read parts of the day's lesson text from the Bible to the children. ... The teacher should develop the ability to read well. The children's appreciation of the Bible will depend in a large measure on the capacity of the teacher to arouse emotional responses.

The children may read passages in the Bible individually for enjoyment after the vocabulary study and the reading of the story in the text. . . . The reading of the Bible will then be an easy and enjoyable experience because the pupil will bring to the task an understanding of the Old English vernacular of the Bible and an appreciation of the story. It is essential that we do not permit our children to develop faulty habits of inaccuracy in reading the Bible, or to acquire an emotional blocking against private reading of the Bible because it seems to be a "hard" book.'

References in the Companion Book (workbook) were not to be read by all children, for those who could not read well enough "should not be required to stumble through the Scriptural reading, lest they develop an aversion to the Bible. "2 Regarding the references in the Spirit of Prophecy books, the following comments appeared in the teachers' edition:

Spirit of Prophecy References: In general, the chapter references are for the use of the teacher only. To force the children to read at length in books of adult level will often spoil the beauty and help which these books can give in later years. Children of advanced reading ability should be encouraged to read Patriarchs and Prophers or Prophets and Kings on their own initiative. Special references to these books are often given in the

General Conference of Seventh-day Adventists. Teacher's Guide and Key for Messengers of the Promise. Senies $1 I^{\circ}$. Odd Year. Bible Lessons tor Grades Five and Six (Mountain View. Calif.: Pactic Press Publishing Association. 1952), 3.

:Ibid., 6. 
Companion Book to be read by all the children. By such reading the children can become familiar with the Spirit of Prophecy books. ${ }^{1}$

Seventh and Eighth-grade Texts

Witnesses for Jesus, the seventh- and eighth-grade textbook published in 1952, replaced Alma McKibbin's Part I, "In the Days of the Apostles," contained in the 1940 edition of The Gospel to All the World. The maps for Paul's missionary joumeys were retained in the new book, which, like Alma McKibbin's, devoted a third of its space to those missionary joumeys. Both began about the time of Jesus' ascension and ended approximately at Paul's death, but there the similarities ended. The 1952 book was written in narrative style; children read the Bible story in modern English in the text, which was at a readabiity level of 7.5, compared with 7.1 for Alma McKibbin's version. References were supplied at the end should the student or teacher wish to pursue further study.

The story you have just read was taken from the references given below. They are given for your convenience. If you are interested in learning more about the story, or if you have a question about some incident, look up the references and read for yourself just what the Bible and the Spirit of Prophecy say. The reading of all these references is not required. This plan of providing the references is used throughout the book. ${ }^{2}$

ibid.. 4 .

'General Conference of Seventh-day Adventists, Department of Education. Witnesses for Jesus, Series IVo. Odd Year, Bible Lessons for Grades Seven and Eight (Mounlain View. Calif.: Pacific Press Publishing Association. 1952), 7. 
At the end of some chapters was a section called "Use Your Bible," in which students were asked to make use of their Bible in various ways, such as to (1) learn the names of the gospels and be able to spell them: (2) count the chapters in each of the four gospels that give the story of Jesus' life; and (3) give the references for the crucifixion story.' Other sections, called "Things To Do," or "Find and Tell," assigned some map work or study in Bible references, such as a Bible atlas or dictionary. Occasionally thought questions appeared in a section entitled, "Things to Think About."

Sarah Peck's God's Great P!an. 1922, for eighth grade, followed Alma McKibbin's Bible Lessons in Old Testament History, Book Four, 1912, for seventh and eighth grades, in which Aima McKibbin had written two parts; "The Acts of the Apostles." and "The Plan of Salvation." The second part. "The Plan of Salvation." on Bible doctrines, considered too difficult for eighth graders, was replaced by Sarah Peck's book. Both God's Great Plan and Part II, "The Plan of Salvation" had a Fry readability level of \$.0.

God's Great Plan was a 500-page book that swept through the ages. from the plan of creation in heaven to the holy city descending from heaven in the new earth. Alma McKibbin's Part II, which Sarah Peck's book had replaced, had treated a list of forty doctrinal subjects, beginning with the word of God, the persons of the godhead. God's law, the angels. Lucifer, the Sabbath.

Ibid.

Tlbid.. 7. !67, 10s. 
conversion, the nature of man, three angels's messages, sanctuary, second coming, seven last plagues. millennium, resurrection, and the new earth. Miss Peck's 93 topics and twenty-seven revie:v chapters covered such subjects as the following: why God could not prevent sin, why sin was allowis :o continue, why it was necessary for Jesus to die; the prophecies of Daniel and Revelation, and "Bible studies" on the sanctuary, conversion, and baptism.

The doctrinal lessons in God's Great Plan were in standard question format followed by Bible references. The other lessons were largely narrative, written at grade reading level, with the reterences that were used for each lesson listed in fine print at the bottom of the page. After several lessons, a review lesson followed, with questions and textual reterences to the Bible.

In 1926, Gladys Robinson Stearns revised "The Plan of Salvation," the second part of Alma McKibbin's 1912 Bible Lessons in Old Testament History. Book Four.' The revised "Plan of Salvation" was a narrative text that described the history of the Christian church from the days of the Apostles, through the dark ages, to modern times. The revised text had a Fry readability level of 9.3; Alma McKibbin's Part II, which it replaced, tested at level 8.0.

It is a conundrum why Part II was retanned and revised. It had onginally been commssioned and written tor two grades (both seven and elght), but was used for one grade (seventh). Teachers had complained that the hook contanned too much content for one grade. In 1926. church school eighth graders were already using Sarah Peck's God's Great Plan, so the use of Part II was unneccessary for the elghth grade. One wonders why the General Conference didn't cease prnting Part II. The Plan of Salvation. 
Ninth-grade Manual of

Old Testament History

There were many similarities between Alma McKibbin's ninth-grade

Manual of Lessons in Old Testament History (1927) and the General Conference Life and Times of the Old Testament (1949). It appears that the major contributors to the latter book, Elders H. E. Weaver and R. Willard Wentland, borrowed heavily from the earlier text. These men cited Alma McKibbin's Old Testament History in the bibliography of Life and Times, frequently used quotations from Alma McKibbin's book in the new lessons, and expressed appreciation for having been able to use Mrs. Alma E. McKibbin's Old Testament History as a background for the $19+9$ text.'

The table of contents in the two books were similar in content: many of the titles were identical. The new book was similar in format to the McKibbin text in that headings in boldface set off clusters of questions, which were in some cases identical to those in the McKibbin book. References were included either in headings or with questions. Vocabulary words were listed at the end, possibly for further student assignments. Thought questions for discussion were under the heading, "What Do You Think?" Occasionally there was a memory verse, and there were nine review sections. The questions in the reviews were different from Alma McKibbin's, but the format was the same:

General Conterence of Seventh-day Adventists. Department of Education, Life and Times of The Old Testamem (Mountain View. Calit.: Pacilic Press Publishing Association. 1949), ii, 11. 14. 566. 


\section{2}

tirst, questions on the preceding lessons, and second, a section !abeled, "Who Said, To Whom, and under What Circumstances?"

Life and Times included several maps, many in several colors, the Jewish Calendar, Table of the Judges, and a chronological chart of Judean and Israelite rulers and their contemporary propiets and neighboring kings.

Perhaps the greatest difference between the 1949 book and that of Alma McKibbin's was that often a narrative quotation, from the Bible or some other reference, answered the questions asked. The following example asks who had to make the tinal decision as to whether Rebekah would accompany Eliezer back to marry Isaac, and demonstrates the narrative answer:

Who had to make the tinal decision?

After the consent of the family had been obtained. Rebekah herself was consulted as to whether she would go to so great a distance from her father's house. 10 marry the son of Abraham. She believed, from what had taken place, that God had selected her to be Isaac's wife. and she said. "I will go." [Genesis 24:58]--Patriarchs and Prophers, 173:3.

In some lessons, most of the questions had answers provided in the textbook: in others, none of them did.'

The Fry readability level for Life and Times of the Old Testament is 8.7: that of Alma McKibbin's A .Manual of Lessons in Old Testament History, 1927 revision. 7.9.

Ibid. 92-94. 174-175. 
Life and Times was revised in 1957 and used until the 1970s, when a new series, completely different in format and somewhat dissimilar in content, replaced the old.

Use and Opinion of Alma McKibbin's Bible Texts

Over fifty people who used Alma McKibbin's texts were interviewed by or corresponded with the author. Their comments are summarized or quoted in the following paragraphs.

Besides the official use already described, Alma McKibbin's books were employed in diverse ways. One student used them for almost 3 years in the eariy 1920s in a home school in southern Illinois. ${ }^{1}$ Many folks kept the McKibbin books for reference purposes. ${ }^{2}$ Others saved them because they liked the author. One student, who did not have Mrs. McKibbin as a teacher but who used her books, asked, "Who is this 'Mrs. McKibbin'? Usually textbooks are written by men. ${ }^{3}$ Hills. Calif.

'Aileen Smithwick, telephone interview by author, 23 Febrarary 1991, Los Altos

:John M. Staples, interview by author, 6 March 1991, Angwin, Calif; Carl Anderson, telephone interview by author, 27 March 1991. Robert Jacobs, interview; Grace B. Pitcher. Camden. Maine, to autbor, 19 February 1991; idem, telephone interview by author. 6 December 1990; Ethelyn Marie Payne, Rochester, Wash., to author, 18 February 1991.

${ }^{3}$ Robert Jacobs, interview. 
Alma McKibbin's texts were used throughout the United States and in many countries overseas.: She wrote regarding one experience,

My little textbooks have made many unknown triends. Last fall a young Egyptian called to see me. His father sent him to our school thirty miles from Cairo. Here he studied from my Old Testament History and became a Christian. He said. "I love the book because it brought me to Christ and I wanted to meet the author." He has translated the book into Arabic, and also Patriarchs and Prophets and Prophets and Kings, and is going to publish them.

"So," he said, "all the Arabic world can learn of Christ and understand their own history."

In the late 1940s through mid 1950s. Alma McKibbin's books were translated and published for use in Spanish-speaking countries.

John Staples studied from Alma McKibbin's books as a boy in a church school in Claremont, a sudurb of Capetown, South Africa, about 1927 28. Now a religion teacher retired from Paciñc Union College, he attributes not only his whole foundation of biblical knowledge, but his entire direction in life to Mrs. McKibbin's books and to the inspiration of his teachers who used her books.

Staples remembers a rigorous Bible program in the Adventist church school and high school connected with Helderoerg College. South Africa, which was on the British system. His teachers were dedicated, believed in what they taught, were interested in their students. and were $\vec{n} r \mathrm{~m}$ disciplinarians. They

\footnotetext{
"Alma McKibbin Celebrates Hundredth Birthday Soon." Pacific Union Recorder 71 no. 19 (15 November 197!): i.

"Alma E. McKibhin, Educatonal History. TMls [photocopyl, n. d.. in the hand of Else Nelson. Grand Terrace. Calif. This manuscript has some changes trom the 1957 copy.
} 
assigned homework and daily memory verses; forty or tifty verses had to be learned by the end of the quarter. Bible was as important to them as any other subject and not an appe.idage to the other course work. Staples kept his Old Testament History from Helderberg High School, not for memory's sake, but as a reference tool in which information could be located quickly and easily.

Dr. Staples felt that students who came to college having studied Alma McKibbin's books were well prepared for their college courses.'

Some former students remember feeling that the McKibbin books were too difficult. One declared, "Her books were known for being ton hard."2 Another student failed the eighth-grade Bible course in his home town in Idaho, where he had used Alma McKibbin's books in grades four through seven, because he couldn't pis the conference examination given to eighth graders. When he moved to Mountain View in 1921, he had to make up the work of that Bible course before he was allowed to graduate from Mountain View Academy. While there, ne had A'ma McKibbin tor a teacher and passed when he took Bible from her.'

Some teachers also considered Alma Mckibbin's books too difficult for their students and for themselves. Many of the Bible and reference passages in

John M. Staples. interview.

Ivan Neill Jones, interview by author, 9 March 1991. Middleton. Idaho.

Interviewee 439 , who wished to remain anonymous. it must be remembered that in 1922 Sarah Peck's God's Grear Plan was used for elght-grade Bible: in 1915 Max Hill's book was used in the Pacific Union: and Mrs. McKibbin's Bonk Four. although commussioned (c. 1909) by the General Conterence for both seventh and etghth grade. Was used for seventh grade. it is uncertain then. whether the elghth grade text menuoned ahove was Mrs. McKibbin's. 
the Bible lessons were too difincult for instructors, let alone for children, to comprehend. Some educators noted that children over a period of fifty years had changed and no longer wished to study as diligently or as many hours as students of bygone years. Other administrators felt, in some ways, that Alma McKibbin expected too much of teachers, who had too little time to spend in the classroom teaching an increasing burden of subjects and skills required by the state.

Axel C. Nelson, Director of Education tor the Pacific Union for twenty-five years, made the following comment on the criticism of Alma McKibbin's books: "Some tolks' philosophy is, 'Get by as easy as you can." "2 He recalled that he had passed along the suggestions of teachers who used her books to Alma McKibbin, who incorporated many of these recommendations into her textbooks.

By no means did everyone think the books were too difficult. F. O. Rittenhouse, who used and taught in 1920 from her books at Mount Ellis Academy, Montana. felt they were neatly done with "Iessons clearly set forth. They were not too hard. . . made you think, and always had some questions to encourage cogitation." 3 Some student, too, ielt that Alma McKibbin's Bible books were written in language students used: "[Old Testament History] wasn't

Interviewees $\$ 87 . \neq 117, \$ 27$. and $\$ 123$, who wish to remain anonymous.

:Axel C. Nelson. intenilew by author. 2? February 1991. Angwin. Calif.

F. O. Rittenhouse, interview. 
too much above our heads--the type of questions a teen would ask." "They were written in language I could understand, and they led me to a real knowledge of Jesus and the plan of salvation." "They seemed easy and understandable, and always projected hope and confidence in God and His word." 3

Some believed that the difficulty of the McKibbin books proved she did not understand the abilities and reading levels of children, and that denominational Bible textbook writers had a greater knowledge than Mrs. Alma McKibbin did of principles of child development and learning theory affecting the children and youth who would be using the bonks.' Howevar, many over the years gave evidence that Alma McKibbin did not lose touch with children and did understand their capacities for leaming. These individuals reasoned that her later popularity with youth in groups, as well as in personal counseling, attested to her ability to understand young people.

Certain students remembered the methods their tiachers used to teach Bible, using the McKibbin books. Several remembered studying a memory verse every day. One remarked, "Those are the ones I still remember. The

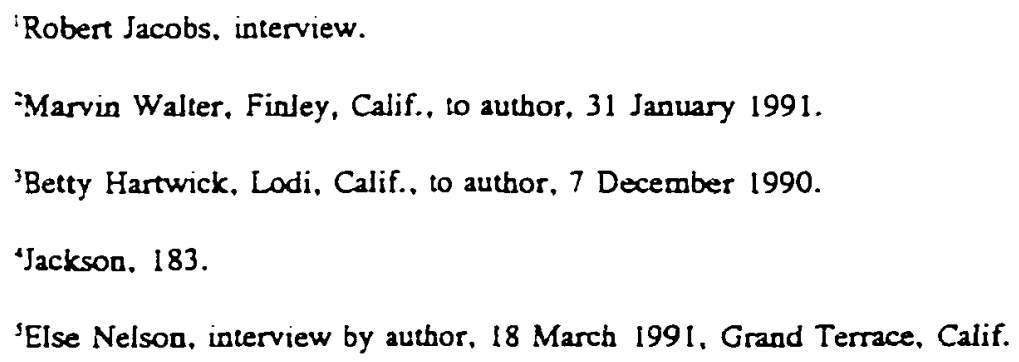


ones I learned in college I don't remember. Those [earlier] verses have stayed with us." 1

Some teachers said they enjoyed teaching from Alma McKibbin's books. One teacher felt that the applications in the notes provided a solid foundation on which to build students' lives. ${ }^{2}$

\section{Alma McKibbin's Opinion}

According to some administrators and students, Alma McKibbin's concern about the revision or discontinuance of her textbooks was not based on a jealous or proprietary interest in her books. Several educators believed that her refusal to submit her books for revision was born of a genuine concern for the future children of the church. Alma McKibbin often quoted Ellen White's phrase that children were our hope for the future. She felt that by providing answers in the text or paraphrasing Bible stories in narrative form, a great dimension of teaching would be lost. She feared that the textbook material would be watered down; that unless the Bible was used primarily, children would merely be reading stories, answering questions, and spitting back factual material, in place of learning a new way to live. She was distressed at the prospect that youngsters would not know their Bibles or practice biblical

\footnotetext{
'Lois Berry, telephone interview by author, 5 March 1991. St. Helena, Calif.

:Marjorie Clark, telephone interview by author, 12 February 1991: Grace Jacques. interview.
} 
principles.' She was also concerned that teachers were taking Christ and the Bible out of classes and books. Some people remembered her saying, "Bible is being taught as a subject, not as a way of life." Apparently she felt that students were memorizing facts for a grade, rather than practicing and integrating the principles they learned into their daily habits. ${ }^{2}$

In the 1930s Aima McKibbin confided to a student that she foresaw that her Bible books would be "pushed aside. ${ }^{3}$ In the 1960 s she made it clear to a friend that she was not hurt that the conference was no longer using her books. Ohers, however, felt that Alma McKibbin did feel hurt. ${ }^{+}$At the end of a composition on church school history in 1957, Alma McKibbin wrote:

Now all of my books are out of print because new ones have been prepared. They are in story form. I refused to paraphrase the Bible, so my books were finally rejected."

\section{Summary and Observations}

Integration of Alma McKibbin's Faith and Methodology

In various ways, Alma McKibbin integrated her value system into her Bible books. Perhaps the principles she cherished most came from the writings

Interview with \#108, who wished to remain anonymous.

Howard Larkin, telephone interview by author, $10 \mathrm{March}$ 1991, Nampa, Idaho: Gladys Scharff Jones, interview by author, 10 March 1991. Middleton, Idaho; Naomi Hagood, telephone interview by author. 23 February 1991. Mountain View, Calif.

'Gladys Scharff Jones, interview by author. 9 March 1991. Middleton. Idaho.

'Interviewees $\$ 123$ and $\$ 27$, who wish to remain anonymous.

'McKibbin. "Educational History," 22. 
of Ellen G. White, who encouraged her by lending her an unpublished manuscript and a box of books from her own personal library. Since Mrs. McKibbin's values originated from the Bible and the Spirit of Prophecy, these sources were prominent throughout the Bible Lessons in reterences, notes, suggestions to teachers, and recommended bibliographies.

Mrs.McKibbin believed that the Bible should be the foundation for all education. The format of her books reveals this conviction requiring students to answer questions by going directly to the Bible for answers. The content for the answers was Bible history, which Alma McKibbin felt was toundational to understanding the doctrines and principles of life. She also considered hands-on experience with the Bible, the primary source tor moral instruction, to be superior to other methods of Bible teaching. In this respect she departed from the practice of Protestant educators in the public schools, who used secondary sources for religious instruction. She believed the words of the Bible authors to be the norm for expressing biblical principles. and preferred memory work and written assignments to be done in the exact words of Scripture. Moreover, Mrs. McKibbin desired the Bible to be not just a textbook but a guide tor daily living. Students were to learn Bible history and stories, not for a grade or to excel in school, but to better understand how to live the Christian life. She advised teachers to take care to model balanced Christian living to their students, who would learn more quickly to integrate biblical principles by example than through instruction alone. 
She believed the teacher's role to be the key to successiul Bible teaching. As mentioned above, successiul Bible teacning meant that the learner would integrate biblical principles into the daily life. For children to accomplish this integration, teachers must model biblical principles for their students. Mrs. McKibbin encouraged instructors to prepare for lessons and bring to class their own experience, thereby putting vitality into an otherwise dull lesson. She ieared that becoming dependent on the notes and outlines prepared in Bible Lessons would rob teachers of the opportunity to develop original, independent thought, and thereby rob children of an enthusiastic, interesting, and meaningful presentation. She encouraged teachers, through suggestions in introductory notes and manuals, to put forth their best efforts and most creative ideas to make Bible the most interesting subject of the curriculum.

Alma McKibbin's personal background and experience can be witnessed in her Bible books. The format of these books was similar to both the international Sunday school lessons she used in her youth, and to the Sabbath school lessons, which incorporated Biblical reterences with each question. Her past experience in Sunday school with Bible reterences and map study and her love for geography and history also played major roles in her methodology, as outlined in the manuals and suggestions ior teachers.

She incorporated principles of teaching from her normal training into the Bible curriculum. including: 
1. giving memory work to siudents in order to strengthen their

memory,

2. delivering clear instructions (such as spending a week teaching children how to study a Bible lesson).

3. relating prior learning to the learning task (via charts and diagrams, using the concrete to teach the abstact;,

4. using a variely ot methods (such as charts, diagrams, time lines, maps, dramatization, and drill), and

5. correlating Bible with orher subjects.

She correlated Bible with other subjects for several reasons and advantages:

1. nistory and geography provided a contextual background that assisted the students in capturing the meaning of Bible passages;

2. language skills were integrated with meaningiul biblical content, rather than learned in isolation:

3. students practiced reierence skills as they used Bible concordances, dictionaries, and commentaries to complete their assignments:

4. applications of Bible stories to modern-day countries and events make the Bible real to pupils understariding. and

5. Aima McKibbin agreed with Mrs. White that children should be firmly grounded in the tundamentals of learning. She theretore spent time 
drilling the students on pronunciation and spelling of biblical names, also giving students oral and written exercises while using the Bible for content material.

\section{Controversies over Alma MlcKibbin's}

Bible Books

Former students recalled Mrs. McKibbin's books with a variety of feelings. It is impossible to determine what percentage of students experienced positive or negative feelings, due to the inadequacy of sampling, the length of time since they used the books, their possible bias toward Alma McKibbin as a revered figure in the church, and the tendency of the human mind to remember the past subjectively. However, in spite of these difficulties, several individuals were willing to share their recollections of some of the more broad generalizations they had heard and their personal experiences with Mrs. McKibbin's books, and some were able to recall specific details. In general, those who experienced difficulty with the Mckibbin texts felt there was an overabundance of material to cover and heavy amounts of memory work. Those who enjoyed her books still remembered the verses they had learned and felt the questions and material were at appropriate levels of comprehension.

Some teachers deemed the level of the reterences, notes, and content of several Bible stories to be above the average child's comprehension ability, especially in the younger grades. Those teachers who enjoyed the books felt they were spiritually uplifting for children, and that the questions and other 


\section{4}

inquiries that emerged from reading and discussing the Bible stories encouraged students to think.

Teacher educators and conference textbook writers had a variety of feelings about her books. In general, many agreed that (1) the Bible should be used as a resource on a regular basis; (2) the use of a certain amount of narrative material to supplement and aid comprehension of Scriptures is beneficial; (3) the goal of Bible study was for the student to love the Bible and integrate its principles into daily living; (4) mere learning and drill of tactual material did not comprise appropriate Bible teaching, and $(5)$ the Bible should be the foundation of all true education.

Mrs. McKibbin disagreed in two major respects with other conference educators about how to write Bible books.

1. The biggest problem occurred over whether children could read and understand the Bible. Mrs. McKibbin telt they could. Her overriding concem was that children love biblical principles and integrate them into their daily lives. The way to accomplish this integration involved preserving the old question-andanswer system that brought students in direct contact with the primary source. the Bible. Other conterence textbook writers. on the other hand, feared that if efforts to read Scripture resulted in tailure or frustration, children who were not fluent in Bible reading would grow to dislike the Bible. Disturbed that no child would accept something he or she did not like. textbook authors paraphrased 
Bible passages in narrative form at what they felt to be the students' level of fluency. ${ }^{1}$ The overriding concern of these writers seemed to focus on the child's enjoyment of Bible class.

2. The second major difference between Alma McKibbin and other church Bible textbook authors was over the notes in her Bible textbooks. To preserve originality and independence of thought, Mrs. McKibbin believed that it was detrimental to include a great deal of supplementary material for teachers in the Bible textbooks. She hoped that their own personal study would result in fresh and interesting lessons springing from the teacher's own experience, which would be superior to the use of the notes Alma McKibbin included. Some conference educators, however, alleged that the following concerns took precedence over Alma McKibbin's objections to publish what she felt were too many notes for teachers: (a) additional state requirements and other responsibilities added to the schedules of the already overburdened church school leachers: (b) students were tending to study less as the diversions and enterainment of an increasingly urban society competed for pupils' time, and (c) the existing Bible program was deteriorating into dull memorization of factual material. These administrators promoted material that took less teacher time and seemed to stimulate higher student interest as part of the solution.

\footnotetext{
'Several conference textbook writers confirmed that, to their knowledge, no readability testing had been done on either Alma McKibbin's books or those that replaced them. See Ethel Young, telephone interview by author, 6 September 1991; Else Nelson, telephone interview by author, 6 September 1991; Ruth Carr Wheeler, telephone interview by author, 6 September 1991. Readability testing, using Fry's graph (see Table 6, p. 246), demonstrated that two-thirds of Alma's books but only half of the conference books tested were at grade level.
} 
However, by the 1940s, teachers. who as a body in the 1920s had allegedly been requesting more notes, were proclaiming the notes too difficult for the students' comprehension level. By then, the issues over using the Bible as a primary source versus using narrative material that was more easily comprehended by children had developed into an either-or situation. in which there seemed to be no compromise. 


\section{CHAPTER 5}

\section{LATER TEACHING YEARS}

$1911-1927$

Still teaching, reading, praying, and leading, Twice blessed--herself and others.

President Irwin had called Alma McKibbin to teach Bible History before Pacific Union College opened in $1909 .{ }^{1}$ but she had felt that the environment of a new college was unsuitable tor her invalid mother. Besides, annual rainfall could reach sixty-tive inches on Howell Mountain. where the college was located, causing muddy conditions on the unpaved roads. In addition, no adequate !iving quarters were available at the time.:

After sending her brother Lonnie up to Pacific Union College for the 1910-11 school year. ${ }^{3}$ Alma McKibbin remained in Healdsourg. This was a

Pacific Union College. Minutes of the Pacitic Lnion College Commuttee. 9 February 1910, 2. Adventist Heritage Center. Pactic Linon College, Anguin. Calif.

:Utt. Diogenes Lantern. 66: McKibbin. Interview, 2 August 1967. 27.

Hereafter. Pacific Lnon Cullege may be abbreviated. "PLC." 
difficult year, when she laid her mother to rest, ${ }^{1}$ pastored the Healdsburg Church, and was an assistant for the Califomia Conference Young People's Department. After solving a sticky church quarrel by vindicating the name of a doctor friend who attended the Healdsburg Church, she recuperated from stressful pastoral duties at the Healdsburg Sanitarium for approximately seven months. ${ }^{2}$

\section{Bible Teacher, Pacific Union College}

$\underline{1911-1928}$

After recovering from the stress and a long hospitalization, Mrs.

McKibbin was able to answer the call to teach Bible History at P.U.C. Mrs. McKibbin felt that the new college had the same spirit as did Healdsburg. After listening to Lonnie's reports before she moved to the college, Alma McKibbin went to visit and see for herself. She later reported:

I came, I saw, I was convinced. I saw more than the boy did. I saw, I realized that the new school had the same spirit, the same principles, the same standards as the old that I had loved so much. It was indeed the old school risen from the dead. Here was the same high purpose and deep consecration with the old time simplicity and democratic ways. It was a miracle, but I believe in miracles. ${ }^{3}$

Stella Antoinette Baker died in Healdsburg on April 8, 1911. Sce Rine, 23.

McKibbin, interview, 2 August 1967, 27; Harry Critchlow and Levona Critchlow, Healdsburg, Calif., to Alma McKibbin, Sanitarium, Califorma, 11 May 1911; L. F.. Healdsburg, Calif., to Alma McKibbin, Sanitarium, Calif., 17 July 1911: Mrs. Wallace to Alma McKibbin, St. Helena Sanitarium, Sanitarium, Calif., 27 August 1911, in the hand of Paul Ricchiuti, Nampa. Idaho.

"Mckibbin. "Unchanging Values," 5. 
Figure 11. Faculty, Paciñc Union College, 1911-12. Courtesy of Pacific Union College Adventist Heritage Center. Alma Kibbin is the shortest woman in the front row. 


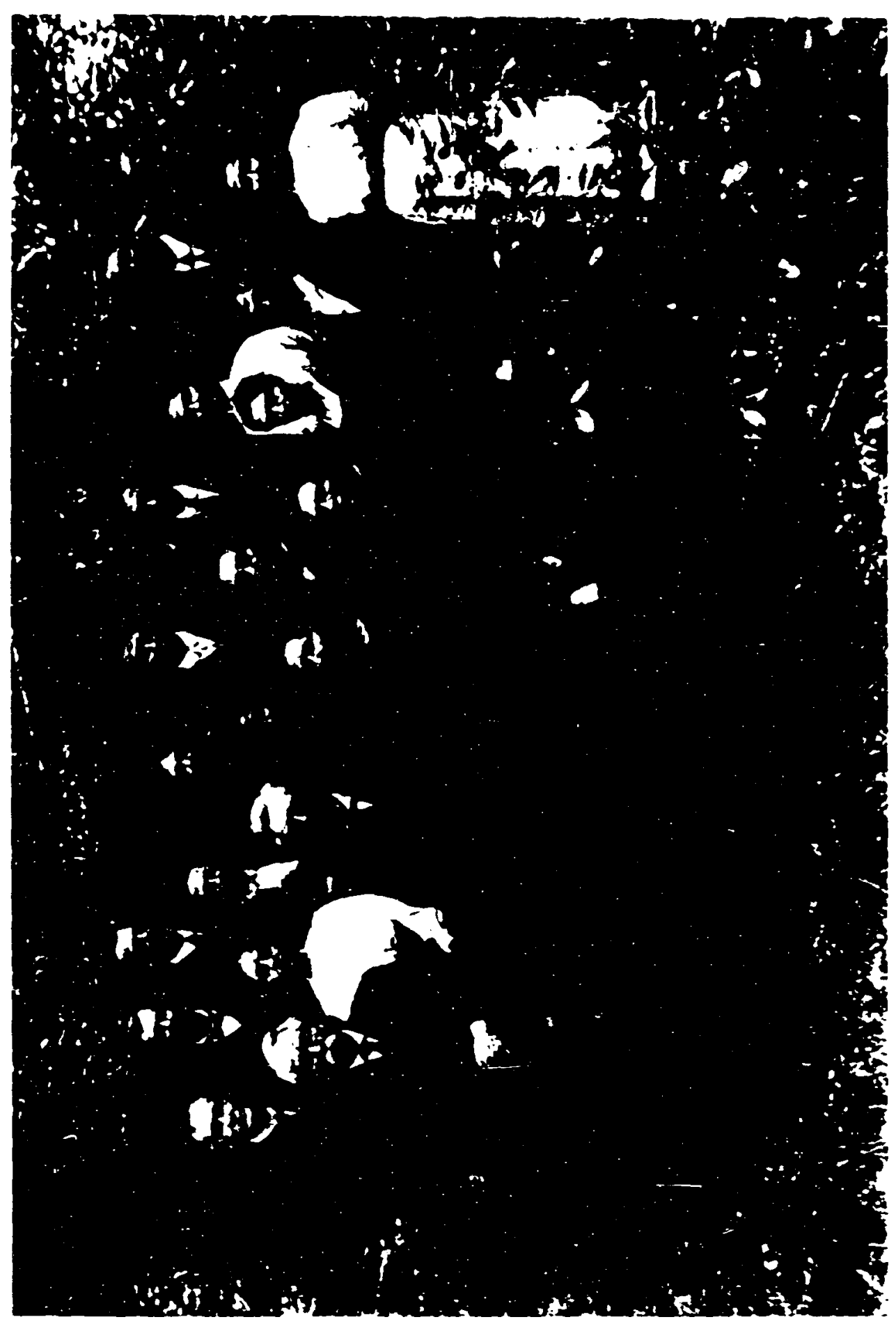


Pacific Union College was situated at the top of a 1600 -foot mountain, on what was believed to be a crater from an extinct volcano. The first college buildings were those of the Angwin Resort, a property purchased only one month before school started on September 29, 1909, from Edwin Angwin. The carriage drive up the mountain was eight miles from the base of Howell Mountain at St. Helena, along a very winding road.

Many parents sacrificed to send their children to this college. One father, who wanted his six children educated in a Christian college, kept his business in Burlingame, Califomia, where there was neither Seventh-day Adventist church nor school, but sold his home and sent his wife and children to rent a home in Angwin so that he could educate his family there. He rented a room for himself in the very home he had just sold in Burlingame. He visited his family once a month, taking the train to San Francisco, a boat to Vallejo, the inter-urban to St. Helena, and walking the eight miles up the mountain to the college. He learned to take shortcuts across the vineyards. However, one foggy night he spent lost in the vineyards. He found his way back only with the aid of daylight. The only car on the mountain at the time, a 1907 Ford belonging to Professor Newton, rarely passed for him to catch a ride. ${ }^{1}$

Mrs. McKibbin moved into temporary quarters at Pacific Union College with Lonnie in the old Tumer House halfway up to the Observatory.

EIna Anderson Quade, interview by author, 25 February 1991, Yountville. Calif. 
She later relocated in a comiortable cottage.

Alma McKibbin's living conditions at PUC were primitive at first.

Her roof leaked, as did everyone else's. She later told audiences:

We just brought out all the pans and pails and put them under the leaks, and we didn't fuss about it because, while I was putting pans under the leaks in my little house, I knew everybody else was doing the same. There was no place for envy, you know, because we were all doing the same thing. ${ }^{2}$

Mrs. McKibbin, Lonnie, and one of Lonnie's friends, Ben Grant, stayed in the little three-room home, which included a porch. The porch was divided into three bedrooms. One bedroom was made into Professor Miller's studio for music lessons. Apparently this arrangement caused some problems, for Mrs. McKibbin stated:

To reach it one had to go through the middle room which was the kitchen. the pantry, and the bathroom. The only place we could find for the bathtub was behind the stove! At times it was very inconvenient for pupils to go through the kitchen to the studio so Professor Miller bethought himself of a bright idea. On the backside of his studio was a window, and beneath it the stump of a tree. He posted a notice on the front of the house: "Music students please enter by rear window." ${ }^{3}$

Rents were from $\$ 7$ to $\$ 10$ in 1910 , and from $\$ 8$ to $\$ 12$ in $1915 .^{4}$

'M. W. Newton. 'Reminiscences of Early Days, "Founders' Day Address, 12 April 1948. TMs. p. 7. Adventist Heritage Center. Pacific Union College, Angwin. Calif. The cottage, which was built for AIma McKibbin, existed where the duplex was, which in 1948 housed Mrs. Burman and Miss Walker.

:MeKibbin, Mrs. McKibbin and Sister White," 35 .

'Alma McKibbin. quoted in Uit. Diogenes Lansern. 81.

Ibid., Westphal to author. 
Financially, teachers were "not treated with excessive generosity. "1 Alma

McKibbin's wages in 1919 were apparenily $\$ 10$ per week, with a bonus of $20 \%$ and textbook royalties that ranged from $\$ 125$ to $\$ 335$ annually..$^{2}$ Apparently as a Bible teacher she qualified to be paid from the tithe monies of the California Conference. $^{3}$

Alma McKibbin revealed in an interview that she felt her best work was accomplished at Pacific Union College:

The best work I ever did, I think I did up at the college. The surroundings were so favorable. We were right up there among the hills, you know, away from cities, away from everything. And we could get the full attention of everybody there. . . . There were no disciplinary problems; the boys worked, and the giris worked. Everyone must work two and a half hours a day, and by the time you got your lessons, you [hadn't] time for anything else.

Mrs. McKibbin said she didn't spend time exnorting her pupils to study--they were too busy building the college. She laughed at her brother and his friends when they came in looking like black men from having stoked "Old Maude," the steam tractor. In spite of the students' hard work, she remarked, "I had the

\footnotetext{
'Walter C. Utt. A Mountain. A Pickax, and a College (Angwin. Calif.: Alumni Association of Pacific Union College, 1968), 61.

'General Conference of Seventh-day Adventists (Washington, D.C.), Sustentation Fund Application for Alma E. McKibbin, 17 December 1919 D. Alma McKibbin's salary is listed as \$10/week in the faculty minutes at Pacific Union College. See Pacific Union Coliege. Mirutes, 21 February 1916, 4: 12 November 1916: 12 December 1916, 15: 18 Decemter 1917. 4: 1 July 1919. Adventist Heritage Center. Pacific Union College, Angwin, Calif. Her wages were raised to $\$ 11$ per week, plus bonus of 10 percent. See Pacific Union College, Minutes, 14 September 1919. Adventist Heritage Center, Pacific Union College, Angwin. Calif.

${ }^{3}$ Pacific Union College, Minutes, 28 December 1912, 1. Adventist Heritage Center. Pacific Union College, Angwin. Calif.

'McKibbin, interview, 2 August 1967. 27.
} 
most studious pupils there that I ever had anywhere. "I She attributed the

students' study habits to the merits of the work-study program:

When they worked, they could study better; they had good circulation: their brains were clear, and you know, they were always ready for extracurricular activities. I know, because I was given this duty. ${ }^{3}$

\section{Classes Alma McKibbin Taught}

It is uncertain just when her health recovered sufficiently for her to begin teaching, but apparently she was living at the college in March of 1912 , possibly in time to begin teaching spring quarter. ${ }^{\star}$ Alma McKibbin taught her

McKibbin, Mrs. McKibbin and Sister White." 35.

:McKibbin, interview, 2 August 1967. 27; Pacific Union College, Minutes, 30 April

1911. 2.

${ }^{3} \mathrm{McKibbin}$, interview, 2 August 1967, 27.

'Pacific Union College, Minutes, Special Meeting, Pacific Union College Board, 27 February 1911. Adventist Heritage Center. Pacific Union College, Angwin. Calif. The minutes read. "Moved ... that Professor Invin be requested to correspond with Mrs. Edwards and Mrs. McKibbin to ascertin if the condition of their health is such as will enable them to accept positions on the faculty, it being understcod that we will not expect either of them to carry any very heavy burdens. Alma McKibbin is listed in the Pacific Union College school bulletins for both 1910-11 and 1911-12 as being on the faculty to teach Bible history. A postcard was addressed to Alma McKibbin at Pacific Union College on March 5. 1912. and Mrs. McKibbin herself mentions that she taught during the 1911-12 school year at Pacific Union College. See Pacific Union College, Caiendar of Pacific Union College, 1910-1911 (St. Helena. Calif.: Pacific Union College Press. [1910]), 2; Pacific Union College. Announcement of Pacific Union College, 1911-1912. Supplement to Calendar 1910-1911 (St. Helena. Calif.: Pacific Union College Press. [1911]), 2, Adventist Heritage Center, Pacific Uaion College, Angwin, Calif.; Lotta E. B., San Jose, Calif., to Alma McKibbin, Pacific Union College, St. Helena, Calif., 5 March 1912; McKibbin, interview, 2 August 1967, 25. Another article in the Recorder announced, Mrs. Alma E. McKibbin, health permitting, will have charge of the Bible history instruction." See "The Faculty," Pacific Union Recorder 11, no. 6 (7 September 1911): 5. Please note on pp. 263-64 the tables of Alma McKibbin's Classes Taught At Pacific Union College," in which no classes are listed for 1911-12. It is possible that Alma McKibbin began teaching at PUC in the summer of 1912. An undated sustentation application she completed at age forty (she tumed forty on November 26, 1911) asked for temporary relief and listed as an address. "Pacific Union College." Another application, 22 September 1930, dated her work at PUC from 1912 to 1920. On December 17. 1919, when she completed yet another application for sustentation. she wrote that she had worked at Pacific Union College for eight years as 
classes in the Preparatory School, which was comprised of grades nine through twelve and was considered part of the college. ${ }^{+}$School was held in the recreation hall of the old Angwin resort; chapel was held in the former ballroom, and Bible was held in the bowling alley. "Oh, we just did anything and everything to get along, and I never heard anybody complain about it."

The classes Mrs. McKibbin taught are listed on the following pages.

Alma McKibbin's name was listed in the school calendars as teacher of Bible History from 1911 to 1917. For the 1917-18 school year, her name was under English and Bible History. The next two calendars, from 1918-1920, listed her name under "Bible History."

\section{Faculty Duties}

Although Alma McKibbin taught at the Preparatory school, in 1912 that school was considered (as previously noted) a part of the college. Because it was thought that regular college Bible classes were too advanced for college students who had had no previous background in Bible, these students were

teacher. See General Conference of Seventh-day Adventists (Washington, D. C.), Sustentation Fund Applications [c. 1912] D. 22 September 1930 D. 17 December 1919 D. Preparatory School.

Seventh-day Adventist Encyclopedia, 1976 ed., s. v. 'Pacific Union College

-McKibbin. 'Mrs. McKibbin and Sister White, 35.

${ }^{3}$ Pacific Union College. Calendar of Pacific Union College, 1911-1912, 1912-13. 1913-14, 1914-15, 1915-16. 1916-17, 1917-18, 1918-19, 1919-20 (St. Helena. Calif.: Pacific Press Publishing Association, [1911-1919]. Adventist Heritage Center. Pacific Union College, Angwin. Calif. 
Table 7. Alma McKibbin's Classes at Pacific Union College 1912-i916'

\begin{tabular}{|c|c|c|c|c|c|}
\hline Year, Class & $\begin{array}{l}\text { School in } \\
\text { Which Alma } \\
\text { McKibbin } \\
\text { Taught }\end{array}$ & $\begin{array}{l}\text { Amount of } \\
\text { Credity } \\
\text { Duration }\end{array}$ & $\begin{array}{l}\text { Number of } \\
\text { Students: } \\
\text { Autumn } \\
\text { Quarter }\end{array}$ & $\begin{array}{l}\text { Number of } \\
\text { Students: } \\
\text { Winter } \\
\text { Quarter }\end{array}$ & $\begin{array}{l}\text { Number of } \\
\text { Students: } \\
\text { Spring } \\
\text { Quarter }\end{array}$ \\
\hline \multicolumn{6}{|l|}{$1912-13$} \\
\hline N.T. History & Secondary & 1/3 unit/Qtr & 12 & 15 & 13 \\
\hline \multicolumn{6}{|l|}{$1913-14$} \\
\hline $\begin{array}{l}\text { Methods I: } \\
\text { Bible }\end{array}$ & College & $\downarrow$ hours/Qtr & 7 & 10 & 8 \\
\hline Mechods II: & College & + hours/Qtr & 4 & 8 & 6 \\
\hline $\begin{array}{l}\text { Prophetic } \\
\text { History }\end{array}$ & Elementary & & 1 & 6 & \\
\hline O.T. History & $\begin{array}{l}\text { Secondary } \\
\text { College }\end{array}$ & $\begin{array}{l}1 / 3 \text { unit/Qtr } \\
4 \text { hours/Qtr }\end{array}$ & $\begin{array}{l}61 \\
15\end{array}$ & $\begin{array}{l}52 \\
16\end{array}$ & $\begin{array}{l}16 \\
17\end{array}$ \\
\hline $\begin{array}{l}\text { Denom. } \\
\text { History }\end{array}$ & $\begin{array}{l}\text { Secondary } \\
\text { College }\end{array}$ & $\begin{array}{l}\text { 1/3 unitiQtr } \\
4 \text { hours/Qtr }\end{array}$ & $\begin{array}{c}22 \\
4\end{array}$ & & \\
\hline \multicolumn{6}{|l|}{$1914-15$} \\
\hline $\begin{array}{l}\text { Methods I: } \\
\text { Bible }\end{array}$ & College & $\begin{array}{c}2 \text { hoursi } \\
6 \text { wk. course }\end{array}$ & & & $8($ or 4$)$ \\
\hline $\begin{array}{l}\text { Methods II: } \\
\text { Bible }\end{array}$ & College & $\begin{array}{c}2 \text { hours/ } \\
6 \text { wh. course }\end{array}$ & & & 8 \\
\hline N.T. History & Secondary & 1/3 unit/Qtr & 24 & 29 & 26 \\
\hline O.T. History & $\begin{array}{l}\text { Secondary } \\
\text { College }\end{array}$ & $\begin{array}{l}\text { //3 unit/Qtr } \\
+ \text { hours/Qtr }\end{array}$ & $\begin{array}{c}53 \\
4\end{array}$ & $\begin{array}{c}55 \\
4\end{array}$ & $\begin{array}{l}45 \\
4\end{array}$ \\
\hline \multicolumn{6}{|l|}{$1915-16$} \\
\hline Reading & Secondary & no credit & 12 & 13 & 12 \\
\hline O.T. History & Secondary & 1/3 univ/Qtr & 24 & 23 & 22 \\
\hline N.T. History & Secondary & 1/3 unit/Qtr & 28 & 26 & 27 \\
\hline $\begin{array}{l}\text { Life and } \\
\text { Teachings of } \\
\text { Jesus }\end{array}$ & College & 4 hours/Qtr & 8 & 5 & 3 \\
\hline
\end{tabular}

'These data were hand-tabulated by Gwen Spuehler at the Registrar's Office, Pacific Union College, Angwin, Calif. Although data were available for 1911-12. Mrs. McKibbin's slasses were not listed. These records are likely incomplete (see McKibbin, "Courtesy, 22). 
Table 8. Alma McKibbin's Classes at Pacific Union College 1916-1919

\begin{tabular}{|c|c|c|c|c|}
\hline Year, Class & $\begin{array}{l}\text { School in } \\
\text { Which Alma } \\
\text { McKibbin } \\
\text { Taught }\end{array}$ & $\begin{array}{c}\text { Type of Credit } \\
\text { Duration }\end{array}$ & $\begin{array}{l}\text { No. of Students } \\
\text { 1st Semester }\end{array}$ & $\begin{array}{c}\text { No. of } \\
\text { Students } \\
\text { 2d Semester }\end{array}$ \\
\hline \multicolumn{5}{|l|}{$1916-17$} \\
\hline N. T. History & Secondary & 1/2 unut/sem. & 20 & 25 \\
\hline O. T. History & Secondary & 1/2 unit/sem. & 31 & 31 \\
\hline $\begin{array}{l}\text { Advanced } \\
\text { O. T. History }\end{array}$ & College & t hours/sem. & 4 & 4 \\
\hline $\begin{array}{l}\text { Life and } \\
\text { Teachings of } \\
\text { Jesus }\end{array}$ & College & $f$ hours/sem. & 3 & 3 \\
\hline \multicolumn{5}{|l|}{$1917-18$} \\
\hline $\begin{array}{l}\text { College } \\
\text { Rhetoric }\end{array}$ & College & 3 hours/sem. & 11 & 10 \\
\hline O. T. History & Secondary & 1/2 unit/sem. & 26 & 28 \\
\hline $\begin{array}{l}\text { Advanced } \\
\text { O. T. History }\end{array}$ & College & 4 hours/sem & 12 & 12 \\
\hline \multicolumn{5}{|l|}{$1918-19$} \\
\hline Reading & $\begin{array}{l}\text { Secondary } \\
\text { College }\end{array}$ & $\begin{array}{l}\text { no credit/ } \\
1 \text { hour (?) }\end{array}$ & $\begin{array}{c}17 \\
5 \\
\end{array}$ & $\begin{array}{l}17 \\
+ \\
\end{array}$ \\
\hline N. T. History & Secondary & 1/2 unit/sem. & 20 & 17 \\
\hline O. T. History & $\begin{array}{l}\text { Secondary } \\
\text { College }\end{array}$ & $\begin{array}{l}1 / 2 \text { unit/sem. } \\
3 \text { hours/sem. }\end{array}$ & $\begin{array}{c}+2 \\
8\end{array}$ & $\begin{array}{l}40 \\
3\end{array}$ \\
\hline
\end{tabular}


assigned to Alma McKibbin's preparatory classes but received college credit. ${ }^{1}$

A college teacher's load in 1919 was fifty-four hours per week:

$\begin{array}{lcl}\text { Manual labor } & 15 & \text { hours } \\ \text { Preparing for same } & 3 & \text { hours } \\ \text { Teaching regular classes } & 12.5 & \text { hours } \\ \text { Preparing for same } & 12.5 & \text { hours } \\ \text { Committees and chapeis } & 5 & \text { hours } \\ \text { Personal work for students } & 6 & \text { hours }\end{array}$

Preparatory teachers' full work was not to exceed twenty sixty-minute hours per week. including vocational and drill subjects. ${ }^{3}$

Apparently the line between the faculty of the preparatory school and that of the college was a fine one, for Alma McKibbin carried responsibilities with both. On 24 September 1912, Mrs. A. E. McKibbin's name appeared on the roster of staff present at the college faculty meeting. By September 30 she was listed on a committee to make plans for recommendations for missionary meetings and students' bands. Other duties included: (1) being on a discipline committee, (2) holding devotional meetings for the young women at the college and women in the neighborhood on Sunday aftemoons, (3) being advisor for Girls' Reading Bands, (4) acting on a committee for uniform young ladies' graduation dress, (5) belonging to a committee to arrange for three literary programs to be given by the students during the year, (6) giving chapel talks,

'Walter Macpherson, M.D.. interview by author. 13 March 1991. Glendale. Calif.

iUtt. A Mountain, a Pickax, and a College, 62; Pacific Union College Faculty Minutes, 19 January 1919, 31.

'Marion C. Cady, 'Seventh-day Adventist Denominational Schools on the Pacıric Coast." M.A. thesis. University of California. 1916, 238. 
(7) working on a committee to consider having reading classes, (8) arranging a program to set forth the principles of etiquette. (9) organizing a program to commemorate the 100th anniversary of the founding of the American Bible Society, (10) being on a committee to work with students to send items of interest about the college each week to the Pacific Union Recorder, and (11) working on a committee to arrange for Saturday night programs. ${ }^{1}$

Some students remembered the Saturday night programs Alma McKibbin was in charge of. She explains how those programs became her responsibility:

Professor Irwin didn't believe in paying people to come there and entertain us. You remember he was doing his bookkeeping with black ink, and he didn't hire famous people at a large sum to come and play for us or to lecture to us, but he asked me, for one thing, once a month to give a program on Saturday night. I did that for eight years, and in all those eight years I had but one refusal, and that was after the World War began and the students were so disturbed over that that they couldn't think of much of anything else.?

One who attended those Saturday night programs commented, "In those days the college had no social committee nor a contract with lecture tours for entertainment. We had Mrs. Alma McKibbin. ${ }^{{ }^{3}}$ Those evenings included talent shows, drama, poetry, and music, produced by Lonnie, his friends, Alma

Pacific Union College. Minutes. 24 September 1912, 10; 30 September 1912, 16; 25 August 1917. 2: 9 March 1913, 55; 5 October 1913, 1-2; 29 March 1914, 2; 26 April 1914, 1:8 November 1914, 1; 8 October 1915, 2; 10 October 1915, 1; 31 October 1915, 1: 16 January 1916. I: 2 April 1916. 1: 1 October 1916. 2; 8 October 1916. 1.

-McKibbin. "Mrs. McKibbin and Sister White." 35.

'Westphal to author. 
McKibbin, the girls from South Hall, and students trom her classes. She would practice with participants: "She could get them to do "most anything." Mrs.

McKibbin rewrote stories from the Sarurday Elening Post and other sources.

One of her student periormers recalied:

One of the most talented pertormers was Eugene Maxson, son of Dr. Harriet Maxson, who lived across the meadow. I can hear the cadence of his voice. . . .

"Boots--boots--boots--boots,

Moving up and down again!

There's no discharge in the war!"

Or a pretty girl declaiming with swinging arms.

"Curtew must not ring tonight."

Mrs. McKibbin asked Cacharine Anderson to recite "Home Folks" in a program featuring James Whitcomb Riley. Catharine, one of a large family from Burlingame, California, had never done anything in public; yet, she thought so much of Mrs. McKibbin she couldn't reruse. Alma McKibbin inspired her to do it: even Catharine believed she could. When it was over. Catharine felt she had really accomplished something.'

No one had cars. and President Irwin said that anything put on at the college was for the sommunity. so surrounding residents and staff, with their families, walked through the woods with a llashlight to attend Saturday night programs.

Ibid.

Ibid.

:Cathenne Mane Anderson Edwards, intervew by author. 26 February 1991. Angwin. Calif. 
In recalling some of the more memorable chapel talks of the year, a senior wrote:

Mrs. McKibbin in a most instructive talk told how we like Pilate are often impatient to find out "what is truth," and as a consequence feed our minds on fiction, and allow our lives to be warped by false ideas. ${ }^{1}$

Alma McKibbin taught a course in the training of the voice in speaking, as well as a weekly reading class. ${ }^{2}$ In addition to teaching English classes, she spoke at faculty meeting on the methods of teaching English at the college. $^{3}$ One student remembered Mrs. McKibbin say in a reading class, "We use our lips when we speak." She drilled the students repeatedly until they articulated their words just right. "Use your lips!" she would cry. Some students had a hard time.

Mrs. McKibbin also conducted weekly Bible studies at the normal school for the Parent-Teacher Association, which was organized at the opening of the 1915-16 school year.'

Teachers were expected to contribute to and join in the spiritual activities of the school. Faculty on the committee on religious work decided that each teacher should supervise an assigned group of students. Teachers were to give certain chapel talks on material found in the writings of Ellen White, to 12.

'Inez Eddy, "Chapel Talks," Pacific Union Recorder 16, no. 44 (6 September 1917):

:Pacific Union College, Minutes, 12 March 1919. 50: 16 February 1919, +2.

'Tbid.. 7 October 1917, 18.

'Jessie O. Barber Osborne, 'Parent-Teacher Association." Pacific Union Recorder 16. no. 44 (6 September 1917): 13. 
attend early morning prayer bands conducted by the students, and assist with and attend evening and moming worship periods in each dormitory during Week of Prayer. The faculty were also called upon to search the Testimonies of Ellen White for statements relating to specific subjects that should be taught in the college.

During summer institutes and other conventions Alma McKibbin continued to educate teachers in Bible classes and methods of teaching Bible. "Mrs. Alma E. McKibben [sic], Author of Bible Lesson Series, Books I-IV," was listed on the faculty for the Pacific and North Pacific Union Conferences' Joint Summer School in Portland, Oregon, June, 1912. At this conference she taught Methods II in Bible and History, and Bible Doctrines and Old Testament History as content area subjects.

Her duties extended to doing work for the General Conference at its educational convention at Pacific Union College, June 4-14, 1915.

In order to release Mrs. McKibbin from part of her class work that she might accomplish for the General Conference what they have requested in reference to normal work, and on motion of $E$. W. Famsworth, seconded by W. C. White, it was voted to ask Miss $H$. Andre to return and take part of Mrs. McKibbin's classes for the balance of the year. ${ }^{3}$

Pacific Union College, Minutes, 23 September 1917. 13:10 November 1918, 17:24 November 1918, 21: 2 March 1919. 49.

:Pacific Union and North Pacific Union Conferences, Joint Union Summer School, Porland. Oregon. 27 June to 7 August 1912, n. p.

'Pacific Union College, Minutes, 15 January 1914, 2. 


\section{Ellen G. White}

Alma McKibbin remarked that Mrs. White came up to the college from her home five miles down the mountain at Elmshaven as often as she could, in order to speak to and encourage the taculty and students. There came a time of longer absence than usual, and the students and faculty requested that she come to pay another visit. Approximately eighty-five years of age, she traveled the night betore so she could get a good night's rest in order to be able to speak for even ten minutes to the student body. While she spoke, her son Willie supported her. Alma Mckibbin remembered the content of that last chapel talk at Pacific Union College in 1913:

"My dear young people. I am gratetul to God thai He has given me strength, once more, to come to speak to you. You have a rare privilege of establishing a new school. You may have some inconveniences, but yours is a great privilege to establish a school on right principles.

I was young like you when God called me to His Work, and I put my armor on. and I have never taken if off. and I never shall, until my work is done. Dear young people, when you put your hand to the plow, never turn back. I hope that every one of you has consecrated your life to the work of God. Count the cost. my young iriends. and when you have determined to do that. don't let anything hinder you--don't be discouraged." 1

Mrs. White paused and told the students about the work she was busy doing, gathering material for another book. The book was Prophets and Kings, which was not published until atier her death. Although she never saw it in book form, she had most of the manuscript for Prophets and Kings ready before she died. Then she said. "I think I can'! speak anymore to you today, but 
remember, put your armor on. and never take it orf. I will never take my armor off until my work is done." I

When Mrs. McKibbin told this story, she wept as she recounted how strong men had to carry away the aging prophet, and that all of the students and aculty knew that they likely would never see Mrs. White again.

They took her out and put her in a chair on the porch--an open porch. There was a glass door. We sat in the chapel. . . She seemed to torget where she was and began to sing. As nearly as I can remember, it was this, "Jesus is coming again. coming again. I have waited long. Jesus is coming again." They say it is an old Advent hymn. . . . Tears ran down our faces, for we all telt that we had seen and heard her tor the last time.?

Mrs. White iell on February 13, 1915. Her hip was broken, requiring her to be bedfast, and she died tive months later. Mrs. McKibbin said her last words were, "I know in whom I have believed."

\section{Alma McKibbin's Teaching Methods and Philosophy at Paciric Union College}

The intluence of Mrs. White atfected Alma McKibbin's teaching methods all her life. The tirst words she heard the prophet speak in 1889 at the Healdsburg Church were about the importance of understanding the child. In later years. Mrs. McKibbin wrote an article entitled. "An Understanding Heart." in which she related an experience about a student who was placed in her ninth-

Ibid., 37.

"McKibbin. "My Memories of Sister White." I9.

'Tbid. 
grade Old Testament history class at Pacintc Union Coilege. He was about

twenty-two or twenty-three and had linished only eight grades of education

several years before attending the college.

[He] was very earnest and diligent. He studied. I marked the notebooks every six weeks.

The tirst time I returned his notebook--it was very well done--I marked it "Excellent." But when he opened it and lcoked at it page by page, the frown on his face grew deeper and deeper. He said. "Don't I get a star for all this work?"

"No." I said. "We don't give stars in the ninth grade." After another six weeks he handed in his notebook again. and it was beautifully done. perfectly done, and I gave him another good mark--"Excellent. 100 percent."

But he was more dissatistied than ever. He said, "Not a star anywhere in this book." And I thought. What is the matter with that young man? I could not understand.

One day two young men came to visit me. One was his roommate. He said to me, "My roommate is very discouraged. He is threatening to leave the school: in fact. he said he might pack up this evening when he comes in."

"What is the matter?" I asked.

"No matter how hard he works in class. he can never get a star."

"Well," I said, "you know we don't give stars except in the primary department here."

"Yes, we know that. but it has been such a long time since he was in school, and evidently his teachers then. even in the eighth grade. placed stars on their students' work. And he just thinks that he isn't succeeding.

"Well," I said. "doesn't he know that no other student in the class is getting stars?"

"Yes, he knows that, but it doesn't seem to impress him. We wondered. if we got some stars and put them in his notebook, would it be all right with you?"

All at once my poor slow thinker caught up. I said, "Boys, can you go to his room and get the notebook for me without his knowing it?"

"Yes," they said. "he is out at work this aiternoon."

"Good," I said. "Get his notebook and bring it here." We made that notebook shine! At last the teacher understood. . . The next morning the happiest. most radiant student in that whole school walked into my 
classroom. And he kept on coming--he came for four years until he tinished the academy course. He is now the elder of a church.'

Years later, when Mrs. McKibbin visited the church that young man attended, hearing him teach the lesson study on the life of Moses, she thought. "What if those two young men had not understood and had not come to me and helped me to understand?"2

A student of Mrs. McKibbin's at PUC consented to be interviewed, providing the following information: ${ }^{3}$

Elna Anderson entered PUC as a girl of fifteen (minimum entrance age for academy), having had no Bible classes and having attended only public school. It was Elna's father who kept his job in Burlingame while commuting monthly to PUC to visit his wife and family of six children. Before the family moved to the college, Elna and her sister Catharine boarded together in the dormitory.

Elna, a social creature, had "breezed" through public school. Studies had come easily and she had not leamed good study habits.

Apparently Alma McKibbin did not let her desire to understand students get in the way of expecting mastery of the subject matter. Elna, who was not used to memory work, flunked the final test in Mrs. McKibbin's Old

Alma E. McKibbin, "An Understanding Heart." Review and Herald 148 (25 November 1971): 6. 9.

:Ibid.

The following material is from an interview with Elna Quade. 
Testament history class. After spending most of the night crying, she mustered up enough courage to go to Mrs. Mckibbin's house and ask her what she should do:

What I remembered when she opened the door was the smell of fresh bread. Oh, it sme!led like home, and oh, I was homesick! I could hardly get out the words, when Mrs. Mckibbin threw her arms around me and cried with me. She explained the things I hadn't understood, gave me special helps to study, and marked them. She taught me how to study and get organized: what to remember. what things were important, and what was the lesson to remember trom each Bible passage. She told me, "If you could think of the lesson in the story, you would remember." I guess I got more interested in the home work because she took such an interest in me.'

Elna studied that summer while she staved in the dormitory and worked at the college, took the test over. and passed. She had to go back and read a lot, she said. She felt that Mrs. Mckibbin wanted her to be a better Bible student. As she continued to take classes. she began to realize that her teacher wanted her students to experience the lessons taught in class, not just read about them.

New Testament. Elna said. was easter. consisting in part of reading material from The Desire of tyess. At 9l. Elna was still able to remember some of the geography, the Lord's plan tor His people. and some of the lessons. Her favorite story was of the birth of Jesus. When Alma McKibbin described the life of Christ, Elna said Mrs. McKibbin would get so caught up in the story that

Quade. interview. 
tears would be streaming down her face. "How could you forget those stories? ${ }^{n 1}$

Alma McKibbin took one of her ciasses to Elmshaven, five miles by carriage down the mountain. All of Mrs. White's writings were in the tank house on the property, and students were able to view them. ${ }^{2}$ In spite of these efforts, Mrs. McKibbin penned the following words many years later:

I laught [denominational history] for seven years, and never in all my experience as a teacher did I ever have such difficulty in interesting a class in any subject. ... I studied methods of presentation more diligently than even for my Bible classes, but in the end I had the heart sickening realization that with a few exceptions, my pupils were not interested. ${ }^{3}$

Mrs. McKibbin believed "we have the most thrilling history of any denomination in the world. "S She puzzled over why students didn't appreciate this history. As she listened, students told her that they were disillusioned with present-day church workers, and therefore all church workers, because of all the hypocrisy among them. She lamented, "The answer is criticism. They have heard the work and workers criticized 'till they have no faith in either, as a few frankly told me."s

She used maps as an aid to teach Bible history. The calendars for Pacific Union College announced that Old Testament history required all students

Trid.

:Jack Craver. telephone interview by author. 26 February 1991. Angwin. Calif.

"McKibbin. "Courtesy.' 22.

${ }^{4}$ Ibid.. 23.

'Ibid. 
who took this subject to make maps, charts, and chronological tables under the direction of the teacher (Alma McKibbin).' She used a Rand McNally Bible Atlas and ordered enough for every church school teacher in California to have one. 'She felt the atlas was particularly helpiul because it included Bible history with its geography. ${ }^{3}$

In one class, Mrs. McKibbin took her students to her home garden:

The boys dug out the Great Sea (Mediterranean), the Jordan River, Sea of Galilee, and, after the destruction of Sodom and Gomorrah, the Dead Sea.

The girls piled up the mountains and fumished bluing for "Blue Galilce," and salt for the Dead Sea--ideal class participation.

Years after, one student who was privileged to fly over Palestine, wrote me that "it looked just like the map we made. ${ }^{n 4}$

When Alma McKibbin first began teaching at the academy at PUC, she had no textbook. She wrote the outlines on the board, and the students copied them into their own notebooks, adding notes. Toward the end of her career at PUC, she was sick most of the time, leading to an incident involving the grading of notebooks:

The notebooks, 125 of them, became an intolerable burden. One Sunday I collapsed on the couch in my sitting room, surrounded by notebooks. which I was too sick to inspect and mark any longer. I really felt that I was going to die, and in my half-delirious state it seemed notebooks were the cause, and strange thoughts came into my mind.

Pacific Union College, Calendars, 1919-20, 27: 1916-17, 11.

:McKibbin, interview, 2 August 1967, 29.

'Ibid.

Alma E. McKibbin. Mountain View. Calif., to Ethel Young, Washington, D. C., February 1964, in the hand of Ethel Young. Russell. Penn. 
Just then, Mrs. Osborne came in, and I said to her, "Brother isn't here, so I must give you a message for him. Tell him to put on my tombstone a corrected notebook like this one, 'bleeding at every vein' (as Professor Rine used to say when he had used an extra amount of red ink on a paper)--and under the notebook, these words:

'This is how she lived,

And why she died."

I was in dead earnest. Mrs. Osborne hastily left the room. I thought she went out to weep, but instead she was convulsed with laughter. Later she returned with a dish of hot soup. "Now, Sister, take this soup, and I think you will feel better and be able to finish these notebooks." And I think she was wise.

Hot soup and an understanding heart restored my morale, and I finished the notebooks and decided to keep on living.'

Alma McKibbin believed that the Christian teacher "is a tool in the hand of God to remold distored characters and restore the image of God in the soul. ${ }^{n 2}$ She tried to integrate this philosophy in the following episode, as told by a friend:

There was a boy in her classes who habitually fooled around and didn't get serious about his school work. His grades were suffering. She couldn't seem to motivate him at school. So she told us that she put on her hat. She emphasized that she actually put a hat on in that primitive, pioneering setting where hats weren't the usual thing for walking around in Angwin. She walked with dignity to his home to pay him a formal call. He was at home, and she asked to speak with him. They sat down together, and she visited with him in a respectful, adult way. She asked what he might like to do when he was grown. He told her, and . . . then she very politely suggested that, with his future plans running in that direction, perhaps she and he would do well to place a little extra emphasis on precision in language. It would be important to him in his career. ${ }^{3}$

:Alma E. McKibbin. Mountain View. Calif., to Fedalma Ragon, January 1. 1953.

McKibbin. 'A Teacher's Satisfactions," 12.

"Maryan Stirling, San Jacinto. Calif., to author, + December 1990. 
Somehow, the student linked his dream to the moment-by-moment choices he was faced with in Mrs. McKibbin's English class, and her visiting strategy worked. The student took "a step forward in maturity that he needed to make just then. He came around a comer, and she was so happy as his grades picked up."

Her Relationship with Students

Former students whom I interviewed said that Mrs. McKibbin was an affectionate person who loved her students. When Dr. Rossiter's children, Margaret and Henry, lost their mother, Mrs. McKibbin remembered the first anniversary of the mother's death. She spoke to Henry comforting words about Jesus' soon coming, when the youth could again see his mother. ${ }^{2}$ Margaret said that her former teacher took a personal interest in her and followed her through life. Alma McKibbin wrote her a letter of condolence for the loss of her son, Donald White, in 1948. "There was something intangible about her that you loved--she didn't have an outstanding personality. ${ }^{3}$

: lbid.

'Barbara Osborne Westphal, interview by author. 26 February 1991. Calistoga. Caiif. Margaret Rossiter White Thiele, interview by author, 4 March 1991, Angwin. Calif. 
One tormer student observed that "Mrs. Mckibbin was common. She wore mostly skirts and blouses, with a lovely pin at her throat."' The daughter of a very close iriend described Mrs. McKibbin's commonness:

Sometimes as I looked down on "Sister's" [Sister McKibbin's] house a homesick student would tall into Sister's arms for comfor. ${ }^{2}$

People just naturally went to her for counseling. Anyone who wanted to tell somebody, she'd listen. Everybody could talk to her. She'd be very plain spoken if something were wrong, and she'd tell it like it is. She had a good sense of humor.

When a good-looking and well-respected former student from a wealthy family began to pay attention to a girl another boy was going with, Mrs. McKibbin told him to stay away. He could get anybody else he pleased, she said. but let that girl alone. Those wo had been engaged, and the engaged young man was not as presentable as the good-looking boy, who could get almost any giri.

Alma McKibbin enjoyed relating to the boys at the college. She once commented to a triend that she really loved ail children. "but everybody likes little girls. So I emphasize that / like little boys!"' In addition to boarding Lonnie and Ben Grant. she entertained and mothered many of Lonnie's friends. She also entertained George Ham. the son of an old friend from Saguache.

Calif.

Ruth Carr Wheeler. telephone interview hy author. 26 February 1991. Angwin.

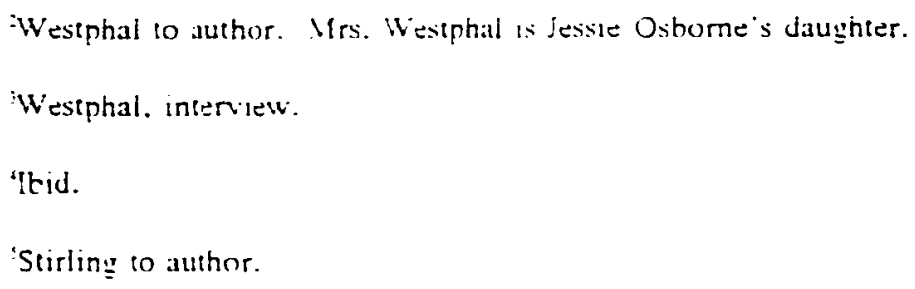


Figure 12. Dedication, Mountain View Academy Annual. 1924-25. 
To Mrs. Alma E. McKibbin,

\author{
whose influence has \\ hallowed the Mountain \\ View Academy, and \\ whose constant sympathy \\ and marure judgment have \\ guided our lives unto the \\ life eternal--to her, this \\ Annual is lovingly \\ dedicated.
}


Colorado, and they talked about Saguache together over bean soup. In class she especially enjoyed relating to Charles Weniger, whom she felt was the most responsive student she had ever had. He told her that with the diagram she made, he would never get lost in Bible history.: When George L. Wilkinson, class of '13, asked if he could pick some of Mrs. McKibbin's roses for his girlfriend, she assented. She later told the story "with great relish," ${ }^{3}$ about how George, perched precariously on a ladder, answered her mild precautions with a melodramatic pose and the words. "If I tall" (hand over his heart), "tell her I died picking roses for HER!"s

Former students recalled happy evenings in Mrs. McKibbin's home:

And there were those happy evenings in her home--bright with stories and poetry, hot rolls and preserves. How we treasured the hours, seasoned with her quiet counsel, not preached at us, but gently, tirmly. positively implanted in our consciousness. We didn't always realize it but as we walked back to the dormitory in the dark. something burned within us--now we know what it was."

Dr. Walter Macpherson recalled how airaid Alma McKibbin was to have so many college students in her Old Testament class in 1918. Although she didn't tell them her true ieelings immediately. it was early in the course when

\footnotetext{
Ham to Macpherson.

:Lonne and Charles Wenger were reportedly !ifelong triends. Edwards, interview; Stirling to author: Mckibbin. Intervew. 2 August 1967. 29. 29.

Stirling to suthor.

thid.

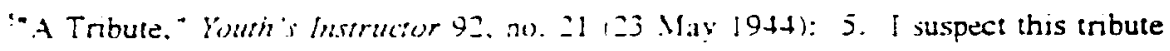
might have been writen by Charies Weniyer.
} 
she confessed to them her fears of handling so many college and academy students together. Perhaps in part due to Alma McKibbin's willingness to openly share her feelings with the class, there gradually grew an affinity between students and teacher.

It became apparent as time went on that she had an affection for us "outsiders."1 Soon we began to realize how she felt toward us, and we reciprocated. By the time the course was over, we had become good friends-how good, we would learn as the years went by. ${ }^{2}$

How did she communicate this affinity and love? It was her attitude, the things she told students, and the way she taught, said Dr. Macpherson. "She sort of adopted us all--even in class. ${ }^{3}$ He remembers her giving students priority, even when they interrupted her busy schedule. Her students were not just "kids" entering and leaving her classes--she was interested in them for the rest of their lives. "We knew she liked us--she didn't have to tell us; we felt it. $^{n 4}$

\section{P.U.C. Students' Opinions of Mrs. McKibbin and Her Teaching}

When interviewed, some of Alma McKibbin's students compared her to Dr. Mary MacReynolds, who was a very forceful, strong woman, an

'The term, "outsiders," meant those College students who had neither formerly attended church school nor had taken any previous Bible classes. They were therefore required to take the more basic Bible classes taught by Alma McKibbin at the academy.

:Macpherson. interview.

'tbid.

'tbid. 
authoritative and dynamic teaciler at Pacinic Union Coliege, atter Mrs.

McKibbin left. Both were good public speakers and held students' attention;

both were firm in principle. kind. understanding. and loved their students. but

Mrs. McKibbin apparently was a bit sotter. more motherly, gentle and nurturing.'

One student commented.

I was not her stident, but I was only tifteen when I came to the college, and perhaps my childishness appealed to her. I needed a mom. She'd ask how I was--she knew I was homesick. She would come over to the dorm and speak tor women's worships, and seemed concerned about the students. I brightened whenever I saw her, tor I felt she was interested in us. ${ }^{2}$

Catharine Anderson Edwards. Elna's older sister, remembered those Sunday evening worships. She said the girls looked forward to Mrs. McKibbin's coming, for she would tell stories of her own adolescence. of some of her younger days in Colorado--stories that illustrated what she was trying to teach ihe girls. Catharine remembered in particular a story about a certain ox that refused to wear the yoke. The young ox was hitched to an older one, in the hope that it would learn to submit to its masters more easily. Mrs. McKibbin noticed this ox as it went by her home many times and witnessed it finally learn to wear the yoke, but not unil it bore many unnecessary scars. Young people,

Westphal, interview: Wheter, interitew.

Wheeler. interiew. 
said Alma McKibbin. needed to learn to wear the yoke of service and of obedience, but it is a yoke that is light in comparison with the burden of $\sin .^{1}$

Students thought of Mrs. McKibbin as a literary person, an intellectual, and an authority on the Bible. She was regarded as well read and educated. "She was considered a sharp teacher." - All the students admired her. They marveled at how quickly she could draw on the blackboard a map of Palestine and fill in the geographical names. ${ }^{3}$

Margaret Rossiter remembered dramatizing the story of Joseph in Old Testament history class. Each student played a part. using the old King James English. Having come trom the public schools. Mfargaret felt Mrs. McKibbin's refreshing intluence when she entered the classroom.

Margaret remembered in particular tima McKibbin's college course in rhetoric. The inrst assignment was for each student to write out a list of all the books they had read. Since people weren't the readers they are now, most students listed four or tive utles. Margaret compiled a list of three pages. Her mother was a university protessor, daughter of Mrs. S. M. I. Henry. Mrs. McKibbin told Dr. Rossiter. Margaret's tather. that his daughter had read more books than the teacher. ${ }^{+}$

Edwards, inteniew. See Alma Mckibbin E. Mckibbin. Beanng the Yoke." Signs of the Times $74(4$ March 1947): 16.

:Edwards, interitew: Westphal. enteritew: Juhnson. intervew.

Edwards, interview.

Thiele. interiew 
When asked, students didn't recal! discipline problems. They felt her influence took care of classroom discipline. "We were expected to sit quietly in her classes."

Dr. Walter Macpherson recailed that Alma McKibbin taught Old Testament history as current events. as though students had just read the story in the newspaper. She taught as though she were acquainted with men and women, as if they existed as modern-day people, present in today's setting, pointing out in their lives some of the qualities of human nature. Those people were like we are: they did bad things, ioolish ieats, and fun activities, just like the students. "She never missed a chance to get that point across--that Bible characters were real people. Listening to her Bible stories. one would think they happened yesterday, not 2000 years ago." = Dr. Macpherson attributed his teacher's success to the lact that she created the class and the text herself--what she taught was of her own invention. He ielt that in part Alma McKibbin's success was due to her genuine interest in what she was teaching, which in turn influenced her students to become interested.

In comparing her class with that of contemporary teachers, the doctor felt that rather than teach isolated facts or texts, her Bible classes integrated the facts and texts into a meaningtul whole. Students were not learning just names and places, but studying real people and incidents. all of which were important,

Ibid.

-Macpherson. interiew. 
and she helped them understand why they were important. The tacts, names, and people were a part of a continuing story of civilization. which she tied together with a jorest view. She didn't isolate a person in the Bible from the world in which she or he lived: she presented characters in context.

Alma McKibbin saw Bible characters as people. with feelings and emotions, not just names. Elijah was scared, ran, and hid--he was not much different trom other people. On the other hand, he had a philosophy that was different from that of most other people of his times. She tried to present Paul as the man for the job--the mammoth job of establishing Christianity in the tirst century. She compared Paul to Peter, who himself likely couldn't have carried the load that Paul carried: Peter lacked the necessary talents. When the class studied the rebelliousness of the Jewish nation. Mrs. McKibbin wanted students to discern why the Jews did what they did--and to relate the reason to why people do what they do today. "She had a tendency to see Bible people in their context, and in a small way got some of those broader views across to her students." 1

Although he had no background in a tormal Bible class, Dr. Macpherson felt that neither he nor the other students considered Mrs. McKibbin's class difficult. "She didn't burden students, and she realized we had Other responsibilities and classes." She required students to know the names of people and what they did. Students were to compare or contrast people of 


\section{1}

different categories, such as the Israelites with some of the other nations of the

Old Testament. An example might have been. "In what ways did the Israelites differ from the Philistines and the Babylonians?"

Dr. Macpherson was relieved to attend Alma McKibbin's classes before being required to take more advanced college Bible classes, such as Daniel and Revelation, which is what he would have been required to take if he had had a church school background in Bible. He jelt that her classes were memorable:

Of course. I could only gliess as to how much effort she put in to make those characters real. It looked as though it came naturally, with no effor, like watching olympic skaters--as though it were an interest, an ability. She liked what she was doing--it was not a burden. How deep a student she was, I don't know, but from what she said in class, and from what I've heard, she dug out what she was teaching pretty much by herself--in that respect she was a scholar. Writing that textbook was no small feat.

That Bible course was not just something you could take and forget about.'

Her students knew she was interested in their salvation. Her greatest

desire, they said. was for her students to know Jesus and be saved. She "always brought cut the mercy and sutfering of God." - Her aim for us was to see and know Jesus through Old Testament stories. She showed that she felt deeply about the things she spoke: the tears otten ran. "When a teacher showed ther

lbid.

:Edwards, incerilew. 
feelings about what she taught] so plainly, it was bound to make an

impression." !

One student wrote a tribute to Alma .McKibbin:

"I don't like to teach school, but I love to teach boys and girls."

And THERE was all the difference between a mere vocation and an art. It was an Old Testament history class in Pacific Union College thirty years ago. The artist was Mrs. Alma McKibbin E. MrcKibbin--no, no! not an artist with brush and pigment, but an artist with the plastic minds and hearts of her students in her hands.

Yes, we learned the chief tacts of Old Testament history and leamed them thoroughly--she saw to that--but. more important. we learned how to live honestly and gentlemanly, heartily and creatively. For with Mrs.

McKibbin the tacts of Bible history and doctrine were only a means toward an end. Life was to be lived brimiul.

I see her standing behind the desk as we swarm into old room five-short but erect, chubby hands lightly tolded over her notebook, the smiling love of God lighting her face. The bell rings, there is a brief prayer, the enchantment begins, and seventy of us sit enthralled. Elisha lives anew. $\mathrm{He}$ is introduced, not in his own right. but as "Elisha the son of Shaphat, which poured water on the hands of Elijah." By the sudden alchemy of her teaching, we learn the greatness of real service. which exalteth a man in due season. ...

To her, we who sat at her ieet proudly dotf our caps. We stand and call her blessed. Yea, blessed is a great teacher. for. reflecting the Master. such a one shall shine as the stars iorever and ever."

The Elfect of the Intluenza Epidemic of 1918

Alma McKibbin's last days at Pacific Union College were sad ones.

The intluenza epidemic of 1918 spread throughout the college like a plague, and she came down with the tlu three times. At a general board meeting at the college in December. 1919. it was voted that "Mrs. Alma McKibben [sic] be

Ibid.

$\therefore$ Tribute. 5 
recommended to the General Conference for the Sustentation Fund at the rate of $\$ 8.00$ per week." On April 28, 1920, that same board voted "that Mrs. McKibben [sic] be advised to spend another year out of school work. " 2 She lamented conceming the influenza, "It left me with a fiu heart, and I had to leave that altitude. Oh, my heart broke the day I had to leave there." ${ }^{3}$

\section{The Move to Mountain View}

Mrs. McKibbin said that she "wandered about for two years and at last settled in Mountain View." A postcard addressed to her in Reno, 9 July 1920, and one to her in care of her sister Anne in Geyserville, California are the only records of her "wanderings" before she settled there in 1921.5

She likely chose Mountain View not only because of its lower altitude, but because her brother Lonnie was editor of the Signs of the Times at the Pacific Press, which was then located in Mountain View. He states that he

'Pacific Union College, Minutes, 3 December 1919, 2.

:ibid.. 28 April 1920, 2.

'McKibbin, interview, 2 August 1967, 27. It is uncertain just when Alma McKibbin left Pacific Union College. The last postcard on record sent to her at Pacific Union College was dated August 15. 1919, and the Pacific Union College board hired her for the 1919-20 school year. On September 14, 1919, the board sent her a letter informing her that her salary was \$11.00 per week. The last time she was present at a faculty meeting was 23 March 1919 . See Florence Thornton Hill. Los Angeles, to Alma McKibbin. Pacific Union College, St. Helena. Calif.. 15 August 1919; Pacific Union College, Minutes, March 1919: 14 September 1919.

‘McKibbin. Step by Siep, 95.

'Ruth. Kansas City, Kansas \& Dodge, R. P. O., to Alma McKibbin, Geyserville. Calif., 24 October 1920: Florence Thomton Hill, Los Angeles, Calif., to Mrs. Alma E. McKibbin. Reno. Nevada, 9 July 1920: McKibbin. Step by Step, 95. 
invited her to come, and that he was instrumental in helping her secure a vacant lot across the street from his on Palo Alto Avenue.

Alma McKibbin loved her little two-bedroom home at 525 Palo Alto Avenue, apparently built by Mr. Robert Osborne.: One feature of the home was a wall lined with built-in bookcases with glass doors. Another was a wall lined with pull-down cloth maps, which she used frequently for Bible studies and tutoring at her home. Friends and students remembered her saying, "This is the most comfortable home I ever had. ${ }^{3}$ She felt the location, as well as things in the home, was convenient. Her home was within walking distance of the academy, the Pacific Press, and the Mountain View Church, which was convenient, since she had no car.

Soon after Alma McKibbin settled in Mountain View, her father, at her invitation, came to live with her. He had been in a veteran's hospital in Sawtelle. California, and she had taken him to the White Memorial Hospital for surgery. He lived with her for seven years, until he died of diabetes mellitus on November 27, 1928.

:Baker. My Sister Alma McKibbin and I. 83. Waterford, Calif.

- Nettie Lindholm Jenecke, telephone interview by author, 24 February 1991.

'Amold Weseman, interview by author. 20 February 1991, Mountain View, Calif. The house still stands, now surrounded by neighboring homes, much like it looked when Alma McKibbin lived there. She had a large garden in the back yard, with fruit trees.

4McKibbin. Step by Step, 95: Baker, My Sister Alma McKibbin and I, 88; California. Department of Health Services. Sacramento, Calif., Standard Certificate of Death, No. 28-060040. 27 .November 1928. The death certificate states that Alonzo Baker resided at Mountain View for eight years. He was almost 83 when he died. 
The 1920s were difficult years for Alma MrcKibbin. She wrote later, "There was a period in the middle 20s of about eight years when I was not able even to go to church. and that is almost a blank in my memory." She wrote that she was both in poor health and "poor in pocket." - Her neuralgia, as she called it, had begun as headaches in Centralia. but became a continuous pain in her head during the 1920s. ${ }^{3}$ Although both Alma McKibbin and Lonnie wrote of their father's mellowing when he came to live with his daughter Alma, others confirmed that the senior Baker was difficult to live with. Alma McKibbin herself admitted that he was "very suspicious of motives, critical, and difficult to please." Also during the 1920s. other Baker relatives came to visit their tather. some living in the surrounding area, such as Alma McKibbin's sisters Anne and Nell. Apparently these sisters, who later stopped speaking to each other for years, were trials to Mrs. Mckibbin, who needed to live alone in order to maintain her serenity. Of the care she gave to her bather during these years, one

Alma E. MiKibbin. Mountan View. Calit.. io Ethel Young. Washington, D.C.. 7 April 1966.

ibid. Alma Mckibhin states in this same letter that atter the elght-year penod of poor health, she suffered a memory loss and subsequently tried to keep a diary in order to compensate for her detictent memory. The diary has not been located.

Mekihhin. Sopp by Step. 95: Weseman. :ntervew.

McKibbin to Parmentier. 
observer commented, "Wasn't it something how Mrs. McKibbin retumed love for her father's cruelty?"

\section{Mountain View Academy}

Mountain View Academy traces its origin to 1906, during the rebuilding of the Pacific Press after the fire. Beginning as a church school for Press employees' children, the Mountain View school hired as its first teacher Viola Miller, who used Alma McKibbin's Bible lessons, which were not yet in book form. In 1915 the school was enlarged to ten grades. When an eleventh grade was added in 1921. Alma McKibbin was asked to teach it. ${ }^{2}$ In 1922 the school became a full academy, with Harland Johnston as principal. ${ }^{3}$

Thus, Alma McKibbin was one of the charter faculty of this academy. Because her health was poor, she did not want to teach when Harland Johnston approached her to lend her expertise to the founding of the new school. Perhaps because she needed the finances in order to care for her father or to make house payments, or perhaps because Mr. Johnston prevailed on her to help with so great a need, she accepted the position of Bible teacher for the 1921-22 school year. She taught most of the Bible classes: Old Testament history, New

\footnotetext{
Westphal, interview: Evelyn Anderson, interview by author, 19 February 1991. Mountain View, Calif.: Taylor, to author: McKibbin to Parmentier.

:A History of Mountain View Union Academy," 1947 TMs, pp. 2. 5. 7. 8. Adventust Heritage Center. Pacific Union College, Angwin. Calif.

'Tbid., 9. 11; Seventh-day Adventist Encyclopedia, 1976 ed., s. v. "Mountain View Union Academy."
} 
Testament history, denominational history, Bible doctrines, and English

literature.' When he was well, Harland Johnston taught Bible doctrines. Alma

MicKibbin apparently taught English literature for a semester during the 1923-24

school year, when the regular English teacher had to leave. She apparently

taught full-time from 1921 to 1926 and part-time as the need arose from 1926 to

1932.

\section{Her Teaching Methods and Philosophy}

Alma McKibbin required her students to make notebooks for their class

work in Bible. These notebooks were not as comprehensive as those she had

required of her academy students at Pacific Union College:

When I came here to teach, notebooks had only 25 pages, not all filled, and most were maps pasted in.

I decided that I would try to put most of the knowledge in the heads of my pupils rather than in notebooks. It is so much more convenient when you want to use it. ${ }^{2}$

Some students took pride that Mrs. McKibbin did not make a correction or a

mark in their notebooks. One student remarked, "If I had made a mistake,

\footnotetext{
Weseman. interview; Bessie Bobst Martella, Hanford, Calif., to author, 10 December 1990: Dorothy Kuninobu, Honolulu. Hawaii, to author, 17 February 1991; Madge Haines Nelson, interview by author, 27 February 1991. Angwin, Calif.; Lois M. Flory, St. Helena, Calif., to author, 24 April 1990: Tait and Tait, interview; Elsie Lindholm Kerber. telephone interview by author, 21 February 1991. Oakland, Calif.. Unfortunately, neither Mountain View Academy nor the state or union conferences have any record of Mrs. McKibbin's classes. However. Madge Nelson saved a personal booklet called "Commencement Memories." in which Alma McKibbin signed her full name. "Alma E. McKibbin." and wrote in ber own hand the three subjects she taught Madge: -O. T. Hist., N. T. Hist., Den. Hist." The other Bible class. Bible Doctrines, was usually taught by Harland Johnston.
}

:McKibbin to Regon. 
she left a note at that place on a smail piece of paper. and I made the correction. . . She respected my caretulness. "t

Alma McKibbin used a variety of methods to teach Bible class. She displayed pictures, had many Bible games tor the students to play, drilled students on the pronunciation of the names of kings, nations, and places, and dramatized Bible characters. either herself or by asking the students to play their parts. Pictures lined the walls of the Bible classroom. She would bring more pictures, either cut out or still intact in books. to show students. One day the students came to their denominational history class only to ind the door locked. It was the day of their tinal exam. But when the bell finally rang, the classroom door opened. Inside they saw chairs lining the room on all sides, with several tables rilled with objects in the centar of the room. On these tables were pictures or objects representing places, people, camp meetings, and buildings. Students were to match each item with its corresponding number on the test. There were pictures of the Review and Herald building, Battle Creek Sanitarium, and different pioneers of the Seventh-day Adventist Church. Aithough she would not show anyone the answers when they were tinished, students were to self-correct their own exams using whatever resources they chose. She did not care what grade they had, as much as whether they had learned the material.'

Martella to author. 10 Decemher 1990.

:Nelson, intervew: Weseman. inteniew: Anderson, interview. 
A more typical examination incorporated questions and short or multiple-choice answers. Alma .IIckibbin's preferred method was to use essay questions, such as. "How would you react to __?" Before the test, she reviewed the material in class so the students could pass the examination even if they had done nothing more than listen in class. She would put all the questions on the board. admonish the students to study them, and then test them over those same questions. "She was tair: she didn't pull any quickies." "2

Alma McKibbin contunued the use of maps in her teaching at Mountain View Academy. When students studied the three missionary joumeys of Paul, they were required to know which direction he traveled and the order in which he went on the journeys. However, the lessons did not end with names and locations.

She made it clear that Paul's journeys were the commencing of the Christian Church. She wasn't backward in letting us know that these were our roots--our beginnings. She made us teel that Paul's travels were an imporant part of the Christian heritage. "Just think where he went to," she'd say. "in just one litetime. If it weren't for Paul. there might not be a Christian religion. It might have died out. Peter couldn't have done it; he wasn't qualified. It took a man like Paul."

You became inspired as you !istened. You thought. "Here's a person who believes what she's teaching. and she wants me to believe, too."

She made it important--Bible xasn $:$ just a class. To her. Bible was the main part of school.'

\footnotetext{
Velson, interitew: Weseman. interiest.

:Kerber. interview.

Weseman, interitew.
} 
Another student commented regarding Paul's missionary journeys: "It wasn't just memorizing details--she made Paul come alive, and put flesh on his bones. Some teachers took her books and didn't make the characters come to life." Many students commented, "She made the characters real. "2

It is fortunate that she wrote out one of the Bible stories in detail; one that illustrates both her methods and what others may have meant by the expression, "She makes the Bible characters real."

The following story is about Mephibosheth's relationship with David after the deaths of Saul and Jonathan. Alma McKibbin told this story as if it were told to a crippled boy who was indulging in self-pity over being bound to a wheel chair.

Why must he be bound while others were free? One day when he was feeling just a wee bit rebellious, a dear friend told him this story. And as he listened he took heart. His mind is not crippled. ${ }^{3}$

Second, she provided a geographical and historical context in story form:

\footnotetext{
'Verna Nelson Ladd, telephone interview by author. 12 May 1991.

'Lawrence Anderson, telephone interview by author, 12 May 1991; Ladd, interview, Edwards, interview; Meikle, interview; Rogers, interview; Gladys Jones, interview; Ivan Jones. interview; Maryan Stirling, interview; Madge Nelson, interview; Aline Tait, telephone interview by author. 17 January 1991; Evelyn Anderson, interview; Weseman, interview: Kerber, interview: Jenecke. interview; Bessie Bobst Martella, interview by author. 25 February 1991. Hanford, Calif.; Quade. interview; Robert Jacobs, interview; Donna Jacobs, interview; Macpherson, interview.

'Alma E. McKibbin. TThe Prince Who Couid Not Walk." Youth's Instructor 97 (29 November 1949): 14.
} 
The sun shone warm and comiorting in the courtyard of the home of Machir, of Lodebar. Machir was a man of the tribe of Manasseh and lived in the land of Bashan. east oi the Jordan River.

A door to one of the rooms surrounding the courtyard opened, and servants appeared. They assisted a young man from his chamber to a place upon a couch in the half shade of the veranda. With every mark of respect and solicitude they arranged pillows and adjusted the canopy above his head. This done, and bowing respectiully, they retired-all, save one.

Ziba breaks the silence. "Master," said he, "the last of thy grandfather's sons is dead. Dost thou not know that thou art heir to the throne of Israel--thou, the son of Prince Jonathan should now be king of Israel."

"No, no. Ziba." answered the young man. "speak not so to me. My Uncle Ishbosheth attempted to succeed my grandiather King Saul, and some thousands rallied to his standard: but the forces of David, the shepherd of Bethlehem, were too strong for him. and he was defeated and afterward slain by two of his own officers. What could I a cripple do against the man who reigns at Jerusalem?'

Ziba was dismissed, and Mephibosheth reflected on his childhood memories of the fountain and tlower-tilled court of his grandfather, of the fear he had of King Saul, and of his contrasting love for his tather Jonathan. Mrs. McKibbin then wove into the story the universal human emotions of resentment and bittemess:

"But for the faith of my tather. I had gone with the heathen long ago, for God hath dealt very strangely. very bitterly with me." and the youth glanced once more at his broken. bandaged teet.:

At this point Mephibosheth recalled his last encounter with his father: the last embrace, his last loving words to his son. He would never see his father again. Then events moved rapidly; soon atier the last encounter with Saul followed the frantic escape from the palace:

\author{
Ibid. \\ Itbid.. 5.
}


My nurse started away on toot. I could not run so tast as she could walk, so she took me in her arms and strode on as quickly as she could go. But I was a sturdy boy, too heavy even for the strength of a serving woman. She stumbled over the rough ground and let me fall into a gorge that leads down to the Jordan. I remember the shock and the fright as I fell and rolled over and over on those rough boulders. Nurse scrambled after me, but when she tried to lift me, I screamed with pain--the awful pain in my feet--ior both were broken. crushed!'

A visitor interrupted these thoughts and fed them:

Then Shimei brought forth the old arguments that filled the mind of Saul himself until he lost his reason--the reasonings that he had allowed to obsess his mind until he was convinced that David was his enemy, and that David, and not God, had determined to take the kingdom away from him.

Long after Shimei had departed Mephibosheth pondered his words, and the poison entered his soul . . . the root of bitterness in the heart of Mephibosheth grew, and became stronger and still more bitter.'

Providence brought Mephibosheth to the court of King David, who wished to remember the kindness of his triend Jonathan by caring for his only living son. Mephibosheth's loyalties became transierred to King David but were later tested when Absalom took over the palace. Ziba, contiscating Mephibosheth's mule so he had no way of escape. lied to David that the young prince had remained in Jerusalem to receive his rightrul throne. Later, when David encountered Mephibosheth, the young prince expressed his lidelity to his benefactor in such a way that the King. overcome to see a loyalty of the same spirit and devotion as that of Jonathan. sang to him the requiem he had composed after learning of the deaths of Saul and Jonathan.

Ihid.

Ibid. 
There was a long silence when the song was ended. Then David spoke. "Mephibosheth. son of my triend. thou art to me a son." His voice taltered. He could say no more. Was he thinking of Absalom, who lay in a stone-heaped grave in the lonely woods of Ephraim?

So Mephibosheth. the prince who could not walk, lived in the palace of the king as a beloved son. And he came to know truly that love heals all wounds, and that there are no handicaps to him who loves God with all his heart and his neighbor as himself.'

When she was illustrating a lesson in a Bible story, Alma McKibbin related anecdotes and stories from her own experience. She told students about her brother Lonnie, when he was still attending Pacific Union College (class of 1916), and his iavorite baseball idol. Ty Cobb. Alma McKibbin had been concerned during his college years, for she did not want Lonnie's life interests to be bound up in baseball. She prayed that the Lord would take control of his life, and felt that her prayers were answered. Then she related the story to the day's lesson. One student remarked. "She didn't just tell stories to entertain--there was a spiritual lesson in everything she did."'

She assigned no homework in her academy classes, but students were expected to complete assignments during their study periods. Those assignments were "not too easy, but required an honest amount of time for your lesson."

Students respected Mrs. Mckibbin, resulting in tew discipline probiems. She had a personal quality. students said. that commanded respect--a

Ibid.. I7.

Ladd. intenre:w.

Weseman, interiew. 


\section{i2t}

"little dignity about her person." Some ielt the effect of her godly example and saw that the Holy Spirit was directing her life. "She was a disciple of the Lord.

She had a loving quality that made us respect and admire her--it had an influence on our lives." 2 One student described Alma McKibbin's classroom:

It was academy day at the church school, and we eighth-graders were visiting ninth-grade classes over at the academy, which was in a separate building. The freshman general science class was raucous and loud, impressing me with its noise. Mrs. McKibbin's Bible class followed next period, and when we got out of that science class, we all tramped directly across the hall for Bible. There sat Mrs. Mckibbin, serene, hands folded demurely. The blinds were pulled down half way, soltening the light in the room, and before my eves and ears a hush fell over those students as they crossed the threshold. We sat as though transtormed. ${ }^{3}$

When the boys in Old Testament history class began tittering at some of the phrases used in the King James Version, Mrs. McKibbin remarked, "No, it's not pornography--it's simply the way they used to talk in those days." Her demeanor and matter-ot-tact attitude calmed the boys so there was no further problem. When students did disrupt class, they were asked to leave. One student remembered her saying. "We have only so much time for class."

Alma McKibbin was in charge of the study hall. She sat at the head of the room, overseeing students at their desks. In the back of the room were study tables and a library. Verna Velson Ladd was in the back chatting with another

Ibid.

:Ladd. interitew.

Tait, interites.

'Ibid.

Weseman. inien:lew. 
student. Suddenly she heard a voice: "Miss Nelson, will you please take your seat?" Vema was chagrined, but knew she deserved it. ${ }^{1}$

\section{Her Relationship with Students at Mountain View Academy}

Alma McKibbin was conscious of her age (52) and generational

distance from her students and related in the following anecdote how she tried to bridge the gap:

He who would win a girl or a boy, must adapt himself to the life and customs of this generation without compromising his faith or being false to principle. We must keep up with these young people, or we never can help them. How it may be with you, I do not know, but for me this is a very great difficulty, for I am old fashioned, hopelessly so, my friends say.:

Mrs. McKibbin illustrated how she tried to "keep up with the times" in order to influence young people for God's service. The theme of the following article, written during the years she taught at Mountain View, was how to love and understand today's youth:

I do not enjoy an automobile ride. To be whirled through the air in a gasoline wagon so fast I can see nothing, enjoy nothing, is no treat for me.

Now you know that I am clear out of date, so much so that unlike people of genius who are usually born at least a hundred years before their time, it has been suggested that I belong to a far past generation--to the age of the oxcart and tallow dip. ...

[But] it is for me to demonstrate that the gospel of Jesus--love for others--can teach me to quicken my pace and help me to make such an adaptation of my own tastes and preferences to the conditions of this present time, that I may still be companionable to the modern youth.

:Ladd, interview.

Alma E. McKibbin, "Winning the Girl," Sabbath School Worker 41, no. 3 (March 1925): 72. 
So I accept an invitation from Laddie for a ride on the highway,-accept it with a smile, though my heart beats with a sickening dread, knowing I may never come home again. But I am courting Laddie, you know, hoping to win him for Jesus. But while I am willing to risk my life to win him, yet at the same time I must remind him of the law and the safety of others, for we fly along at a fearful rate, and "cut in" here and there at times. So I suggest that if the traffic officer were along here now, he might hale us to court.

"Not you," my young gallant rejoins. "He would take me, perhaps."

"Well, I do not know all the rules, but I thought perhaps that I being older, he would consider me responsible. Anyway, I should never forgive myself if we should hurt someone today."

Laddie shakes his head, but I notice our speed diminishes, and we turm the next comer on all four wheels. Somehow while he may be ready to suffer for his reckless driving himself, he does not want me to suffer for or with him. And I do not tell him how much I should prefer a quiet jog down a country lane behind old Dobbin. One is tactful when one is courting.'

Alma McKibbin's students in Mountain View remembered that she kept their names in a book and prayed for them. Some felt that her prayers for students were what made her successful as a teacher. ${ }^{2}$ "We felt we were being taught by someone with whom the Spirit of the Lord was directly working. ${ }^{3}$ Another said, "How could we do anything bad for a woman who believed in us? ${ }^{\text {n4 }}$

One day her students, wanting to please her, asked permission to rearrange the classroom. Consenting, she left the room, while they moved

'Tbid., $72-73$.

-Tait and Tait, interview: Martella to author, 24 January 1991: Gladys Scharff Jones, telephone interview by author, 11 October 1990.

'Ladd, interview.

¿Nelson, interview. 
furniture. When she returned, she complimented them on their work. As the day wore on, however, her eyes suffered. She had had the chairs adjusted so that the light fell over the !ett shoulders of her students, but when the chairs were changed, the light hit her eyes, causing her pain. Her students reversed their experiment.'

Students at Mountain View Academy liked Alma McKibbin as a person. Once some young girls got together and rang her doorbell, running to hide before she could answer. Oni her porch they left a small bouquet of flowers. Mrs. McKibbin put them in a vase and set them on the window sill, for all to see. Although one of the girls suspected Mrs. McKibbin knew their identity, she never revealed it it she did.:

When a student had a need, she did what she could to meet it. One of her students, Verna Ladd, Wst her eighteen-year-old brother because of a ruptured appendix. Mrs. McKibbin noticed that Verna. nearly the same size as herself, had tew changes of clothing. She asked Verna whether she would be offended if she offered her a dress. Verna was thrilled and could describe the suit seventy years later: a navy-blue serge wool gabardine two-piece ensemble with a long top coat. She wore it every Sabbath all year long. ${ }^{3}$

Ihid.
:Ibid.
:Ladd. Interview.


Alma McKibbin followed her students through life. One student commented, "She would call me by my first name, and write down how many children I had." She wrote their names, along with their number, in her Book of Remembrance. Gladys Jones remembered being her 1000th student. Another former student commented, "Many times through the years as I visited her, she had me sign the book which she had kept, and every time a student visited, it was recorded." ${ }^{2}$ One student offered Mrs. McKibbin's message in her autograph book:

Dear Madge,

You are one of the class that was my first in Mountain View-the class I have had the privilege of directing for three years in their Bible study, and therefore holding a peculiar place in my heart and memory. You will go on in your work, but I shall never forget when you were mine.

Your teacher and friend, Alma E. McKibbin. ${ }^{3}$

Some of the students who felt more on the "fringes" of academy life were drawn to Mrs. McKibbin:

I was a rough kid. I was raised a Seventh-day Adventist, but I was a revolutionary, and I was finally thrown out of academy. Mrs. McKibbin didn't treat me any differently than anybody else, but when I was in school, it seemed like she did. I left academy and finished in the public high school, and then went to San Jose State University. She never let go her faith in me--it was like a guiding light to me all my life--made me a better person. Mrs. McKibbin always kept in touch with me. Her dedication stayed with me--I came back to it. Because of her, I've always leaned

:Weseman, interview.

Martella to author, 10 December 1990: Gladys Scharff Jones, telephone interview by author, 13 September 1990.

${ }^{3}$ Alma E. McKibbin. autograph in Madge Nelson's autograph book. 3 June 1924. In the band of Madge Haines Nelson. Angwin. Calif. 
toward the Seventh-day Adventist taith. It I ever had to choose a church, it would be her church.:

It was one of her values :0 iry:0 understand her students, regardless of their personalities, mistakes, choices. or backgrounds. She later wrote about one of the students at Mountain View who apparently did not receive this understanding during a crucial time in her life:

Long ago. when a certain giri came to Mountain View Academy, the students all said. "She is different. She is strange. We don't understand her." She had beautiful long hair and braided it in two braids, wrapping them around her head. One of the girls sald to her one day, "Why do you comb your hair that way? Why don't you cut it and wear it like the rest of us?"

She answered. "My tather likes it this way."

"He must be very old iashioned." ihey replied. It seemed to hurt her.

It went on like this for a long time. She was a very good student part of the time. But there were days when if asked a question she would say, "Please excuse me today." As the days went on she grew sadder and often asked to be excused from reciting.

Then one day she came to school. and everyone could see that the light had gone out of her life. At recess the principal came to her and ti ied to cheer her up a bit. He rinally suggested that she take a little walk. He said. "Walk around the block. I think you will probably feel better."

So she walked out alone. No one said. "Let me go with you." She walked down the street untul she came to the corner. She stood there a while. Neighbors across the way saw her standing there. She looked this way, and she looked that way, and linally started walking. She walked and walked and walked until she came to the railroad track. The engineer saw her, but it was too late--he couldn't stop.

They went to tell her mother. and tound her all alone. She told them. "There was trouble in our home. Has been for a long time." That moming when the girl got up. her tather was gone--the lather she loved so much. And the mother told her. Your lather has gone. And he'll never come back. And you'll never see him again. And I'm glad."

That's what had taken the light out of her life. And nobody understood." ?

Intervesee $\neq 12+$. Who whined to reman anonymous.

Mlekibhin. An Lnderstanding ileart. 
In this same article she wrote.

Most of the crouble in the world is caused by misunderstandings, whether it be among nations or among people or among students in school. Most of it is because we do not understand one another. . . We need what Solomon prayed for--an understanding heart.

\section{Mountain View Academy Students Opinions of Mrs. Mckibbin and Her Teaching}

The tormer students interiewed barted in their descriptions of Alma McKibbin. One said, "She was short of stature, plump, round, freckled face, thin, wispy hair, and we thought she was beautitul."' Another commented:

"She was quiet, reserved." And still another reminisced:

She was the most caring teacher . . very digniñed, yet human, tenderhearted. She was very trank. When she said something, she meant it. She didn't rush, and she was very deliberate. In every Bible class she shed tears over some aspect of the lesson."

One student remarked that when he went to college atter having had Alma McKibbin's Bible classes, he felt well prepared. "I felt like I had this class betore."

Ibid.. 6.

:Marella to author. It January 1991.

Ienecke. interview.

'Kerber. intervitw.

'Weseman. interitew. 
A nurse tried to emulate Alma Mlckibbin's teaching methods: "I have had a fair amount of :eaching connected with my work . . and have tried to teach as she did."'

Some students telt that, in addition to taching them Bible and denominational history, Alma McKibbin taught them how to live. She did this by her own attitude. high standards, and example, which were daily portrayed before them. Several said that she intluenced them more than any other person outside their immediate bamily during their teen years. to set their goals for life. Due to her influence, many iurthered their education for God's service.:

Some remarked that it was not the content or material of her Bible classes that mattered or stayed with them. although these in themselves were important, so much as Alma Mckibbin's own personal life, high standards, and treatment of students with respect." "She had an ideal of what a Christian should be like, and she got it across ihrough her personality--there was something about her that gave her this ideaiism."

She didn't preach at us--she didn't need to. She taught us through her own example and by the way she handled us students. She gave us self worth, because she noticed us--she remarked about the dress I had picked out myself: said it was in good taste for a Christian girl. She kept track of us--if any of us did anything up tront in church. she wrote us letters and

Martella to author, 10 Decemher 1990.

ibid., Cathryn Rogers, interiew hy author. 20 Fobruary 1991. Mountain View. Calif.: Meikle. intentew: Edwards, intervew: S.dul intervew: Verna Velson Ladd. College Place. Wash. to author. 19 Novemher 1990.

Velson. intervew: Martella wo atuhur. It danuary 1991.

"Ladd. Interitew. 
notes of encouragement. She had contidence in us and was proud of our accomplishments. Perhaps her greatest contribution to students was giving us self worth and having us set high goals.

\section{Other tctivities}

During the vears $(1921-32)$ she was teaching at Mountain View Academy, Alma Mckibbin was busy in other sapacities, such as coming every Friday for assembly and presenting a halt hour of current events to the student body and faculty.:

During her academy teaching years. Alma McKibbin attended conference teachers' meetings. While attending the Pacific Union Conference Academic Teachers' Council at Paciric Union College in Angwin. 1926, she took part in the discussion on applying the principles of Seventh-day Adventist educational philosophy to the area of home ecoromics. She felt that the "fundamental object in all phases of industrial lines is to teach love of work." ${ }^{3}$ Alma Mckibbin aiso engaged in activities of the Mountain View Seventh-day Adventist church. She was achve in Sabbath school, taught the lesson. and told stories tor children at thetr Missionary Volunteer meetings."

Nelson, interview

:Kerber, interitew.

'Pacific Lnion Conterence. A Angwin. Calit.) Minutes of the Pacific Union Conference Academic Teachers Councsi. 19-2t Angust 1926. 10.

Weseman, intenites. 
Alma McKibbin no longer taught Bible at the academy after $1927 .{ }^{1}$

She had to cease full time work there because of her failing health. Headaches that had begun in Centralia now became continuous, and she again went back to St. Helena Sanitarium. ${ }^{2}$

\section{Summary and Observations}

Integration of Her Faith with Her Methodology

Alma McKibbin integrated her beliefs with her teaching and content in many ways during her later teaching years. In keeping with her personal value of wanting to live a life of service, she continued to serve her church in Sabbath school and other church duties. She also accepted a position in the new academy in Mountain View, in spite of poor health and her father's living with her.

During these later teaching years, she tried to apply her beliefs in the principles she leamed in the Spirit of Prophecy. At Pacific Union College and

'Weseman. interview; Seventh-day Adventist Yearbook (Washington. D. C.: Review and Herald Publishing Association, 1926), 239; "History of Mountain View Union Academy." 11-12; Aline Tait, interview; Jenecke, interview; General Conference of Seventh-day Adventists. Sustentation Application, 30 September 1930. Alma McKibbin is not listed in the 1927 yearbock because she substituted for Harland Johnston. who was ill during the 1926-7 school year. Unfortunately, the 1924-25 annual is the only school annual available during those years. One student stated that Alma McKibbin taught a Bible class sometime while she was enrolled at Mountain View Academy from 1928-32. See Flory to author.

Tn July of 1927, mail was again addressed to Alma McKibbin at the St. Helena Sanitarium. A Sabbath school pupil wrote to Alma McKibbin at the sanitarium to say bow much she missed Alma McKibbin as her Sabbath school teacher. By August, mail addressed to St. Helena had been crossed out and readdressed to her old address on Palo Ailo Avenue in Mountain View. See Mrs. Huestus, Redwood City, Calif., to Alma McKibbon [sic], St. Helena Sanitarium, Sanitarium, Calif., 19 July 1927: Blanche Morgan, Mountain View. Calif., to Alma McKibbin. St. Helena Sanitarium. Sanitarium. Calif., 19 July 1927: Alber Westcott. Orlando. Fla., to Alma McKibbin, Mountain View. Calif., 3 August 1927, in the hand of Paul Ricchiuti. Nampa. Idaho. 
Mountain View Academy she loved and tried to understand her students as she had been admonisned to do in the tirst sermon she heard Mrs. White give in Healdsburg on a September Sabbath morning in 1989. Trying to foster his success, she pasted stars all over one student's notebook, and, on another, attached small notes so that she made no marks; both these actions illustrate her respect for what was meaningtul to her pupils. She attributed a student's suicide to the lack of understanding on ihe part of significant others in the student's life. and declared the world wanting for lack of understanding hearts. She tried to love the rebels as well as those who were responsive.

Alma McKibbin believed what she taught. Students felt impressed that if she valued the Bible teachings as to be so deeply moved in class, then perhaps they would do well to value them. too. Many set their goals for life in her classes, influenced by both her teaching and her example.

She believed and made the students ieel as though Bible was the main part of school. not just a class. Paul's missionary journeys were not just travels: he was making history. Without him the Christian Church might not have existed. Her "enchantment." as one student described her storytelling, wove the history and geographical context into the story. Mrs. McKibbin went to some lengths to have her students acquire context. including having students dig maps in her garden and spending time herself to research a story to make it more interesting. She applied the principies sine wanted students to remember by 
citing personal experiences in class and by exhorting her students to adopt biblical guidelines tor their own.

One of Alma IIcKibbin's values sas for a teacher to become a tool to remold distorted characters. In keeping with this conviction, she donned her hat one day for a visit to a pupil who was dragging his teet, persuading him to align his actions with his stated goals. The visit apparently did its work. Other students felt that her discipline was of the no-nonsense variety. She asked students to leave it they were disruptive. reminding them that there was "only so much time for class."

Her method of transmitting values was not to preach, but to model and hold up the ideal. She was able to reach and intluence students' lives, partly by example and partly by weaving in stories that spoke to their needs and interests. Her emotions and warmth underscored her words through tears as she told the stories or through quiet counsel with students in a home setting while serving warm rolls and jam. Alma Mckibbin encouraged students for the rest of their lives to adhere to their calling to Christian service. She treated them with respect; she prayed for them and presented the Bible characters as real people with emotions and troubles like those of her students. She told experiences from her own life that caught their interest--stories about baseball heroes and stubborn oxen, and related these stories to the lesson. She contessed her fears of having college students in her class. and this openness endeared her to her pupils. 
Apparently she didn't have to talk about her love for students; they read it intuitively in her body language. demeanor, and actions.

Her relationship with students was, to them, one of her strong points. Alma McKibbin remembered a lamily death on the tirst anniversary, and sent cards when she heard of a student's loss of a loved one. When one girl lost her brother, she gave her some much-needed clothes from her own wardrobe.

Alma McKibbin used many methods that were commonly accepted in education during the tirst quarter of the wentleth century, such as pronunciation drill, notebooks, maps, memorization, comparing and contrasting, pictures, review, essay, and multiple choice questions. She aligned her curriculum with her goals, reviews, and tests. She used several innovations. such as having students dig up the soil in her garden to resemble the terrain of Palestine, giving a test with pictures and objects, Uramatizing Bible stories, integrating Bible with current events, and tleshing out the Bible stories with thorough, painstaking research. 


\title{
CHAPTER 6
}

\section{RETIREMIENT YEARS}

\author{
$1927-1974$
}

Her spirir is nor dim, while she's waiting for Him. Though evil must bring its storms.

Alma McKibbin spent her retirement years in Mountain View.

California, trom 1927 until she was taken to a nursing home in 1968. While

living in Mountain View. she continued to stay at her own home at 525 Palo

Alto Avenue.' Mountain View was the home of the Pacinic Press. a publishing

firm that employed hundreds of Seventh-day Adventist workers. The Mountain

View church. which served most of the Press workers, was the "mother church"

of several nearby smaller places of worship that were spawned by it. The

membership at Mountain Vian was about nine hundred in the 1960s.

"History of Mlountan View Lnon Academ: "3: Soventi-don Adventist Encyclopedia, 1975 ed.. s. $\because$ "Mountan View Lnı.)n Academy. Alma was listed in the Mountain View City Directories at 525 Palo Alto Avenue from 1926 to 1968 . There were no records avallable between 1920 and 1926. See hountun View Ciry Directory, 1926-1968, n. p., a. d.. Mountan View Historical Society. Mountann Vieu. Calit. 
Figure 13. Alma E. McKibbin. ¿. 1960. Courtesy of Paciric Press Publishing Association. 


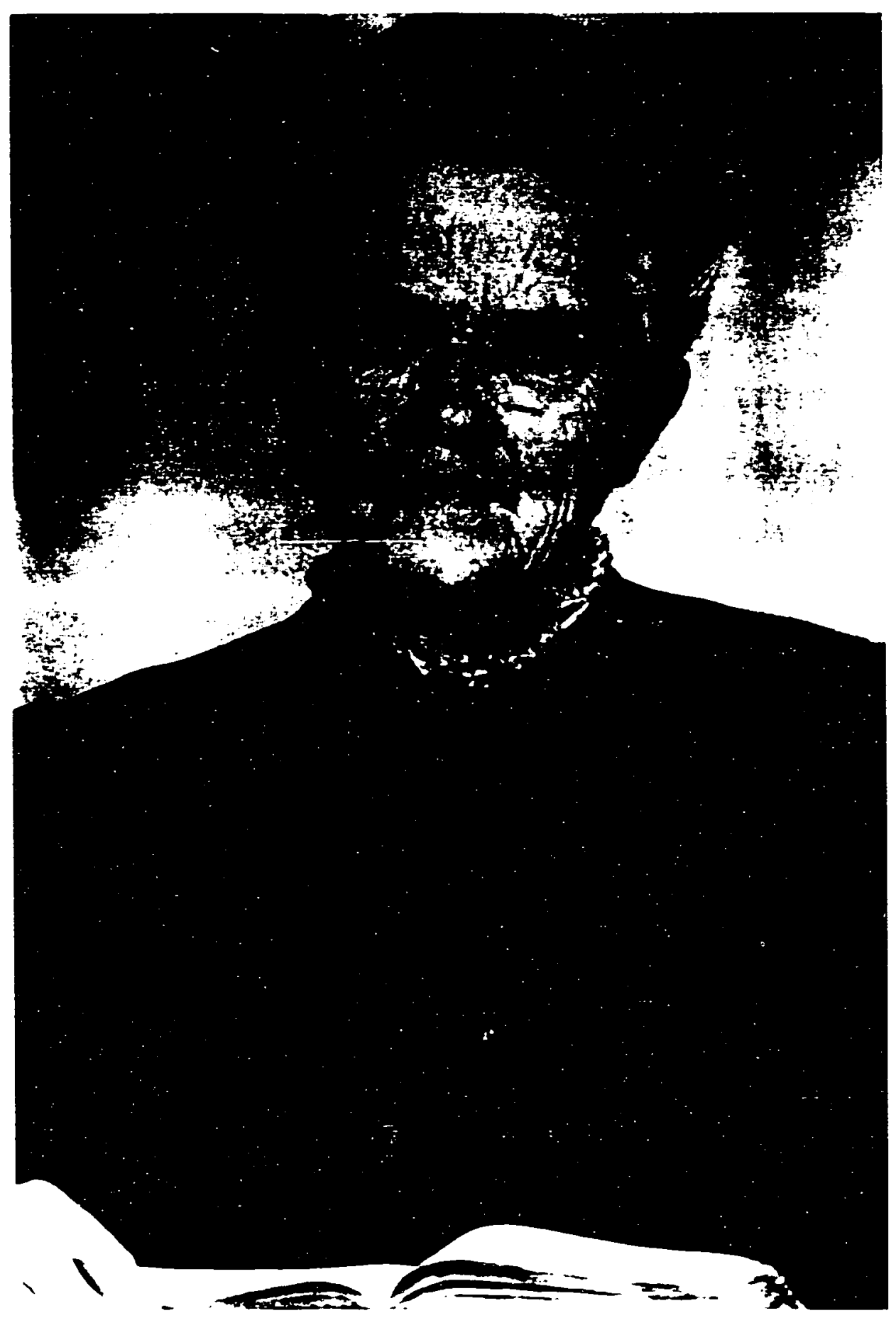


Figure 14a. Alma Mckibbin's Home. 525 Palo Alto Avenue. Mountain View. California.

Figure 14b. Mountain View Seventh-day Adventist Church on Springer Road, built in 1968, which Alma McKibbin attended in her later years. 

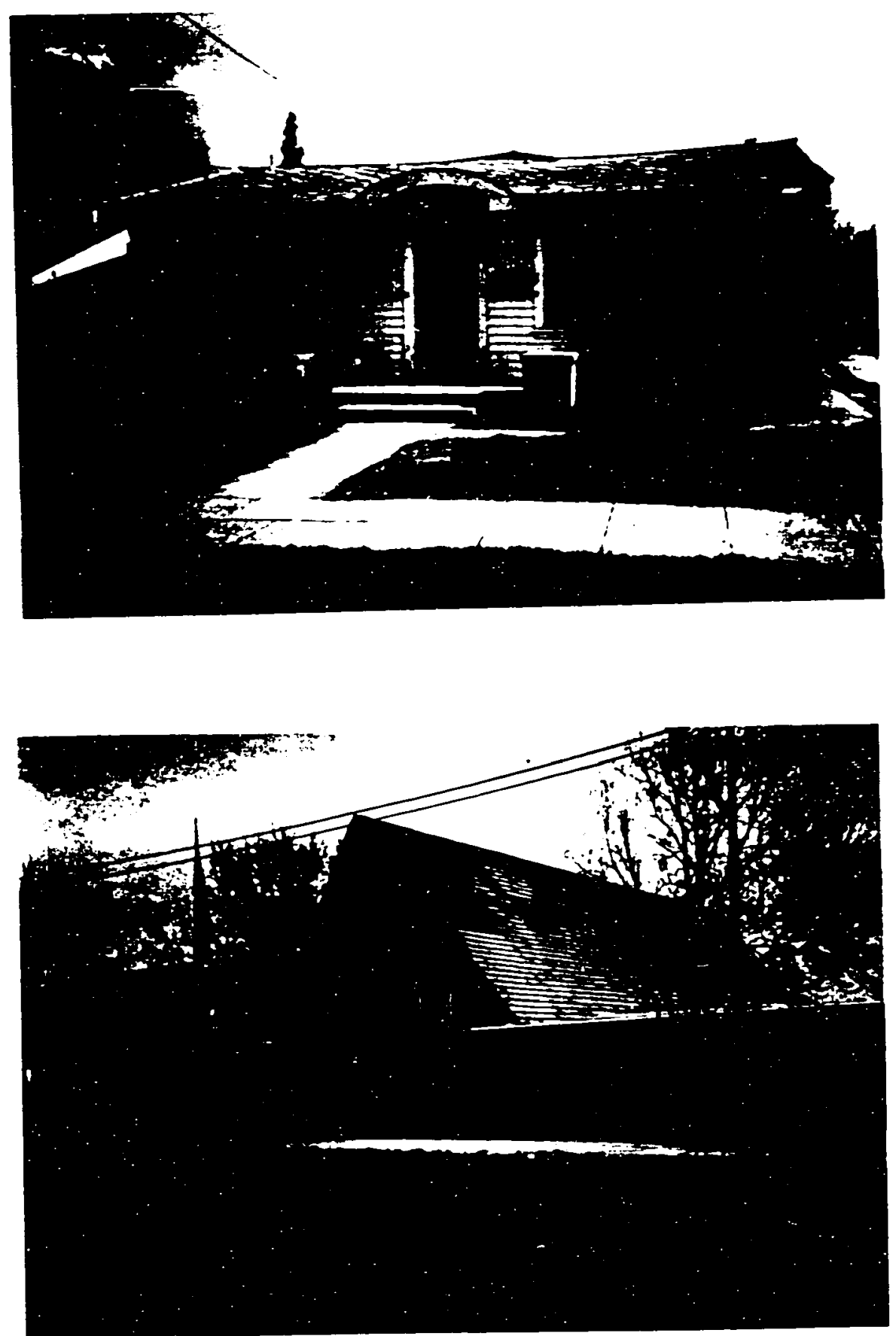


\section{Sabbath School Teacher}

General Lesson Study

Mrs. McKibbin continued teaching Sabbath school classes and teachers' classes while attending the Mountain View Seventh-day Adventist church during her retirement years.' She also taught the general lesson study at camp meeting on occasion.' Many attended and enjoyed these classes. ${ }^{3}$ One person remarked, "It was a high day when she taught the lesson study. "The Mountain View church had no Sabbath school rooms, so the format for Sabbath school was usually general lesson study.

When tape recorders began to be used by the general public in the late 1950s, several individuals recorded church speakers at the Mountain View church. Fortunately, three of Mrs. McKibbin's general lesson studies for the adult Sabbath school were recorded during the early 1960s. They are analyzed on the following pages: (1) "Spirit of Prophecy" (1962), (2) "Prophecy, a Guiding Light" (1962), and (3) "The Seven Deacons" (1965).

'Lennart Ahlkvist, telephone interview by author, 14 January 1990: Loma Tobler. telephone interview by author. 23 February 1990. Sunnyvale. Calif.

SPaul Ricchiuti, telephone interview by author, 9 January 1990.

${ }^{3}$ Herbert E. Perrine, Dayton, Ohio, to author, 9 February 1991; Ricchiuti, interview.

¿Ivan N. Jones, interview.

'Alma E. McKibbin, "Sabbath School Lesson on the Spirit of Prophecy," 16 June 1962. class taught at Mountain View Seventh-day Adventist Church, Mountain View, Calif., tape recording, in the hand of Paul Ricchiuti, Nampa. Idaho; idem. Sabbath School Lesson. "Prophecy: A Guiding Light," [1962], class taught at Mountain View SDA Church, Mountain View, Calif., tape recording, in the hand of Paul Ricchiuti, Nampa, Idaho; idem, "Sabbath School Lesson on the Seven Deacons." 11 November 1965, class taught at Mountain View SDA Church. Mountain View, Calif; tape recording, in the hand of Gustav Tobler, Sunnyvale. Calif. 
Alma McKibbin taught the lesson on the Spirit of Prophecy when she was ninety years old. She seemed to follow an organized outline with major points supporting one central theme. There was not a great deal of audience participation.' Her outline on the lesson was as follows:

Spirit of Prophecy²

I. Definition of a prophet

II. Roles of a prophet

A. Seer

B. Guard

1. Protection against dangers in the church

a. Fanaticism in 1840s

b. Fanaticism today

2. Protection against dangers outside the church

a. Spiritualism, mesmerism in 1848

b. Spiritualism today (personal experience)

C. Guide to understanding Christian truth

1. Understanding the Bible's meaning

2. Personal guidance

a. Paul's call to Macedonia

b. Church organization

(1) Seven deacons in early church

(2) Choosing a church name in 1863

(3) Health message (personal experiences)

D. Preserver of God's people

1. Historical illustration: Jehoshaphat's choir in battle

2. Future persecution: develop faith now for future victory

No other taped recordings of Alma's discourses at the Mountain View SDA Church haye been located as of the writing of this dissertation. Although many other McKibbin lectures were recorded. some may have been lost or destroyed in consequence of the Mountain View church fire, and others in the move to the new church location on Springer Road. It is possible that some recordings reside within the homes of private individuals.

'Ray Hixson, interview by author, 13 March 1991. Loma Linda. Calif.

"All quotations under the section header "Spirit of Prophecy" are from McKibbin. 'Sabbath Schooi Lesson on the Spirit of Prophecy." 


\section{4}

Mrs. Mckibbin appeared to use common, everyday phrases and a light, conversational style to describe the sacred and hallowed stories of the Bible and Seventh-day Adventist history. as in the following examples:

1. When describing the work of the tirst Seventh-day Adventist overseas missionary. J. V. Andrews, who went to Switzerland to start a church publishing operation in $187+$. Mrs. McKibbin queried. "And whom do you think was the prootreader? His own little girl. Wasn't that wondertul?"

2. While narrating the extremes to which Adventists went after the discrediting of William Miller's interpretation of the 2300-day prophecy of Daniel chapter eight. she commented. "You can imagine . . you can imagine-the reproach they brought on God and His people."

3. She described Ellen White at the time God called her to be His special servant:

Now then. here was this little girl. this litle girl--she was only seventeen years old. and she rinally married a school teacher. . . That little girl had to correct [the errors of fanaticism in the church], and she was only seventeen years old. called to go out. tumid, self conscious. embarrassed among strangers. She must go to these people and tell them they were wrong--point out their errors. and show them a better way.

4. When God called James White, a penniless church pioneer, to start a publishing work. Mrs. Mckibbin prompted the audience. "Did he do it? Did he do it? Oh. yes, he did . . and what is the name of that little paper today?"'

The paper. which started sut "ittle' in 1549. sas Present Truth, a religious publication onginally published to persuade disappomed former Millente Adventists to keep the Sabbath. Changing in 1850 io the them Rewess and Sabboth Herald, it is stull being published today as the The Advemrst Revew, hy the Review and Herald Puhlishing Assoctation. Hagerstown, Md. 
5. When contemplating the courage of the church leader to persist with the publication of Prese'm Trum in the tace of many difficulties, she shared her own weakness: "My taith is so weak compared with theirs."

6. When the armies of Mloab. Edom, and Ammon were assembling for battle against Judah, King Jehoshaphat turned to God for help. Mrs. McKibbin commented. "Does God ever furn away [from listening] to a sincere prayer? No. never." Regarding Jehoshaphat's battle, she paraphrased God's words: "Jehoshaphat. you won't need to right in this war. You can march out your army, but you won't need to night."

7. When she said that "it was very hard for our people to organize-they thought that organization would stitle our work and we'd be creed-bound," she added, "Why. it wasn't so at all. . . . it wasn't so at all."

3. She used phrases such as. "All they had to do was . . and what do you think of that?" "And what happened?"

Alma Mckibbin captalized on the pause. She asked her audience if they had ever learned any classical poerry that narrated some of the events in the Bible. "Well, I did." she began, and hen launched into Lord Byron's poem describing the 185.000 Assyrians lying slain in the battletield with all their spoil, as discovered by Jehoshaphat and his army. She recited it slowly. deliberately, pausing tor etfect. When sne was inisiced. there was silence.

She then made the transition from the ancient battle to today's battles: "And the Lord saves his peopie in the last days. not trom armed foes. but from 
themselves." She tollowed with some illustrations of how inadequate medical knowledge had been prior to the health reform message given to Ellen White in 1863.

When she told a well-known story to illustrate the ignorance of the American people with regard to preventing iilness and treating the sick prior to the 1860 s, she used repetitive questions to build momentum and audience interest. The question-answer sequence seemed to iall into a pattem or cadence in which both leader and audience knew what to do, as in a game. Regarding George Washington's illness and death she asked.

Why did he die while still a strong man? Yes. he caught a cold. What did the doctor do? (audience answered. "Lanced him!"). The nexi day he was no better. What did the doctor do again? (Audience repeated same answer). The next day he was worse. What did the doctor do? (Audience repeated same answer). He died from lack of blood.

She continued to use questions to keep her audience with her. These questions were usually simple, requıring Sabbath school members to recall prior knowledge that stimulated their interest in the current topic. Sometimes she asked a question in order to have the audience wonder. and then she would answer, as though she knew her audience did not know: "What toreign nation assauited Judah? Assyria." Occasionally she would use questions to test audience listening. After mentioning that Hezekiah was king, she discussed what his concerns were. Then followed the question "Who was king?" She answered with the audience. "Hezekiah." 
Mrs. McKibbin used some traditional methods of Sabbath school

leaching: she occasionally called on people by name to answer questions, and

she began the lesson by asking her audience to recite the memory verse.

Sometimes she illustrated a point with a personal story. After

discussing the lack of medical knowledge in George Washington's day, she

added a story about her grandfather:

Well, my grandfather was bom in 1804 . When he was eighteen, he got typhoid fever. Grandfather was an orphan brought up by Aunt Betsy. What should Aunt Betsy do with a raging fever? The first thing she did was to close up the windows, and she took out all the water. Then she drew the curtains around his four-post bed. Now what do you think of that--a buming tever, no fresh air, and not a drop to drink. Did Grandfather live? (ChuckJe). Grandfather ... (pause) could think. He didn't believe a word of it. He had a new jacknnife, which in those days was quite expensive. He looked out the window, and saw a young buddy out there. He opened the window, when Aunt Betsy was gone, and beckoned the boy over. "Will you do something for me, and never tell anybody about it? If you do, I'll give you this jackknife when I get well."

"What is it you want me to do?"

"I want you to go down to the spring, get a jug, and fill it full of water every night, and leave it here by my window." Weil, Buddy did it. When Grandfather heard a noise outside, he opened the window, when Aunt Betsy was not in the room, of course. He would drink the water, and put it under the bed, and drink it all the next day. The next evening, there'd be a fresh jug of water. And so, Grandfather lived. That was the state of medical knowledge in those days.

Alma McKibbin then asked the audience what was the first point of the health message that God gave to Mrs. White in 1863. She answered her own question:

Why, it was to open the windows. People believed that the night air was dangerous, and Sister White said no, the night air is no more dangerous than the day air. Be sure and get plenty of fresh air in your bedrooms. 
She explained what kinds of medicines were given to people in the

nineteenth century, mentioning calomel. She told an anecdote about her father:

My father only has one tooth. When he was a young tellow, he was sick, and his mother gave him caiomel to drink. Do you know what the teeth do if you drink enough calomel? it makes all your teeth fall out. It loosens the teeth. I used to say to my lather. "Why do you bother to keep that tooth?"

"How would I ever prove to people I ever had teeth?" (audience laughter).

Oh. how we needed the health message. I wonder if we appreciate what a healthy, happy people we are!

Alma Mckibbin liked to chuckle. When Jehoshaphat was told to ready

his army for marching against the enemy, she asked her audience.

He also called out what? (chuckle). The choir! That great choir, that had been first called together by David. That choir. 4000 voices that sang as one man. He called that choir out. And he put that choir in the forefront of the battle. Now, did you ever hear of an army marching to battle with a choir and a band? They did! Can't you see them, coming out of Jerusalem, marching down Jerusalem. down Mount Zion, with a choir, singing? The mercy of the Lord endureth forever: the mercy of the Lord endureth forever. And they marched down. Elear down through Judah, and when they got to the place where Moab. Ammon, and Edom were waiting for them, what did they tind? Why, the battle was over. Moab and Edom had gotten to righting among themselies. And they just pretty nearly wiped one another out of existence. And all that was lett on that battletield was dead bodies and spoil.

Mrs. McKiobin added detals that provided a background for better understanding. When the children of Moab. Ammon. and Edom died in battle. they left their spoil. She explained the reason tor this:

"Now, I never could understand it. but in ancient times, the people took gold and silver, precious ornaments and jewels to the battlefield. I can't understand why. They did it even in kater imes. you know; in France once there was a batile called. "he battle of the tield of gold." because their tents were made of golden materiai. Will you think of it? So they'd taken all of these things-they used to take the jeivels and string them along the 
horses' bridles. Think of that--just cross the horses' bridles with jewels, and their saddles, and their own garments. when they went to battle. Now they were dead, and there they lay. And it took the army of Jehoshaphat-all they had to do--they didn't do any fighting--all they had to do was to gather up the spoil, and it took them three days. That whole army--it took three days to gather up the spoil, and then they marched back to Jerusalem with the spoil, with the choir singing, "The mercy of the Lord endureth forever." Now, that was victory, wasn't it?

She immediately followed with the lesson:

How was it accomplished? Through following the word of the Prophet. . . . He did just what the prophet said. Now, that's the message of the church today. We won't need to fight in this battle, but we do need to have faith--the faith that will go singing no matter what persecution may come.

Oh, may we develop faith now, that when that day comes, we may not fear, but claim victory, and be true to the truth--keep the commandments of God no matter what it means. . . Will we do it? (Softer) Will we do it? (Whisper) Yes, will we do it? [Jehoshaphat] said to them, before they went out, "Believe in the Lord; so shall ye be established. Believe in His prophets; so shall ye prosper. And that word applies just as much today, as it did then. Believe in the Lord your God; so shall ye be established. Believe in the Spirit of Prophecy ... so shall ye prosper.

\section{Prophecy, a Guiding Light ${ }^{1}$}

The second lesson, "Prophecy, a Guiding Light," seemed to be a subject Alma McKibbin considered of utmost importance. After expressing her gratitude for God's mercy in waming His people ahead of time what will happen in the last days so they need not fear the future, she sounded a serious note of waming: church members must heed the prophecies, which were to be a protection and help so that they would not be deceived, and that their names may be written in the book of life.

\footnotetext{
"All quotations under the section header "Prophecy, a Guiding Light" are from McKibbin. "Sabbath School Lesson: "Prophecy, a Guiding Light."
} 
She highlighted the following counsel. which she believed had been given to help the church prepare for the tinal events of history:

1. People in the last days will be in gross darkness, spiritually and in other ways.

2. There will come a time or trouble such as never was, but God's people, whose names are written in the book of lite. shall be delivered.

3. God is holding court !n heaven. deciding our cases, now.

4. Some will be resurrected to everlasting life: some to shame and everlasting contempt.

5. Take vour children out of the public schools, permeated with talse teachings, to prepare them for Christ's coming.

6. Many prophecies on health given to Mrs. White were part of a holistic message to prepare a people spirituaily. mentally and physically to meet their God.

7. We live in a time when the prophecy. "Men's hearts will fail them for fear," is being fulfilled.

Mrs. Mckibbin demonstrated the chtirch's need for this counsel by using stories and personal expertences. To illustrate the need for a message on heaith, she told the story of medical ignorance in the case of her grandfather when he contracted typhoid fever. as described in the previous Sabbath school lesson. She also recalled a special gathering of the church women at a 
Califomia camp meeting in 1891. in which a lady physician revealed the importance of a mother's influence on her unborn child.

To explain how the warnmg. "Men's hearts will tail them for fear," is now being fulfilled, she shared two personal experiences:

1. One occurred in the 1990 s. when she had driven a minister to Escondido to meet his train. He had asked her if she would be afraid to make the retum trip alone. "Oh. no." she replied. "I make this trip once a week to sell butter and eggs." He counseled. "There will come a time when no man will be strong enough to guard a woman." She emphasized to her audience that they were now living in a time when those words were irue.

2. Finally, she shared that she locked her own doors, both in the day and at night, and recounted an incident of crime that had occurred to a neighbor only two blocks from her home.

Alma Mckibbin often made an appeal when speaking to her audiences. and she did so in this Sabbath school lesson. After presenting the guiding light of prophecy for the church. she asked the audience. with tears in her voice. "Then, how shall we live? Oh. does not this call for a time to give up everything?" She explained that she was waiting for the time of repentance and reformation, when the Spirit of God would be poured out on his people, and when the warning and good news would be shared with everyone. She appealed.

Wonderful light has been given to us through the Spirit of Prophecy. Have we tollowed it? Are we iving up to it? Can we expect the blessing of God--can we expect His light to arise upon us and shine upon us if we do not obey all the light that has come to tis through the long years? 
He tells us not to be unequally yoked with unbelievers. Now that means more--as we understand. it applies to marriage--but it applies to business, and it applies to many other things. I think we're yoked with unbelievers today in our diet. and in our dress. and in our habits of life, and in our amusements and entertamment--altogether too much ...

altogether too much . . altogether too much. We must be separate; we must be what God wants us to be--else $\mathrm{He}$ can never pour out His Spirit upon us, and that power that He longs to do--the power that will give us the glory, and the power that will give us an ability to warn the whole world.

Oh, when I think of the many wno do not yet know the way of life, and who are following the talse principles of this world. I say to myself, "Have you done what you could? is there one more thing that you could do?" If we have. then God "rites this: that He will save us in that day, because thou hast kept the word of my patience. I also will keep thee from the hour of temptation that shail come upon all the world.

Recently l've been reading the last chapters of The Great Controversy and the awrul position in winich Sabbath keepers will finally tind themselves--when they're iorbidden to buy or seil, when they have to flee to the mountains. I also asked myseli the same question that Jesus asked, "When the Son of Man cometh. will He tind faith on the earth?" Day by day my prayer is. "Oh. God. increase my iaith." These things are coming. They're right at our doors. Are we ready for them? Are we ready to flee from our comiortabie homes: ake reiuge in the mountains, or in some other desert place, and believe--do you have taith to believe--that He will deliver us in that day? He says He will if we have done His will.

(With tears in her voice) Oh. my dear iriends. I read in this guiding light that many who now proiess this taith. in that day of temptation are going to give up . . . give up--give up this blessed faith, give up this blessed hope. and not only that. Jut ium against their brethren. I can't bear to think of it! I love you. my people, I love you. everyone--I can't bear to think that the day might come. when you would turn against me. But, unless we love the truth and obev it. 've'll do it . . we'll do it. Isn't it an awful thought? I can't bear to think of it-it would crush me, if I did. I can only pray. "Lord. help me to he!p my brethren to tollow in the light that God has given :Is." 
The Seven Deaconst

The topic of the final Sabbath school lesson that was preserved on a tape recording was on the seven deacons in the book of Acts. When Mrs.

McKibbin taught this lesson, she was ninety-four years old. The outline appears to have been as follows:

I. Historical background--foundation of first Christian church

II. Growth of the early Christian church

III. First problem

A. Disciples too busy to preach and distribute food

B. Deacons selected

(1) number (seven)

(2) qualifications

(3) selection process

(4) definition of a deacon

IV. Modern-day application

A. Election of 40 deacons at Mountain View

B. Personal experiences with deacons and deaconesses

V. Closure--gratitude to deacons and deaconesses, and encouragement for them to continue their ministry

In this lesson Mrs. McKibbin began by providing a frame of reference

for the audience. She first discussed the final forty days Christ spent with the eleven disciples on earth, followed by Pentecost. She described the preparing of these men for the work of proclaiming the gospel to the world: "And so the leaders of the church were thus prepared for their work." She then rehearsed how that church grew:

There were twelve men to begin with on the day of Pentecost. It was forty days after Passover. They went out and baptized 3000 souls. Three thousand souls and 120 men make 3,120. After the healing of the lame man, 5000 more were added. That made 8000 members: 8000 avowed

\footnotetext{
All the quotations under the section header, "The Seven Deacons," are from McKibbin. "Sabbath School Lesson on the Seven Descons."
} 
Christians. Aiter Ananias and Sapphira and their terribie judgments, we read that the believers multiplied ewen more-even multitudes were added. We could sately say that there were 10.000 people in the tirst Christian church. Now our lesson begins.

After the introduction. Mrs. McKibbin provided a more immediate setting for the story of the seven deacons by declaring that all was not easy for the disciples. They were placed in prison. delivered, and put in prison again. The town leaders feared the reaction of the people it the disciples were put to death, so they gave them a scourging and sent them on their way. The disciples rejoiced to be ascounted worthy to surfer for Christ's name. "That was the spirit of the leaders of the rirst Christian church."

Mrs. Mckibbin referred to the first problem in the Christian church, which up to that time had been prospering, by citing poetry:

Now there was a rift in the lute That makes the music mute.

She brought out the problem inrough questioning: "Thev [the disciples] were busy doing what? Preaching the gospel. Then what did they suggest? Someone tell us." No one did, so she answered: because the disciples were busy preaching, ihey needed help with the distribution of food to the needy Christians. It was their plan to select a number of deacons to help with this work. She then asked.

How many men were selected" Seven. I wonder, why seven? I can't iell you--can you tell me?

The disciples called them together--i don t know how they did it. because there were so many--they !ust couldn': do both [preaching and distributing loodl and do it well. 
Mrs. Mckibbin then eliciled some pror learning and experience from

the audience:

A tew Sabbaths ago we elected ofiticers of the church. That tirst church had how many deacons? Seven. And it had 8,000 to 10,000 members. How many deacons did we elect? About 40; I counted them up. We should be well cared for. shouldn 't we? (audience laughter).

She proceeded to relate two personal experiences to iilustrate the work

of deacons and deaconesses:

You know, when I came here. nany years ago. they had a custom that I wish might be revived. The congregation was divided up into sections, and a deacon and a deaconess were appointed over each section. Now I discovered this in a very pleasanc way. while in a time of need, if you please. Hadn : been here very long, until I had a sick spell . . . seems to be my habit, and I was trying :o care for my aged tather at the same time. And you may believe that though I gor up and stumbled about, and got our meals, and so on. that it wasn t too well done. But one day as I lay down, while resting on the couch. my door sotily opened, and a sister stepped in, and she said. simply. "I am your deaconess. And I've come to do whatever you might need to have done. We understand that you are in poor health, and that you have your aged tather to care for. Now don't get up: just let me go about and see what needs to be done." She put my house in order-oh. I'll never forget her. Ind she was so very thorough. Often as I lie there on that same couch. I look across the room at the baseboards that she so carefully wiped and dusted. as well as the lloor and the drawers. A very careful housekeeper. and wial a beattiful thing she did for me. Then she went to my reirigerator and found it in a bad state. Twas nearly empty. But then mealtime came again. and I went to the retrigerator: 'twas in a very different condition. It was weil supplied. I knew she'd been busy in the kitchen. And then with a prayer for my restoration, she went away.

You know. I'd been here quite a long while, and I hadn't gotten acquainted. but now I iclt acquanted with the church! Through that one faithful deaconess. It changed the whole atmosphere for me: I had been remembered: I had been recognized as a member of this church. And so may it be. The ofiticers of the church--what are they for? To help us in times of need: for physical. but also spiritual--ihey were to help us in our spiritual needs. these deacons. And they do it--they do th. for me. And I'm very grateful. Oh. how wondertul hat God should recognize our needs. and put it in the hearts of wise men to provide us with these officers of the church. 
Then Alma McKibbin related another experience:

When I bought my little place, there was no fence around it. I won't tell you all that happened in my yard that shouldn't have--I wished I had some place where I could walk in the open air and feel alone, and not have all the neighbors know I was walking in the garden, and someone call to me, "Mrs. McKibbin, you've walked enough today. You're not strong enough to do so much walking. Go right back in the house and lie down!"

And one day--my brother had given me a ladder, a very light ladder-I'd climbed up one of the trees and gathered some fruit. Oh, a whole deputation came at once. "You get right down out of that tree!" Well, that was some of the kindness of my friends. But, you know, one morningFriday, came a big truck, and it deposited in my driveway a lot of lumber and stakes, and drove away. Well, there's always the question as to whom that belongs, whether to me or to the neighbors, so I thought, "Weil, that's for the neighbors." But on Sunday morning, before the sun was up, there was a group of deacons out there, and what were they doing? Cleaning away the old dead hedge that had passed for a guard and a division line, and put up a fence all around. And my garden, my backyard, was my own. I can walk there; I can do anything I wish to do, and it's such a relief somehow. Who instituted that? The good deacons. And constantly, through the years that I've lived here, I've been visited by deaconesses and many others, and time would never permit me to tell you all that has been done for me and for mine, since I have lived here. Oh, this ministry, this ministry of fellow believers; how precious it is. I thank the Lord for what He's done for me, and please continue it to everyone in the church. Let us all help one another, as Jesus taught.

\section{Teacher of Teachers}

When teaching teachers, several said Alma McKibbin advised instructors to "keep the lesson simple. The average person doesn't understand much of the lesson. Bring it down to his level. "I The average person's thinking, she said, was not much above fourteen years of age. She explained

:Robert Jacobs, interview. 
difficult portions of the texts, boiled down the lesson to four or five main points, and tried to simplify the lesson with an outline on the board.

As we have seen, another tool Mrs. McKibbin used to add color to the lesson was stories. One student commented, "She used graphic applications that were always relevant, and the church members never forgot them. ${ }^{\text {I }}$ When trying to illustrate the need for varying methods of discipline, Alma told the following story, as recalled by Althea Schneider:

Mrs. McKibbin was annoyed by an old tomcat in her yard. When she tried to scare him away with a sudden noise, he didn't mind; he'd move a little, sit down, and glare at her--just defiant and ornery. So, she got the garden hose and doused him good. She got his attention, and he retreated. Her point was that she had needed to use extreme discipline on him in order to get him to obey. ${ }^{2}$

Students of Alma McKibbin's teachers' class said that she used the blackboard extensively and often gave out handouts that were usually hand-drawn and hand-duplicated. Handouts might be a map, a list of the kings of Judah, the lesson outline, a poem, or the Ten Commandments. Students marveled at how much time it must have taken her to produce materials for them to use. "She valued peoples' time." ${ }^{3}$

At first Mrs. McKibbin taught an 8:30 class on Sabbath momings at the Mountain View church. Later. classes were added on Monday evenings for those who could not attend early Sabbath morning, and stiil later, on Tuesday

\footnotetext{
'Althea Schneider, interview.

:Tbid.

'Tbid.
} 
aftemoons, for those who found it difficult to get out in the evening. Any church members who desired to attend were welcome.' Some who came were mothers, and at least one teacher from the kindergarten attended "to learn more." 2

Class members felt that Alma McKibbin's life experience coordinated with her lessons; that is, she lived what she taugh:. They referred to her simple home, clothes, habits, and love for people. She also spent many hours studying the Bible in preparation for class. ${ }^{3}$

One person remembered that the "regular Sabbath school teachers mention[ed] in their classes some point that Mrs. McKibbin had brought out to them. ${ }^{n 4}$

Alma McKibbin's main objective for teachers was for them to win their unconverted students to devote their lives to God's service. ${ }^{s}$ To accomplish this, she believed it was necessary for teachers to interact with their students outside of class:

'Bertha Parmentier. 15 August 1975 Tms, in the hand of Bertha Parmentier, Deer Park. Calif.: Althea Schneider, Nampa, Idaho, notes to author, 11 March 1991. The class times referred to the 1960s. In the 1940s, Alma taught a teachers' meeting for the "junior teachers" on Monday evenings, and for the seniors on Sabbath mornings. See Alma E. McKibbin. Mountain View. Calif., to Fedalma Ragon, 5 July 1944.

:Alice Moore, telephone interview with author. 10 March 1991.

'Meikle, interview; Tobler, interview, 23 February 1991; Rober Jacobs, interview.

'Madge Nelson. Angwin. Calif., io author, 9 April 1990.

'Alma E. McKibbin. The Soul-Winning Teacher." Sabbath School Worker, November, 1918, 244-5. 
The surest way to gain the love and confidence of any one is to try to understand him. . . . Such an understanding cannot be obtained in the hour that teachers and pupils are together in the Sabbath school. It comes as a result of a cordial and intimate acquaintance while engaged in the busy activities of life. ${ }^{1}$

\section{Teacher and Tutor}

Although Alma McKibbin retired from full-time school teaching because of illness, and was sick for long periods throughout her retirement, she continued to teach Bible classes, but usually at home. She also substituted for a church school or academy teacher who might be ill for several weeks or a semester (as late as 1929), and she taught Bible in summer school for Mountain View Academy.

One student, Gladys Scharff Jones, believes she is the last student Mrs. McKibbin taught who received credit from Mountain View Academy for a Bible class.' When Gladys, age 15, approached Mrs. McKibbin in 1935 to ask her to teach her Old Testament history that summer for academy credit, Mrs.

McKibbin declined. In spite of her mother's warnings that "if you take from Mrs. McKibbin you'll have to dig in and work harder than for the other teachers." Gladys begged her to reconsider. Mrs. McKibbin relented, but

ilbid.

Eldene Childs, interview by author, 3 March 1991. St. Helena, Calif.; Leonard Hoyt, telephone interview by author, 14 January 1990: Gladys Jones, interview, 9 March 1991. Unfortunately, all records from the 1920 s and 1930s from Mountain View Academy registrar's office have been lost or destroyed. 
reluctantly. "I'm going to have to really push you." she warned Gladys, "and you will be my last summer-school sudent tor academy credit."

Class was he!d in Alma MlKibbin's home irom 8:30 A.M. to 1:00 P.M., with ten-minute breaks every hour. Alternoons were devoted to study and research. Gladys described her experience:

I had never learned "rescarch" irom orher teachers. No one had required this. Some people thought Mrs. Mckibbin overdid it, but I really leamed.

She dramatized the Bible characters with her mannerisms, enthusiasm, facial expression. and descriptive language. She was never at a loss for words. She modernized the Bible stontes. and added many details that she got from other sources.

Alma Mckibbin combined geography with Bible history. She asked Gladys to study a map: "Sudy the valleys. :owns, and rivers." Gladys said she had to memorize the maps and be able to iraw them. putting the cities in the right locations. She taught Gladys how to make a map look more protessional. They spent much time looking Bọ Bible !ocations on maps. Mrs. McKibbin urged Gladys to "go on doing this. or you'll lose $1 t . "$

Gladys learned to use Bible references. Mrs. McKibbin had many resources: Bible dictionaries, reference books, and also maps. many of which she had made herselt. She asked, "How arge was that tield? Well, we're going

\footnotetext{
Gladys Jones. intervew, March !oo!. Gladys expianed that her mother. Mrs. Schartf, was very well acumanted wh thma, aho took a sectal interest in the children. Their famly iived across the street from Alma : house n ?alo Alo Avenue in Mountan View. Calif. Because Alma was acquanted wh her. Glady : ielt that Alma pushed her more. Alma knew that Gladys was a good student.

-rbid.

Ibid.
} 
to look it up." The Bible did not give the answer. but when they found the information they needed in order to inier the size of the tield. Mrs. McKibbin pictured it in concrete terms: "That's [so many] city blocks." Apparently she did not require the quantity or depth of research of the other academy students that she did of Gladys, but only because of lack of time. Sometimes she spent a whole morning teaching Gladys how to use Bible dictionaries, Bible geographical aids, or biographies that would add detall to the Bible stories.

Alma Ifckibbin requred a lot of outside reading. When they studied David and Jonathan. Gladys recalled that her teacher advised her to read a biography about Jonathan.

The more Gladys accomplished. the more Mrs. McKibbin taught her. When Gladys responded, her teacher wanted to impart more. She gave Gladys encouragement: she liked her book reports and maps. Gladys worked as tast as she could all summer. having begun the day atter school ended, but did not finish before academy began in the ball. The wo continued on Sundays for two months into the school year. when Gladys completed the course.

Alma Mckibbin's prase was sparmg. She saved it for when Gladys had "really eamed" it. If Giadys was discouraged. Mrs. McKibbin offered her extra time and heip.

When Gladys became overured. she cold Mrs. McKibbin she needed a little break. Alma relented and iomed her student for some physical exercise, a 


\section{i6?}

walk outside, or in getting a drink of water. She remarked. "Anytime the sessions are too long, we'll just string it out during the school year."

"Oh," Gladys confessed. "I didn't want that!"!

There were many times when Gladys noticed that Mrs. McKibbin was sensitive to her moods and needs. Mrs. Mrckibbin once declared, "I know you're tired." She then interjected. "I'm going to tell you a tunny little story." They both laughed, and then started in again on "the heavy stuff."

Standards of work varled: Bible lessons were important: each one was to be outlined. Book reports. however, could be brief; books were "man's work." The Bible, however. was the authority.

Mrs. Mckibbin orten quizzed Gladys orally to train her listening ability and memory. Gladys learned to look tor details. The questions forced her to think: "Now, what kind of a man do you think Uzzah was? Short, tall? What do you think his character was like? Why did he touch the ark?"3 For every Bible character. Mrs. Mckibbin quizzed and encouraged her student to think by asking stimuiating questions until Gladys acquired the habit of asking those kinds of questions ior herselt. If Gladys couldn 't answer a question after

lbid.

Ibid.

Ibid. 
$\therefore 6$

an appropriate amount of time. Alma Mckiobin docked her grade and said. "Now you're not thinking: you didin': really study."

The inal exam consisted of three difierent questions conducted over three consecutive Sundays. Gladys had spent her evenıngs reviewing for those exams, for she did not know what kind of est Mrs. Mckibbin would give. Much memory work and recollection of detail were involved. Exams were three hours long, and the more Glady's :urote, the better. The tirst Sunday, she was to tell the story of Eliiah. She urote several pages. describing in detail Elijah's character, personality. and actions. The xecond Sunday, she was required to draw a map or Palestine tree iand. putting in as many details as she could remember. Gladys saved it. along with others. which she hung in her room at home:

When Gladys tinisined the course. Mountain View Academy was reluctant to give her credil. "Mrs. Mckibnin isn't on our statf." they announced. However, :hey shanged therr mnds : hen Gladvs described what she had done. She felt that "he school may have glven her credit because Mrs. McKibbin had denominatonal cerunication."

Alma Mckibbin collowed Giadys through life. She wrote her name in her Book of Remembrance as her one-thousandth student. When in later years

Ibid.

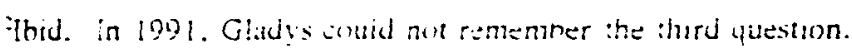

'bid. 
Gladys taught a Sabbath school class in the Mountain View Church, she was delighted to receive a letter from Alma, complimenting her:

It [your lesson study] was comprehensive and included many things that many do not know about his [Paul's] two imprisonments. . . . I am not the only one who appreciated your good lesson. Many have said to me, "I always enjoy S. School, but Gladys' lesson was best of all."

Gladys felt she learned more than "just Bible." She learned habits of research, carefuiness and accuracy that have stayed with her throughout life.?

Alma McKibbin continued to tutor students from time to time, but not as a rule. She wrote, "Occasionally a boy or a girl calls for a little help on some perplexing lesson, and I spend a happy hour helping him or her over the difficulty-and am very happy. ${ }^{3}$ She discovered that one twelve-year-old boy was having trouble with history because he did not know geography. She pulled down her maps and set about to change that situation. ${ }^{+}$

She also tutored slow students.' Shortly before she taught Gladys, she was employed to tutor a little girl in "numbers" at the girl's home. ${ }^{6}$ This student challenged her teaching ability:

'Alma E. McKibbin, Mountain View, Calif., to Gladys Jones, Mountain View. Calif., 2 April 1968, in the hand of Gladys Jones, Middleton, Idaho.

'Tbid.

${ }^{3}$ Alma E. McKibbin. Mountain View. Calif.. to Fedalma Ragon, 25 March 1953. Adventist Heritage Center. Loma Linda University, Loma Linda. Calif.

Tobler, interview, 7 March 1991.

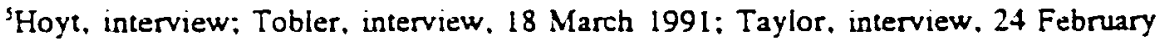
1991. I. 134.

"McKibbin, What We Miss When We Are Not Members of the Sabbath School-Part 
She had no great liking for mathematical problems, but we got on fairly well in addition. . Sut when se came to subtraction, that was quite a different matter. To subtract 2 apples irom 3 apples and leave only 1 , or to take 2 dolls irom Z dolls and leave none at all was all wrong; it was not tair, and she would have none of such nonsense. Subtraction was not necessary, and her itule bram closed up tight as a clamshell, and rerused to receive the idea.

Atter vainly irying for severa days by all the methods I knew to get her to see that orten in real lite us must give up. subtract, diminish, decrease, or take away some things from our possessions, I came at length to realize that subtraction is really an abnormal process. It belongs to a world gone wrong.

One afternoon as I was on the way to her home. I caught a grasshopper and put him in a box. . . tor while Leta had no use for subtraction, she was passionately cond oi bugs. . . I showed her the box, and told her there was something wonderrully interesting in it.

"Is it alive?"

"Yes, it is alive. and a an !ump arther than you can."

She did not believe that. Jut her merest was at white heat. She wanted to see it immediately. Yo. sine must walt till we had the number lesson. She really tred that day to think subtraction, but she did not and could not. Finally I said. "Now you have tone your best. and we will let the hopper out of his box. Jut you must be quick and catch him because he can jump."

Oh. the breathless interest as we cautrously opened that box. She held her little hands close to cath him as he should emerge, but he was too quick for her. and made a tremendous jump from the box to somewhere in that room.--where, we newer inew. hough we searched and searched. . . When she was convinced that the grasshopper was really gone, and could not be tound. she stood in the madde of the thoo and with a tragic gesture expressed this very sad problem and result:

"I hopper: take away i hopper 'aves no hopper at all."

I had no rurther dificulty in caching subtraction. She never enjoyed the process. but she accented it as a part of learning and of life. Subtraction had entered her consciousness.

When in her anewes. Vma Mckibbin apparenty still tutored students who had trouble with school work.

\section{Ibid.}

Tobler, interiew. Z: Fonruar: :mi: Cori Inderoon. interiew. 
Mrs. McKibbin enjoyed teaching Bible classes throughout her

retirement years. In the late 1920 s or early 1930 s when her young niece came to visit, she taught her Bible lessons every day out in the backyard, under the fig tree, as reiated by the niece:

My folks had a big social life, and so I had often had to stay with someone. Aunt Aima made the Bible interesting. She drew maps, and traced where Jesus and His disciples went. She also made copies of maps on [hectograph] paper with a purple jelly. I liked the attention she gave me. ${ }^{1}$

In 1951 Mrs. McKibbin taught a baptismal class for the fifth and sixth grades at Miramonte Seventh-day Adventist Church School in Mountain View,

Califomia.: One of these students later described Alma McKibbin:

She was dressed old-fashioned for those days. She wore high-top shoes and long black dresses, and some of the girls saw little old ladies in black dresses as negative. Yet, we all grew to love and appreciate her because of her warmth and love.

She came in that day very matter-of-factly, introduced herself and wanted to know who everybody was. She put us at ease immediately. She made us feel she was always interested in us. She accepted kids.

Her method was to put everything in very simple language. She spoke confidently, with no hesitation, and was easy to understand. She chose spiritual topics that she made down to earth and homey. She was dramatic, although it was probably unconscious. She would incorporate little pauses into her stories. ${ }^{3}$

Janet Taylor, interview. 24 February 1991 . These visits were likely in the late 1920 s and eariy 1930s.

'Strachan. interview: Dierdre Maxwell, interview, + Marci 1991: Sylvia Ward Henderson, interview by author. 11 March 1991. Nampa, Idaho.

'Dierdre Maxwell, interview, \& March 1991. Alma did wear long black dresses that were out of step with current fashion but resembled what women of ber age had worn in earlier docades. Beulah Simms occasionally bought her a dress. and Mrs. Lucille llchuk sewed her a new one when she needed it. 
None of the girls in the baptismal class could remember what Alma McKibbin taught, but they remembered her as a gentle, kind, cheerful lady. One of the girls, who graduated from academy seven years later, recalled that Alma remembered her graduation with a gift, a small volume about Albert Schweitzer.'

In the 1950s, several Pathfinder leaders were studying to become Master Guides ${ }^{2}$ and needed their certification for denominational history in order to complete the requirements. Alma McKibbin taught classes twice a week to enable these youth leaders to pass the conference exams in denominational history. ${ }^{3}$

For many years, Mrs. McKibbin taught Bible to adults in her home. Many of her students needed help learning the doctrines of the Seventh-day Adventist Church, or knew little Bible historical background. Others came just because they were interested. This second group felt Mrs. McKibbin "opened new windows so they could see better. Her spiritual approach and experiences

\footnotetext{
'Strachan, interview.

"See Glossary under "Pathfinder" and "Master Guide."

'Philip Gray, telephone interview by author, 6 February 1991: Clifford Russell, Concrete, Wash.. to author, 7 February 1991.

${ }^{4}$ Francis White, interview by author, 25 February 1991. Yountville, Calif.; Paul Ricchiuti, interview by author, 10 March 1991. Nampa, Idaho: Leonard Hoyt, interview; Ray Kixson, interriew: Alma E. McKibbin. Mountain View. Calif.. to Fedalma Ragon, 13 November 1960: idem to Ragon. 5 July 1944.
} 
drew them closer to God." She asked her students to bring their Bibles and expected class participation. Although she did not have much participation in her large Sabbath school classes, she intended for people in these smaller Bible study groups to demonstrate their thinking by participating. She answered questions in due time, but not until the students had done some thinking. "She prodded us." 2

For two students who had little Bible background, Mrs. McKibbin used her Old Testament history book for the ninth grade, 1927 edition. $^{3}$ One of these students in paricular took extensive notes, and another filled in several outline maps in fine detail. A study of these notes and maps reveals the kinds of methods Alma McKibbin used in her Bible teaching:

1. Use of prior leaming. On a lesson about God's law, Mrs.

McKibbin related the law to the writing of the United States Constitution:

Our Constitution is the Will of the men who made it. When they prayed. they were able to agree [on its principles], but not before. Ben Franklin was 81 when the Constitution was drawn up. He told them [the writers] to pray.

'Ray Hixson, interview: Franze Edmond Cox, telephone interview by author. 27 November 1990.

itbid.

${ }^{3}$ McKibbin, A Manual of Lessons in Old Testamens History for Academic Grades. Mary Gray, interview by author, 21 February 1991, Santa Clara, Calif.: Philip Gray, interview.

"Mary Gray, notes, [1953] AMs, in the hand of Mary Gray, Santa Clara. Calif. 
2. Emphasis on Bible reading. Mary, Alma McKibbin's student, had written in her notes, "Write out every text. Be sure to understand texts. "

3. Encouragement of affective domain in learning. Mary remembered pleasant surroundings and fellowship: Mrs. McKibbin's old piano, the handmade tatted doilies on the furniture, the singing of a hymn (Mary played the accompaniment), and the cookies and punch after the study. ${ }^{2}$

4. Homework. Students were to write out the answers to all questions. Assignments included readings in the Spirit of Prophecy. ${ }^{3}$

5. Integrating Bible geography with Bible history. Mrs. McKibbin used Hurlbut's Bible Atlas from which to copy outline maps. Phil and Mary carefully filled in several maps, on the average of one per week, that (a) described the peopling of the earth, (b) the settling of the twelve tribes, (c) Israel's neighboring nations, (d) Abraham's world, and (e) many other elements of Bible history. ${ }^{5}$ As Phil and Mary studied various rulers and heads of state who had contact with the Israelites, they learned both the biblical names and titles, and those from secular history.

\footnotetext{
Ibid.

:Mary Gray, interview.

"Mary Gray, notes.

'Jesse Lyman Hurlbut. A Bible Atlas: A Manual of Biblical Geography and History (Rand McNally \& Company, 1928).

'Philip Gray, interview: Phil Gray, maps of California counties [1953], in the hand of Phil Gray, Santa Clara. Calif.
} 
6. Concrete illustrations. When describing Lucifer as an angel of light, Mary wrote a description of the seven bands of color that appear when light is passed through a three-sided prism. She explained, "Light is composed of color."1

7. Research to add details to Bible stories. In the lesson about the building of the ark and the Flood, Mary noted that Noah had put all his fortune into the building of the ark. She aiso recorded the height of the Flood's waters, the length of time Noah and his family were in the ark, and the kind of wood of which the ark was constructed.

8. Explanations of difficult Bible passages.

9. Use of constructs, organizers, overviews, charts, and diagrams.

10. Memory work. Mary wrote, "Study page 44 carefully. Try to memorize the people who came from the sons of Noah."

11. Use of Bible references and other resources. In the margin of her notes on the lesson about the Tower of Babel, Mary recorded, Empires of the Bible, A. T. Jones.' She placed his name next to information about the earth's tirst monarchy, started by Nimrod. ${ }^{3}$

12. Emphasis on the lessons the Bible stories taught.

'Mary Gray, notes.

:Jones, The Empires of the Bible.

'Mary Gray, notes. 
13. Demonstration of "threads," or patterns, in the stories. In lessons tifteen through twenty-three, on three different occasions Alma pointed out Abraham's lack of faith. She then asked why Abraham was called the friend of God and the father of faith. The answer was found in the lesson twenty-four, in which Abraham was willing to sacrifice his only son. However, though Abraham apparently leamed the lesson of trust in God, his son Isaac aped his father's lack of faith when he lied to the King of Philistia that his wife was his sister. The thread of lack of trust in God passed to son Jacob, and to his sons, as noted in Mary's notes of subsequent lessons.

Phil and Mary described Alma McKibbin's methods:

Mrs. McKibbin made the Bible stories so interesting, partly by bringing experiences that she'd had. She was happy to answer questions, and we were rewarded for asking them by getting her undivided attention. Everything would stop while she answered your question. Your question was worthy; it was important; she was happy to answer it. It was very important to her that you learned.

She was patient, not rushed: she didn't cut you off when you were talking. She welcomed comments; she enjoyed them. If someone asked a question off the subject, she would still try to answer it.

She asked questions that forced you to think, such as, "Why did the Lord put David through all this experience?"!

Phil listed the following reasons why Mrs. McKibbin made it easy to learn Bible history:2

1. She was interested in her subject.

2. She believed and had confidence in "the Word."

\footnotetext{
:Philip Gray, interview.

The following points are from Philip Gray, interview. 21 February 1991.
} 
3. She reiniorced iaith in the Bible.

4. She was a happy, positive person.

5. She had lived an exemplary iite.

6. She shared her own temptations: sine was human.

7. She was a good storyteller.

8. Her enthusiasm inspired students interest.

9. Geography olended with history made the Bible relevant and fun.

10. She customized the stories to make them practical and relevant.

11. Her lists and diagrams bolled down history and made it clear.

Alma Mckibbin stopped this particular series of lessons betore they were completed. likely duc to ill health (Phil could not remember the reason for sure). She did not forget Phil and Mary, however. In 1970, when Phil had his right kidney removed, he recelved a ard from her.

Alma McKibbin worked with a Bible instructor at the Mountain View church from 1961 to $196 t$. When the instructor same to the study on the Spirit of Prophecy, she and her students would tirst study that topic from the Bible itself, and then she would ask Mrs. Mckibbin to accompany her to share experiences and answer questions about Mrs. Ellen G. White.'

It is uncertain just when Mrs. Mckibbin ceased having Bible classes in her home. She wrote as iaie as if July : 966 . "I still :ach the Bible to those

!bid.

Myrale James, :elerhone intervew ns uthor. :? Vosember 1990. 
who come to me and seem to remember the Word of God very well." When Jim Nix interviewed her in August 1967, she told him the doctors had asked her to give up teaching to allow her throat condition to heal.'

\section{Author of Books and Articles}

During her retirement years, Alma McKibbin did much writing for church periodicals, and two of her series were published as books.' Several of her articles were reprinted in later publications. She wrote over cne hundred articles, beginning in 1900 for the Sabbath School Worker ${ }^{3}$ and ending in 1971 with a reprint in the Review and Herald." She wrote her last article in 1968." Much of her writing was done for the Sabbath School Worker on the subjects of how to teach Bible, how to lead Sabbath school, and how to win souls through the Sabbath school. Occasionally she wrote about what the Sabbath school meant to her, repeating personal experiences. ${ }^{6}$ She also wrote,

\footnotetext{
${ }^{1}$ Alma E. McKibbin, Mountain View, Calif., to Brother Kozel. 14 July 1966.; James Nix, telephone interview by author. 9 January 1990; Nix, interview 12 March 1991; Alma E. McKibbin. Mountain View, Calif., to James Barnard. Bakersfield, Calif., \& September 1967, in the hand of James Nix, Loma Linda, Califoraia.

:Step by Step, her autobiography, was originally published in the Review and Herald as a series of twelve articles in 1962 (See appendix and bibliography). Half Hours with the Bible was originally published in the Signs of the Times in 1945, over a period of forty-ight weeks (see Bibliography).

3.

McKiboin. "What May Reasonably Be Expected of Officers and Teachers." Parts 1 -

\author{
'McKibbin, "An Understanding Heart." \\ 'McKibbin. "Alma McKibbin Remembers."
}

'See Alma McKibbin's Bibliography under Periodicals.
} 
in two series, about her acquaintance with Ellen White. ${ }^{1}$ In 1945, after World War II, the editors of the Signs of the Times requested her to write a series of short weekly Bible studies on doctrinal and devotional topics for the year. H. M. S. Richards, Sr., of the Voice of Prophecy radio broadcast asked Mrs. McKibbin's permission to publish those studies in book form to give to Bible correspondents. Later, they were published by the Pacific Press under the title, Half Hours with the Bible.

Alma McKibbin wrote for church educational journals on how to teach Bible to children. Some of her material from early teachers' manuals was reprinted in Joumal of True Education. ${ }^{3}$

Louis Schutter, for many years editor of the Our Little Friend and Primary Treasure, asserted that Mrs. McKibbin wrote articles for the Our Little Friend when Emest Lloyd was editor from approximately 1921 to 1946. Schutter was editor from 1963 to 1985 and reprinted some of her articles in Our

\footnotetext{
McKibbin. "Sister White Was My Friend." Parts 1 and 2; idem. 'My Memones of Ellen White," Parts 1-3.

Alma E. McKibbin. Half Hours with the Bible (Mountain View, Calif.: Pacific Press Publishing Association, 1946), Adventist Heritage Center, Pacific Union College, Angwin. Calif. Alma considered this to be her most popular book. See idem, interview, 25 March 1959. Ama wrote to a friend that the Bible studies in this book were "only revisions of lessons I wrote long ago for the eighth grade. but which for a long time have been out of print. I am adding other subjects occasionally." See idem. Mountain View, Calif., to Fedalma Ragon, 29 January 1945 .
}

"McKibbin, "How to Teach the Bible;" idem. "A Story of the Origin of Bible Lessons for the Church Schools." A complete listing of her articles and books can be found in the first subsection of the bibliography of this dissertation. called Bibliography of Alma E. McKibbin. 
Little Friend.' He felt her literary, teaching, and lecturing abilities were outstanding. :

In later years, Mrs. McKibbin was called on to write the history of the church schools, as well as the history of the Mountain View Church. ${ }^{3}$

One booklet, Outline Studies for Patriarchs and Prophets, was temporarily misplaced at the Ellen White Research Center. It is presumed that she wrote it for one of her home study groups. ${ }^{*}$

\section{Public Speaker}

Alma McKibbin did a lot of public speaking during her retirement years. Much of her speaking was done in Mountain View, in connection with church-sponsored activities, and often to the young people at the Mountain View Academy." She was asked to give a series of three lectures about Eilen White

:To date, the author has not undertaken a careful search for those articles. Jean Stafford also asserted that Alma wrote stories for the Little Friend. See Jean Stafford, telephone interview by author. 12 May 1991.

'Louis Scbutter, telephone interview by author, 21 May 1991. Richard Utt said that Mrs. McKibbin's manuscripts sent to the Press needed very little editing, according to past Pacific Press book editor. Dr. Richard Lewis. See Richard Utt. telephone interview by author, 4 December 1990.

"Alma E. McKibbin, "History of Our Church," article in first Church Pictorial, Mountain View SDA Church, Mountain View. Calif., 1963; idem to Young, 6 February 1966.

4Alma E. McKibbin, Outline Studies on Parriarchs and Prophets (Washington, D.C.: Review and Herald Publishing Association, n.d.), Ellen G. White Research Center, Document File \#967, Andrews University, Berrien Springs, Mich.

'Ahlkvist, interview: Utt, interview, 4 December, 1991; Elna Quade, interview: Ama E. McKibbin. "The Understanding Heart." Talk given to the Young People's Society, Mọuntain View, Calif.. I February 1963. Tape recording. In the hand of Paul Ricchiuti. Nampa. Idaho. 
at the Mountain View church for prayer meeting. Paul Ricchiuti described Alma as a speaker:

On the nights she spoke, every seat in the criurch was filled. People brought their children to the meetings because for many this would be the only time they would ever see or hear a pioneer of the early Adventist church.

When she stood to speak, a hush would fall over her audiences, and they remained that way until she finished.'

Perhaps the greatest reason Alma McKibbin was asked to speak for various gatherings was her knowledge of denominational history:

History is my favorite subject. I seem to remember it better than most other things, so while I was still able to attend Teachers' Institutes, I was often asked to relate how I came to teach church school. ${ }^{2}$

Mrs. McKibbin was asked to speak on Founders' Day at Pacific Union College several times, including the seventy-fifth anniversary of that institution. ${ }^{3}$ On that particular occasion, she feared she would offend some: "The principles I expressed are so contrary to those now taught and practiced, I feared they would not be well received."

She spoke about denominational history in varied settings: (1) at a chapel program at the Pacific Press that commemorated the ninetieth anniversary of the Signs of the Times, in which she told about her experience as a two-year-

'Paul B. Ricchiuti, 'Alma Remembers." chapter in End-of-ihe-World-Man and Other Siories (Hagerstown, Md.: Review and Herald Publishing Association, 1989), 67.

McKibbin to Young, 6 February 1966.

"- Commemorating the Founding of Pacific Union College at Healdsburg in 1882," program notes. Pacific Union College Day, 30 March 1957. Angwin. Calif.: McKibbin. 'Founders' Day Address:" idem. "Reminiscences:" idem. "Unchanging Values."

'Alma E. McKibbin. Mountain View, Calif., to Fedalma Ragon, 14 June 1954. 
old at the Yountville camp meeting, and (2) at the one hundredth anniversary of the Seventh-day Adventist Sabbath school, when she spoke on the "Early Beginnings of the Sabbath School in Califomia" at the Mountain View church.'

Educational administrators invited Mrs. McKibbin to teachers' conventions in various cities in Califomia and elsewhere. Their purpose was to acquaint the teachers with the history of the educational work. They felt she inspired them to do their best for the children. "She was the first teacher. She set the pattem," one administrator explained. "She gave [our teachers] a picture of what it meant to be a Christian teacher."2

The academies in the 1950 s and 1960 s also enjoyed naving Alma McKibbin speak to their future teachers' clubs in order to recruit and inspire future teachers. ${ }^{3}$ She spoke at chapels regarding opportunities for young people to enter the teaching profession. One of these talks was labeled, "Why We Have Church Schools." ${ }^{-1}$ Mrs. McKibbin wrote regarding this address,

:Our Cover," Impression 5. no. 4 (July-August 1964): 1: This was a bi-monthly publication of the Pacific Press Publishing Association, now located in Nampa, Idaho; "The One Hundredth Anniversary of the Sabbath School, 1852-1952," program notes, 26-27 September 1952. Mountain View SDA Church, Mountain View, Calif.

'These teachers' conventions occurred from the 1940s to the 1960s. Else Nelson, interview, 18 March 1991; idem, telephone interview by author, 9 January 1990; Axel Nelson. interview: Madge Haines Nelson, telephone interview by author, 9 January 1990: Dr. Thomas Geraty, telephone interview by author, 14 January 1990.

'Else Nelson, interview, 9 January 1990; Alma E. McKibbin, Mountain View, Calif.. Christmas letter, December 1961 in the hand of Bertha Parmentier, Deer Park. Calif.: idem. Mountain View, Calif., to Bertha Parmentier. Mountain View, Calif., in the hand of Bertha Parmentier, Deer Park. Calif. [February 1961]; idem, Mountain View, Calif.. to Fedalma Ragon, I5 March 1961. Adventist Heritage Center. Loma Linda University, Loma Linda. Calif.

'McKibbin. Christmas letter. December, 1961. 


\section{$\therefore 9$}

Nothing gives me greater pleasure than to review how "God has led us in the past" and to encourage our young people to become teachers. All classes of workers are needed. but ieachers most of all.'

At one point. she was able to sneak at three different locations within a short period, requiring her to travel by plane. Coming back from Teacher Promotion Day at Lynwood Academy. she was very tired and slept peacefully on the plane. When the plane landed, the lady behind her spoke up.

"Pardon me." she said. "but! must lell you how much you have helped me today. I am very nervous and atraid on a plane. I was about to cry. Then I looked at you. Asleep and a calm, peacetul look on your face, and I said, "Here is an old lady traveling alone and she is not afraid. How calm and peacerill she looks. and you gave me courage and I enjoyed the rest of the trip. Let me carry your bag. But tell me, please, why the beautiful corsage?"

"A token of apprecration for in old school teacher." I replied. "I taught my tirst school near the Lynwood Academy, and gave a little talk to encourage young people to become ieachers. The corsage was my reward." So I learned we may help another even when we are asleep! ${ }^{2}$

An educational administrator. who accompanied Mrs. McKibbin on approximately twenty-two speaking engagements. explained that her visits to the future teacher clubs contirmed their inportance. This educator commented,

At academy atter academy. I saw the way those students tlocked around her after her talks. wanung iner autograph. . . D During her talk I saw them, watching. listenıng. chuckling. applauding when she was through.

Alma Mckibbin orten spoke so young people. For a chapel talk at

Pacific Union College, she discussed the sopic of determination. A piano student

Ibid.

Mckibhin to Ragon. 15 Marih $196 \%$

Else lelson. Interier. is Mlarin ingl. 
who had been practicing daily to learn Mendelssohn's Concerto in G minor was inspired by this talk. She wrote notes in her Mendelssohn book, which had been in her lap. "I have to be determined to get this concerto," she resolved. She was so inspired that soon she played the first movement from memory at a chapel service. Years later, she still remembered Mrs. McKibbin's conclusion, using the words of a soldier:

Ours is not to question why, Ours is but to do or die.'

Alma McKibbin also spoke often to the young people at Mountain View Academy, not just for their religious services, but also during classes. One pastor who taught Old and New Testament classes invited her to come in once a year for both of these classes during the years 1957 to 1964. The students enjoyed her visits. ${ }^{2}$

Church school teachers asked Mrs. McKibbin to talk at Junior Missionary Volunteer meetings in the 1950s. ${ }^{3}$ Long afterward, Robie Hightower reported:

'Ruth Schutter, telephone interview by author, 29 March 1991. The lines of the poem are from Alfred Lord Tennyson's "Charge of the Light Brigade."

Zennart Ahlkvist, Coulterville, Calif., to author, 5 May 1990; idem, interview by author, 2 March 1991, Angwin, Calif.; Richard Utt, telephone interview by author, 12 March 1991. Loma Linda, Calif.; Strachan, interview; Dick Stafford, telephone interview by author, 10 March 1991. Nampa, Idaho.

'Robie Hightower, telephone interview by author, + March 1991. Angwin. Calif.: Alma also spoke in June Eihler's room at the Miramonte Church School. Mountain View, Calif. See Alma E. McKibbin, Mountain View, Calif., to Fedalma Ragon, [1940?]. Adventist Heritage Center, Loma Linda University, Loma Linda, Calif. 
Mrs. McKibbin came several times. She usually chose a Bible story or character. The children listened carefully; she kept their interest. She was calm and never got ruffled or excited. There was a serenity about her; she never raised her voice. Her quiet manner had a calming influence on the children.'

Camp meetings, church services, chapels at the Pacific Press, and

conference workers' meetings were other occasions at which Alma McKibbin

spoke. ${ }^{2}$ Richard Utt remembered when Mrs. McKibbin made a speech at a

church business meeting in which members were discussing tearing down the old

Mountain View Church after it was replaced by the new one:

She felt that it would be unthinkable in rebuilding a new [church] to destroy the old one. It was a sacred place; pioneers spoke here. She felt the brethren should leave the church for those who would like to attend. She went along with the brethren when they decided to build a new church, but not to tear the old one down. She spoke out with conviction, but never a suggestion of rancor or sarcasm. She was such a good speaker that all she needed to do was say clearly and simply what was on her mind, and sit down. Her words had plenty of weight without tearing or cutting down. She knew that, too. ${ }^{3}$

On yet another occasion, Alma gave an acceptance speech at the dedication of McKibbin Hall, the preparatory school building at Pacific Union College, in 1941. She asked the prayers of everyone there. Richard Utt quoted her as saying,

\footnotetext{
'Hightower. interview.

Eleanor Rowland, telephone interview by author, 24 January 1991: Stirling. interview; Bertha Parmentier, notes of Alma E. McKibbin's address on Christian dress at the California Conference Workers' Meeting, November 5, 1962. longer there.

'Utt. unterview, 12 March 1991. The old Bailey Avenue Mouniain View church is no
} 
We think only the young people have temptations, but also the older ones. I want to be preserved from the temptations older people have--from bittemess, and from being demanding.'

\section{Counselor and Mentor}

Through the years, many people sought advice or counsel from Mrs. McKibbin. Since she spoke her mind on issues as they came up in church meetings, and since she also took an active role speaking, writing, and teaching in the church, the people she influenced came to consider her as a mother figure, a leader in spiritual affairs. Her past acquaintance with Ellen White also elevated her influence, and several felt that she resembled the prophet in manner and in dress. ${ }^{2}$ Others sensed her importance as a pioneer in the Adventist church. She came to be revered by many. ${ }^{3}$

Still others appreciated her care and sense of guardianship over them. whether they were former students or friends. When Mrs. McKibbin took the responsibility of being a deaconess at the Mountain View church, she took her duties seriously. In 1960 at age 87 , she visited each family in her jurisdiction to

Tbid.

:Hightower, interview; Ivan Jones, interview; Carl Anderson, interview; Emily Hixson, interview; Childs, interview; Rogers, interview; Muir, interview; Tobler, interview. 7 March 1991.

'Larkin, interview: Rittenhouse, interview; Louis Venden, telephone interview by author. 5 March 1991. Angwin, Calif.: Ham. interview: Bertha Parmentier. Mountain View, Calif., to Alonzo Baker. Riverside. Calif.. 15 August 1975. 
see whether there was anything she could do for them. She had no car, so she either walked or secured rides to see them. ${ }^{1}$

Although she made no claims to be a professional counselor, Alma McKibbin was interested in people and listened to them. If she felt it was necessary, she spoke plainly what she felt their duty to be; if she did not know, she would clearly say so. Many people went to her for her good sense, and came away feeling she was wise. ${ }^{2}$ For example, one woman wondered if she should move to a certain country location in order to offer her boys the advantages of a more simple, practical life than they were living in Mountain View. Mrs. McKibbin encouraged her to continue teaching her boys at home, but added:

I cannot say whether you should go to [a certain area] or not, but I am praying as you requested that this will be made plain to you. [God] has promised to guide and $\mathrm{He}$ will not fail you. ${ }^{3}$

Several people said that many individuals "beat a path to her door. ${ }^{n 4}$ Her sister-in-law said she was "counselor three-fourths time." Gladys Jones remarked, "She didn't have a telephone, but she always had a stream of

'Tobler, interview; Meikle, interview.

'Stirling, interview.

'Alma E. McKibbin. Mountain View, Calif., to Maryan Stirling, Mountain View, Calif., 13 December 1959, in the hand of Maryan Stirling, San Josinto, Calif.

'Tbid., Janet Taylor, telephone interview by author. 13 September 1990; Edith Meikle, Los Gatos, Calif., to author. 6 May 1990: James, interview.

'Eleanor Baker, interview. 
visitors." ${ }^{1}$ Gladys also mentioned that Mrs. McKibbin had had to give up all her morning counseling appointments in order to teach her, changing them to the afternoons. Evenings were for Sabbath school teachers' classes, making the teacher's day a full one.

Alma McKibbin counseled new Adventists with whom she was studying biblical doctrines. ${ }^{2}$ She also advised pastors and administrators. ${ }^{3}$ Apparently President Irwin counseled with Mrs. McKibbin about getting Pacific Union College accredited. In the 1920s, accreditation was a debated issue in the church. Mrs. McKibbin evidently told President Irwin that if the leadership had been following the Spirit of Prophecy counsel, they wouldn't need accreditation. The problems they were having with students were from not following the counsel given. One observer commented, "She would speak her mind if asked. ${ }^{n t}$ One pastor used to say that if Alma McKibbin shook her head "No," while he was speaking in the church, he would have to schedule a pastoral visit, because he knew he had done something wrong. ${ }^{5}$

\footnotetext{
Gladys Jones, interview, 13 September 1990.

¿Cox, interview: Elizabeth Marshall, interview by author, 10 March 1991, Nampa, Idaho.

'Pastor Robert Moon. Sr., telephone interview by author, 29 January 1991: Venden. interview: James, interview.

"Martella, interview.

STames Nix. Director of Adventist Heritage Center. Loma Linda University, Loma Linda. Calif., telephone interview by author, 22 January 1990. Berrien Springs, Mich. The pastor was Elder Louis Venden.
} 
Mrs. McKibbin criticized a well-known church author for his artist's depiction of Adam and Eve in the garden of Eden without their garments of light. ${ }^{1}$

One young man who attended Pacific Union College in the 1940s became acquainted with Mrs. McKibbin through his girlfriend in Mountain View, who lived across the street from her. He described his discussions of the latest theological issues with her:

My youthful exuberance was often brought down by her sage comments. When I was taking biological science, I discussed with her a statement by Ellen White that mothers were birthmarking their children by their attitudes while carrying the baby. There was no evidence in science that supported such a premise. Mrs. McKibbin wasn't worried by the biological issues I was considering, even though these issues tended to disprove what Mrs. White said. There was no nervous connection between the mother and child, and I thought the possibilities for a mother to so influence her baby before birth were quite remote. Of course, science has since proved there is such a connection through the hormonal system. ${ }^{2}$

This young man was influenced by these discussions:

[Mrs. McKibbin] was old, but youthful. It was a privilege to talk with someone with her background and wisdom. There was often opposition between us--it was more over the authority of a prophetic figure. We were really discussing the nature of inspiration. Through these numerous visits, she provided a sense of security and confidence in Ellen White's writings--it was okay with her if they couldn't be explained. Her influence was subliminal. I was questioning; she was very wise. She was tolerant, honest, decent, and treated me with open respect. She was delighted for me to bring up the next issue. She provided a sounding board for my own

'The author was Arthur S. Maxwell, in The Bible Story, vol. 1 (Washington. D.C.: Review and Herald Publishing Association, 1954), as told by Loma Tobler, interview, 23 February 1991.

:Provonsha, interview. 
questioning. To have her take a stance as she did allowed me to postpone having a rational answer. ${ }^{1}$

Many young people wanted Mrs. McKibbin's counsel. Several confided in her not only because they needed help, but because sometimes they needed an understanding heart. People heard her say, "Some people think that children don't have troubles or problems, but I know better. ${ }^{22}$ In 1955 or 1956 , Mrs. McKibbin had been giving the Week of Prayer meetings in Mrs. June Eihler's room at the Miramonte Seventh-day Adventist Church School. Shortly after these meetings ended, a young boy saw her coming out of the little store across the street from the academy. He pedaled over to her on his bike, screeched to a halt, jumped off his bike, and ran up to her. Maryan Stirling related what happened:

Faltering, his voice small and full of pain, he cried, "Mrs. McKibbin, I've got an awful problem!"

"Tell me about your problem, my dear," she said.

"Well, my mother and dad are going to--they're getting divorced. And I don't know-I don't know what's going to happen to me."

Before she could say anything more, a woman took her arm and demanded her attention. She was only talking to a "kid" on a bike. It couldn't be important.

When the boy realized an older lady wanted to talk to Mrs. McKibbin, he was back on his bike and gone before she could stop him. She didn't know who he was. She longed for another chance to interact with him. I don't know if she ever found him. ${ }^{3}$

One young woman, about eighteen years old, had attempted suicide and gone to Mrs. McKibbin for help. An ambulance was called from a

irbid.

Maryan Stirling, telephone interview by author. 17 November 1990.

'Stirling, interview. 
neighbor's phone, and after the girl retumed from the hospital, Mrs. McKibbin

encouraged her in the following way:

She had me lie down on her day bed by the window and covered me up. Then she looked me right in the eyes as she sat in her rocker and asked me, "Don't you remember how you loved Jesus when you were a little girl?"

I'll never forget her light blue eyes as they looked into mine-questioningly.

How I crumpled into tears as I thought back to the happiness I had known. . . . Of course I remembered, but somehow I had forgotten . . .

Because I knelt with her and asked God to forgive me and I started over again on the narrow path, the only path that leads to heaven, I am what and who I am today. ...

She didn't allow me to go back to my home ... despondent or discouraged, but started me back on the path to heaven right there with her in her home. . . . She took the time to help me admit my love for [Jesus], and that $\mathrm{He}$ is the only One worth living for day by day. . . .

Mrs. McKibbin had a great influence on me, because she loved me. She showed me she did by giving me her time, her friendship, and, most importantly, of herself. . . . She opened her home to me and always found time to listen to me. . . . She didn't let me keep to myself, but usually wanted my company. She kept our channels of communication open. . . . I promised her that one day I'd meet her in heaven, and I surely don't want to disappoint her.'

\section{Student Contacts}

Alma McKibbin followed her students throughout their lives. As we have mentioned before, she kept a Book of Remembrance in which she inscribed students' names, dates, and little anecdotes. She remarked,

That way I kept a vision in my mind of the boys and girls, and had their names. Children change wonderfully, and this way I'd still know them when they grew up.'

\footnotetext{
:Anonymous to author.

:Alma E. McKibbin, interview by Eric Kreye, 29 November 1970, tape recording in the hand of Paul Ricchiuti, Nampa, Idaho.
} 
She once wrote to a friend, "Of late I have been almost overwhelmed by callers, especially old students." ${ }^{\prime}$ She then described her reunion with a student of long ago:

One rang my door bell. There she stood, white hair, but with the same deep blue eyes that looked into mine 53 years ago. She said, "I am Evangeline Hyatt. Of course you do not remember me, but I can never forget you, " and she wept in my arms. I showed her her name in my Book of Remembrance with about 1,300 others.

"You have kept our names!"

"Yes, I have kept your names in my book and you in my heart." And she wept again.

Life is sweet to an old teacher to be thus remembered. ${ }^{2}$

An administrator quoted Alma McKibbin as saying, "I have children all over the world. ${ }^{3}$ One student called on her from Toronto, Canada. She could not remember having taught him, but he informed her that he had studied her Bible books while attending Oshawa College. Students wrote her letters from mission fields, thanking her for instilling in them the value of service to their church; others called on her to share their dilemmas. Mrs. McKibbin mentioned pilots who stopped by before leaving for a dangerous mission during World War II; some wrote for courage to perform great responsibilities. She related her response to these requests and visits: "With a tear in her eye, the

\footnotetext{
'Alma E. McKibbin, Mountain View, Calif., to Fedalma Ragon, 1957.

Tbid.

'Else Nelson, interview, 18 March 1991.

'Tbid.
} 
teacher smiles as she whispers, Here am I, Lord, and the children whom Thou hast given me.' 1

\section{Awards and Recognition}

Throughout most of her lifetime, Alma McKibbin's impact on the Seventh-day Adventist church school system went largely unrecognized.

However, many of her students showed their appreciation for her, and near the end of her life, she received several awards:

1. Mountain View Academy students and faculty dedicated two annuals to her: 1925 and $1956 .^{2}$

2. In 1942, McKibbin Hall, the new academy building on the Pacific Union College campus, was opened, dedicated, and named in honor of Alma E. McKibbin. ${ }^{3}$

3. In 1960, four of her former students at Pacific Union College paid for her flight to Washington, D.C. for an hororary dinner and tour of the city. 4. In December, 1965, the fourth grade of the Miramonte School in

'McKibbin. 'A Teacher's Satisfactions," 13.

:Mounain View Academy Annual, Senior Class (Mountain View, Calif.: Pacific Press Publishing Association. 1925), 3: El Camino Real (Mountain View, Calif.: Pacific Press Publishing Association, 1956),4.

${ }^{3}$ Pacific Union College Preparatory School. Official Bulletin, 1990-1991 (n. p.. 1990), 7; Alma E. McKibbin, Mountain View, Calif., to A. R. Monteith. Angwin. Calif., 28 January 1942, 26 March 1942, 3 April 1942, 21 April 1942, 23 April, 1942. The foregoing letters are in the hand of Else Nelson. Grand Terrace. Calif.

"Mountain View Teacher, 88. Chooses Jet for First Plane Trip." The Regisser Leader. II May 1960. 
Mountain View, Califomia, performed a program in her honor. ${ }^{1}$

5. Numerous one-hundredth birthday cards, including one from President Richard Nixon, flooded her mail in 1971.

6. The Mountain View Church dedicated a special Sabbath school program to her on the Sabbath after her 100th birthday to honor her years of service. When she was asked what she would like for her birthday, she replied that she longed for a horse and buggy ride. This wish was granted. ${ }^{2}$

7. In her 101st year, the General Conference of Seventh-day Adventists awarded her the Medallion of Merit, an award given only to individuals who have done outstanding work in the field of Adventist education. ${ }^{3}$

8. In 1972, Facific Union College awarded her a Doctor of Literature degree in recognition of her years of service to Adventist education and to Pacific Union College in particular. ${ }^{\star}$

'Barbara Slabach, Sunnyvale, Calif., to Ethel Young, Washington, D. C.. 15 January 1966, in the hand of Ethel Young, Russell, Penn.

-Mountain View Seventh-day Adventist Church, Bulletin, 27 November 1971 , Mountain View, Calif., in the hand of Emily Hixson, Loma Linda, Calif.: "Action Line." San Jose Mercury, 26 November 1971: 'Alma McKibbin 100 Years Old,' St. Helena Star, 16 December 1971: "Birthday Wish Comes True," Courier, December 1971 (Cupertino, Calif.); -Mt. View Woman Thankful for 100 Good Years of Life, Palo Alto Times, 25 November 1971; "Mrs. Alma E. McKibbin Marks 100th Birthday," Valley journal, 24 November 1971, 1; "100th Birthday: Wanted to Ride in Buggy Again." Palo Alto Times. 28 November 1971: "She Trots Into Her Second Century,' San Jose Mercury, 5 December 1971.

3* 100-Year-Old Educator Is Awarded the Medallion of Merit," Pacific Union Recorder 71, no. 40 (17 April 1972): 1.

4. W. Cassell, "Citation: Alma Estelle McKibbin, Doctor of Literature," 11 June 1972 TMs. Pacific Union College, Angwin. Calif., in the hand of Shari Lowe, Modesto, Calif.: Richard Bralliar, "313 Awarded Degrees." Campus Chronicle 48, no. 24 (4 July 1972), 1: Pacific Union College, Spring Commencement Program Notes, 9-11 June 1972. Angwin, Calif. Adventist Heritage Center, Pacific Union College, Angwin. Calif.: 'Honorary Doctorates Conferred at Commencement Services." Pacific Union Recorder 71, no. 50 (26 June 1972): 8. 
Figure 15. Alma McKibbin's Birthday Surrey Ride. Courtesy of Pacific Press Publishing Association. 


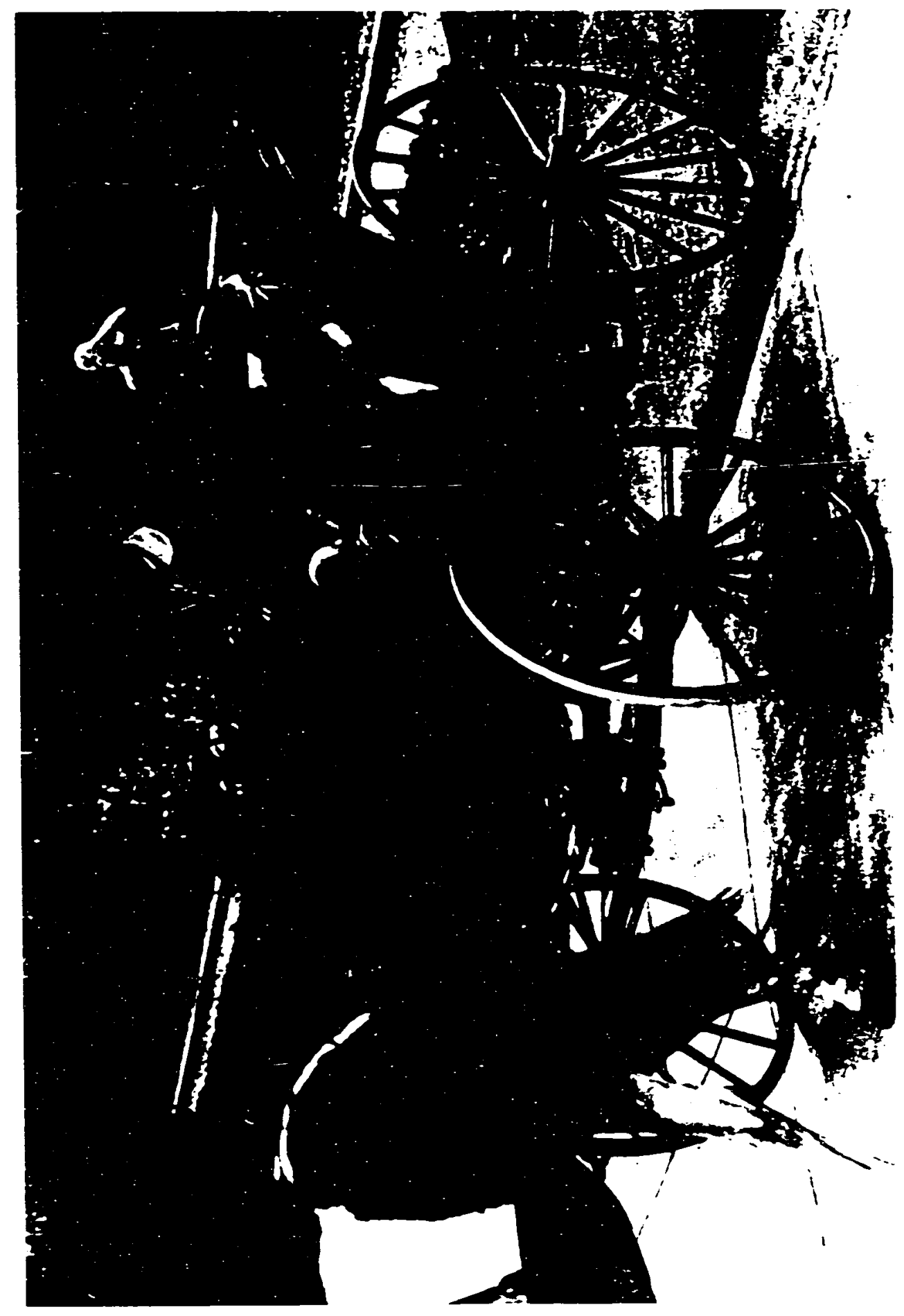




\section{The End}

Alma suffered from poor health all of her life, and her final years were no exception. In 1966 she developed a skin cancer on her eariobe which became infected and caused deafness.' Perhaps a precipitating factor that led her to sell her home and move to a rest home was the danger of falling. She wrote, "I am 94 years old and get along very well except when I have a fall. They come suddenly without waming."2

Alma did not want to go to a rest home. For some years, she had a nurse care for her in her home. ${ }^{3}$ She confessed to a friend, "You never want to go to a rest home. You fold your hands and rest your mind. ${ }^{n 4}$ Several of her friends feel she went to the Crystal Springs Manor, a retirement home on the St. Helena Sanitarium grounds, on 3 September 1968, against her will. ${ }^{s}$ Others feel that it was dangerous for her to live alone, and that she had shown some signs of being confused, leaving stove bumers unattended, and not being able to find her way home. ${ }^{5}$

\section{McKibbin to Young, 1 March 1966.}

McKibbin to Kozel. If July 1966.

${ }^{3}$ Tbid.

"Meikle, interview.

'Utt, interview, 12 March 1991: Crystal Spnngs Manor Sanitarium. Calif., Admission form for Alma McKibbin. 3 September 1968; Meikle, interview: Bertha Parmentier, Deer Park. Calif., to author, 14 November 1990.

'Parmentier to author: Dorothy Muir, interview by author, 2 March 1991. Angwin. Calif. 
However, when she did move into the rest home, she apparently tried to make the best of it. She wrote to a friend, "I am trying to be brave and smile though I miss home and friends. " ${ }^{\text {I }}$ In October, Alma fell on the cement steps on the walk to the dining facilities, which were located in a separate building. This fall resulted in hospitalization and a need for assistance to walk for the rest of her life. She received physical therapy until December 6, 1968, when her brother Alonzo brought her to Cupertino, nearer to her old home and friends in Mountain View. ${ }^{2}$

While at the Pleasant View Convalescent Hospital in Cupertino, Alma kept busy in various ways. She pushed patients in their wheelchairs when they needed help, read to patients, received visitors and citations, wrote letters, read many books and periodicals, and was interviewed by church journalists. ${ }^{3}$

Although her mentation diminished in her final years, Mrs. McKibbin's physical therapist remembered that "she was still brighter than the rest of us. " ${ }^{\text {"t }}$ When she began losing her sight, she asked to be read to. Her favorite book was her Book of Remembrance, for it became a conversation piece

\footnotetext{
'Alma E. McKibbin, Mountain View, Calif., to Bertha Parmentier, Mountain View, Calif., IS September 1968.

'Errestine Estis. Loma Linda. Calif., to author, 19 November 1990. Mrs. Estis was Alma's physical therapist at Crystal Springs Manor, Sanitarium, Calif.

'Althea Schneider, Nampa, Idaho, to author, 11 March 1991; Estis to author; Macpherson, interview: Merikay Silver, Alma McKibbin," Hers 1, no. I (1973, a one-time edition created by Merikay Silver, in the hand of Elizabeth Marsbail. Nampa. Idaho): 45; Mckibbin. interriew.

'Estis to author.
} 
about her students' lives and personalities. She was able to retum a thank-you written in her own hand to at least one person who sent her a birthday card for her hundredth birthday.

Friends and deacons took Mrs. McKibbin to church until she became too disoriented when leaving the rest home. The physical therapist who cared for her after the fall in Crystal Springs occasionally paid her a visit in Cupertino, although not professionally. This therapist recalled that one of the last things Mrs. McKibbin did for her was to order her a meal when she came for a visit. Alma McKibbin died a month later on July 16, i974, aged 102.2

\section{Summary of Interviewees' Comments about Alma McKibbin}

Mrs. McKibbin was loved and revered by many, and people seemed to be eager to share their opinions about her. A summary of interviewees' comments is presented in the following paragraphs.

Ibid., Macpherson, interview; Muir, interview; Gertrude Schweitzerhof. Cupertino, Calif., to author, 12 February 1991; Donna Jacobs, interview.

:"McKibbin," Review and Herald, 28 November 1974, 31.: "McKibbin. Alma E.." Pacific Union Recorder, 2 September 1974, 8: California, Departmeat of Health Services, Sacramento, Calif., Certificate of Death, No. 4300-04071, 16 July 1974; "Alma E. McKibbin," funeral program notes, 27 July 1974, Mountain View Seventh-day Adventist Church, Mouncain View. Calif., in the hand of Bertha Parmentier, Deer Park, Calif., General Conference Archives. Silver Spring, Md.: "Alma McKibbin." St. Helena Star. 25 July 1974; 'McKibbin." Palo Alto Times, 18 July 1974, 16; "Alma McKibbon [sic], Adventist Teacher and Textbonk Writer. Dies at 102." Palo Alto Times, 18 July 1974, 2; "Adventist Teacher Dies at 102." San Jose Mercury, 20 July 1974; "McKibbin, Alma E.," San Jose Mercury, 20 July 1974, 50. Alma McKibbin died of congestive heart failure. 
Her teaching siyle was ariculate and deliberate, with no rapid

movements. Although she was not authortarian. she maintained a quiet, controlled, and reserved manner.

Alma Mckibbin apparenty maıntanned an individuality that could not easily be intimidated. She was heard to say. 'I love the brethren, but I wouldn't trust a one of them!": Those who knew her said she used no props, had no weaith or prestige. and did not want power: nor did she want a following. ${ }^{3}$ "She had her own brand of presiger." One person commented. "She couldn't be lined up in anybody"s court. secause no une siood to gain from any of her positions." This same person added. "Where most of us give lip service or use rhetoric, she bought into the gospet for its own sake--she didn't use it, but acted on it."

She was organized. Each of her presentations had a theme or a premise, evidence. and a conclusion.

Tohler, :nterview. - Marsin 1991; jean Staliurd, ielephone interview by author. 12 May 1991: Edwards. mernew: Dierdre Maxwell, inteniew, 4 March 1991.

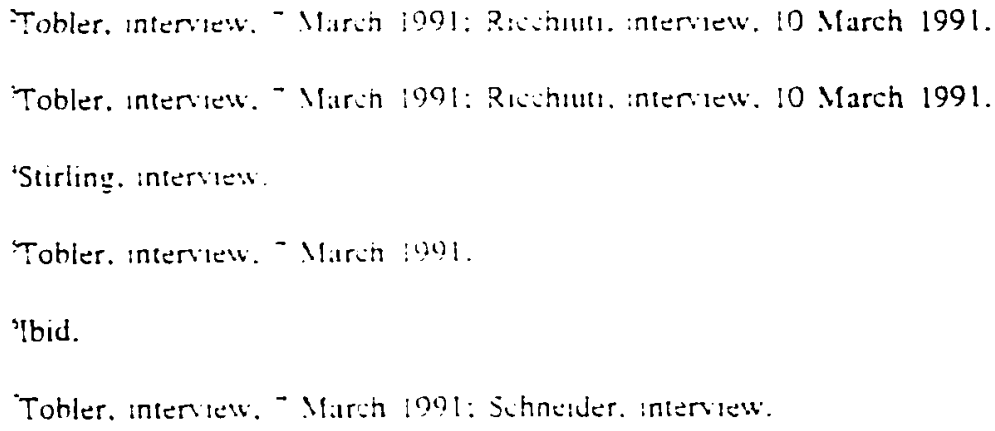


Alma McKibbin had her own style of speaking, teaching, and writing. She tended to make "inspirational points." "She was full of lessons of the McGuffey genre--little morals. ${ }^{2}$ She brought the Bible stories up to date by using modern language and by imagining how people felt. "She was not an analytical person; there were certain things she did not question; yet she was an excellent scholar. She was a gatherer and synthesizer of information. ${ }^{\text {"3 }}$

Those who knew her attributed many labels to Alma McKibbin: "a kind of church treasure," "good listener," "Mother in Israel," "the village elder," "a commanding presence," "a pervading influence," "a real person-not a phony," "a person with a mission," "energized pioneer," "master of the pause," "wise sage," and "a real Christian."

People described Mrs. McKibbin's personality as "very retiring," "timid," "single-minded," "quiet," "aesthetic," "very social," "warm, inviting," "regal," and "courtly." Several felt she was a character of high grace, who could easily mix with people of high society. "She was a jolly person--pretty upbeat. She laughed a lot. ${ }^{n t}$ One friend described her humor:

She was very entertaining. I don't remember any loud, uproarious laughter when she spoke, but there was a warm, spontaneous, appreciative chuckle ... She mentions in the book that she was an expert on low

'Ricchiuti, interview, 10 March 1991.

-Loma Tobler. interview by author, 7 March 1991.

'Tbid., Ricchiuti, interview, 10 March 1991: Gladys Jones, interview, 10 March 1991: Else Nelson, interview.

‘Ricchiuti, interview, 10 March 1991: Dierdre Maxwell, interview. 4 March 1991. 
finance. When she told us that, her :ming was good: her eyes sparkled. and she knew it was a good line--sice used! : well:"

Others made the tollowing generalizations about her:

"She was the tirst teacher--she sat the pattern."

"She was used by God to inelp this church."

"She lived what she believed."

"You can't separate God"s Spirlt trom her work and life."

"The theme of her life was doing the will of God."

"Her main purpose was reiatmo to and enabling others to become what they were meant to be."

"Her stories added color :o the !esson."

"She never lost her sense of wonder about the Bible."

"When she described characters, you ielt she was talking about you."

"Her visit was a work of art."

"She had time ior people."

"She was moraily independent :11 Łood Adventist tradition."

"She didn't imitate anyiondy."

"She couldn't be boughin--you couidn': own her."

"She was her own porson."

"She belonged to the shole church."

"She occupied a nuge space in the sinurch."

Stirling to author. 
"We revered her."1

When asked, "What do you think made Alma McKibbin stand out as an extraordinary teacher?" people responded:

"She recreated the contextual background of the Bible stories."

"Her great interest in the Bible made her a great teacher."

"Her love for teaching."

"Her fertile mind."

"Her humility."

"Her deep love and reverence for God."

"She had a Bible verse to answer questions--that's where her authority came from."

"She tried to build characters--she wanted the Bible to be a part of us."

"She lived close to the Lord."

"She really knew the Lord."

"She lived by the Bible--that's why she was respected and loved."

"A youngster was as important when he became forty years old as when he was her student--her concem for children didn't quit."

"She had faith in each one of us; she respected us."

"Her unselfish and impartial love for people.

'Individual quotations are cited from the following: Else Nelson, interview. 18 March 1991: Axel C. Nelson, interview; Robert Jacobs, interview; Rogers, interview; Childs, interview: Donna Jacobs, interview; Loma Tobler, interview, 7 March 1991: Lester Quade. interview by author, 25 February 1991. Yountville, Calif.: Ricchiuti, interview, 10 March 1991; Louis Schutter, interview; Emily Hixson, interview; Elna Quade, interview. 
"She had a way of making you feel secure; there was an emotional

bond between us."

"She took an interest in us."

"She valued peoples' time--she didn't ad lib, but prepared materials for

all of us."

"She accepted us as we were; she wasn't judgmental; she didn't

censure."

"She held us spellbound by making the Bible characters come alive."

"People needed her to 'open their windows."

"She made the lessons interesting and clear."

"She cared what was going on in the world; she kept up with current

affairs. $^{n !}$

\section{Summary and Observations}

This chapter has focussed on Alma McKibbin's activities and teaching in her senior years. She was active in teaching, public speaking, writing, and counseling until she was almost ninety-seven years old. The following two sections summarize observations about her methodology and integration of faith and practice.

Individual quotations are cited from the following: Else Nelson, interview, is March 1991: Martella, interview: Childs, interview; Parmentier to Baker; Schneider, interview; Aline Tait. interview; Taylor, interview, 24 February 1991: Melissa Kokka, interview by author, 24 February 1991. Modesto. Calif.: White, interview: Ray Hixson, interview; Mary Gray, interview; Philip Gray, interview; Nix, interview, 12 March 1991; Macpherson, interview. 
Mechocolog:

Mrs. McKibbin used the iollowng methods to teach a general Sabbath school class: (1) language of the common people. 12) pause for reflection and absorption, (3) repetition and repetutive questions to build involvement and sense of unity, (4) personal experiences and stortes. 15) details. 16) eliciting of prior knowledge to engage audience :nterest. $1^{-7}$ inspirational lessons. (8) varying voice tones, (9) appeals. and (10) noetry.

To teach Sabbath schooi :cachers. N/ma Mckibbin centered the lesson around four or tive man pounts. explammg diriticuit portions, using visual aids and illustrations, and applying lessons. By modeling and exhortation, she urged her students to get to know their students outsicie of class in order to effectively help them change their iives.

She used the following methods in iner Bible classes during her retirement years: (1) rescarch ior cictals to add background to Bible narratives. (2) modernization of Bible stories is reianng them to current atiairs or personal experiences: (3) maps. (4) retiences. 151 expianation of difficult passages, (6) organizers, (7) memory work. (3) amaiysts of material to tind threads and pattems, (9) student follow-up. (10) accuracy. 1!1) eliciting prior learning, (12) involvement of the affective domam. 1 S integration of geography with history, (14) illustrations, (15) lessons. (16) use of Bible reterences. and (17) encouragement of pupli questuons io sumulate thinking. 
(1)!

Students ielt Alma was a successitul eacher because: (1) she was enthusiastic and contident about ner sublect malter. (2) she was a positive person. (3) she modeled the lessons she wished to teach. (4) she was human and shared her own temptations and tailings. 15) she was a good story teller, (6) she customized the stories to make them relevant :o modern situations, (7) she blended geography with history to make Bible more interesting, (8) she used lists and frameworks that organized icarning. and $(9)$ she genuinely loved her stidents.

Peopie telt this last pomt was one of the most important qualities that made Alma MrKibbin successiul as a ieacher. Others cited her love as an outgrowth of her philosophy and sharacter.

\section{ineoramon of Fath und Pracuce}

Contemporaries of Ama Mckibbin who are still living ieel there was no dichotomy between her inith and pracuce. Sudents "knew" she was close to God. She did not just "say" she cared--she acied by: (1) helping a young girl

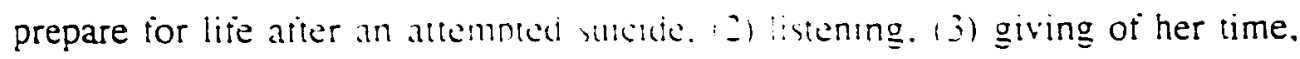
(4) writing articles and books. 151 exhorming. (t) speaking her mind to leaders and others. and (7) by getung 'nsicic stutents inin' enough to appeal to their interest, even if it meant catching a grasshopper.

Mrs. Mckibbin's mann nurnose in thie was to relate to and educate others, enabling them to hecomic anat :hey yerc meant to be. She used her alents in the service of others. Her anties xersuaded Sabbath school teachers 
to get close to their students outside of chass. as she did. Some of her articles

related her life story. an encouragement :o :hose who ake on seemingly

impossible tasks in God's service. In lecures. site used humor and personal

experiences to bond her audience to her heart and to appeal to their emotions, as

well as to their reason. to follow God's iancinings. Her personality drew people

to her, and she used their trust as a bridge to connect them to God, as in the

attempted suicide incident.

In the closing vears of her lite. although greatly disappointed by having

to sell her home and move to a rest home. she accepted the unwelcome change.

She still helped others within her area of intluence. She continued corresponding

with former students and friends and to cheer rest home residents and visitors.

In so doing, she seemed to follow the worcis she penned in a letter to a friend:

But old age has us compensations. I think I must enclose a poem for your mother. It is the most beaututul thing I have ever found upon the subject. Old age is almost unversally dreaded and shunned, but the author of this poem rinally accents the newable whth a sweet spirit of resignation because of what is bevond-onernetual youth.

Old Age came slowiy down the path of Years

I saw him from atar--oray-lested. shadowy:

I turned astie and dailied whth iny icars.

Fair crystal springs were nurmuring by the way:

I lingered. wearted. toving with their depth:

I gathered autumn towers where jrigint heaves lay.

I heard the birds--it was their wenng song--

I breathed the tragrance of the sleapmy tlowers:

The shadow's on the grass were growing long.

I made as if 'Were momng ail the day.

And yet I knew that orm was drawng near.

And soon its siradow xould engutit the way. 
And then he came--his name I would not know--

I only telt the world grown wondrous kind:

We walked rogether. tho his steps were slow.

He told me stories of forgotten days

The iriends and scenes of other years were mine:

The child I once was came with winning ways.

We walk together now--the Child, Old tge, and I.

Sometimes his shadow darkens all the world:

But there is beauty in the sunset sky.

And har away. above the distant hills.

There is a realm of light. entulgent. mystical.

Whose ravs shall sure! y guke the thither-awhen God wills.'

Miss Christune Bondi. an her aunelleth hirthdaly. Enclosed in MfcKibbin to Ragon, 5 July 1944. 


\section{CHAPTER 7}

\section{CONCLUSIONS}

She lives by faith and dwells benearh the Everlasting Arms.

The purpose of this dissertation has been to examine the contributions of Alma E. McKibbin to the Seventh-day Adventist church school system, accentuating her Bible books, teaching methods, and how she integrated faith, learning, and practice. In this final chapter, a brief summary of her achievements is followed by some suggested implications from her Bible curriculum, teaching methodology, and from the integration of her faith, learning, and practice. Recommendations for researchers and practitioners conclude the chapter.

As stated in the preface. the problems Alma McKibbin faced were not unlike those faced by educators and lay persons of the generation of the 1990s. An initial, necessarily incomplete list of implications that may be drawn from her experiences is included in this chapter, not as the answer to today's church school perplexities but as a springboard for future researchers and readers who care to make their own applications to today's instructional dilemmas. 


\section{Summary of Alma McKibbin's Contributions}

The following paragraphs briefly summarize Alma McKibbin's contributions to the Seventh-day Adventist church school system.

Alma McKibbin taught the first Seventh-day Adventist church school in California. The success of this first church-sponsored elementary school at Centralia was very influential in changing the negative attitude toward church schools that had persisted among Seventh-day Adventists in California until the turn of the century. Mrs. McKibbin had to conquer many obstacles, and her efforts inspired others to advance the educational work for children.

Having caught a vision of what church schools could be, Mrs. McKibbin instructed teacher recruits during the initial stages of establishing church schools in Califomia. By providing altematives for those who were bound to the public school system, she helped to solidify and systematize the burgeoning conference church school organization.

Alma McKibbin forged the first Seventh-day Adventist church school Bible curriculum, the influence of which persisted in the United States and various countries into the 1970s. She did this by first printing her own books and later having them published by the General Conference of Seventh-day Adventists.

She further extended her influence to Seventh-day Adventist church schools by membership on many textbook committees. 
From 1893 to 1967 she taught over 1300 students by precept and example, following them for years via her Book of Remembrance, correspondence, and private conversations.

From 1887 to 1967 she rendered service to the Seventh-day Adventist Sabbath School Department in California. She taught in the children's and adult divisions, encouraged isolated members, and trained teachers in methods of teaching the lesson. She contributed many aricles to the Sabbath School Worker, a publication that promoted Seventh-day Adventist Sabbath schools in English-speaking countries.

Mrs. McKibbin authored many articles and books. Over one hundred articles for church periodicals were on topics about parenting, Sabbath school, church school history, Ellen G. White, Bible doctrines, life experiences, appropriate reading material, and denominational history. She wrote tive Bible textbooks, a manual for teaching Bible, a devotional book, a study guide for Parriarchs and Prophets (see Bibliography), and an autobiography.

Alma McKibbin served her church in many other capacities: as young peoples' leader, pastor, and deaconess in her local congregations and as counselor and advisor to church members, pastors, and others. She provided Bible classes in her home to church members, ne:v converts, church leaders. teachers, and students.

She also shared her talents as lecturer and speaker at church services. camp meetings, young people's meetings and classes, teachers' conventions, and 
future teachers' clubs. By speaking about her friendship and acquaintance with the Seventh-day Adventist prophet, Ellen White, and about events in Seventh-day Adventist history, Alma McKibbin reinforced church members' faith in their heritage and beliefs.

Perhaps more subtle, yet integral to all of the above achievements, was the quiet influence she exerted by personal example. She rose above poverty, poor health, a provincial background, a divided home, failure in school, personal losses, hardships, and discouragements to choose new values and friends, and provided a noble example of the Christian life that her students and others could follow. Possibly the most powerful example she gave was her love for her students and the Word of God.

\section{The Bible Curriculum}

\section{Summary}

Alma McKibbin's Bible books were the texts authorized by the General Conference for use in Seventh-day Adventist church schools all over the world for over fifty years. Why were these books used and prized by so many for so long? As one religion professor cited, they provided a solid foundational background and adequate preparation for more in-depth study in college. Others agreed that her books made the study of the Bible rigorous and challenging. Mrs. McKibbin's practical applications of Bible stories to students' everyday life in her methods classes and teaching manuals claimed for the Bible its own relevance that withstood the test of time. Perhaps the greatest strength of the 
books lay in requiring students to spend quality time with the Bible itse!f. Many students seemed to appreciate the resulting intimate acquaintance with the Bible and its Savior. Many were also grateful for the large amounts of required memory work, remembering the verses and stories for years, and counting it a privilege to have been able to use their knowledge in later writing, research, and teaching roles in the church.

How was it, then, that Mrs. McKibbin's books fell into disuse? The changeover from her books to others was not abrupt: it was a gradual process, occurring over time. The following paragraphs summarize the main reasons Alma McKibbin's Bible books ceased to be used in Seventh-day Adventist church schools.

Much like her predecessors at Harbor Springs, Michigan, in 1891, Alma McKibbin struggled to integrate with her teaching the far-reaching aim of making the Bible foundational to the education of church school students. Her goal for children was for the Bible to become the ultimate guide for their daily living. However, as she attempted to employ the Bible as the foundation of education. Alma McKibbin differed sharply from the views of later, more contemporary conference educators on two main issues, which resulted in the eventual termination of the use of her books in the church school curriculum. These two issues were (1) to what extent children could with understanding read the King James Version of the Bible with its increasingly archaic language, and 
(2) how many helps teachers should be provided in order to adequately teach Bible.

Mrs. McKibbin believed that in order for the Bible to become a part of her children's daily lives, they must spend time actually reading it. She maintained that with the help of a teacher, even young children were capable of reading and comprehending the Bible. Writing answers and stating them orally in the exact words of Scripture were preferable to answering them in the children's own words. It seems that in Alma McKibbin's mind, the revision of Bible textbooks into narrative form, when they were written to send the student to the Bible itself for answers, was tantamount to paraphrasing God's word. Such paraphrasing, she believed, undermined the children's dependence on the primary source, the Bible.

Many conference educators and textbook writers, on the other hand, felt that children could not readily comprehend the language of the Bible or the meaning of many of its stories, and that through use of Mrs. McKibbin's books, the Bible curriculum degenerated into memorization of isolated facts and names. These authors promoted rewriting the Bible stories in narrative form. using language easily comprehended by children, and employing the Bible itself in supplementary activities after the children had read and comprehended the narrative.

Alma McKibbin also differed with other conference educators over the amount of supplementary material that should be provided for church school 
Bible teachers. It appears that she believed that fewer notes for teachers would foster their independent thinking and stimulate more interesting, original Bible lessons. That teachers might not study or work hard without notes does not seem to have occurred to her; she considered personal study imperative.

On the other hand, in trying to provide overworked teachers with more easily available source materials, other conference textbook authors might have assumed that teachers would employ these extra activities simply because they were available.

\section{Implications}

Although it is beyond the scope of this dissertation to solve the conflicts that arose over the McKibbin textbooks, the following perspectives may aid readers in reaching their own conclusions:

First, the either/or positions taken by Mrs. McKibbin and other conference educators over whether children could understand the Bible may have presented a talse dichotomy, when in reality both approaches are necessary. Children need exposure to the authoritative, inspired answers that Bible texts offer and will benefit from viewing the Bible as normative. On the other hand, ability to understand some biblical concepts--even Bible stories--can come only from broad reading and from the inferential, analytical, and synthesizing levels of comprehension. The broader, deeper, or more complex concepts (for example, the great controversy, God's purpose for Israel, and the nature of man) can only be understood in their relationship to the whole, and cannot be derived 
from the more narrow focus on a few texts or passages. Research has supported that different ways of organizing units of content, such as relating parts to the whole, can foster students' abilities to think at higher levels of cognitive and affective complexity (more than focusing student attention on one minute information fragment at a time). ${ }^{1}$

Second, educators today may learn from Alma McKibbin's belief that all children in all grades are not only capable but should be required to read the Bible, as their abilities allow. If reading or studying the Bible is not regularly practiced, children may not acquire the habit of picking up their Bibles for answers to life's questions.

Although it was hardly the intent of Mrs. McKibbin's contemporary textbook authors to undermine student use of the Bible as a primary source, the following practices may have militated against its frequent use: (1) many teachers required only the textbook material to be read, and not the Bible; (2) students who finished their Bible assignment early often were handed further work to do ("optional" or suggested activities), using the Bible. Thus, they may have felt "penalized" for working hard, perhaps experiencing negative feelings toward the Holy Scriptures; (3) the extra activities available for study in the Bible often required added work for the teacher (in planning, directing, and correcting), thus inadvertently reinforcing the use of the predigested material;

Gary D. Borich, Effective Teaching Merhods (Columbus: Mernll Publishing Company, 1988), 112. 
(4) Students were not often encouraged to "prove" the narrative material in the text by the Bible norm to ascerain its correctness, a lack which encouraged a tendency to accept others' accounts as normative, and (5) most activities promoting use of the Scriptures were not mandatory, downgrading the Bible to an elective or option.

One cannot help but wonder whether there might be a connection between the less central role of the Bible in church schools since the 1950s and the dissatisfaction with Bible texts and classes on the part of teachers and students in Seventh-day Adventist schools in the latter part of the twentieth century. In a study of Seventh-day Adventist teachers who ranked all the subjects in the curriculum, Bible textbooks were rated the lowest by secondary teachers in 1988 and second lowest by both elementary and secondary teachers in 1991.' In another study, Seventh-day Adventist academy students registered dissatisfaction with their Bible classes.' Student reasons for dissatisiaction were:

"We've heard these same stories over and over since kindergarten"; "All the teacher does is preach at you"; Filling out all these pages in the workbook is a drag"; If you disagree with something you're labeled as having a bad attitude"; and "Who wants to memorize all these dates, people, piaces, and key texts?" 3

iSee Paul Brantley, Profile 87 , Report C (North American Division Office of Education, 1988), 3; idem. Profile '91. (North American Division Office of Education, 1991), 16.

:Roger L. Dudley, Why Teenagers Rejec Religion . . and What To Do abous It. Hagerstown. Md.: Review and Herald Publishing Association, 1978), 23-24.

'Tbid. 
A more recent study of Seventh-day Adventist church schools, grades six through twelve, revealed that students would like to leam more about the Bible and that "the great hunger of our young people seems to be for a deeper relationship with God."

Third, that Alma McKibbin's Bible books and manuals encouraged the use of all of the levels of Bloom's taxonomy is well worth emulation. Her strong emphasis on chiidren's memorization of Bible texts and on learning well the meaning and application of Bible stories and verses built a solid knowledge base on which successive college Bible teachers and also on which the students themselves, as future Sabbath school teachers, could build. Research and experience have supported that material that is not learned well at the lower levels cannot be used at higher levels. ${ }^{2}$

The McKibbin Bible books required the teacher's use of activities, applications, and personal preparation in order to foster higher cognitive levels of thinking. Students leamed to compare and contrast Scriptural accounts with current events and to apply their leaming by helping others outside of class. Activities Mrs. McKibbin used to foster higher levels of thinking and which are considered examples of good teaching by 1990 s standards $^{3}$ included (1) attaining

'Roger Dudley with V. Bailey Gillespie, Valuegenesis: Faith in she Balance (Riverside. Calif.: La Sierra University Press, 1992), 229.

'Borich. 91.

'See Gary D. Borich. Effecrive Teaching Methods (New York: Macmillan Publishing Company, 1992), 171: Dolores Durkin. Teaching Them to Read (Boston: Allyn and Bacon, 1989), 14-15. 
attention and interest by tying in the day's story with the news or personal experiences; ${ }^{1}$ (2) reviewing previous lessons and providing enrichment and details not present in the reading selection;' (3) asking questions before, during, and after reading the selection; ${ }^{3}$ and (4) providing opportunity for student reactions and sharing of ideas, ${ }^{4}$ either verbal or written, followed by summative assessment.

Fourth, Mrs. McKibbin felt strongly that without personal study on the part of teachers, the Bible curriculum was doomed to failure. Although she supplied many ideas and resources, the success of the Bible curriculum fell heavily on the teacher's preparation and ability and willingness to lead his or her students to discover for themselves the relevance of Scripture. Preparation time, cited as one of her books' major weaknesses, might have been one of their major strengths. In light of the crucial role in Seventh-day Adventist education that 1990s teachers play, personal study and preparation for Bible class might be the sine qua non for the contemporary Bible curriculum.

Fifth, many reasons might explain the alleged "difficulty" of the McKibbin textbooks. It was likely not over readability levels, which were supported by the Fry Readability Graph as slightly more readable than the

'Tbid., 157.

Thid. 190-201.

'JoAnne Caldwell. "A New Look at the Old Guided Reading Lesson." Wisconsin Stase Reading Associasion Journal 35, no. 2 (Spring 1991): 2-4.

'Ibid., 16. 
conference texts replacing them. Some leaders hypothesized that most of those who felt her books were too difficult were not interested in challenges. The unfortunate binding of the seventh- and eighth-grade texts into one volume, followed by the blunder of officially advertising the two-year book for the seventh grade only, caused many misunderstandings over having to cover too much material. Although the Peck workbooks that accompanied the texts offered delightful activities, one wonders what uses and abuses busy teachers might have loaded into already-crowded student schedules by requiring work from both texts and workbooks. Whatever the reasons cited for the difficulty of the McKibbin texts, no one feit the arguments were important enough to remove the books from school inventories for over fifty years.

Perhaps more important, those books appealed to the brightest minds the church had to offer: Walter E. Macpherson, past president of Loma Linda University, Charles E. Weniger, past dean of the Seventh-day Adventist Theological Seminary and of the Andrews University School of Graduate Studies, John Staples, former chair of the religion department at Pacific Union College, Axel Nelson, earlier educational superintendent for the Pacific Union Conference of Seventh-day Adventists, F. O. Rittenhouse, past president of Andrews University, and many others who shared great responsibilities all over the world.

Finally, one cannot help but identify with the struggle Alma McKibbin and many other educational pioneers had in applying principles of education to 
current contexts, especially the principle of making the Bible the foundation of edication. It is understandable that Mrs. McKibbin believed that preserving the literal words of the Bible might teach children respect for the Word of God as the most important element in church school. Would that all Seventh-day Adventist students still maintained that same respect! The question, however, still remains for 1990s educators: how can we make the Bible foundational in our educational setting? One way might be to cause the teachings of Scripture, not necessarily its literal wording, to become the norm for the curriculum. One need only consider Bible paradoxes to realize the limitations of interpreting the Bible at only the literal level of comprehension.

In the broadest sense, making the Bible "the foundation of all true education" may call for careful Bible study on the part of theologians, teachers, and students--each person leaming at his or her present ability. The all-or-none, either/or questions about Bible teaching turn into when-and-how questions when Bible study is approached as developmental, gradual, and cumulative in the life of each person.

The developmental view of Bible study ${ }^{1}$ accommodates many levels and types of study. The method(s) employed match the level of the student's readiness and abilities to read and interpret (the "when"). There is room for verse-hunting, fact-finding, "proof-texting," memorization, map-drawing, and drill--and there is also room for broad overviewing, narrative-reading, concept-

'As proposed by Dr. Charlotte J. Oliphant in "A Developmental Model of Bible Teaching," TMs, July. 1991, in the hand of the author. 
forming, problem-solving, reasoning, analyzing, synthesizing, evaluating, reflecting, ferreting out principles, and constructing meaning (the "how"). At whatever spiritual and intellectual level the student is, he or she treats Bible teachings as normative and as seriously significant, and the student applies whatever is learned to daily life.

On a developmental basis, students regularly read the Bible, even if they also regularly read about the Bible. The teacher assists the student in selecting readings, however short and simple, at the student's level of interest and fluency, preparing him or her for reading success and perhaps reading with the student in unison. The purpose of having all students habitually read the Bible is to reinforce its normacy.

It is possible that a developmental approach to Bible learning and Bible teaching might spare 1990 s educators from some of the either/or debates which created controversy over Alma McKibbin's Bible books.

\section{Her Teaching Methods}

\section{Summary}

The following paragraphs summarize several of Alma McKibbin's teaching methods that may have some bearing on the teaching dilemmas educators face in the 1990s.

While it is uncertain just what method Alma McKibbin used, she learned that it was possible and advantageous for beginning readers to read and comprehend Bible passages. In San Pasqual. Alma McKibbin taught her students 
to read and write, using the Bible as a textbook, along with stories from the Little Friend. Within eight months these students were reading stories from the Little Friend, and sometime during that eight months, at least one of the children began reading the Bible, apparently with expression and meaning.

Second, while Alma McKibbin used the predominant teaching methods of the 1890s when she taught church school, she discriminated among which methods to use and when to use them, adapting them for the multigrade, Christian classroom. (1) She did not accept the prevailing custom of incorporating high-interest myths and fairy tales or the universal classics, into her reading curriculum. (2) True to her Pestalozzian training, she nurtured children and tried to encourage their interests; however, in keeping with her belief that she was a molder of distorted characters, she departed from Pestalozzi by adding appropriate, reasonable corporal punishment and other consequences when necessary. (3) When she wrote the Bible lessons, she adapted them for multigrade use by doubling up on the grades, writing one lesson for the upper grades and one for the younger children.

Mrs. McKibbin wanted to become a better disciplinarian. At the end of her three-year elementary school experience she apparently overcame her lack of dicipline, which she considered a great weakness ("They did not behave, and my first school almost ran away with me"). Instead of avoiding her mistakes or keeping them to herself, she worked hard to remedy her deficiencies. The

McKibbin, The Joy and Reward of the Christian Teacher, 2. 
data do not indicate that a disciplinary problem persisted in her teaching at the secondary and college levels.

Fourth, Mrs. McKibbin was concemed for the at-risk student. Her goal was to get to know this type of student personally so that she could appeal to his or her interests and attract him or her to Christ. Relationships were important.

Finally, she integrated the attitudes of repentance and humility into a life entirely devoted to God. She modeled, "Anything you ask me to do, Lord, I'll do." In addition, she modeled a devotional relarionship with God, a desire to know more about Him, a lifelong attempt to become as much like Him as she could, and a life of sharing what she learned about Him with others.

\section{Implications}

The following is an initial list of implications derived from Alma McKibbin's teaching methods, based on the above summary paragraphs.

First, if beginning readers are taught Bible words and verses incrementally, reading caretully chosen, concrete texts at their level of fluency, and with heavy use of prompts and cues, they can learn to master reading a succession of Bible verses. Subsequently, via the whole passage method, they can learn to read Bible passages very quickly. ${ }^{1}$

Durkin. 159; Ruth Beechick. Teaching Primaries (Denver: Accent-B/P Publications, 1990). 
Second, if students wait to read the Bible until they have mastered reading, too many impressionable habit-building years are lost; opportunities for them to read at family worships and other religious social gatherings are forfeited, and the children do not begin thinking of the Bible as life's guide at an early age.

Third, Adventist educators and teacher trainers in the 1990s can make the Bible foundational by (1) choosing only those prevailing methods, theories, and resources which align with biblical and Seventh-day Adventist educational philosophy;' (2) leaming to use those methods, theories, and resources appropriately, and (3) adapting them to multigrade schools. Teacher educators are responsible for sorting through the voluminous maze of educational literature, theories, reforms, and methods that keep accumulating, for sifting out those that are not in harmony with Christian philosophy, and for teaching principles that will enable their students to do the same. It is unfortunate when educators indiscriminately pass on many variations and methods to preservice teachers in the name of eclecticism, putting the burden on students to weed out inappropriate material.

Fourth, Alma Mckibbin serves as a model of one who took disciplinary problems very seriously, opening herself to the Lord for solutions. Although teachers should not carry a level of concern so high as to jeopardize

\footnotetext{
As outlined at the beginning of chapter 3 and in the book Education, by Ellen $G$. White (Mountain View, Calif.: Pacific Press Publishing Association, 1903.
} 
their health, most would do well to take the necessary time to get healthy results with a good discipline system.

Fourth, teachers and students in the 1990s, as well as others, would do well to follow Alma McKibbin's example in relating to their students. Her deep love for students is worthy of honor, as evidenced by her use of the Book of Remembrance and by students' looking her up years later. This discipling orientation became one of her greatest strengths. Borich's summation and analysis of selected research studies of classroom discipline have shown that many problems and misunderstandings may be prevented, and teaching can be more eiffective, when teachers understand the needs and backgrounds of their students. It may not be possible in this fast-paced age to interact with all pupils outside of class, although this is ideal; on the other hand, teachers may devise ways to build relationships in class.

Opportunities to establish relational bonds with students in class in order to adapt instruction to their needs might include (1) special occasions, such as birthdays, celebrating a closure, farewell, or introducing new students, (2) special projects; and (3) teaching relational skills through cooperative learning groups which meet for part of the time.

Christian teachers can build on relationships to draw their students to Christ. They can teach their at-risk students that Jesus' love for them is stable, though the world they live in may not be. They can study Mrs. McKibbin's way Ibid.. 36-37. 
of relating to all students, gifted or slow, emulating her model of humility and repentance to know God's will in how best to establish relationships.

Finally, everyone in the 1990s can strive for and follow Alma McKibbin's personal goals and attitudes of repentance and humility, integrated into a life entirely devoted to God. If God could help Mrs. McKibbin, who had no more advantages and perhaps more troubles than the ordinary person, to do a work that needed to be done, He can do the same for anyone else.

\section{Integration of Faith, Leaming, and Practice}

Although the ways in which Alma McKibbin blended her faith with her teaching methods and Bible curriculum have been reviewed in the preceding paragraphs, the following thoughts are additional implications on the integration of faith, learning, and practice.

The phrase, "integration of faith and learning," includes more than separate tracking, worship in classes, or religious activities. Helping students integrate their faith with what they learn is a challenge for Christian educators. Many people feel that the process of integration involves teaching "Bible" during one hour, and teaching "English. science, or social studies" during the next. A prayer at the beginning of class, or a field trip for students to perform Christian service duties, while appropriate and respectable activities, does not embody the full meaning of "the integration of faith and leaming."

Integration of faith and learning means a continual process of 
(1) applying one's faith to one's learning and evaluating information and ideas in light of one's faith; and (2) applying one's leaming and cognitive abilities to the growth and practice of one's faith. Thus, when educators use the customary phrase, "the integration of faith and learning," they more accurately mean, "the integration of faith, learning, and practice.

Integration of faith, learning, and practice includes appropriately generalizing what is learned to various situations. The teacher must ask, "How can I take this principle and apply it in this particular situation?" Or, "Is the principle I applied in situation A equally applicable in similar situation B? If so, should the method of application also be the same? For example, a teacher might want to integrate his belief in kindness with his classroom practices, but how does he apply kindness when a student has turned in a test with answers in the exact words of the textbook? One teacher was so upset when this happened that he planned to fail the offending student. When he later took time to investigate why she copied the textbook verbatim, he discovered that the student was from a country where it was common practice for students to write answers memorized from the textbook. In this case, kindness was applied by incident analysis and listening.

On the other hand, a teacher dealing with a rebellious, argumentive student might apply the principle of kindness by giving a negative consequence. And, in the application of learning to faith, what a teacher learns about the 
psychology of discipline may help him or her understand God's dealing with Israel.

Integration involves relating or incorporating learning into one's practice. Good medical doctors continually apply what they learn and read to the treatment of patients. As they study and apply their secular learning, their medical knowledge grows and is strengthened. There is a danger that their religious knowledge, if it does not increase and become incorporated into simultaneous secular leaming, may begin to seem distant and irrelevant, almost childish. For that reason, physicians who attend Loma Linda University, the Seventh-day Adventist medical school in Loma Linda, Califormia, are challenged to discover and incorporate religious principles into the ethical dilemmas they face. Students leam to question their own medical and religious assumptions and beliefs.

Ideally, the following components can be integrated as in a cycle: religious learning, secular learning, and students' ability to understand and higher levels of thinking. As learning increases, students must apply their learning to life.

How can Christian teachers and students integrate their faith with learning and practice? Educators may look for principles of Christianity that apply to their fields of expertise. They can teach their students principles of Christianity that apply to the classroom. 
For example, when reading the professional literature, educators must ask themselves, "What does this have to do with what I already know about (1) the secular knowledge base in my field, (2) my prior religious knowledge, (3) my life, and the life of my students?" They should be constantly looking for places to apply the learning.

The teacher's purpose in getting to know students is to be able to relate class material to their lives. The whole Bible must be integrated with or related to the whole course, which is then to be related and applied to the student's whole life. The effort put into the integration process keeps faith, learning, and practice together cyclically.

\section{Recommendations}

For Researchers

After the data were gathered and analyzed for this study, several areas were discovered that were not possible to investigate, and these are listed in the following paragraphs as recommendations for further research.

1. An analysis of the Seventh-day Adventist Bible curricula from 1903 to the present, including changes, revisions, and the reasons for those changes. Two sources basic to the study are Alice Goertzen's comparison of the 1952 and 1972 curricula $^{1}$ and Sally Saulsbury's evaluation of the 1975 curriculum..$^{2}$

\footnotetext{
'Alice Goertzen. A Comparison of the New Religion Curriculum with the Preseat Curriculum in Grades One to Four in Seventh-day Adventist Elementary Schools" (M. A. project. Andrews University, 1972).
} 
2. Research on the elementary Bible curricula in foreign countries, including the use and/or influence of Alma McKibbin's books on the present curriculum in those countries.

3. An inquiry into how to apply the principles of educational reform to the contemporary American Seventh-day Adventist church school curriculum.

4. A complete history of the Seventh-day Adventist church school movement. Although several sources for the church school movement are cited in this study, they are only incidental to the major study of which they are a part. To date, there is no complete, documented study of the church school movement in the United States or in foreign countries.'

5. An analysis of Alma McKibbin's influence on the church school movement in light of recent research and theory of change and innovation in education. Considering the resistance in California when the Church School Movement began, her achievements were remarkable. Some of the ingredients present in the late 1890s are still considered necessary for restructuring education in the 1990s, such as grass roots conception, field-testing, intensive training, ready-for-use curriculum materials, transter of learning, teacher and

"Sally Saulsbury, "Evaluation of the New Bible Series Curriculum" (M. A. project. Andrews University, 1975).

Although her study is not documented. Miriam Wood did research the lifestyles of Seventh-day Adventist church school teachers during the second quarter of the twentieth century. Her unpublished manuscript is in the files of the Adventist Heritage magazine. La Sierra University, Riverside, Calif. See Wood, "Good Old Adventist Goldea Rule Days." 
administrative collaboration, continuity of leadership, and the Holy Spirit as change agent.

6. An analysis of Mrs. McKibbin's possible use of integrated thematic instruction. In several places she mentions correlating subjects, such as Bible, geography, history, language arts, and math. A thorough comparison of current research on curriculum integration to the teaching practices prevalent during the Church School Movement, as well as to Alma McKibbin's methods, might prove enlightening.

7. An inquiry into the differences in pedagogical methodologies, if any, that Mrs. McKibbin made between elementary, secondary, and college levels.

8. A study of the stories Alma McKibbin wrote for children. According to Louis Schutter, former editor of Our Little Friend and Primary Treasure, Mrs. McKibbin wrote several stories for Our Little Friend, especially during the years when Emest Lloyd was editor. These stories were apparently reprinted in later editions of the Little Friend and Primary Treasure. ${ }^{1}$ depending on their content, these stories might provide another source of information for Adventist educational history.

9. The author has materials on the following and would be willing to share them: (1) the relationship of Alma McKibbin with Sarah Elizabeth Peck (Sarah Peck wrote the workbooks that accompanied Alma McKibbin's texts);

Louis Schutter, interview. 
(2) the effect of the Peck workbooks on the Bible curriculum: (3) the influence of Alma McKibbin on the life of her brother Alonzo L. Baker; and (4) the relationship of Alonzo L. Baker with J. H. Kellogg (the Heritage libraries at Loma Linda University, Loma Linda, California, and La Sierra College, Riverside, California, have a set of oral history tapes on this subject).

10. Although Alma McKibbin's diary and Book of Remembrance have not been located, it is possible that these books may one day be donated to one of the Adventist Heritage Centers, providing a source of information for further research on her life and on the life of her students.

\section{For Practitioners}

The following recommendations are for practitioners of church school education:

1. An openness to consider a more structured, field-tested Bible curriculum, based on surveyed teacher needs. Several questions have challenged curriculum planners with regard to how best to serve 1990s Bible teachers, such as: how do 1990s educators match the curriculum to the needs of those who will teach that curriculum? Should future textbook writers cater to novice teachers who need more structure, or to creative, experienced teachers, who might like more freedom in teaching? What, if anything, have we learned from Alma McKibbin that might shed light on this curriculum dilemma?

To venture a suggestion that may partially answer such questions, a continuum could be drawn as follows: 
What is $<$ $>$ Ideal

The circumstances, the "What is," are different in the 1990s from the 1890s. Students of the 1990s appear to be less motivated to leam than their 1890s counterparts. Many teachers are not trained or inclined to be thinkers and may not practice innovations that would depart in large measure from the established curriculum. Many are overworked, underpaid, and drained by daily discipline problems and/or problems at home. A teacher who is thus burdened is not likely to be innovative. A few teachers are lazy, especially if subject matter is hard or disagreeable. Novice teachers have all they can handle without the exira work of researching material and designing units and lessons. These teachers may not be motivated to devise their own materials. The more creative may be capable of putting their creativity to work whether or not they are provided with materials.

Under these circumstances, which are not ideal, it may be best to choose the more realistic rather than the ideal side of the above continuum. A curriculum based on surveyed teacher needs might have a better chance of implementation. Teachers may tend to use what they have had a part in choosing. Some freedom might empower the top percentage of innovative teachers to try imaginative, higher-level cognitive and affective approaches to Bible teaching. This top percentage may be assisted by optional idea sheets, mentoring, workshops, and quiet recognition. 
2. Inservice training in the use of new Bible curriculum materials.

Such training may be as beneficial for current Seventh-day Adventist teachers as it was for Alma McKibbin's recruits. Providing the theory and philosophy behind research-based teaching methodologies may also help motivate teachers to prepare well-planned lessons. Inservice training might be reinforced with subsequent regional summer sessions on religious education, inciuding the use of supplementary materials. Follow-up activities may facilitate transfer of new learning and also provide some social bonding for lonely, isolated church school teachers.

3. Incorporation of coaching into inservice programs for religious education. Research has shown coaching to greatly increase transfer of learning,' as it apparently did when Alma McKibbin spent a great deal of time and effort coaching teachers in religious education.

4. Application of the Bible to secular learning. Bible teachers need to integrate students' academic learning with spiritual instruction in order to keep the latter from lagging behind the former and to keep students from compartmentalizing religious education from secular applications.

5. Careful comparison and adaptation of current research and knowledge bases to biblical principles rather than being bound to or limited by the current research-based literature. Some excellent religiously and philosophically-based teaching methods can't be supported by research or

Beverly Showers. 'Teaching Coaching Teachers.' Educational Leadership 42, no. 7 April i985): $44-45$. 
knowledge bases because they haven't been tried at all, haven't been given a fair long-term trial, or haven't yet come to the attention of researchers.

6. Professional consultants for church school teachers who wish to innovate. College and university professors of education could provide such services via an 800 number or through electronic mail.

7. A broadening of methodology in Bible teaching to include all the methods of Bloom's taxonomy, with progressively higher levels of thinking in each unit, such as problem-solving and concept formation, appropriate to student readiness. Much past Bible curricula have been devoted to lower thinking levels that include memorization of facts, with some application, and these practices need to continue. However, emphasis also needs to be given to more relevant application, to analysis (contextualizing and comparing scripture with scripture), to synthesis (seeking to build timely, coherent, useful "wholes" out of the parts), to proving nonbiblical material by biblical standards, and to life integration. "Every youth should be taught the necessity and the power of application. Upon this, far more than upon genius or talent, does success depend. "1

8. An openness toward a more developmental approach to Bible teaching that addresses all aspects of student development. Such openness might resolve the problem of dissatisfaction with Bible that came to light in recent research studies and also bypass the difficulties experienced by Alma McKibbin

White, Educarion, 232. 
and other conference educators over using the Bible as primary source vs. using books about the Bible.

A developmental model of Bible teaching would incorporate both higher and lower levels of cognitive, affective, and psychomotor domains ${ }^{i}$ and would foster integration of the domains: spiritual (conscience and the will), cognitive, physical, aesthetic, social, sexual, emotional, and attitudinal.'

The following are five possible steps in a developmental model of Bible teaching, which could be applied to every grade level (see fig. 6):

1. Know. The child hears/reads the story, episode, fact, or saying, and rells it to someone. (David the shepherd boy cared for sheep).

2. Contexiualize. What did the story, episode, fact, or saying mear to the people to whom it was first written? (David did his job faithfuliy, depending on God for help).

3. Analyze. Students (usually with help) compare the story, episode, fact, saying, and apparent meaning with other verses on the same topic in order to ascertain what God was trying to teach, in this case, through the story of David the shepherd boy. (Samuel performed his tasks faithfully; so did boy king Josiah). The use of time lines and chronological lists of Bible stories and events facilitates comparisons.

:Borich, 91.

Tbid., 37, 63-64. 
4. Modernize. What could the story, episode, fact, saying, or principle mean to us now? (Children today can do their work faithfully, obeying and depending on God).

5. Personalize/apply/do. What does the story teach me to do? What will I do more, better, or differently because I know this? (Be faithful in the duties God wants me to do; i. e., keep my room clean, help parents with chores; do my homework daily.)

A rationale for the five steps of the biblical model might include the following elements: Step I: because students cannot use the higher levels of Bloom's taxonomy without first mastering the lower levels, ${ }^{\prime}$ the first step is to know literally what the passage says. Step 2, to contextualize, is based on the hermeneutical principle that the cultural factors must be considered at the time of writing to discem the true meaning of biblical and prophetic writings. ${ }^{2}$ Step 3: analyzing what the text or selection says in light of what one or all the Bible writers have said on a topic provides internal and external consistency and validity. ${ }^{3}$ The rationale for steps 4 and 5 , understanding the present-day meaning of a passage and relating it to one's personal life, is based on the principle that success follows when leaming is applied."

ibid.. 91.

'Roger W. Coon, "Hermeneutics: Interpreting a Nineteenth-Century Prophet in the Space Age, Journal of Adventist Education 50, no. 5 (Summer 1988): 17-18.

'Tbid., 19.

White, Education. 232. 
For example, when a student leams the story of David the shepherd boy, he imitates and applies the lessons to the domains in his life. He may not tend sheep, but he can depend on God and be faithful in cleaning his room, studying his lessons, and building a strong body as David did.

Although all student domains can be applied at each grade level, the extent of teacher help decreases, and the depth and breadth of study increases, as children progress in age and development. The synthesis of a fourth grader's diorama of the sanctuary is on a micro level in comparison, for example, with a synthesis of readings on "The Judgment" by a high school senior. The goals are the same at each level: io integrate spiritual development with secular. cognitive, social, sexual, emotional, physical, aesthetic, attitudinal, and behavioral development; and with will and conscience. The learning agent must be the Holy Spirit.

At each level, students use the Bible for normacy reinforcement, that is, as a standard for appropriateness and use of material that is taught. Secondary sources and books and stories about the Bible or other related topics may be used for readability, comprehension, and overviewing.

There is another dimension of the developmental model: growth tracks on which students mature through life, such as cognitive, motivational, emotional, experiential. and the development of compassion. Studies have shown that individuals operate on different levels of cognitive complexity and that these levels can be improved if matched to the learning environment. The 
Fig. 16. An example of how to teach a story according to the development model of Bible teaching, with adaptation for multigrade schools.

Level: Seventh and eighth grades

Course: Old Testament

Unit: Captivity of Judah

Lesson: Daniel's faithfulness when taken into captivity.

Objectives: 1. To repeat the story of Daniel's exile, after having read it in Dan. 1:1-7 and in Arthur S. Maxwell's The Bible Story, Vol. 5.

2. To understand what the story meant to Daniel and his 3 friends. Study 2 Kings 21-25; 2 Chron. 33-36; Teachers: Propriets and Kings, 381-476.

3. Analyze Daniel's exile in the context of Israel's captivity (2 Kings 15:27-29; 2 Kings 17:1-18), and compare his experience of asking permission to abstain from foods prepared for idols with the experience of the little maiden, who was in bondage to Captain Naaman and yet remained obedient to her parents' faith (2 Kings 5:1, 2); with Joseph, who was true to his father's God when sent away captive (Gen. 37:28, chapter 39); and with Samson, who was not true to his parents' commands (Judges 13:24-14:3). References for teachers: White, Prophets and Kings 279-292; 293-300, 649. What was God trying to teach us? (Jerusalem had been repeatedly wamed and rejected warnings; in its judgments, the innocent suffered with the guilty; Daniel's life of faithfulness, and the life of others he helped were blessed by God; all are free to choose their way or God's way; superiority and mercy of God's way).

4. Compare and apply the meaning of Daniel's march to us in today's setting. Might God allow adversity to come to Christians, or groups of Christians, if they ignore His instruction and warnings?

5. Apply this story to what it teaches me personally: (1) What will I do more, better, or differently because I know this? Can I think of any way that I have not responded to God's instructions or wamings? (2) Will I be faithful to God if He allows adversity to come to me, even when I am doing my best? If you find something in your life you want to change, make a plan to change. 
Figure 16. con't.

Grades one and wo: Child studies Daniel and his three friends in the king's palace, refusing the food offered to idols. Compares it with stories of other young people doing ight, such as Abel, when offering the sacrinice God asked for; and Josiah, who destroyed all the places of idol worship. Focus on obedience.

Grades three and four: Students study Daniel and his three friends in context of captivity. The prophets Habakkuk, Zephaniah, Jeremiah, and contemporary rulers are studied to show God's mercy in giving warnings and small judgments before the irreversible ones. Students study how God works to encourage obedience: i. e., not forcing, giving plenty of time, giving choices.

Grades five and six: Children compare story of Daniel and his three friends not eating food offered to idols with other stories in the Bible about unclean meats, and the lists in Leviticus. Students study story of Peter getting vision of unclean meat and being asked to eat the unclean meat. Compare this story with other stories about unclean meat; Paul's admonition not to be a stumbling block to brothers who do not eat meat offered to idols. In their comparisons of these stories with Daniel and his three friends' refusal to eat meat offered to idols, students are asked if the meaning is the same in all three passages. The story of Peter is read further, and its true meaning ascertained. Students may broaden their study to include other related issues, such as racial equality and healthful ating. 
lowest level utilizes categorical, black-white, and simplified thinking, while a moderate level of complexity broadens thinking to include several alternative ways of viewing the world. Moderately high complexity levels use alternative systems of interpretation, while high complexity thinking utilizes and sees even more interacting variables. ${ }^{\prime}$ In a developmental model of Bible teaching, each student is facilitated to move as fast as possible on a cognitive complexity growth track and on other growth tracks as well.

At each level, the parts (pieces, sayings, stories, episodes) and the whole (the whole great panoramic sweep of the great controversy from etemity to eternity) are taught and interrelated. At the earliest level, students learn an oversimplified picture of the whole, with few interrelationships. More parts and stories are added through the levels, until a complex, accurate whole picture with breadth, depth, understanding, and meaning develops at the highest levels. This deeper conceptual understanding demonstrates many parts and interrelationships among parts and parts, and between parts and the whole.

The developmental model, which makes the Scriptures foundational to students' and teachers' lives, might have pleased Alma McKibbin, who spent her life trying to achieve the goal of making the Bible the foundation of education. When once asked why she felt it imperative for Seventh-day Adventists to maintain their own church school system, she replied that children would know,

See Bruce Joyce and Marsha Weil, Models of Teaching, 3rd ed. (Englewood Cliffs, V. J.: Prentice-Hall Publishing Company, 1986), 452-24. 
when taught to believe in the Bible and practice its principles. "more than the wise men of earth. ${ }^{n 1}$

Studying the life of a Christian educator fumishes many insights, which have been summarized in the preceding pages. Mrs. McKibbin provides an example of how a pioneer Christian educator integrated her beliefs with her methodology, writing, and practice in the historical setting of the Seventh-day Adventist church school movement. Her story is not unlike those of educators today, if they choose to wrestle with ways to blend Christian values with teaching, learning, and practice. Perhaps in the following words, written after returning from a speaking engagement to the future teachers of America. Mrs. McKibbin leaves no greater challenge than for all Christian educators to persist in this process:

I did appreciate being permitted to express once more my faith in the principles of Christian Education. Perhaps we believe in them as firmly as ever, but somehow I seldom hear them mentioned. Perhaps now they are taken for granted, but I think it well that we examine ourselves from time to time to see if we "be in the faith," and perhaps we older teachers can do nothing better than to remind all of these fundamental principles.:

\footnotetext{
Alma E. McKibbin, [no title] AMs, p. 2, Adventist Heritage Center. Andrews University, Berrien Springs, Mich.
}

:McKibbin to Ragon, 5 July 1944. 
APPENDIX A

SAMPLES DF MCKIBBIN BIBLE BOOKS

Reproduced with permission of the copyright owner. Further reproduction prohibited without permission. 


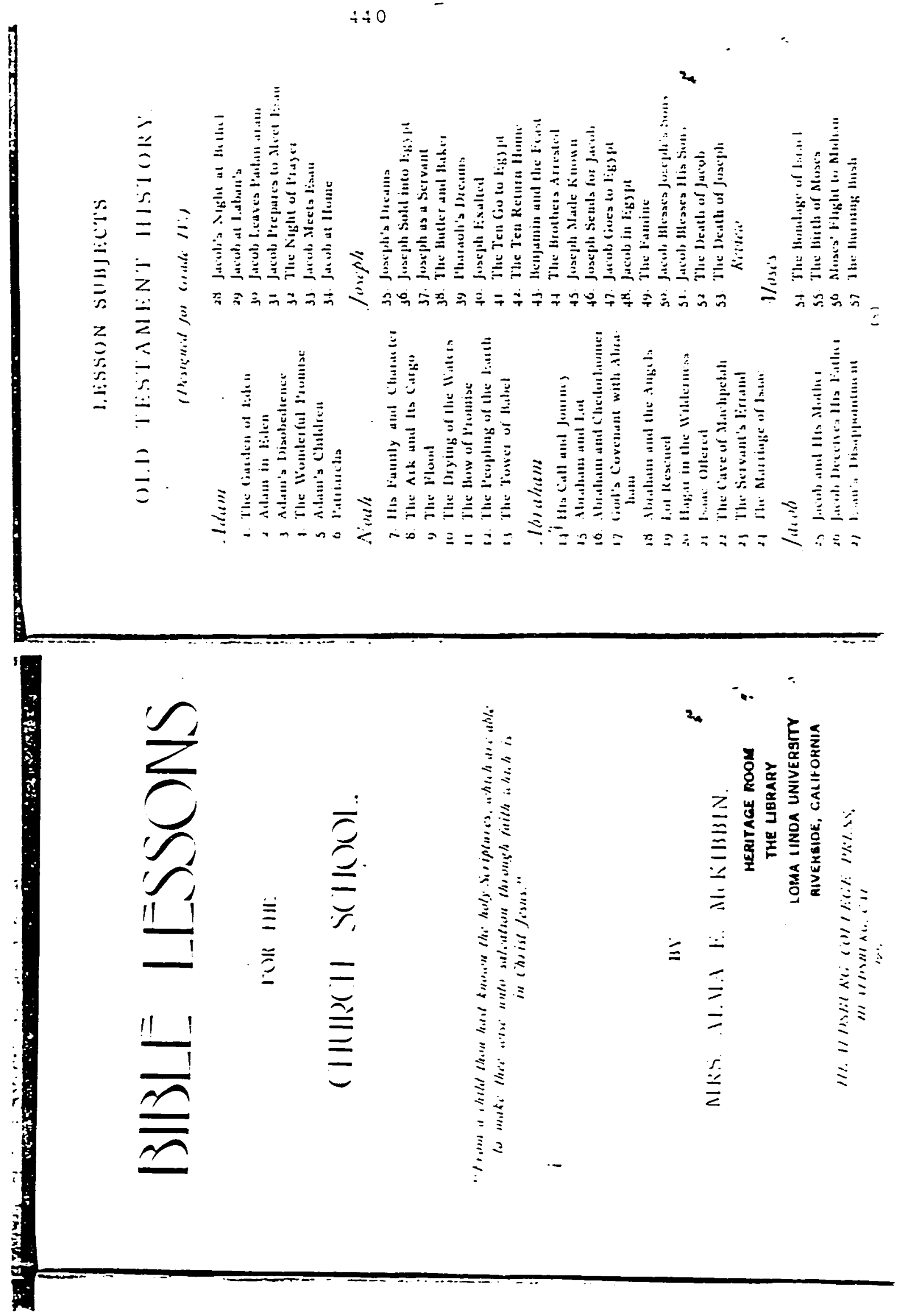



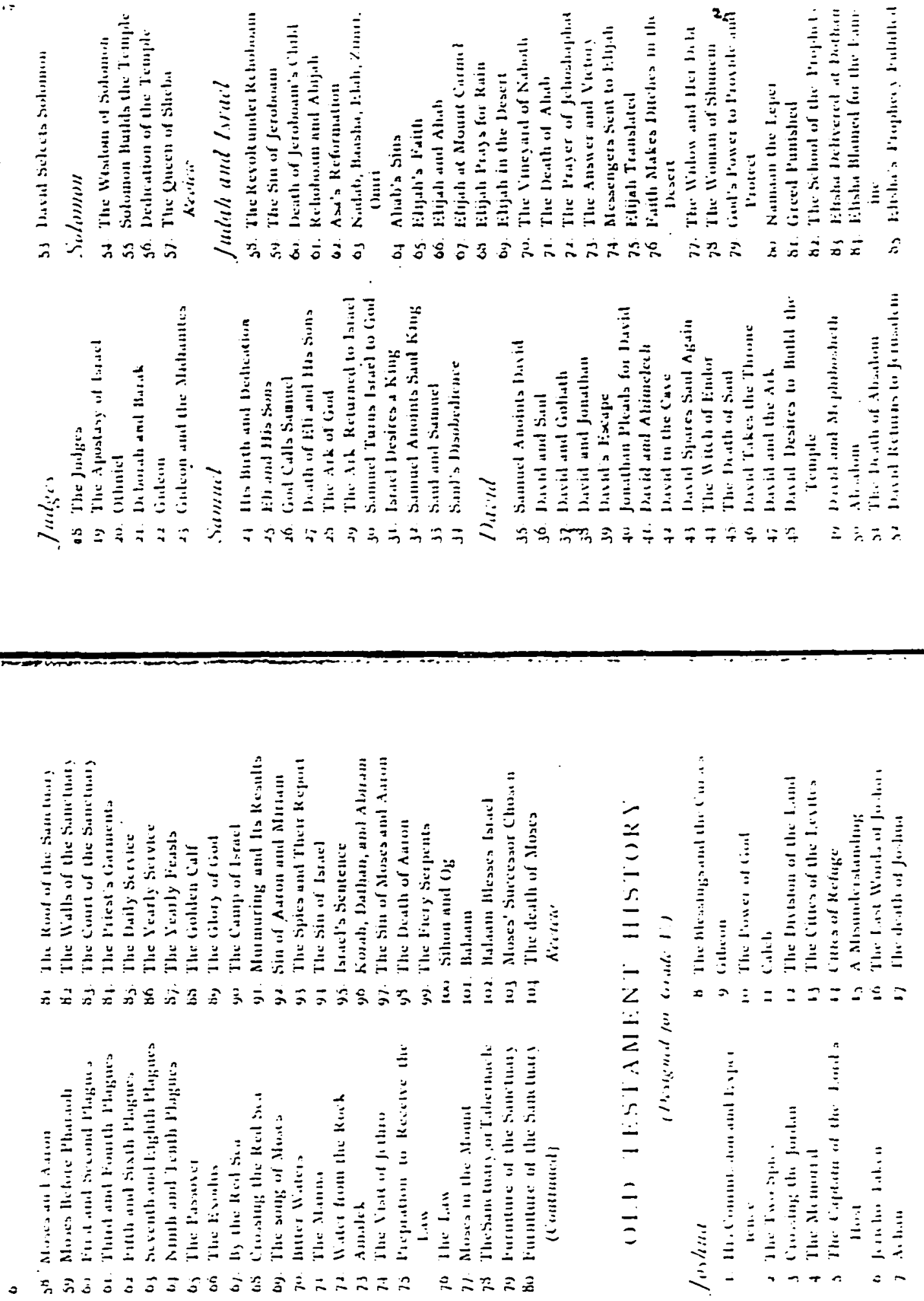
$=$

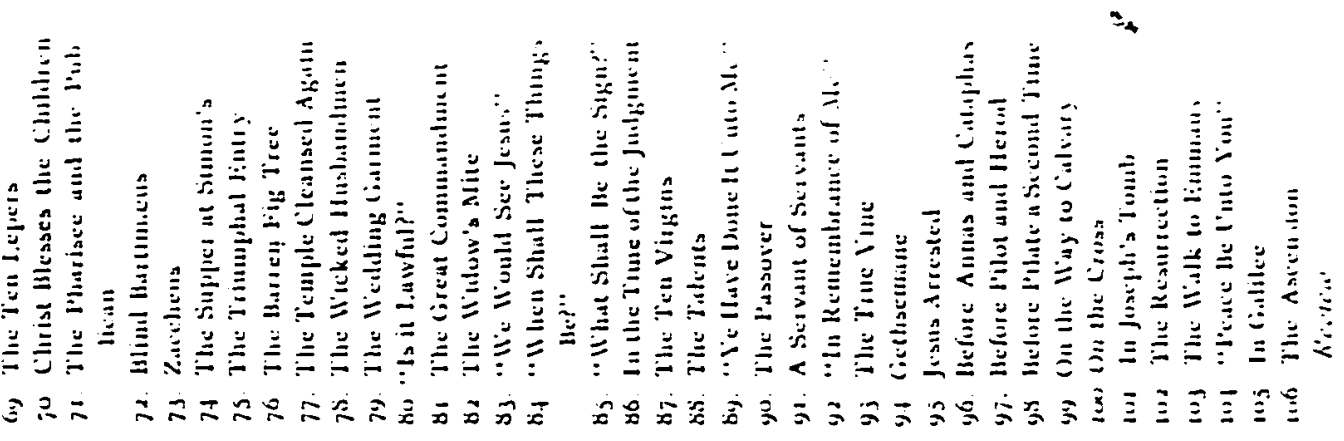

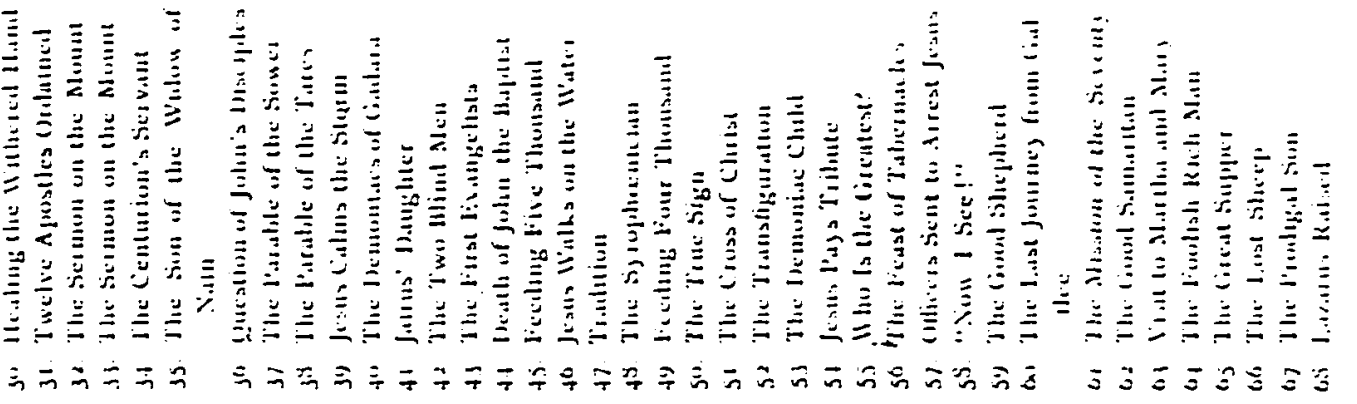

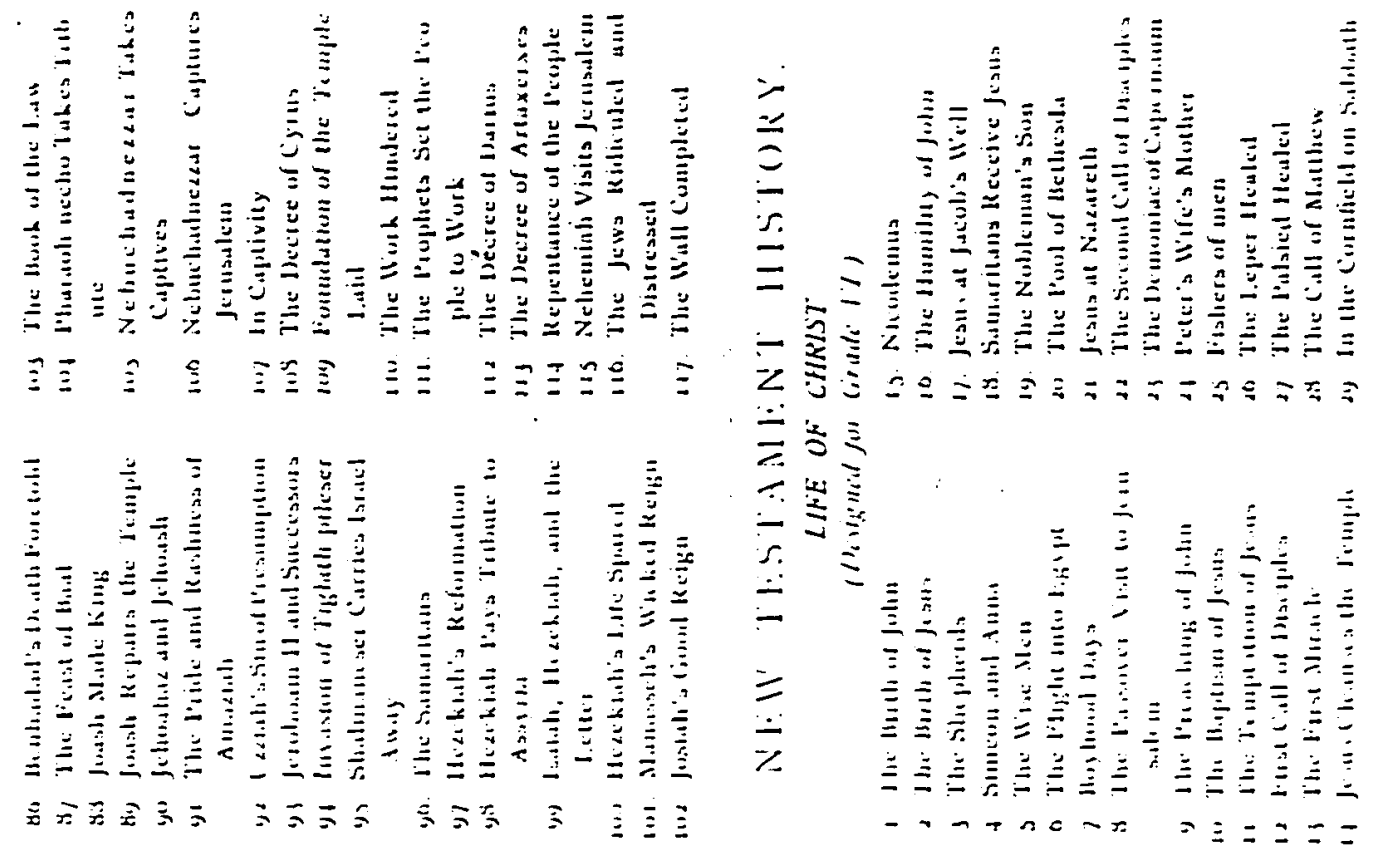




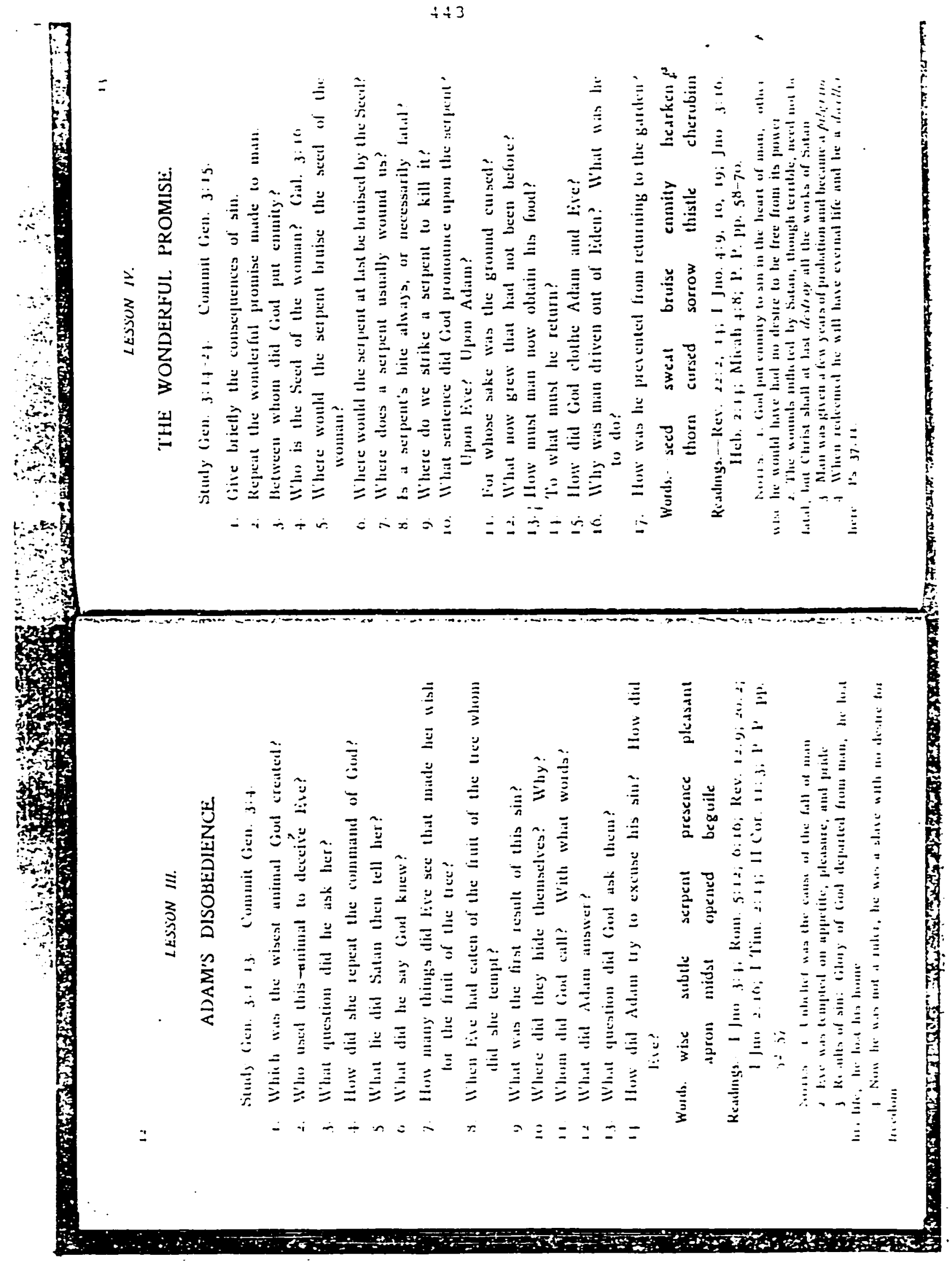



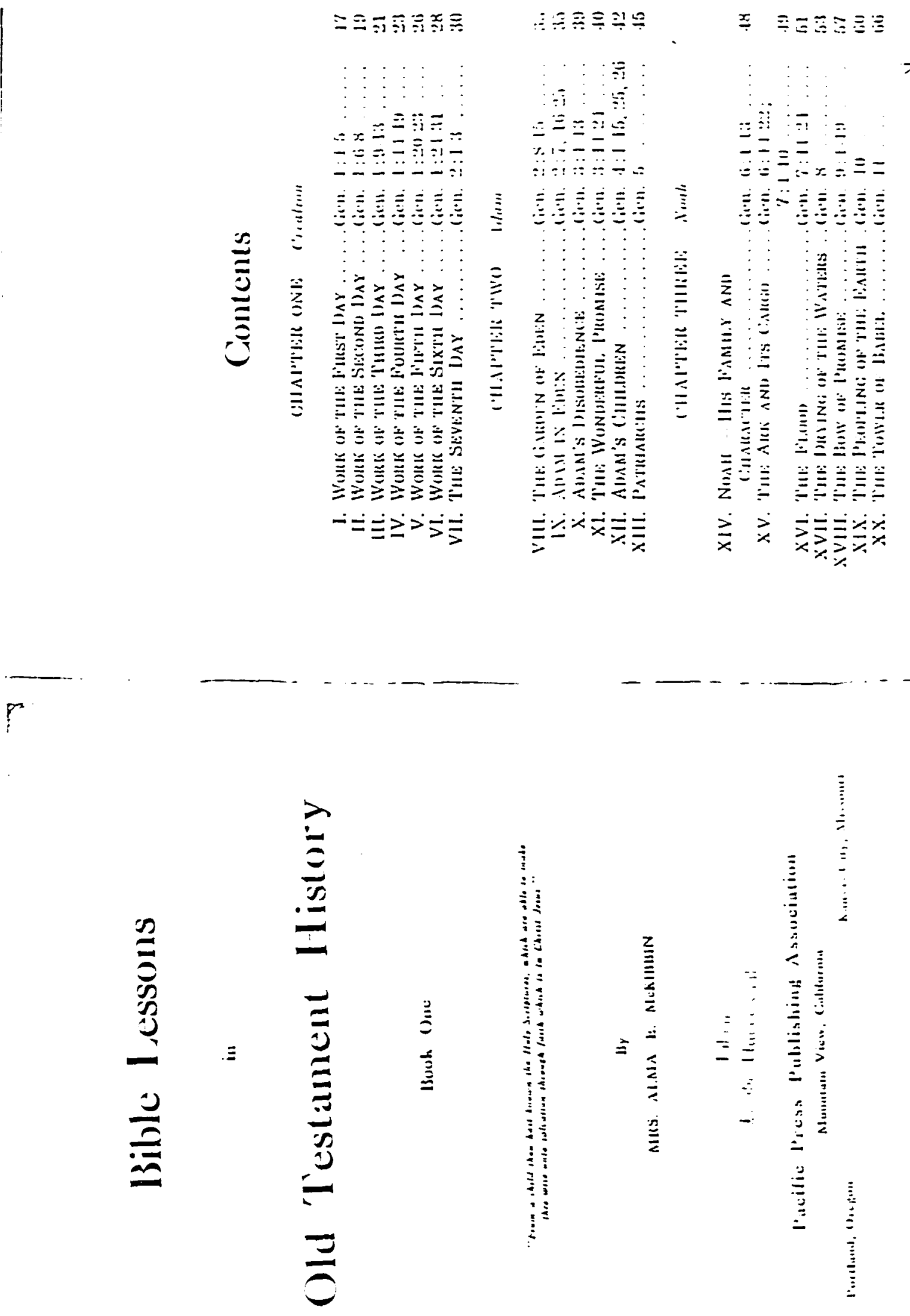

?े 


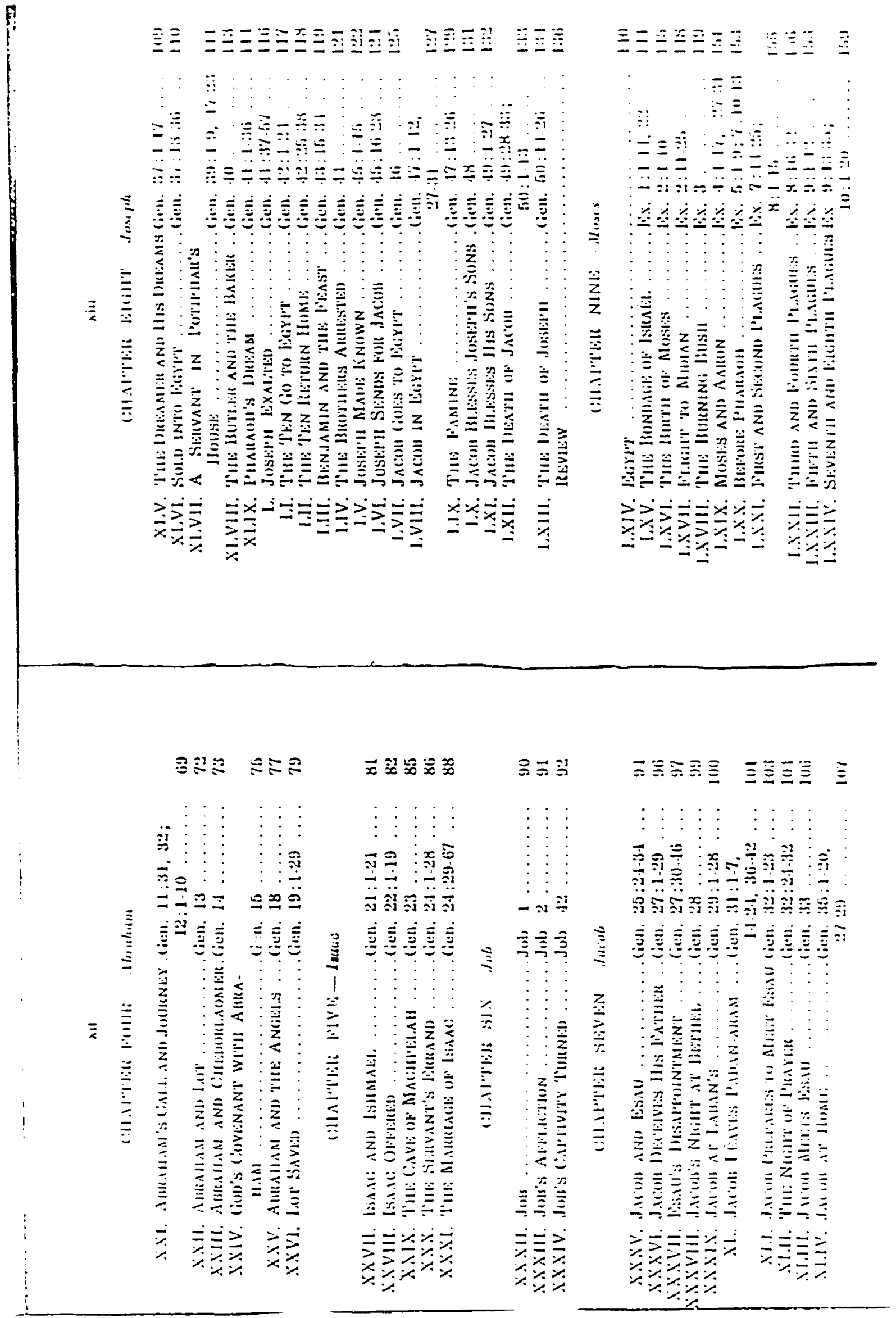




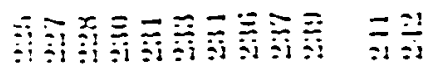

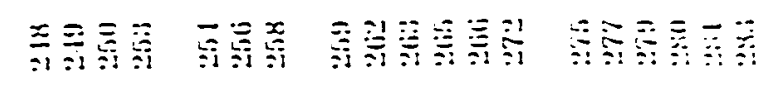

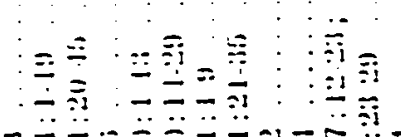

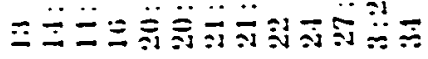

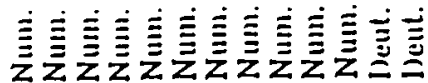

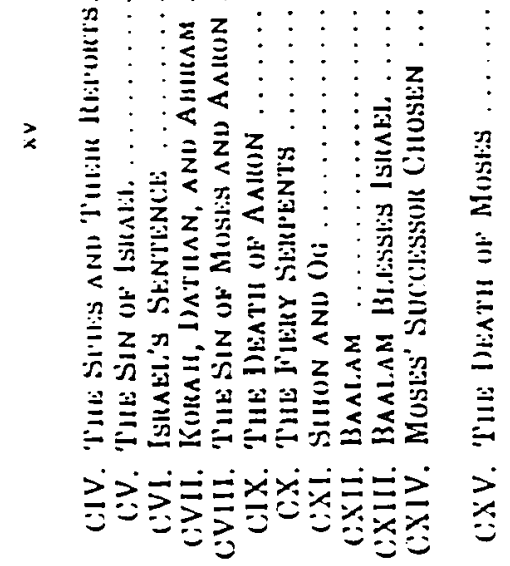

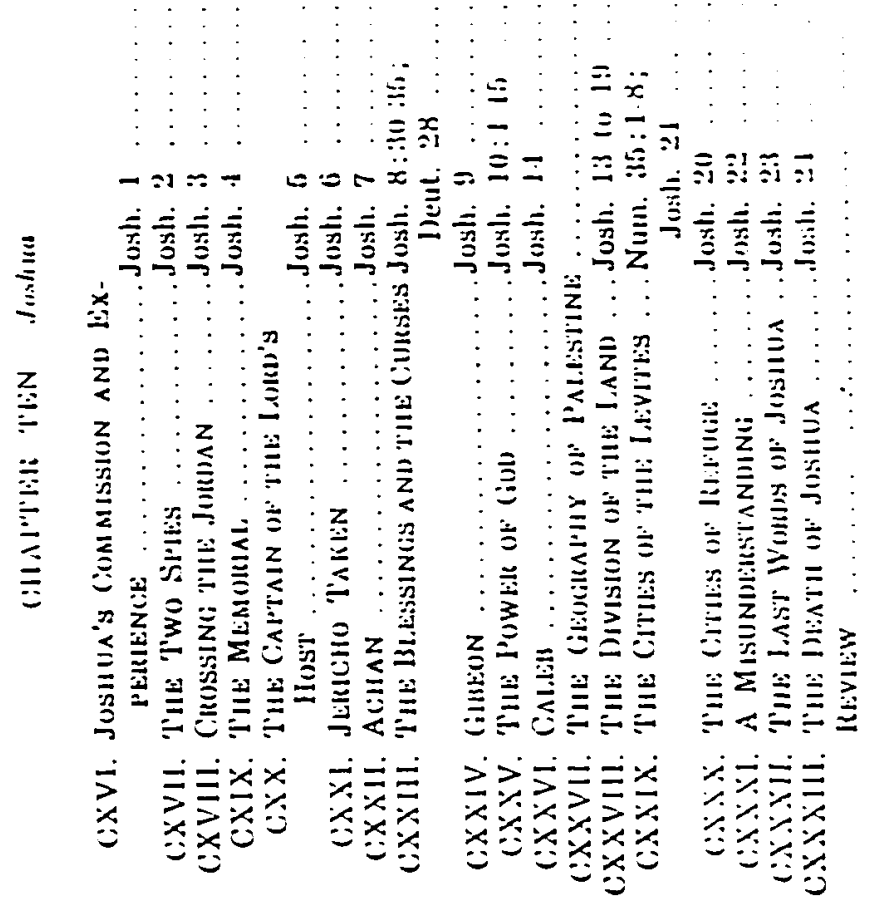

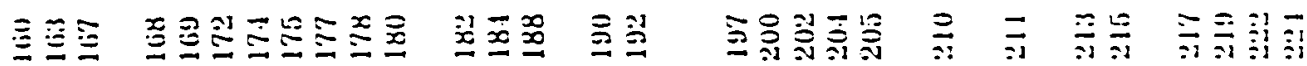

$=$

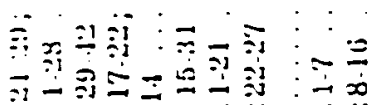

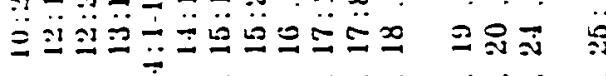

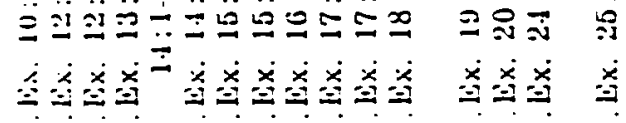

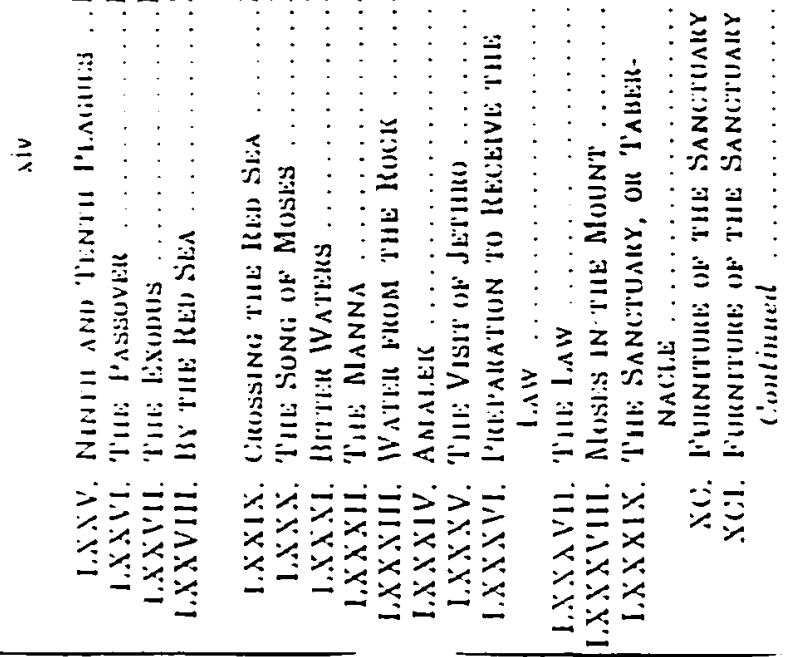



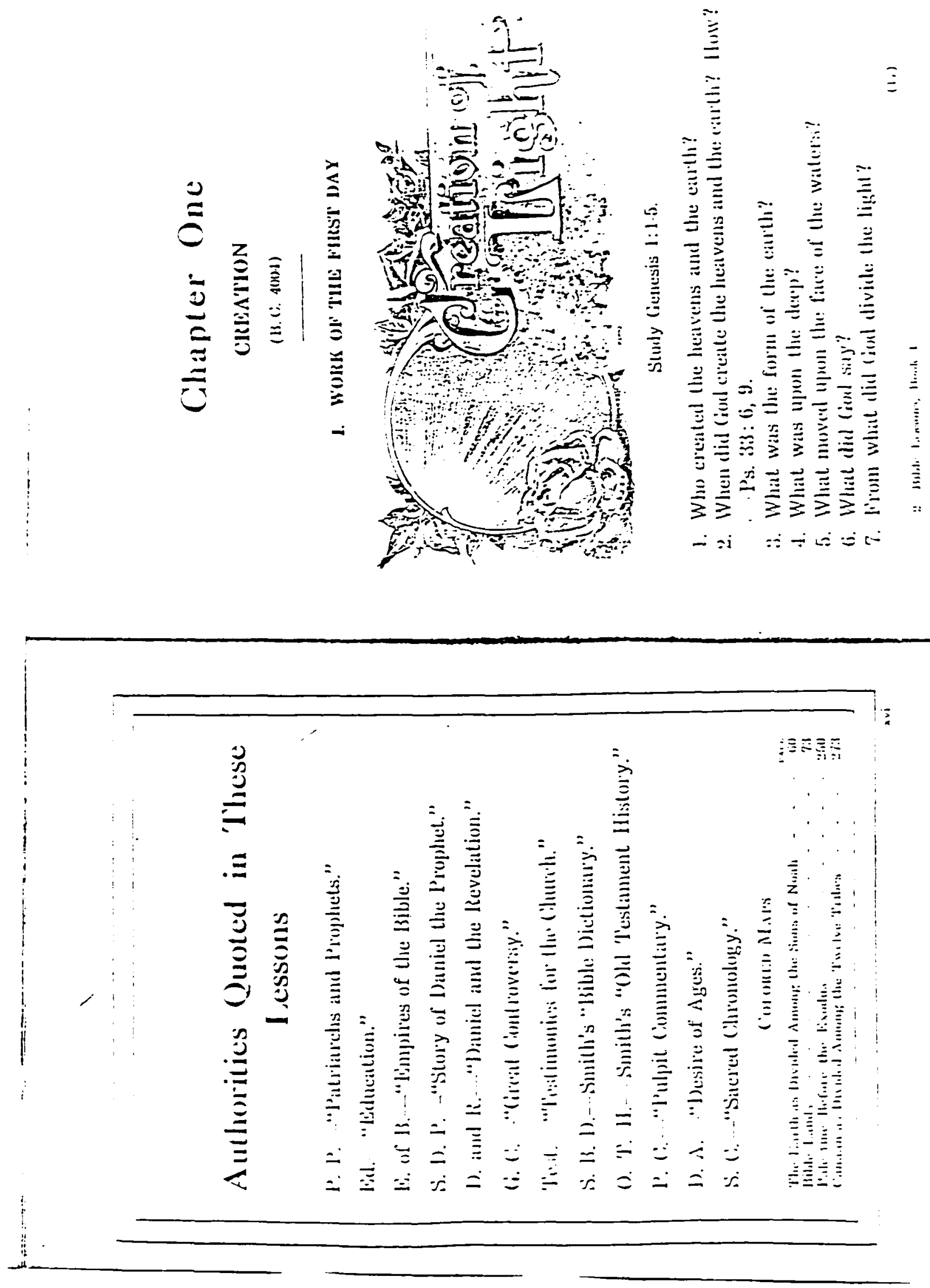
18

8. What did He call the light? the datkness?

9. ()f how many palts wats the first day composed?

10. Whith wats first, the morning or the evening?

\section{Readsuts}

H1:L. $1: 1: 10 ; 11: 3$

(iol. 1:12.17

P's. 89:11, 12; 102:26

\$oler. $10: 12$

1 'I'ill. 6: 10

2 Cor. 1: 6

Lipl. 5: 13

Julul $1: 19 ; 8: 12 ; 9: 5$

Py. $7 \cdot 1: 10$

Mult. 17::2

1 Julin $1: 5$

Jub $38: 1-7$

Woids

eatllh voidl night morn'ing dark'ness

leav'en deep light e'vening begin'ning

\section{Memuly Verac}

By the word of the lord were the heavens made; and all the hesst of them by the breath of His mouth. P's. 33: 6 .

\section{Notes}

1. 'lhis song is sung around (iod's throne: "lhou hast crealed all things, and for 'Thy pleasure they are and were createal." liev. 4:11.

2. Civol talkes pleasure in everything He createy, if it does the llimg for which the mate it.

3. (ion "formed the earth to be imhabited." "This was His purposic, His platsure.

4. Only (iod can cleate, for to crealle means lo callse somelhing lo be that has not existed before in any form. It means lo malie simmelling ont of mothing.

5. 'llae worlds were made by Jesus. "liy Him were all lhing:i creatled, that ate in lieaven, and that are in eath." (iol. $1: 16$

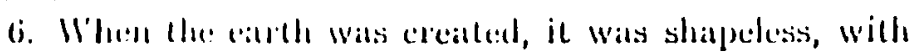

I!)

mothing in it not upou it, but simply a mil:., of mand anıl Water covered will darliness.

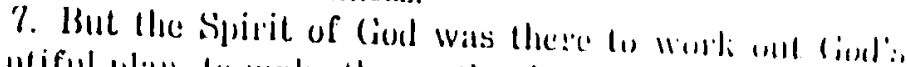
beantiful plan, to make the earth what lle wi:ilal it lo la.

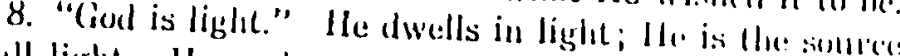

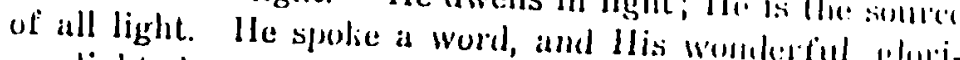
ous light shone upon the earth.

9. What is the color of light? Of what culul'i i:i it eum

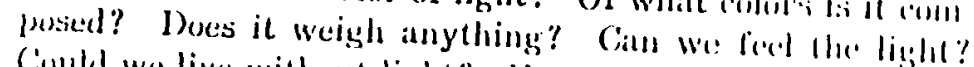
('ould we live withont light? How many thime: have in order to live? Is light one of theill?

\section{WOIEK OF 'IILS SLCONI) IDA}

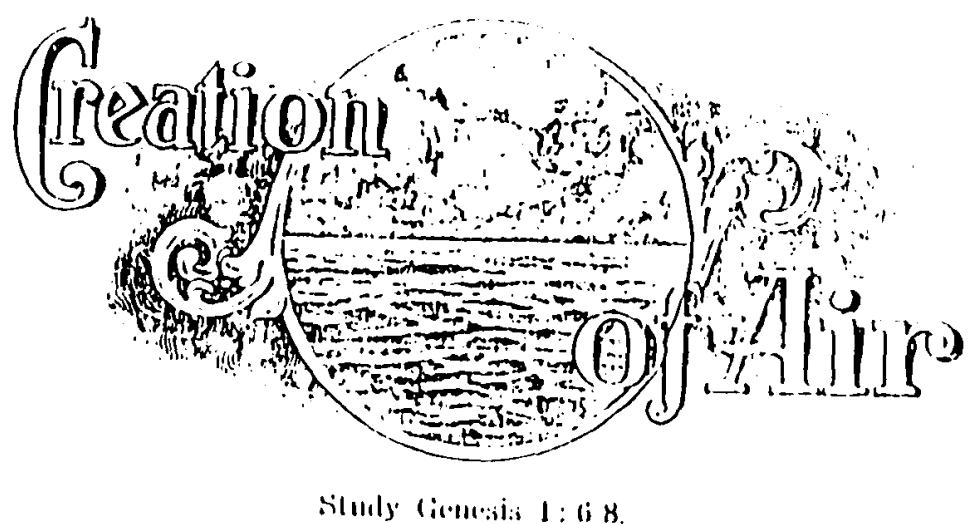

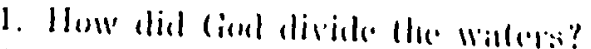

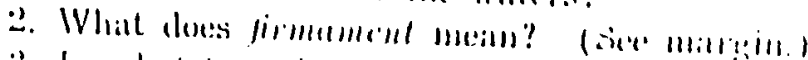

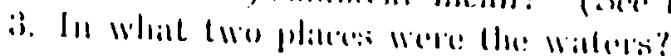




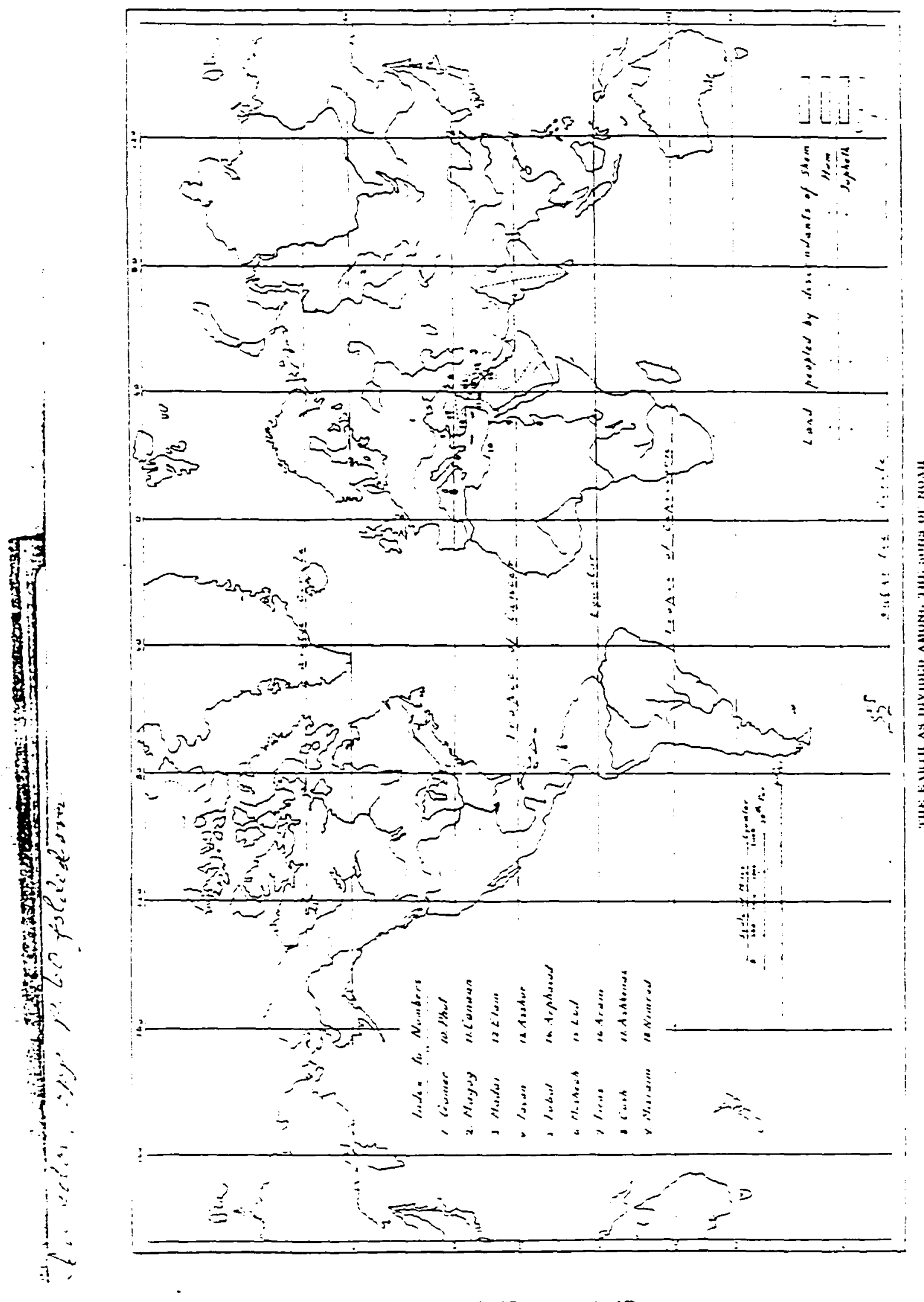




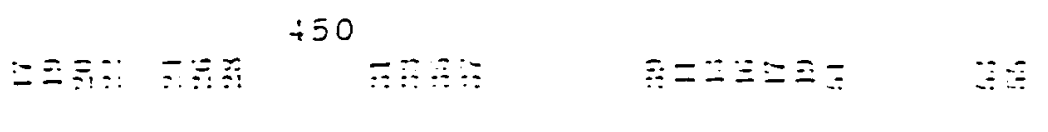

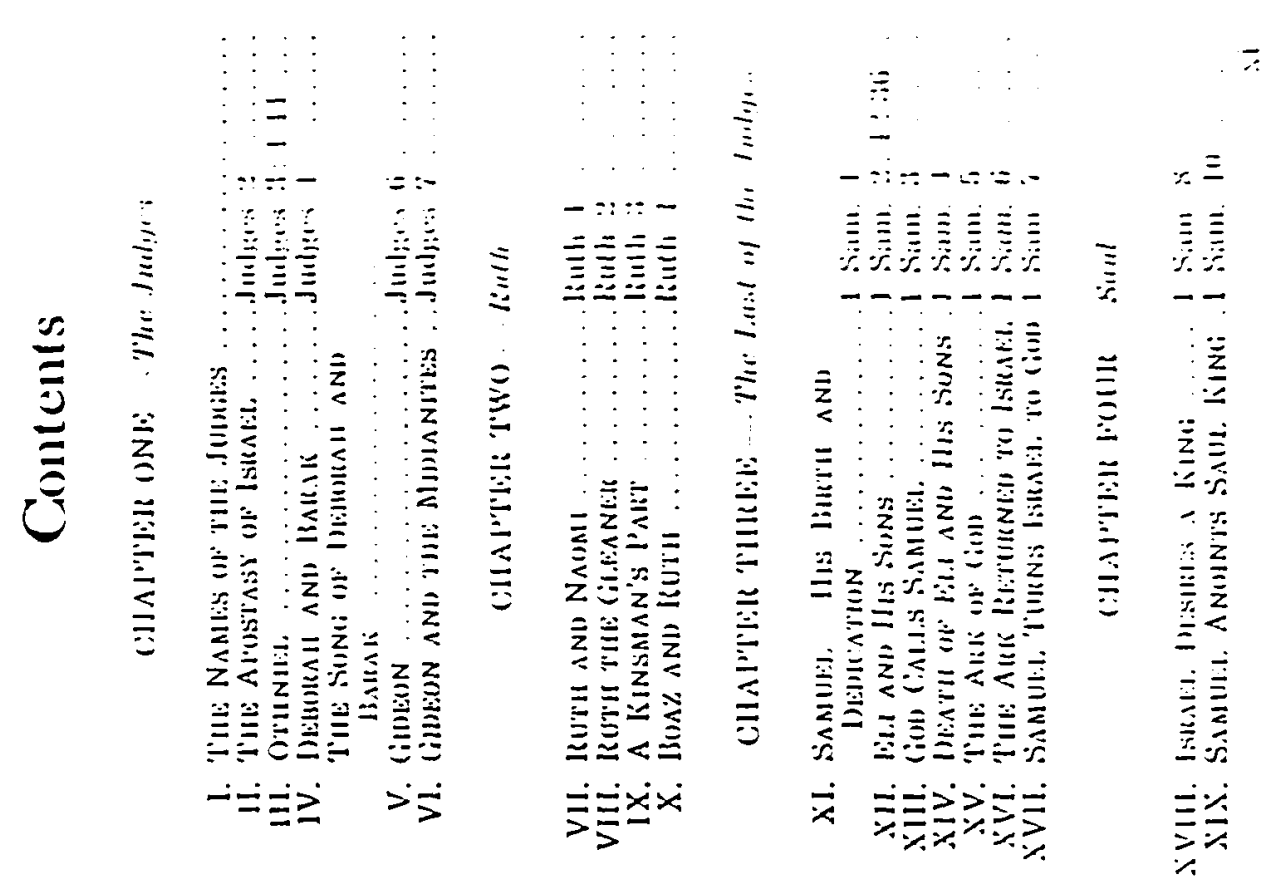

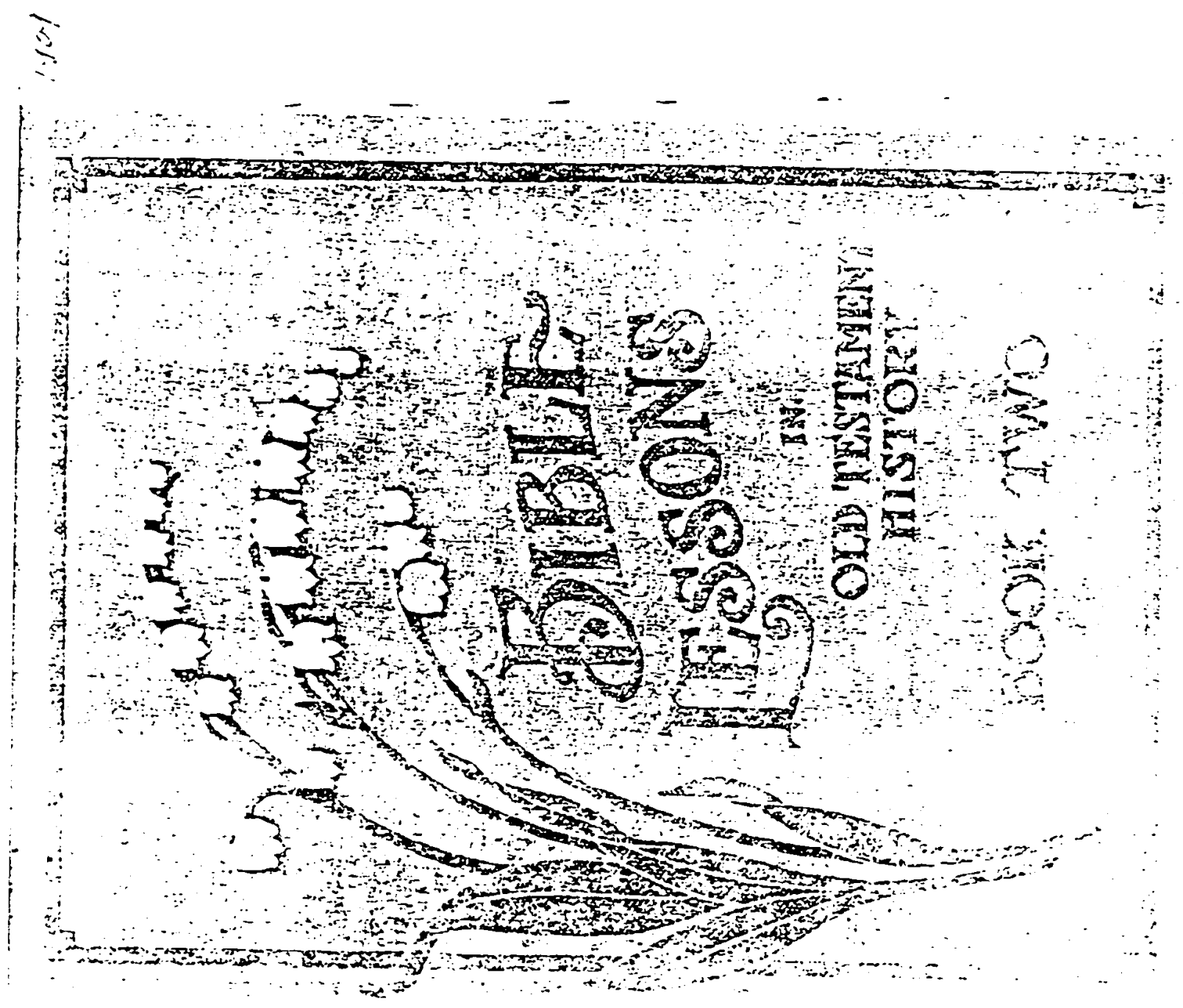




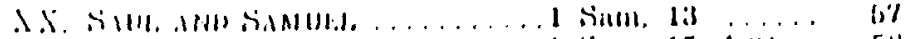
Xil. 1 Simm 15:1-31

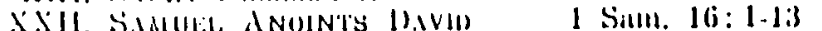

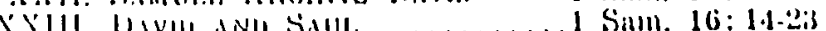
XIV M.11

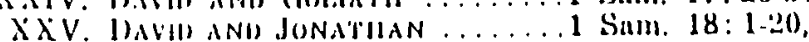
28.30

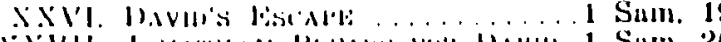

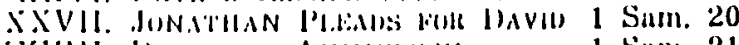

Sivill lowin

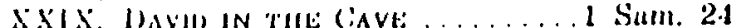

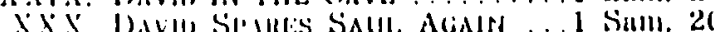

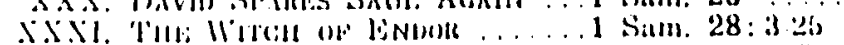

犬.

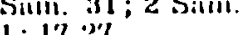
$1: 17 \cdot 27 \ldots \ldots$

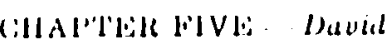

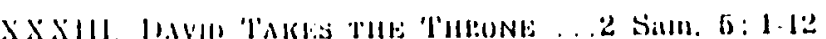

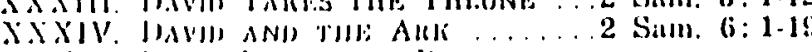

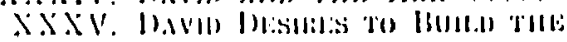
plimiliti:

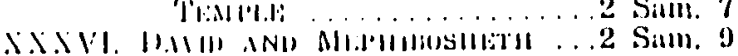

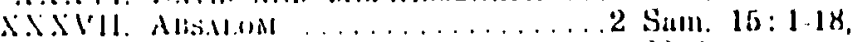

2i3, $30 \ldots \ldots \ldots$

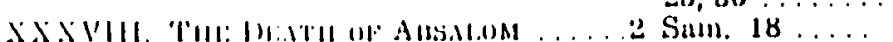

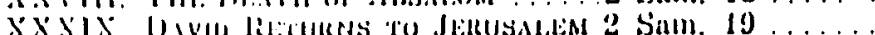

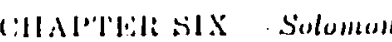

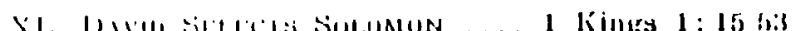

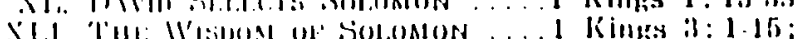

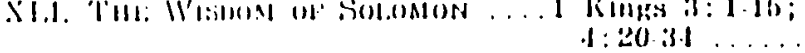

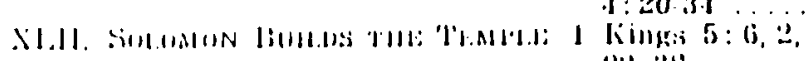

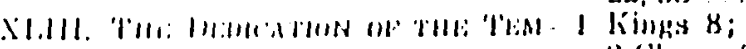

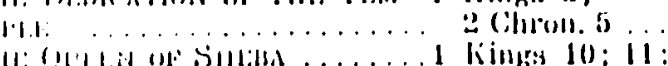

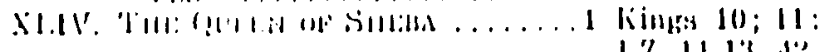
$1-7,11 \cdot 13,12 \ldots \quad 101 i$

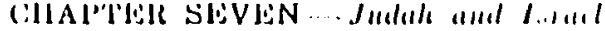

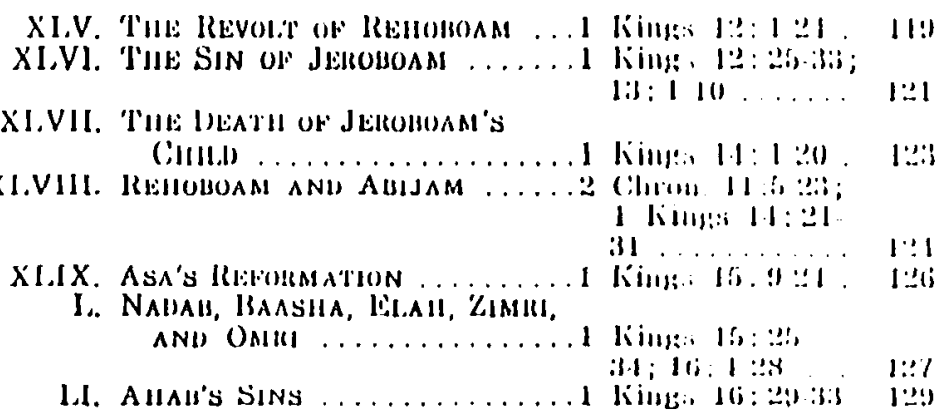

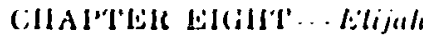

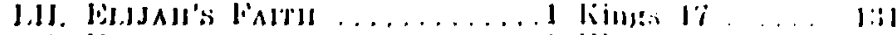

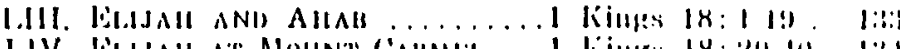

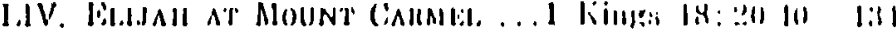

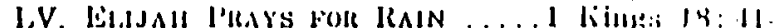
lli: $1: 1: 1: 3$

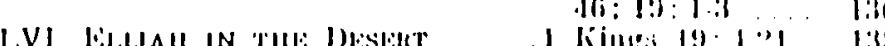

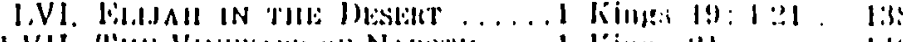

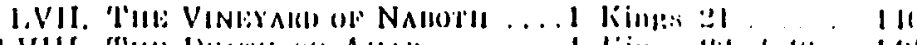

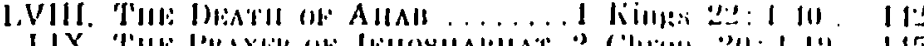

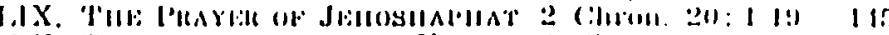

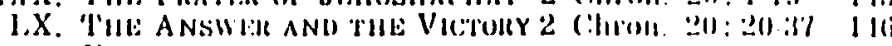

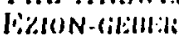

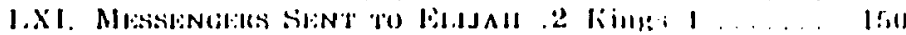

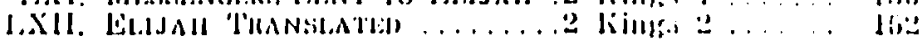

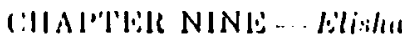

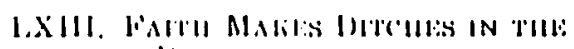

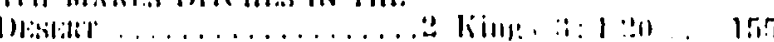

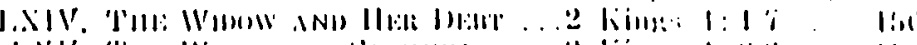

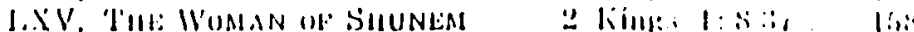




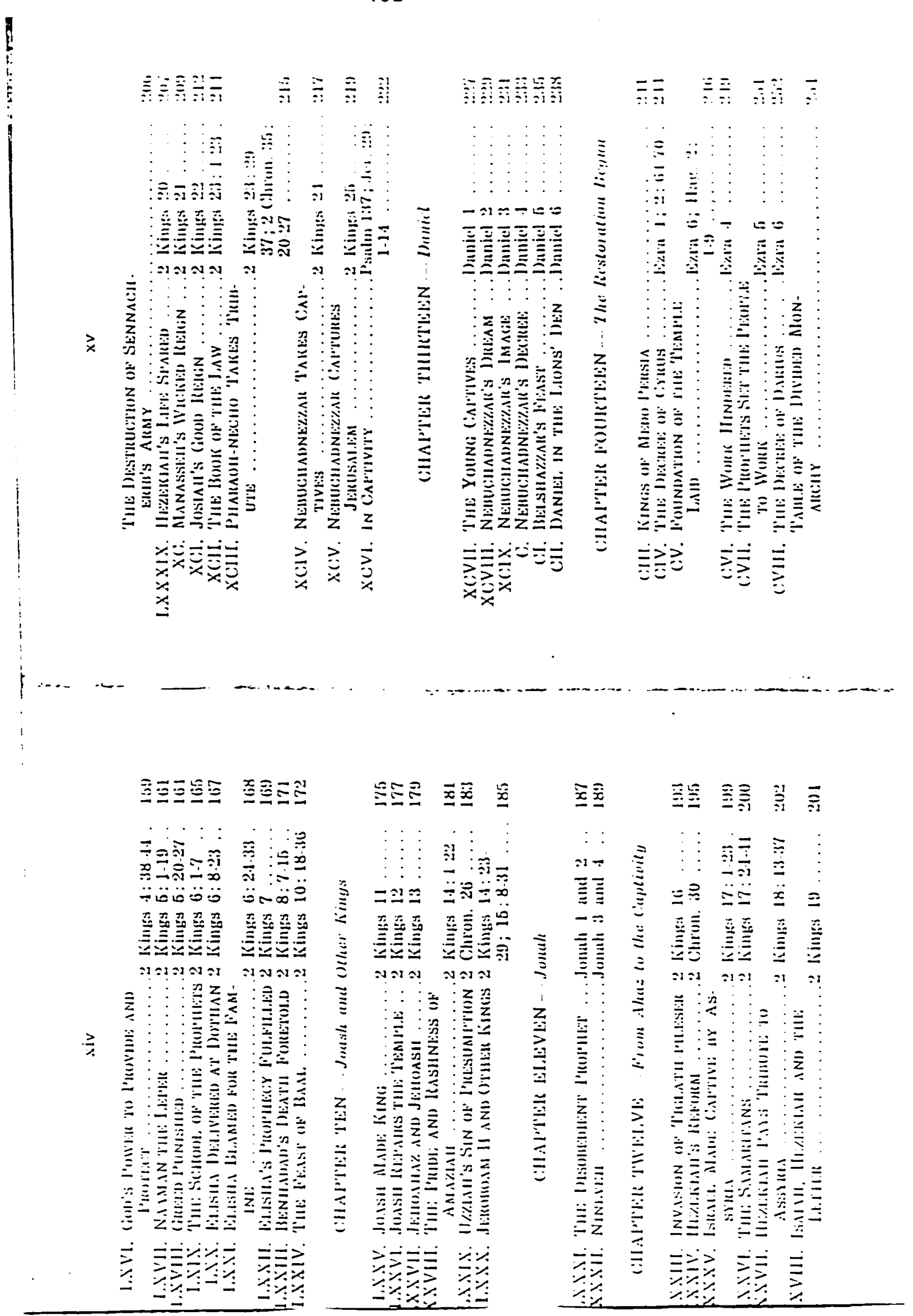



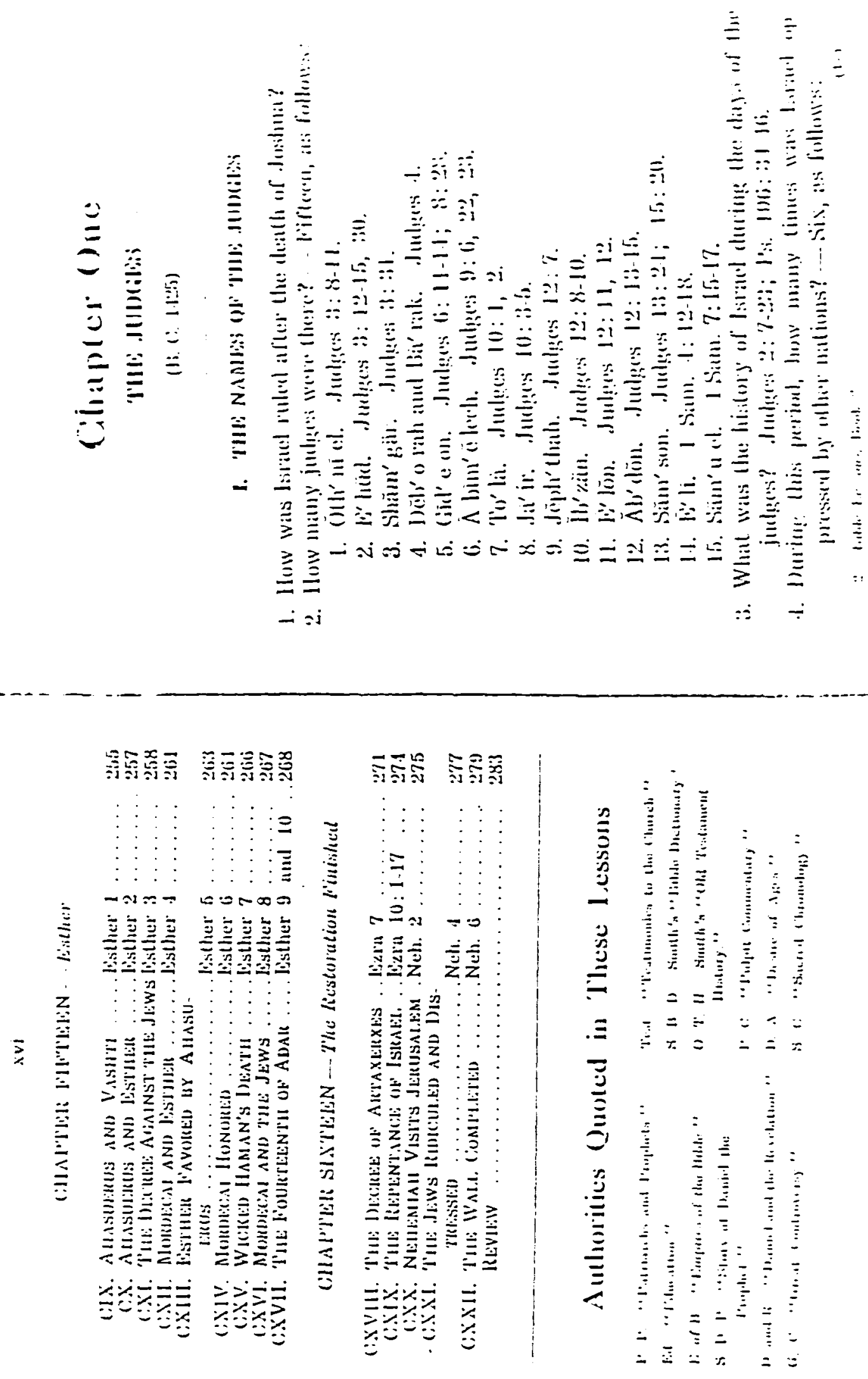


\section{0}

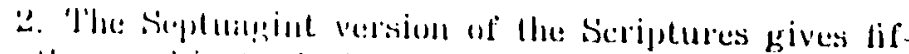

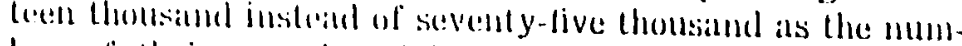

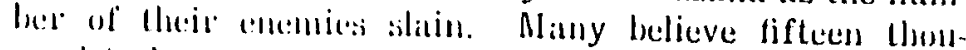
sialld to be correce. 'lihe Jews were only fighting to save

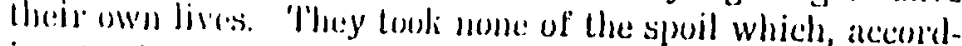
ing to the usianess of will, rightefully belonged to them.

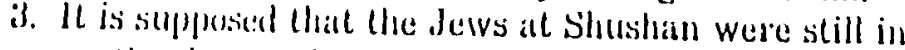
dithger all lle chese of the thirleenth of Adar. Listher there fore asked that lleeg mignht be allowed to stand on bie de demsive for anollure diay.

4. 'The dews in the povinces had mate the fontecenth diag of Mdar a diay of thathlistriving; the Jews of Shushan

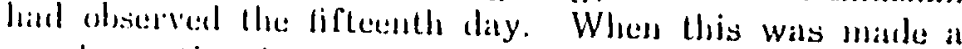

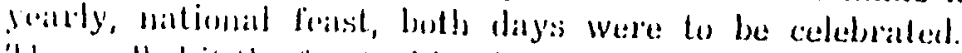

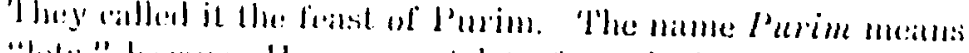

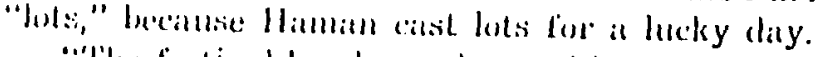

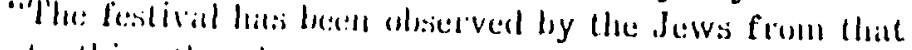

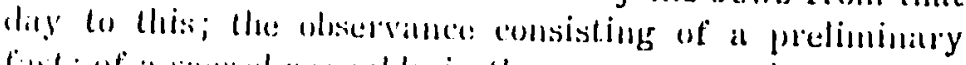

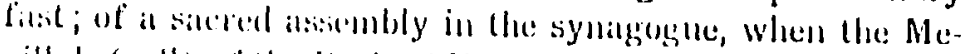

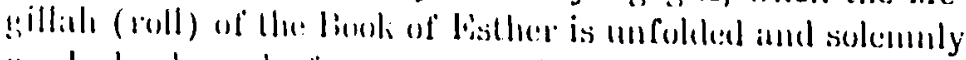
reald alould; and of a repatst at home, followed by merry-

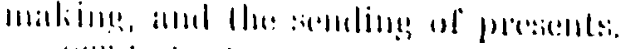

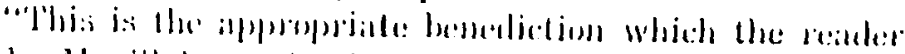

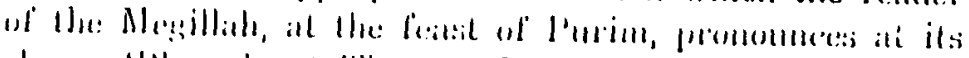

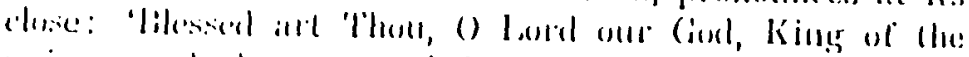

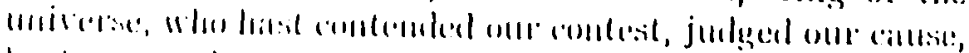

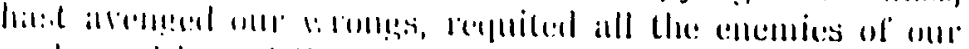

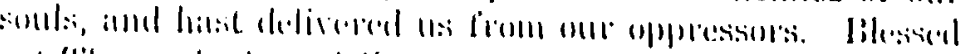

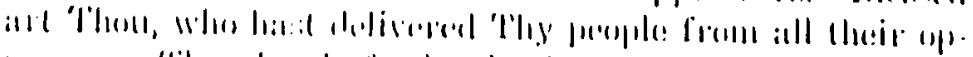

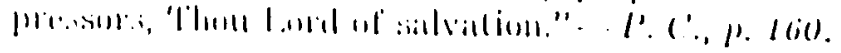

\section{Cihapter Sixteen

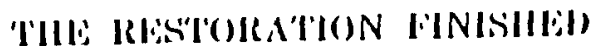

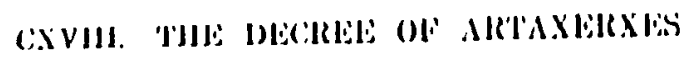

\author{
(1i. (i. 45 ii) \\ Silul) bis, i
}

1. ()f What tribe and family Wats liatal?

2 What was his poufessimu?

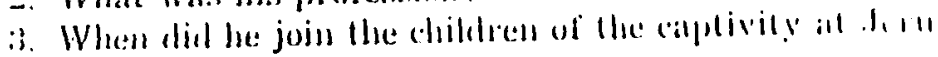
sillioli!?

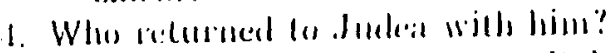

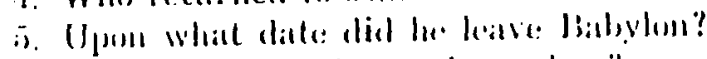

i. When did he arrive all lormsiale m?

7. What had borat prepalled lo dos? Howe?

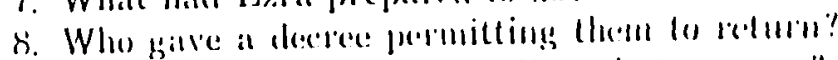

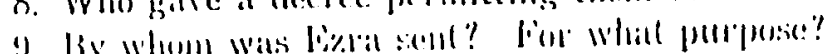

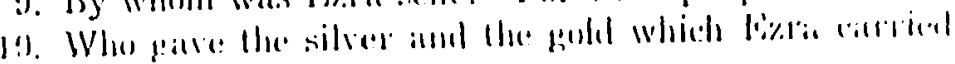

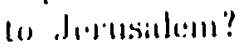

11. IVhall was he lo hoy with il?

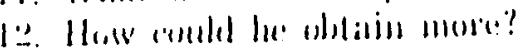

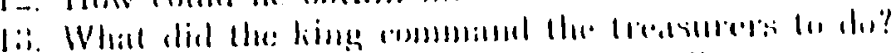

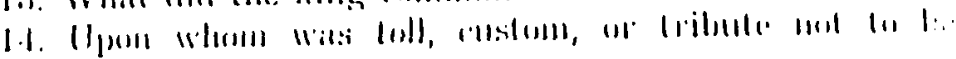
impusect?

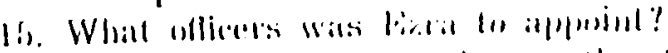

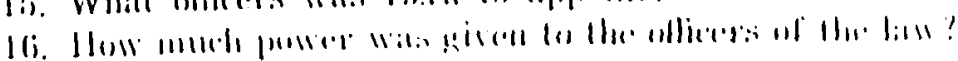

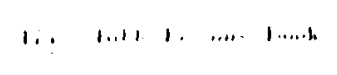



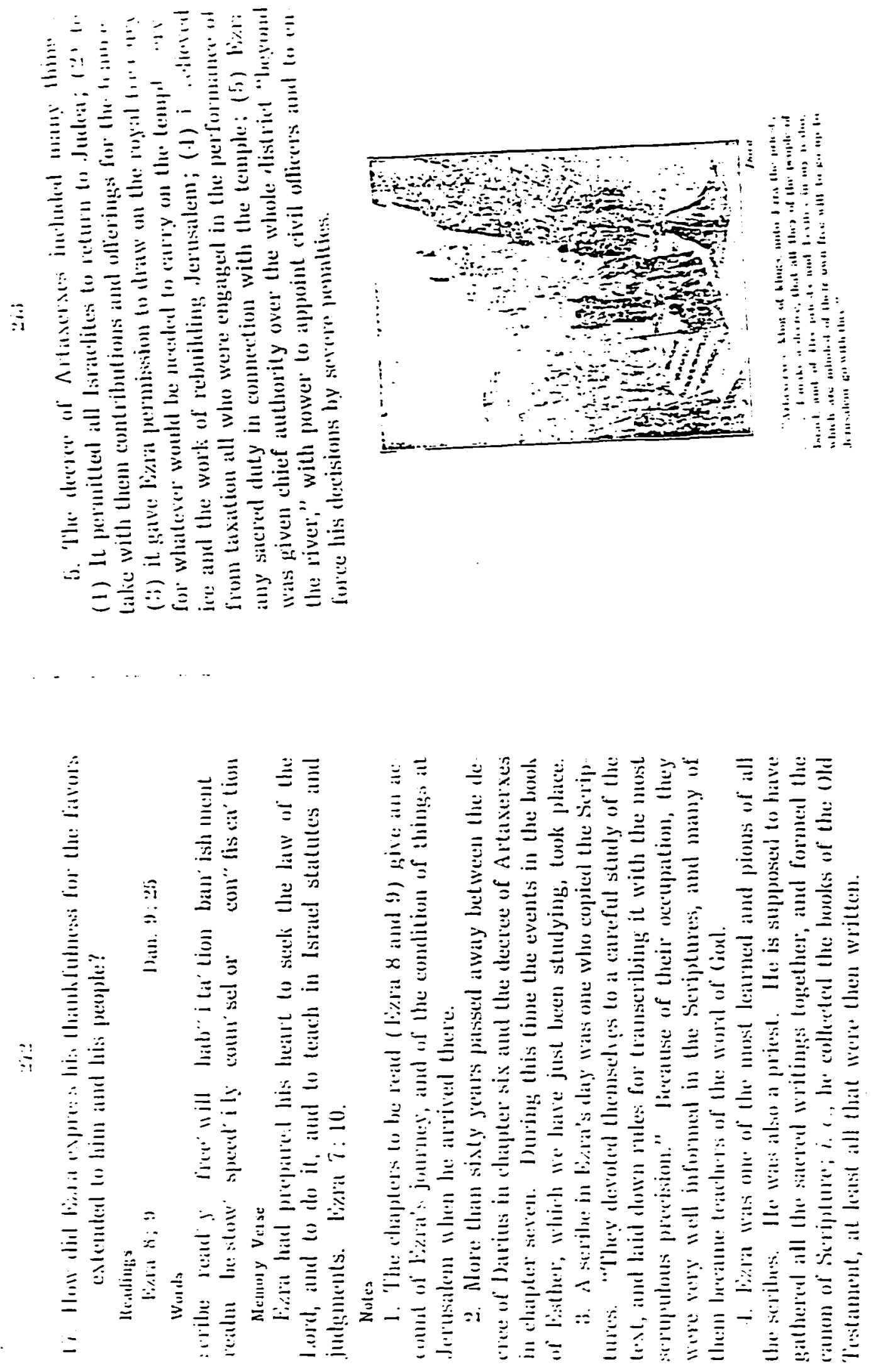


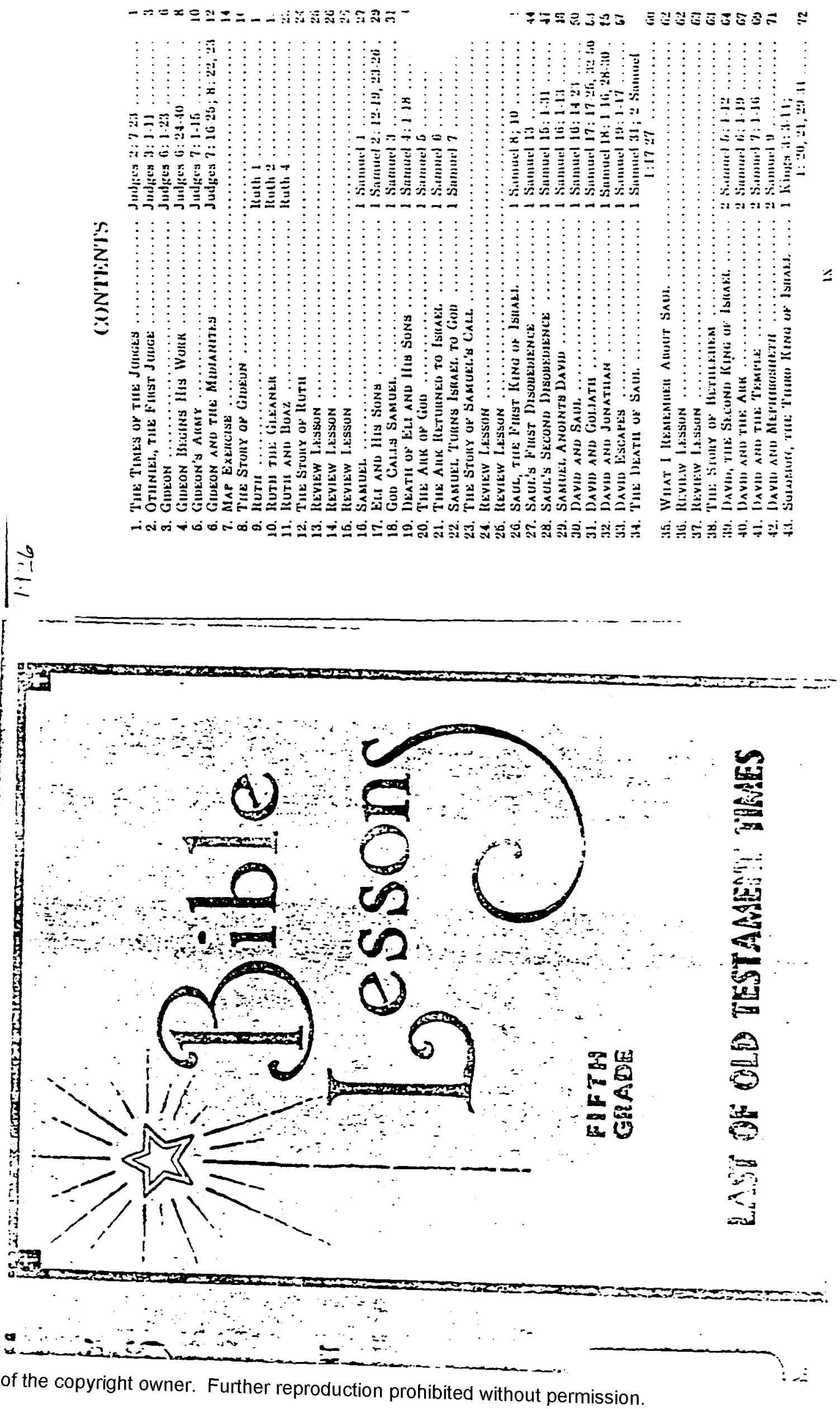

Reproduced with permission of the copyright owner. Further reproduction prohibited without permission. 


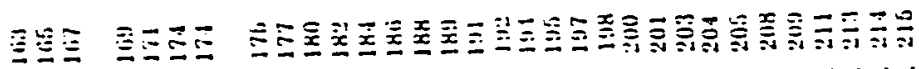

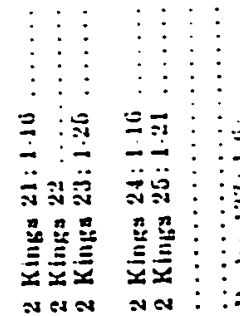

$$
\begin{aligned}
& \bar{z}:=
\end{aligned}
$$

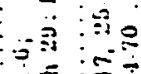

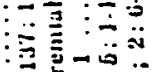

\section{-

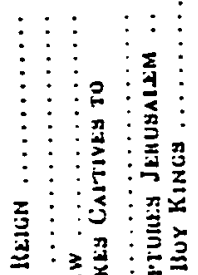

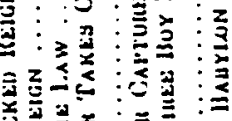

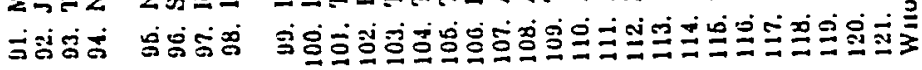

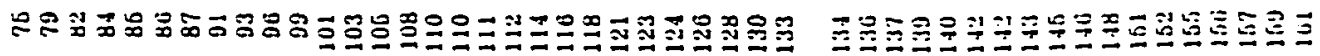




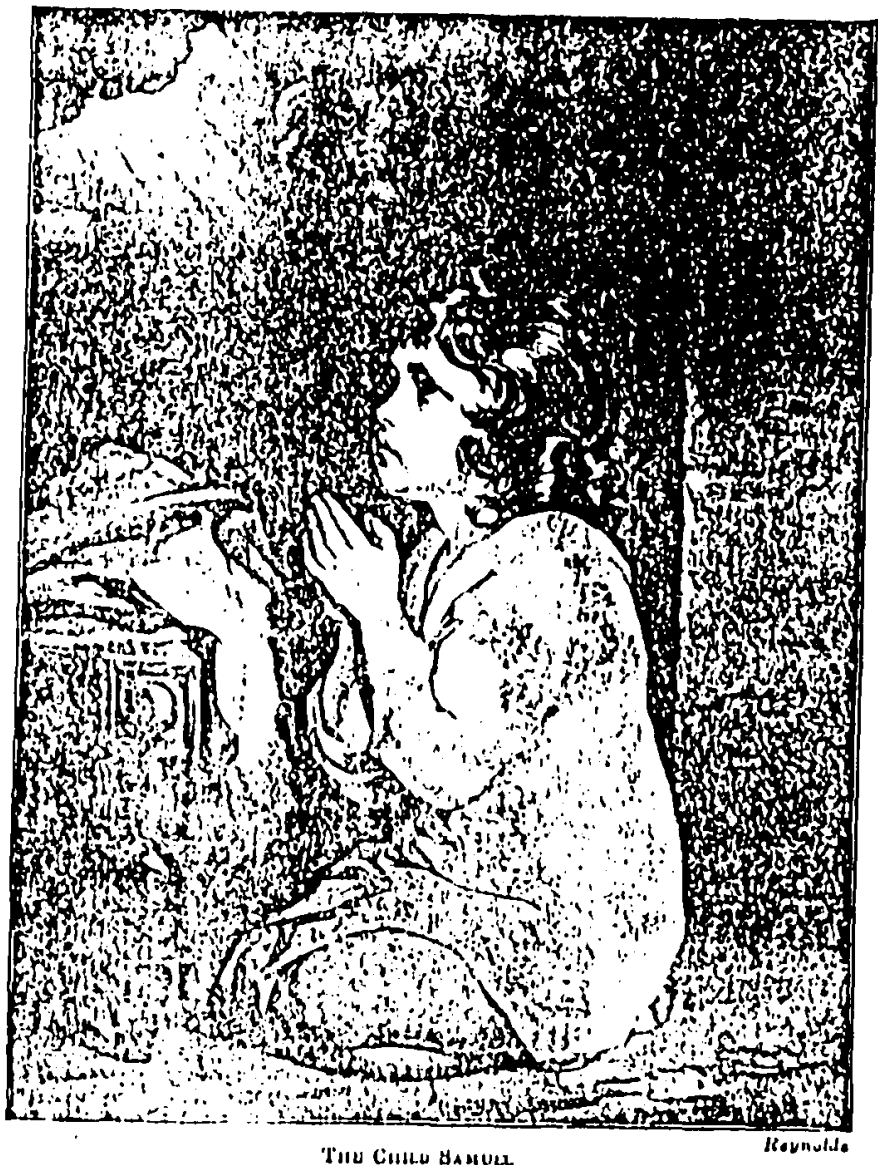

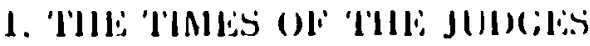

Study Judges $2: 7-23$

laract fiorsatees the loord. Judgey 2:7-15

1. How long did lstatel serve the lord?

2. How old was Joshera when he died? Where wats he: buried?

3. What difference was there in the next gencration after Joshuia?

4. What gods did the new generation serve?

5. Into whose hands were they delivered?

'The Lord Gives 'Them Judges. Judgey $2: 16-19$.

6. Whom did the I cord raise up to lielp lstatel?

7. What did the lord help the judges to do?

8. Were the people obedient to the I oril?

9. When a judge died, to what stubborn way dis the people again Lum?

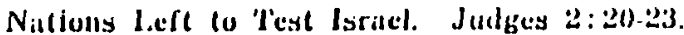

10. Why did the ford not drive out any more of the nattions left when Joshua died?

11. How would these malions test, or prove, limalel?

lromounce
lia il
Asth' las roll
(iai" isil
13a' al im
Asli' to reth
ls' lat el
Josht 11 at
(tim' nath-ho' loce)

Mlemary Verse

The people served the Iord all the days of Joshuar, and all he:

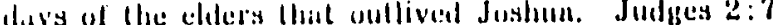


Nules

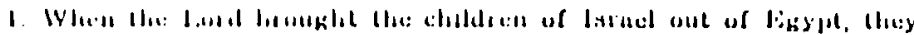

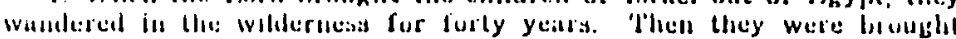

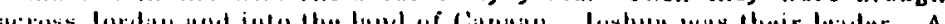

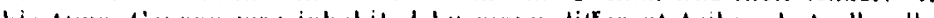

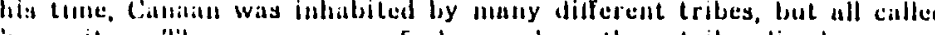

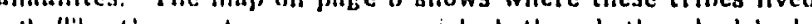

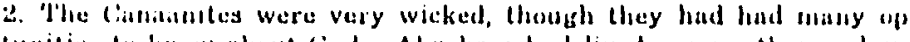

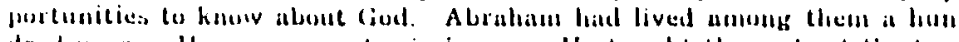
dreal years. He was a grealt missiomary. He taught them about the true (iod. Isare and Jatobs also had lived there. The Canamites had heard of all the wonderful things (jod did tor larael in beypt and in the wilderneys. but they would hot repent. They hated (iod and Hlis people. So they must leave Caman or he destroyed. I'teir land way to be given to the childeen uf Israt.

3. Jushua uverciane and destroyed many of the Canamiles. When he died, the lourd told lsraet they mist drive ont the rest. 'The tribes of Judah, liphrain, and Manassel, destroyed a lew of the Conannite towns; hat they sount trew weary, and the rest of tho tribes did disthings at all.

1. 'lhere were lwo reasons why the lis-

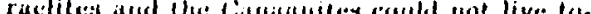

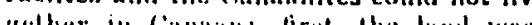
simill for bo uniny sileill for so miny people; secolli, the Cilllaill.

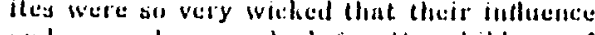

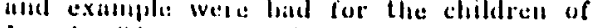

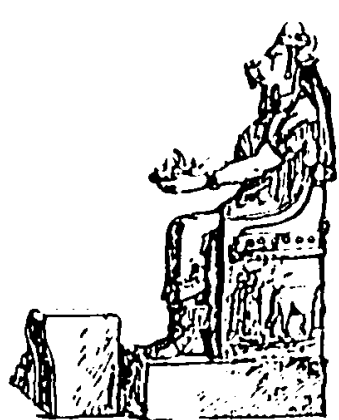

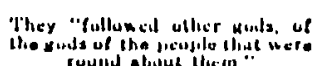

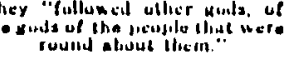

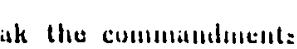
of liod.

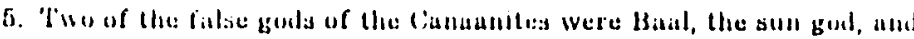

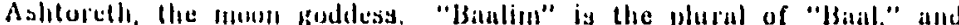
"Ashtiroth" is the plural of "Ashtureth." Mlany other nations, also, worsliphed lliest: gind:

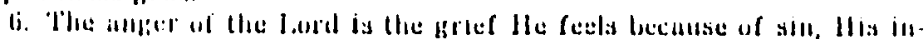

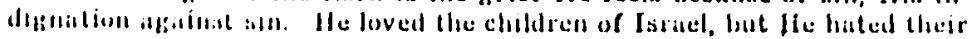

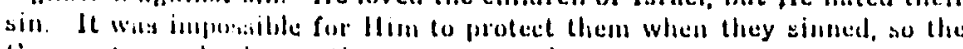
Canaballes and other mations overtiane them.

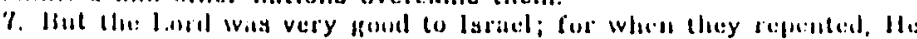

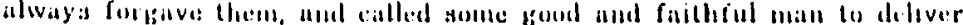

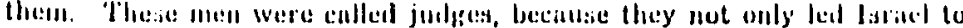

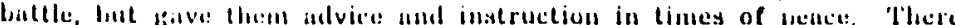

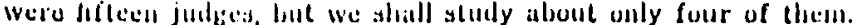

\section{2. o'THNILI., 'THL: lills' JUIMil:}

Study Jurlge:s i : 1.11

'The Canamite Nalluns. Juilgey 3: 1-7.

1. What nations were still left in (ianatin?

"2. What did the ehildien of lstacl learn fiom thesit nat tions?

3. How close to these mations did tsitalel live?

4. Whom did some of the lsmatiles marry?

5. What gods did they serve?

Chushau-rishahaim Oppresses Isracl. Judgey $3: 8$

(i. Who was king of Mesopotamia?

7. How long did (hushan-rishathaim oppress lailan!

Othnicl Delivery Isianel. Judges $3: 9-11$.

8. In Lheir distress, to whom did Isratel cry?

9. Who was catlled to deliver them?

10. Who was Othuiel's father? His uncle?

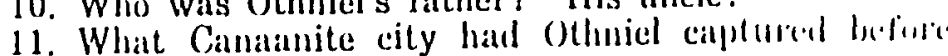
this time? Judges $1: 12,1: 3$

12. What was given to Othniel that made him able lo be a judge?

13. How long did ()thiniel judge lsiatel?

Pronounce

\begin{tabular}{|c|c|c|}
\hline Oth' ni el & Si do' ni an & Ach sals \\
\hline I.ēl' a n non & Bián im & $\left(\bar{a} k^{\prime}\right.$ sa $)$ \\
\hline Iler' mon & Jëb' li sile & Mes" o joulí mi a \\
\hline Cat nalan ite & $K e^{\prime} n i l \%$ & Kir jath-se pluce \\
\hline nan ile) & III'vite & $\left(k u a^{\circ}\right.$ jathli-ia: fol ) \\
\hline mallh & l'è̃ r' iz \%ilte & C'hu sham-rish at lha im! \\
\hline II & lhi lis line & $\left(k u^{\prime}\right.$ shatll-ri \\
\hline $0 \mathrm{j}$ it & $\left(j \mathrm{l} \mathrm{c}^{\prime} \mathrm{tiu}\right)$ & \\
\hline
\end{tabular}

Noteit

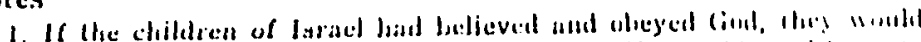

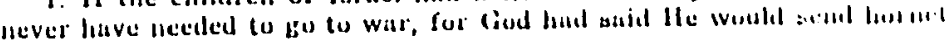

2. II. L. linthiliandi: 

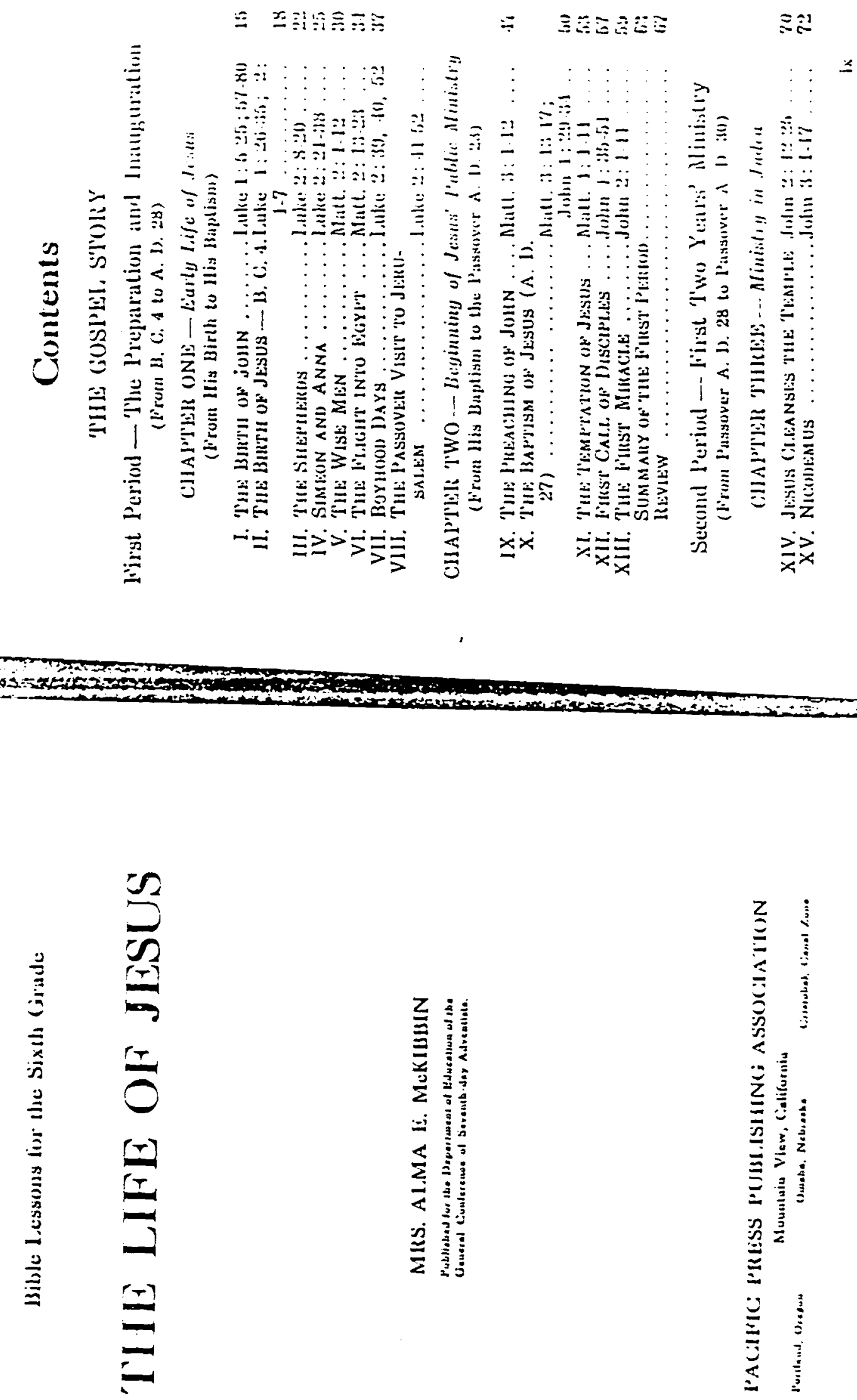


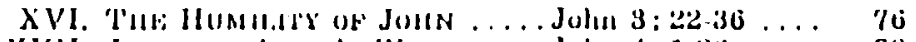

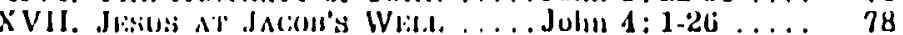

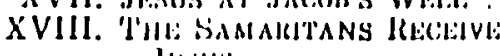

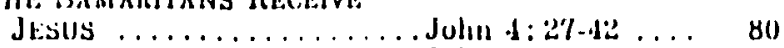

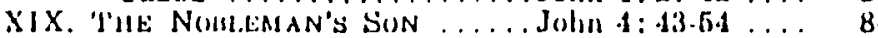

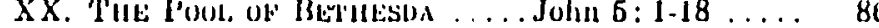

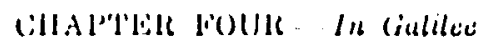

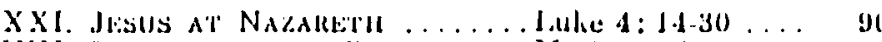

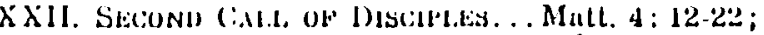
luke $6: 1-11 \ldots 0.93$

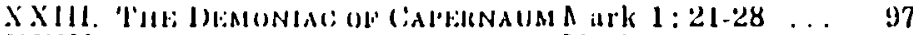

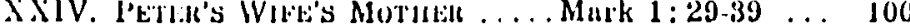

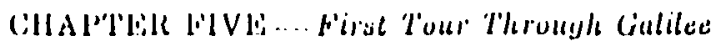

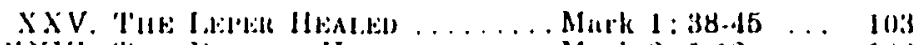

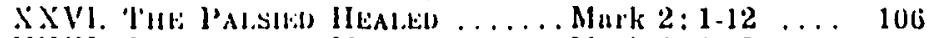

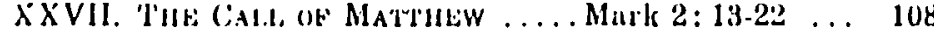
XXVIII. 'IIE SAlum

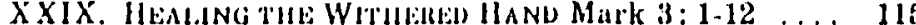

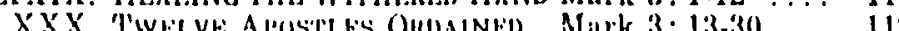

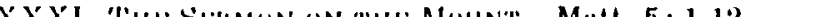

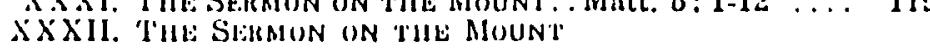

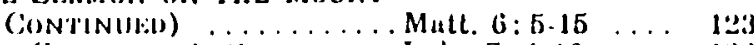

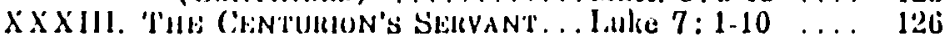

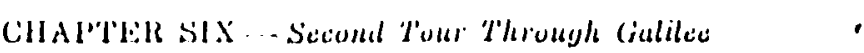

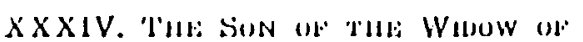

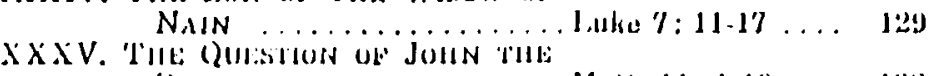

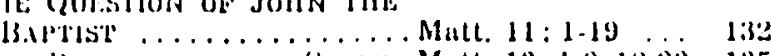

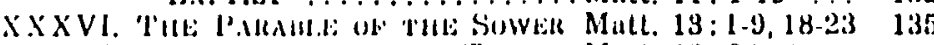

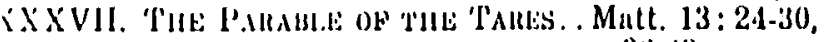

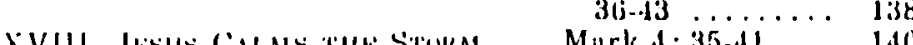
Mark d: $35-41 \quad \ldots \quad 1.10$

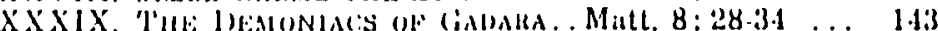

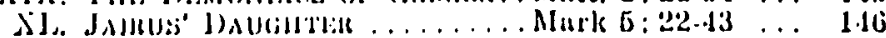

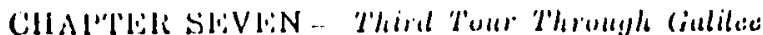

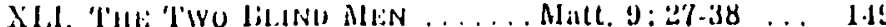

$x$

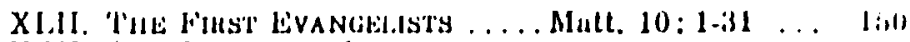

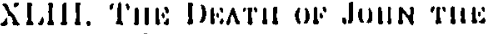

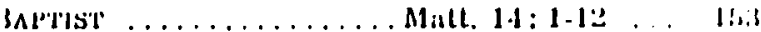

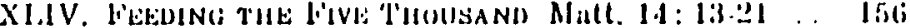

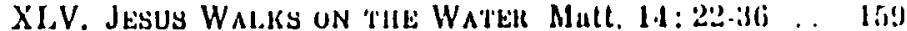

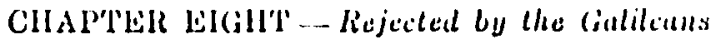

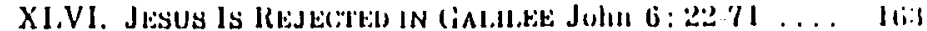

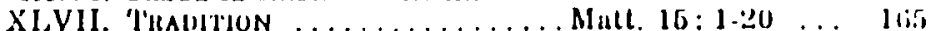
SUMMAIIY or 'Rl: Sitcond

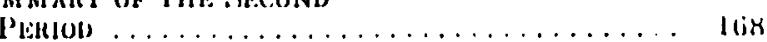

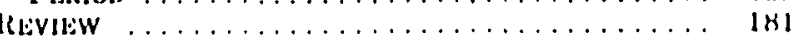

'l'hird Period - - Chose of Jesus' liarthly Ministry (from l'aysover A. 1), 30 to the Ascemsion)

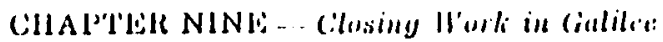

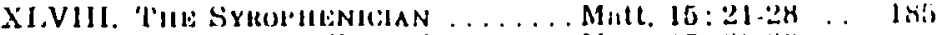

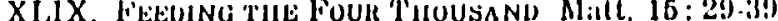
Mlurk $7: 31: 37$ p pis

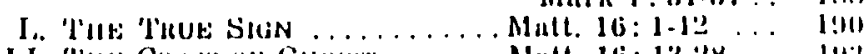

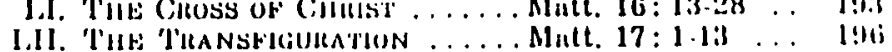

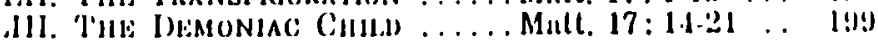

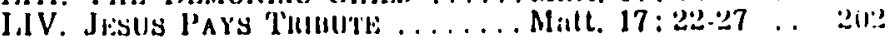

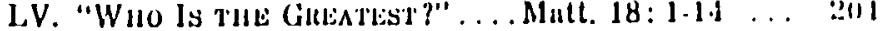

CHA P'TEll I'liN -. Jesus in Jerusulem

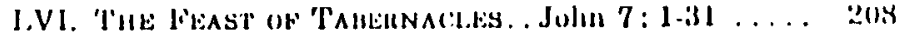

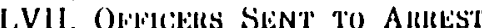

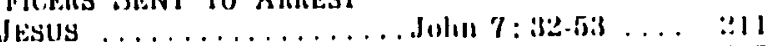

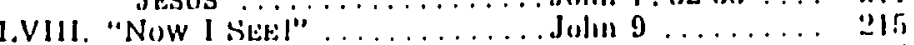

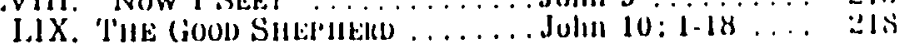

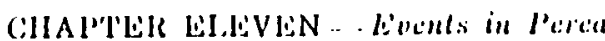

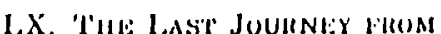

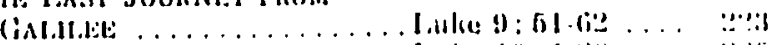

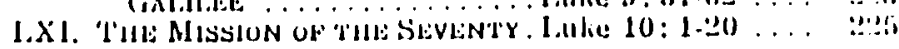




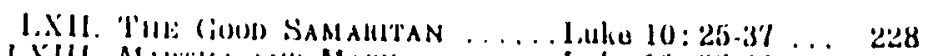

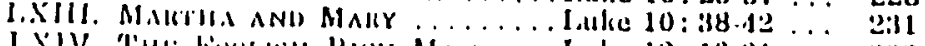

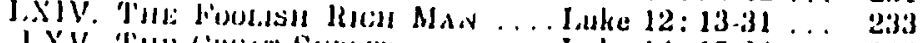

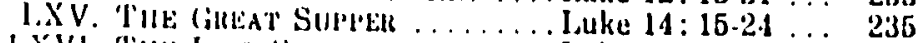

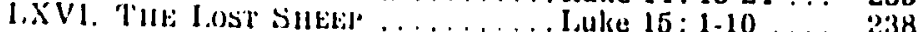

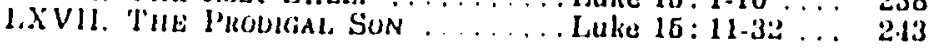

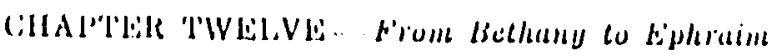

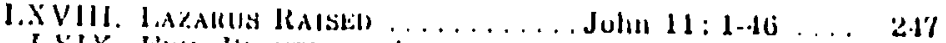
I.XIX. Livil. l'LUTINGS ALininst Jisus ............. Juhn 11:47-6.1 . . 250

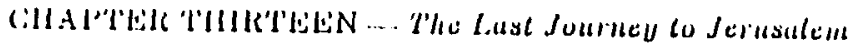
I.XX. "l'HI: l'UAUISI:L ANU THE P’UU.

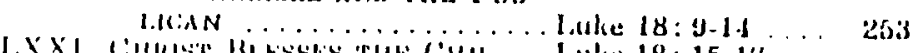

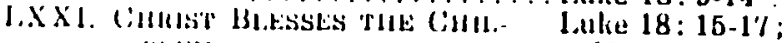

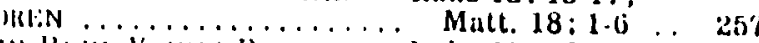

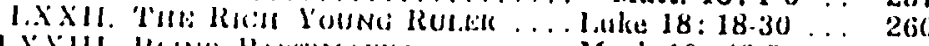

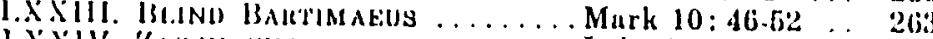

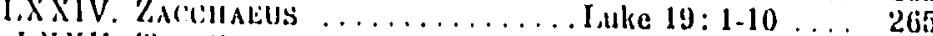

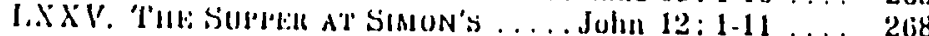

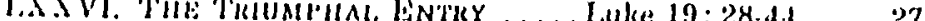

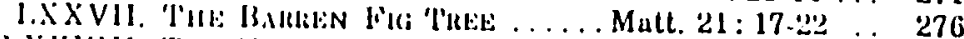

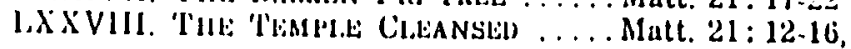

.

l.XX. Matt. $21: 33.40$. 28.

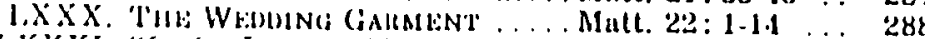

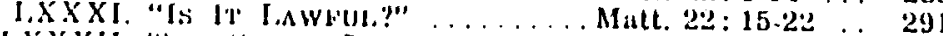

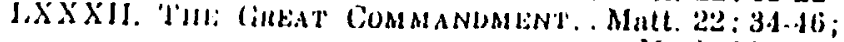

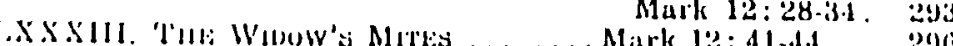
Miark 12:41-4.1 2906 Julin 12:20-13 ... 2!y!

I.XXXV. "IVIILN SHIALL 'I'HESE 'I'IIINISS

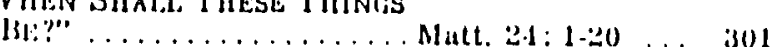

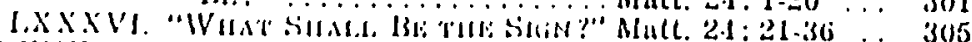

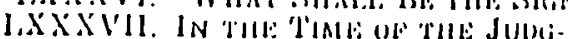

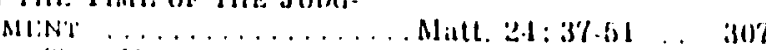

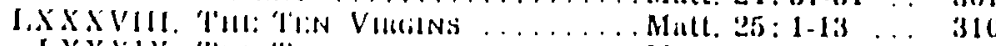

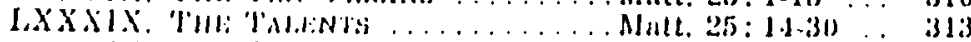

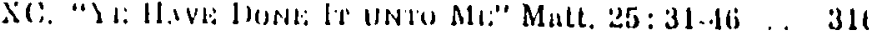

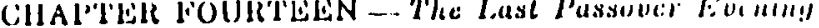

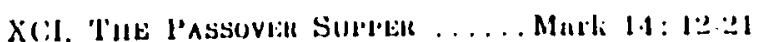
X(:il. A Sh:mvan't of Sellvants ... Johin 1:1:1-17 XCIV. THE TuUE VINE ......... Juhn 16:1.17.

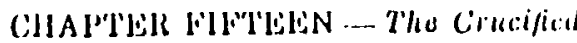

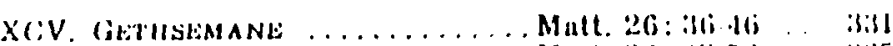

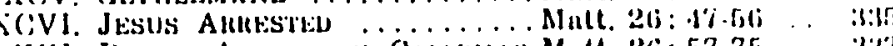

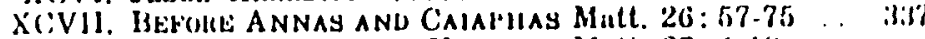

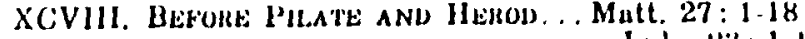

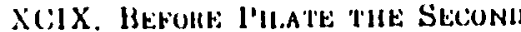

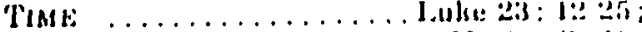

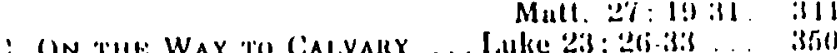

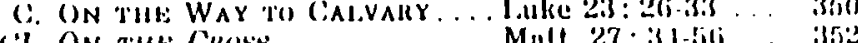

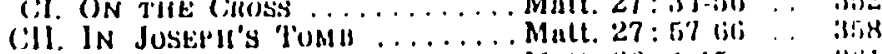

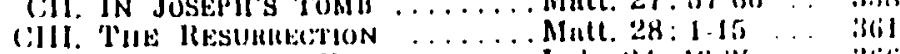

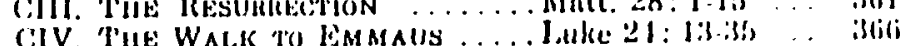

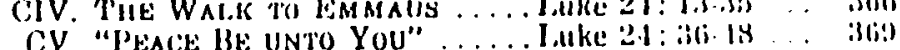

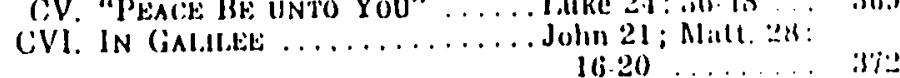

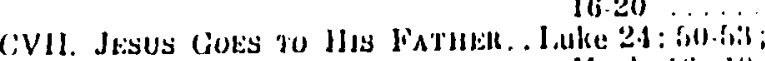
Miuk $1(j: 19,: 20$ :3i5

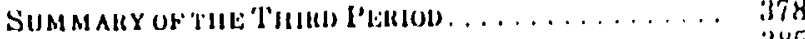



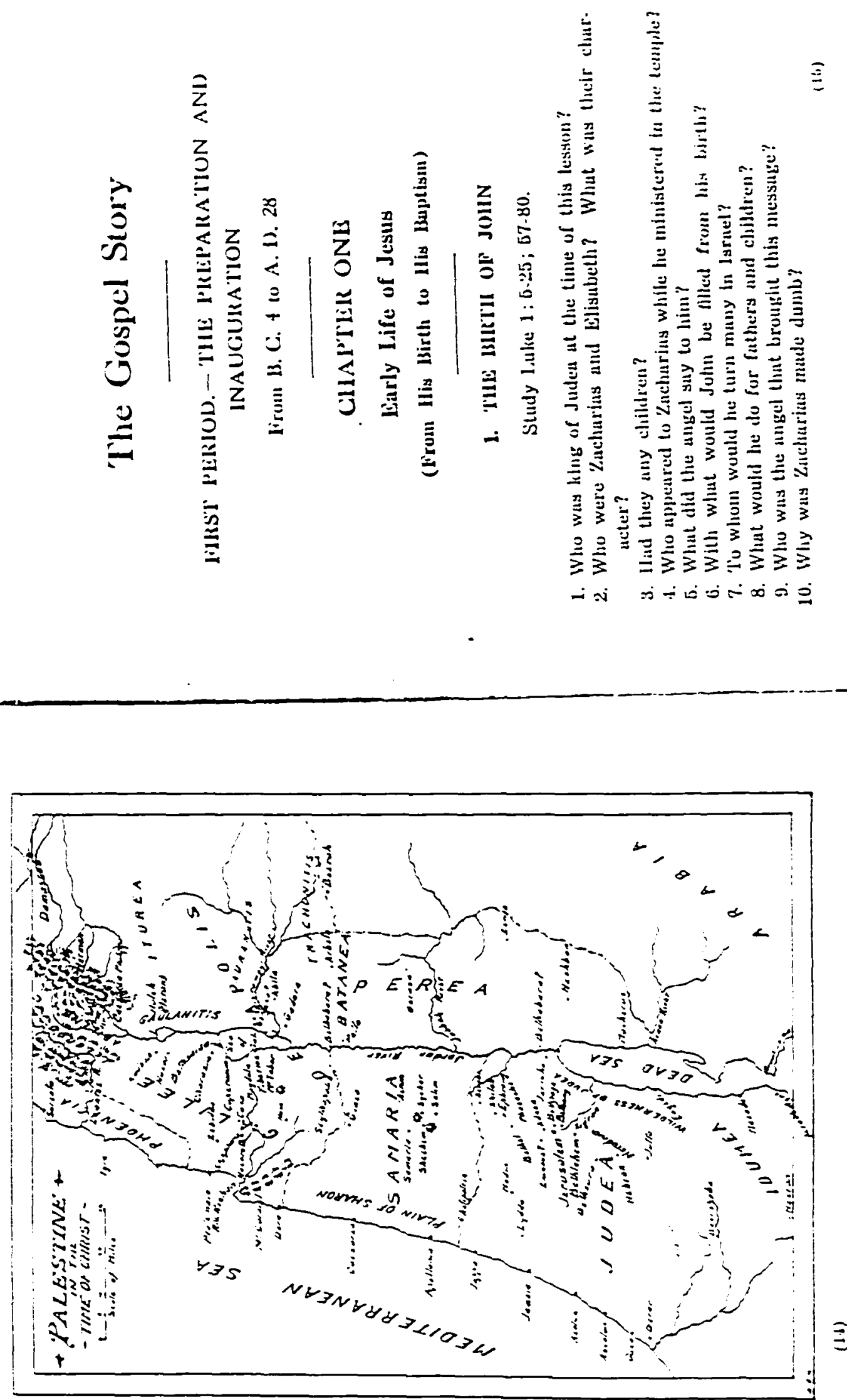

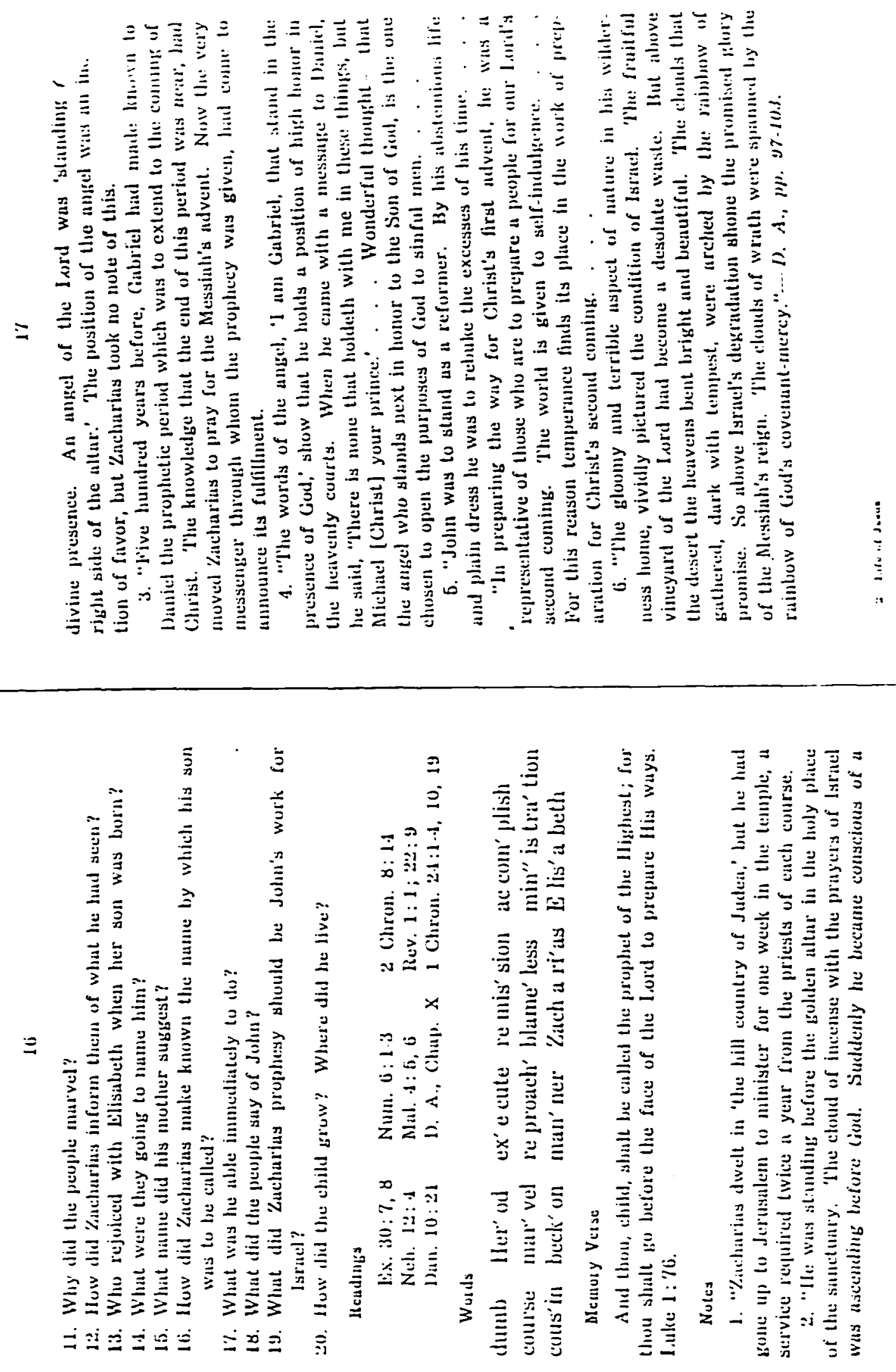

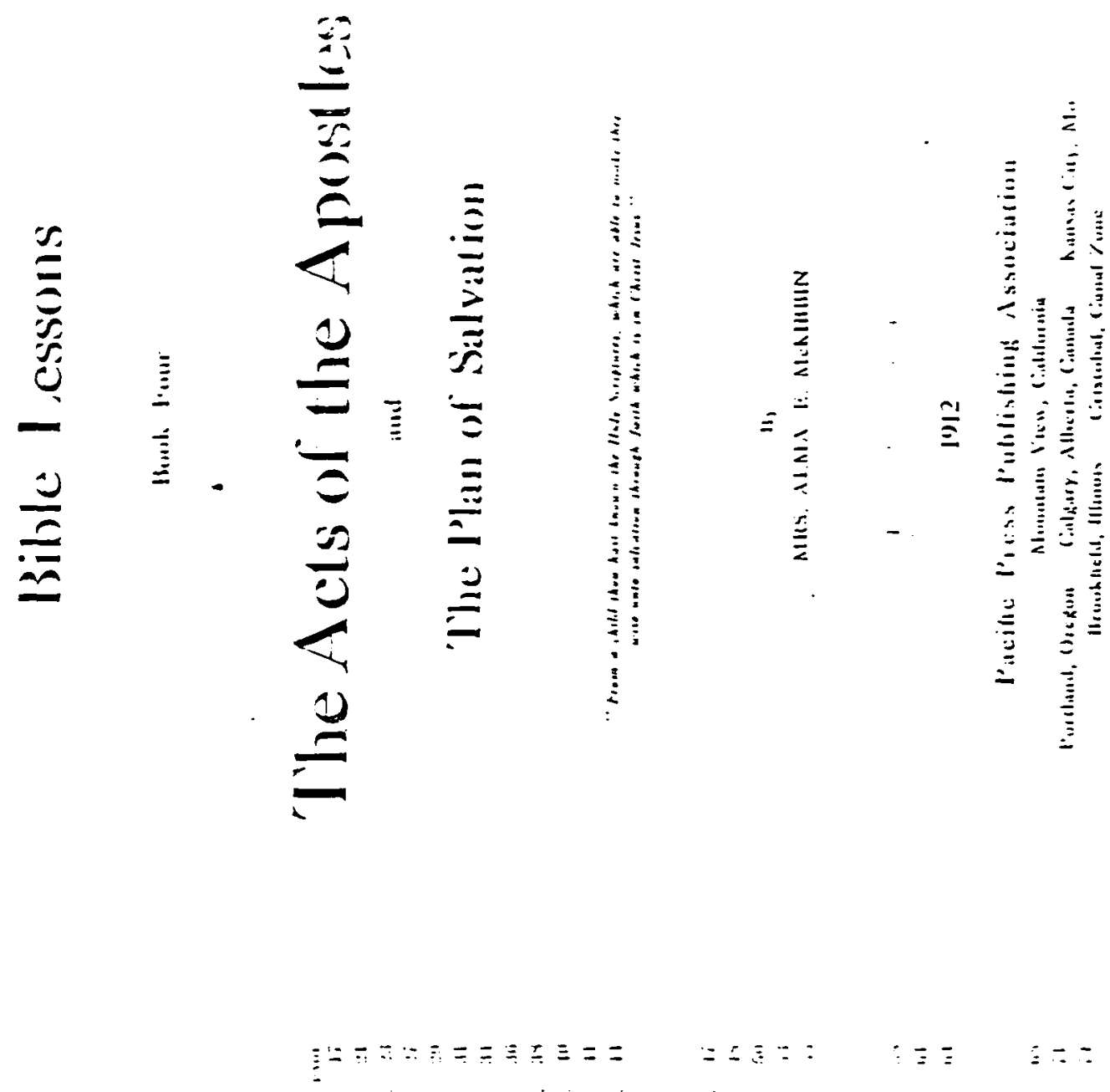

$\vdots \equiv \equiv:$

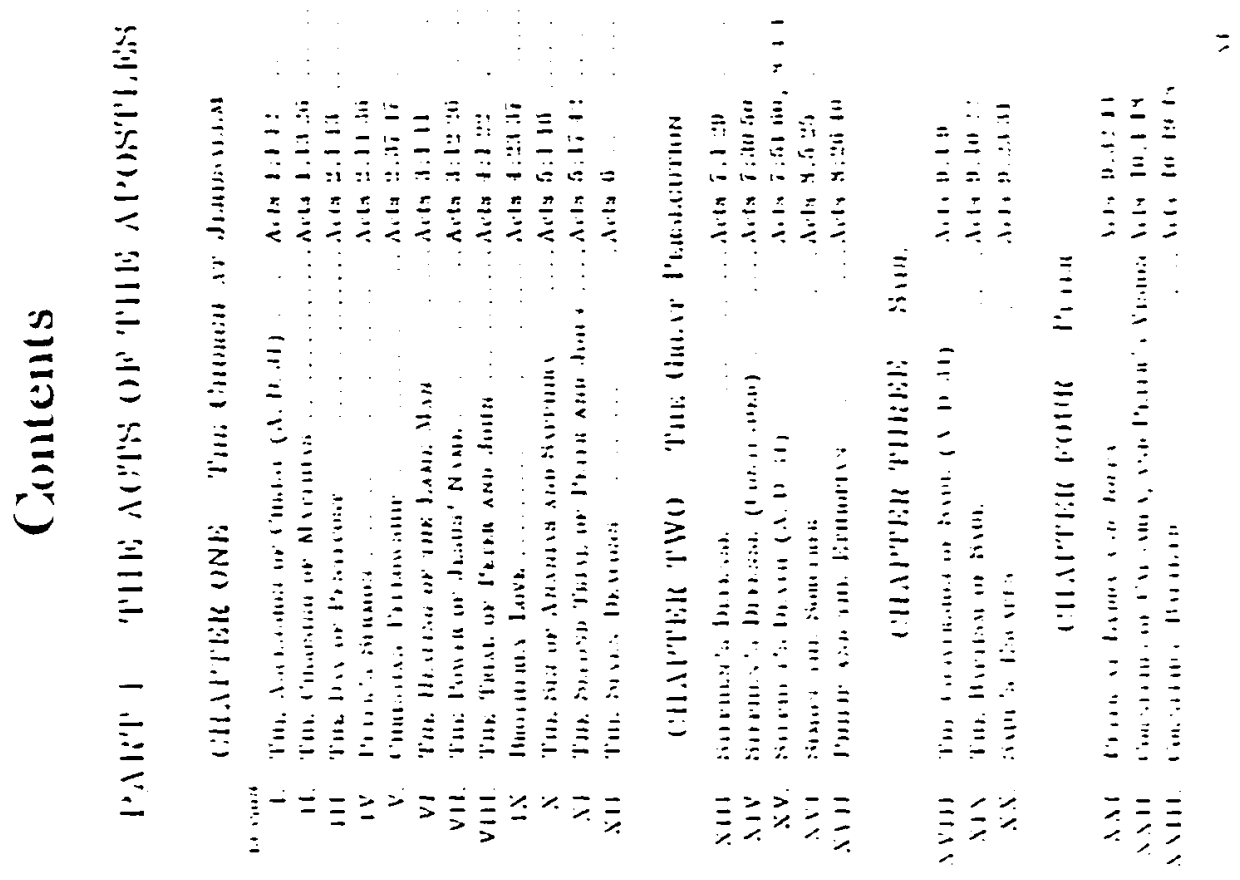



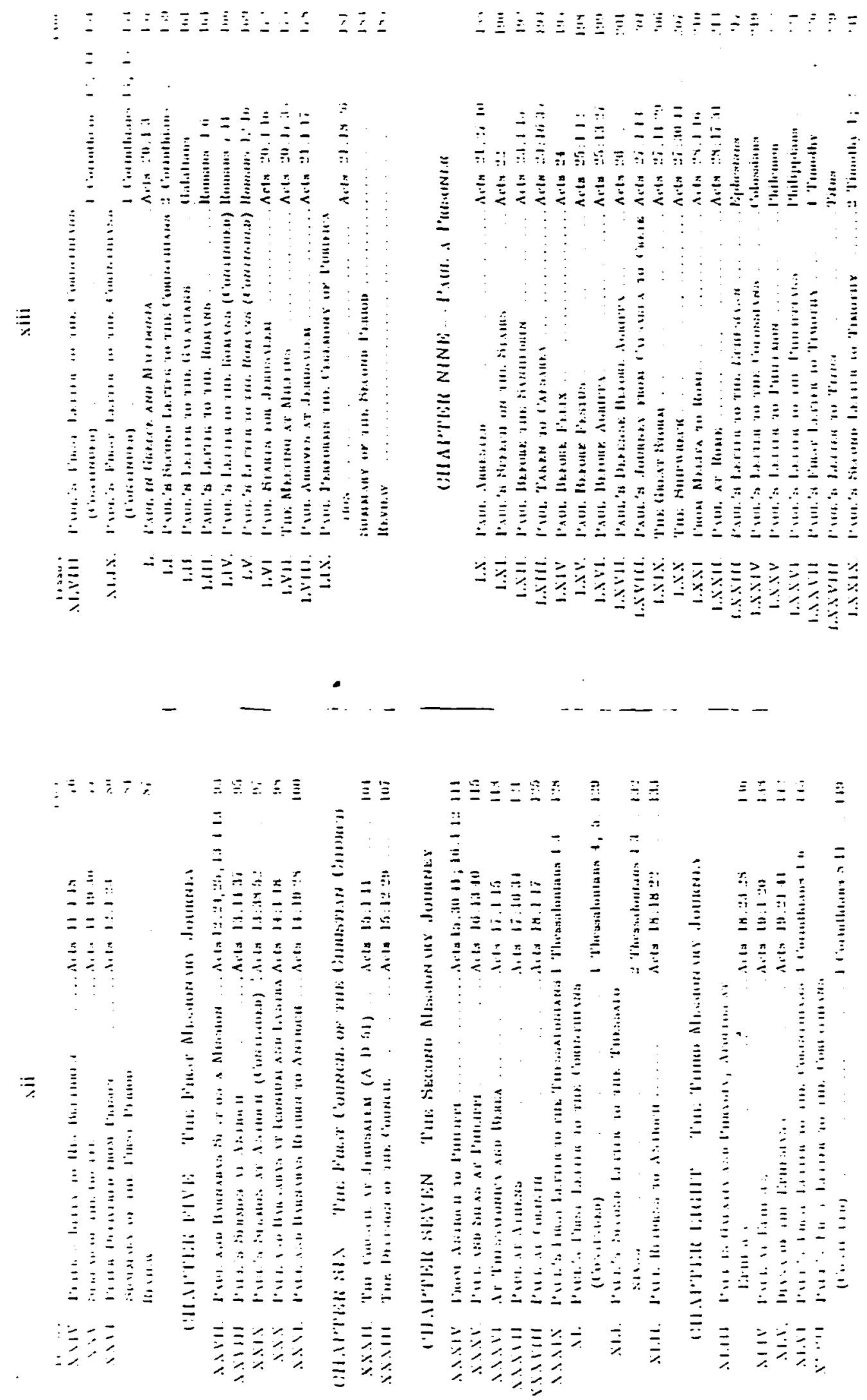

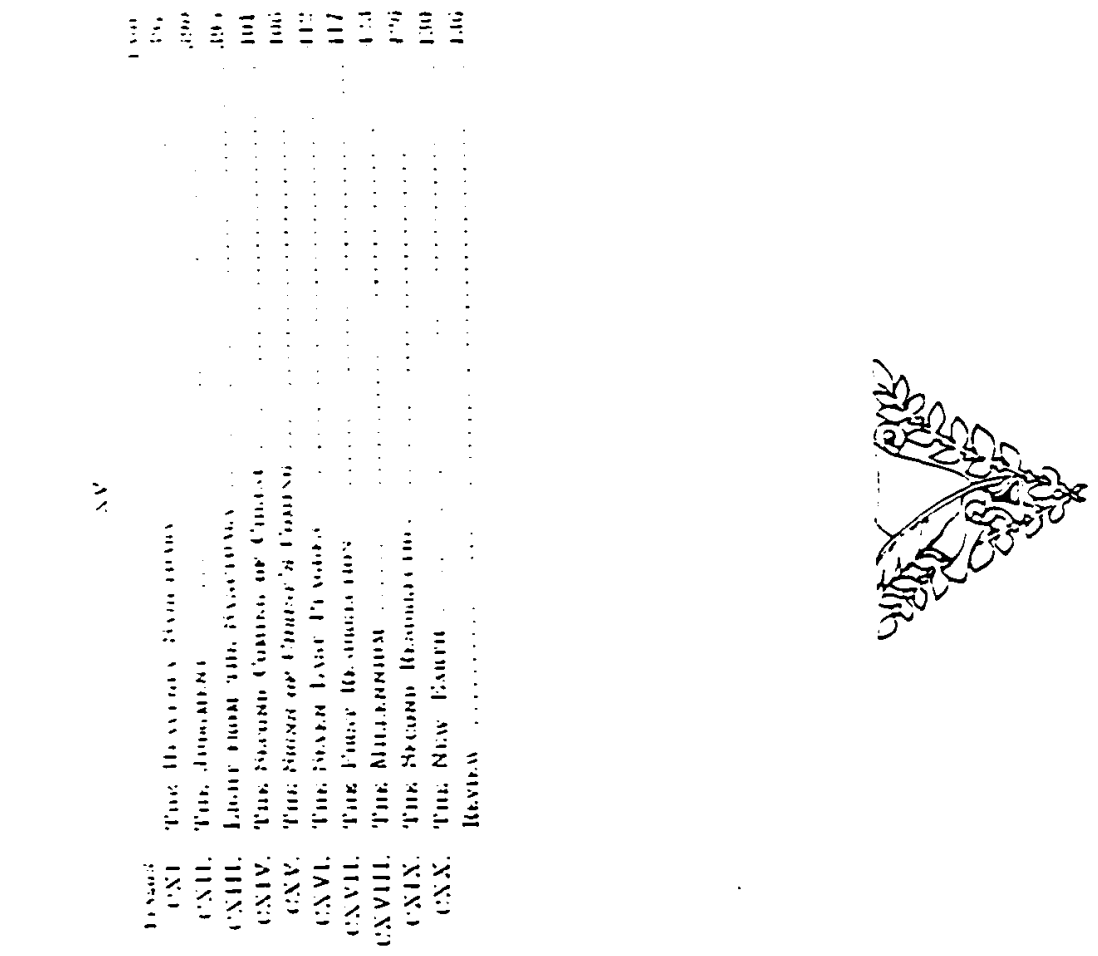

-

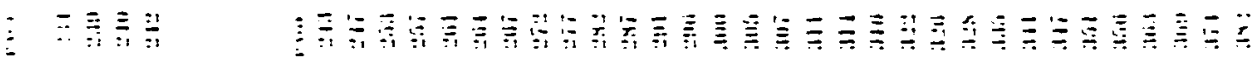

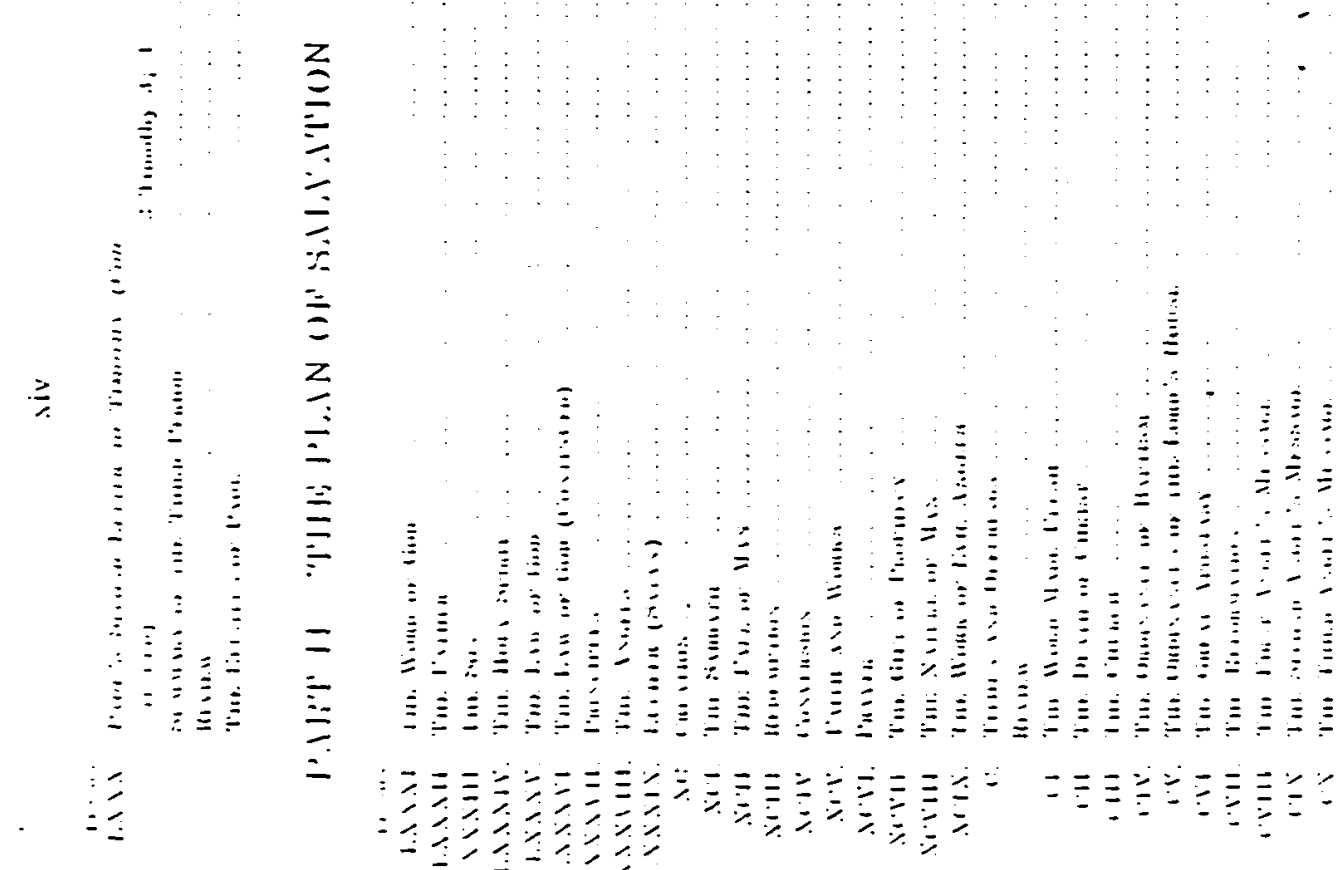



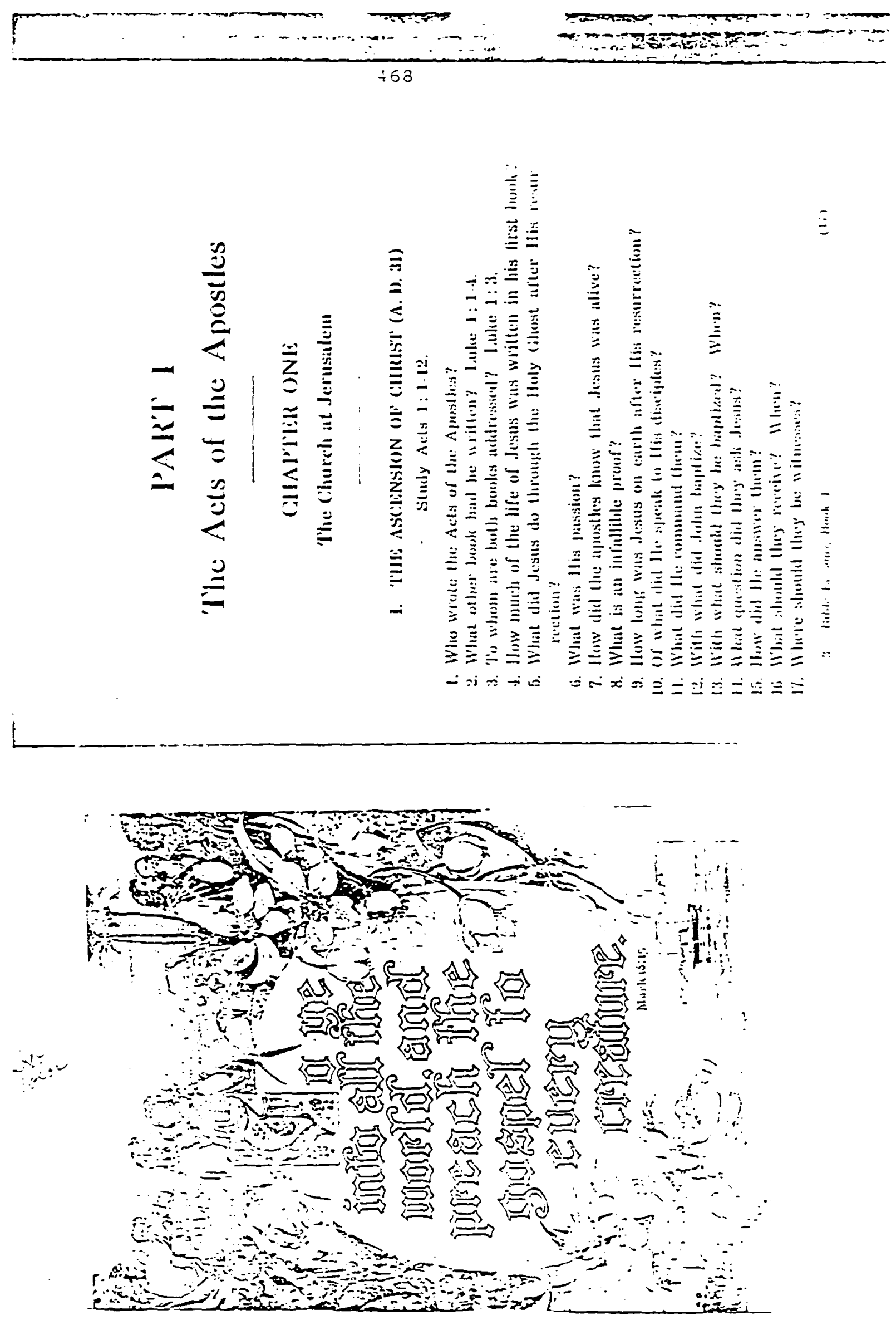


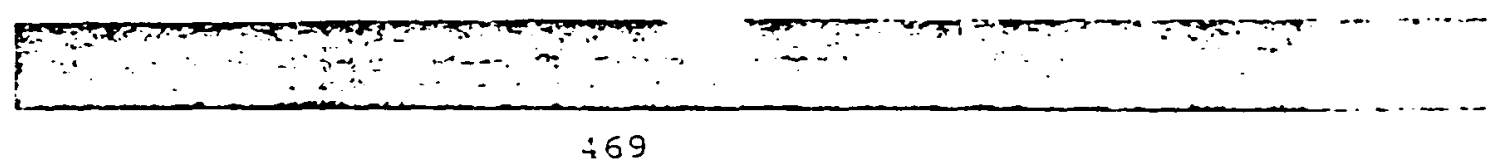

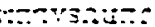

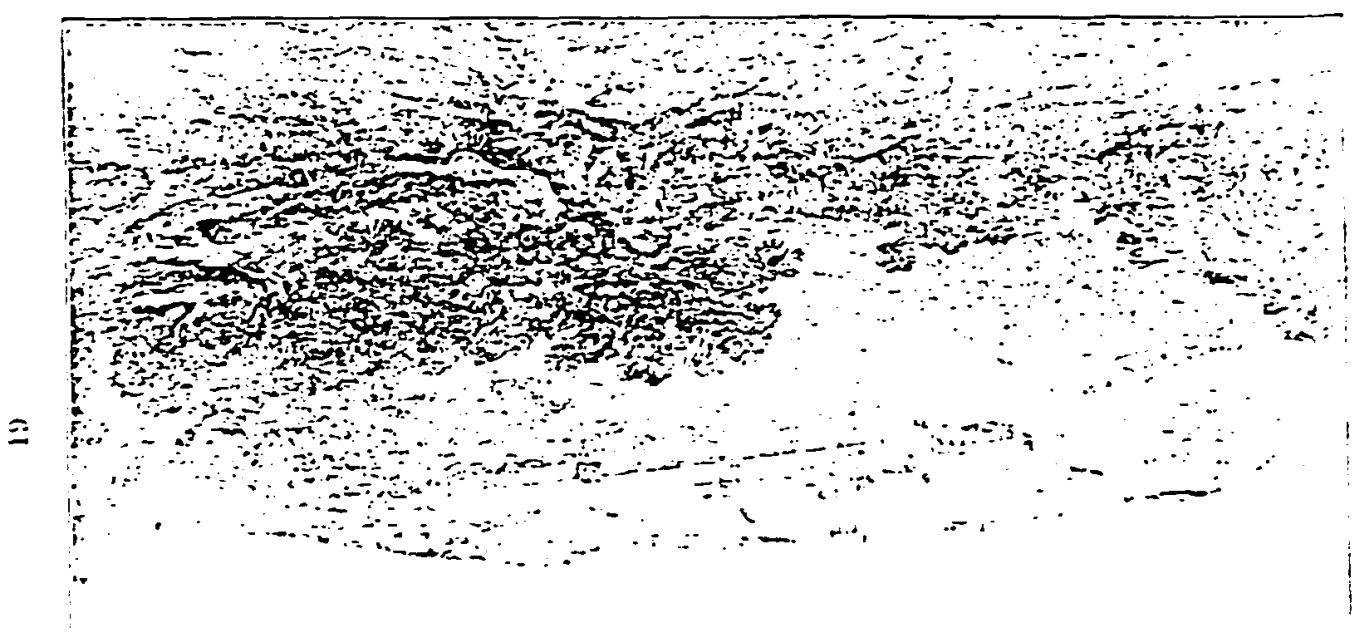

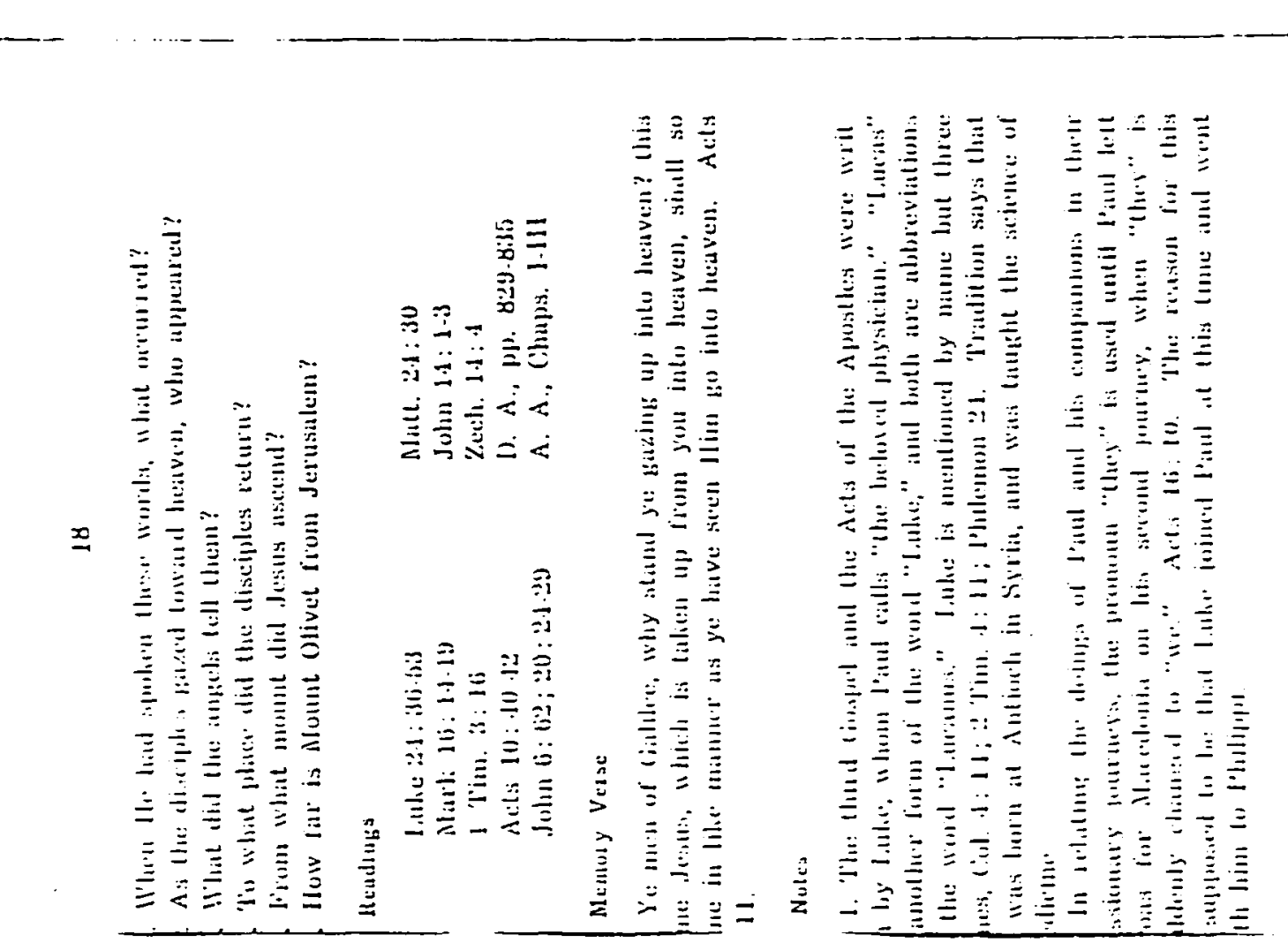




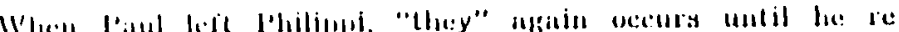

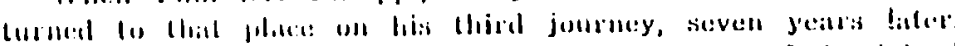

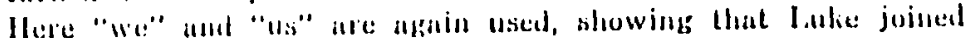

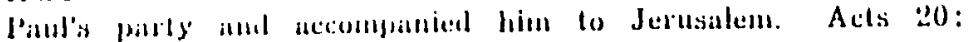
5; $21: 18$.

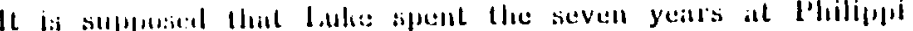
in the work af llace gospel as a medient evangelist. IVe next lind him with l'anl on his journey lo lome, Acts 2'l: 1 . He Wils olle of these who was with l'aul during his liost intprisomment. (iol. f: 1.1 .

When lant wats inumboned the second time, he iveole to

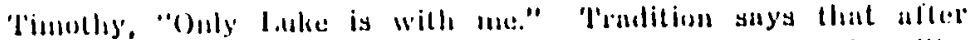

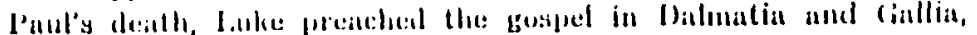
and wats matrlyod hetween A. D. 75 and A. I), 100.

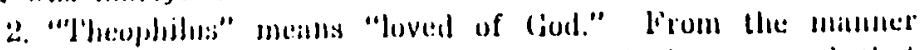
in which luke spreaks of hime louke $1: 3$, it is supposised that he ledel $n$ pesilion of honer and responsibility in the carly ciluistian churrets.

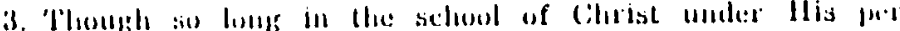
somal intstruction, the disitilles were mot rendy even to hepin lloeir wosk unlil they received the Holy Spritit.

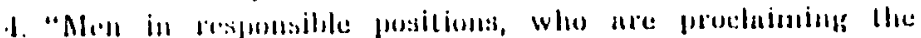

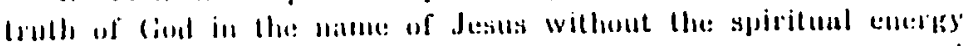

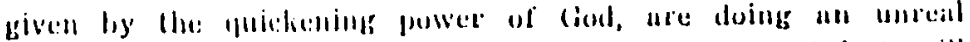

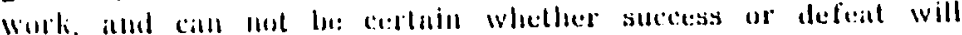

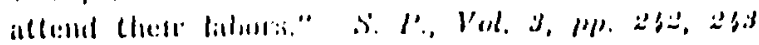

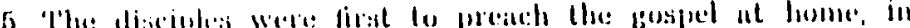

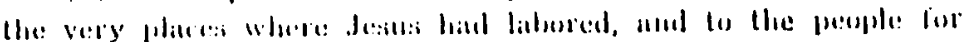

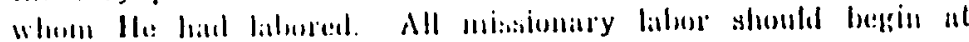

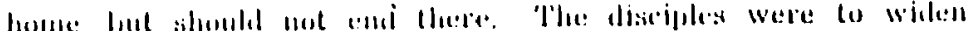

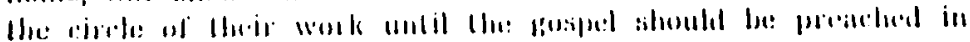

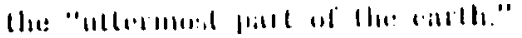

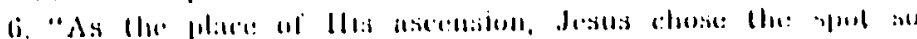

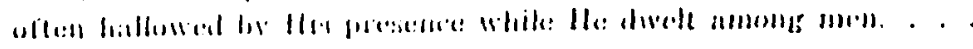

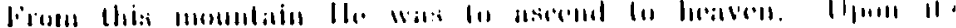

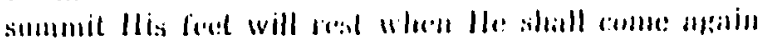

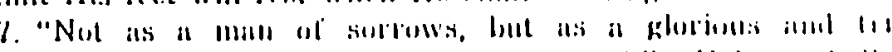

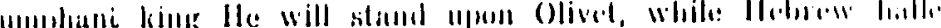

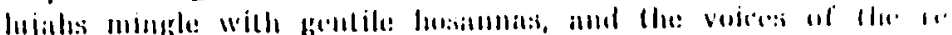

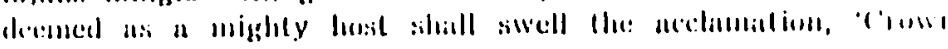
llim lond of all.'.

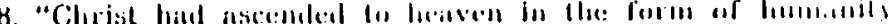

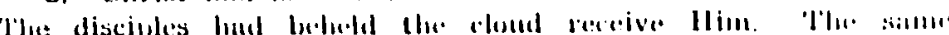

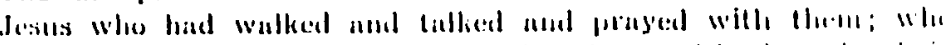

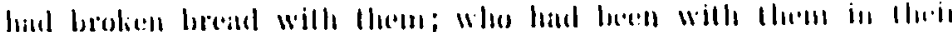

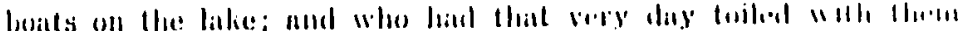

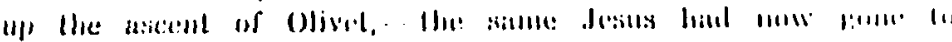

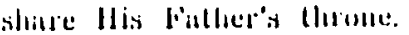

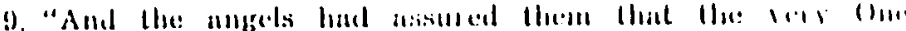

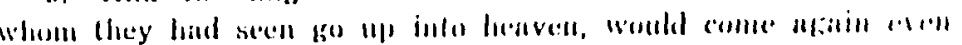

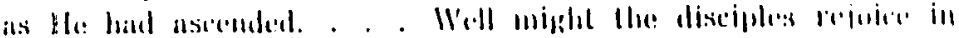

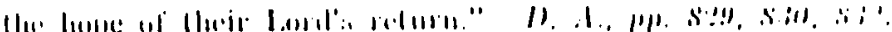

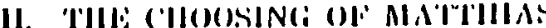

\section{Silualy dil:i 1: I:3 20 (i.}

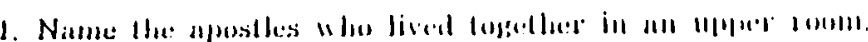

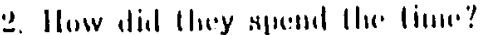

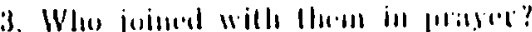

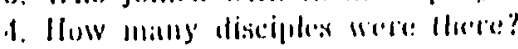

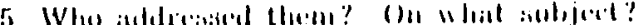

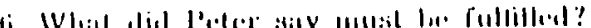

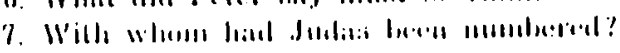

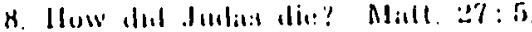

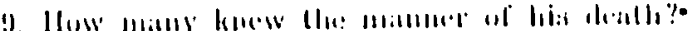



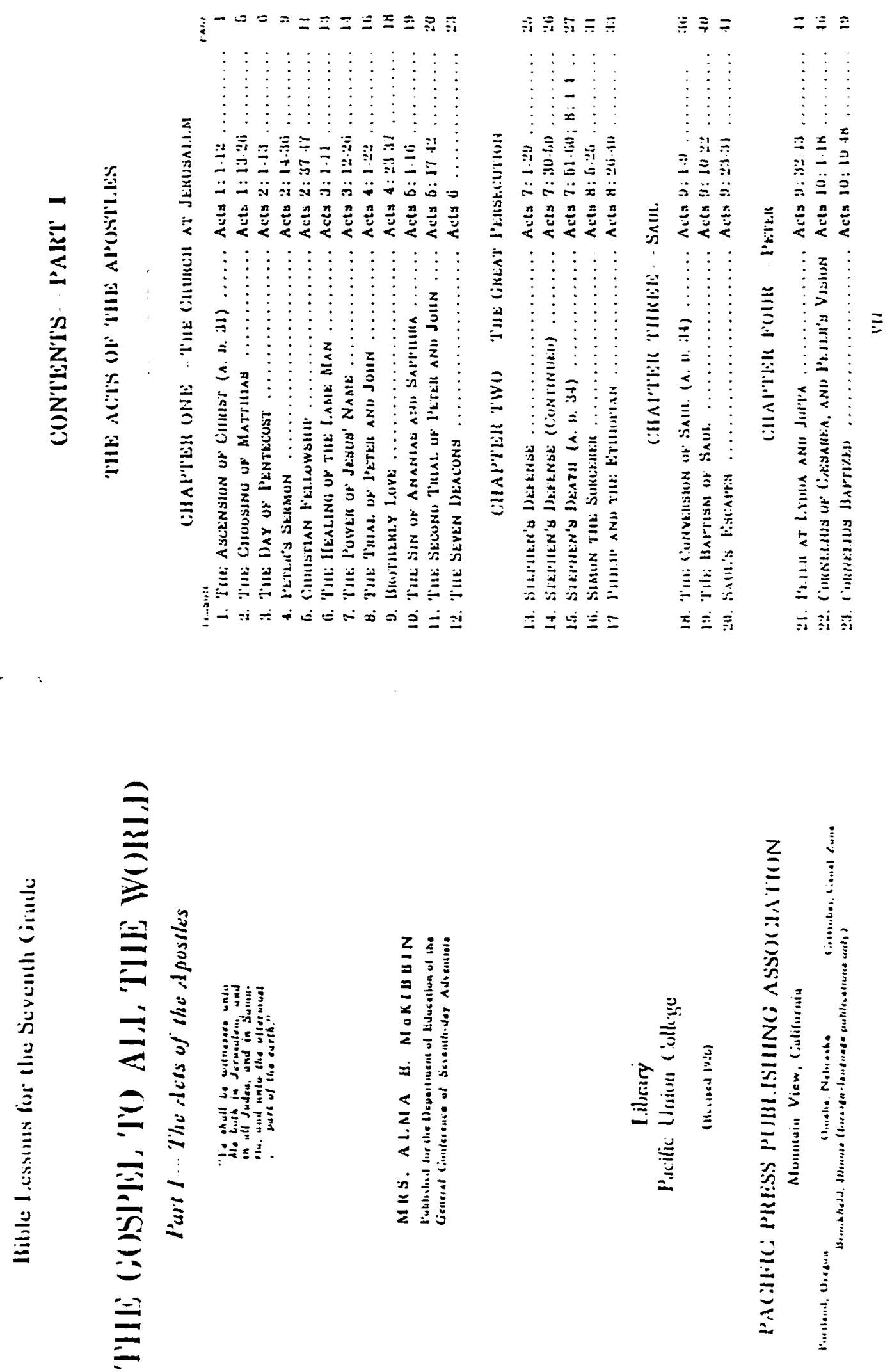


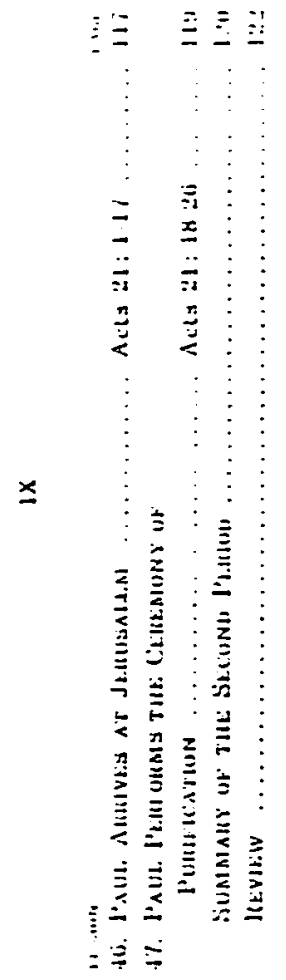

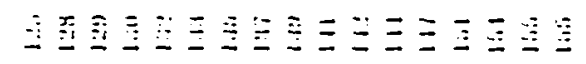
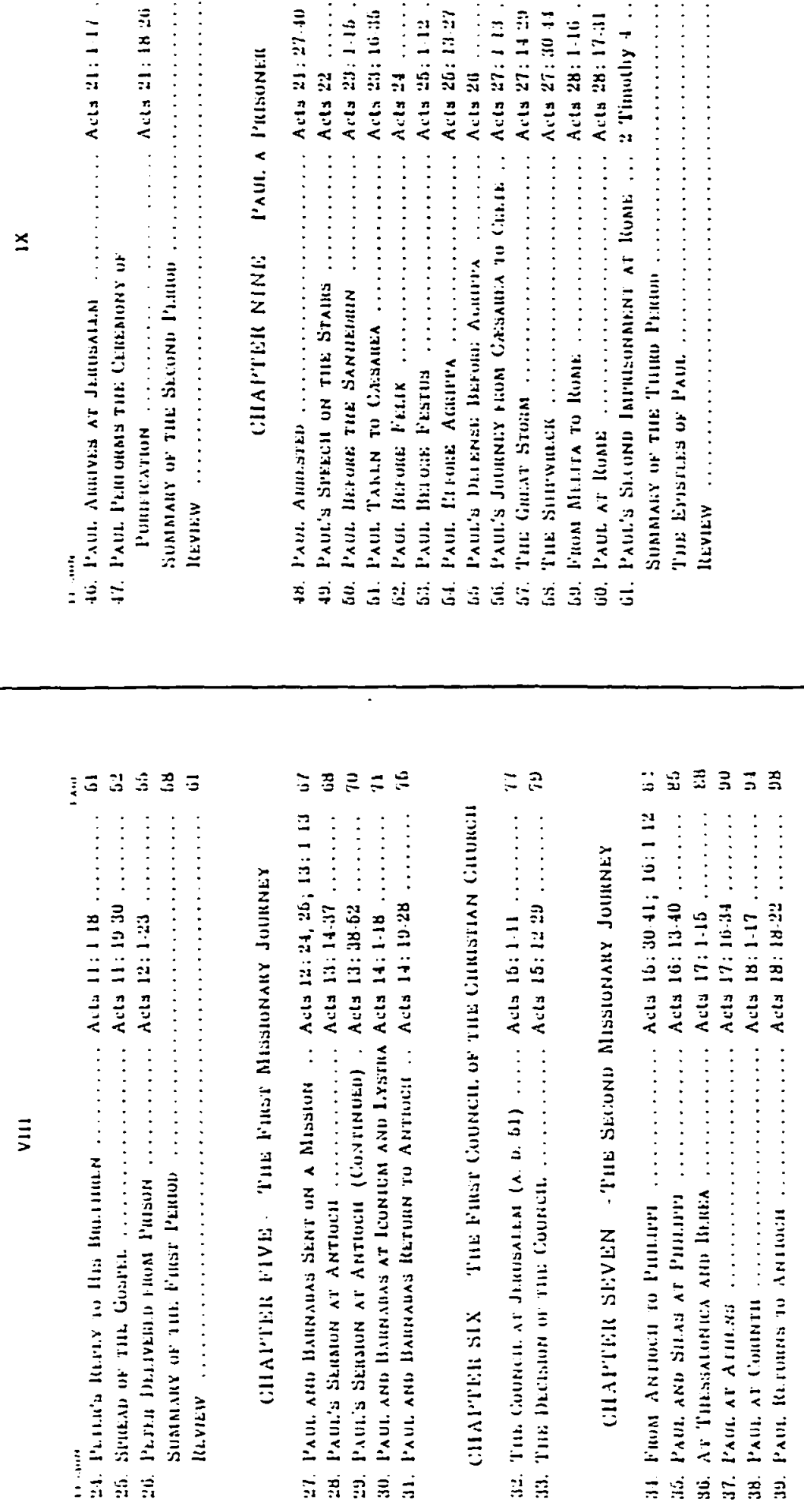

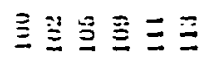

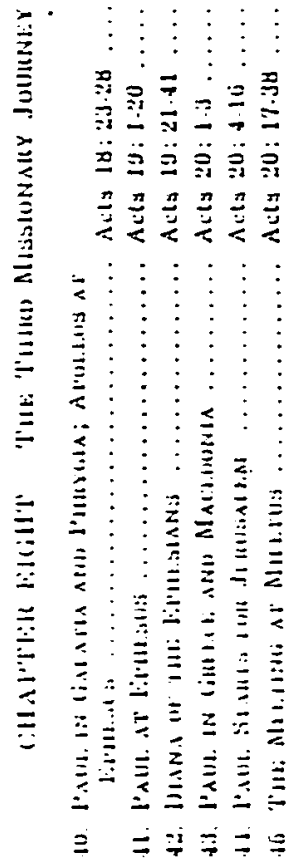



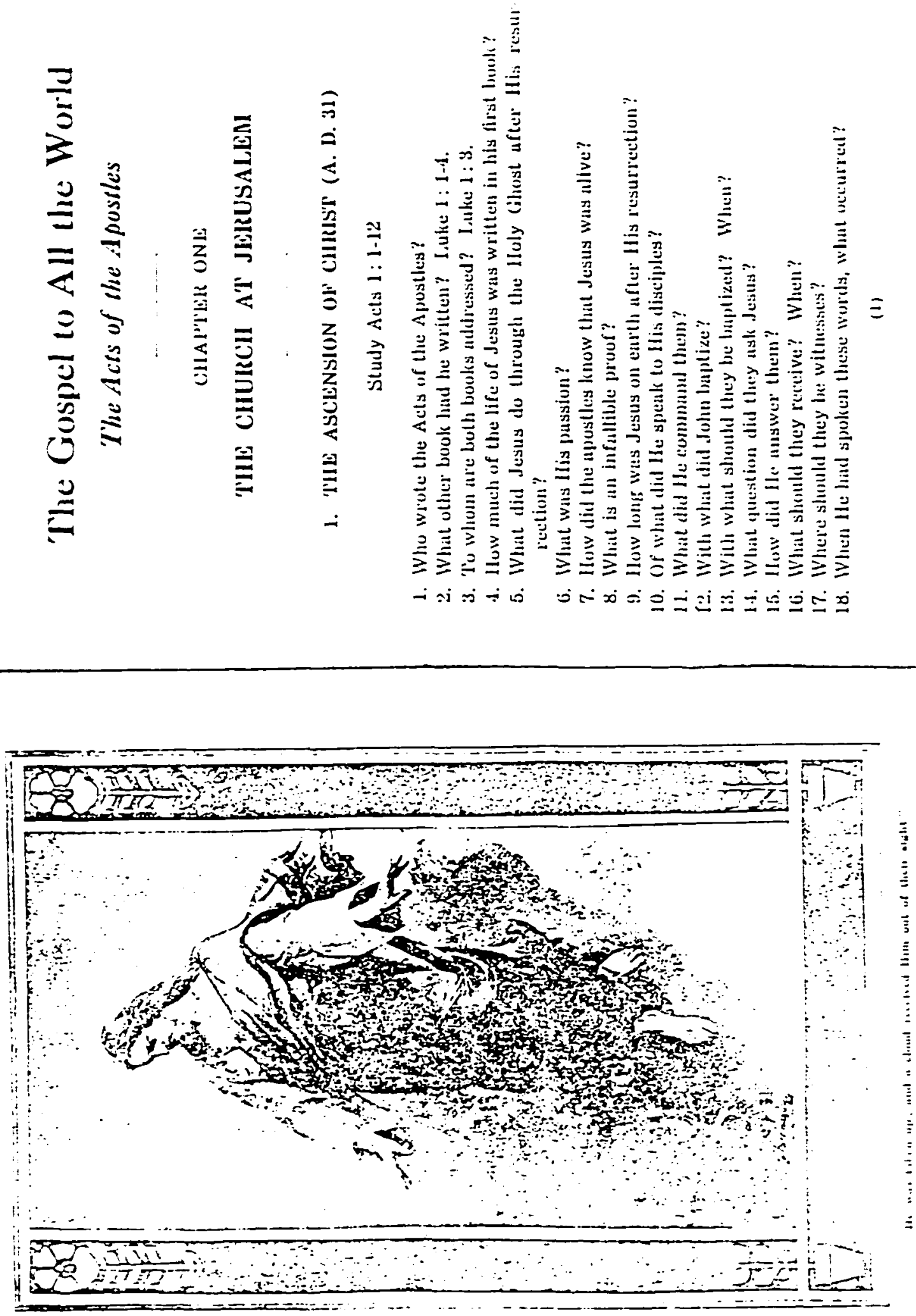

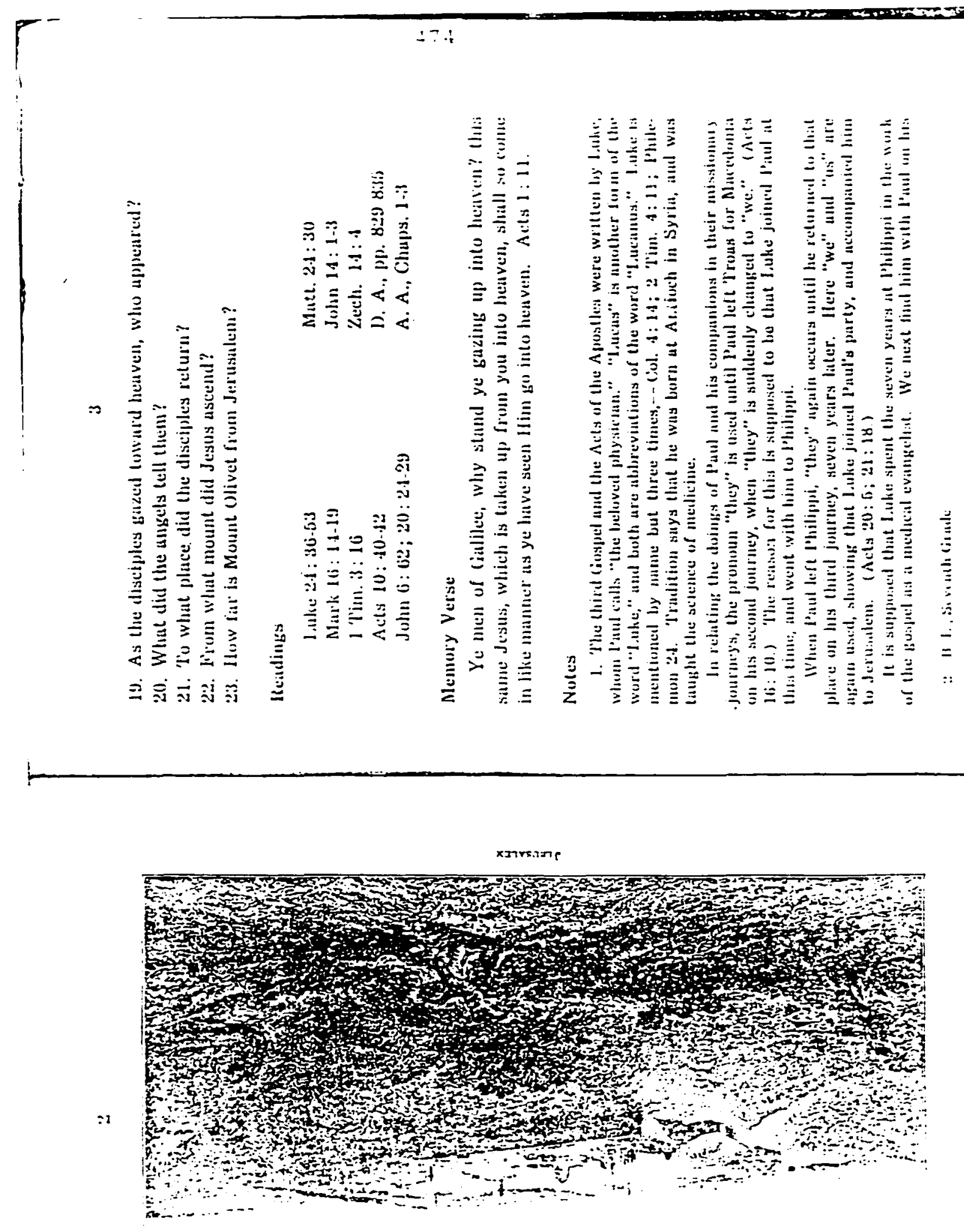


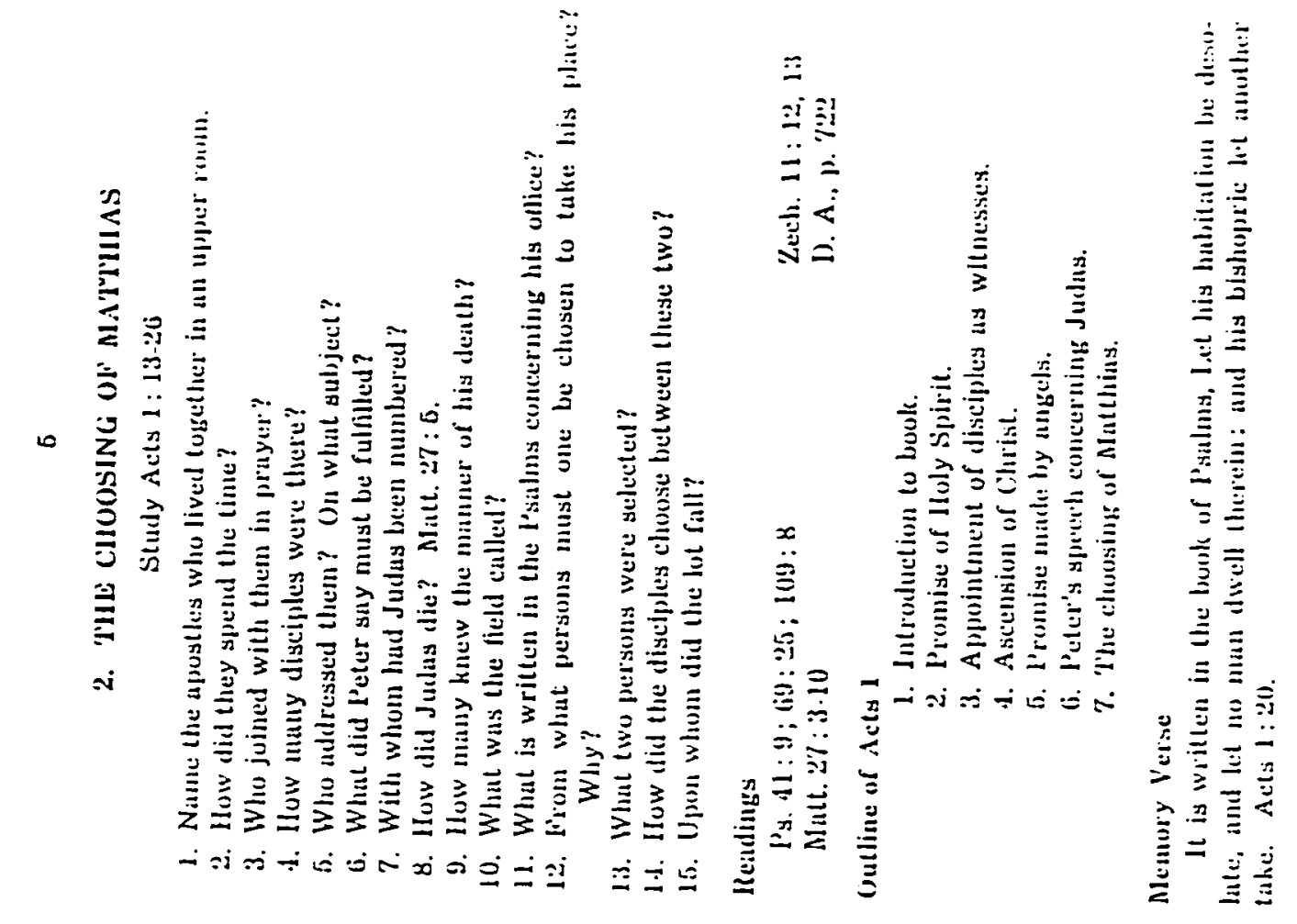




\title{
PLeAse note
}

\begin{abstract}
Copyrighted materials in this document have not been filmed at the request of the author. They are available for consultation, however, in the author's university library.
\end{abstract}

The Gospel To All The World $476-483$

University Microfilms International 


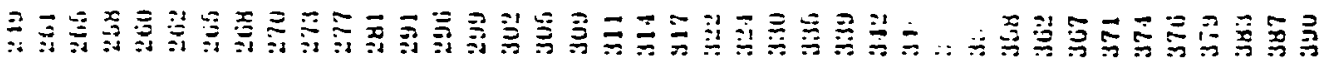

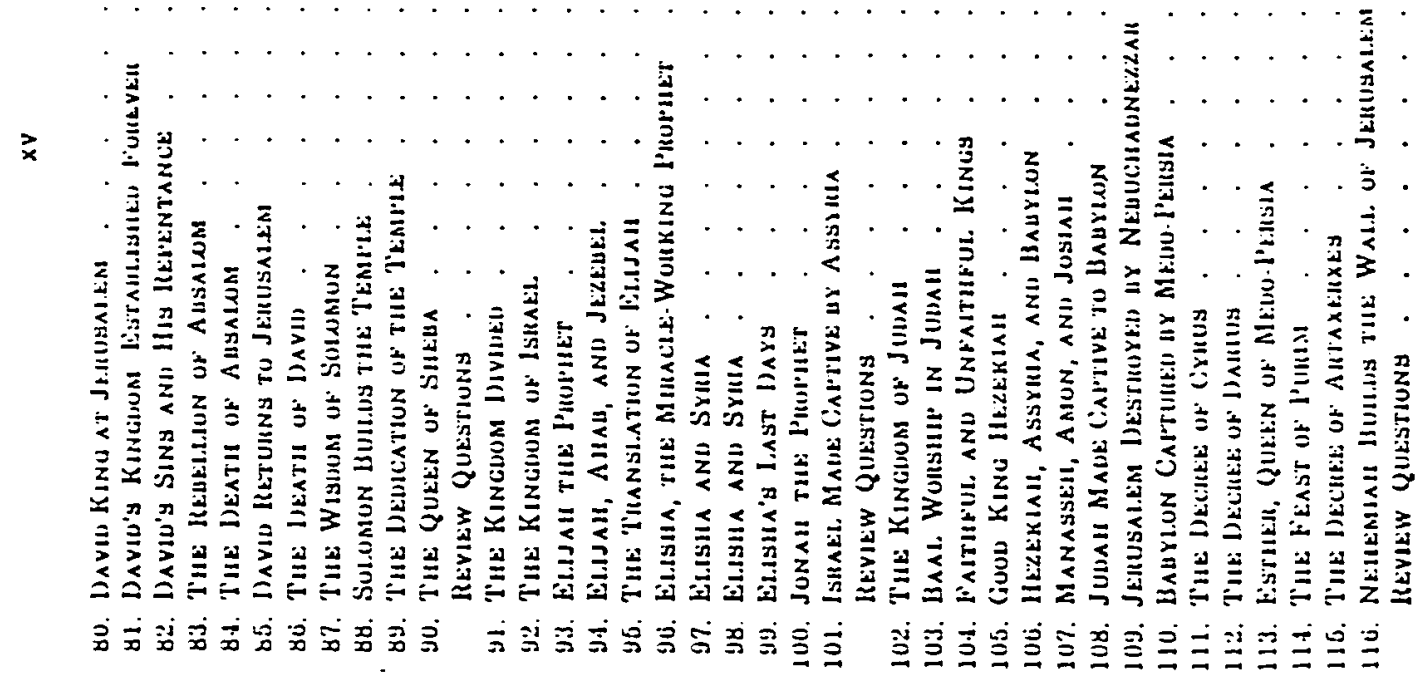

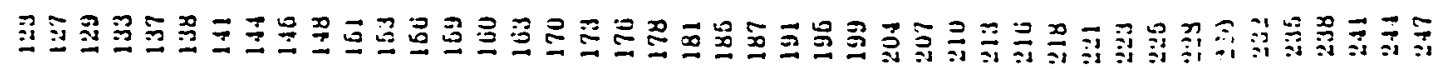

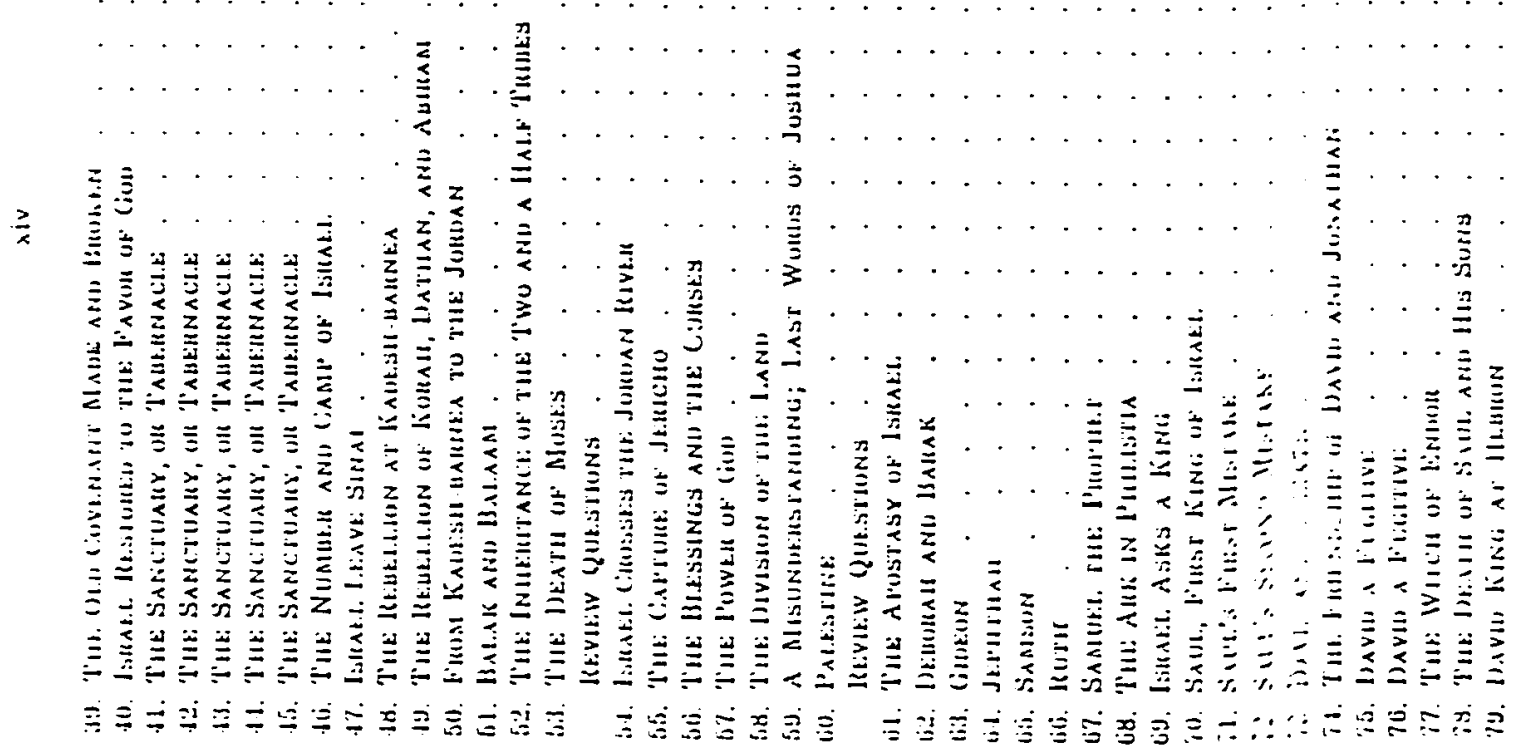




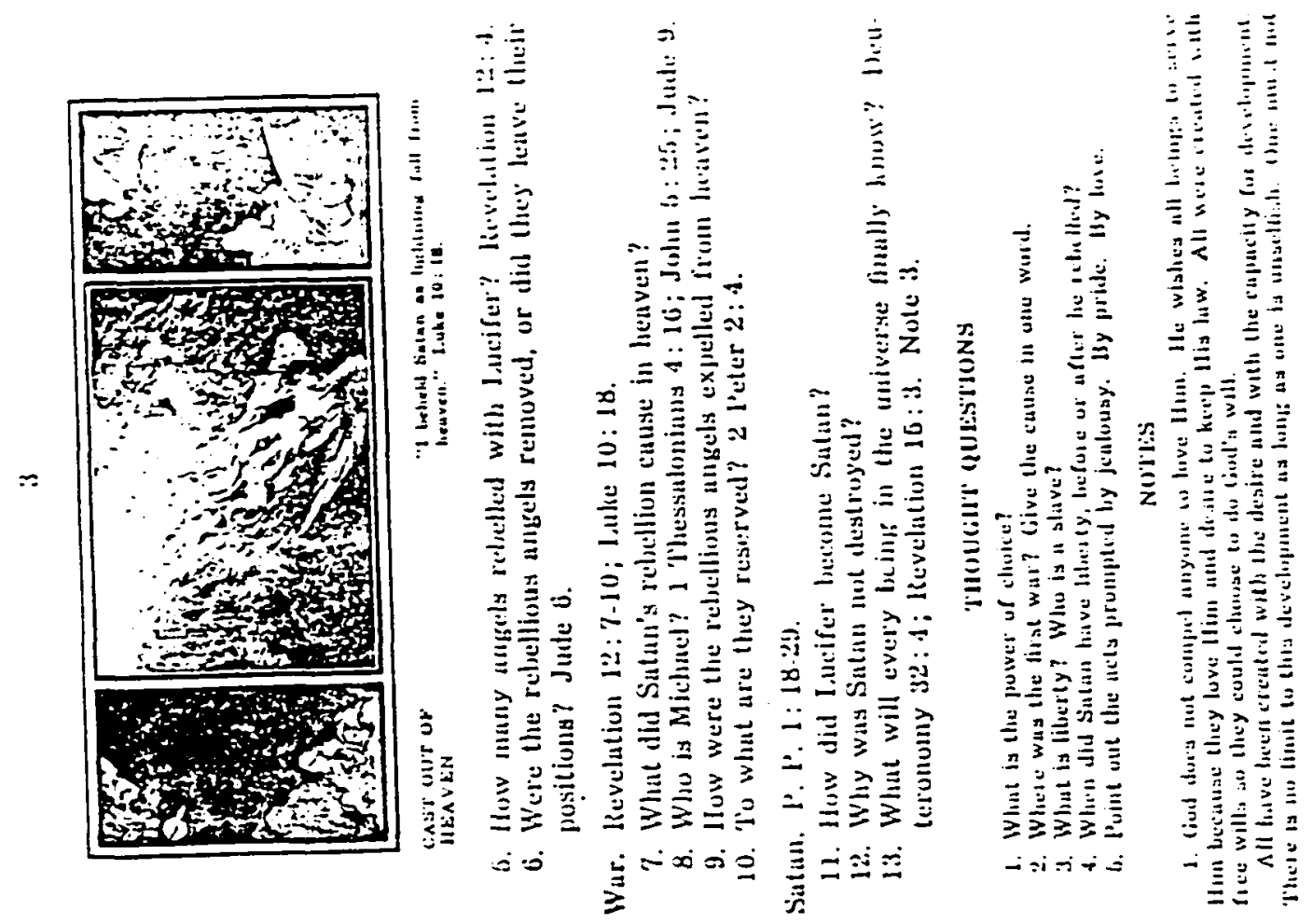

Fin

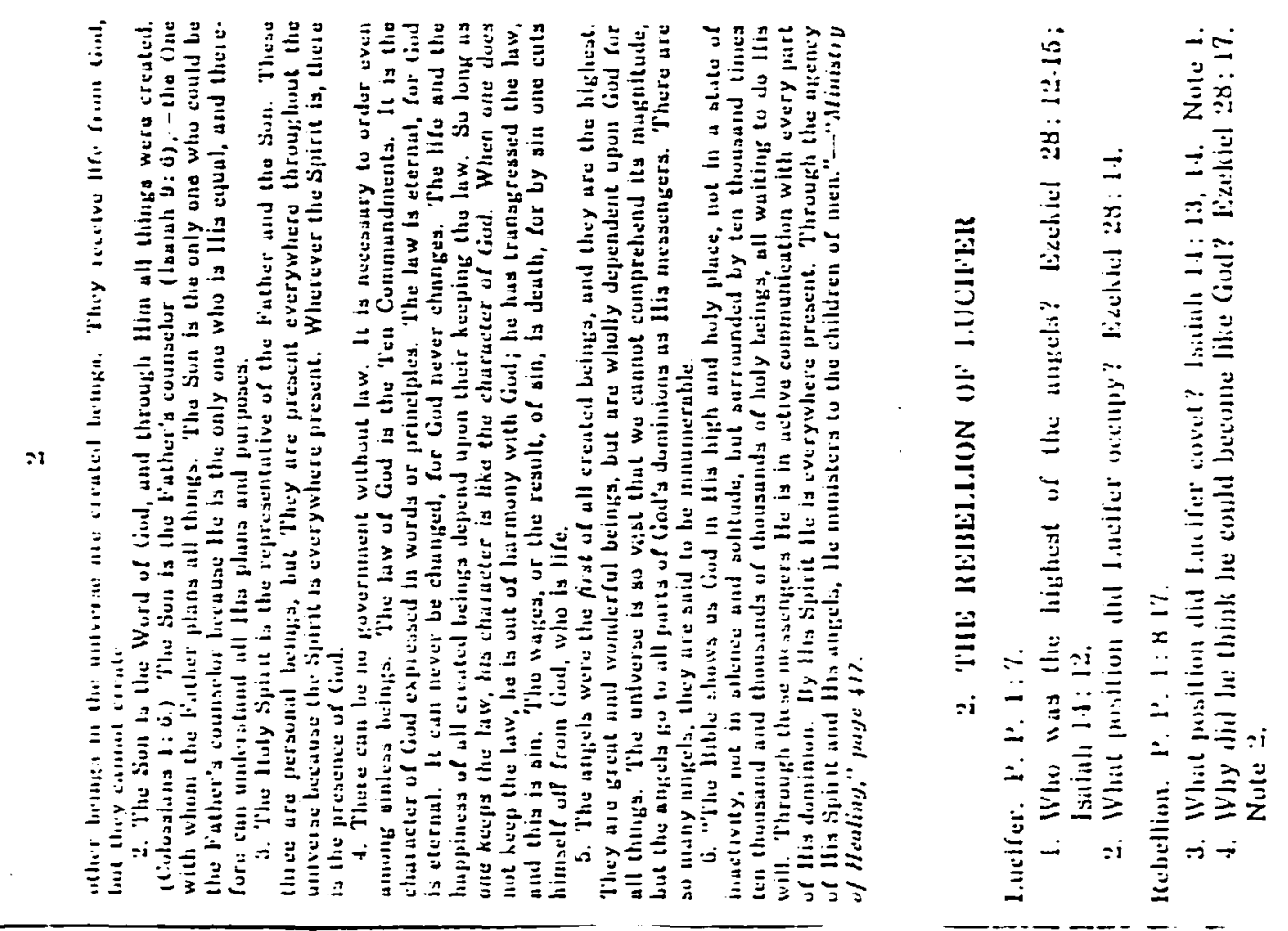



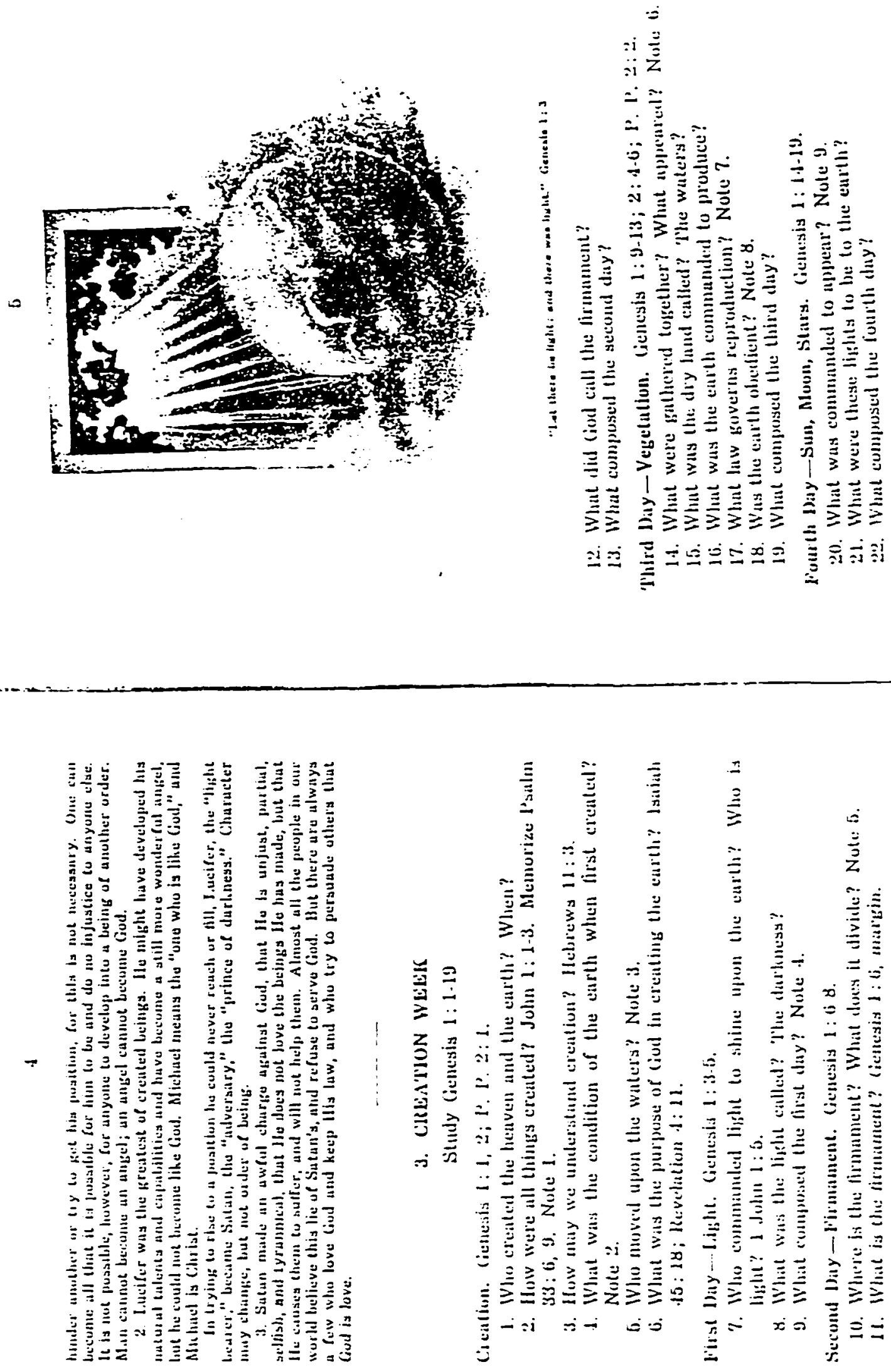


\title{
PLEASE NOTE
}

\author{
Copyrighted materials in this document have \\ not been filmed at the request of the author. \\ They are available for consultation, however, \\ in the author's university library. \\ Life and Times of The old Testament \\ 488-491 \\ 493-550
}

University Microfilms International 
APPENDIX 3

HE LEADETH YE, BY ALMA E. MCKIBBIN 
GLOSSARY

Reproduced with permission of the copyright owner. Further reproduction prohibited without permission. 


\section{GLOSSARY}

Academv: The dominant secondary school in America before the public high school. Academies were religiously oriented and usually boarded their students. The curriculum often included vocational and classical courses. although some schools offered only a college preparatory program. In the first part of the twentieth century and thereafter, "academy" among Seventh-day Adventists came to mean a Seventh-day Adventist high school. Most Seventh-day Adventist students boarded, often coming from long distances.

Biblical Dept.: At Healdsburg College, a program of studies consisting of four years of courses in Bible and religious studies. The name was later changed to Religion Dept.

Catechism: An elementary book containing a summary of the principles of the Christian religion, especially as maintained by a particular church, in the form of questions and answers. The child was required to memorize both questions and answers.

Catechetical Method: Question and answer method used for teaching and testing a student's knowledge. Originally used as an authoritarian method to indoctrinate children with biblical principles they would not understand until they were older, its usage in every subject became prevalent.

Church School: A day school conducted by a local church or by a group of churches (occasionally by a denominational institution) providing Christian training and general elementary education. The term "church school" is generally used synonymously with the term "elementary school," although some churches conduct a nine- or ten-grade school. In Alma McKibbin's day, the nine- or ten-grade school was officially called an intermediate school but is now called a junior academy. ${ }^{\prime}$ In the 1890 s a church school might consist of six, seven, or eight grades. At Healdsburg Preparatory School, the church school included grades 1-8 from 1899 to 1901, and grades 1-7 in 1901-02.

SDA Encyclopedia, 1975 ed., s. v. "Church School." 
Classical Course: At Healdsburg College, a program of studies consisting of three years of Latin and Greek.

Collegiate Dept.: The department which taught the classical program of studies or the scientific course for four years. Prerequisites were two years of the preparatory course.

Common Branches: The fundamental subjects; reading, writing and arithmetic; the basic skills taught in schools that students needed to function in society.

Common School: A school attended in common by all children, in which a common political and social ideology was taught.

Concentration: The interrelationship between the different sciences so that unity may spring out of the variety of knowledge. Synonym: correlation.

Conference: A geographical area of church organization.

Correlation: Integration of subjects with each other into a unified whole.

Critic Teacher: The training teacher who taught teachers; also, the cooperating classroom teacher who was in charge of the classroom management and who supervised the student teacher in his or her practice teaching.

Crusade: A church-sanctioned series of meetings to proselytize.

Day School: A private school for pupils who lived off campus.

Drill: Repetition of material leamed until the student could do it automatically. Understanding meaning was considered secondary.

Elementary Department: A four-year course equivalent to the four upper grades of elementary school, the same as the Grammar Course of the elementary schools.

Elementary School: The grades preceding the intermediate school. Loosely used to mean grades four through eight, or one through eight, or one through six.

General Conference: Goveming body for the Seventh-day Adventist world church.

Grammar Course: The program of studies in grades six through nine. 
Grammar Grades: Grades six through nine in 1895: later, grades four through eight in elementary school.

Grammar School: A graded school intermediate between a primary school and a high school. Same as Intermediate Course.

Health Reform: A holistic way of living healthfully designed to reduce disease, advocating a retum to man's original diet at creation.

Hecrograph: A process for making copies of a document, etc., from a prepared gelatin surface to which the original document was transferred.

High School: The education between elementary school and college; grades nine through twelve.

Industrial School: An intermediate school especially designed to educate youth ages fourteen through twenty and to provide work opportunities for every student so that, regardless of their economic situation, all could attend.

Intermediate Course: Loosely used to mean grades four to eight, seven and eight, eight and nine, or seven, eight and nine.

Intermediate Department: At Healdsburg Preparatory School, this department consisted of grades 4-8. See Intermediate Course. By 1903-04, however, this department consisted of only grades 8 and 9 .

Intermediate Grades: Same as Intermediate Course.

Intermediate Industrial School: A school consisting of the intermediate grades. whose chief industries were agriculture and horticulture. In the Timberland Industrial School, students could work to pay almost all school expenses.

Intermediare School: A nine- or ten-grade day school.

Junior Year: The first year of a three-year course at a normal school.

Junior Missionary Volunteer Sociery: A Christian children's society or club.

Master Guide: A leader of Christian youth qualified to teach classes in crafts, recreation, industrial work, camping, and other Pathfinder endeavors.

Middle Year: The second year of a three-year course at a normal school. 
Missionary Volunteer Sociery: A group of Christian young people who held weekly religious meetings on Friday evenings or Sabbath afternoons. Very much like the Christian Endeavor Society.

Vormal Department: That branch of a school which trained teachers and usually included a training school.

Vormal School: In 1889-92 when Alma took her normal training, a normal school was an educational institution that only trained teachers.

Object Lesson, or Object Method: A method of instruction that relied upon observation of actual things and natural objects rather than upon books and reading, thus developing the perceptive faculties.

Pathfinder: A youth from ten to fifteen years of age who was a member of the Junior Missionary Volunteer Society.

Pedagogy: The study or science of teaching.

Preparasory Course: The course of studies consisting of prerequisites for college, comparable to high school, but consisting of from two to four years' duration. Sometimes the innal years of intermediate school (grades eight and nine) were the preparatory course. At Healdsburg, the college preparatory course consisted of two years of courses beyond the intermediate grades.

Preparatory Department: At Healdsburg, those grades that preceded and prepared for entering college, called "first through fourth years," somewhat equivalent to sixth through tenth grade. Later, at Pacific Union College, the "Preparatory Department" consisted of grades nine to twelve. The term was also used in Healdsburg in 1901-02 for the first nine grades.

Primary Grades: In 1895, grades one through five; in 1899, one through four.

Primary Department: Consisted of grades one through five in 1895, or the lower elementary grades. See Primary Grades.

Quarters: At Healdsburg College, one quarter equalled one class per quarter year. It is possible that classes met daily, but nowhere is it specified how often or for what duration. A full load was considered to be three quarters, or three classes. 
Recitarion: A method of testing students' knowledge by having them read aloud, repeat a passage aloud from memory, or repeat the teachers' sayings aloud. Recitations could also be oral replies to questions. The onus for learning was on the student, and meaning may or may not have been important. For example, in an English literature class the recitation could consist of an outline of the day's lesson, showing its connection with prior lessons; a discussion of the characters in a novel and how they affect other characters and the plot; oral and written reports. rapid questioning, informal discussion, and the reading aloud of certain passages. In a math class, recitation might consist of repeating the basic facts together as a class in concert.

Readability: The quality of a piece of reading matter that makes it interesting and comprehensible to those for whom it is written, at whatever level of educational experience.

Readability Formula: A technique for determining the difficulty of reading materials, generally taking into account vocabulary and sentence length, although additional aspects are included in different formulas.

Readability Index: A composite score designed to indicate the level of difficulty of a piece of reading matter. The score is usually expressed in terms of school grades.

Readability Test: Any formula devised to estimate the difficulty of any printed material. The Fry formula utilizes the number of words per sentence and syllables per word; other formulas may include other aspects, such as the number of words not on a general list and considered unfamiliar.

Rod: The term commonly used among Christians at the turn of the century for last-resort, reasonable corporal punishment.

Rural Schools: Schools located in districts serving towns of fewer than four thousand people.

Sabbath: Holy day set apart for entering into a worship relationship with God, the Creator of man. For Seventh-day Adventists, it begins at sundown on Friday evening and ends at sundown on Saturday evening, which is the time kept holy by Jesus and the early Christians.

Sabbath School: Same as Sunday School, except believers meet on Saturday mornings instead of on Sunday momings.

Sabbath Keeper: One who keeps the seventh-day Sabbath. See Sabbath. 
Select School: A school that charged individual students for the teacher's salary.

Senior Year: The final year of the normal school course.

Sciensific Course: A four-year course that included a heavy concentration of sciences, including physics, chemistry, physiology, and anatomy.

Sloyd: A system of manual training (originally Swedish) which used wood carving as a means of training in the use of tools.

Signarure: a sheet with several pages printed on it, folded, to form a book.

Summer School: Normal school preparation for teachers during the summer. At the turn of the century, no certification was available at Healdsburg for summer course work completed; however, the teachers were given "credentiais" that enabled them to teach in church schools.

Teachers' Institute: A shor session for teachers, normally of several weeks' duration in the summer, several weeks' duration, at which teachers learned pedagogical methods.

Testimony: If italicized or underlined, one of a series of messages by Ellen $G$. White, believed to be based on special revelation by God, and written for church members. The term also refers to a personal comment of repentance, sorrow, happiness or praise toward God shared in public or in private; a confession of faith.

Tent Crusade: A church-sanctioned series of meetings to proselytize.

Training School: The school in which a normal student did practice teaching and observation under the supervision of a critic teacher. 
3IBLIOGRAPHY

Reproduced with permission of the copyright owner. Further reproduction prohibited without permission. 


\section{BIBLIOGRAPHY}

The bibliography is divided into two sections: first, material generated by Alma E. McKibbin, followed by a general bibliography on p. 573. All documents are arranged alphabetically, except for Mrs. McKibbin's published books, which are listed chronologically.

\section{Bibliography of Alma E. McKibbin}

Unpublished

\section{Letters and Autographs}

McKibbin, Alma E., Mountain View, Calif., to R. H. Adair, Washington, D.C., 1 January 1962. Generai Conference Archives, Silver Spring, Md.

, Mountain View, Calif., to Dr. and Mrs. Paul Adams, n. d. (c.1968).

Ellen White Research Center, Andrews University, Berrien Springs, Mich.

, Mountain View, Calif., to George S. Ashlock, Knoxville, Tenn., 13

August 1954. In the hand of George S. Ashlock, Squaw Valley, Calif.

, Mountain View, Calif., to George S. Ashlock, Knoxville, Tenn., 7

March 1955. In the hand of George S. Ashlock, Squaw Valley, Calif.

McKibbin, Alma E. Autograph in Madge Nelson's autograph book, 3 June 1924. In the hand of Madge Haines Nelson, Angwin, Calif.

- Autograph in Bessie Bobst Martella's autograph book, 30 May 1925.

In the hand of Bessie Bobst Martella, Hanford, Calif.

, Mountain View, Calif., to James Bamard, Bakersfield, Calif., 4 September 1967. In the hand of Jim Nix, Loma Linda, Calif.

Mountain View, Calif., Christmas or New Year's letters, December 1961, December 1964, January 1965. In the hand of Bertha Parmentier, Deer Park, Calif. 
Mountain View, Calif., to H. H. Cobban, Assistant Treasurer, General Conference, Washington, D. C., 3 May 1932, 18 May 1933, 6 October 1936, 1 March 1938. General Conference Archives, Silver Spring, Md.

Mountain View, Calif., to Claude Conard, Washington, D. C., 10 February 1931. General Conference Archives, Silver Spring, Md.

, Mountain View, Calif., to Alta Ellegard (Robinson),

Oakland, Calif., 17 April 1928. Ellen G. White Research Center, Andrews University, Berrien Springs, Mich.

, to future teachers, 1965, at the request of Mrs. Bernice Hanson, Elementary Supervisor of Education, Central California Conference of Seventh-day Adventists. In the hand of Else Nelson, Grand Terrace, Calif.

, Mountain View, Calif., to Ray and Emily Hixson, Mountain View, Calif., 3 January 1966. In the hand of Ray and Emily Hixson, Loma Linda, Calif.

, Mountain View, Calif., to Gladys Jones, Mountain View, Calif., 2 April 1968. In the hand of Gladys Jones, Middleton, Idaho.

, Mountain View, Calif., to Brother Kozel, Washington, D. C., 14 July 1966, 9 December 1965, 8 February 1966, 3 May 1966, 29 November 1967, 2 September 1968. General Conference Archives, Silver Spring, Md.

Mountain View, Calif., to Sister Mohr, Buffalo, N. Y., 15 June 1953. In the hand of Bertha Parmentier, Deer Park, Calif.

Mountain View, Calif., to A. R. Monteith, Angwin, Calif., 28 January 1942, 26 March 1942, 3 April 1942, 21 April 1942, 23 April 1942. In the hand of Else Nelson, Grand Terrace, Calif.

Mountain View, Calif., to James Nix, Bakersfield, Calif., 6 June 1967, 24 July 1967, 14 August 1967. In the hand of James Nix, Loma Linda, Calif.

Mountain View, Calif., to James R. Nix, Riverside, Calif., 15 September 1967, 26 September 1967, 25 January 1968. In the hand of James Nix, Loma Linda, Calif.

Mountain View, Calif., to Jessie Paap, 10 January 1927. In the hand of Harold Oliver McCumber. 
Mountain View, Calif., to Bertha Parmentier, [1949?], 13 December 1948, 26 February 1953, 3 February 1958, 11 August 1958, 4 June 1959, [February 1961), 3 March 1961, 11 March 1961, Spring, 1966, 24 March 1961, 10 September 1968, 15 September 1968. In the hand of Bertha Parmentier, Deer Park, Calif.

Mountain View, Calif., to Fedalma Ragon, [1940?], 5 July 1944, 29 January 1945, 1 January 1953, 25 March 1953, 13 October 1953, 14 June 1954, 1956, 1957, 21 December 1959, 13 November 1960, 15 March 1961. Adventist Heritage Center, Loma Linda University, Loma Linda, Calif.

Mountain View, Calif., to Maryan Stirling, Mountain View, Calif., 13 December 1959. In the hand of Maryan Stirling, San Jacinto, Calif.

Mountain View, Calif., to Aline Tait and Betty Tait, 18 January 1968. In the hand of Aline and Betty Tait, Napa, Calif.

Mountain View, Calif., to Lew E. Wallace, 7 November 1964. In the hand of Lyie Marie Stockton, Loma Linda, Calif.

Mountain View, Calif., to Ethel Young, Washington, D. C., 27 January 1964, February 1964, 6 February 1966, 1 March 1966, 18 March 1966, 7 April 1966, 26 August 1966. In the hand of Ethel Young, Russell, Penn.

\section{Manuscripts}

Alma E. McKibbin. [no title] AMs [photocopy], p. 2. Adventist Heritage Center, Andrews University, Berrien Springs, Mich.

Book of Remembrance. The location of this book is unknown. Mrs. McKibbin's relatives say they do not know its location.

. "Church School Beginnings in California." Talk given in 1957.

TMs. Transcript in Adventist Heritage Center, Loma Linda University, Loma Linda, Calif.

"Church School History, 1957 (?)" TMs [photocopy]. Mentioned in Spalding's Origin and History of Seventh-day Adventists. Vol. 2, but not able to locate. This manuscript is likely the one called, "Educational History," also 1957. 
"Courtesy" [c. 1945] AMs. Talk given at a Young Peoples' Society Meeting, Mountain View SDA Church, Mountain View Church, Mountain View, Calif. In the hand of Elna Quade, Yountrille, Calif.

"Educational History" [1957], AMs [photocopy]. Adventist Heritage Center, La Sierra College, Riverside, Calif.

"Educational History" [n. d.], TMs [photocopy]. In the hand of Else Nelson, Grand Terrace, Calif., and George Ashlock, Squaw Valley, Calif.

"Experiences" [n. d.], AMs [photocopy]. Adventist Heritage Center, La Sierra College, Riverside, Calif.

"Founders' Day Address," 9 April 1954. TMs [photocopy]. Adventist Heritage Center, Pacific Union College, Angwin, Calif.

"The Joy and Reward of the Christian Teacher." Address given at Teachers' Institute, I December 1942. TMs, San Jose, Calif. In the hand of Else Nelson, Grand Terrace, Calif.

. "I Knew Sister White." See "Mrs. McKibbin and Sister White."

"Look and Live." Poem read at teachers' class, 8 February 1964, Mountain View, Calif. In the hand of Bertha Parmentier, Deer Park, Calif.

"Mrs. McKibbin and Sister White," [May 1962) TMs [photocopy]. Talk given at Mountain View Seventh-day Adventist Church, Mountain View, Calif. Another name for this transcript is "I Knew Sister White." Tape recordings and transcript. In the hand of Paul Ricchiuti, Nampa, Idaho.

"My Beloved Friend, Clara Couey Burg," [n. d.], TMs [photocopy]. Paper written in remembrance of Clara Couey Burg. In the hand of Verda Burg Becraft, Shingletown, Calif.

"My Memories of Sister White" TMs [photocopy]. Lecture given at the Mountain View Church prayer meeting, Mountain View, Calif., 15 February 1956. Ellen G. White Research Center, DF 967. Andrews University, Berrien Springs, Mich.

"Reforms and Reformers," [n. d.], AMsS. In the hand of Ethel Young, Russell, Penn. 
"Reminiscences." Address at Pacific Union College Seventy-fifth Anniversary Alumni Homecoming. TMs [phctocopy]. 30 March, 1957 TMs [photocopy], Angwin, Calif. Adventist Heritage Center, Pacific Union College, Angwin, Calif.

. "Unchanging Values." Address on Founders' Day, 1946, TMs [photocopy]. Adventist Heritage Center, Pacific Union College, Angwin, Calif.

"The Way the Lord Has Led Us." November 1943, TMsS

[photocopy]. Address given at Teachers' Institute, La Sierra College, La Sierra, Calif. In the hand of Ethel Young, Russell, Penn., and George S. Ashlock, Squaw Valley, Calif.

"The Way the Lord Has Led Us." [1944] TMs. Transcript of address given at Teachers' Institute, La Sierra College, La Sierra, Calif. In the hand of Eise Nelson, Grand Terrace, Calif.

\section{Interviews and Tape Recordings}

Alma E. McKibbin. "Development of the Seventh-day Adventist Church School System," 1956. Tape recording. In the hand of Robert and Donna Jacobs, Angwin, Calif.

"I Knew Sister White." Series of three talks given at prayer meetings, Mountain View Church, Mountain View, Calif., 9, 16, and 23 May 1962. Tape recordings and transcripts. In the hand of Paul Ricchiuti, Nampa, Idaho, and Ford Lewis, Cassopolis, Mich.

. Interview by Eric Kreye, 29 November 1970. Tape recording. In the hand of Paul Ricchiuti, Nampa, Idaho.

Interview on 1888 [by Eric Kreye], 23 May 1962. Tape recording. In the hand of Paul Ricchiuti, Nampa, Idaho.

Interview by James Nix, Mountain View, Calif., 1 June 1967. Tape recording. Adventist Heritage Centers, Andrews University, Berrien Springs, Mich., and Loma Linda University, Loma Linda, Calif.

Interview by James Nix and James Barnard, Mountain View, Calif., 2 August 1967. Tape recording and transcript. Adventist Heritage Centers, Andrews University, Berrien Springs, Mich., and Loma Linda University, Loma Linda, Calif. 
Interview by James Nix and James Bamard, 30 September 1967. Transcript. Adventist Heritage Center, Loma Linda University, Loma Linda, Calif.

- Interview by unnamed person, 25 March 1959. Adventist Heritage Center, La Sierra College, Riverside, Calif.

. Interview by Walter C. Utt [1955]. Transcript, Adventist Heritage

Center, Pacific Union College, Angwin, Calif.

"Mrs. White." Talk at Jackson, Calif., 1953. Tape recording. Adventist Heritage Centers, Andrews University, Berrien Springs, Mich., and Loma Linda University, Loma Linda, Calif.

. Sabbath School Lesson. "Prophecy: A Guiding Light." Class

taught at Mountain View SDA Church, Mountain View, Calif., n. d. Tape recording. In the hand of Paul Ricchiuti, Nampa, Idaho.

. Sabbath School Lesson on the Seven Deacons. Class taught at Mountain View SDA Church, Mountain View, Calif., 18 November 1965. Tape recording. In the hand of Gustav Tobler, Sunnyvale, Calif.

Sabbath School Lesson on the Spirit of Prophecy. Class taught at Mountain View SDA Church, Mountain View, Calif., 16 June 1962. Tape recording. In the hand of Paul Ricchiuti, Nampa, Idaho.

. "The Understanding Heart." Talk given to the Young People's Society, Mountain View, Calif., I February 1963. Tape recording. In the hand of Paul Ricchiuti, Nampa Idaho.

Published

\section{Periodicals}

Alma E. McKibbin. "Alma McKibbin Remembers Elder J. N. Loughborough." Pacific Union Recorder 67 (4 March 1968): 2. 6-8.

"Amusements." Pacific Union Recorder 9, no. 42 (19 May 1910): 
"Answering Children's Questions. Christian Education 2, no. 3 (January-February, 1911): 43-46; reprint, Christian Education 4, no. 5 (February 1913): 195-7 (Part 1) and 4, no. 6 (March 1913): 227-8 (Part 2).

"As I Remember." Signs of the Times 71, no. 22 (6 June 1944): 6. 12-13.

"The Babe in Arms." Review and Herald 137 (10 November 1960):

. "Bearing the Yoke." Signs of the Times 74 (4 March 1947): 16.

"Bible Study for the Children." Christian Education 1, no. 5

(May-June 1910): 30-32.

'Bible Teaching (Selections from the New 'Bible Lessons'

Manual by Mrs. Alma E. McKibbin)." Christian Educarion 6, no. 4 (December 1914): 115-16.

"The Child's Sense of Security." Review and Herald 137 (17 November 1960): 12.

17-18.

"The Christian Teacher." Review and Herald 120 (18 March 1943):

"Contentment." Signs of the Times 74 (1 July 1947): 16.

"A Crushing Disappointment." Review and Herald 139, no. 11 (15

March 1962): 6-7; reprint, Chapter 6, Step by Step, Washington, D. C.:

Review and Herald Publishing Association, 1964 (included in Appendix B).

"The Cultural Training of Our Children." Home and School 26, no. 2 (October 1933): 3-6.

10. 11.31 .

"The Days of Old." Review and Herald 127 (2 February 1950):

"Early Days in Signs History." Signs of the Times (4 June 1964):

"The Easier Load." Signs of the Times 74, no. 11

(March 18 1947): 16. 
"The Freckle-Removing Lotion." Review and Herald 139, no. 8 (22 February 1962): 5-6; reprint, Chapter 3, Step by Step Washington, D. C.: Review and Herald Publishing Association, 1964 (included in Appendix B).

37. "Fundamental Principles of Fiction." Ministry 14 (August 1944):

"Ganham Almas: as Escolas Primarias Adventistas?" Portuguese story found in Segunto, Spain, by Ethel Young. English translation: "Do Church Schools Win Souls?" In the hand of Ethel Young, Russell, Penn. American version was printed in the Review and Herald, 18 March 1943, under the title, "The Christian Teacher."

"God Gave Me Strength for My Burdens." Review and Herald 139, no. 16 (19 April 1962): 8-9; reprint, Chapter 11, Step by Step, Washington, D. C.: Review and Herald Publishing Association, 1964 (included in Appendix B).

"Half Hours With the Bible." Signs of the Times 72, nos. 1-29, 3135, 37-50 (2 January to 18 December 1945), reprint, Mountain View, Calif.: Pacific Press Publishing Association, 1946.

"He Leadeth Me." Review and Herald 139, no. 6 (8 February 1962): 2. 3; reprint, Chapter 1, Step by Step. Washington, D. C.: Review and Herald Publishing Association, 1964 (entire twelve chapters included in Appendix B).

"History of Our Church," 1963. Article in first Church Pictorial, Mountain View SDA Church, Mountain View, Calif.

"How to Teach the Bible," Journal of True Education 27, no. 3 (January-February 1965), 6-8.

"I Go to College." Review and Herald 139, no. 10 (8 March 1962): 4-5; reprint, Chapter 5, Step by Step, Washington, D. C.: Review and Herald Publishing Association, 1964 (included in Appendix B).

"I Was a Modern Jonah." Review and Herald i39, no. 14 (5 April 1962): 10-12; reprint, Chapter 9, Step by Step, Washington, D. C.:

Review and Herald Publishing Association, 1964 (included in Appendix B).

"If I Were a Girl Again." Christian Education 3, no. 6 (July-August 1912): 14. 
"In Conflict with Evil Spirits." Review and Herald 139, no. 13 (29 March 1962): 7-9; reprint, Chapter 8, Step by Step, Washington, D. C.: Review and Herald Publishing Association, 1964 (included in Appendix).

. "The Influence of Parents and Teachers, Part 1." Review and Herald 137 (3 November 1960): 18. The other four parts are under different titles; Part 2, "The Babe in Arms," Part 3, "The Child's Sense of Security," and Part 4, "Understanding the Slow Child."

"Into the Sunset." Review and Herald 139, no. 17 (26 April 1962): 6-7; reprint, Chapter 12, Ste by Step, Washington, D. C.: Revie $N$ and Herald Publishing Association, 1964 (included in Appendix B).

"Joys and Sorrows." Review and Herald 139, no. 12 (22 March 1962): 6-7; reprint, Chapter 7, Step by Step, Washington, D. C.: Review and Herald Publishing Association, 1964 (included in Appendix B).

1906): 66-7.

. "The 'Leaders' in Sabbath School." Sabbath School Worker 26, no. 2 February 1910): 20-22; reprint, Sabbath School Worker 40, no. 2 (February 1924): 41-42.

"The Light from Heaven." Signs of the Times 77

(22 August 1950): 7.

. "Literature for Children." Pacific Union Recorder 7, no. 51 (23 July 1908): 2-4.

- "Little Dunce." Review and Herald 139, no. 7 (15 February 1962): 4-6; reprint, Chapter 2, Step by Step, Washington, D. C.: Review and Herald Publishing Association, 1964 (included in Appendix B).

"Marcia Phelps Tucker." Obituary. Review and Herald 82 (16 November 1905), 23.

"Meeting New Challenges." Review and Herald 139, no. 15 (12 April 1962): 5-7; reprint, Chapter 10, Step by Step, Washington, D. C.: Review and Herald Publishing Association, 1964.

"My Memories of Ellen White." 3 parts. Review and Herald 135 (17 July 1958): 5; (24 July 1958): 6; (31 July 1958): 4. 
"The Plan of Salvation." 2 parts. Signs of the Times 64 (21

September 1937): 6; (29 September 1937): 6.

"The Prince Who Could Not Walk." Youth's Instructor 97 (29

November 1949): 14.

"Sensitiveness." Journal of True Educarion 18, no. 1 (October

1955): 7, 27.

"Sister White Was My Friend," 2 parts. The Youth's Instructor 112

(2 June 1964): 3-4, 22; (9 June 1964): 16-18.

"The Soul-Winning Teacher." Sabbath School Worker 34, no. 11

(November 1918): 244-5; reprint, Sabbath School Worker 45, no. 1

(January 1929): 5-6.

"The Spell Was Broken." Review and Herald 139, no. 9 (1 March 1962): 6-8; reprint, Chapter 4, Step by Step, Washington, D. C.: Review and Herald Publishing Association, 1964 (included in Appendix B).

"The Spiritual Training of Our Children." Home and School 23, no. 6 (June 1931): 16.

"A Story of the Origin of Bible Lessons for the Church Schools."

Journal of True Educarion 27, no. 3 (January-February 1965): 18-19, 24.

"Teach Me to Understand." 3 parts. Review and Herald 120 (13

May 1943): 14-15; (20 May 1943): 14; (27 May 1943): 14-15. Paper

read at Home and School meeting, Mountain View, Calif.

"A Teacher's Satisfactions." Youth's Instructor 92, no. 21 (23 May 1944): 5, 12-13.

"An Understanding Heart." Review and Herald 148 (25 November 1971): 6, 9. Condensed from talk given to Missionary Volunteer Society at Mountain View Church, Mountain View, Calif., 1 February 1963.

"Understanding the Slow Child." Review and Herald 137 (24

November 1960): 12. Part 4 of the series, "The Influence of Parents and Teachers."

. "Vital Religion-A Retrospect." Christian Education 4, no. 4 (January 1913): 142-3. 
"What May Reascnably Be Expected of Officers and

Teachers." 2 parts. Sabbarh School Worker 16, no. 9 (September 1900): 131-2; (1 October 1900): 147-8.

"What the Time Spent in School May Mean to a Young Man or a Young Woman." Christian Education 1, no. 5 (May-June 1910): 14-15.

"What We Miss When We Are Not Members of the Sabbath School." 2 parts. Sabbath School Worker 50, no. 5 (May 1934): 134-5; no. 6 (June 1934): i64-66.

"Winning the Girl." Sabbath School Worker 41, no. 3 (March 1925): $71-73$.

\section{Books and Pamphlets}

Alma E. McKibbin. Bible Lessons for the Church School. [Books 1-3]. Shoestring ed. Healdsburg, Calif.: Healdsburg College Press, 1903; reprint, Healdsburg, Calif.: Healdsburg College Press, [1904, 1905]; reprint, Mountain View, Calif.: Pacific Press Publishing Association, 1905. Adventist Heritage Centers: Andrews University, Berrien Springs, Mich.; Loma Linda University, Loma Linda, Calif.; Pacific Union College, Angwin, Calif., La Sierra College, Riverside, Calif.; in the hand of Luan Wallace Strachan, Deer Park, Calif.; in the hand of Jim Nix, Loma Linda, Calif.

Bible Lessons in Old Testament History, Books 1-2. New rev. ed. Mountain View, Calif.: Pacific Press Publishing Association, 1909; reprint, 1915. Ellen G. White Research Centers and Adventist Heritage Centers: Andrews University, Berrien Springs, Mich., La Sierra College, Riverside, Calif.: Pacific Union College, Angwin, Calif.; Loma Linda University, Loma Linda, Calif.; Pacific Press Publishing Association, Nampa, Idaho.

Bible Lessons: The Life of Jesus, Book 3. 2d ed., new rev. ed. Mountain View, Calif.: Pacific Press Publishing Association, 1909. Teaching Materials Center, Andrews University, Berrien Springs, Mich.; Adventist Heritage Centers: Andrews University, Berrien Springs, Mich.; Pacific Union College, Angwin, Calif.; La Sierra College, Riverside, Calif.; Loma Linda University, Loma Linda, Calif.; Pacific Press Publishing Association. Nampa, Idaho. 
Bible Lessons: The Acts of the Apostles and The Plan of Salvation. Book 4. Mountain View, Calif.: Pacific Press Publishing Association, 1912. Ellen G. White Research Centers and Adventist Heritage Centers: Andrews University, Berrien Springs, Mich.; La Sierra College, Riverside, Calif.; Loma Linda University, Loma Linda, Calif.; Pacific Union College, Angwin, Calif.; Pacific Press Publishing Association, Nampa, Idaho.

Bible Lesson Manual for Parents and Teachers. Mountain View, Calif.: Pacific Press Publishing Association, 1914. Adventist Heritage Centers: Andrews University, Berrien Springs, Mich.; Loma Linda University, Loma Linda, Calif.; Pacific Union College, Angwin, Calif.; Pacific Press Publishing Association, Nampa, Idaho.

A Manual of Lessons in Old Testament History for Academic Grades. Mountain View, Calif.: Pacific Press Publishing Association, 1918. Ellen G. White Research Centers and Adventist Heritage Centers: Andrews University, Berrien Springs, Michigan; Loma Linda University, Loma Linda, Calif.; Pacific Union College, Angwin, Calif.; La Sierra College, Riverside, Calif.; Pacific Press Publishing Association, Nampa, Idaho.

. "How to Teach the Bible," chapter in Teacher's Handbook on the Elementary Curriculum. Mountain View, Calif.: Pacific Press Publishing Association, 1918. Cited in Alma E. McKibbin, "How to Teach the Bible" Journal of True Educarion 27, no. 3 (January-February 1965), 26.

. Bible Lessons: The Life of Jesus, for the Sixth Grade. $2 \mathrm{~d}$ ed., rev. Mountain View, Calif.: Pacific Press Publishing Association, 1921; reprint, 1924, 1928. Adventist Heritage Centers, Pacific Union College, Angwin, Calif.; Andrews University, Berrien Springs, Mích.; Loma Linda University, Loma Linda, Calif.; La Sierra College, Riverside, Calif.; Pacific Press Publishing Association, Nampa, Idaho.

Bible Lessons: The Gospel to All the World. Seventh Grade. Rev. ed. Mountain View, Calif.: Pacific Press Publishing Association, 1926. Adventist Heritage Centers, Pacific Union College, Angwin, Calif.; La Sierra College, Riverside, Calif., Andrews University, Berrien Springs, Mich.; Loma Linda University, Loma Linda, Calif. Part II was written by Gladys Robinson Stearns. 
Bible Lessons for the Fifth Grade: Last of Old Testament Times: Stories from Israel, 2d ed., rev. Mountain View, Calif.: Pacific Press Publishing Association, 1926. (This is a revision of Bible Lessons in Old Testament History, Book 2, 1909). Adventist Heritage Centers: Andrews University, Berrien Springs, Mich.; La Sierra College, Riverside, Calif.; Pacific Union College, Angwin, Calif.; Loma Linda University, Loma Linda, Calif.; Pacific Press Publishing Association, Nampa, Idaho.

A Manual of Lessons in Old Testament History for Academic Grades.

2d. ed., rev. and enl. Mountain View, Calif.: Pacific Press Publishing Association, 1927. Ellen G. White Research Centers and Adventist Heritage Centers: Andrews University, Berrien Springs, Mich.; Loma Linda University, Loma Linda, Calif.; Pacific Union College, Angwin, Calif.; Pacific Press Publishing Association, Nampa, Idaho.

The Gospel to All the World: Bible Lessons for the Seventh Grade. Rev. ed. Mountain View, Calif.: Pacific Press Publishing Association, 1940. Adventist Heritage Centers: Andrews University, Berrien Springs, Mich.; Loma Linda University, Loma Linda, Calif.; Pacific Union College, Angwin, Calif.; La Sierra College, Riverside, Calif.; Pacific Press Publishing Association, Nampa, Idaho; Teaching Materials Center, James White Library, Andrews University, Berrien Springs, Mich. (Part II was written by Gladys Robinson Steams and revised by Sarah Elizabeth Peck).

Half Hours With the Bible. Mountain View, Calif.: Pacific Press Publishing Association, 1946; reprint, 1946. James White Library, Andrews University, Berrien Springs, Mich.; Adventist Heritage Center, Pacific Union College, Angwin. Calif.

Los Ultimos Tiempos del Antiguo Testamenso (Last of Old Testament Times) Vol. 3, Serie de Lecciones Biblicas (Bible Lessons Series) Buenos Aires: Casa Editora Sudamericana, 1947. Adventist Heritage Center, Andrews University, Berrien Springs, Mich.

La Vida de Cristo (The Life of Christ) Vol. 4, Serie de Lecciones Biblicas (Bible Lessons Series) Buenos Aires: Casa Editora Sudamericana, 1947. Adventist Heritage Center, Andrews University, Berrien Springs, Mich.

El Evangelio al Mundo Entero... Los Hechos de los Apostoles (The Gospel to All the World: Acts of the Apostles). Vol. 5, Serie de Lecciones Biblicas (Bible Lessons Series) Buenos Aires: Casa Editora Sudamericana, 1950. Adventist Heritage Center, Andrews University, Berrien Springs, Mich. 
Lecciones Biblicas de Historia en el Antiguo Testamento (Bible Lessons in Old Testament History). Vol. 1, Serie de Lecciones Biblicas (Bible Lessons Series) 1955 [Mimeographed copy]. Adventist Heritage Center, Andrews University, Berrien Springs, Mich.

- Ourline Studies on Patriarchs and Prophets. Washington, D. C.: Review and Herald Publishing Association, n. d. Ellen G. White Research Center, Document File \$967, Andrews University, Berrien Springs, Mich.

Siep by Step. Mountain View, Calif.: Pacific Press Publishing Association, 1964. James White Library, Andrews University, Berrien Springs, Michigan. 


\section{General Bibliography}

Unpublished

\section{U. S. Census, City and County Records}

Andreas, Tom. "Patrons List." Allas of lowa. Webster County Genealogical Society, For Dodge, Iowa.

California. Department of Health Services, Sacramento, Calif. Standard Certificate of Death. No. 28-060040. 27 November 1928.

Department of Health Services, Sacramento, Calif. Certificate of Death. No. 4300-04071. 16 July 1974.

Iowa Genealogical Society. Surname Index. Iowa Genealogical Society, Des Moines, Iowa, n. d.

Mountain View City Directory, 1926-1968. N.p., n.d. Mountain View Historical Society, Mountain View, Calif.

U. S. Bureau of the Census. 1880 Census D. Denver, Colo., 1880. Microfilm.

- First Census of the State of Colorado: Population of Saguache Counsy. Denver, Colo.: Division of State Archives and Public Records. 1885 D. Central Microfilm Unit. USA 123:11/67 (250).

Webster County [Iowa] Genealogical Society. Application for marriage license. 25 November 1870 D. For Dodge, Iowa.

$$
\text { Webster County Marriages. Fort Dodge, Iowa, n. d. }
$$

\section{Minutes of Meetings}

California Conference of Seventh-day Adventists (Oakland, Calif.). Minutes, 1 June 1904, 123-128. 
General Conference of Seventh-day Adventists. Department of Education. Educational Recommendations, 1918-19. Microfiche. Adventist Heritage Center, Andrews University, Berrien Springs, Mich.

. Department of Education. Staff Minutes 1909-1974. Microfiche.

Pacific Press Publishing Association (Mountain View, Calif.). Minutes of the Board of Directors, 7 April 1909; 5 May 1912.

Pacific Union College. Minutes of the Pacific Union College Committee, 1909 1921. Pacific Union College, Angwin, Calif.

Pacific Union Conference. Minutes of the Pacific Union Conference Academic Teachers' Council, Angwin, Calif., 19-24 August 1926.

University of Califormia, Los Angeles. Series $\$ 252$. California State Normal School, Los Angeles. Minutes of Meetings of Faculty and Administrative Committees, 1883-1918.

. Series \#1. California State Normal School, Los Angeles. Mirutes of Meetings of the Board of Trustees, 1887-1919.

\section{Letters}

Ahlkvist, Lennart, Coulterville, Calif., to author, 5 May 1990.

Baker, Alonzo L., Mountain View, Calif., to W. H. Branson, Washington, D.C., 28 May 1933. General Conference Archives, Silver Spring, Md. , Mountain View, Calif., to J. L. Shaw, Washington, D. C., 28 May 1933. General Conference Archives, Silver Spring, Md.

Becraft, Verda Burg, Shingletown, Calif., to author, 7 February 1991.

Bennett, Harry, National City, Calif., to author, 6 June 1990.

Bitterlich, Dennis L., Assistant Archivist, University of Califomia Library, Los Angeles, to author, 13 December 1990.

Childs, H. G., Mountain View, Calif., to F. T. Oakes, San Jose, Calif., 9 December 1937. General Conference Archives, Silver Spring, Md. 
Cobban, H. H., Assistant Treasurer, General Conference, Washington, D. C., to Alma E. McKibbin, Mountain View, Calif., 8 May 1932, 24 May 1933.

General Conference Archives, Silver Spring, Md.

Washington, D. C., to W. H. Branson, Washington, D. C., 7 June

1933. General Conference Archives, Silver Spring, Md.

Washington, D. C., to Alonzo L. Baker, Mountain View, Calif., 12 June 1933. General Conference Archives, Silver Spring, Md.

Conard, Claude, Washington, D. C., to Alma E. McKibbin, Mountain View, Calif., 7 February 1932. General Conference Archives, Silver Spring, Md.

Critchlow, Harry and Levona Critchlow, Healdsburg, Calif., to Alma McKibbin, Sanitarium, Calif., 11 May 1911. In the hand of Paul Ricchiuti, Nampa, Idaho.

Estis, Emestine, Loma Linda, Calif., to author, 19 November 1990.

Flory, Lois M., St. Helena, Calif., to author, 24 April 1990.

Hagen, Miriam Westcott, Riverside, Calif., to author, 21 June 1991.

Haloviak, Bert, Assistant Director, Archives, General Conference of Seventh-day Adventists, Silver Spring, Md., to author, 10 June 1991.

Ham, George H., M.D., Angwin, Calif., to Walter E. Macpherson, M.D., Glendale, Calif., 26 February, 1990. Angwin, Calif., to author, 6 December 1990.

Hartwick, Betty, Lodi, Calif., to author, 7 December 1990.

Hill, Florence Thomton, Healdsburg, Calif., to Alma McKibbin, Sanitarium, Calif., 17 July 1911. In the hand of Paul Ricchiuti, Nampa, Idaho.

Los Angeles, Calif., to Alma McKibbin, Pacific Union College, St. Helena, Calif., 15 August 1919. In the hand of Paul Ricchiuti, Nampa, Idaho.

Los Angeles, Calif., to Mrs. Alma E. McKibbin, Reno, Nevada, 9 July 1920. In the hand of Paul Ricchiuti, Nampa, Idaho. 
Howell, W. E., Washington, D. C., to General Conference Sustentation Committee, 6 June 1933. General Conference Archives, Silver Spring, Md.

Huestus, Mrs., Redwood City, Calif., to Alma McKibbon [sic], St. Helena Sanitariurin, Sanitarium, Calif., 19 July 1927. In the hand of Paul Ricchiuti, Nampa, Idaho.

Kellogg, Alvin S., Nice, Calif., to Alma E. McKibbin, Mountain View, Calif., 26 March 1946. Adventist Heritage Center, Pacific Union College, Angwin, Calif.

Kirk, Jack, Mariposa, Calif., to author, 3 December 1990.

Kreye, Eric, Estacada, Oregon, to author, 6 June 1990.

Kubrock, Gladys, Elmshaven, Saint Helena, Calif., to author, 12 May 1990.

Kuninobu, Dorothy, Honolulu, Hawaii, to author, 17 February 1991.

Kutsch, Robert, Florence, Oregon, to author, 27 May 1991.

Ladd, Vema Nelson, College Place, Wash., to author, 18 November 1990.

Layton, Betty J., Library and Archives Assistant, American Baptist Historical Society, American Baptist Archives Center, Valley Forge, Penn., to author, 30 November 1990.

Lewis, Glenn, San Pasqual, Cadif., to author, 10 February 1991.

Lotta, E. B., San Jose, Calif., to Alma McKibbin, Pacific Union College, St. Helena, Calif., 5 March 1912.

Martella, Bessie Bobst, Hanford, Calif., to author, 10 December 1990; 24 January 1991.

Meikle, Edith, Los Gatos, Calif., to author, 6 May 1990.

Miller, Delpha S., College Place, Wash., to Alma E. McKibbin, Gaston, Oregon, 27 July 1909. In the hand of Paul Ricchiuti, Nampa, Idal ${ }_{\iota}$.

Miller, Raul A., Escondido, Calif., to author, 28 April 1991. 
Mitchel, Carmelita Parks, Carson City, Nev., to author, 16 November 1990. Mrs. Mitchel is the daughter of Levona Critchlow, who used to sit with Alma McKibbin's mother in Healdsburg, c. 1909-11.

Mitcheil, Doris, Mountain View. Calif., to author, 14 February 1991.

Morgan, Blanche, Mountain View, Calif., to Alma McKibbin, St. Helena Sanitarium, Sanitarium, Calif., 19 July 1927. In the hand of Paul Ricchiuti, Nampa, Calif.

Nelson, Madge, Angwin, Calif., to author, 9 April 1990.

Payne, Ethelyn Marie, Rochester, Wash., to author, 18 February 1991.

Paulin, Mary, Escondido, Calif., to Alma McKibbin, Mountain View, Calif., 6 June 1922. In the hand of Paul Ricchiuti, Nampa, Idaho.

Parmentier, Bertha, Mountain View, Calif., to Alonzo Baker, Riverside, Calif., 15 August 1975. In the hand of Bertha Parmentier, Deer Park, Calif.

Deer Park, Calif., to author, 14 November 1990.

Peck, Sarah Elizabeth, Sanitarium, Calif., to Alma E. McKibben [sic], Healdsburg, Calif., 19 March 1806 [sic]. Should be 1906. Ellen G. White Research Center, General Conference of Seventh-day Adventists, Silver Spring, Md.

Perrine, Herbert E., Dayton, Ohio, to author, 9 February 1991.

Peterson, Myrtle, Roseburg, Oregon, to author, 21 November 1991. , to author, 25 January 1991.

Poirier, Tim, General Conference Archives, Silver Spring, Md., to author, 11 November 1990.

Pitcher, Grace B., Camden, Maine, to author, 19 February 1991.

Ruth, Kansas City, Kansas, to Alma McKibbin, Geyserville, Calif., 24 October 1920. In the hand of Paul Ricchiuti, Nampa, Calif.

Russell, Clifford, Concrete, Wash., to author, 7 February 1991.

Schneider. Althea, Nampa, Idaho, to author, II March 1991. 
Schweitzerhof, Gertrude, Cupertino, Calif., to author, 12 February 1991.

Shaw, J. L., Washington, D. C., to Alonzo L. Baker, Mountain View, Calif., 2 June 1933. General Conference Archives, Silver Spring, Md.

Slabach, Barbara, Sunnyvale, Calif., to Ethel Young, Washington, D. C., 15 January 1966. In the hand of Ethel Young, Russell, Penn.

Stirling, Maryan, San Jacinto, Calif., to author, 4 December 1990.

Stockdale, Lyle Marie, Loma Linda. Calif., to author, 26 November 1990.

Taylor, Althea, Maitland, N.S.W., Australia, to author, 22 February 1991.

Vielhauer, E. Frances (Reed), Lebanon, Oregon, to author, 31 December 1990.

Von Pohle, Clinton, Mountain View, Calif., to author, 5 December 1990. Mountain View, Calif., to author, 23 January 1991.

Wallace, Mrs. [Lew E.], to Alma McKibbin, St. Heiena Sanitarium, Sanitarium, Calif., 27 August 1911. In the hand of Paul Ricchiuti, Nampa, Idaho.

Walter, Marvin, Finley, Calif., to author, 31 January 1991.

Westcott, Albert, Orlando, Fla., to Alma McKibbin, Mountain View, Calif., \& August 1927. In the hand of Paul Ricchiuti, Nampa, Idaho.

Westphal, Barbara Osborne, Calistoga, Calif., to atthor, 3 December 1990.

White, Ellen G., to W. C. White, 5 May 1897. Letter 141. Ellen G. White Research Center, Andrews University, Berrien Springs, Mich.

White, W. C., Sanitarium, Calif., to Alma McKibbon [sic], Healdsburg, Calif.. 17 December 1907. Ellen G. White Research Center, Andrews University, Berrien Springs, Mich.

to "Dear Cousin Mary," 11 June 1913. W. C. White Letter Book 17-19, WA-WH. General Correspondence. Ellen G. White Research Conter, Andrews University, Berrien Springs, Mich.

Wood. Miriam, Silver Spring, Md., to author, 17 February 1991. 


\section{Manuscripts and Maps}

"Alma E. McKibbin." Funeral program notes, 27 July 1974, Mountain View Seventh-day Adventist Church, Mountain View, Calif. In the hand of Bertha Parmentier, Deer Park, Calif.; General Conference Archives, Silver Spring, Md.

Cassell, J. W. "Citation: Alma Estelle McKibbin, Doctor of Literature," 11 June 1972, TMs, Pacific Union College, Angwin, Calif. In the hand of Shari Lowe, Modesto, Calif.

"Commemorating the Founding of Pacific Union College at Healdsburg in 1882." Program notes, Pacific Union College Day at Healdsburg, Angwin, Calif., 30 March 1957.

"Commencement Memories." Scrapbook in the hand of Madge Nelson, Angwin, Calif.

Crystal Springs Manor, Sanitarium, Calif. Admission form for Alma E. McKibbin, 3 September 1968.

Dexter, Herben H. n. d., no title, TMs. [photocopy]. Adventist Heritage Center, Pacific Union College, Angwin, Calif.

"Ellen G. White, Her Friends and Fellow-Workers: Mrs. Alma McKibben" [sic] (1970) TMs [photocopy]. 1969-1970 Spiritual Emphasis Week Materials. Document File 967, Ellen G. White Research Center, Andrews University, Berrien Springs, Mich.

Finley, S. H., C. E. [Cartographic Editor]. Map of Orange County, Calif. 1900 County Courthouse Time Capsule Contents 1889-1900. Orange County Archives. Santa Ana, Calif., [1900].

Fry, Edward. Fry Readability Graph. New Jersey: Rutgers University Reading Center, 1977.

General Conference of Seventh-day Adventists (Washington, D. C.). Sustentation Fund Application for Alma E. McKibbin. [c. 1912], 17 December 1919, 25 April 1928, 22 September 1930 D.

. Sustentation Questionnaire for Alma E. McKibbin. 1928.

Gray, Mary. Notes, [1953] AMs. In the hand of Mary Gray, Santa Clara, Calif. 
Gray, Phil. Maps of California counties [1953]. In the hand of Phil Gray, Santa Clara, Calif.

"A History of Mountain View Union Academy." 1947 TMs. Adventist Heritage Center, Pacific Union College, Angwin, Calif.

Johns, Warren H. "Title Index of Books Advertised in Seventh-day Adventist Periodicals, 1855-1905," 4 May 1883 TMs. Adventist Heritage Center, Pacific Union College, Angwin, Calif.

Johns, Warren H., Tim Poirier, and Ron Graybill. "A Bibliography of Ellen G. White's Private and Office Libraries," January 1983 TMs. Ellen G. White Research Center, Pacific Union College, Angwin, Calif.

Johnson, G. E., n. d., no title, AMsS. Adventist Heritage Center, Pacific Union College, Angwin, Calif.

Lewis, Charles Clark. "Historical Sketch of Educational Work of Seventh-day Adventists." Paper presented at the Educational Council, General Conference Educational Convention, College View, Neb., June 10-July 19, 1906 TMs [photocopy]. College View: [College Press], 1906.

Lockett, Maude. "Early Days of Saguache" [1951) TMs. Colorado Historical Society, Denver.

Mountain View Seventh-day Adventist Church, Bulletin, 27 November 1971, Mountain View, Calif. In the hand of Emily Hixson, Loma Linda, Calif.

Newton, M. W. "Reminiscences of Early Days." Founders' Day Address, 12 April 1948, TMs, Adventist Heritage Center, Pacific Union College, Angwin, Calif.

Oliphant, Dr. Charlotte J. "The Guided Reading Lesson: A Tentative List of Possible Pre-reading Activities and Guidelines," TMs, June 1991, in the hand of the author.

"A Developmental Model of Bible Teaching." TMs. July 1991, in the hand of the author.

"The One Hundredth Anniversary of the Sabbath School, 1852-1952." Program notes, Mountain View SDA Church, Mountain View, Calif., 26-27 September 1952. 
Pacific Union College. Spring Commencement Program Notes, 9-11 June 1972, Angwin, Calif., Adventist Heritage Center, Pacific Union College, Angwin, Calif.

Parmentier, Bertha. 15 August 1975 TMs. In the hand of Bertha Parmentier, Deer Park, Calif. These are notes about Alma McKijubin, written in response to a request from Alonzo Baker, Jr., as manuscript material for his book, My Sister Alma and I.

Notes of Alma McKibbin's talk on Christian dress at the California Conference Workers' Meeting, November 5, 1962.

Roberts, Elizabeth Judson. "A Historical Gathering." 14 May 1950, AMs. San Pascual Adventist Academy, Escondido, Calif.

Rogers, Cathryn. " Of Alma E. McKibbin on Her 93rd Birthday." Poem written for Alma McKibbin. 26 November 1990, TMsS. Mountain View, Calif.

Saguache, Colo. Map. Orange County Archives, Santa Ana, Calif., 1879.

Schneider, Althea, Nampa, Idaho, notes to author, 11 March 1991.

Sparks, Enid. In Miriam Wood. "Good Old Adventist Golden Rule Days." 1990 TMs. Adventist Heritage files. La Sierra College, Riverside, Calif.

"Then and Now--A History of San Pasqual Academy and Its Valley." AMs. San Pascual Adventist Academy, Escondido, Calif.

White, Ellen G. MS 21, 1889. Ellen G. White Research Center, Andrews University, Berrien Springs, Mich.

Wood, Miriam. "Good Old Adventist Golden Rule Days," [1990] TMs. Adventist Heritage files, La Sierra College, Riverside, Calif.

\section{Theses and Dissertations}

Ashlock, George S. "The Establishment of White Seventh-day Adventist Elementary Schools in the United States." M.S. thesis, University of Tennessee, 1959. 
Ashworth, Warten Sidney. "Edward Alexander Sutherland and Seventh-day Adventist Educational Reform: The Denominational Years, 1890-1904." Ph.D. diss., Andrews University, 1986.

Burton, Wilbur Arthur. "A History of the Mission of Seventh-day Adventist Education 1844-1900." Ph.D. thesis, Kansas State University, 1987. Ann Arbor, Mich.: University Microfilms, 1989.

Cadwallader, Edward Miles. "Principles of Education in the Writings of Ellen G. White." Portion of doctoral thesis, Union College, n. d.

Cady, Marion C. "Seventh-day Adventist Denominational Schools on the Pacific Coast." M.A. thesis, University of California, 1916.

Christensen, Lars C. "A Short History of the Beginnings and Development of the Seventh-day Adventist Work in Califomia." B.A. thesis, Pacific Union College, 1938.

Engel, Richard John. "The History of Healdsburg College." M.A. thesis, Pacific Union College, 1957.

Goertzen, Alice. "A Comparison of the New Religion Curriculum with the Present Curriculum in Grades One to Four in Seventh-day Adventist Elementary Schools." M.A. project, Andrews University, 1972.

Haussler, John C. "The History of the Seventh-day Adventist Church in California." Ph.D. diss., University of Southem Califomia, 1945.

Jackson, George Fred. "The History of Seventh-day Adventist Education in California." Ed.D. diss., University of California, 1959.

Lindsay, Allan Gibson. "The Influence of Ellen White upon the Development of the Seventh-day Adventist School System in Australia, 1891-1900." M.A. thesis, University of Newcastle, N.S.W., Australia, 1978.

- "Goodioe Harper Bell: Pioneer Seventh-day Adventist Christian Educator." Ed.D diss., Andrews University, 1982.

Little, Mary Kelly. "Development of the Elementary Schools of Seventh-day Adventists in the United States." M.A. thesis, University of Washington. 1932.

McCumber, Harold Oliver. "Beginnings of the Seventh-day Adventist Church in Califomia." Ph.D. diss., University of California, 1934. 
Perry, Kenneth Blaine. "Educational Trends in American Education from 18301870 Influencing the Formation of the Seventh-day Adventist Educational System." M.A. thesis, Seventh-day Adventist Theological Seminary, 1952.

Saulsbury, Sally. "Evaluation of the New Bible Series Curriculum." M.A. project, Andrews University, 1975.

\section{Interviews and Tape Recordings}

Ahlkvist, Lennart. Telephone interview by author, 14 January 1990. . Interview by author, 2 March 1991, Angwin, Calif.

Anderson, Carl. Telephone interview by author, 27 March 1991.

Anderson, Evelyn. Interview by author, 19 February 1991, Mountain View, Calif.

Anderson, Lawrence. Telephone interview by author, 12 May 1991.

Ashlock, George S.. Telephone interview, 20 January 1990.

Baker, Alonzo L. Interview by Kent Hansen, spring 1976, Riverside, Calif. Transcripts, Tapes 1-11. Tapes 1-6 are in the hand of Kent Hansen, Corona, Calif., and tapes 7-11 are in the Adventist Heritage Center, $\mathrm{La}$ Sierra College, Riverside, Calif.

Baker, Alonzo. "When P. U. C. Was Young." [1976?], Pacific Union College, Angwin, Calif. Tape recording. In the hand of Robert and Donna Jacobs, Angwin, Calif.

Baker, Eleanor. Interview by author, 24 February 1991, Modesto. Calif.

Berry, Lois. Telephone interview by author, 5 March 1991, St. Helena, Calif.

Bowen, Ruth. Interview by author, 6 March 1991, Los Gatos, Calif.

Childs, Eldene. Intersiew by author, 3 March 1991, St. Helena, Calif.

Clark, Marjorie. Telephone interview by author, 12 February 1991.

Collings, Ruth. Inteview by author, 15 March 1991. 
Cox, Franze Edmond. Telephone interview by author, 27 November 1990.

Craver, Jack. Telephone interview by author, 26 February 1991, Angwin, Calif.

Edwards, Catherine Marie Anderson. Interview by author, 26 February 1991 , Angwin, Calif.

Engelkemier, Joel. Telephone interview by author, 24 April 1991.

Finnerty, Margaret. Interview by author, 9 February 1991, Saguache, Colo.

Geraty, Dr. Thomas. Telephone interview by author, 14 January 1990.

Gordon, Paul. Interview by author, 22 January 1990, Berrien Springs, Mich. . Telephone interview by author, 24 April 1991.

Gray, Mary. Interview by author, 21 February 1991, Santa Clara, Calif.

Gray, Philip. Telephone interview by author, 6 February 1991.

Green, William. Interview by author, 17 February 1991, Berrien Springs, Mich.

. Interview by author, 21 February 1991, Santa Clara, Calif.

Hagood. Naomi. Telephone interview by author, 23 February 1991, Mountain View, Calif.

Ham, George H., M.D. Interview by author, 28 February 1991, Angwin, Calif.

Hansen, Kent. Telephone interview by author, 5 June 1990, 18 June 1990.

Harris, Richard. Telephone interview by author, 3 May 1991.

Harlein, Marian. Telephone interview by author, 24 April 1991.

Henderson. Sylvia Ward. Interview by author, 11 March 1991, Nampa, Idaho.

Hightower. Robie. Telephone interview by author, 4 March 1991. Angwin, Calif.

Hixson, Emily. Interview by author, 12 March 1991, Loma Linda, Calif. 
Hixson, Ray. Interview by author, 13 March 1991, Loma Linda, Calif.

Hodgen, Maurice. Telephone interview by author, 9 January 1990.

Hoffman, Martha. Telephone interview by author, 24 February 1991, Mountain View, Calif.

Hovt, Leonard. Telephone interview by author, 14 January 1990.

Jacobs, Donna. Interview by author, 26 February 1991, Angwin, Calif.

Jacobs, Robert. Interview by author, 26 February 1991, Angwin, Calif.

Jacques, Grace. Interview by author, 25 February 1991, Yountville, Calif.

James, Myrtle. Telephone interview by author, 27 November 1990.

Jenecke, Nettie Lindholm. Telephone interview by author, 24 February 1991, Waterford, Calif.

Johnson, Vera Wheeler. Interview by author, 2 March 1991, Angwin, Calif.

Jones, Gladys Scharif. Telephone interview by author, 13 September 1990.

- Telephone interview by author, 11 October 1990.

. Interview by author, 9-10 March 1991, Middleton, Idaho.

Jones, Ivan Neill. Interview by author, 9 March 1991, Middleton, Idaho.

Judson, Julit. Telephone interview by Ruth Collings, February 1991, Escondido Historical Society Research Volunteer, Escondido, Calif.

. Interview by author, 15 March 1991, San Pascual Valley, Calif.

Kerber, Elsie Lindholm. Telephone interview by author, 21 February 1991, Oakland, Calif.

Kokka, Melissa. Interview by author, 24 February 1991, Modesto, Calif. Grand-niece of Alma McKibbin.

Kutsch, Robert. Telephone interview by author, 16 May 1991.

Kyle, Delmer. Telephone conversation with author, 15 November 1990. 
Ladd, Verna Nelson. Telephone interview by author, 12 May 1991.

Larkin, Howard. Telephone interview by author, 10 March 1991, Nampa, Idaho.

Lester, Vera. Telephone interview by author, 12 January 1991, 17 January 1990.

Logan, Cindy. Telephone interview by author, 17 January 1991. Grand-niece of Alma McKibbin.

Lowe, Shari. Interview by author, 24 February 1991, Modesto, Calif. Grandniece of Alma McKibbin.

Macpherson. Walter, M. D. Interview by author, 13 March 1991, Glendale, Calif.

Marshall, Elizabeth. Interview by author, 10 March 1991, Nampa, Idaho.

Martella, Bessie Bobst. Interview by author, 24-25 February 1991, Hanford, Calif.

Matheson, Maurice. Telephone interview, 27 February 1991, Angwin, Calif.

Maxwell, C. Mervyn. Telephone interview by author, 13 November 1989.

. Interview by author, 10 December 1990.

Maxwell, Dierdre. Interview by author, 4 March 1991. Angwin, Calif.

. Telephone interview by author, 27 May 1991.

Maxwell, Malcolm. Telephone interview by author, 12 June 1991.

Meikle, Edith. Interview by author, 19-22 February 1991, Los Gatos, Calif.

Miller, Mabel. Telephone interview by author, 10 June 1991.

Moon, Pastor Robert, Sr. Telephone interview by author, 29 January 1991.

Moore, Alice. Telephone interview by author, 10 March 1991.

Muir, Dorothy. Interview by author, 2 March 1991, Angwin, Calif. 
Neilsen, Alice. Telephone interview by author, 24 April 1991.

Nelson, Axel C. Interview by author, 27 February 1991, Angwin, Calif.

Nelson, Else. Telephone interview by author, 9 January 1990.

. Interview by author, 18 March 1991, Grand Terrace, Calif.

. Telephone interview by author, 6 September 1991.

Nelson, Madge Haines. Telephone interview by author, 9 January 1990.

. Interview by author, 27 February 1991, Angwin, Calif.

Nix, James, Director of Adventist Heritage Center, Loma Linda University. Telephone interview by author, 9 January 1990.

. Telephone interview by author, 22 January 1990, Berrien Springs, Mich.

. Interview by author, 12 March 1991. Loma Linda, Calif.

Pitcher, Grace B. Telephone interview by author, 6 December 1990.

Plubell, Gilbert. Telephone interview by author, 4 October 1990.

Price, Bill. Telephone interview by author, 4 March 1991, Angwin, Calif.

Provonsha, Jack. Telephone interview by author, 26 March 1991.

Quade, Elna Anderson. Interview by author, 25 February 1991, Yountville, Calif.

Quade, Lester. Interview by author, 25 February 1991, Yountville, Calif.

Rassmussen, L. R. Telephone interview by author, 23 July 1991.

Ricchiuti, Paul. Telephone interview by author, 9 January 1990.

Interview by author, 10 March 1991, Nampa, Idaho.

Rittenhouse, F. O. Telephone interview by author, 27 February 1991, Angwin. Calif. 
Rogers, Cathryn. Interview by author, 20 February 1991, Mountain View, Calif.

Rowland, Eleanor. Telephone interview by author, 24 January 1991.

Schneider, Althea. Interview by author, 11 March 1991. Pacific Press Publishing Association, Nampa, Idaho.

Schneider, Violet Robinson. Telephone interview by author, I July 1991. Her mother is Gladys Robinson Stearns, who wrote a Bible textbook with Alma McKibbin.

Schutter, Louis. Telephone interview by author, 21 May 1991.

Schutter, Ruth. Telephone interview by author, 29 March 1991.

Smithwick, Aileen. Telephone interview by author, 23 February 1991, Los Altos Hills, Calif.

Stafford, Jean. Telephone interview by autior, 12 May 1991.

Staples, John M. Interview by author, 6 March 1991, Angwin, Calif.

Stirling, Maryan. Telephone interview by author, 17 November 1990. . Interview by author, 14 March 1991, Loma Linda, Calif. . Telephone interview by author, 8 January 1990 .

Strachan, Luan Wallace. Interview by author, 4 March 1991, Deer Park, Calif. Stafford, Dick. Telephone interview by author, 10 March 1991, Nampa, Idaho.

Stafford, Jean. Telephone interview by author, 12 May 1991.

Strutz, Helen. Telephone interview by author, 31 January 1991.

Tait, Aline and Betty Tait. Interview by author, 5 March 1991, Napa, Calif.

Tait. Aline. Telephone interview by author, 17 January 1991.

Taylor, Janet. Telephone interview by author, 14 January 1990. Alma McKibbin's niece: Alonzo L. Baker's daughter. 
. Telephone interview by author, 13 September 1990.

. Interview by author, 24 February 1991, Chowchilla, Calif.

Thiele, Margäet Rossiter White. Interview by author. 4 March 1991, Angwin, Calif.

Tobler, Gustav. Telephone interview by author, 15 May 1991.

Tobler, Lorna. Telephone interview by author, 23 February 1991, Sunnyvale, Calif.

_. Interview by author, 7 March 1991, San Jose, Calif.

Utt, Richard. Telephone interview by author, 4 December 1990.

. Telephone interview by author, 12 March 1991, Loma Linda, Calif.

Venden, Louis. Telephone interview by author, 5 March, 1991, Angwin, Calif.

Weseman, Amold. Interview by author, 20 February 1991, Mountain View, Calif.

Westphal, Barbara Osborne. Interview by author, 26 February 1991, Calistoga, Calif.

Wheeler, Ruth Carr. Telephone interview by author, 26 February 1991 , Angwin, Calif.

Telephone interview by author, 6 September 1991.

White, Francis. Interview by author, 25 February 1991, Yountville, Calif.

Willis, Craig. Interview by author, 13 June 1991, Berrien Springs, Mich.

Young, Ethel. Telephone interview by author, 6 September 1991. 
Published

Catalogues and Bulletins

General Conference of Seventh-day Adventists. Department of Education (Washington, D. C.). Bulletin 3, no. 8 (Fourth Quarter 1900): 216.

Department of Education (Washington, D. C.). Bulletin 4, no. 3 (Third Quarter 1901): 535.

1915.

Department of Education (Washington, D. C.). Bulletin. No. 13,

. Department of Education (Washington, D. C.). Bulletin. No. 14, 1916.

Pacific Union College. Healdsburg College Catalogues. Healdsburg, Calif.: Healdsburg College Press, 1886-1907. Registrar's files, Pacific Union College, Angwin, Calif.

Pacific Union College Calendars. St. Helena, Calif.: Pacific Union College Press, 1911-1920. Adventist Heritage Center, Pacific Union College, Angwin, Calif.

Pacific Union College Catalogue. Mountain View, Calif.: Pacific Press Publishing Association, Angwin, Calif., 1917. Adventist Heritage Center, Andrews University, Berrien Springs, Mich.

Pacific Union College Preparatory Schooi. Official Bulletin, 1990-1991. п. p.

San Jose State University. California State Normal School Catalogues. Sacramento: Supt. of State Printing, 1889-90; 1892, 1898. Special Collections, San Jose State University Library, San Jose State University, San Jose, Calif.

University of California. California State Normal School Catalogue. Sacramento: Supt. of State Printing, 1893. University of California Library, University of Califomia, Berkeley, 1893. 


\section{Newspapers and Periodicals}

"A Notice to Teachers." Pacific Union Recorder 15, no. 6 (16 September 1915): 6.

Ackley, Lida. "Secretary's Day-by-Day Report of the California-Nevada Teachers' Institute." Pacific Union Recorder 10, no. 9 (29 September 1910): $4-5$.

"Action Line." San Jose Mercury, 26 November 1971.

"Adventist Teacher Dies at 102," San Jose Mercury, 20 July 1974.

"Alma McKibbin Celebrates Hundredth Birthday Soon," Pacific Union Recorder 71, no. 19 (15 November 1971): 1.

"Alma McKibbin 100 Years Old," St. Helena Star, 16 December 1971.

"Alma McKibbon, [sic] Adventist Teacher and Textbook Writer, Dies at 102," Palo Alto Times, 18 July 1974, 2.

American Baptist Publication Society, The Advanced Quarterly. International Lessons 10, no. 4 (October 1888): 98-124. American Baptist Historical Society, Valley Forge, Penn.

. The Intermediate Quarterly. International Series 5, no. 2 (April to June 1884): 34-63. American Baptist Historical Society, Valley Forge, Penn.

. The Primary Quarterly. Intemational Series 2, no. 1 (January to March 1885): 6-30. American Baptist Historical Society, Valley Forge, Penn.

. The Primary Quarterly. International Sunday School Lessons 12, no. 4 (October 1895): 9-20. American Baptist Historical Society, Valley Forge, Penn.

'The following periodicals are available in Adventist Heritage Center. Andrews University, Berrien Springs, Mich.: Christian Educaror, Christian Advocase. Educurional Messenger, Pacific Union Recorder, Sabbath Review and Advent Herald. Signs of the Times, and Yoush's Instructor. 
The Senior Quarterly. International Series 1, no. 1 (January to March 1884): 1-11. International Sunday School Lessons 12, no. 4 (October 1895): 9-20. American Baptist Historical Society, Valley Forge, Penn.

Baker, Alonzo L. "Baseball or Books?" Youth's Instructor 69 (1 November 1921): 16.

"When Brawn Educates Brains." Christian Educator 13, no. 10 (June 1922): 299.

Bailenger, E. S. "Church-Schools." Pacific Union Recorder 1 (1 August 1901): 10 .

Beddoe, Ben E. "The Missionary Volunteer Department Report for 1910." Pacific Union Recorder 10, no. 32 (9 March 1911): 4-6.

"Birthday Wish Comes True." Courier, December 1971 (Cupertino, Calif.).

Bralliar, Richard. "313 Awarded Degrees." Campus Chronicle 48, no. 24 (4 July 1972), 1 .

Cady, Marion Ernest. "Nature Study at Home." Christian Educator 1, nos. 3 and 4 (September and October 1897): 58.

"Educational and Young People's Work," Pacific Union Recorder 15, no. 18 (9 December 1915): 1-2.

Caldwell, JoAnne. "A New Look at the Old Guided Reading Lesson." Wisconsin State Reading Association Journal 35, no. 2 (Spring 1991): 1-7.

Christian Education. 4, no. 1 (September-October 1912): 30.

"Church School." Christian Educator 1, no. 1 (July 1897): 15-16.

"Church Schools, Attention." Pacific Union Recorder 6, no. 24 (10 January 1907): 8 .

"Church Schools; Notice to Churches in Healdsburg College District." Pacific Union Recorder 1, no. 1 (1 August 1901): 10.

Colcord, I. C. "Report of the Church School Department." Pacific Union Recorder, 9, no. 30 (24 February 1910): 13-15. 
Conard, Claude. "California Conference Missionary Credentials." Pacific Union Recorder 10, no. 31 (2 March 1911): 2-3.

Coon, Roger W. "Hermeneutics: Interpreting a Nineteenth-Century Prophet in the Space Age." Joumal of Adventist Education 50, no. 5 (Summer 1988): 16-31.

Cottrell, H. W. "The Pacific Union College." Pacific Union Recorder 8, no. 12 (22 October 1908), 1-2.

"Course of Study for Church Schools." Pacific Union Recorder 4, no. 6 (8 September 1904), 5-6.

"Courses of Study, Church Schools." Pacific Union Recorder 4, no. 9 (29 September 1904), 6.

DeGraw, M. Bessie. "Church Schools." Training-School Advocate 1, no. 1 (January 1899): 88-90.

"An Educational Conference." Review and Herald 80, no. 21 (26 May 1903): 16-17. 1903): 20.

"Educational Institute." Review and Herald 80, no. 30 (28 July

Eddy, Inez. "Chapel Talks." Pacific Union Recorder 16. no. 44 (6 September 1917): 12.

Edgerton, Russ, Marcia Mentkowski, and Austin Doherty, "Abilities That Last a Lifetime," American Association for Higher Education Bulletin 36, no. 6 (February 1984): 3-6, 11-14.

"Eighth-grade Bible Textbook." Pacific Union Recorder 15, no. 6 (16 September 1915): 7.

Escondido Times, 26 January 1893.

Evans, Mary Anne. "She Knew Him, but He Didn't Know It Until 72 Years Later." Sunnyvale Daily Standard. 31 July 1961, 9.

"The Faculty." Pacific Union Recorder 11, No. 6 (7 September 1911): 5.

Gillespie, V. Bailey. "Valuegenesis Report III: Where Do We Go from Here?" Journal of Adventist Education 54, no. 4 (April-May 1992): 10-13. 
Griggs, Frederick. "New Textbooks." Review and Herald 86 (26 August 1909): 10.

Haskell, Stephen N. Article. Review and Herald 62 (14 April 1885): 12. 1909): 16.

"The New California College." Review and Herald 86 (21 October

"Teachers' Institute." Pacific Union Recorder 10, no. 9 (29 September 1910): 7-8.

"Honorary Doctorates Conferred at Commencement Services." Pacific Union Recorder 71, no. 50 (26 June 1972): 8.

[Howe, Frank W.]. Christian Educator 1, no. 1 (July 1897): 17.

Knight, George R. "Early Adventist Education in Australia: A Report of Recent Research." The Joumal of Adventist Education 44, no. 4 (AprilMay 1982): $10-11,45-46$.

"Spiritual Revival and Educational Expansion." Adventist Review 161, no. 13 (29 March 1984): 8-11.

"Probing the Roots of Adventist Education: A Report of Recent Research." The Journal of Adventist Educasion 46, no. 3 (Febriary-March 1984): 18-19, 44.

Kreye, Eric. "One Hundred Years with Gcd: An Interview with Alma McKibbin." Review and Herald, 25 November 1971, 7-8.

"McKibbin." Palo Alto Times, 18 July 1974, 16.

"McKibbin." Review and Herald, 28 November 1974, 31.

"McKibbin, Alma." St. Helena Star, 25 July 1974.

"McKibbin, Alma E." Pacific Union Recorder, 2 September 1974), 8.

"McKibbin, Alma E." San Jose Mercury, 20 July 1974, 50.

"Mountain View Teacher, 88, Chooses Jet for First Plane Trip." The Register Leader. 11 May 1960. 
"Mt. View Woman Thankful for 100 Good Years of Life." Palo Alto Times, 25 November 1971.

"Mrs. Alma E. McKibbin Marks 100th Birthday." Vailey Journal, 24 November 1971, 1.

Nelson, Else. "Alma Baker McKibbin." Joumal of Adventist Education 40, no. 5 (Summer 1978): 16-17.

"New Textbooks." Review and Herald 86, no. 34 (26 August 1909): 18.

New York Times, 26 November 1871, 1.

"Notice." Pacific Union Recorder 1, no. 23 (19 June 1902): 16.

"100-Year-Old Educator Is Awarded the Medallion of Merit." Pacific Union Recorder 71, no. 40 (17 April 1972): 1.

"100th Birthday: Wanted to Ride in Buggy Again." Palo Also Times, 28 November 1971.

Osborne, J. S. "Report of the Church-school Work in the Califormia Conference for the Years 1902-04." Pacific Union Recorder 4, no. 3 (18 August 1904): 5-7.

Osborne, Jessie O. Barber, "Teacher Education in the Early Days." Journal of True Education 15, no. 5 (June 1953): 11-13.

"Parent-Teacher Association." Pacific Union Recorder 16, no. 44 (6 September 1917): 13.

Osborn, Richard. "Measuring Quality in Adventist Schools: A Review of Valuegeneis III." Joumal of Adventist Educarion 54 no. 4 (April-May 1992): 5-19, 39.

'Our Cover." Impression, 5, no. 4 (July-August 1964).

"Pacific Union Educational Council." Pacific Union Recorder 3, no. 30 (28 July 1904): 6-7.

"Frogram of Teachers' Institute at Healdsburg, California. Augus: 26 to Sept. 13." Pacific Union Recorder 1, no. 3 (15 August 1901): 11. 
"Recommendations Passed at the Paciric Union Conference Teachers' Institute, July 3, 1908." Pacific Union Recorder 7, no. 49 (9 July 1908): 2.

Reiter, Paula J. and John E. Penick. "Elementary Science Teacher Education: Seven Exemplars." Journal of Science Teacher Education 2, no. 1 (Winter 1991): 22-7.

Rine, George W. "Stella Antoinette Baker." Obituary. Review and Herald 88, กo. 19 (11 May 1911): 23.

Sabbath School Lessons for Senior Classes From the Old Testament. Bible Students Library, no. 91 (Oakland, Calif.: Pacific Press Publishing Company, March 1892). Adventist Heritage Center, Andrews University, Berrien Springs, Mich.

Sharpe, E. D. "Announcement of the Pacific Union Normal Institute." Pacific Union Recorder 7, no. 7 (12 September 1907): 2.

"Fall Announcement of the Western Normal Institute, Lodi, Califomia." Pacific Union Recorder 8, no. 5 (3 September 1908): 2-3.

"A Statement of the Organization and Present Standing of the Westem Normal Institute, and Recommendations Concerning Its Future." Pacific Union Recorder 9, no. 29 (17 February 1910): 1-4.

"She Trots Into Her Second. Ceniury." San Jose Mercury, 5 December 1971.

Showers, Beverly. "Teachers Coaching Teachers." Educarional Leadership 42, no. 7 (April 1985): 43-48.

Silver, Merikay. "Alma McKibbin." Hers 1, no. 1 (1973): 45. A one-time edition, in the hand of Elizabeth Marshall, Nampa, Idaho.

Spalding, Maude Wolcott. "Volunteers of '97." The Journal of True Education 15, no. 5 (June 1953): 8-10.

"Story of the Convention." Central Union Conference Bulletin 2, no. 3 (October 1906): 31-33.

"Suggestive Outline for Courses of Study." The Educarional Messenger 2, nos. 14 and 15 (15 July 1906): $4-5$.

Sutherland, E. A. "Support of Church Schools." Training-School Advocare 1, no. I (January 1899): 90-91. 
"Teachers' Institute." Pacific Union Recorder 7, no. 40 (7 May 1908): 2.

Tobler, Lorna. "Mrs. Alma McKibbin 80 Years Experience and Still Teaches." The Yoice of the Mountain View Seventh-day Adventist Church 1, no. 4 (November-December 1967): 4.

"A Tribute." Youth's Instructor 92, no. 21 (23 May 1944): 5.

Walch, Timotny. "Catholic School Books and American Values: The Nineteenth Century Experience." Religious Educarion 73, no. 5 (Sept/Oct 1978): 582-91.

White, Ellen G. "Teachers and Teaching." Christian Educator 1, no. ! (July 1897): $1-2$.

Wilson, Mr. and Mrs. W. G. "Mountain View Church School." Pacific Union Recorder 10, no. 26 (26 January 1911): 6-7.

Wood, Miriam. "A Room for the Teacher." Adventist Heritage 13, no. 2 (summer 1990): 37-47.

Young, Ethel L. "Our Elementary Schools of Yesterday, Today, and Tomorrow." Review and Herald 149 (6 April 1972): 10-11.

\section{Books and Pamphlets}

"Alonzo Lafayette Baker" (no author). In Progressive Men of Western Colorado, 457-8. Chicago: A. W. Bowen and Company, 1905.

Andross, Matilda Erickson. Story of the Advent Message. Washington, D. C.: Review and Herald Publishing Company, 1926.

Armor, Samuel, Charles. C. Chapman, William Loftus, G. W. Moore, and Linn L. Shaw, eds. History of Orange County California with Biographical Sketches of the Leading Men and Women of the Counry, Who Have Been Idensified with the Growth and Development from the Early Days to the Present Time. Los Angeles: Historic Record Company, 1911.

Baker. Alonzo L. My Sister Alma and I. Mountain View, Calif.: Pacific Press Publishing Association, 1980.

Beach, John G. Notable Women of Spirit. Nashville: Southem Publishing Association, 1976. 
Beechick, Ruth. Teaching Primaries. Denver: Accent-B/P Publications, 1990.

Bell, Goodloe Harper. Bible Lessons for the Sabbarh School, Number One. Progressive Series, No. 1. Battle Creek, Mich.: Steam Press of the Seventh-day Adventist Publishing Association, c. 1877. Adventist Heritage Center, Andrews University, Berrien Springs, Mich.

\section{- Progressive Bible Lessons for Children: To Be Used in Sabbath}

Schools and Families. Battle Creek, Mich.: Steam Press of the Seventhday Adventist Publishing Association, 1872. Adventist Heritage Center, Andrews University, Berrien Springs, Mich.

- Progressive Bible Lessons for Youth: To Be L'sed in Sabbath Schools, Bible Classes, and Families. Battle Creek, Mich.: Steam Press of the Seventh-day Adventist Publishing Association, 1877. Adventist Heritage Center, Andrews University, Berrien Springs, Mich.

Bellon, Jerry J., Elner C. Bellon, and Mary Ann Blank. Teaching from a Research Knowledge Base. New York: Macmillan Publishing Company, 1992.

Benson, Peter L., and Michael J. Donahue. Valuegenesis: Repor 1. Minneapolis: Search Institute, 1990.

Bible Readings for the Home Circle: To Which Is Added the Game of Life, a Pictorial Allegory. Battle Creek, Mich.: Review and Herald Publishing Company, 1888.

Borich, Gary D. Effective Teaching Methods. Columbus: Merrill Publishing Company, 1988.

- Effective Teaching Methods. New York: Macmillan Publishing Company, 1992.

Brantley, Paul. Profile '87, Report C. North American Division Office of Education, 1988.

. Profile '91. North American Division Office of Education, 1991.

Brereton, Virginia L. "The Public Schools Are Not Enough: The Bible and Private Schools." Chap. in The Bible in American Education, edited by D. L. Barr and N. Piediscalzi, 41-75. 1982. Philadelphia, Penn.: Fortress Press, 1982, and Chico, Calif.: Scholars Press, 1982. 
Brown, Walton J. Chronology of Seventh-day Adventist Education. 2d ed. Washington, D. C.: General Conference Department of Education, 1979.

Butts, R. Freeman, and Lawrence A. Cremin, A History of Educarion in American Culsure. New York: Henry Holt and Company, 1953.

Cadwallader, Edward Miles. A History of Seventh-day Adventist Education. 3d ed. Lincoln, Nebraska: Union College Department of Education, 1958.

Califormia Conference of Seventh-day Adventists. Church School Manual. Oakland, Calif.: Pacific Press Publishing Company, 1900. Mentioned in Haussler, 186; M. E. Cady, "Educational and Young People's Work," Pacific Union Recorder 15, no. 18 (9 December 1915): 1.

California and Northwestern California Conferences of Seventh-day Adventists. Pacific Union Conference Church Schools of Seventh-day Adventists, Announcement for 1916-17. Oakland, Calif.: Pacific Press Publishing Association, [1916]. Adventist Heritage Center, Pacific Union College, Angwin, Calif.

Chamber of Commerce, Santa Ana, Calif. Orange Counsy, California-lis Progress, Resources, Prosperity. 1900 County Courthouse Time Capsule Contents 1887-1900. Orange County Archives. Bolsa. Calif.: R. O. Shively, [1899].

Colorado State Teachers Association. Educarion in Colorado 1861-1885. Denver: News Printing Company, 1885.

Colorado Association of County Commissioners. Colorado Counties. Edited by Irving A. Lipson. Denver: Colorado Association of County Commissioners, 1963.

Cuban, Larry. How Teachers Taught. New York: Longman, 1984.

Curry, Catherine Ann. "Public and Private Education in San Francisco: The Early Years, 1851-1879. In Religion and Sociery in the American West, ed. by C. Alvarez and D. Guarneri. Lanham, Md.: University Press of America, 1987.

Deering, James H. The Political Code of the State of California. San Francisco: Bancroft-Whitney Co.. 1897.

Dudley, Roger L. Why Teenagers Reject Religion . . . and What To Do about It. Hagerstown, Md.: Review and Herald Publishing Association, 1978. 
600

Dudley, Roger L. with Bailey Gillespie. Valuegenesis: Faith in the Balance. Riverside, Calif.: La Sierra University Press, 1992.

Durkin, Dolores. Teaching Them to Read. Boston: Allyn and Bacon, 1989.

El Camino Real. Mountain View, Calif.: Pacific Press Publishing Association, 1956.

Finkelstein, Barbara. Governing the Young. New York: Falmer Press, 1989.

Fisher, James. The Westminster Assembly's Shorter Catechism Explained, by Way of Question and Answer. Philadelphia: Presbyterian Board of Publication and Sabbath-school Work, 1902.

General Conference of Seventh-day Adventists. Department of Education. A Century of Adventist Educational 1872-1972 Fact Kit. Pamphlet report for distribution to Adventist educators. Adventist Heritage Center, Andrews University, Berrien Springs, Mich., 1978.

. Church School Manual for Parents and Teachers. Missionary Educational Convention. Held at College View, Nebraska, June 29 to July 10, 1906. Mountain View, Calif.: Pacific Press Publishing Association, 1906. James White Library, Andrews University, Berrien Springs, Mich.

- Proceedings of the Educational and Missionary Volunteer

Departments of the General Conference of Seventh-day Adventists in World Convention, Washington, D. C.: Review and Herald Publishing Association, 1923.

The School Manual, Elementary and Intermediase. Washington, D.C.: General Conference of Seventh-day Adventists, Department of Education, 1950.

School Manual for Secretaries and Superintendents,

Elementary, Insermediate, and Normal Teachers, School Patrons and Church Members, Local Church School Boards. Mountain View, Calif.: Pacific Press Publishing Association, 1918. Adventist Heritage Center, Andrews University, Berrien Springs, Mich.

School Manual for Secretaries and Superintendents, Elementary, Secondary, and Normal Teachers, School Bcards, Patrons and Church Members. Mountain View, Calif.: Pacific Press Publishing Association, 1924. 
601

. Teachers' Guide and Key for Day by Day With Jesus. Series III $^{\mathrm{R}}$. Bible Lessons for Grades Five and Six. Mountain View, Calif.: Pacific Press Publishing Association, 1951.

. Teachers' Guide and Key for Messengers of the Promise. Series III ${ }^{\circ}$. Bible Lessons for Grades Five and Six. Mountain View, Calif.: Pacific Press Publishing Association, 1952.

Teacher's Handbook on the Elementary Curriculum. Mountain View, Calif.: Pacific Press Publishing Association, 1918. Quoted in Alma E. McKibbin. "How to Teach the Bible," Joumal of True Educarion 27, no. 3 (January-February 1965): 6-8.

Wimesses for Jesus. Series IV , Odd Year, Bible Lessons for Grades Seven and Eight. Mountaini Vicw, Calif.: Pacific Press Publishing Association, 1952.

North American Division Office of Education. Educarion Code, $K-12$. Washington, D. C.: Review and Herald Publishing Association, June, 1978.

Glatthom, Allan A. Curriculum Leadership. Glenview, Ill.: Scott, Foresman and Company, 1987.

Good, Harry G., and James D. Teller. A History of American Educarion. 3d ed. New York: Macmillan Company, 1973.

Hittell, Theodore H. History of Califormia. 4 vols. San Francisco: N. J. Stone and Company, 1897.

Hodgen, Maurice, Comp. School Bells and Gospel Trumpers. Loma Linda, Calif.: Adventist Heritage Publications, 1978.

Hunt, Thomas C., and Marilyn M. Maxson, eds. Religion and Moraitity in American Schooling. Washington, D. C.: University Press of America, 1981.

Huribut, Jesse Lyman. A Bible Aclas: A Manual of Biblical Geography and History. Rand McNally \& Company, 1928.

Jones, Alonzo Trevier. The Empires of the Bible. Battle Creek: Review and Herald Publishing Company, 1897. 
Joyce, Bruce, ed. Changing School Culiure Through Staff Development Alexandria, Va.: Association for Supervision and Curriculum Devclopment, 1990.

Joyce, Bruce, and Marsha Weil. Models of Teaching, 3rd. ed. Englewood Cliffs, N. J.: Prentice-Hall, 1986.

Keiser, Mary. The Spirit of San Pasqual: A Guide to Scenic San Pasqual Valley. Privately printed, 1986.

Kellogg, John H. Harmony of Science and the Bible on the Nature of the Soul and the Doctrine of the Resurrection. Battle Creek, Mich.: Steam Press of the Seventh-day Adventist Publishing Association, 1879. Adventist Heritage Center, Andrews University, Berrien Springs, Mich.

Kennedy, William Bean. The Shaping of Protestant Educarion. Monographs in Christian Education, ed. C. Ellis Nelson, no. 4. New York: Association Press, 1966.

Knight, George R. Early Adventist Educarors. Berrien Springs, Mich.: Andrews University Press, 1983.

Lake and Columbia Union Conferences, Departments of Education. The Course of Siudy, as Adoptea and Arranged for the Elementary and Intermediate Schools in the Lake and Coiumbia Union Conferences of Seventh-day Adventists [Berrien Springs, Mich.]: Lake and Columbia Union Conferences, Departments of Education, 1944.

Lake Union Conference of Seventh-day Adventists. Manual of Proceedings of the Lake Union Conference Educational Board. Berrien Springs, Mich.: Emmanuel Missionary College Press, 1913.

Land, Gary. The World of Ellen G. White. Washington, D. C.: Review and Heraid Publishing Association, 1987.

Lankard, Frank Glenn. A History of the American Sunday School Curriculum. New York: Abingdon Press, 1927.

Lawrence, John. Frontier Eyewitness: Diary of John Lawrence, 1867-1908. Edited by Bernice Martin. Saguache County Museum. Monte Vista, Colo.: San Luis Valley Historian [1987]. 
Loughborough, J. N. Rise and Progress of the Severth-doy Adventists. Battle Creek, Mich.: General Conterence Association of Seventh-day Adventists, 1892.

Lynn, Robert W., and Elliott Wright. The Big Litrle School: 200 Years of the Sunday School, 2d ed. Birmingham, Ala.: Religious Education Press, 1980.

Maxwell, Arthur S. The Bible Story, Vol. 1. Washington, D. C.: Review and Herald Publishing Asscciation, 1957.

McCumber, Harold O. Pioneering the Message in the Golden West. Mountain View, Calif.: Pacific Press Publishing Association, 1946.

McMurry, Charles A. The Elements of General Method Based on the Principles of Herbart. Bloomington, Ill.: Public School Publishing Company, 1901.

Moore, Mary Hunter. They That Be Teachers. Nashville: Southem Publishing Association, 1937.

Mountain View Academy Annual, 1924-25. Mountain View, Calif.: Pacific Press Publishing Association, 1925.

Newmark, Nathan. The Political Code of the State of California as Enacted in 1872, and Amended in 1889. San Francisco, Bancroft-Whitney Company, 1889; Sacramento: California State Library Law Dept.

Noble, Stuart G. A History of American Educasion. New York: Holt, Rinehart and Winston, 1954.

North American Division Conference of Seventh-day Adventists. Council Proceedings of the Joint Council of the Educarional and Missionary Volunteer Departments. Washington, D. C.: Review and Herald Publishing Association, 1915.

Oisen, M. Ellsworth. Origin and Progress of Sevenih-day Adventists. 2d ed. Washington, D. C.: Review and Herald Publishing Association, 1926.

O'Rourke, Paul M. Frontier in Transition: A History of Southwestem Colorado. Cultural Resource Series, no. 10. Denver: Bureau of Land Management, 1980. 
604

Orange County Board of Education. Manual of the Public Schools of Orange Counry, Calif., Consaining the Course of Study, Suggestions to Teachers. List of Library Books, and Miscellaneous Marters. 1900 County Courthouse Time Capsule Contents 1887-1900. Orange County Archives. Santa Ana, Calif.: Evening Blade Office, 1895.

[Pacific Union Conference of Seventh-day Adventists]. Church School Manual. Oakland, Calif.: Pacific Press Publishing Company, 1903. Quoted in Haussler, 186; M. E. Cády, "Educational and Young People's Work," Pacific Union Recorder 15, no. 18 (9 December 1915): 1.

Pacific Union and North Pacific Union Conferences. Joint Union Summer School. Portland, Oregon, 27 June to 7 August 1912, n. p. Adventist Heritage Center, Andrews University, Berrien Springs, Mich.

Peck, Sarah Elizabeth. God's Great Plan. Bible Lessons for Grades Seven and Eight. Mountain View, Calif.: Pacific Press Publishing Association, 1922.

Peet, Mary Rackwood. San Pascual: A Crack in the Hills. Ramona, Calif.: Ballena Press, 1949.

Price, James N. The Railroad Stations of San Diego County: Then and Now. San Diego, Calif.: Price and Sieber, 1988.

Proceedings of the Second Annual Session of the Colorado Teachers' Associarion as Boulder, January 3 and 4, 1877. Denver: Tribune Steam Printing House, 1877.

Progressive Men of Western Colorado. Chicago: A. W. Bowen and Company, 1905.

Raub, Albert N. Methods of Teaching. Lock Haven, Penn.: E. L. Raub \& Co., 1884.

Reid, Ethna R. Teaching Literal and Inferential Comprehension. Salt Lake City: Cove Publishers, 1983.

Ricchiuti, Paul B. "Alma Remembers," chap. in End-of-the-World-Man and Other Stories. Hagerstown, Md.: Review and Herald Publishing Association, 1989.

Rockwell, Esther Francis. Bible Lessons for the Third Grade: When the World Was Young, The Story of Genesis. Mountain View, Calif.: Pacific Press Publishing Association, 1921. 
San Jose State University. Historical Sketch of the State Normal School at San Jose, California. Sacramento: State Office, J. D. Young, Supi. State Printing, 1889.

Sanders, Ella King. Bible Lessons for the Fourth Grade: From Egypt to Canaan, The Story of the Exodus. Mountain View, Calif.: Pacific Press Publishing Association, 1925.

Seventh-day Advensist Encyclopedia. 1975 ed. S. v. "California Conference," "Church School," "Lodi Academy," "McKibbin, Alma E. Baker," "Mountain View Union Academy," "Pacific Union College," " Pacific Union College Preparatory School," and "San Pascual Academy."

Simmons, Virginia McConnell. The San Luis Valley: Land of the Six-Amed Cross. Boulder, Colo.: Pruett Publishing Company, 1979.

Spalding, Arthur Whitefield. Origin and History of Seventh-day Adventists. Vol. 2. Washington, D.C.: Review and Herald Publishing Association, 1962.

Stadtman, Verna A. The University of California, 1868-1968. New York: McGraw-Hill Book Company, 1970.

Straw, W. E. Manual of Proceedings of the Lake Union Conference Educational Board. Berrien Springs, Mich.: Emmanuel Missionary College Press, 1909.

Taylor, Irwin. Public School Law of the United States, as Administered by the Courts. Topeka, Kans.: George W. Crane and Company, 1892.

Utt, Walter C. A History of Pacific Union College. Angwin, Calif.: Alumni Association of Pacific Union College, 1968.

A Mountain, a Pickax, and a College. Angwin, Calif.: Alumni Association of Pacific Union College, 1968.

ed. Diogenes Lantern. 75th anniversary ed. Angwin, Calif.: Student Association, 1957.

White. Arthur L. Ellen G. White: The Early Elmshaven Years. Vol. 4 Washington, D. C.: Review and Herald Publishing Association, 1981. 
White, Ellen G. The Acts of the Apostles in the Proclamation of the Gospel of Jesus Christ. Mountain View, Calif.: Pacific Press Publishing Association, 1911.

. Christian Education. Battle Creek, Mich.: Intemational Tract Sosiety, 1893.

. Christ's Object Lessons. Battle Creek, Mich.: Review and Herald Publishing Association, 1900.

"Church Schools." n. p., [1900]. Compiled by Sarah Elizabeth Peck, given in talk by Ellen White in Australia. 1899. In the hand of Ethel Young, Russell, Penn. Also found in Testimonies for the Church, Vol. 6, 193-205. Mountain View, Calif.: Pacific Press Publishing Association, 1900.

Counsels to Parents, Teachers and Students. Mountain View, Calif.: Pacific Press Publishing Association, 1913.

The Desire of Ages. Oakland, Calif.: Pacific Press Publishirg Association, 1898.

Education. Mountain View, Calif.: Pacific Press Publishing Association, 1903.

Fundamentals of Christian Education. Nashville: Southem

Publishing Association, 1923.

- The Great Controversy Beween Christ and Satan During the Christian Dispensation. Oakland, Calif.: Pacific Press Publishing Association, 1888.

. The Ministry of Healing. Mountain View, Calif.: Pacific Press Publishing Association, 1905.

Patriarchs and Prophets. Oakland, Calif.: Pacific Press

Publishing Association, 1890.

. "Proper Education." In Testimonies for the Church. Vol. 3, 131-60. Mountain View, Calif.: Pacific Press Publishing Association, 1872.

Sketches from the Life of Paul. Battle Creek, Mich.: Review and Herald Publishing Company, 1883. 
Special Testimonies on Education. Battle Creek, Mich.: Review and Herald Publishing Association, 1897. Ellen G. White Research Center, Andrews University, Berrien Springs, Mich.

The Story of Prophets and Kings as Illustrated in the Captivity and Restoration of Israel. Mountain View, Calif.: Pacific Press Publishing Association, 1917.

. Testimonies for the Church. Vol. 6. Mountain View, Calif.: Pacific Press Publishing Association, 1900.

. Testimonies for the Church, No. 29. Battle Creek, Mich.: Seventhday Adventist Publishing Association, 1880), 422.

Wiebe, Robert H. The Search for Order 1877-1920. New York: Hill and Wang, 1967.

Wilson, Paul T. Let's Think About Reading and Reading Instruction. Dubuque: Kendall Hunt Publishing Company, 1988.

Year Book of the Califormia Conference of Seventh-day Adveniists. Oakland, Calif.: Pacific Press Publishing Association, 1894.

Yearbook of the Seventh-day Adventist Denomination. Washington, D. C.: Review and Herald Publishing Association, 1923-26. 
VITA

NAME:

Marie L. Myers

DATE OF BIRTH: October 31,1944

PLACE OF BIRTH: Milwaukee, Wisconsin

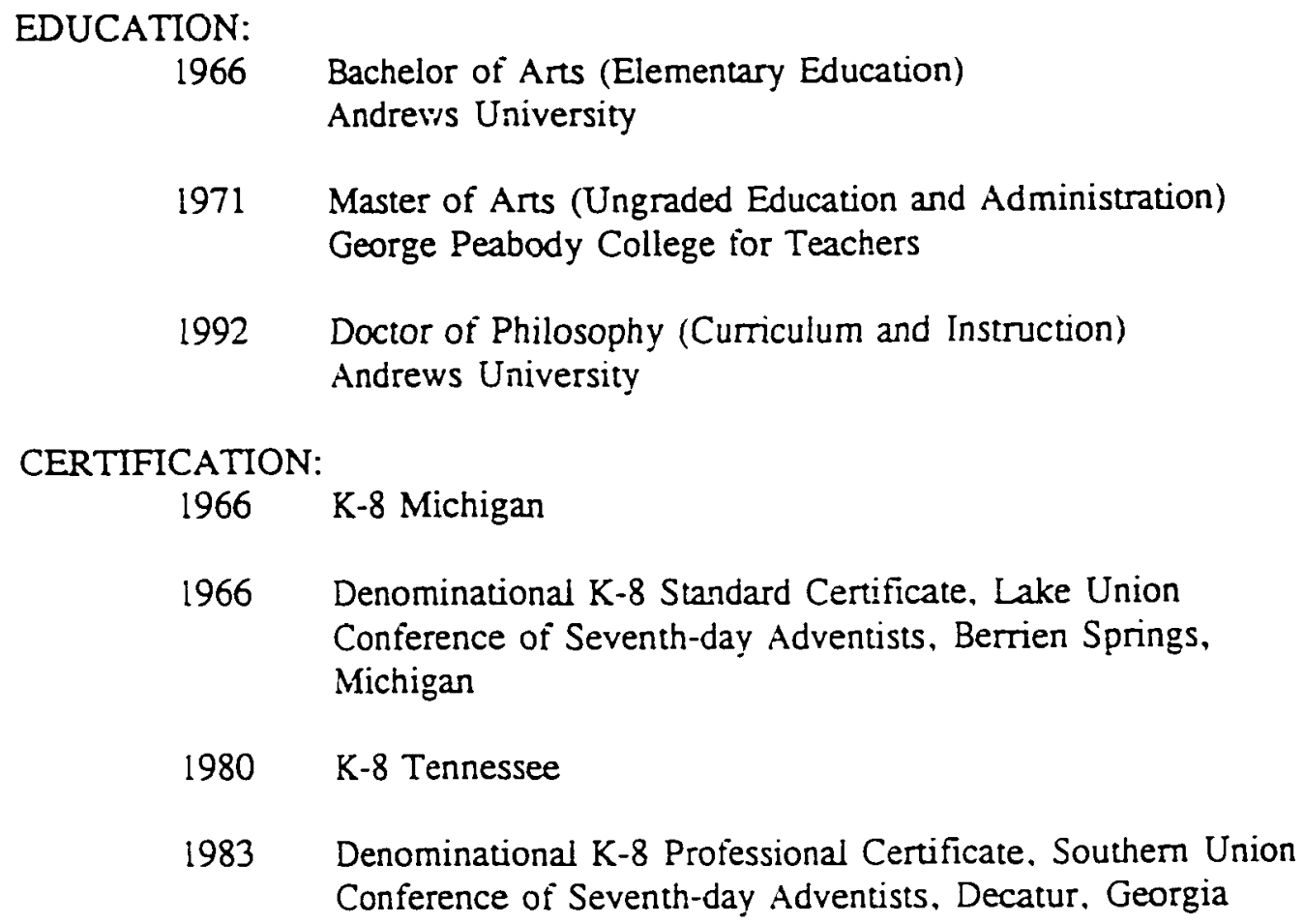

1966 Bachelor of Arts (Elementary Education) Andrews University

1971 Master of Arts (Ungraded Education and Administration) George Peabody College for Teachers

1992 Doctor of Philosophy (Curriculum and Instruction) Andrews University

\section{CERTIFICATION:}

1966 K-8 Michigan

1966 Denominational K-8 Standard Certificate, Lake Union Conference of Seventh-day Adventists, Berrien Springs, Michigan

$1980 \quad$ K-8 Tennessee

1983 Denominational K-8 Professional Certificate. Southem Union Conference of Seventh-day Adventists. Decatur. Georgia

\section{PROFESSIONAL EXPERIENCE:}

1966-1968 Elementary Teacher, Guadalajara. Mexico

1975-1980 Elementary Teacher. Michigan

1980-1985 Elementary Teacher, Tennessee

$1991-$

Assistant Professor. Teaching and Leaming, Andrews

University 